\title{
GEOGRAPHIC, GEOLOGIC, AND HYDROLOGIC SUMMARIES OF INTERMONTANE BASINS OF THE NORTHERN ROCKY MOUNTAINS, MONTANA
}

By Eloise Kendy and Ruth E. Tresch

\section{U.S. GEOLOGICAL SURVEY}

Water-Resources Investigations Report 96-4025

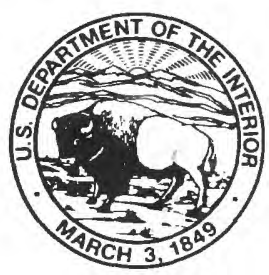




\title{
U.S. DEPARTMENT OF THE INTERIOR BRUCE BABBITT, Secretary
}

\author{
U.S. GEOLOGICAL SURVEY \\ Gordon P. Eaton, Director
}

For additional information write to:

Copies of this report may be purchased from:

District Chief

U.S. Geological Survey

Federal Building, Room 428

Helena, MT 59626-0076
U.S. Geological Survey

Branch of Information Services

Box 25286

Denver, CO 80225-0286 


\section{CONTENTS}

Abstract

Introduction

Purpose and scope

Description of study area

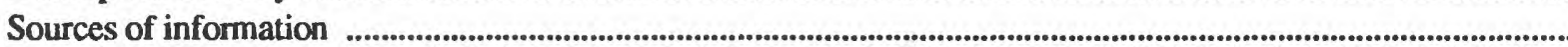

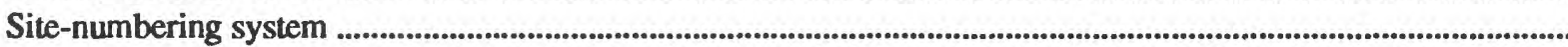

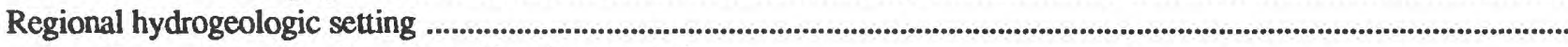

Hydrogeologic units and aquifer characteristics.................................................................................................... 8

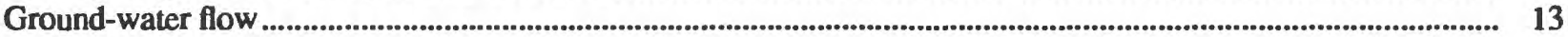

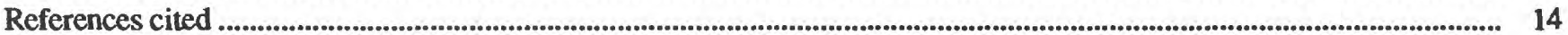

Geographic, geologic, and hydrologic summaries of intermontane basins...................................................................... 17

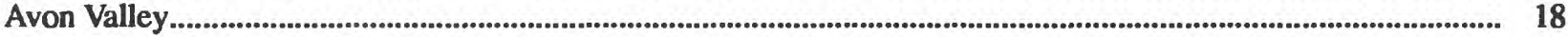

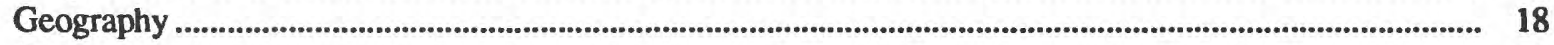

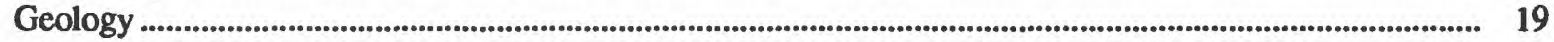

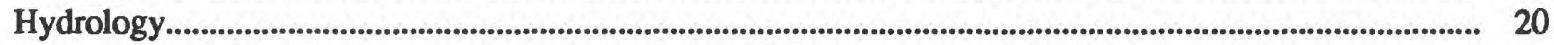

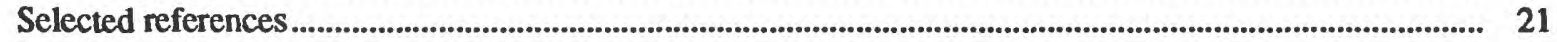

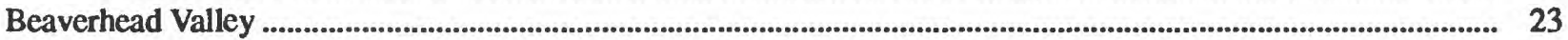

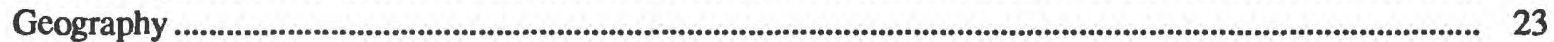

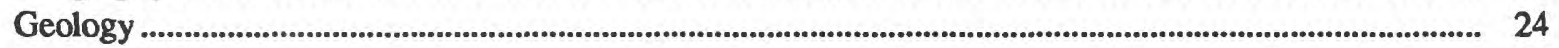

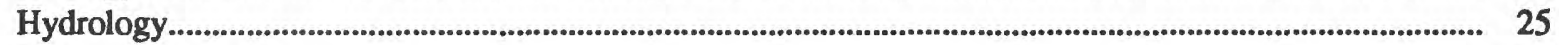

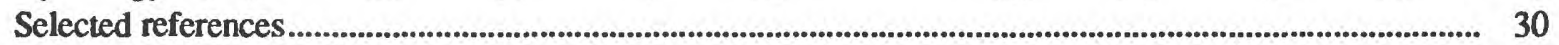

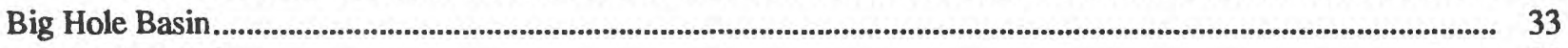

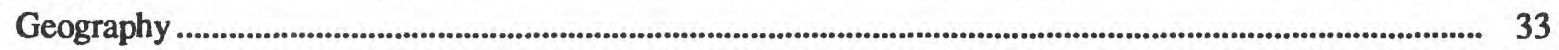

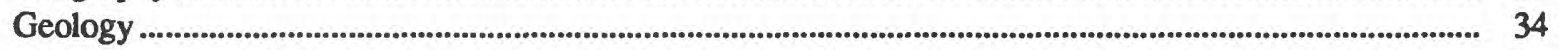

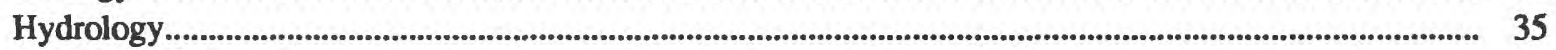

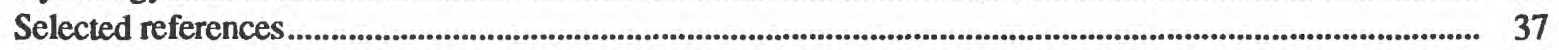

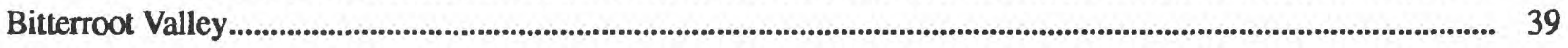

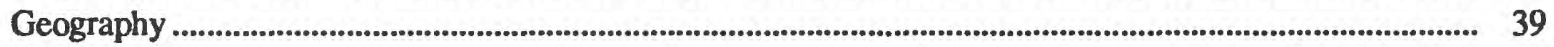

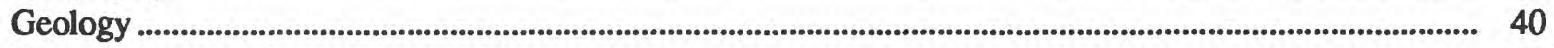

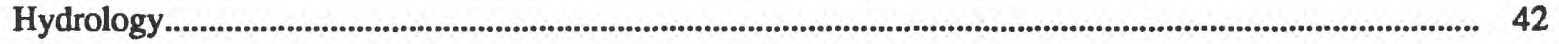

Selected references.............................................................................................................................................. 47

Blackfoot-Clearwater Valley................................................................................................................................................ 49

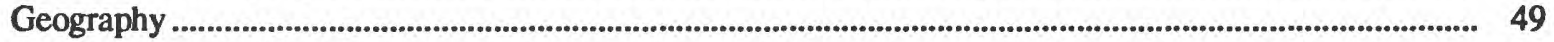

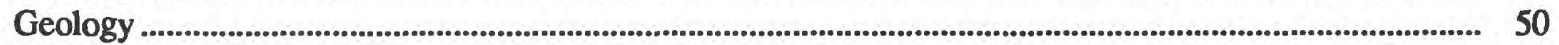

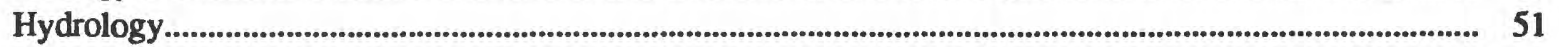

Selected references............................................................................................................................................... 54

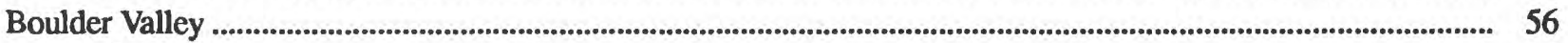

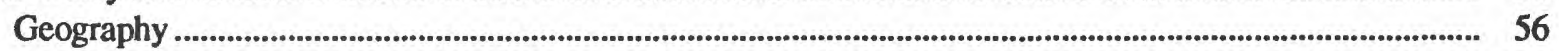

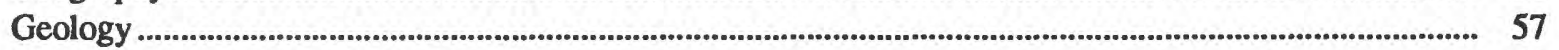

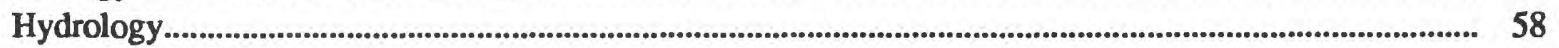

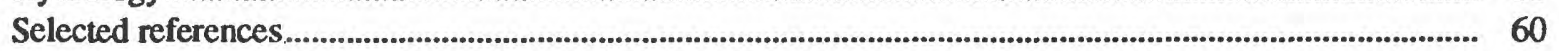

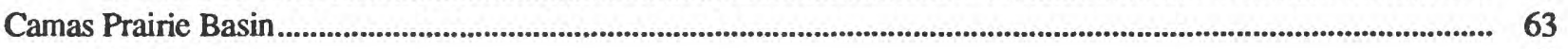

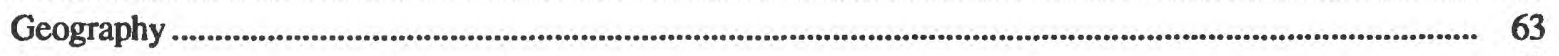

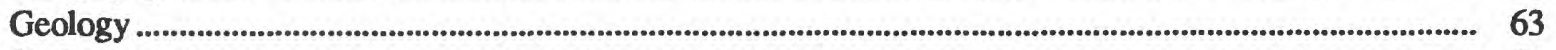

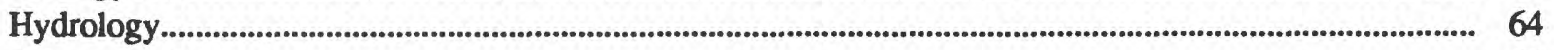

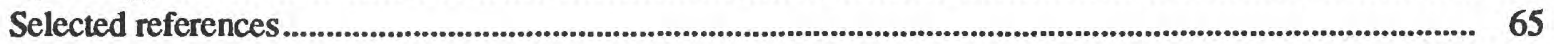




\section{CONTENTS--Continued}

Geographic, geologic, and hydrologic summaries of intermontane basins (Continued)

Centennial Valley.

Geography

Geology

Hydrology

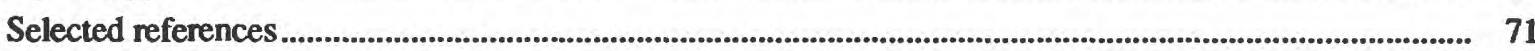

Gallatin Valley

Geography

Geology

Hydrology

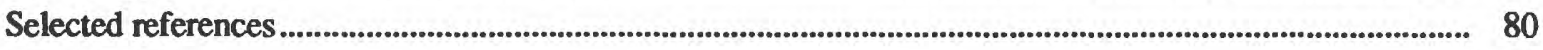

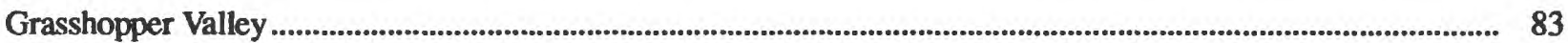

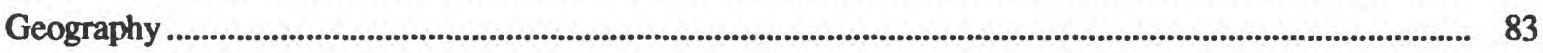

Geology ............................................................................................................................................................. 84

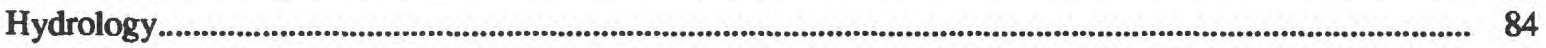

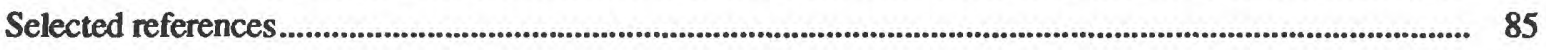

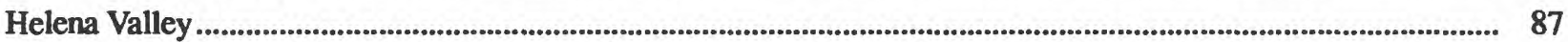

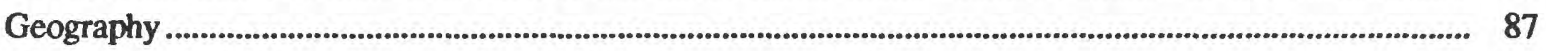

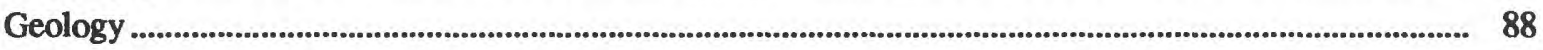

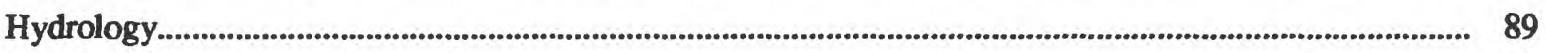

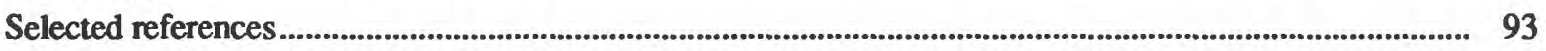

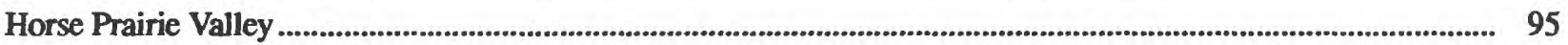

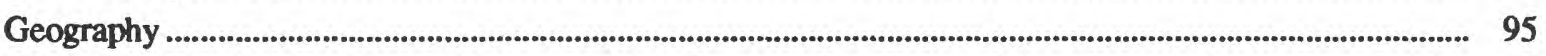

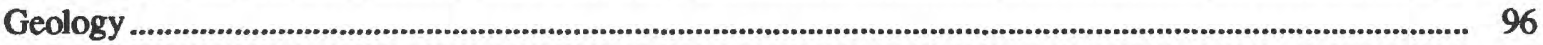

Hydrology....................................................................................................................................................... 97

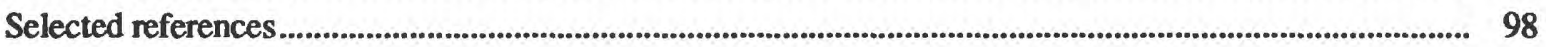

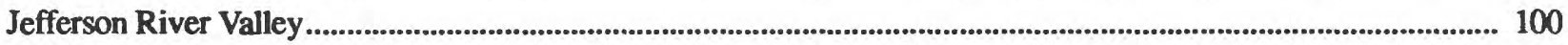

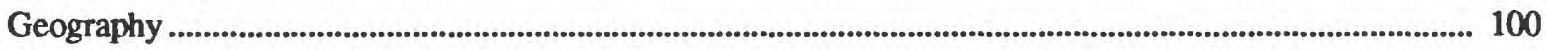

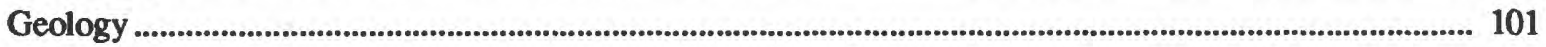

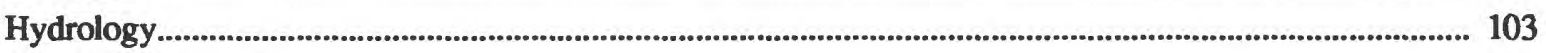

Selected references.................................................................................................................................................. 105

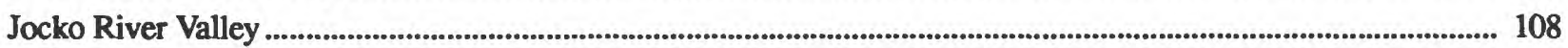

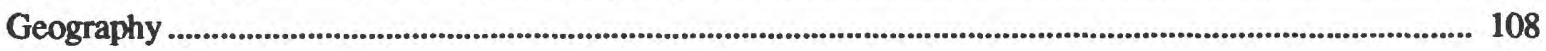

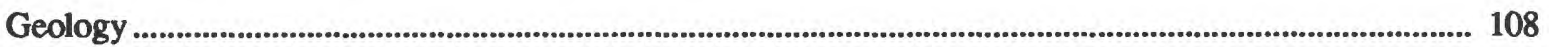

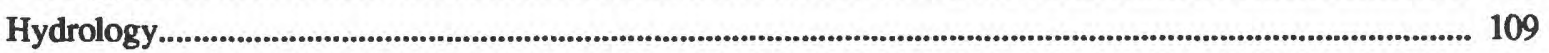

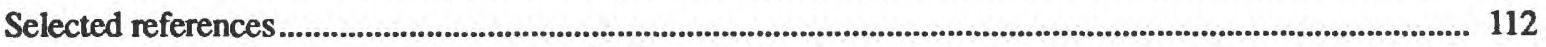

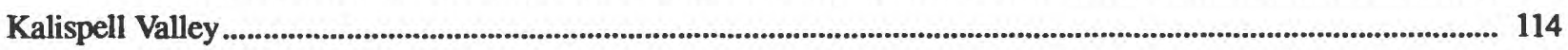

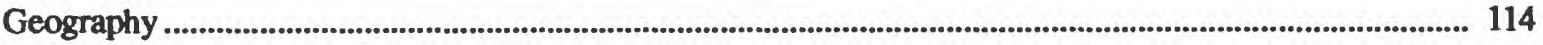

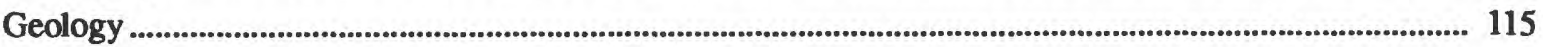

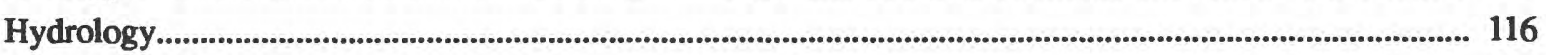

Selected references ................................................................................................................................... 121 


\section{CONTENTS--Continued}

Geographic, geologic, and hydrologic summaries of intermontane basins (Continued)

Lake Creek Valley

Geography

Geology

Hydrology

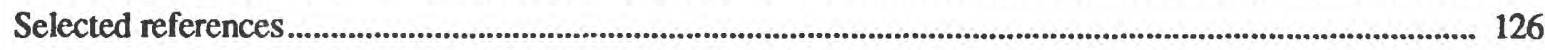

Libby Creek Valley ............................................................................................................................................................ 128

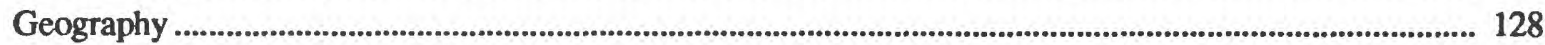

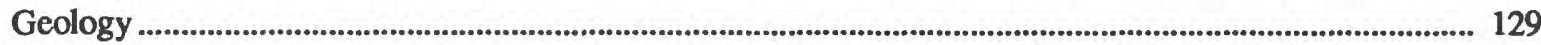

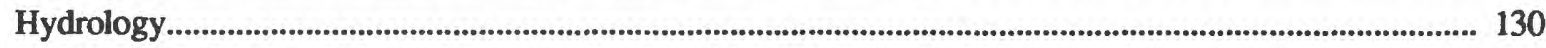

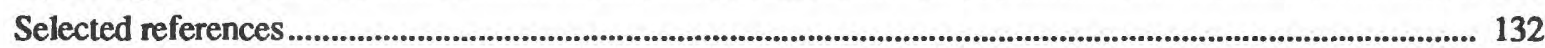

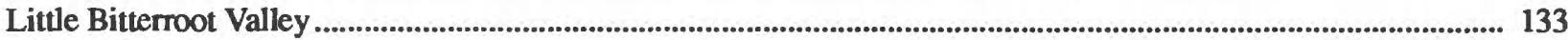

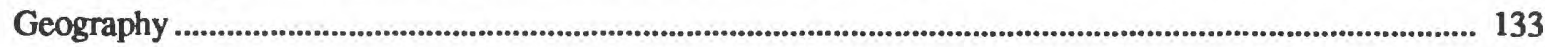

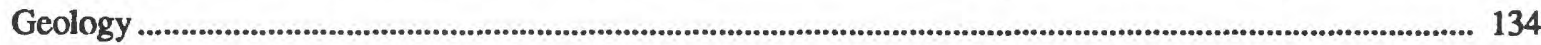

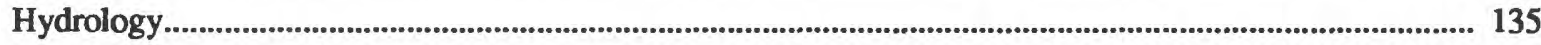

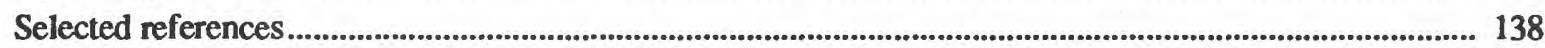

Lower Clark Fork Valley .......................................................................................................................................... 141

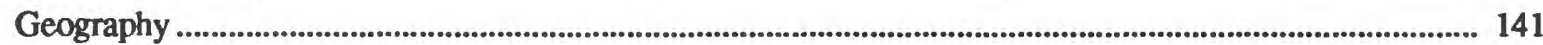

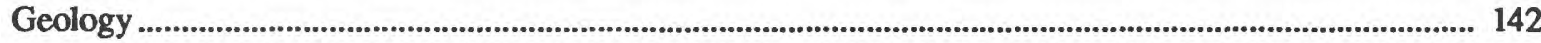

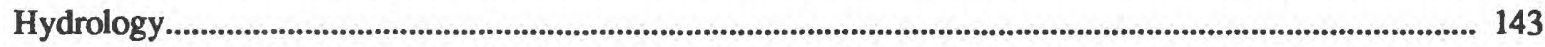

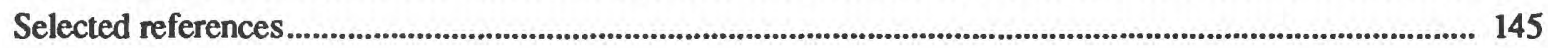

Madison River Valley .................................................................................................................................................... 147

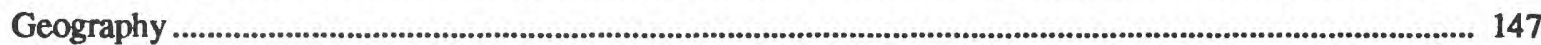

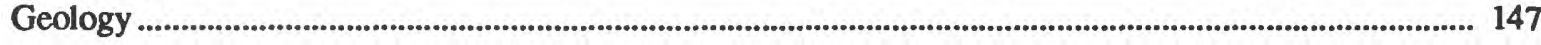

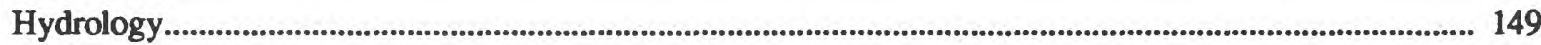

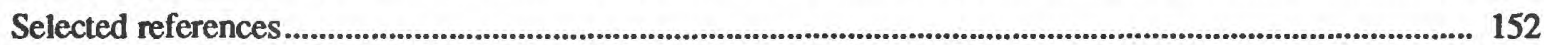

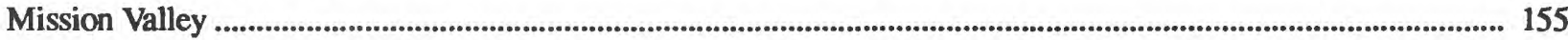

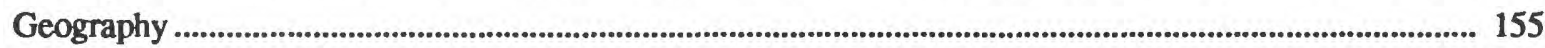

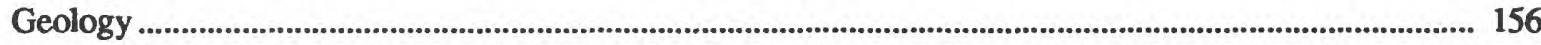

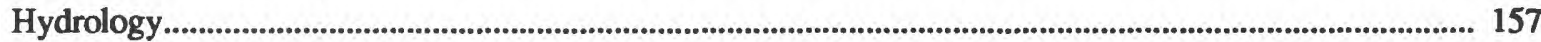

Selected references ............................................................................................................................................... 160

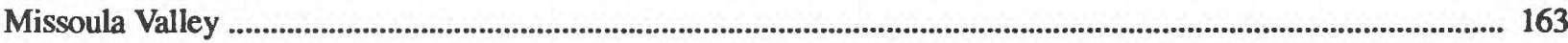

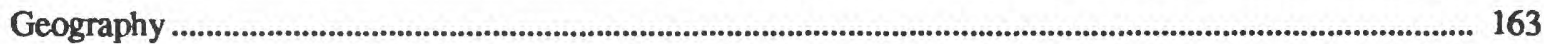

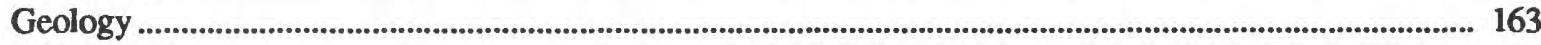

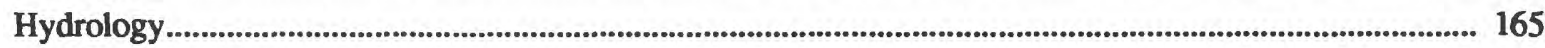

Selected references................................................................................................................................................... 168

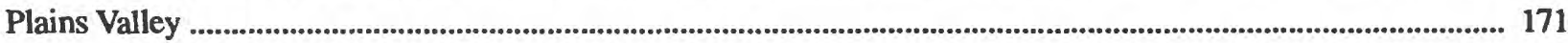

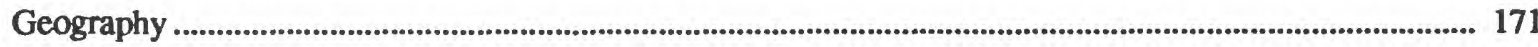

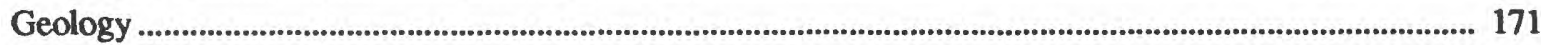

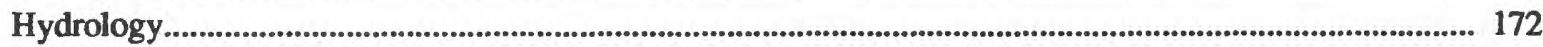

Selected references................................................................................................................................................ 173 


\section{CONTENTS--Continued}

Geographic, geologic, and hydrologic summaries of intermontane basins (Continued)

Red Rock Valley 174

Geography

Geology .

Hydrology

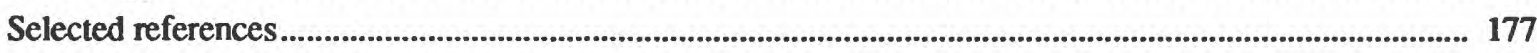

Swan Valley

Geography

Geology

Hydrology

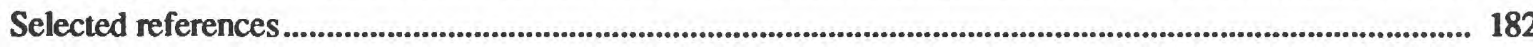

Tobacco Valley.

Geography

Geology

Hydrology

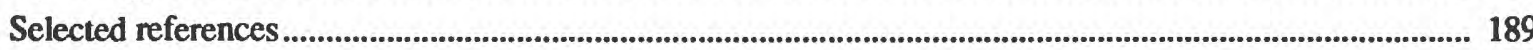

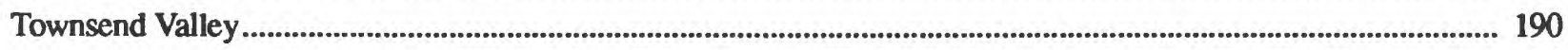

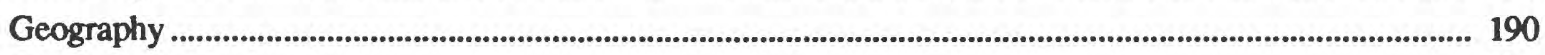

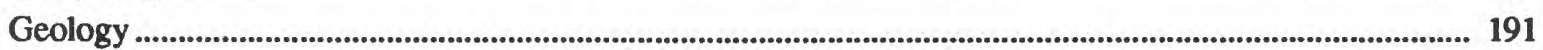

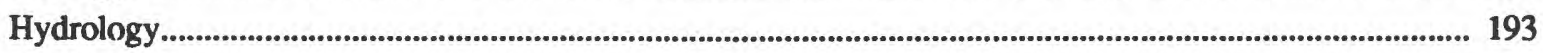

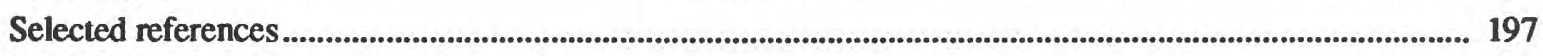

Upper Blackfoot River Valley................................................................................................................. 199

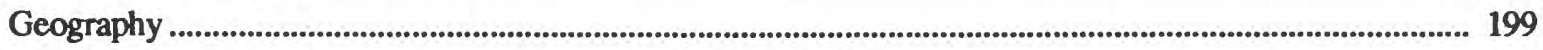

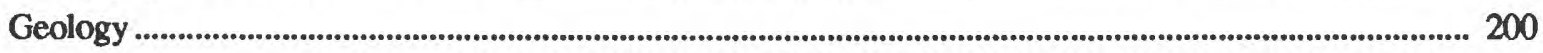

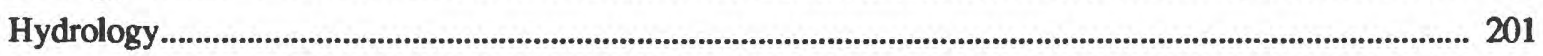

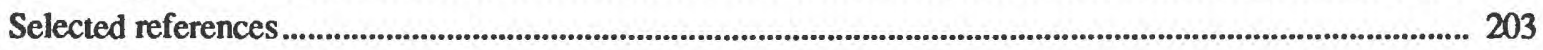

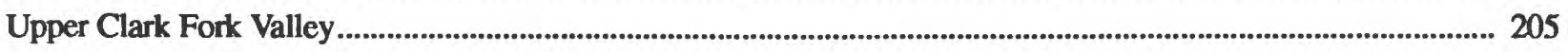

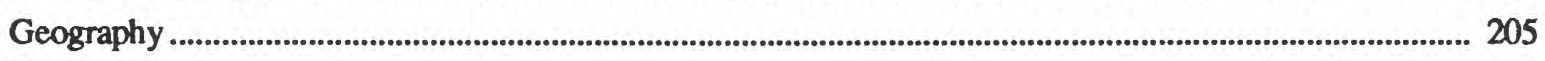

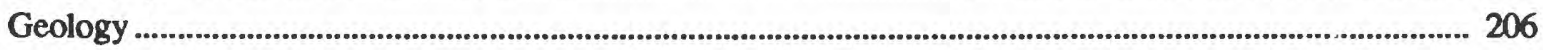

Hydrology....................................................................................................................................................... 208

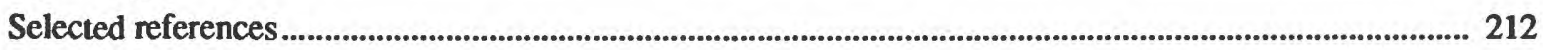

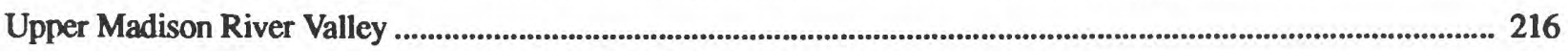

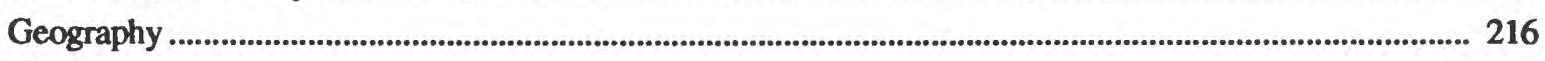

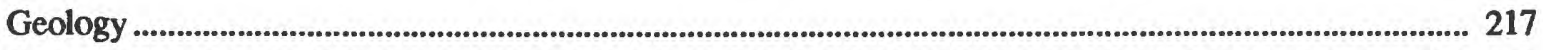

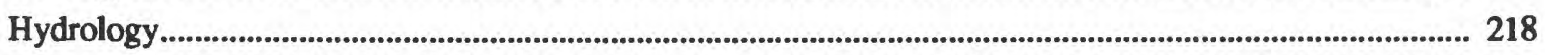

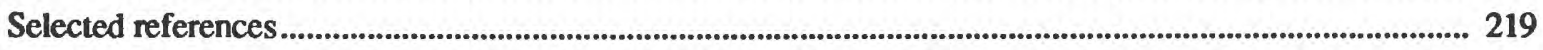

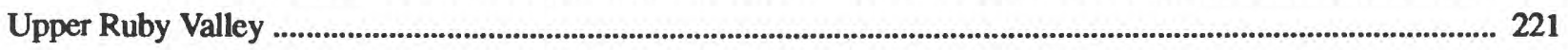

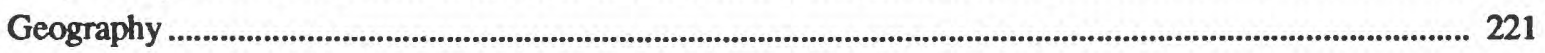

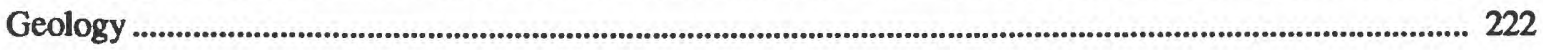

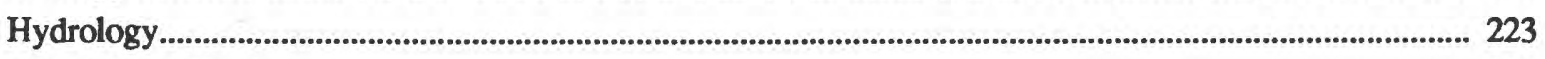

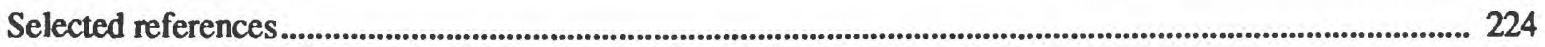




\section{CONTENTS--Continued}

Geographic, geologic, and hydrologic summaries of intermontane basins (Continued)

Western Three Forks Valley................................................................................................................................................... 225

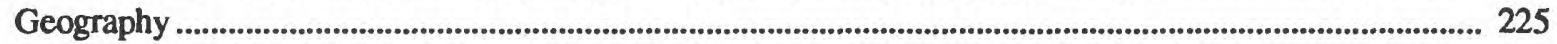

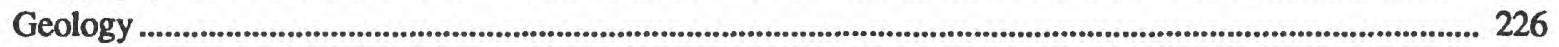

Hydrology........................................................................................................................................................ 228

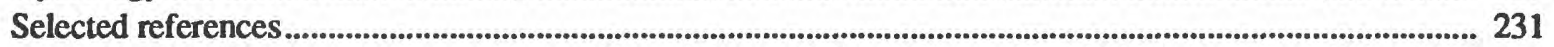

\section{ILLUSTRATIONS}

Plate 1. Map showing locations of intermontane basins, gaging stations, observation wells, and ground-water contribution areas ..................................................................................................................... in pocket

Figure 1. Map showing location of study area and names of basins in Montana ............................................................ 4

2. Schematic diagram showing the relation between intermontane basins, ground-water contribution areas,

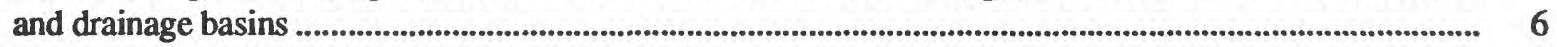

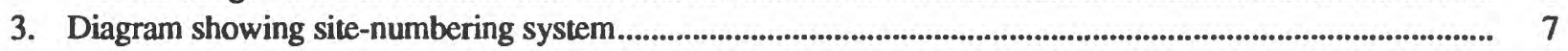

4. Map showing generalized geology of the Northern Rocky Mountains, Montana............................................ 11

5-12. Graphs showing mean monthly precipitation and temperature at:

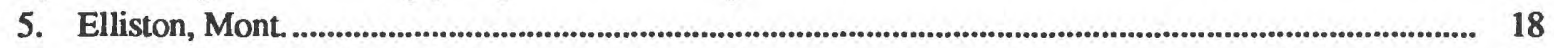

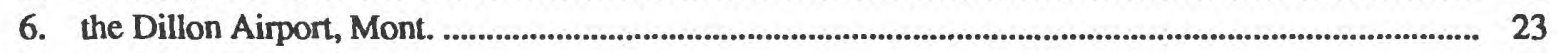

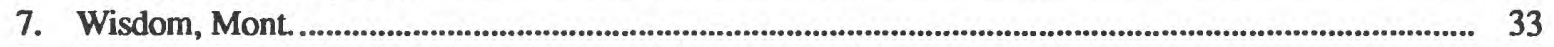

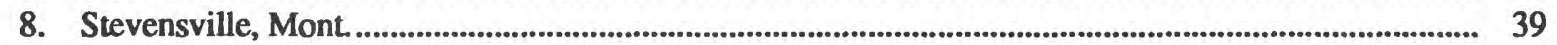

9. the Seeley Lake Ranger Station, Mont. .......................................................................................................... 49

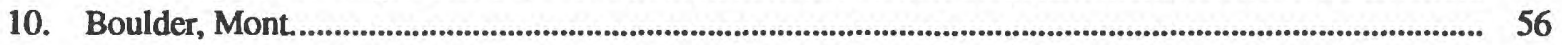

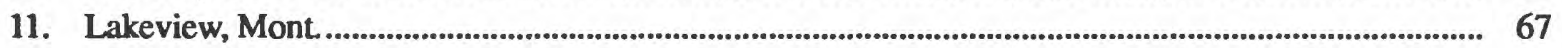

12. the Belgrade Airport, Mont. .................................................................................................................... 73

13. Graph showing mean monthly precipitation at Polaris, Mont. ........................................................................ 83

14. Graph showing mean monthly precipitation and temperature at the Helena Regional Airport, Mont............. 87

15. Graph showing mean monthly precipitation 4 miles northeast of Grant, Mont.. ............................................ 95

16-33. Graphs showing mean monthly precipitation and temperature at:

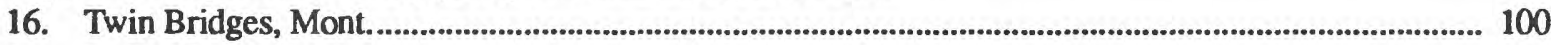

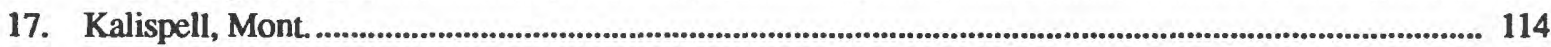

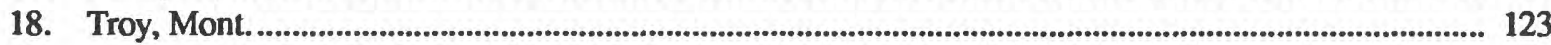

19. the Libby Ranger Station, Mont. ....................................................................................................... 128

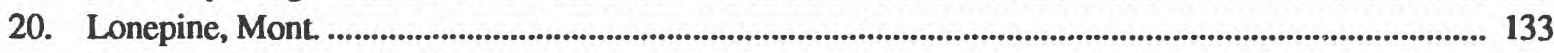

21. the Trout Creek Ranger Station, Mont. ........................................................................................... 141

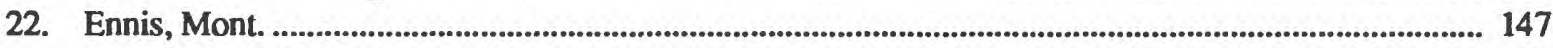

23. St. Ignatius, Mont. ................................................................................................................................ 155

24. the Missoula Airport, Mont. .......................................................................................................................... 163

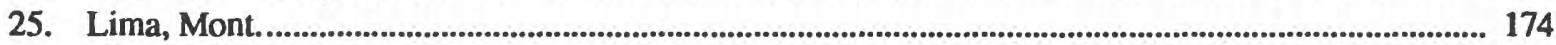

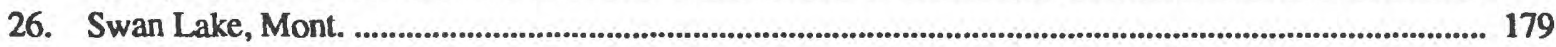

27. the Eureka Ranger Station, Mont. ….................................................................................................... 184

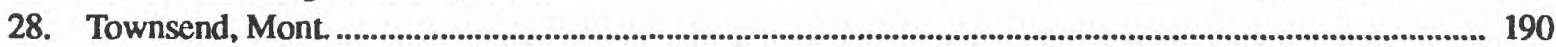

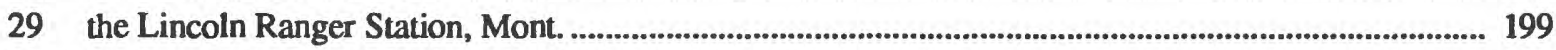

303 miles west of Deer Lodge, Mont. ............................................................................................................. 205

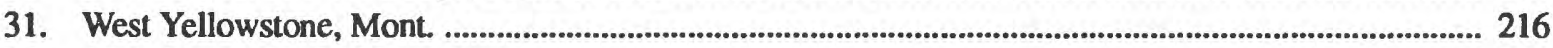

32. 17 miles south of Alder, Mont. .................................................................................................... 221

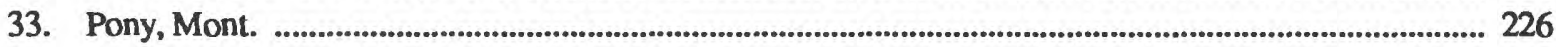


TABLES

Table 1. Sources of information for geographic, geologic, and hydrologic summaries of intermontane basins............ 7

2. Generalized hydrogeologic units and water-yielding properties .................................................................... 9

Avon Valley

3. Geologic and geophysical maps of the Avon Valley, Montana .............................................................. 19

4. Summary of water-level data for selected wells in the Avon Valley, Montana...................................... 21

Beaverhead Valley

5. Geologic and geophysical maps of the Beaverhead Valley, Montana

6. Summary of data for U.S. Geological Survey streamflow-gaging stations in the Beaverhead Valley, Montana

7. Summary of data for yield and specific capacity of wells completed in selected hydrogeologic units in the Beaverhead Valley, Montana.

8. Summary of water-level data for selected wells in the Beaverhead Valley, Montana

Big Hole Basin

9. Geologic maps of the Big Hole Basin, Montana

10. Summary of data for U.S. Geological Survey streamflow-gaging stations in the Big Hole Basin, Montana.

11. Summary of data for yield and specific capacity of wells completed in selected hydrogeologic units in the Big Hole Basin, Montana

\section{Bitterroot Valley}

12. Geologic and geophysical maps of the Bitterroot Valley, Montana

13. Summary of data for U.S. Geological Survey streamflow-gaging stations in the Bitterroot Valley, Montana.

14. Summary of data for yield and specific capacity of wells completed in selected hydrogeologic units in the Bitterroot Valley, Montana

15. Potentiometric-surface maps of the Bitterroot Valley, Montana............................................................. 45

16. Summary of water-level data for selected wells in the Bitterroot Valley, Montana................................. 46

\section{Blackfoot-Clearwater Valley}

17. Geologic and geophysical maps of the Blackfoot-Clearwater Valley, Montana

18. Summary of data for U.S. Geological Survey streamflow-gaging stations in the Blackfoot-Clearwater Valley, Montana

19. Summary of data for yield and specific capacity of wells completed in selected hydrogeologic units in the Blackfoot-Clearwater Valley, Montana

Boulder Valley

20. Geologic and geophysical maps of the Boulder Valley, Montana

21. Summary of data for U.S. Geological Survey streamflow-gaging stations in the Boulder Valley, Montana.

22. Summary of data for yield and specific capacity of wells completed in selected hydrogeologic units in the Boulder Valley, Montana.

\section{Camas Pairie Basin}

23. Geologic and geophysical maps of the Camas Prairie Basin, Montana. 
Centennial Valley

24. Geologic and geophysical maps of the Centennial Valley, Montana

25. Summary of data for U.S. Geological Survey streamflow-gaging stations in the Centennial Valley, Montana.

Gallatin Valley

26. Geologic and geophysical maps of the Gallatin Valley, Montana

27. Summary of data for U.S. Geological Survey streamflow-gaging stations in the Gallatin Valley, Montana.

28. Summary of data for yield and specific capacity of wells completed in selected hydrogeologic units in the Gallatin Valley, Montana ..

29. Summary of water-level data for selected wells in the Gallatin Valley, Montana

30.

Helena Valley

31. Geologic and geophysical maps of the Helena Valley, Montana

32. Summary of data for U.S. Geological Survey streamflow-gaging stations in the Helena Valley, Montana.

33. Potentiometric-surface maps of the Helena Valley, Montana ..................................................................... 92

34. Summary of water-level data for selected wells in the Helena Valley, Montana .................................... 93

Horse Prairie Valley

35. Geologic maps of the Horse Prairie Valley, Montana

36. Summary of data for yield and specific capacity of wells completed in selected hydrogeologic units in the Horse Prairie Valley, Montana.

\section{Lefferson River Valley}

37. Geologic and geophysical maps of the Jefferson River Valley, Montana. 102

38. Summary of data for U.S. Geological Survey streamflow-gaging stations in the Jefferson River Valley, Montana 103

39. Summary of data for yield and specific capacity of wells completed in selected hydrogeologic units in the Jefferson River Valley, Montana

Jocko River Valley

40. Geologic maps of the Jocko River Valley, Montana 109

41. Summary of data for U.S. Geological Survey streamflow-gaging stations in the Jocko River Valley, Montana.

42. Potentiometric-surface maps of the Jocko River Valley, Montana 111

Kalispell Valley

43. Geologic and geophysical maps of the Kalispell Valley, Montana. 116

44. Summary of data for U.S. Geological Survey streamflow-gaging stations in the Kalispell Valley, Montana.

45. Hydraulic characteristics of selected aquifers in the Kalispell Valley, Montana .................................... 118

46. Potentiometric-surface maps of aquifers in the Kalispell Valley, Montana........................................... 120

47. Summary of water-level data for selected wells in the Kalispell Valley, Montana.................................. 120

\section{Lake Creek Valley}

48. Geologic and geophysical maps of the Lake Creek Valley, Montana

49. Summary of data for U.S. Geological Survey streamflow-gaging stations in the Lake Creek Valley, Montana.

50. Summary of water-level data for selected wells in the Lake Creek Valley, Montana............................... 126

\section{Libby Creek Valley}

51. Geologic and geophysical maps of the Libby Creek Valley, Montana 129

52. Summary of data for U.S. Geological Survey streamflow-gaging stations in the Libby Creek Valley, Montana. 
Libby Creek Valley (Continued)

53. Summary of data for yield and specific capacity of wells completed in selected hydrogeologic units in the Libby Creek Valley, Montana.

Little Bitterroot Valley

54. Geologic and geophysical maps of the Little Bitterroot Valley, Montana

55. Summary of data for U.S. Geological Survey streamflow-gaging stations in the Little Bitterroot Valley, Montana.

56. Potentiometric-surface maps of the Little Bitterroot Valley, Montana .

57. Summary of water-level data for selected wells in the Little Bitterroot Valley, Montana.

Lower Clark Fork Valley

58. Geologic and geophysical maps of the Lower Clark Fork Valley, Montana

59. Summary of data for U.S. Geological Survey streamflow-gaging stations in the Lower Clark Fork Valley, Montana and Idaho

60. Summary of data for yield and specific capacity of wells completed in selected hydrogeologic units in the Lower Clark Fork Valley, Montana.

Madison River Valley

61. Geologic and geophysical maps of the Madison River Valley, Montana

62. Summary of data for U.S. Geological Survey streamflow-gaging stations in the Madison River Valley, Montana.

63. Summary of data for yield and specific capacity of wells completed in selected hydrogeologic units in the Madison River Valley, Montana.

Mission Valley

64. Geologic and geophysical maps of the Mission Valley, Montana

65. Summary of data for U.S. Geological Survey streamflow-gaging stations in the Mission Valley, Montana.

66. Potentiometric-surface maps of the Mission Valley, Montana.

67. Summary of water-level data for selected wells in the Mission Valley, Montana

Missoula Valley

68. Geologic and geophysical maps of the Missoula Valley, Montana

69. Summary of data for U.S. Geological Survey streamflow-gaging stations in the Missoula Valley, Montana.

70. Summary of data for yield and specific capacity of wells completed in selected hydrogeologic units in the Missoula Valley, Montana

71. Hydraulic characteristics of aquifer units in the Missoula Valley, Montana................................................ 167

72. Potentiometric-surface maps of the Missoula Valley, Montana................................................................... 167

73. Summary of water-level data for selected wells in the Missoula Valley, Montana .................................. 168

Plains Valley

74. Geologic and geophysical maps of the Plains Valley, Montana

75. Summary of data for yield and specific capacity of wells completed in selected hydrogeologic units in the Plains Valley, Montana

\section{Red Rock Valley}

76. Geologic and geophysical maps of the Red Rock Valley, Montana

77. Summary of data for U.S. Geological Survey streamflow-gaging stations in the Red Rock Valley, Montana

Swan Valley

78. Geologic and geophysical maps of the Swan Valley, Montana

79. Summary of data for U.S. Geological Survey streamflow-gaging stations in the Swan Valley, Montana

80. Summary of data for yield and specific capacity of wells completed in selected hydrogeologic units in the Swan Valley, Montana 
Tobacco Valley

81. Geologic and geophysical maps of the Tobacco Valley, Montana 185

82. Summary of data for U.S. Geological Survey streamflow-gaging stations in the Tobacco Valley, Montana

83. Summary of water-level data for selected wells in the Tobacco Valley, Montana. 188

Townsend Valley

84. Geologic and geophysical maps of the Townsend Valley, Montana 192

85. Summary of data for U.S. Geological Survey streamflow-gaging stations in the Townsend Valley, Montana

86. Summary of data for yield and specific capacity of wells completed in selected hydrogeologic units in the Townsend Valley, Montana.

87. Summary of water-level data for selected wells in the Townsend Valley, Montana.

88. Potentiometric-surface maps of the Townsend Valley, Montana

\section{Ujoer Blackfoot River Valley}

89. Geologic and geophysical maps of the Upper Blackfoot River Valley, Montana

90. Summary of data for U.S. Geological Survey streamflow-gaging stations in the upper Blackfoot River Valley, Montana.

91. Potentiometric-surface maps of the Upper Blackfoot River Valley, Montana....................................... 203

92. Summary of water-level data for selected wells in the Upper Blackfoot River Valley, Montana .......... 203

\section{Upper Clark Fork Valley}

93. Geologic and geophysical maps of the Upper Clark Fork Valley, Montana

94. Summary of data for U.S. Geological Survey streamflow-gaging stations in the Upper Clark Fork Valley, Montana

95. Summary of data for yield and specific capacity of wells completed in selected hydrogeologic units in the Upper Clark Fork Valley, Montana

96. Summary of data for transmissivity of aquifers in the Upper Clark Fork Valley, Montana ................... 210

97. Potentiometric-surface maps of the Upper Clark Fork Valley, Montana .................................................. 211

98. Summary of water-level data for selected wells in the Upper Clark Fork Valley, Montana.................... 212

\section{Upper Madison Biver Valley}

99. Geologic maps of the Upper Madison River Valley, Montana

100. Summary of data for U.S. Geological Survey streamflow-gaging stations in the Upper Madison River Valley, Montana

\section{Upper Ruby Valley}

101. Geologic and geophysical maps of the Upper Ruby Valley, Montana 222

102. Summary of data for U.S. Geological Survey streamflow-gaging stations in the Upper Ruby Valley, Montana

\section{Western Three Forks Valley}

103. Geologic and geophysical maps of the Western Three Forks Valley, Montana

104. Summary of data for U.S. Geological Survey streamflow-gaging stations in the Western Three Forks Valley, Montana

105. Summary of data for yield and specific capacity of wells completed in selected hydrogeologic units in the Western Three Forks Valley, Montana 


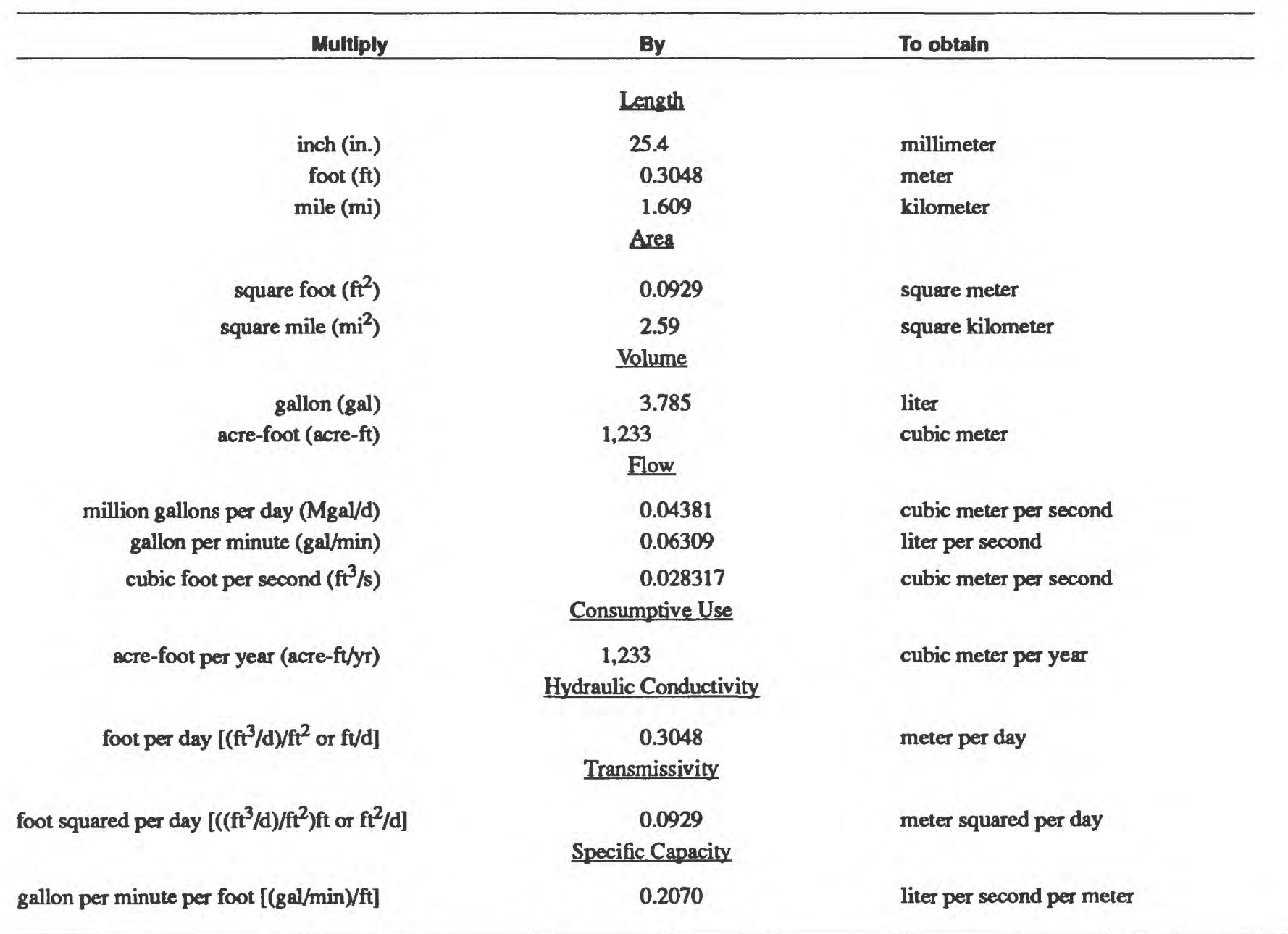

Temperature can be converted to degrees Celsius $\left({ }^{\circ} \mathrm{C}\right)$ or degrees Fahrenheit $\left({ }^{\circ} \mathrm{F}\right)$ by the equations:

$$
\begin{aligned}
& { }^{\circ} \mathrm{C}=5 / 9\left({ }^{\circ} \mathrm{F}-32\right) \\
& { }^{\circ} \mathrm{F}=9 / 5\left({ }^{\circ} \mathrm{C}\right)+32
\end{aligned}
$$

Sea level: In this report, "sea level" refers to the National Geodetic Vertical Datum of 1929 (NGVD of 1929)--a geodetic datum derived from a general adjustment of the first-order level nets of both the United States and Canada, formerly called Sea Level Datum of 1929.

Abbreviations and acronyms used in this report

GIS

RASA

USGS

WATSTORE

Water-quality units

$\mu \mathrm{g} / \mathrm{L}$

$\mathrm{mg} / \mathrm{L}$
Geographic Information System

Regional Aquifer System Analysis

U.S. Geological Survey

National Water-Data Storage and Retrieval System

micrograms per liter

milligrams per liter 


\title{
Geographic, Geologic, and Hydrologic Summaries of Intermontane Basins of the Northern Rocky Mountains,
} Montana

\author{
By Eloise Kendy and Ruth E. Tresch
}

\section{Abstract}

This report combines a literature review with new information to provide summaries of the geography, geology, and hydrology of each of 32 intermontane basins in western Montana. These basins range in area from about 30 to 710 square miles, and have populations ranging from less than 100 to about 50,000 residents. The basins are filled with unconsolidated to poorly consolidated Tertiary and Quaternary deposits. Maximum known thickness of the deposits in individual basins ranges from several hundred to about 16,000 feet. Alluvial deposits are the most productive aquifers in most basins. Although geographically separate, through-flowing streams provide a hydraulic connection between basins.

The summary of each intermontane basin includes concise descriptions of topography, areal extent, altitude, climate, 1990 population, land and water use, geology, surface water, aquifer hydraulic characteristics, ground-water flow, and ground-water quality. If present, geothermal features are described. Average annual and monthly temperature and precipitation are reported from one National Weather Service station in each basin. Streamflow data, including the drainage area, period of record, and average, minimum, and maximum historical streamflow, are reported for all active and discontinued U.S. Geological Survey streamflow-gaging stations in each basin. Monitoring-well data, including the well depth, aquifer, period of record, and minimum and maximum historical water levels, are reported for all long-term U.S. Geological Survey monitoring wells in each basin. Brief descriptions of geologic, geophysical, and potentiometric-surface maps available for each basin, including scales and contour intervals, also are included. The summary for each basin also includes a bibliography of hydrogeologic literature.

This report complements other products of the Northern Rocky Mountains Intermontane Basins Regional Aquifer-System Analysis (RASA). While the focus of other RASA publications is generally regional in context, this report emphasizes local information. When used alone or in conjunction with regional RASA reports, this report provides a practical starting point for site-specific hydrogeologic investigations.

\section{INTRODUCTION}

The Regional Aquifer-System Analysis (RASA) program is a series of studies by the U.S. Geological Survey (USGS) to analyze regional ground-water systems that comprise a major portion of the Nation's water supply (Sun, 1986). The Northem Rocky Mountains Intermontane Basins is one of the study regions in this national program. The main objectives of the RASA studies are to: (1) describe the ground-water systems as they exist today, (2) analyze the known changes that have led to the system's present conditions (3) combine results of previous studies in a regional analysis, where possible, and (4) provide means by which effects of future ground-water development 
can be estimated. The purpose of this study, which began in 1990, was to increase understanding of the hydrogeology of the intermontane basins of the Northem Rocky Mountains area.

\section{Purpose and Scope}

This report provides summaries of the geography, geology, and hydrology of 32 intermontane basins in western Montana. The summaries contain compilations of hydrogeologic data, synopses of interpretive studies, and literature citations of geologic and hydrologic studies relevant to each basin.

Prior to the basin summaries, this report describes the hydrogeologic setting of the Northern Rocky Mountains, to place the individual basin summaries in a regional context. References cited in the introductory chapters are listed before the basin summaries, distinguishing these general references from those specific to particular basins.

Each basin summary includes descriptions of the location, areal extent, topography, climate, 1990 population, land and water use, geology, surface-water hydrology, aquifer hydraulic characteristics, ground-water flow, and ground-water quality of a basin. If present, geothermal features also are described. Average annual and mean monthly temperature and precipitation are reported from one National Weather Service station in each basin. Streamflow information, including the drainage area, period of record, average discharge, and historical minimum and maximum discharge, are reported for all active and discontinued USGS streamflow-gaging stations in each basin. Monitoring-well data, including the well depth, aquifer, period of record, and historical minimum and maximum water levels, are reported for all long-term USGS monitoring wells in each basin. Brief descriptions of geologic, geophysical, and potentiometric-surface maps available for each basin, including scales and contour intervals, are included. The summary for each basin includes a bibliography of hydrogeologic literature.

These compilations are based on USGS ground-water and surface-water databases, publicly available databases from other government agencies, published scientific literature, graduate-student theses and dissertations, government documents, and interpretations based on field observations during the course of the study. When used alone or in conjunction with other products of the Northern Rocky Mountains Intermontane Basins RASA (Briar and others, in press; Tuck and others, in press; Clark and Dutton, in press; Dutton and others, 1995), this report provides a practical starting point for site-specific hydrogeologic investigations.

\section{Description of Study Area}

The Northern Rocky Mountains Intermontane Basins study area encompasses about 77,500 $\mathrm{mi}^{2}$ (fig. 1), $41,500 \mathrm{mi}^{2}$ of which are in western Montana. Within Montana, 34 intermontane basins have been delineated on the basis of topography, stratigraphy, geologic structure, extent of basin fill, and results of previous studies (fig. 1). All but two of the intermontane basins are described in this report. The North Fork Flathead River Valley is not addressed because very little information is available, particularly with regard to the hydrogeology of this sparsely populated basin. The Silver Bow Creek Valley is not addressed because numerous investigations conducted under the Comprehensive Environmental Response Compensation and Liability Act of 1980 (CERCLA) have generated a comprehensive, detailed database that is beyond the scope of this report to summarize. These data are available from the Natural Resource Information System, Montana State Library, Helena, Mont. Related technical reports are available from the U.S. Environmental Protection Agency.

In this report, "basin" or "intermontane basin" refers to a topographic and geologic feature that is structurally downdropped relative to the surrounding mountains and filled with unconsolidated to poorly consolidated deposits (fig. 2, pl. 1). Intermontane basins addressed in this study are delineated on plate 1 and in figure 1 . Intermontane basins of the Northern Rocky Mountains typically are surrounded by relatively impermeable bedrock, thereby restricting ground-water flow through the mountain masses separating the basins. All basins have perennial streams with recent flood plains. In most southem basins, these flood plains are adjacent to older river terraces which grade 
to pediments or alluvial fans that meet mountain fronts with an abrupt change in slope. In northem basins, recent flood plains are adjacent to glacial deposits which extend to mountain fronts; in some areas, the glacial deposits reach an altitude of as much as $6,000 \mathrm{ft}$ above sea level. Mountain fronts commonly coincide with faults or fault systems along which the basins have been downdropped relative to the mountains.

In this report, "drainage area" or "drainage basin" refers to the land area from which surface runoff drains into a stream system (Fetter, 1980, p. 471). In contrast, the term "ground-water contribution area" is used to refer to that part of the drainage basin that most likely contributes ground water directly to the unconsolidated to poorly consolidated deposits in an intermontane basin. The ground-water contribution area does not include areas that contribute ground water directly to streams that flow between intermontane basins. A drainage basin may be coincident with, or larger than, the ground-water contribution area for a given intermontane basin, depending on the position of the intermontane basin within the regional drainage system (fig. 2, pl. 1).

Intermontane basins of Montana range in size from about 30 to $710 \mathrm{mi}^{2}$ and are filled with unconsolidated to poorly consolidated Tertiary and Quatemary deposits. These deposits generally range from several hundred to several thousand feet thick. The maximum known thickness of these deposits is about $16,000 \mathrm{ft}$ in the Big Hole Basin.

The Continental Divide separates the area into two major drainage systems - the Missouri River drainage to the southeast and the Clark Fork of the Columbia River drainage to the northwest (fig. 1). Major tributaries of the Missouri River drainage basin in the study area include the Beaverhead, Ruby, Big Hole, Jefferson, Madison, and Gallatin Rivers. Major tributaries of the Clark Fork drainage in the study area include the Kootenai, Blackfoot, Bitterroot, and Flathead Rivers.

The climate is characterized by cold winters and mild summers. West of the Continental Divide, the climate is more humid and mild than east of the Divide because of the moderating influences of moist Pacific Ocean air masses. Both seasonal and diumal temperature fluctuations are more pronounced east of the Divide. Summers generally are warm and dry in the basins, and cool in the surrounding mountains. The growing season typically extends from May to September or October, but in some basins is as short as July to August. Winters are cold, and a thick snowpack accumulates in the mountains. Following periods of extreme cold, mountainous areas often warm up more rapidly than the basins, causing pronounced temperature inversions. Occasionally during the winters, warm, dry chinook winds blow down eastern slopes of the Rocky Mountains and melt accumulated snow in the basins. The prevailing wind in most of the study area is from the west and strong, gusty winds are common yearround.

Precipitation reaches the basins primarily as winter and spring frontal systems and summer convection storms. Annual precipitation in the study area ranges from about $10 \mathrm{in.}$ in the basins of southwestern Montana to about 100 in. in the mountains of northwestern Montana. Most basins receive about 10 to $30 \mathrm{in}$. of precipitation per year, with more than one-half falling in winter and spring. Large winter snowpacks in the mountains gradually release their water content as snowmelt that maintains streamflow well into summer (Briar and Madison, 1992; Clark and Kendy, 1992).

Topography in the study area is varied. In the northwestern corner of Montana, mountain ranges typically are separated by narrow, steep-sided valleys that have little or no basin-fill deposits-primarily the result of erosion by glaciers and streams. In contrast to these narrow, erosional valleys, intermontane basins are wide, deep, and filled with sediment - the result of structural downdropping due to block faulting. Aquifers in the Tertiary and Quaternary deposits that fill these basins are the focus of this RASA.

Aquifers in Tertiary and Quaternary deposits provide water for public-supply, domestic, stock, irrigation, commercial, and industrial use. The largest uses of ground water are irrigation and public supply, although most water for irrigation is obtained from surface-water sources. Most households rely on ground water from wells or springs for domestic use. About 100 million gallons of ground water per day were withdrawn from aquifers in the area in 1985 (Clark and Kendy, 1992). 


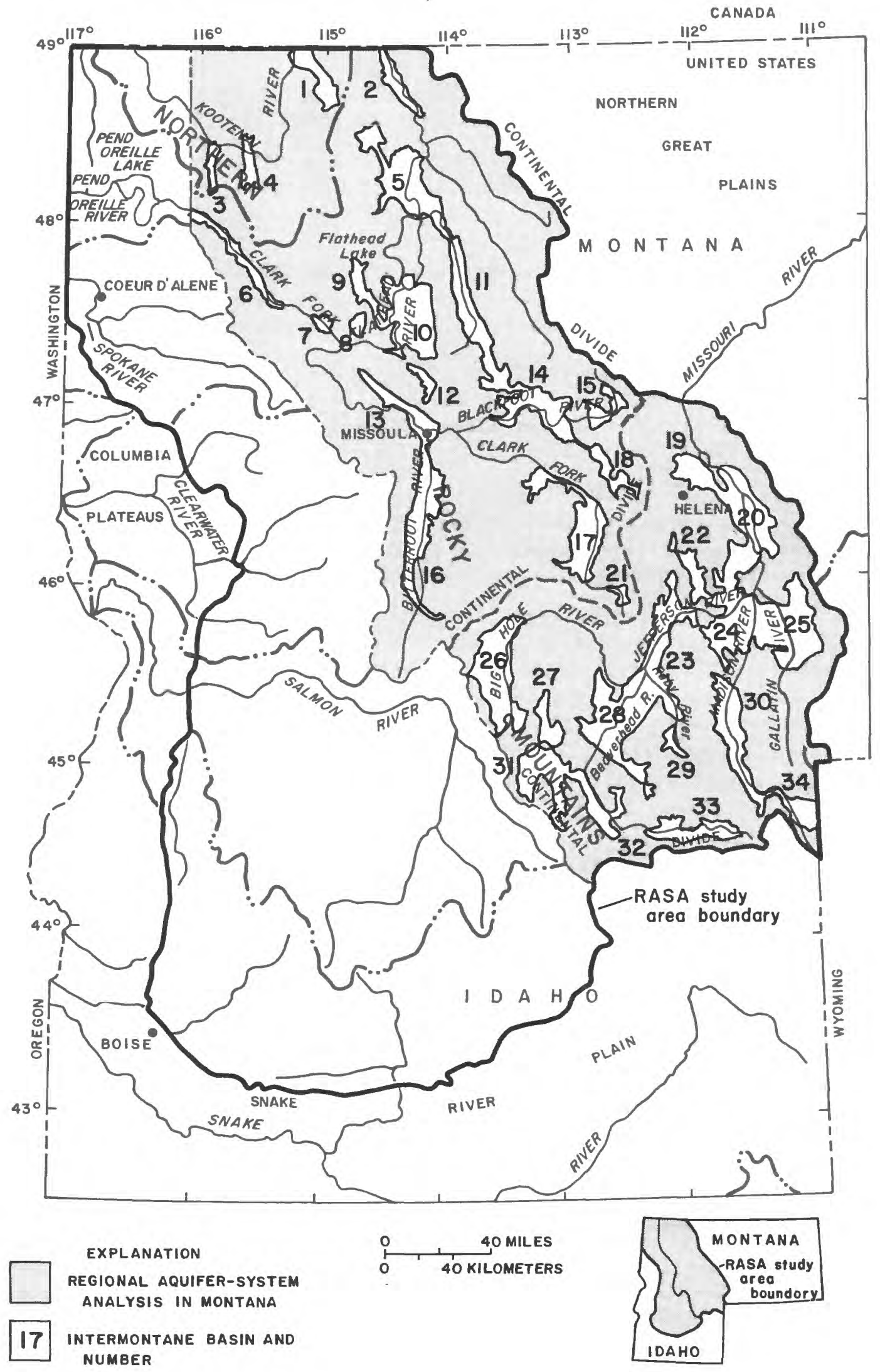

Figure 1. Location of study area and names of basins in Montana. 
Figure 1. Basin names list

\section{Basin Names}
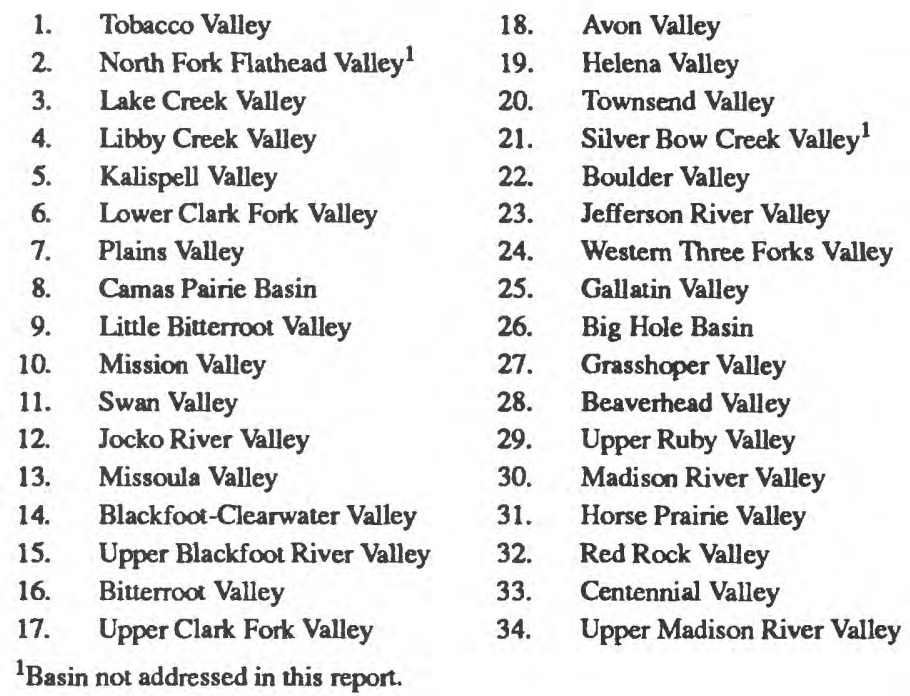

Primary land uses in the basins include rangeland and irrigated and dryland hay and grain production, while mining and timber harvesting are important in the mountains surrounding the basins. In some areas, recently accelerated residential development is replacing agricultural land uses. Populations of individual basins range from less than 100 to about 50,000 residents.

\section{Sources of Information}

Basin summaries were compiled from the information sources listed in table 1. Information included in the basin summaries that is not specifically referenced to literature citations, nor listed below, is based on previously unpublished field observations.

Digital information processed by a geographic information system (GIS) was used extensively in compiling the basin summaries. A GIS is a computer system designed to capture, store, manipulate, and analyze all forms of geographically referenced information. Individual GIS data sets can be combined to determine the relation between features in each data set. For example, a GIS data set describing the area within each basin boundary was combined with a data set describing 1990 census information to obtain the population within each basin, as reported in the basin summaries.

\section{Site-Numbering System}

The location of wells and springs is designated by a site number, which is based on the rectangular system for the subdivision of public lands (fig. 3). The number consists of as many as 14 characters and is assigned according to the location of the site within a given township, range, and section. The first three characters specify the township and its position north $(\mathrm{N})$ or south $(\mathrm{S})$ of the Montana Base Line. The next three characters specify the range and its position west $(\mathrm{W})$ or east $(\mathrm{E})$ of the Montana Principal Meridian. The next two characters indicate the section. The next three or four characters indicate the position of the well within the section. The first letter denotes the quarter section (160-acre tract); the second, the quarter-quarter section (40-acre tract); the third, the quarter-quarterquarter section (10-acre tract); and the fourth, the quarter-quarter-quarter-quarter section ( $21 / 2$-acre tract). The 


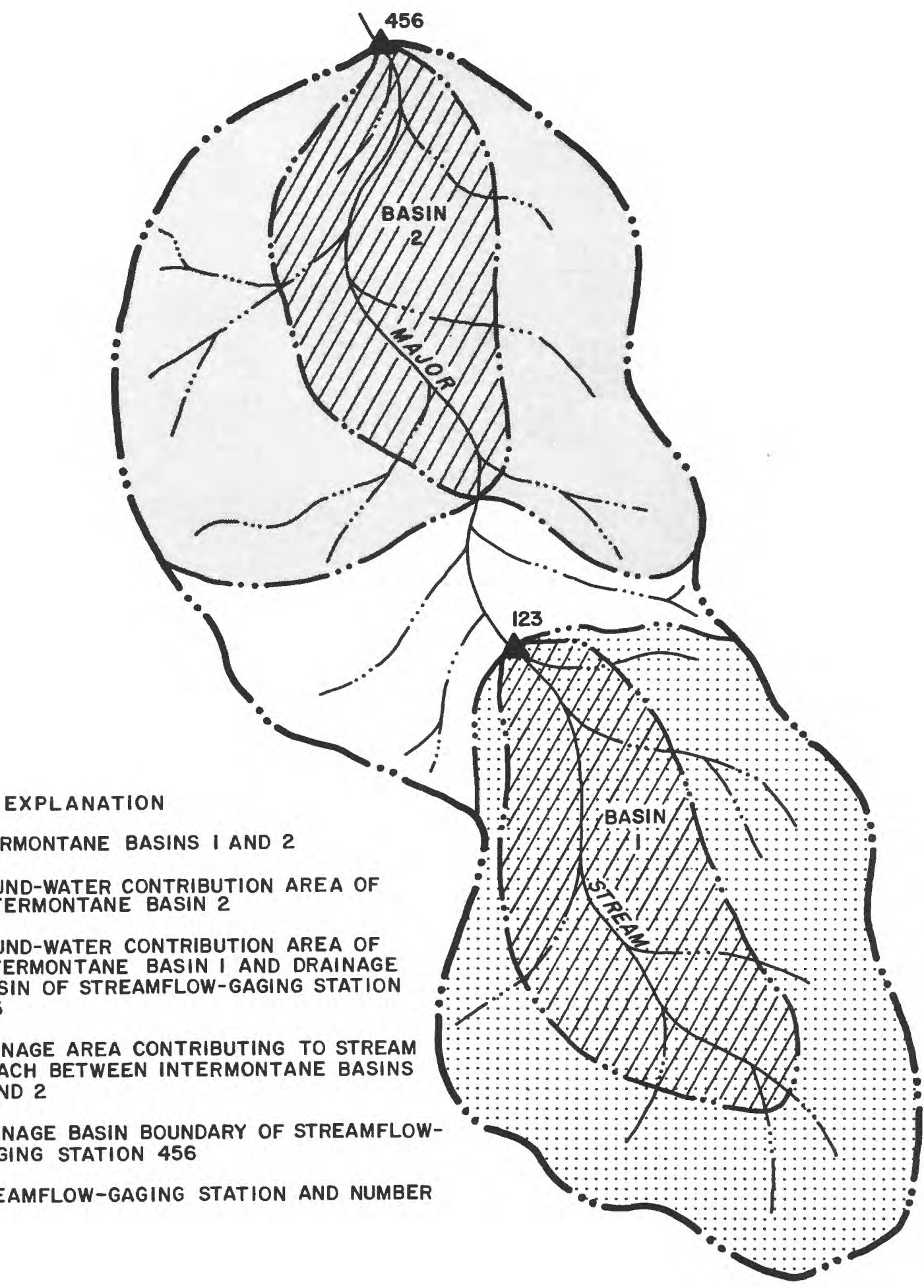

Figure 2. Relation between intermontane basins, ground-water contribution areas, and drainage basins. 
Table 1. Sources of information for geographic, geologic, and hydrologic summaries of intermontane basins

\begin{tabular}{|c|c|}
\hline Topic & Sources of information \\
\hline Major towns and populations & $\begin{array}{l}\text { 1. Populations of cities and towns: U. S. Department of Commerce, Buresu of the Census, } 1990 \\
\text { Census of Population and Housing, Public Law 94-171 file } \\
\text { 2. Populations of unincorporated areas: Montana Department of Commerce, Census and Economic } \\
\text { Information Center, Jan. } 1994\end{array}$ \\
\hline Basin population & $\begin{array}{l}1990 \text { tract-level census data from: } \\
\text { U.S. Department of Commerce, June 1990, TIGER/Line Precensus Files } \\
\text { Bureau of the Census, Data User Services Division } \\
\text { Washington, DC } 20233\end{array}$ \\
\hline Basin altitude & $\begin{array}{l}\text { USGS quadrangle maps, United States 1:250,000-scale series (topographic), contour interval } 200 \mathrm{ft} \text {. } \\
\text { Altitudes interpolated to nearest } 100 \mathrm{ft}\end{array}$ \\
\hline Basin area & $\begin{array}{l}\text { GIS data set of intermontane basin boundaries (pl. 1), compiled and digitized by USGS staff, } 1992 \text { - } \\
\text { 1993, scale 1:250,000 }\end{array}$ \\
\hline Climate & $\begin{array}{l}\text { National Oceanic and Atmospheric Administration (1962, 1972, 1982, 1992); U.S. Department of } \\
\text { Commerce (1965) }\end{array}$ \\
\hline Topography & $\begin{array}{l}\text { USGS quadrangle maps, 7.5-minute series (topographic), scale 1:24,000; cited literature; field } \\
\text { observations }\end{array}$ \\
\hline Land and water use & Cited literature and field observations \\
\hline Streamflow & $\begin{array}{l}\text { USGS Water-Data Reports, issued annually. Periods of record summarized in this report extend to } \\
\text { November } 1994\end{array}$ \\
\hline Hydrogeology & Cited literature and maps; Briar and others (in press) \\
\hline Ground-water contribution area & $\begin{array}{l}\text { GIS data set of ground-water contribution areas compiled and digitized by USGS staff, 1993, scale } \\
1: 250,000\end{array}$ \\
\hline Observation wells & $\begin{array}{l}\text { USGS National Water-Data Storage and Retrieval System (WATSTORE) database. Periods of record } \\
\text { summarized in this report extend to February } 1995\end{array}$ \\
\hline Geology & Cited literature and maps; Tuck and others (in press) \\
\hline Hydraulic characteristics & Dutton and others (1995) and other cited literature \\
\hline Ground-water quality & Clark and Dutton (in press) and other cited literature \\
\hline Geothermal features & Cited literature \\
\hline
\end{tabular}

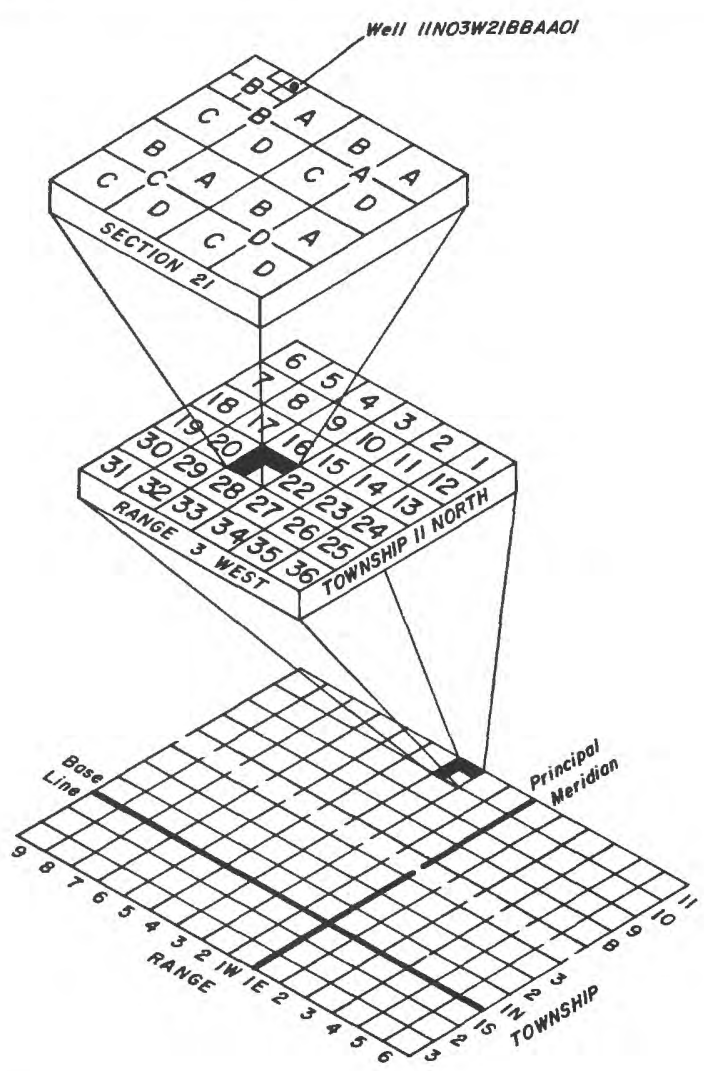

Flgure 3. Site-numbering system. 
subdivisions of the section are numbered A, B, C, and D in a counterclockwise direction beginning with " $A$ " in the northeast quadrant. The last two characters, if present, form a sequence number that is assigned on the basis of order of inventory within that tract. For example, the site number 11N03W21BBAA01 represents the first well inventoried in the NE1/4 NE1/4 NW1/4 NW1/4 sec. 21, T. 11 N., R. 3 W.

In this report, site numbers with sequence numbers indicate the locations of wells that the USGS has inventoried, and for which information is stored in the USGS WATSTORE database. Site numbers without sequence numbers indicate locations of sites such as test wells, springs, and oil wells that are reported in the literature or in non-USGS databases.

\section{REGIONAL HYDROGEOLOGIC SETTING}

The geology of the intermontane basins of the Northern Rocky Mountains has been studied relatively extensively, yet investigators agree on few aspects of the common origin of these basins. In questioning the artificial grouping of basins, Robinson (1961) succinctly stated the extent of discrepancy between different geologic interpretations:

"...the basins are primarily structural (Peale, 1896; Pardee, 1950), or they are primarily erosional (Atwood, 1916; Perry, 1934); they began to form in Paleocene time (McMannis, 1955; Freeman et al, 1958) or they formed in Oligocene time (Atwood, 1916; Pardee, 1950; Alden, 1953); early Tertiary drainage was to the south (Atwood, 1916; Perry, 1934) or to the east (Klepper et al, 1957; McMannis, 1955); accordant summits are remnants of an Eocene peneplain (Billingsley, 1915; Atwood, 1916; Pardee, 1950) or remnants of a Pliocene peneplain (Blackwelder, 1917; Atwood and Atwood, 1938); the Tertiary deposits are mainly lacustrine (Peale, 1896) or mainly fluviatile (Matthew, 1899, and many others); the basins have been greatly modified by Quaternary deformation (Pardee, 1950), or there is no evidence of important Quaternary deformation (Lowell, 1956); and so on. All the divergent opinions are founded on local evidence, and the suspicion grows that the supposed unity is an illusion."

More than thirty years later, the debate continues. Recent workers have concluded that the intermontane basins formed as a result of Cenozoic block uplifts (Ruppel, 1982), strike-slip displacement (Ruppel, 1993), or gravitational collapse (Constenius, 1996); they began to form in Late Cretaceous (Schmidt and others, 1994) or in middle Eocene time (Constenius, 1996); regionally consistent Cenozoic stratigraphy may be traced between basins (Fields and others, 1985), or the established Cenozoic stratigraphy is too locally varied to apply regionally (Hanneman and Wideman, 1991). Tuck and others (in press) recently summarized the geologic history of the Northern Rocky Mountains, emphasizing the forming and filling of the intermontane basins, and deemphasizing the differences between competing theories.

\section{Hydrogeologic Units and Aquifer Characterlstics}

Hydrogeologic units in the Northern Rocky Mountains Intermontane Basins RASA study area include consolidated bedrock and semiconsolidated to unconsolidated basin-fill deposits. For this study, the diverse assemblage of rocks and deposits has been subdivided into ten hydrogeologic units on the basis of geologic age, water-yielding characteristics, and lithology (table 2). Bedrock units that are aquifers in the study area include Quaternary through Cretaceous extrusive rocks (QTKe), Tertiary through Cretaceous intrusive rocks (TKi), Paleozoic carbonate and clastic rocks (Pzls), and Middle Proterozoic metasedimentary rocks (Yms). Other bedrock units, including Mesozoic clastic and carbonate rocks (Mzsh) and Cretaceous through Archean metamorphic rocks (KAm), might yield water locally, but their water-yielding characteristics are largely unknown. Basin-fill deposits that are aquifers include Holocene and Pleistocene alluvial deposits (Qal), Pleistocene glacial deposits (Qg), Quaternary and Tertiary undifferentiated deposits (QTd), and Tertiary sedimentary deposits and rocks (Ts) (Tuck and others, in press). 
Table 2. Generalized hydrogeologic units and water-yielding properties (modified from Tuck and others, in press)

Hydrogeologic unit and general character
Areal extent of outcrops
Water-ylelding propertles
Qal--ALLUVIAL DEPOSITS (Holocene and Pleistocene): Unconsolidated stream-laid gravel, sand, silt, and clay, that is poorly to moderately well sorted. Includes some talus, colluvium, landslide, and placer deposits, mine tailings, and Pleistocene glacial outwash

Qg-GLACIAL DEPOSTTS (Pleistocene): Unconsolidated gravel, sand, silt, and clay, that is very poorly to moderately well sorted. Includes less permeable glacial deposits such as moraines, drumlins, broad areas of hummocky deposits, glacial debris, and lakebed deposits

\section{QTd--UNDIFFERENTIATED DEPOSITS}

(Quatemary and Tertiary): Unconsolidated to semiconsolidated gravel, sand, silt, clay, ash, ash-fall tuff; locally contains lignite and limestone. Includes colluvium and landslide deposits, extensive alluvial-fan deposits within and outside of basins, alluvium on some alluvial fans, Tertiary deposits and rocks with a veneer of Quatemary deposits. Includes areas where Quatemary and Tertiary deposits are indistinct

\section{Ts--SEDIMENTARY DEPOSITS AND} ROCKS (upper Pliocene through middle to upper Eocene): Unconsolidated to consolidated gravel, sand, silt, clay, ash, ashfall tuff, and bentonite that is poorly to moderately well sorted. Locally includes massive conglomerate, sandstone, siltstone, shale, and interbedded volcanic and volcaniclastic rocks, lignite, and limestone

QTKe--EXTRUSIVE ROCKS (Quatemary through Cretaceous): Pyroclastic rocks, lava flows, ash-flow tuffs, welded tuffs, and breccia that range in composition from rhyolite to basalt. Includes water-lain, interbedded volcaniclastic rocks such as tuffaceous conglomerate, coarse-grained sandstone, and mudstone

TKi-INTRUSIVE ROCKS (Tertiary through Cretaceous): Primarily granite and rocks of granitic composition related to the Idaho and Boulder Batholiths, smaller plutons, stocks, dikes, and sills
Mainly present along present-day stream channels, flood plains and low-level terraces near rivers in larger basins and as smaller deposits near perennial and ephemeral streams. In mountainous areas, Qal is found as narrow deposits that are not laterally or vertically extensive

Extensive deposits are present in the northem half of the study area. Scattered deposits of $Q 8$ are found in the southern half of the study area near the basin margins or in mountainous areas, except for the Centennial Valley, which contains Q8 throughout its extent

In southwestem Montana, QTd is present mostly near the basin margins or as scattered erosional remnants where streams and rivers dissect these deposits

Deposits and rocks crop out in the southern half of the study area. Ts is mainly found near basin margins, as erosional remnants within the basins, and as isolated outcrops on uplifted fault-bounded blocks which form mountains

Most outcrops are found in two general areas: extreme southwestem Montana where scattered rocks crop out, and west-central Montana between Ovando and the Butte-Three Forks area

Extensive outcrops in west-central Montana are part of the Idaho Batholith. Outcrops between Helens and Divide are part of the Boulder Batholith
Deposits yield abundant water to wells throughout the study area. Reported estimates of transmissivity include: 87 to $45,600 \mathrm{ft}^{2} / \mathrm{d}$ in the Mission Valley (Slagle, 1988); 2,670 to $23,400 \mathrm{ft}^{2} / \mathrm{d}$ in the Upper Clark Fork Valley (Konizeski and others, 1968); and 2,000 to $38,000 \mathrm{ft}^{2} / \mathrm{d}$ in the Bitterroot Valley (McMurtrey and others, 1972)

Generally, a limited source of water to wells owing to the fine-grained material and very poor sonting of some deposits. Yields are variable and might depend on hydraulic interconnection of more permeable units including interbedded gravel. Reported estimates of transmissivity range from 0.01 to $22,000 \mathrm{ft}^{2} / \mathrm{d}$ (Slagle, 1988)

Yields are variable and might depend on hydraulic interconnection with more permeable units and extent of interbedded gravel

Yields are variable and might depend on hydraulic interconnection with more permesble units and extent of interbedded gravel. Reported estimates of transmissivity include: 3.2 to $18 \mathrm{ft}^{2} / \mathrm{d}$ in the Litule Bitterroot Valley (Slagle, 1988); 80 to $9,360 \mathrm{ft}^{2} / \mathrm{d}$ in the Upper Clark Fork Valley (Konizeski and others, 1968); and 320 to $1,500 \mathrm{ft}^{2} / \mathrm{d}$ in the Bitterroot Valley (McMurtrey and others, 1972)

Yields are variable and depend on the occurrence and extent of fractures, faults, breccia, and permeable zones between lava flows

Yields are variable and depend on the occurrence and extent of fractures and joints. One reported estimate of transmissivity is 890 $\mathrm{ft}^{2} / \mathrm{d}$ for a weathered sill in the Upper Blackfoot Valley (Coffin and Wilke, 1971) 
Table 2. Generalized hydrogeologic units and water-yielding properties (modified from Tuck and others, in press) (Continued)

Hydrogeologlc unit and general character
Areal extent of outcrops

Water-ylelding properties
Mzsh-CLASTIC AND CARBONATE ROCKS, UNDIFFERENTLATED

(Mesozoic): Primarily marine shale with interbedded nonmarine sandstone, siltstone, mudstone, and marine limestone

\section{Pzls--CARBONATE AND CLASTIC} ROCKS, UNDIFFERENTIATED

(Paleozoic): Primarily massive and thick - to thin-bedded limestone with dolomite, interbedded phosphatic sandstone, quartzite, siltstone, mudstone, and shale

Yms--METASEDIMENTARY ROCKS, UNDIFFERENTIATED (Primarily Middle Proterozoic): Primarily argillaceous limestone, dolomite, ubiquitous thin-tomedium interbedded siltite and argillite, arkosic conglomerate and sandstone, massive feldspathic quanzite with interbedded limestone, siltite, and conglomerate. Includes local mafic flows, dikes, and sills. Rocks have been subjected to low-grade metamorphism

KAm-METAMORPHIC ROCKS, UNDIFFERENTIATED (Primarily Archean): Metamorphosed granitic plutons, dikes and sills, quartzo-feldspatic gneiss, amphibolite, anorthosite, schist, dolomitic marble, quartzite, and iron formation
Most of these racks are present as isolated outcrops east of longitude $113^{\circ} 15^{\prime}$ in the troughs of synclines within uplifted fault-bounded mountain masses and as scattered outcrops along the eastern edge of the study area

Paleozoic rocks are generally present in uplifted fault-bounded blocks which form mountains in southwestem and extreme northwestem Montana

Metasedimentary rocks primarily crop out in the northem half of the study area. These rocks are also found along the Montana-Idaho State boundary in the southem part of the Bitterroot Range

Metamorphic rocks primarily crop out in southwestem Montana between Yellowstone National Park and Missoula
Generally consists of low-permeability shale. Water-yielding zones depend on occurrence and extent of more permeable conglomerate and sandstone. Wells have been completed in this unit where it crops out near basin margins. Can yield water locally, but generally water-yielding properties are unknown

Yields are variable and depend on the occurrence and extent of fractures, caverns, and breccia. One spring discharges in excess of 5 million gal/d (Lorenz and McMurtrey, 1956). In some basins this unit probably supplies lange volumes of subsurface recharge to basin-fill deposits

Yields are variable and depend on the occurrence and extent of fractures. In some basins this unit probably supplies subsurface recharge to basin-fill deposits through extensive fracture systems

The study area has a complex geologic history of sedimentation, compressional deformation, igneous activity and, most recently, extensional block faulting. The complex geologic history of the area has resulted in a diverse assemblage of bedrock that, for this report, has been grouped into six general categories on the basis of areal distribution, age, lithology, and hydrologic character. In ascending order, the bedrock units are: (1) primarily Archean metamorphic rocks, (2) primarily Middle Proterozoic metasedimentary rocks, (3) Paleozoic carbonate and clastic sedimentary rocks, (4) Mesozoic clastic and carbonate rocks, (5) Tertiary through Cretaceous intrusive rocks, and (6) Quaternary through Cretaceous extrusive (volcanic) rocks. The generalized distribution of these rocks is shown in figure 4. In the figure, bedrock units (3) and (4), which commonly crop out in close proximity to one another, are grouped together as "Mesozoic through Paleozoic sedimentary rocks."

Primarily Archean metamorphic rocks consisting of marble, quartzite, schist, and gneiss presumably underlie the entire area, but crop out only in the southeastern part of the study area (Wilson, 1983). These rocks generally are a barrier to ground-water flow. However, the upward migration of deep-circulating water associated with faults in the bedrock is expressed by thermal wells and springs in some basins.

Middle Proterozoic metasedimentary rocks of the Belt Supergroup are exposed in isolated areas in the southern part and throughout most of the northern part of the study area where maximum thickness exceeds 60,000 $\mathrm{ft}$ (Harrison and others, 1974). These rocks originated as fine-grained terrigenous and carbonate sediment in a 

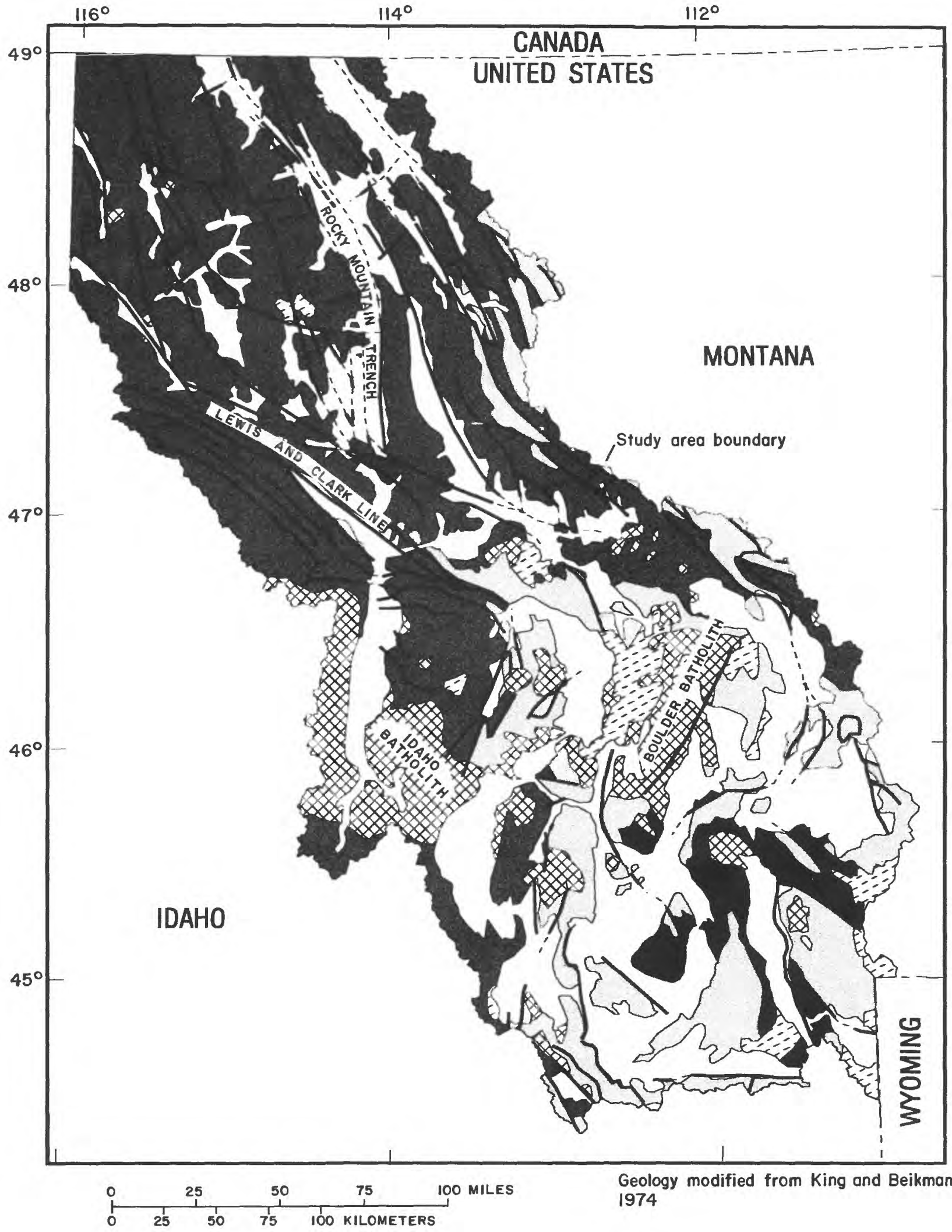

Geology modified from King and Beikman, 1974

Figure 4. Generalized geology of the Northern Rocky Mountains, Montana. 


\author{
EXPLANATION FOR FIGURE 4 \\ QUATERNARY THROUGH TERTIARY BASIN-FILL DEPOSITS \\ QUATERNARY THROUGH CRETACEOUS EXTRUSIVE ROCKS \\ TERTIARY THROUGH CRETACEOUS INTRUSIVE ROCKS \\ MESOZOIC THROUGH PALEOZOIC SEDIMENTARY ROCKS \\ PRIMARILY MIDDLE PROTEROZOIC METASEDIMENTARY \\ ROCKS \\ PRIMARILY ARCHEAN METAMORPHIC ROCKS \\ GEOLOGIC CONTACT \\ FAULT--Dashed where inferred
}

subsiding basin but have undergone regional low-grade metamorphism to argillite and quartzite. These rocks supply unquantified but potentially large volumes of subsurface flow to basin-fill aquifers through fractures.

Several thousand feet of Mesozoic through Paleozoic sedimentary rocks crop out in the southern and eastern parts of the study area, where they have been extensively folded and thrust faulted. The Paleozoic rocks mostly are marine carbonates and are relatively nonporous (Perry, 1988). However, cavernous limestone in parts of the Mississippian Madison Group might be an important source of recharge water to basin-fill aquifers and a possible conduit for interbasin ground-water flow. The Mesozoic rocks primarily are marine shale interbedded with nonmarine mudstone and sandstone. Although primarily fine grained, Mesozoic rocks can transmit water in areas where more permeable conglomerate and sandstone layers are present.

During Cretaceous to early Tertiary time, magma intruded bedrock of the Northern Rocky Mountains area producing intrusive rocks of the Idaho Batholith in central Idaho and southwestern Montana and the Boulder Batholith in southwestern Montana. Intermontane basins generally are absent from the batholithic terrane. Several episodes of volcanic activity related to the intrusions emplaced thousands of feet of volcanic rocks on top of and adjacent to the intrusive rocks. Permeability of the intrusive and volcanic rocks generally is less than that of the basin fill; however, fractures in these rocks may store and transmit substantial amounts of water in places.

Episodes of extensional block faulting and basin subsidence occurred intermittently throughout the Tertiary Period. The intermontane basins of the Northern Rocky Mountains are thought to have attained their modern configurations during the Miocene Epoch, when Basin and Range tectonics created an area of broadly distributed crustal extension characterized by an extensive number of normal faults. As the crust extended, downthrown fault blocks became basins, while upthrown blocks became the intervening mountains (Eaton, 1979). Most of the basins trend northerly to northwesterly, roughly parallel to basin-marginal normal faults and perpendicular to regional extension. In the southern part of the study area, basin-marginal faults define the few east-west trending intermontane basins adjacent to the Snake River Plain. These basins are related more closely to extension and uplift associated with the Snake River Plain than to Basin and Range tectonics (Johnson, 1981; Sonderegger and others, 1982).

Basin subsidence, mountain uplift, and volcanism throughout the Tertiary Period resulted in sedimentary basin-fill deposits and rocks as thick as $16,000 \mathrm{ft}$. Names for Tertiary deposits vary within the study area; however, the stratigraphy is correlative from a regional perspective. In southwestern Montana, Tertiary deposits have been grouped into two units: a lower, predominantly fine-grained unit, and an upper, predominantly coarse-grained unit. Most of the lower unit is composed of lacustrine sediments consisting primarily of ash- and fresh-water shale and marl deposited in broad, sometimes closed, ancestral basins (Fields and others, 1985). The lower unit generally is 
considered to be too deep and impermeable to be a productive aquifer. In contrast, the upper unit consists of locally derived, unconsolidated, coarse clastic material resulting from Miocene to Pliocene basin development (Fields and others, 1985). Localized gravel deposits in the upper unit form the most productive deep aquifers in the basins (Noble and others, 1982). In some areas, Tertiary deposits extend outside the present basin boundaries owing to differential uplift.

Quaternary fluvial and glacial deposits typically overlie Tertiary deposits. In southern basins, Quaternary deposits primarily consist of alluvium along rivers and streams, and colluvial and alluvial-fan deposits near mountain flanks. Quaternary alluvium underlying the flood plains of rivers and streams contains some of the most productive shallow aquifers in the basins. In the northern basins, glaciers reworked pre-Pleistocene surfaces and contributed large volumes of glaciolacustrine deposits, till, and outwash. Glaciolacustrine deposits and till commonly provide a limited source of water owing to the poorly sorted, fine-grained nature of the deposits. Although outwash commonly is also poorly sorted, it typically is coarse grained and is a productive aquifer in places. In figure 4, all Quaternary and Tertiary basin-fill deposits are grouped together as a single geologic unit.

\section{Ground-Water Flow}

Many basin-fill aquifers are constricted by bedrock canyons at the downgradient ends of the intermontane basins. Therefore, ground-water flow systems within the basin fill are largely restricted to the basins themselves, with little or no known subsurface hydraulic connection between unconsolidated deposits of adjacent basins. Through-flowing streams, however, provide a hydraulic connection between basins. For example, surface water used for irrigation in one basin can infiltrate to become ground water, flow dowrigradient until it discharges as surface water, then flow to the next basin, where it might again be diverted and used for irrigation.

Although most bedrock surrounding the basins is less permeable than basin fill, some ground water might flow between basins along zones of permeable bedrock. Some faults, for example, might have zones of increased permeability, owing to extensive areas of shattered rock or brecciation (Wallace and others, 1990) that would conduct ground water between basins. Deep circulation of water along Tertiary and Quaternary extension faults (Perry, 1988) could be another conduit for interbasin ground-water flow. Interbasin ground-water flow in most areas probably is a minor part of the total ground-water flow system.

Aquifers in Quaternary deposits can be unconfined, leaky confined, or confined. Most shallow alluvial aquifers are unconfined. Fine-grained confining units or leaky-confining units are commonly discontinuous, allowing interconnection between permeable deposits. In northern parts of the study area, some aquifers in Quaternary deposits are confined by overlying glacial lakebed deposits or till.

Fine-grained layers within the Tertiary deposits probably confine permeable layers. With depth, these finegrained layers become more consolidated and, therefore, less permeable. Although some aquifers in Tertiary deposits have recently been developed, hydrogeologic information about them is sparse. With few exceptions, aquifers in Quaternary and Tertiary deposits within a basin probably are hydraulically connected.

Water levels in basin-fill aquifers typically rise in the spring and early summer, and fall from late summer through winter. Hydrographs for 32 wells completed in basin fill are shown in Dutton and others (1995, p. 84-94).

Basin-fill aquifers are recharged by leakage of water from streams, subsurface inflow from surrounding bedrock near mountain fronts, and to a lesser extent by direct infiltration of precipitation. In some areas, infiltration of applied irrigation water and leakage from irrigation canals also provides substantial recharge. The largest component of discharge from basin-fill aquifers is leakage to rivers and streams. Basin-fill aquifers also are discharged by evapotranspiration, pumping, and seepage to springs and irrigation drains.

In some areas, subsurface recharge from bedrock is substantial. For example, the Mississippian limestone aquifer adjacent to the Townsend Valley is postulated to recharge basin-fill deposits from which numerous irrigation wells withdraw ground water (Lorenz and McMurtrey, 1956). The hydrogeologic units TKi and Yms can also supply large volumes of subsurface recharge to basin-fill deposits through fractures and faults. Briar and Madison (1992) estimated that fractured TKi, Pzl s, and Yms surrounding the Helena Valley contribute $35.5 \mathrm{Mgal} / \mathrm{d}$ to the 
basin-fill deposits. Hot springs and hot-water wells are found in many basins. This geothermal water probably originates as recharge to bedrock which circulates at depth along fractures and faults.

The configuration of the water table in shallow basin-fill aquifers generally reflects the topography, with flow components trending downvalley and toward major streams. The direction of lateral flow in deeper aquifers might be different than in shallow aquifers in response to confining strata, faulting, or other deep structural controls. Vertical flow between aquifers is dependent upon location and has not been measured in most basins. Ground-water levels range from above land surface at flowing wells, to land surface at springs and wetlands, to hundreds of feet below land surface near basin margins (Clark and Kendy, 1992; Briar and others, in press).

Ground water in most intermontane basins in northwestern Montana has a dissolved-solids concentration less than $250 \mathrm{mg} / \mathrm{L}$ except for parts of the Mission, Tobacco, Little Bitterroot, and Kalispell Valleys. Most basins in the northern part of the study area are surrounded or underlain by thick deposits of slightly metamorphosed, silica-rich shales, mudstones, and sandstones, and some layers of limestone. Glacial or glacial-lake deposits, the principal aquifer material in these northern basins, generally contain smaller quantities of soluble minerals than deposits derived mostly from limestone or other carbonate rocks, and, therefore, the ground water has a smaller dissolvedsolids concentration (Clark and Dutton, in press).

Ground water in the basins in southwestern Montana generally has a dissolved-solids concentration in the 250 to $500 \mathrm{mg} / \mathrm{L}$ range. The slight increase in dissolved-solids concentration in aquifers in parts of southwestern Montana compared to northwestern Montana primarily may be due to differences in rock composition and perhaps to human activities such as irrigation. This part of the study area was affected by geologic processes different from those that affected the northern part of the study area, and the dissolved-solids concentrations are influenced by aquifer material derived in part from deposits and sediments containing larger quantities of soluble minerals. Exceptions are the Big Hole Basin, the Upper Madison River Valley, and large parts of the Madison River, Beaverhead, and Gallatin Valleys where concentrations generally are less than $250 \mathrm{mg} / \mathrm{L}$ (Clark and Dutton, in press).

Some parts of a few basins, including Westem Three Forks, Horse Prairie, and Townsend Valleys, have ground water with dissolved-solids concentrations greater than $500 \mathrm{mg} / \mathrm{L}$. The aquifers in most of these areas are composed of sediments associated with alluvial fans or terraces. These areas generally have little ground-water development because the sediments commonly are fine grained and typically produce small quantities of water of marginal quality, and because some of the areas are sparsely populated (Clark and Dutton, in press).

\section{REFERENCES CITED}

Alden, W.C., 1953, Physiography and glacial geology of western Montana and adjacent areas: U.S. Geological Survey Professional Paper 231, 200 p.

Atwood, W.W., 1916, The physiographic conditions at Butte, Montana, and Bingham Canyon, Utah, when the copper ores in these districts were enriched: Economic Geology, v. 11, p. 697-740.

Atwood, W.W., and Atwood, W.W., Jr., 1938, Working hypothesis for the physiographic history of the Rocky Mountain region: Geological Society of America Bulletin, v. 49, p. 957-980.

Bair, F.E., ed., 1982, The Weather almanac (6th ed.): Detroit, Mich., Gale Research, Inc., p. 516, 624.

Billingsley, Paul, 1915, The Boulder batholith of Montana: American Institute of Mining and Metallurgic Engineers Bulletin 97, p. 31-47.

Blackwelder, Elliott, 1917, Physiographic conditions and copper enrichment (discussion) [age of peneplains in Rocky Mountains]: Economic Geology, v. 12, p. 541-545.

Briar, D.W., and Madison, J.P., 1992, Hydrogeology of the Helena valley-fill aquifer system, west-central Montana: U.S. Geological Survey Water-Resources Investigations Report 92-4024, 92 p.

Briar, D.W., Lawlor, S.M., Stone, M.A.J., Parliman, D.J., Schaefer, J.L., and Kendy, Eloise, in press, Ground-water levels in intermontane basins of the Northern Rocky Mountains, Montana and Idaho: U.S. Geological Survey Hydrologic Investigations Atlas 738-B, 1 sheet, scale 1:750,000. 
Clark, D.W., and Dutton, D.M., in press, Quality of ground water and surface water in intermontane basins of the Northern Rocky Mountains, Montana and Idaho: U.S. Geological Survey Hydrologic Investigations Atlas 738-C, 1 sheet, scale 1:750,000.

Clark, D.W., and Kendy, Eloise, 1992, Plan of study for the Regional Aquifer-System Analysis of the Northern Rocky Mountains intermontane basins, Montana and Idaho: U.S. Geological Survey Water-Resources Investigations Report 92-4116, $16 \mathrm{p}$.

Coffin, D.L., and Wilke, K.R., 1971, Water resources of the upper Blackfoot River Valley, west-central Montana: Water Resources Division, Montana Department of Natural Resources and Conservation Technical Report Series no. 1,82 p.

Constenius, K.N., 1996, Late Paleogene extensional collapse of the Cordilleran foreland fold and thrust belt: Geological Society of America Bulletin, v. 108, no. 1, p. 20-39.

Dutton, D.M., Lawlor, S.M., Briar, D.W., and Tresch, R.E., 1995, Hydrogeologic data for the Northern Rocky Mountains intermontane basins, Montana: U.S. Geological Survey Open-File Report 95-143, 94 p.

Eaton, G.P., 1979, Regional geophysics, Cenozoic tectonics, and geologic resources of the Basin and Range Province and adjoining regions, in Newman, G.W., and Good, H.D., eds., 1979 Basin and Range Symposium: Denver, Colo., Rocky Mountain Association of Geologists, p. 11-39.

Fetter, C.W., Jr., 1980, Applied hydrogeology: Columbus, Ohio, Charles E. Merrill Publishing Co., 488 p.

Fields, R.W., Rasmussen, D.L., Tabrum, A.R., and Nichols, Ralph, 1985, Cenozoic rocks of the intermontane basins of western Montana and eastern Idaho--A summary, in Flores, R.M., and Kaplan, S.S., eds., Cenozoic Paleogeography of the WestCentral United States, Rocky Mountain Paleogeography Symposium 3: Denver, Colo., Society of Economic Paleontologists and Mineralogists, Rocky Mountain Section, p. 9-36.

Freeman, V.L., Ruppel, E.T., and Klepper, M.R., 1958, Geology of part of the Townsend Valley, Broadwater and Jefferson Counties, Montana: U.S. Geological Survey Bulletin 1042-N, p. 481-556.

Harrison, J.E., Griggs, A.B., and Wells, J.D., 1974, Tectonic features of the Precambrian Belt Basin and their influence on postBelt structures: U.S. Geological Survey Professional Paper 866, 15 p.

Hanneman, D.L., and Wideman, C.J., 1991, Sequence stratigraphy of Cenozoic continental rocks, southwestern Montana: Geological Society of America Bulletin, v. 103, p. 1,335-1,345.

Johnson, P.P., 1981, Geology along the Red Rock Fault and adjacent Red Rock Basin, Beaverhead County, Montana, in Montana Geological Society 1981 Field Conference, Southwest Montana: [Billings, Mont.], Montana Geological Society, p. 245-251.

King, P.B., and Beikman, H.M., 1974, Geologic map of the United States: U.S. Geological Survey Special Map, scale $1: 2,500,000,3$ sheets.

Klepper, M.R., Weeks, R.A., and Ruppel, E.T., 1957, Geology of the southern Elkhorn Mountains, Jefferson and Broadwater Counties, Montana: U.S. Geological Survey Professional Paper 292, 82 p.

Konizeski, R.L., McMurtrey, R.G., and Brietkrietz, Alex, 1968, Geology and ground-water resources of the Deer Lodge Valley, Montana, with a section on Gravimetric survey, by E.A. Cremer, III: U.S. Geological Survey Water-Supply Paper 1862, $55 \mathrm{p}$.

Lorenz, H.W., and McMurtrey, R.G., 1956, Geology and occurrence of ground water in the Townsend Valley, Montana, with a section on Chemical quality of the water, by H.A. Swenson: U.S. Geological Survey Water-Supply Paper 1360-C, p. 171290.

Lowell, W.R., 1956, Tertiary geologic history of the Rocky Mountains in Montana, U.S.A. [abs.]: 20th International Geology Congress, Mexico, Proceedings, p. 69.

Matthew, W.D., 1899, Is the White River Tertiary an eolian formation?: American Naturalist, v. 33, p. 403-408.

McMannis, W.J., 1955, Geology of the Bridger Range, Montana: Geological Society of America Bulletin, v. 66, p. 1385-1430.

McMurtrey, R.G., Konizeski, R.L., Johnson, M.V., and Bartells, J.H., 1972, Geology and water resources of the Bitterroot Valley, southwestern Montana, with a section on Chemical quality of water, by H.A. Swenson: U.S. Geological Survey WaterSupply Paper 1889,80 p.

National Oceanic and Atmospheric Administration, 1962, Monthly normals of temperature, precipitation, and heating and cooling degree days, 1931-60, Montana: Climatography of the United States no. 81, Asheville, N.C., unpaged. 
1972, Monthly normals of temperature, precipitation, and heating and cooling degree days, 1941-70, Montana: Asheville, N.C., Climatography of the United States no. 81, unpaged.

1982, Monthly normals of temperature, precipitation, and heating and cooling degree days, 1951-80, Montana: Asheville, N.C., Climatography of the United States no. 81,23 p.

1992, Monthly normals of temperature, precipitation, and heating and cooling degree days, 1961-90, Montana: Asheville, N.C., Climatography of the United States no. 81, unpaged.

Noble, R.A., Bergantino, R.N., Patton, T.W., Sholes, B.C., Daniel, Faith, and Schofield, Judeykay, 1982, Occurrence and characteristics of ground water of Montana--Volume 2, The Rocky Mountain Region: Montana Bureau of Mines and Geology Open-File Report 99, 132 p.

Pardee, J.T., 1950, Late Cenozoic block faulting in western Montana: Geological Society of America Bulletin, v. 61, p. 359406.

Peale, A.C., 1896, Description of the Three Forks sheet, Montana: U.S. Geological Survey Geology Atlas, Folio 24, 5 p.

Perry, E.S., 1934, Physiography and ground-water supply in the Big Hole Basin, Montana: Montana Bureau of Mines and Geology Memoir 12, 18 p.

Perry, W.J., Jr., 1988, A review of the geology and petroleum resource potential of the Montana thrust belt, with a section on Geology of potential Mississippian reservoir rocks, Disturbed Belt sector of the Montana thrust belt, by K.M. Nichols: U.S. Geological Survey Open-File Report 88-450C, 28 p.

Robinson, G.D., 1961, Origin and development of the Three Forks Basin, Montana: Geological Society of America Bulletin, v. 72, p. 1003-1014.

Ruppel, E.T., 1982, Cenozoic block uplifts in east-central Idaho and southwest Montana: U.S. Geological Survey Professional Paper $1224,24 \mathrm{p}$.

1993, Cenozoic tectonic evolution of southwest Montana and east-central Idaho: Montana Bureau of Mines and Geology Memoir 65, 62 p.

Schmidt, R.G., Loen, J.S., Wallace, C.A., and Mehnert, H.M., 1994, Geology of the Elliston region, Powell and Lewis and Clark Counties, Montana: U.S. Geological Survey Bulletin 2045, 25 p.

Slagle, S.E., 1988, Geohydrology of the Flathead Indian Reservation, northwestern Montana: U.S. Geological Survey WaterResources Investigations Report 88-4142, 152 p.

Sonderegger, J.L., Schofield, J.D., Berg, R.B., and Mannick, M.L., 1982, The upper Centennial Valley; Beaverhead and Madison Counties, Montana, with a section on The Madison Valley thermal springs, by G.J. Weinheimer: Montana Bureau of Mines and Geology Memoir 50, 53 p.

Sun, R.J., ed., 1986, Regional Aquifer-System Analysis Program of the U.S. Geological Survey--Summary of projects, 197884: U.S. Geological Survey Circular 1002, 264 p.

Tuck, L.K., Briar, D.W., and Clark, D.W., in press, Geologic history and hydrogeologic units of intermontane basins in the Northern Rocky Mountains, Montana and Idaho: U.S. Geological Survey Hydrologic Investigations Atlas 738-A, 2 sheets, scale 1:750,000.

U.S. Department of Commerce, 1965, Climatic summary of the United States supplement for 1951 through 1960, Montana: Washington, D.C., U.S. Department of Commerce, Weather Bureau, Climatology of the United States no. 86-20, p. 11 and 60.

U.S. Geological Survey, issued annually, Water resources data, Montana: Helena, Mont., U.S. Geological Survey Water-Data Report.

Wallace, C.A., Lidke, D. J., and Schmidt, R.G., 1990, Faults of the central part of the Lewis and Clark Line and fragmentation of the Late Cretaceous foreland basin in west-central Montana: Geological Society of America Bulletin, v. 102, no. 8, p. 1021-1037.

Wilson, M.D., 1983, Origin of Archean lithologies in the southern Tobacco Root and northern Ruby Ranges of southwestern Montana, in Montana Geological Society Field Conference and Symposium Guidebook to Southwestem Montana: [Billings, Mont.], Montana Geological Society, p. 37-43. 


\section{GEOGRAPHIC, GEOLOGIC, AND HYDROLOGIC SUMMARIES OF INTERMONTANE BASINS}

The geographic, geologic, and hydrologic summary for each intermontane basin is organized consistently. First, a section on geography briefly describes the size, shape, and topography of the basin. An index map depicts the general location of the basin in the study area. The local climate is then summarized, followed by a synopsis of major land uses, including the 1990 population of the basin and its major towns.

Second, a section on geology begins with a summary of major structural features and bedrock lithology. If the depth to bedrock is known, it is noted in this section. Following are lithologic descriptions of basin-fill deposits, which are more detailed than those of the surrounding bedrock. This section lists all available geological and geophysical maps of the basin.

Third, a section on hydrology begins with surface water, listing all streamflow data available for both active and discontinued USGS gaging stations in the basin. Surface-water quality is summarized for basins for which data are available. This section then proceeds to hydrogeology, with descriptions of basin-fill aquifers and their hydraulic characteristics. If potentiometric-surface maps are available, they are listed, along with the dates the water levels were measured. Recharge and discharge also are discussed in this section. If the USGS has monitored water levels in the basin, a list of monitoring wells and the dates they were measured is presented. The hydrology section concludes with a summary of ground-water quality.

The summary for each basin concludes with a list of selected references. This includes not only those publications cited in the text, but also other documents relevant to the geography, geology, or hydrology of the basin. 


\title{
Geography
}

The Avon Valley is a northwest-trending intermontane basin near the headwaters of the Clark Fork drainage area. The $70 \mathrm{mi}^{2}$ basin is bounded by the Garnet Range on the west and the mountains along the Continental Divide on the north, east, and south. The drainage divide between the Avon Valley and the Nevada Creek drainage bounds the basin on the northwest (pl. 1). The Little Blackfoot River flows northward into the basin from its headwaters near the Continental Divide; near Elliston, the river bends westward toward its confluence with the Clark Fork and about 11 mi downstream from Avon. North of the Little Blackfoot River, the Avon Valley is wide and open, with distinct lateral terraces, or pediments, flanking the central flood plain. South of the river, the basin consists of two distinct lobes. The western lobe, which is south of Avon, is a large, dry terrace mantled with rounded pebbles and cobbles. The eastem lobe, south of Elliston, is the glaciated, hummocky headwaters area of the Little Blackfoot River. The Avon Valley ranges in altitude from about 4,800 ft where the Little Blackfoot River flows out of the basin, to about $6,300 \mathrm{ft}$ on the highest bench.

The climate of the Avon Valley is typical of higher-elevation intermontane basins of the Northem Rocky Mountains west of the Continental Divide, with cold, snowy winters and mild summers. On the basis of the 195160 period of record, the average annual precipitation at Elliston (altitude 5,080 ft) is $15.6 \mathrm{in}$., and the average annual temperature is $39.4^{\circ} \mathrm{F}$ (U.S. Department of Commerce, 1965). The average last occurrence of $32^{\circ} \mathrm{F}$ is July 1 , and the average first occurrence is August 27 (Natural Resources Conservation Service, U.S. Department of Agriculture, unpub. data, 1994). Mean monthly climatic data for Elliston are plotted in figure 5.

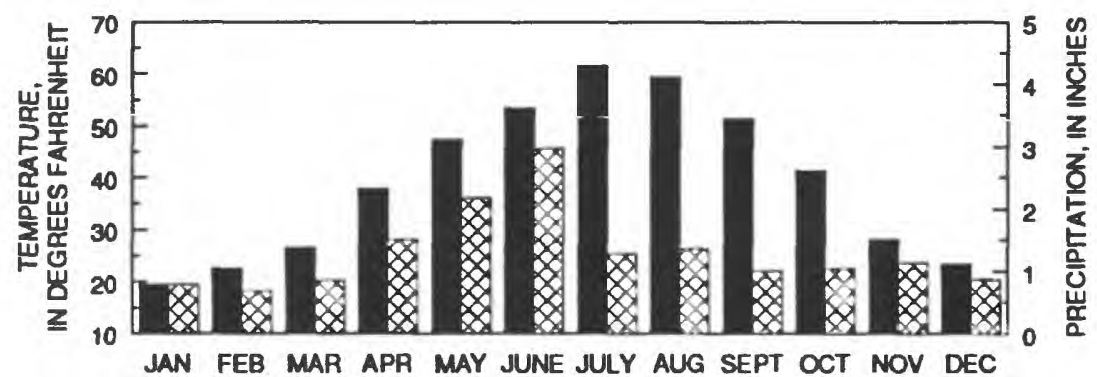

\author{
EXPLANATION \\ MEAN MONTHLY TEMPERATURE FOR \\ 1951-60 PERIOD OF RECORD \\ Q MEAN MONTHLY PRECIPITATION FOR \\ 1951-60 PERIOD OF RECORD
}

Figure 5. Mean monthly precipitation and temperature at Elliston, Mont. Data from U.S. Department of Commerce (1965).

Land uses include rangeland, irrigated pastures, and hay production (J.C. Eggen, Agricultural Stabilization and Conservation Service, oral commun., 1993). Diversions from surface water irrigate about 10,500 acres upstream from Garrison (Shields and others, 1993, p. 428). Pastures along the Little Blackfoot River west of Avon are subirrigated. Historical mining in the headwaters area of the Little Blackfoot River has produced mainly lead, silver, and gold. Exploration is currently underway for placer gold in the mountains east, northeast, and north of Avon, and for gold and silver southeast of Elliston (McCulloch, 1993, p. 42, 45, and 48). About 400 people reside in the basin (1990 census). 


\section{Geology}

The present basin topography began to form by normal faulting during Late Cretaceous and early Eocene time (Schmidt and others, 1994). Structurally, the Avon Valley is continuous with the upper Nevada Creek valley, but a drainage divide separates the two hydrologically (Wallace, 1987; Wallace and others, 1987; Witkind and Weber, 1982).

Several investigators have examined the geology of the Avon Valley. Witkind and Weber (1982) listed the USGS Open-File Reports for 1:24,000-scale and 1:62,500-scale geologic quadrangle maps of the area. More generalized geologic and geophysical maps of the Avon Valley are listed in table 3. The geologic units described by previous investigators are summarized below. These geologic units are referenced to hydrogeologic units defined in this study (table 2 ) to provide a consistent regional framework. In the following discussion, the hydrogeologicunit abbreviations are italicized.

Table 3. Geologic and geophysical maps of the Avon Valley, Montana

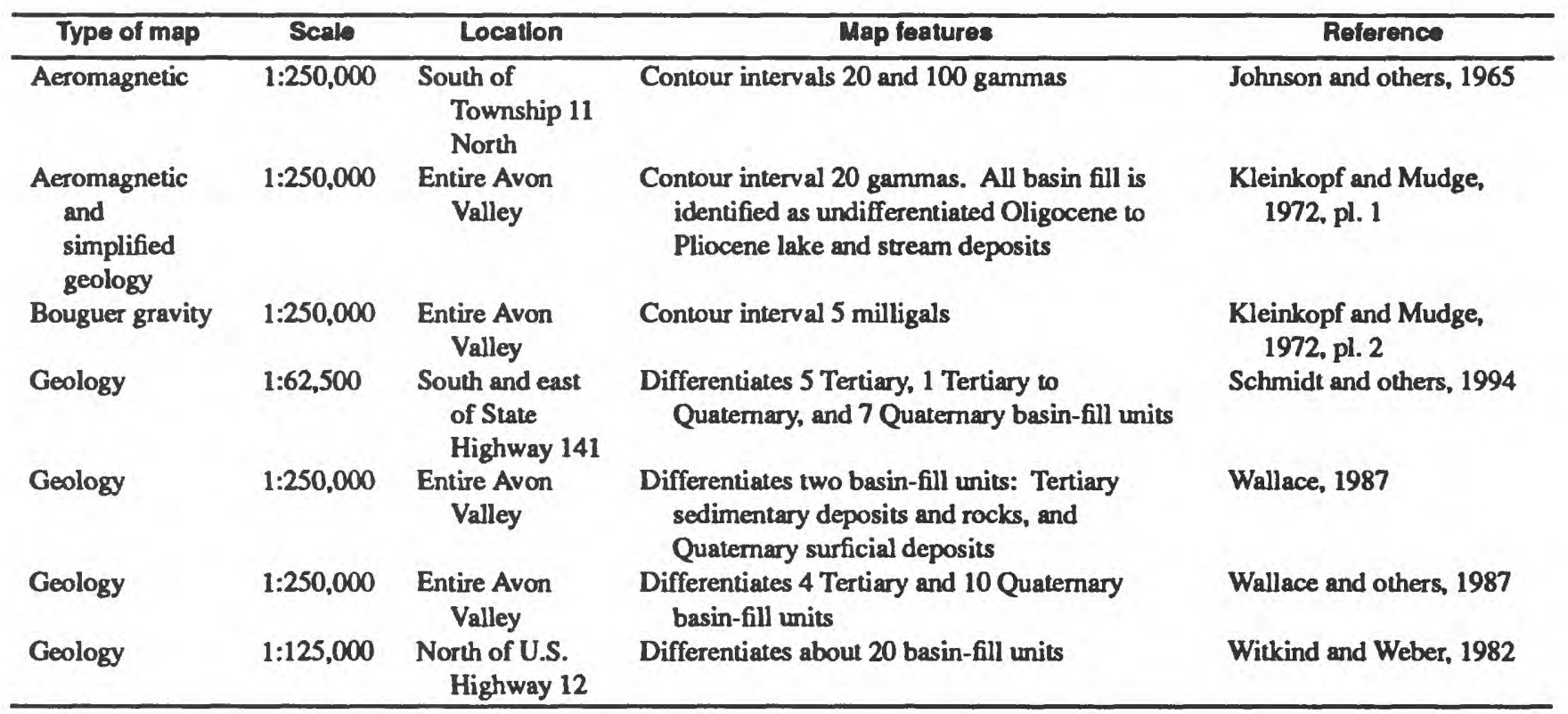

Metasedimentary, sedimentary, intrusive, and volcanic bedrock surrounds and floors the Avon Valley. Northeast of the basin, metasedimentary rocks of the Middle Proterozoic Belt Supergroup ( $Y m s$ ) gently dip northeast. These rocks belong to the Missoula Group, which consists primarily of argillite, siltite, and quartzite. Adjacent to the central part of the Avon Valley, thrust faults have brought Cambrian through Cretaceous sedimentary rocks in contact with basin fill. The Paleozoic rocks $\left(P_{z} l s\right)$ are dominantly limestone, but also include dolomite, phosphatic sandstone, quartzite, siltstone, mudstone, and shale. In contrast, the Mesozoic sedimentary rocks (Mzsh) are principally marine shale interbedded with non-marine mudstone, siltstone, sandstone, conglomerate, and minor amounts of limestone. In the western headwaters area of Snowshoe Creek, a Late Cretaceous biotite monzogranite stock (TKi) intrudes Proterozoic rocks. Terrane bordering the south and west sides of the Avon Valley is largely composed of Cretaceous through Tertiary volcanic rocks (QTKe) representing several episodes of volcanism and ranging in composition from basalt to rhyolite. Tertiary volcanic rocks also crop out in the center of the basin, northeast of Avon (Wallace and others, 1987).

Tertiary sediments (Ts) overlie bedrock throughout the Avon Valley, and crop out on large terraces, or pediments. Schmidt and others (1994) identified four unconformable units of Tertiary sediments: Oligocene deposits similar to the Renova Formation of southwestern Montana (Fields and others, 1985), Miocene deposits tentatively correlated with the Sixmile Creek Formation (Fields and others, 1985), upper Miocene alluvial-fan 
deposits, and Pliocene(?) lag gravel. The oldest unit is the most extensive, and consists of siltstone, sandstone, bentonitic claystone, and lignite interbedded with poorly sorted to moderately sorted, locally cemented gravel and conglomerate. South of Avon, Oligocene deposits are overlain by Miocene deposits consisting of moderately sorted silt and fine-grained sand, volcanic ash, claystone and lignite interbedded with discontinuous lenses of sandstone, gravel, and conglomerate. Along the northern basin margin, alluvial-fan deposits consist of matrix-and frameworksupported, poorly sorted to moderately sorted boulder-and-cobble gravel with sand, silt, and silty clay. Bouldery lag gravel generally less than $10 \mathrm{ft}$ thick mantles pediments in much of the basin (Schmidt and others, 1994).

Pleistocene glacial till $(Q g)$ forms prominent recessional moraines in the southeastern lobe of the basin, flanking the flood plain of the Little Blackfoot River. Heterogeneous, poorly stratified, poorly sorted sand, gravel, pebbles, cobbles, and boulders in a sandy to clayey matrix compose the glacial till (Wallace and others, 1987; Schmidt and others, 1994).

Pleistocene glacial outwash (Qal) was deposited in some northern tributary flood plains by meltwater from alpine glaciers. As glacial ice melted, streams and rivers carried huge loads of glacial debris, which settled out of suspension as unconsolidated, moderately sorted to well-sorted deposits of silt, sand, gravel, pebbles, and cobbles. Glacial outwash forms a broad alluvial fan $5 \mathrm{mi}$ north of Avon, and extends southward to the Little Blackfoot River in a band less than one mile wide. At the head of the deposit is a small area of glacial till $(\mathrm{Qg})$ (Witkind and Weber, 1982; Schmidt and others, 1994).

Holocene alluvium ( $Q$ al) consisting of well-bedded, well-sorted silt, sand, gravel, pebbles, and some cobbles in a clayey matrix underlies flood plains throughout the basin. The most extensive deposit is along the Little Blackfoot River (Witkind and Weber, 1982).

\section{Hydrology}

Few streamflow data are available for the Avon Valley. The closest USGS streamflow-gaging site is station 12324590 (drainage area $407 \mathrm{mi}^{2}$ ) on the Little Blackfoot River near Garrison, about $10 \mathrm{mi}$ downstream from the Avon Valley and $0.5 \mathrm{mi}$ upstream from the mouth (pl. 1). During the period of record from October 1972 to present (1994), discharge at the station ranged from $6.0 \mathrm{ft}^{3} / \mathrm{s}$ on August 24,1977 , to $8,650 \mathrm{ft}^{3} / \mathrm{s}$ on May 21,1981 . The average discharge was $155 \mathrm{ft}^{3} / \mathrm{s}$.

Water-quality and suspended-sediment data were collected at the Little Blackfoot River near Garrison (gaging station 12324590) during 1963, and from 1985 to the current year (Shields and others, 1993). The river has a calcium-bicarbonate type water with an average dissolved-solids concentration of $116 \mathrm{mg} / \mathrm{L}$, according to analyses of five samples (Clark and Dutton, in press). In 1991, a fishkill occurred in the Little Blackfoot River; however, the cause of the kill is unknown (Montana Department of Health and Environmental Sciences, 1992).

The basin-fill aquifer system provides domestic water for nearly all residents of the Avon Valley. However, little information is available regarding ground water in the basin. Wilke (1979) inventoried numerous wells, but did not correlate the wells with the geologic units they tapped. The following discussion, therefore, is generalized.

Quaternary alluvium and glacial outwash are the primary aquifers in this basin. Ground water generally is accessible at shallow depths in alluvium, especially near and west of Avon. Many wells completed in alluvial deposits are less than $60 \mathrm{ft}$ deep. The yields of seven wells completed in alluvium and glacial outwash range from 2.5 to $40 \mathrm{gal} / \mathrm{min}$, with a median yield of $15 \mathrm{gal} / \mathrm{min}$. Specific-capacity values for six wells range from 0.1 to 10 (gal/min)/ft with a median value of 0.6 (gal/min)/ $\mathrm{ft}$ (Dutton and others, 1995). Alluvial and glacial-outwash aquifers are unconfined everywhere in the basin, except where occasional lenses of glacial outwash may be confined beneath glacial till. At least one flowing well is located in Avon. Shallow wells completed in the glacial-till-covered area along the north-flowing reach of the Little Blackfoot River also produce sufficient water for domestic use. While some of these wells may be completed in glacial till, many are located near the river and probably produce from alluvium.

Most wells completed in Tertiary sediments in the Avon Valley produce less than about $20 \mathrm{gal} / \mathrm{min}$ from local, discontinuous layers of coarse-grained material. Specific-capacity values are commonly less than 1 (gal/min)/ft 
(Dutton and others, 1995). Several wells near the basin margins were drilled through more than $200 \mathrm{ft}$ of lowyielding Tertiary sediments in order to obtain ground water from the underlying bedrock.

Bedrock, however, does not generally yield large quantities of water to wells in the Avon Valley. One well completed in volcanic bedrock produces $20 \mathrm{gal} / \mathrm{min}$ and another produces $7 \mathrm{gal} / \mathrm{min}$. Specific capacity values of both are less than 1 (gal/min)/ft. A well completed in Mesozoic sedimentary rocks just west of the basin reportedly produces $5 \mathrm{gal} / \mathrm{min}$ (Dutton and others, 1995).

Little is known about ground-water flow in the Avon Valley. However, a 1:750,000-scale potentiometricsurface map (Briar and others, in press) indicates that ground water generally flows from the uplands toward the flood plain, then west-northwest along the Little Blackfoot River.

Basin-fill aquifers are recharged by precipitation and snowmelt, surplus irrigation water, subsurface inflow from bedrock, and infiltration from the Little Blackfoot River and tributary streams. The ground-water contribution area (fig. 2, pl. 1) is about $370 \mathrm{mi}^{2}$. Infiltration anywhere within this area could potentially recharge basin-fill aquifers in the Avon Valley. Inflow of geothermal water from bedrock is evidenced by Avon Warm Springs (10N08W24BBC). This spring discharges water from Tertiary sediments that overlie volcanic rocks. Water temperature was measured at $26^{\circ} \mathrm{C}$; discharge at $24 \mathrm{gal} / \mathrm{min}$ (Sonderegger and Bergantino, 1981). Ground water discharges from the basin-fill aquifers by evapotranspiration, withdrawals from wells, and seepage to springs, seeps, and stream channels. Some ground water also might enter or leave the basin as deep subsurface interchange with basin-fill aquifers in the Nevada Creek valley.

Historical water-level data for the wells listed in table 4 are stored in the USGS WATSTORE database. Water levels were measured in these wells at least once annually during the period of record.

Table 4. Summary of water-level data for selected wells in the Avon Valley, Montana

[Hydrogeologic unit: Qal, Holocene and Pleistocene alluvial deposits; Ts, Tertiary sedimentary deposits and rocks]

\begin{tabular}{|c|c|c|c|c|c|c|c|}
\hline \multirow{2}{*}{ Location number } & \multirow{2}{*}{$\begin{array}{c}\text { Depth of well, In } \\
\text { feet below land } \\
\text { surface }\end{array}$} & \multirow{2}{*}{$\begin{array}{c}\text { Hydro- } \\
\text { geologic unlt }\end{array}$} & \multirow{2}{*}{$\begin{array}{l}\text { Period of } \\
\text { record }\end{array}$} & \multicolumn{4}{|c|}{ Water level, In feet below land surface } \\
\hline & & & & Highest & Date of highest & Lowest & Date of lowest \\
\hline 10N08W28AAA 03 & 23.4 & Qal & $1961-82$ & 3.06 & 06-09-69 & 10.26 & 03-09-67 \\
\hline
\end{tabular}

The quality of ground water in the basin was determined on the basis of 10 samples analyzed for major ions and measured dissolved-solids concentrations, and 6 samples in which dissolved-solids concentrations were estimated from specific-conductance measurements. Ground water in most of the Avon Valley is a calcium bicarbonate type with dissolved-solids concentrations of generally less than $250 \mathrm{mg} / \mathrm{L}$. Beneath the glacial outwash valley north of Avon, however, dissolved-solids concentrations range from about 250 to $500 \mathrm{mg} / \mathrm{L}$ (Clark and Dutton, in press). Water from Avon Warm Springs has a dissolved-solids concentration of about $650 \mathrm{mg} / \mathrm{L}$ (Sonderegger and Bergantino, 1981).

\section{Selected References}

Boettcher, A.J., and Gosling, A.W., 1977, Water resources of the Clark Fork basin upstream from St. Regis, Montana: Montana Bureau of Mines and Geology Bulletin 104, 28 p.

Briar, D.W., Lawlor, S.M., Stone, M.A.J., Parliman, D.J., Schaefer, J.L., and Kendy, Eloise, in press, Ground-water levels in intermontane basins of the Northern Rocky Mountains, Montana and Idaho: U.S. Geological Survey Hydrologic Investigations Atlas 738-B, 1 sheet, scale 1:750,000.

Clark, D.W., and Dutton, D.M., in press, Quality of ground water and surface water in intermontane basins of the Northern Rocky Mountains, Montana and Idaho: U.S. Geological Survey Hydrologic Investigations Atlas 738-C, 1 sheet, scale 1:750,000. 
Dutton, D.M., Lawlor, S.M., Briar, D.W., and Tresch, R.E., 1995, Hydrogeologic data for the Northern Rocky Mountains intermontane basins, Montana: U.S. Geological Survey Open-File Report 95-143, 94 p.

Fields, R.W., Rasmussen, D.L., Tabrum, A.R., and Nichols, Ralph, 1985, Cenozoic rocks of the intermontane basins of western Montana and eastern Idaho--a summary, in Flores, R.M., and Kaplan, S.S., eds., Cenozoic paleogeography of west-central United States: Denver, Colo., Society of Economic Paleontologists and Mineralogists, Rocky Mountain Section, p. 9-36.

Johnson, R.W., Jr., Henderson, J.R., and Tyson, N.S., 1965, Aeromagnetic map of the Boulder batholith area, southwestern Montana: U.S. Geological Survey Geophysical Investigations Map GP-538, scale 1:250,000.

Kleinkopf, M.D., and Mudge, M.R., 1972, Aeromagnetic, bouguer anomaly, and generalized geologic studies of the Great FallsMission Range area, northwestern Montana: U.S. Geological Survey Professional Paper 726-A, 19 p.

McCulloch, Robin, 1993, Montana mining directory: Montana Bureau of Mines and Geology Bulletin 131, 76 p.

Montana Department of Health and Environmental Sciences, 1992, Montana water quality 1992: Helena, Mont., Water Quality Bureau, Montana 305(b) Report, 42 p.

Peterson, M.P., 1985, The geology of the southwest quarter of the Avon 15-minute quadrangle, Powell County, Montana: Butte, Montana College of Mineral Science and Technology, M.S. thesis, 39 p.

Schmidt, R.G., Loen, J.S., Wallace, C.A., and Mehnert, H.M., 1994, Geology of the Elliston region, Powell and Lewis and Clark Counties, Montana: U.S. Geological Survey Bulletin 2045, 25 p.

Shields, R.R., Knapton, J.R., White, M.K., Brosten, T.M., and Chambers, C.L., 1993, Water resources data, Montana, water year 1992: U.S. Geological Survey Water-Data Report MT-92-1, 534 p.

Sonderegger, J.L., and Bergantino, R.N., 1981, Geothermal resources map of Montana: Montana Bureau of Mines and Geology Hydrogeologic Map 4, scale 1:1,000,000.

Trombetta, MJ., 1987, Evolution of the Eocene Avon volcanic complex, Powell County, Montana: Bozeman, Montana State University, M.S. thesis, 112 p.

Tuck, L. K., Briar, D.W., and Clark, D.W., in press, Geologic history and hydrogeologic units of intermontane basins of the Northern Rocky Mountains, Montana and Idaho: U.S. Geological Survey Hydrologic Investigations Atlas 738-A, 2 sheets, scale 1:750,000.

U.S. Department of Commerce, 1965, Climatic summary of the United States supplement for 1951 through 1960, Montana: Washington., D.C., U.S. Department of Commerce, Weather Bureau, Climatology of the United States no. 86-20, p. 11 and 60.

U.S. Geological Survey, issued annually, Water resources data, Montana: Helena, Mont., U.S. Geological Survey Water-Data Report.

Wallace, C.A., 1987, Generalized geologic map of the Butte $1^{\circ} \times 2^{\circ}$ quadrangle, Montana: U.S. Geological Survey Miscellaneous Field Studies Map MF-1924, scale 1:250,000.

Wallace, C.A., Schmidt, R.G., Lidke, D.J., Waters, M.R., Elliott, J.E., French, A.B., Whipple, J.W., Zarske, S.E., Blaskowski, M.J., Heise, B.A., Yeoman, R.A., O'Neill, J.M., Lopez, D.A., Robinson, G.D., and Klepper, M.R., 1987, Preliminary geologic map of the Butte $1^{\circ} \times 2^{\circ}$ quadrangle, western Montana: U.S. Geological Survey Open-File Report 86-292, scale 1:250,000.

Weber, W.M., and Witkind, IJ., 1979, Reconnaissance geologic map of the northern two-thirds of the Avon quadrangle, Lewis and Clark and Powell Counties, Montana: U.S. Geological Survey Open-File Report 79-437, scale 1:62,500.

Wilke, K.R., 1979, Selected well inventory and chemical analyses of ground water, parts of Missoula and Powell Counties, Montana: U.S. Geological Survey Open-File Report 79-1491, 4 p., 2 tables.

Witkind, I.J., and Weber, W.M., 1982, Reconnaissance geologic map of the Big Fork-Avon environmental study area, Flathead, Lake, Lewis and Clark, Missoula, and Powell Counties, Montana: U.S. Geological Survey Miscellaneous Investigations Series Map I-1380, scale 1:125,000. 


\section{Beaverhead Valley}

\section{Geography}

The Beaverhead Valley intermontane basin as defined in this study includes the Beaverhead River valley and the valleys of its major tributaries, the lower Ruby River, Blacktail Deer Creek, and Rattlesnake Creek, and part of the lower Big Hole River valley. The Beaverhead River valley trends northeast and the tributary valleys trend northwest. The $710-\mathrm{mi}^{2}$ Beaverhead Valley is bounded by the Tobacco Root Mountains on the northeast, the Ruby Range on the east, Burns and Gallagher Mountains on the south, the Pioneer Mountains on the west, and McCartney Mountain on the northwest (pl. 1). The northern boundary is arbitrarily defined as the confluence of the Big Hole and Beaverhead Rivers--the point at which the Jefferson River begins--although the structural basin actually continues northward into the Jefferson Valley. The Beaverhead Valley is one of the widest and flattest intermontane basins

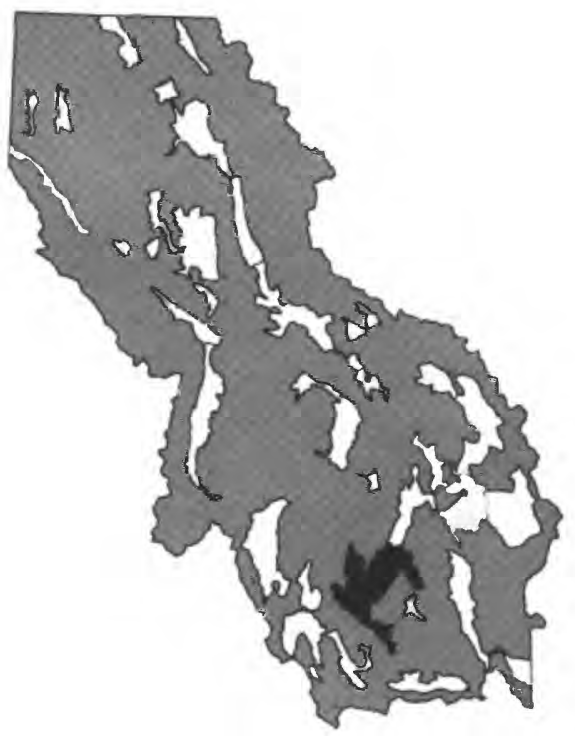
in Montana. South of Dillon, large, gently sloping alluvial fans coalesce on an extensive, gravel-covered planar surface. East of Dillon, the flood plain of the Beaverhead River is flanked on the east by a large, dissected bench, or pediment, that extends to the west flank of the Ruby Range. North of Dillon, the Big Hole, Beaverhead, and Ruby Rivers converge into a wide flood plain containing sloughs and seeps. Flood plains of the major tributaries are narrower than that of the Beaverhead River, and are flanked by pediments and alluvial fans. The Beaverhead Valley ranges in altitude from about 4,600 ft at the confluence of the Big Hole and Beaverhead Rivers to about 7,200 ft on the highest pediment.

The climate of the Beaverhead Valley is typical of higher-elevation intermontane basins of the Northern Rocky Mountains east of the Continental Divide, with cold winters and mild summers. On the basis of the 1961-90 period of record, the average annual precipitation at the Dillon Airport (altitude 5,220 ft) is 10.21 in., and the average annual temperature is $42.9^{\circ} \mathrm{F}$ (National Oceanic and Atmospheric Administration, 1992). The average last occurrence of $32^{\circ} \mathrm{F}$ is June 4, and the average first occurrence is September 13 (Natural Resources Conservation Service, U.S. Department of Agriculture, unpub. data, 1994). Mean monthly climatic data for the Dillon Airport are plotted in figure 6.

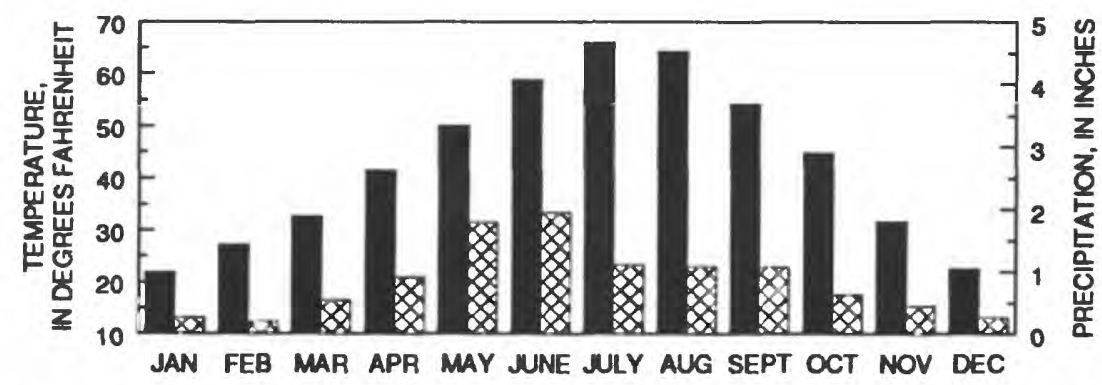

EXPLANATION

MEAN MONTHLY TEMPERATURE FOR 1961-90 PERIOD OF RECORD

MEAN MONTHLY PRECIPITATIONFOR 1961-90 PERIOD OF RECORD

Figure 6. Mean monthly precipitation and temperature at the Dillon Airport, Mont. Data from National Oceanic and Atmospheric Administration (1992).

Land use in the Beaverhead Valley is largely agricultural. The benches flanking the flood plains are used for rangeland and dryland-wheat production. Tributary flood plains and the Beaverhead River flood plain north of 
Beaverhead Rock contain many sloughs and springs, and are used to produce subirrigated hay. The bench east of Dillon produces grain, which is irrigated by canals from the Clark Canyon Reservoir. Higher elevations on the benches are used for dryland wheat and rangeland. The southern part of the basin, the lower Rattlesnake Creek drainage, and the benches west of Alder are irrigated with water from wells. The Lower Ruby Valley receives irrigation water from the Ruby River Reservoir. About 9,000 people reside in the Beaverhead Valley, including 4,001 in the City of Dillon and 652 in the Town of Sheridan (1990 census). Residential development, while not a major land use, has increased in recent years, particularly in the Sheridan area. In contrast, Blacktail Deer Creek valley remains virtually undeveloped.

Mining has been conducted for more than 100 years in many of the mountains surrounding the basin. Dredge tailings associated with mining in the Virginia City area extend well into the basin near Alder. Two cyanide-heapleach operations produce gold, silver, and lead in the southern Pioneer Mountains. Two open-pit mines produce talc at the crest of the Ruby Range. Vermiculite was recently produced from an open-pit mine in a northern tributary to Blacktail Deer Creek. Exploration for gold and copper is underway in the Blacktail Deer Creek drainage area (McCulloch, 1992; 1993).

\section{Geology}

The Beaverhead Valley was formed by downdropping along basin-marginal, north- to northeast-striking, faults. Whereas the west side of the basin is bounded by simple normal faults, the east side is bounded by a zone of complex normal and right-lateral, strike-slip faults. Recent scarps, broken surficial deposits, and disrupted drainages within the basin indicate active basin extension (Ruppel, 1993; Haller and others, 1993).

The maximum depth of the Beaverhead Valley is not known. According to Ruppel (1993), the depth to bedrock beneath basin fill is greatest at the northern end of the basin, where gravity data indicate a depth of about 3,000 to 4,600 ft. However, Petkewich (1972) estimated the depth to bedrock to be more than 8,000 ft in the northern part of the basin, and Noble and others (1982, p. 80-83) estimated a maximum basin depth of $8,500 \mathrm{ft}$ at the southern end of the basin. Ruppel (1993) determined the southern end of the basin to be about 1,500 to 3,000 $\mathrm{ft}$ deep, and the basin margin east of Dillon to be about 3,000 ft deep. Most of the basin may be about 1,500 $\mathrm{ft}$ deep, based on drill-hole data and topographic inference (Ruppel, 1993).

Several investigators have examined the geology of the Beaverhead Valley (table 5). The geologic units described by previous investigators are summarized below. These geologic units are referenced to hydrogeologic units defined in this study (table 2 ) to provide a consistent regional framework. In the following discussion, the hydrogeologic-unit abbreviations are italicized.

Bedrock geology of the area was most recently described by Ruppel and others (1993). Archean and Early Proterozoic gneiss, schist and some marble $(K A m)$ crop out extensively in the Ruby Range, east of the basin. The metamorphic rocks are folded and faulted, and intruded by Middle Proterozoic diabase dikes. North and east of Sheridan, Cretaceous granitic rocks (TKi) intrude Archean metamorphic rocks. Faulted and folded Paleozoic and Mesozoic sedimentary rocks outcrop in mountains south and west of the basin. The Paleozoic sedimentary rocks $\left(P_{z l}\right)$ are primarily carbonates, including Mississippian limestone, and the Mesozoic rocks (Mzsh) are primarily shale. Tertiary volcanic rocks (QTKe), including andesite and dacite, border the basin west of Dillon and southwest of the Rattlesnake Creek drainage area.

Tertiary sediments (Ts) that fill the intermontane basin belong to the Renova Formation and the overlying Sixmile Creek Formation of the Bozeman Group, although it is difficult to distinguish the two formations in this basin. Tertiary sediments are exposed on pediments near the basin margin, including the large bench east of Dillon. The heterogeneous Tertiary sediments consist of light-gray to yellowish-brown, moderately indurated to wellindurated tuffaceous sandstone, siltstone, and mudstone with some lacustrine limestone, marl, tuff, shale, and conglomerate (Hanneman and Wideman, 1991; Ruppel and others, 1993). Fields and Petkewich (1967) described lower Oligocene basin fill about 4 miles south of Sheridan as green and gray mudstone interspersed with pebbles, cobbles, and basaltic and andesitic boulders up to $7 \mathrm{ft}$ in diameter. 
Table 5. Geologic and geophysical maps of the Beaverhead Valley, Montana

\begin{tabular}{|c|c|c|c|c|}
\hline Type of map & Scale & Location & Map features & Reference \\
\hline Geology & $1: 394,000$ & $\begin{array}{l}\text { Northem half of } \\
\text { Beaverhead } \\
\text { Valley }\end{array}$ & Differentiates five "sequences" of Cenozoic basin fill & $\begin{array}{l}\text { Hanneman and Wideman, } \\
\text { 1991, fig. } 5\end{array}$ \\
\hline Geology & $1: 253,440$ & $\begin{array}{l}\text { Blacktail Deer } \\
\text { Creek valley }\end{array}$ & $\begin{array}{l}\text { Differentiates two basin-fill units: Tertiary sedimentary } \\
\text { rocks and Quatemary alluvium }\end{array}$ & Klepper, 1950, pl. 16 \\
\hline Gravity & $1: 850,000$ & $\begin{array}{l}\text { Entire } \\
\text { Beaverhead } \\
\text { Valley }\end{array}$ & Contour interval 10 milligals & $\begin{array}{l}\text { Ruppel, 1993, fig. } 17 \text {, } \\
\text { p. } 26\end{array}$ \\
\hline Principal faults & $1: 500,000$ & $\begin{array}{l}\text { Entire } \\
\text { Beaverhead } \\
\text { Valley }\end{array}$ & $\begin{array}{l}\text { Shows inferred direction and distance of extension } \\
\text { along faults. Also includes locations of oil- } \\
\text { exploration drill holes }\end{array}$ & Ruppel, 1993, sheet 1 \\
\hline
\end{tabular}

Pleistocene glacial till $(Q g)$ fills some tributary valleys, particularly in the area north of Sheridan. The poorly sorted deposits of boulders, gravel, sand, and clay grade into well-sorted, coarser-grained, glacial-outwash (Qal) fans where the tributaries enter the basin.

Quaternary alluvial deposits, including alluvial-fan deposits (QTd) and flood-plain alluvium (Qal), unconformably overlie Tertiary sediments in much of the basin. Alluvial fans flanking the Lower Ruby and Blacktail Deer Creek valleys consist of poorly sorted, silty sand and gravel (Ruppel and others, 1993). Drillers' logs indicate that fans along the north side of the Lower Ruby Valley also contain clay. Alluvial deposits consisting of silt, sand, and gravel extend along channels and flood plains of the Beaverhead River and its major tributaries (Ruppel and others, 1993). South of Dillon, hundreds of feet of sand and gravel with a little silt underlie the planar valley floor. Drillers' logs indicate that, near Dillon, these coarse-grained deposits pinch out. North of Dillon, the alluvium is clayey. Alluvium in the Lower Ruby River Valley is composed primarily of sand and gravel, according to drillers' logs. Geologic contact between Quaternary deposits and the underlying, similarly textured, Tertiary sediments is difficult to distinguish. Therefore, thickness of the Quaternary deposits is unknown (Ruppel and others, 1993).

\section{Hydrology}

The Beaverhead River begins at the Clark Canyon Dam, below the confluence of Horse Prairie Creek and the Red Rock River (pl. 1). The Bureau of Reclamation completed the Clark Canyon Dam and Reservoir Project in 1964, primarily to irrigate the bench east of Dillon. Below the dam, the Beaverhead River flows through a narrow canyon for about 15 mi before entering the Beaverhead Valley. Near Dillon, Rattlesnake Creek joins the Beaverhead River from the west and Blacktail Deer Creek joins from the east. The Ruby River originates in the Gravelly and Snowcrest Ranges, from which it enters the Upper Ruby Valley, is impounded in the Ruby River Reservoir, and is subsequently released into the Beaverhead Valley. The Montana Water Conservation Board completed the Ruby River Reservoir in 1938 to irrigate 34,000 acres in the Ruby and Jefferson River valleys. Near Twin Bridges, the Ruby River joins the Beaverhead River from the east and the Big Hole River joins from the west. The confluence of the Beaverhead and Big Hole Rivers marks the beginning of the Jefferson River. Diversions from the Big Hole, Ruby, and Beaverhead Rivers irrigate more than 270,000 acres, including farmland outside the Beaverhead Valley (Shields and others, 1993, p. 68, 71, and 75).

Streamflow data for gaging stations listed in table 6 are stored in the USGS WATSTORE database. Locations of the stations are shown on plate 1. In addition, USGS has published monthend volume records for Clark Canyon 
Reservoir (gaging station 06015300 , drainage area 2,321 $\mathrm{mi}^{2}$ ) since 1964 and Ruby River Reservoir (gaging station 06020500 , drainage area $596 \mathrm{mi}^{2}$ ) since 1938. Data for years prior to 1961 are published in Water-Supply Papers; more recent data are in annual Water-Data Reports (U.S. Geological Survey, issued annually).

Table 6. Summary of data for U.S. Geological Survey streamflow-gaging stations in the Beaverhead Valley, Montana

[Type of data collected: $c$, water chemistry; $d$, discharge; $s$, suspended sediment; $t$, temperature. Periods of record for stations that were being operated as of November 1994 are indicated by the first year of record followed by a dash only. Abbreviations: $\mathrm{ft}^{3} / \mathrm{s}$, cubic feet per second. Symbol: --, no data]

\begin{tabular}{|c|c|c|c|c|c|c|c|c|c|}
\hline \multirow[b]{2}{*}{$\begin{array}{l}\text { Station } \\
\text { number }\end{array}$} & \multirow[b]{2}{*}{ Station name } & \multirow{2}{*}{$\begin{array}{l}\text { Drainage } \\
\text { area } \\
\text { (equare } \\
\text { miles) }\end{array}$} & \multirow{2}{*}{$\begin{array}{l}\text { Type } \\
\text { of } \\
\text { data } \\
\text { cot- } \\
\text { locted }\end{array}$} & \multirow[b]{2}{*}{$\begin{array}{l}\text { Perlod of record } \\
\text { (calendar year) }\end{array}$} & \multicolumn{5}{|c|}{ Diecharge for period of record } \\
\hline & & & & & $\begin{array}{l}\text { Mean } \\
\text { angual } \\
\left(\mathrm{H}^{3} / \mathrm{s}\right)\end{array}$ & 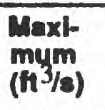 & $\begin{array}{l}\text { Date of } \\
\text { maxi- } \\
\text { mum }\end{array}$ & 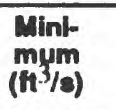 & $\begin{array}{l}\text { Date of } \\
\text { minimum }\end{array}$ \\
\hline 06015400 & $\begin{array}{l}\text { Beaverhead River } \\
\text { near Grant }\end{array}$ & 2,322 & c & $\begin{array}{l}1966-68 \\
1962-83\end{array}$ & 392 & 2,110 & $02-07-63$ & 22 & $10-16-74$ \\
\hline 06015500 & $\begin{array}{l}\text { Grasshopper Creek } \\
\text { near Dillon }\end{array}$ & 348 & d & $\begin{array}{l}1921-33,1945-53 \\
1955-61\end{array}$ & 51.6 & 1,870 & $03-24-56$ & 0 & $\begin{array}{c}\text { Summers } \\
\text { of } 1930 \text {, } \\
1931\end{array}$ \\
\hline 06016000 & $\begin{array}{l}\text { Beaverhead River at } \\
\text { Barretts }\end{array}$ & 2,737 & c & $\begin{array}{l}1907-86,1986- \\
\text { (seasonal } \\
\text { records) } \\
1949-51,1965-78, \\
1986\end{array}$ & 441 & 3,720 & $06-20-08$ & 69 & 01-30-39 \\
\hline 06016500 & $\begin{array}{l}\text { Ratulesnake Creek } \\
\text { near Dillon }\end{array}$ & 23.9 & d & $1946-49$ & 18 & 136 & $05-29-48$ & 6 & $\begin{array}{l}05-10-46 \\
\text { and } \\
04-27-47\end{array}$ \\
\hline 06017000 & $\begin{array}{l}\text { Beaverhead River at } \\
\text { Dillon }\end{array}$ & 2,895 & d & $\begin{array}{c}1907,1950-52 \\
1963-71\end{array}$ & 370 & 1,740 & $06-21-64$ & 18 & $06-19-52$ \\
\hline 06017500 & $\begin{array}{l}\text { Blacktail Deer } \\
\text { Creek nesr Dillon }\end{array}$ & 312 & d & $1946-53,1955-66$ & 54.0 & 426 & $06-08-64$ & 5.6 & $11-09-52$ \\
\hline 06017600 & $\begin{array}{l}\text { Blacktail Deer } \\
\text { Creek at Dillon }\end{array}$ & - & c & 1986 & - & -- & & - & \\
\hline 06018000 & $\begin{array}{l}\text { Beaverhead River } \\
\text { near Dillon }\end{array}$ & 3,484 & d & $1950-52,1963-83$ & 384 & 1,570 & $06-22-64$ & 8.5 & $06-21-52$ \\
\hline 06018500 & $\begin{array}{l}\text { Beaverhead River } \\
\text { near Twin Bridges }\end{array}$ & 3,619 & $\begin{array}{l}\text { d } \\
\text { c }\end{array}$ & $\begin{array}{l}1935- \\
1950-51,1962-81 \text {. } \\
1986\end{array}$ & 405 & 3,130 & $06-12-44$ & 28 & $09-02-88$ \\
\hline 06020000 & $\begin{array}{l}\text { Ruby River at } \\
\text { damsite, near } \\
\text { Alder }\end{array}$ & 592 & d & $1911-14,1935-36$ & $1_{118}$ & 1,800 & $08-14-36$ & 39 & $07-08-36$ \\
\hline 06020600 & $\begin{array}{l}\text { Ruby River below } \\
\text { Reservoir, near } \\
\text { Alder }\end{array}$ & 596 & d & 1962 & 209 & 3,010 & $05-16-84$ & 1.4 & $12-05-74$ \\
\hline 06021500 & Ruby River at Laurin & 650 & d & $1946-61$ & 77.5 & 980 & $06-11-47$ & 8 & $02-26-61$ \\
\hline 06022000 & $\begin{array}{l}\text { Ruby River below } \\
\text { Ramshom Creek, } \\
\text { near Sheridan }\end{array}$ & 843 & d & $1946-53$ & 198 & 1,340 & $06-11-47$ & 52 & $02-21-52$ \\
\hline 06022500 & $\begin{array}{l}\text { Ruby River near } \\
\text { Sheridan }\end{array}$ & 863 & d & $1946-51$ & 226.5 & 1,620 & $06-11-47$ & 56 & $06-14-49$ \\
\hline 06023000 & $\begin{array}{l}\text { Ruby River near } \\
\text { Twin Bridges }\end{array}$ & 935 & c & $\begin{array}{c}1940,1941-43 \\
1946-65,1979- \\
81 \\
1965,1979-81 \\
1986\end{array}$ & 199 & 1,500 & $06-12-47$ & 1.8 & $05-20-34$ \\
\hline 06025000 & $\begin{array}{l}\text { Big Hole River near } \\
\text { Dewey }\end{array}$ & 1,990 & d & $1910-13$ & 1,377 & 11,600 & $06-13-13$ & - & - \\
\hline 06025500 & $\begin{array}{l}\text { Big Hole River near } \\
\text { Melrose }\end{array}$ & 2,476 & d & $\begin{array}{l}1923- \\
1956-57,1960-64 \\
1956-57,1960-64, \\
1977\end{array}$ & 1,118 & 23,000 & $06-14-27$ & 49 & $08-17-31$ \\
\hline 06025800 & $\begin{array}{l}\text { Willow Creek near } \\
\text { Glen }\end{array}$ & 35.6 & $\begin{array}{l}\text { d } \\
\text { c }\end{array}$ & $\begin{array}{l}1962-66 \\
1962-65\end{array}$ & 20.55 & 310 & $06-21-63$ & 3 & $12-17-64$ \\
\hline 06026000 & $\begin{array}{l}\text { Birch Creek near } \\
\text { Glen }\end{array}$ & 36.0 & $\begin{array}{l}\text { d } \\
\text { c }\end{array}$ & $\begin{array}{l}1946-53,1955-76 \\
1958-62\end{array}$ & 29.4 & 427 & $07-05-75$ & 8 & $11-17-58$ \\
\hline 06026210 & $\begin{array}{l}\text { Big Hole River near } \\
\text { Glen }\end{array}$ & 2,655 & c & $1966-68$ & - & - & & -- & \\
\hline 06026400 & $\begin{array}{l}\text { Big Hole River near } \\
\text { Twin Bridges }\end{array}$ & 2,762 & $\begin{array}{l}\text { d } \\
\text { c }\end{array}$ & $\begin{array}{c}1979-81 \\
1967,1980-81 \\
1986\end{array}$ & $1,250.5$ & 8,940 & $06-11-81$ & 55 & $09-17-81$ \\
\hline
\end{tabular}

IData for water year 1936. 
Minimum discharges usually occur during late summer and often result in late-season shortages of irrigation water. The Big Hole River near Twin Bridges was completely dewatered during the summer of 1966 (Braico and Botz, 1975). Stream dewatering jeopardizes fish populations (Missouri River Basin Commission, 1981). On September 1, 1994, during a prolonged drought, the Ruby River Reservoir was completely drained and the river cut down through the sediment that had accumulated behind the dam, flushing large amounts of sediment into the Ruby River. An estimated 10,000 to 15,000 fish-mostly rainbow trout-died in the 2.5-mi silt-choked section below the reservoir (Helena Independent Record, Sept. 22, 1994, p. 8A; Mar. 13, 1995, p. 3A).

With some exceptions, surface-water quality in the Beaverhead Valley is suitable for most uses. Analyses of 345 samples from the Beaverhead River near Twin Bridges (gaging station 06018500) indicate a calcium magnesium bicarbonate type water with an average dissolved-solids concentration of $409 \mathrm{mg} / \mathrm{L}$--the highest concentration in the study area. The water quality upstream, in the Beaverhead River at Barretts (gaging station 06016000), is nearly identical, except for a somewhat lower average dissolved-solids concentration of $332 \mathrm{mg} / \mathrm{L}$ (Clark and Dutton, in press).

Water quality in the Beaverhead River may be influenced by Clark Canyon Reservoir. Smith (1973) attributed observed increases in $\mathrm{pH}$, dissolved oxygen, ammonia, and nitrate, and decreases in turbidity below the dam to the reservoir. In addition, diurnal temperature fluctuations are dampened below the reservoir (Smith, 1973). Periodically, elevated concentrations of hydrogen sulfide in the section of the Beaverhead River from 2.0 to $3.3 \mathrm{mi}$ downstream from Clark Canyon Dam have decreased the fish population. In September 1967, about 3,000 trout, whitefish, and suckers died, and populations have declined significantly at other times. Low dissolved-oxygen concentrations caused by decaying aquatic vegetation in the newly constructed reservoir might have resulted in the elevated hydrogen-sulfide concentrations (Braico and Botz, 1975).

Suspended-sediment loads in the Beaverhead River increase between Clark Canyon Reservoir and Twin Bridges. Possible causes include streambank erosion caused by sediment transport and discharge changes induced by the dam, and sediment loading from Grasshopper Creek. Elevated levels of turbidity and suspended solids in Grasshopper Creek have been attributed to mining and grazing practices downstream of Bannack (Braico and Botz, 1975).

As part of a reconnaissance survey of arsenic in the upper Missouri River basin, six USGS streamflow-gaging stations in the Beaverhead Valley (gaging stations 06015500, 06016000, 06017600, 06018500, 06023000, and 06026400) were sampled for arsenic under various hydrologic conditions from November 1985 to October 1986. The concentration of total recoverable arsenic was $8 \mu \mathrm{g} / \mathrm{L}$ or less for all samples (Knapton and Horpestad, 1987), well below the maximum contaminant level of $50 \mu \mathrm{g} / \mathrm{L}$ arsenic that the U.S. Environmental Protection Agency (1991) established for treated drinking water.

Ground water is an important resource in the Beaverhead Valley, as most residents depend on municipal, community, or private wells to supply their drinking water. Municipal water supplies for Dillon, Twin Bridges, and Sheridan are obtained from wells completed in basin fill. Recognizing the value of its ground-water resource, the Town of Sheridan has developed a formal wellhead protection program.

The primary aquifers in the basin are Quatemary alluvium along the major streams, Quaternary alluvial fans, and, to a lesser extent, Tertiary sediments. Yield and specific-capacity values for wells completed in basin-fill aquifers in the Beaverhead Valley are summarized in table 7 from USGS data. The wide range in yield and specificcapacity values reflect the heterogeneity of aquifer materials both within and between different parts of the basin.

In the Beaverhead River valley, well yields tend to decrease toward the north. About six miles southwest of Dillon, large-diameter irrigation wells produce as much as $2,000 \mathrm{gal} / \mathrm{min}$ with little drawdown. These wells are completed in permeable basin fill at depths of 400 to $500 \mathrm{ft}$, but whether the basin fill is Tertiary or Quatemary in age is not clear from the drillers' logs. These permeable deposits apparently pinch out near Dillon, as wells completed north of Dillon are much less productive. West of Dillon, drillers report that bedrock underlies 30 to 40 $\mathrm{ft}$ of clayey basin fill. 
Table 7. Summary of data for yield and specific capacity of wells completed in selected hydrogeologic units in the Beaverhead Valley, Montana

[Source: Dutton and others, 1995. Hydrogeologic units: Qal, Holocene and Pleistocene alluvial deposits; QTd, Quaternary through Tertiary undifferentiated deposits; Ts; Tertiary sedimentary deposits and rocks. Abbreviations: gal/min, gallon per minute; (gal/min)/ft, gallon per minute per foot]

\begin{tabular}{|c|c|c|c|c|c|c|c|c|c|c|}
\hline \multirow{2}{*}{$\begin{array}{l}\text { Hydro- } \\
\text { geologic } \\
\text { unit }\end{array}$} & \multirow[b]{2}{*}{$\begin{array}{l}\text { Number } \\
\text { of welle }\end{array}$} & \multicolumn{4}{|c|}{ Yield (gal/min) } & \multirow[b]{2}{*}{$\begin{array}{l}\text { Number } \\
\text { of wells }\end{array}$} & \multicolumn{4}{|c|}{ Specific capacity $[(g a l / m i n) / f t]$} \\
\hline & & Mean & Median & $\begin{array}{l}\text { Mini- } \\
\text { mum }\end{array}$ & $\begin{array}{l}\text { Maxj- } \\
\text { mum }\end{array}$ & & Mean & Median & $\begin{array}{l}\text { Mini- } \\
\text { mum }\end{array}$ & $\begin{array}{l}\text { Maxi- } \\
\text { mum }\end{array}$ \\
\hline Qal & 16 & 690 & 35 & 10 & 2,300 & 12 & 31 & 2.4 & 0.9 & 180 \\
\hline QTd & 18 & 870 & 700 & 9.2 & 2,500 & 16 & 61 & 14 & 1.1 & 460 \\
\hline Ts & 30 & 42 & 20 & 1.0 & 500 & 20 & 1.8 & .8 & .2 & 6.0 \\
\hline
\end{tabular}

Aquifer tests in the Beaverhead Valley give variable results. To determine the transmissivity of alluvium just south of Dillon (07S08W19BA), Botz (1967) tested a 14-in.-diameter, 60-ft-deep municipal well completed in 38 $\mathrm{ft}$ of unconsolidated sand and gravel. The result indicated a transmissivity of about $88,000 \mathrm{ft}^{2} / \mathrm{d}$. However, an aquifer test on a nearby (07S08W20A) 390-ft-deep well completed in confined Tertiary sediments resulted in a transmissivity of about $30 \mathrm{ft}^{2} / \mathrm{d}$ (Botz, 1967).

The streambed of the Beaverhead River consists primarily of gravelly alluvium. According to several tests using mini-piezometers and seepage meters, the vertical hydraulic conductivity of the streambed ranges from less than $1 \mathrm{ft} / \mathrm{d}$ to about $6 \mathrm{ft} / \mathrm{d}$. Unsaturated alluvium underlies the least permeable reaches of the streambed (Craig, 1995).

Basin fill in the Lower Ruby Valley has a large range of hydraulic properties. Municipal wells for Sheridan are completed in Quaternary deposits, which might be partially of glacial origin. On the Tertiary pediment west of Alder, diversions from the Ruby Reservoir provide irrigation water, therefore, the area has had very little groundwater development, and aquifer characteristics are unknown. On the Ruby River flood plain, wells completed in sandy, gravelly alluvium are fairly productive. An exception is the area south of Alder, where alluvium is finer grained.

Like the Lower Ruby Valley, alluvium in the Rattlesnake Creek valley is most productive in the lower part of the valley. Numerous irrigation wells in the lower valley produce large quantities of water with little drawdown. In contrast, wells in the upper part of the valley tend to be poor producers, except for at least one artesian well. Tertiary deposits beneath the Rattlesnake Creek valley are heterogeneous and exhibit a wide range of hydraulic properties.

Several 20-in.-diameter wells completed at depths to $200 \mathrm{ft}$ along Blacktail Deer Creek valley produce 1,000 to $2,000 \mathrm{gal} / \mathrm{min}$ from permeable basin fill. Otherwise, ground water in Blacktail Deer Creek valley is largely undeveloped.

The lower Big Hole River valley has had little ground-water development. Most wells completed in rangeland on the Tertiary pediments are low-yielding stock wells. The Big Hole River flood plain is subirrigated by numerous sloughs and springs, and therefore needs no irrigation wells. According to water-rights applications and drillers' $\operatorname{logs}$, the few wells that have been completed in the sandy, gravelly flood-plain alluvium produce from 20 to $75 \mathrm{gal} / \mathrm{min}$.

The Montana Department of Natural Resources and Conservation is conducting an ongoing large-scale study of the hydrogeology of basin fill south of Dillon. Objectives of the study are to determine geometry, water quality, and hydraulic characteristics of aquifers in the Blacktail Deer Creek and Rattlesnake Creek drainages, and the Beaverhead River valley south of Dillon (W.C. Uthman, Montana Department of Natural Resources and Conservation, oral commun., 1994).

Potentiometric-surface maps indicate that ground water generally flows from the uplands toward the flood plains, then northeast along the Beaverhead River. Historical water-level data suggest that, regionally, this pattern is relatively stable. However, comparison between water levels before (Botz, 1967, fig. 2, p. 83) and after (Briar and others, in press) construction of the main irrigation canal on the bench east of Dillon suggests that ground-water 
elevations in the newly irrigated area have risen as much as $100 \mathrm{ft}$. The effect is most pronounced along the northem end of the canal, just south of the Ruby River.

Basin-fill aquifers are recharged by precipitation and snowmelt, surplus irrigation water, inflow from bedrock in the surrounding mountains, and infiltration from streams and rivers. The ground-water contribution area (fig. 2 , pl. 1) is about $1,820 \mathrm{mi}^{2}$. Infiltration anywhere within this area could potentially recharge basin-fill aquifers in the Beaverhead Valley. A large proportion of recharge comes from surface-water sources. On the basis of synoptic streamflow measurements and numerical ground-water flow modeling, Craig (1995) observed significant interactions between the Beaverhead River and ground water in underlying aquifers. In areas served by canals from the Ruby and Clark Canyon Reservoirs, surplus irrigation water is more important than direct precipitation in recharging basin-fill aquifers (Botz, 1967). Ground water discharges from the basin-fill aquifers by evapotranspiration, withdrawals from wells, and seepage to springs, seeps, irrigation drains, and stream channels.

The presence of New Biltmore Hot Springs (04S07W28BDA) indicates a source of geothermal water from bedrock. The spring discharges water with a temperature of $53^{\circ} \mathrm{C}$ at a rate of $260 \mathrm{gal} / \mathrm{min}$. Faulted Paleozoic to Precambrian bedrock beneath the alluvium is probably the geothermal source (Chadwick and Leonard, 1979). Other lower-temperature warm springs discharge from basin fill near Beaverhead Rock (05S07W22ABBD) and southwest of Dillon (08S09W28BDBA) (Sonderegger and Bergantino, 1981).

Water levels for wells listed in table 8 are stored in the USGS WATSTORE database. Water levels are measured in these wells at least once annually. In addition, the Montana Department of Natural Resources and Conservation measures water levels in several large-capacity, large-diameter irrigation wells in the Beaverhead River valley 17 times annually (W.C. Uthman, Montana Department of Natural Resources and Conservation, oral commun., 1994).

Ground water throughout most of the basin is a calcium bicarbonate type. However, ground water in Tertiary sediments east of Dillon has significant amounts of magnesium and sodium (Botz, 1967; Clark and Dutton, in press). Seventy samples were analyzed for major ions and measured dissolved-solids concentrations, and 19 samples had dissolved-solids concentrations estimated from specific-conductance measurements. Analyses indicate that dissolved-solids concentrations range from less than $250 \mathrm{mg} / \mathrm{L}$ beneath the Beaverhead and Big Hole River flood plains to as much as $500 \mathrm{mg} / \mathrm{L}$ in the Blacktail Deer Creek, Rattlesnake Creek, and Lower Ruby River valleys (Clark and Dutton, in press). Water issuing from New Biltmore Hot Springs has a dissolved-solids concentration of 1,860 $\mathrm{mg} / \mathrm{L}$ (Sonderegger and Bergantino, 1981). 
Table 8. Summary of water-level data for selected wells in the Beaverhead Valley, Montana

[Hydrogeologic unit: Qal, Holocene and Pleistocene alluvial deposits; Ts, Tertiary sedimentary deposits and rocks. Periods of record for observation wells that were being operated as of February 1995 are indicated by the first year of record followed by a dash only]

\begin{tabular}{|c|c|c|c|c|c|c|c|}
\hline \multirow{2}{*}{ Location number } & \multirow{2}{*}{$\begin{array}{l}\text { Depth of } \\
\text { well, in feet } \\
\text { below land } \\
\text { surface }\end{array}$} & \multirow{2}{*}{$\begin{array}{l}\text { Hydro- } \\
\text { geologic } \\
\text { unit }\end{array}$} & \multirow{2}{*}{$\begin{array}{l}\text { Perlod of } \\
\text { record }\end{array}$} & \multicolumn{4}{|c|}{$\begin{array}{c}\text { Water level, in feet below or above }(+) \text { land } \\
\text { surface }\end{array}$} \\
\hline & & & & Highest & $\begin{array}{l}\text { Date(s) of } \\
\text { highest }\end{array}$ & Lowest & $\begin{array}{l}\text { Date of } \\
\text { lowest }\end{array}$ \\
\hline 04SO6W16AAAA02 & 57.5 & Ts & $1965-92$ & 19.71 & $08-30-84$ & 36.60 & $06-01-65$ \\
\hline 04SO6W 16DDDD02 & 56.5 & Ts & $1964-91$ & 15.68 & $09-12-73$ & 46.13 & $04-11-65$ \\
\hline 04SO6W26ABB O2 & 61.1 & Qal & $1965-91$ & 16.52 & $09-26-74$ & 44.31 & $04-10-65$ \\
\hline 04S06W27BAAA01 & 145 & Ts & $1963-91$ & 26.24 & $09-12-73$ & 69.00 & $04-16-63$ \\
\hline 04506W29AABA01 & 33.6 & $\mathrm{Ts}$ & $1965-82$ & 2.90 & $\begin{array}{l}09-12-73 \\
03-24-82\end{array}$ & 20.90 & $04-11-65$ \\
\hline 04S06W32CBB 01 & 19.8 & Qal & $1965-82$ & 12.90 & 07-03-79 & 18.92 & $10-06-66$ \\
\hline 04SO6W35BBBB01 & 170 & Ts & $1963-92$ & +17.8 & $\begin{array}{l}08-20-85 \\
08-21-86\end{array}$ & 169 & $04-23-63$ \\
\hline 05S07W14ADDD02 & 62.2 & Ts & $1965-80$ & 38.54 & $10-31-73$ & 45.73 & $04-17-65$ \\
\hline 05SO7W23ABA 01 & 20.0 & Ts & $1964-90$ & 10.71 & $08-30-84$ & 15.39 & $08-04-66$ \\
\hline 05SO7W26CDD 01 & 15.0 & Ts & $1961-82$ & 5.60 & $\begin{array}{l}05-09-80 \\
08-13-82\end{array}$ & 9.95 & $02-06-67$ \\
\hline 05SO7W32ACC 01 & 20.0 & Ts & $1960-82$ & 4.57 & $05-09-80$ & 18.17 & $04-06-66$ \\
\hline 05SO7W34DDDCO1 & 18.0 & Qal & $1962-82$ & 8.67 & $08-02-67$ & 13.00 & $08-01-62$ \\
\hline 05SO7W35BBA 01 & 16.3 & Qal & $1962-81$ & 7.03 & $05-09-80$ & 11.00 & $08-03-62$ \\
\hline 05SO6W04BDA 01 & 160 & Ts & $1964-74$ & 70.83 & $10-31-73$ & 138.54 & $11-17-64$ \\
\hline 05SO6W10BCCA01 & 200 & Ts & $1965-92$ & 101.06 & $09-26-74$ & 175.35 & $06-26-65$ \\
\hline 05SO6W15ACB 01 & 277 & $\mathrm{Tz}$ & $1963-82$ & 176.35 & $12-04-67$ & 249.18 & $05-09-80$ \\
\hline 05S06W17CAB 01 & 310 & Ts & $1963-82$ & 137.54 & $03-24-82$ & 235.8 & $02-28-63$ \\
\hline 05S06W19BDD 01 & 21.0 & Qal & $1973-82$ & 15.84 & 07-03-79 & 20.14 & $08-13-82$ \\
\hline 05SO6W19BDDD02 & 150 & Qal & $1964-91$ & 53.97 & $06-25-91$ & 111.22 & $06-06-68$ \\
\hline O6S08W 12DCBA02 & - & Ts & $1965-91$ & 3.55 & $08-13-82$ & 35.68 & $05-31-65$ \\
\hline 06S08W23AAAD01 & 115 & Ts & $1965-82$ & 25.28 & $08-13-82$ & 37.42 & $02-09-66$ \\
\hline 06SO8W23DAC 02 & 102 & Ts & $1964-91$ & 24.33 & $09-13-73$ & 42.13 & $05-31-65$ \\
\hline $06 \mathrm{~S} 08 \mathrm{~W} 26 \mathrm{CCCAO2}$ & 51.0 & Ts & $1965-92$ & 22.98 & $09-10-92$ & 34.35 & $04-09-65$ \\
\hline 06S08W27DAA 01 & 23.9 & Qal & $1960-82$ & 13.46 & $06-14-73$ & 20.28 & $02-09-66$ \\
\hline O6SO8W35ACD 01 & 16.5 & Qal & $1965-82$ & 4.39 & $06-15-81$ & 11.56 & $10-05-66$ \\
\hline 06507W06AADA01 & 107 & $\mathrm{Ts}$ & $1964-92$ & 38.31 & $08-20-85$ & 67.54 & $05-29-65$ \\
\hline 07S09W35AAA 01 & 26.0 & Qal & $1965-79$ & 2.42 & $10-12-65$ & 16.79 & 04-04-67 \\
\hline 07S08W03BDCA02 & 40.5 & Qal & $1965-93$ & 10.53 & $08-27-73$ & 19.48 & $03-21-77$ \\
\hline 07S08W11BBCB01 & 91.0 & Ts & $1964-91$ & 4.6 & $06-12-91$ & 54.38 & $12-05-64$ \\
\hline O7S08W16AACA01 & 76.6 & Ts & $1964-82$ & 56.48 & $11-16-81$ & 62.24 & $05-31-65$ \\
\hline 07S08W 17DDC 02 & 50.0 & Ts & $1965-92$ & 8.90 & $08-13-82$ & 34.44 & $02-17-87$ \\
\hline 08S09W01CCCC01 & 47.0 & Ts & $1966-$ & 10.78 & $08-06-71$ & 36.07 & $09-20-89$ \\
\hline 08S09W03DAA 01 & 30.0 & Qal & $1965-82$ & 11.88 & $08-03-65$ & 18.19 & $03-24-82$ \\
\hline
\end{tabular}

\section{Selected References}

Botz, M.K., 1967, Hydrogeology of the East Bench Irrigation Unit, Madison and Beaverhead Counties, Montana, in Montana Geological Society 18th Annual Field Conference, August 9-12, 1967, Guidebook for Centennial Basin of Southwest Montana: Billings, Mont., Montana Geological Society, p. 79-88.

Braico, R.D., and Botz, M.K., 1975, Water quality inventory and management plan, upper Missouri tributaries basin, Montana: Montana Department of Health and Environmental Sciences, 167 p.

Briar, D.W., Lawlor, S.M., Stone, M.A.J., Parliman, D.J., Schaefer, J.L., and Kendy, Eloise, in press, Ground-water levels in intermontane basins of the Northern Rocky Mountains, Montana and Idaho: U.S. Geological Survey Hydrologic Investigations Atlas 738-B, 1 sheet, scale 1:750,000.

Chadwick, R.A., and Leonard, R.B., 1979, Structural controls of hot-spring systems in southwestem Montana: U.S. Geological Survey Open-File Report 79-1333, 25 p. 
Clark, D.W., and Dutton, D.M., in press, Quality of ground water and surface water in intermontane basins of the Northern Rocky Mountains, Montana and Idaho: U.S. Geological Survey Hydrologic Investigations Atlas 738-C, 1 sheet, scale 1:750,000.

Craig, W. H., 1995, Ground water-surface water interactions along the Beaverhead River near Dillon, Montana: Missoula, University of Montana, M.S. thesis, 232 p.

Dutton, D.M., Lawlor, S.M., Briar, D.W., and Tresch, R.E., 1995, Hydrogeologic data for the Northern Rocky Mountains intermontane basins, Montana: U.S. Geological Survey Open-File Report 95-143, 94 p.

Fields, R.W., and Petkewich, R.M., 1967, Tertiary stratigraphy and geologic history of the upper Jefferson, Ruby, lower Beaverhead, and lower Big Hole River valleys, in Montana Geological Society 18th Annual Field Conference, August 9-12, 1967, Guidebook for Centennial Basin of Southwest Montana: Billings, Mont., Montana Geological Society, p. 71-77.

Haller, K.M., Dart, R.L., and Stickney, M.C., 1993, A compilation of major active faults for parts of Montana and Idaho: Geological Society of America Abstracts with Programs, v. 25, no. 5, p. 46.

Hanneman, D.L., and Wideman, C.J., 1991, Sequence stratigraphy of Cenozoic continental rocks, southwestern Montana: Geological Society of America Bulletin, v. 103, p. 1,335-1,345.

Hoffman, D.S., 1971, Tertiary stratigraphy, vertebrate paleontology and paleoecology of a portion of the lower Beaverhead River basin, Madison and Beaverhead counties, Montana: Missoula, University of Montana, Ph.D. dissertation, 174 p.

Klepper, M.R., 1950, A geologic reconnaissance of parts of Beaverhead and Madison Counties, Montana: U.S. Geological Survey Bulletin 969-C, p. 54-85.

Knapton, J.R., and Horpestad, A.A., 1987, Arsenic data for streams in the upper Missouri River basin, Montana and Wyoming: U.S. Geological Survey Open-File Report 87-124, 25 p.

Lankston, R.W., and Lankston, M.M., 1986, Analysis of the T. 6 S., R. 7 W., magnetic anomaly, southwestern Montana-Final report of 1985 University of Arkansas summer geophysical field exercise: Montana Bureau of Mines and Geology OpenFile Report 165, 30 p.

Levings, J.F., 1985, Hydrogeologic data related to the potential for stock-water development on federally owned rangeland near Dillon, Montana: U.S. Geological Survey Open-File Report 85-170, 22 p.

McCulloch, Robin, 1992, Montana mining directory 1991: Montana Bureau of Mines and Geology Bulletin 130, 136 p. 1993, Montana mining directory 1992: Montana Bureau of Mines and Geology Bulletin 131, 76 p.

Missouri River Basin Commission, 1981, Upper Missouri River basin level B study report and environmental impact statement: Omaha, Nebraska, 186 p.

[Montana] State Engineer's Office, 1954a, Water resources survey, Madison County, Montana-Part 1, History of land and water use on irrigated areas: Helena, Mont., State Engineer's Office, 68 p.

1954b, Water resources survey, Madison County, Montana--Part 2, Maps showing irrigated areas: Helena, Mont., State Engineer's Office, $62 \mathrm{p}$.

National Oceanic and Atmospheric Administration, 1992, Monthly normals of temperature, precipitation, and heating and cooling degree days, 1961-90, Montana: Asheville, N.C., Climatography of the United States no. 81, unpaged.

Noble, R.A., Bergantino, R.N., Patton, T.W., Sholes, B.C., Daniel, Faith, and Schofield, Judeykay, 1982, Occurrence and characteristics of ground water of Montana-Volume 2, The Rocky Mountain Region: Montana Bureau of Mines and Geology Open-File Report 99, 132 p.

Petkewich, R.M., 1972, Tertiary geology and paleontology of the Beaverhead East area, southwestem Montana: Missoula, University of Montana, Ph.D dissertation, 365 p.

Rasmussen, D.L., and Fields, R.W., 1983, Structural and depositional history, Jefferson and Beaverhead basins, southwestern Montana [abs.]: American Association of Petroleum Geologists Bulletin, v. 67, no. 8, p. 1352.

Ruppel, E.T., 1993, Cenozoic tectonic evolution of southwest Montana and east-central Idaho: Montana Bureau of Mines and Geology Memoir 65, 62 p.

Ruppel, E.T., O'Neill, J.M., and Lopez, D.A, 1993, Geologic map of the Dillon $1^{\circ} \times 2^{\circ}$ quadrangle, Idaho and Montana: U.S. Geological Survey Miscellaneous Investigations Series Map 1-1803-H, scale 1:250,000.

Shields, R.R., Knapton, J.R., White, M.K., Brosten, T.M., and Chambers, C.L., 1993, Water resources data, Montana, water year 1992: U. S. Geological Survey Water-Data Report MT-92-1, 534 p. 
Smith, K.M., 1973, Some effects of Clark Canyon Reservoir on the limnology of the Beaverhead River in Montana: Bozeman, Montana State University, M.S. thesis, 62 p.

Sonderegger, J.L., and Bergantino, R.N., 1981, Geothermal resources map of Montana: Montana Bureau of Mines and Geology Hydrogeologic Map 4, scale 1:1,000,000.

Thompson, G.R., Fields, R.W., and Alt, David, 1981, Tertiary paleoclimates, sedimentation patterns and uranium distribution in southwestern Montana, in Montana Geological Society Field Conference and Symposium Guidebook to Southwest Montana: [Billings, Mont.], Montana Geological Society, p. 105-109.

Tuck, L. K., Briar, D.W., and Clark, D.W., in press, Geologic history and hydrogeologic units of the intermontane basins of the Northern Rocky Mountains, Montana and Idaho: U.S. Geological Survey Hydrologic Investigations Atlas 738-A, 2 sheets, scale 1:750,000.

U.S. Environmental Protection Agency, 1991, Maximum contaminant levels (subpart B of part 141, National primary drinkingwater regulations): U.S. Code of Federal Regulations, Title 40, Parts 100 to 149, revised July 1, 1991, p. 585-588.

U.S. Geological Survey, issued annually, Water resources data, Montana: Helena, Mont. 


\title{
Big Hole Basin
}

\section{Geography}

The Big Hole Basin is a north-trending intermontane basin in southwestern Montana. The $500-\mathrm{mi}^{2}$ basin is bounded by the Beaverhead Mountains on the west, the Anaconda Range on the north, the Pioneer Mountains on the east, and Big Hole Divide on the south (pl. 1). The Big Hole River originates in the mountains to the south, and flows northward, draining the entire basin. The river exits the Big Hole Basin through a bedrock constriction, and joins the Beaverhead River about $25 \mathrm{mi}$ downstream to form the Jefferson River. Within the Big Hole Basin, the river and its tributaries meander across the broad Big Hole River flood plain. The flood plain, which is about $\mathbf{4 0} \mathrm{mi}$ long and as much as $5 \mathrm{mi}$ wide, contains numerous bogs and sloughs. Flanking the flood plain are large, grass- and sagebrush-covered pediments capped with gravel and loess. Pediments in the Big Hole Basin

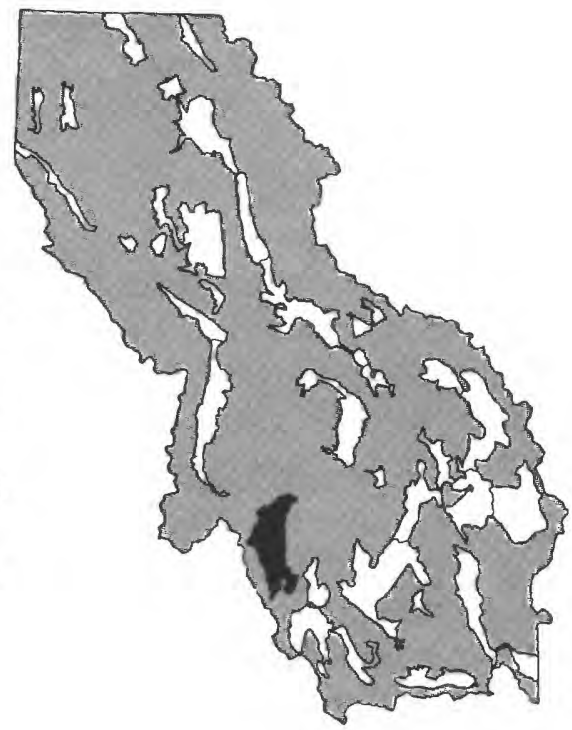
are not as conspicuous as those in other intermontane basins of Montana because their surfaces are approximately level with the flood plain. The change in relief between the relatively level pediments and the steep, rugged mountains that surround the basin is, in many places, concealed by hummocky, forested terraces of alpine glacial drift. The Big Hole Basin ranges in altitude from about 5,900 ft where the Big Hole River leaves the basin, to about $7,700 \mathrm{ft}$ on the highest pediment.

The climate of the Big Hole Basin is typical of higher-elevation intermontane basins in southwestern Montana, with very cold, dry winters and mild summers. On the basis of the 1961-90 period of record, the average annual precipitation at Wisdom (altitude 6,060 ft) is 11.35 in. (National Oceanic and Atmospheric Administration, 1992). Precipitation increases along the edges of the basin; the mountain fronts receive more than 16 in. per year (U.S. Soil Conservation Service, 1977). The average annual temperature at Wisdom is $35.8^{\circ} \mathrm{F}$, which is one of the lowest of all recording stations in the study area (National Oceanic and Atmospheric Administration, 1992). The average last occurrence of $32^{\circ} \mathrm{F}$ is July 19 , and the average first occurrence is August 5 (Natural Resources Conservation Service, U.S. Department of Agriculture, unpub. data, 1994). Mean monthly climatic data for Wisdom are plotted in figure 7.

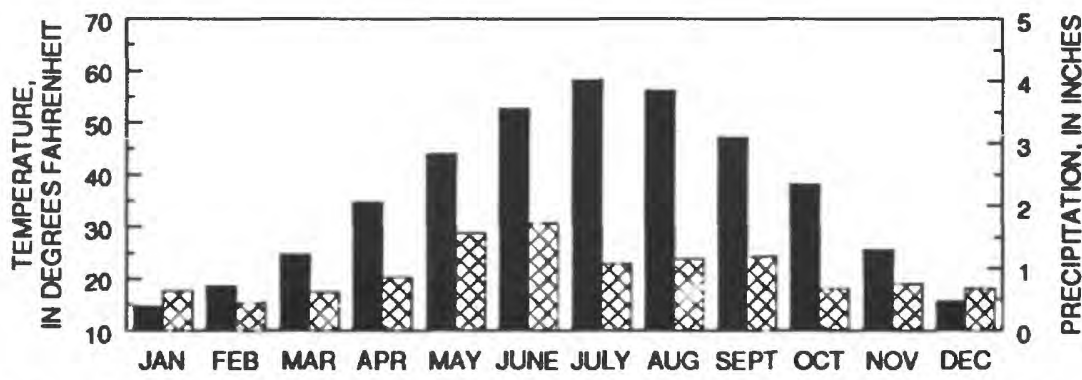

\author{
EXPLANATION \\ MEAN MONTHLY TEMPERATURE FOR \\ 1961-90 PERIOD OF RECORD \\ MEAN MONTHLY PRECIPITATION FOR \\ 1961-DO PEAIOD OF RECORD
}

Flgure 7. Mean monthly precipitation and temperature at Wisdom, Mont. Data from National Oceanic and Atmospheric Administration (1992).

Land uses include rangeland, primarily on pediments, and subirrigated and flood-irrigated hay fields and pastures on the valley floor (J.C. Eggen, Agricultural Stabilization and Conservation Service, oral commun., 1993). Hay, which is cut once a year, is the major irrigated crop. Irrigation water is supplied exclusively by surface-water diversions, whereas ground water is used only for domestic and livestock consumption (Levings, 1986). Mining was historically important in the mountains surrounding the Big Hole Basin. Currently, gold is placer-mined in the 
Trail Creek drainage (McCulloch, 1993, p. 11). About 400 people reside in the Big Hole Basin, including 135 in the unincorporated community of Wisdom (1990 census).

\section{Geology}

The Big Hole Basin formed by east-west extension between rotating fault blocks (Ruppel, 1993, p. 21). The eastern basin margin is defined by a nearly vertical fault that abuts against east-west-trending faults at both ends of the basin (Ruppel, 1993; Hanneman, 1984a, 1984b). Normal faults, downdropped to the east, define the arcuate westem basin margin (Ruppel, 1993). Readily visible scarps in glacial and alluvial deposits demonstrate that faulting has continued into Quaternary time (Levings, 1986, p. 7).

Gravity and drill-hole data indicate that the Big Hole Basin is the largest and deepest intermontane basin in southwest Montana (Ruppel, 1993), and in all Montana basins for which data are available. In 1983, an oilexploration drill hole in the west-central part of the basin (03S16W27AAC) penetrated 15,910 ft of Cenozoic basin fill before reaching Precambrian bedrock. Another exploratory drill hole near Jackson (04S15W31 BBD) penetrated Precambrian bedrock at $9,341 \mathrm{ft}$, overlain by $953 \mathrm{ft}$ of Tertiary volcanic rocks and 8,388 ft of sedimentary basin fill (Montana Board of Oil and Gas Conservation, unpub. data, 1990).

Several investigators have examined the geology of the Big Hole Basin (table 9). The geologic units described by previous investigators are summarized below. These geologic units are referenced to hydrogeologic units defined in this study (table 2) to provide a consistent regional framework. In the following discussion, the hydrogeologic-unit abbreviations are italicized.

Table 9. Geologic maps of the Big Hole Basin, Montana

\begin{tabular}{|c|c|c|c|c|}
\hline Type of map & Scale & Location & Map features & Reference \\
\hline Geology & $1: 24,000$ & $\begin{array}{l}\text { Wisdom quadrangle (lat } \\
45^{\circ} 30^{\prime} \mathrm{N} \text {. to } \\
45^{\circ} 37^{\prime} 30^{\prime \prime} \mathrm{N} \text {., long } \\
113^{\circ} 22^{\prime} 30^{\prime \prime} \mathrm{W} \text {. to } \\
113^{\circ} 30^{\prime} \mathrm{W} \text {.) }\end{array}$ & $\begin{array}{l}\text { Differentiates } 1 \text { Tertiary and } 8 \text { Quatemary basin- } \\
\text { fill units }\end{array}$ & Hanneman, 1984a \\
\hline Geology & $1: 24,000$ & $\begin{array}{l}\text { Mud Lake quadrangle (lat } \\
45^{\circ} 37^{\prime} 30^{\circ} \mathrm{N} \text {. to } \\
45^{\circ} 45^{\prime} \mathrm{N} \text {., long } \\
113^{\circ} 22^{\prime} 30^{\prime} \mathrm{W} \text {. to } \\
113^{\circ} 30^{\prime} \mathrm{W} \text {.) }\end{array}$ & $\begin{array}{l}\text { Differentiates } 1 \text { Tertiary and } 6 \text { Quatemary basin- } \\
\text { fill units }\end{array}$ & Hanneman, 1984b \\
\hline Geology & $1: 384,000$ & Entire Big Hole Basin & $\begin{array}{l}\text { Differentiates } 1 \text { Tertiary and } 5 \text { Quatemary basin- } \\
\text { fill units }\end{array}$ & $\begin{array}{l}\text { Levings, 1986, fig. } 6 \text {, } \\
\text { p. } 8-9\end{array}$ \\
\hline $\begin{array}{l}\text { Principal } \\
\text { faults }\end{array}$ & $1: 500,000$ & Entire Big Hole Basin & $\begin{array}{l}\text { Shows inferred direction and distance of } \\
\text { extension along faults. Also includes locations } \\
\text { of oil exploration drill holes }\end{array}$ & Ruppel, 1993, sheet 1 \\
\hline Geology & $1: 250,000$ & Entire Big Hole Basin & $\begin{array}{l}\text { Differentiates } 1 \text { Tertiary and } 7 \text { Quatemary basin- } \\
\text { fill units }\end{array}$ & $\begin{array}{l}\text { Ruppel and others, } \\
1993\end{array}$ \\
\hline
\end{tabular}

Bedrock that surrounds and underlies the Big Hole Basin is predominantly metasedimentary rocks in the south and igneous intrusive rocks in the north (Thompson and others, 1981; Ruppel, 1993). Metasedimentary rocks of the Middle Proterozoic Belt Supergroup (Yms) form the southem Pioneer and Beaverhead Mountains that border the southern Big Hole Basin. These rocks were also encountered beneath basin fill in the two exploratory drill holes described above. Most of the Middle Proterozoic rocks surrounding the basin consist of quartzite, argillite, and siltite with minor amounts of conglomerate. The Proterozoic rocks are extensively faulted and, in places, intruded by Cretaceous and early Tertiary plutonic rocks (TKi). Northwest of the basin, the Anaconda Range is composed of Tertiary biotite-muscovite granodiorite (TKi) associated with the Idaho Batholith (fig. 4). Northeast of the basin, in the northem Pioneer Mountains, Cretaceous to Tertiary granitic rocks (TKi) intrude metasedimentary rocks of the Missoula Group (Yms). Tertiary volcanic rocks (QTKe) floor much of the basin (Ruppel and others, 1993). 
Tertiary sediments (Ts) crop out on pediments at the bases of the Anaconda Range and Pioneer Mountains. Tertiary sediments along the Beaverhead Mountain front, however, are mostly covered by glacial deposits. Tertiary sediments that fill the Big Hole Basin belong to the Renova Formation and the overlying Sixmile Creek Formation of the Bozeman Group; however, it is difficult to distinguish the two formations in this basin. The heterogeneous sediments consist of light-gray to yellowish-brown, moderately indurated to well-indurated tuffaceous sandstone, siltstone, and mudstone with some lacustrine limestone, marl, tuff, shale, and conglomerate, and are commonly veneered with gravel or occasionally one foot or less of loess (Hanneman, 1984a, 1984b; Ruppel and others, 1993).

Quatemary glacial deposits, including glacial till $(Q g)$ and glacial outwash (Qal), mantle Tertiary sediments along the western basin margin, as remnants of Pleistocene alpine glaciation in the Beaverhead Mountains and the Anaconda Range. Glacial till crops out as dissected terminal moraines overlying pediment gravels, and consists of unsorted clay, silt, sand, cobbles, and deeply weathered boulders. Interfingering with the till and extending well into the central basin are deposits of glacial outwash as much as $100 \mathrm{ft}$ thick. Glacial outwash consists of boulders, cobbles, gravels and sand, generally in well-sorted, stratified lenses. As the distance from the mountain sources increases, the thickness of these deposits decreases, and sorting and particle roundness increase (Levings, 1986; Hanneman, 1984a; Ruppel and others, 1993).

Quaternary alluvium (Qal) underlies the flood plains of the Big Hole River and its major tributaries, and consists of cobbles, gravel, sand, silt and clay. In general, these deposits tend to be coarser with depth (Levings, 1986). Their thickness is indeterminate because it is difficult to discem them from underlying deposits (Ruppel and others, 1993).

\section{Hydrology}

The Big Hole River begins in the mountains south of the Big Hole Basin, and gains water from numerous tributaries during its northward traverse of the basin. Tributaries from the west contribute more water and generally experience peak flows later in the spring than tributaries from the Pioneer Mountains to the east. Diversions from the Big Hole River and its tributaries provide irrigation water for about 115,000 acres (U.S. Geological Survey, 1982, p. 55). Crops are irrigated until about the middle of July, when the canals are closed. The canals are typically reopened in early September, after the annual hay harvest (Levings, 1986). During dry years, such as 1994, lateseason irrigation diversions from seasonally low streamflow might lead to severe dewatering of the Big Hole River for at least 15 miles downstream from Wisdom. Federal and State representatives are working with local irrigators and livestock-water users to prevent future dewatering (Perry Backus, The Montana Standard, Sept. 22, 1994, p. 6A).

Streamflow data for gaging stations listed in table 10 are stored in the USGS WATSTORE database. Locations of the stations are shown in plate 1.

Surface-water quality in the Big Hole Basin is suitable for most uses. Stream water is typically a calcium bicarbonate or calcium sodium bicarbonate type. Sodium concentrations are relatively large in Plimpton and Howell Creeks, where deeply circulated ground water contributes to baseflow. Average dissolved-solids concentrations generally are less than $100 \mathrm{mg} / \mathrm{L}$, with smaller concentrations typically occurring during periods of high flow. However, in Steel Creek, a historically mined watershed in the Pioneer Mountains, the concentration of dissolved solids, including total recoverable metals, increases during high flow (Levings, 1986, p. 27).

As part of a reconnaissance survey of arsenic in the upper Missouri River basin, water samples were collected from the Big Hole River near Twin Bridges (gaging station 06026400) and analyzed for arsenic twelve times under various hydrologic conditions from November 1985 to October 1986. Although the station is located downstream 
Table 10. Summary of data for U.S. Geological Survey streamflow-gaging stations in the Big Hole Basin, Montana

[Type of data collected: $c$, water chemistry; $d$, discharge; s, suspended sediment; t, temperature. Periods of record for stations that were being operated as of November 1994 are indicated by the first year of record followed by a dash only. Abbreviations: $\mathrm{ft}^{3} / \mathrm{s}$, cubic feet per second. Symbol: --, no data]

\begin{tabular}{|c|c|c|c|c|c|c|c|c|c|}
\hline \multirow[b]{2}{*}{$\begin{array}{l}\text { Station } \\
\text { number }\end{array}$} & \multirow[b]{2}{*}{ Station name } & \multirow{2}{*}{$\begin{array}{l}\text { Dralnage } \\
\text { area } \\
\text { (square } \\
\text { miles) }\end{array}$} & \multirow{2}{*}{$\begin{array}{l}\text { Type } \\
\text { of data } \\
\text { cot } \\
\text { lected }\end{array}$} & \multirow[b]{2}{*}{$\begin{array}{l}\text { Perlod of record } \\
\text { (calendar Year) }\end{array}$} & \multicolumn{5}{|c|}{ Discharge for perlod of record } \\
\hline & & & & & $\begin{array}{l}\text { Mean } \\
\text { annual } \\
\left(\mathrm{ft}^{3} / \mathrm{s}\right)\end{array}$ & $\begin{array}{l}\text { Maxt- } \\
\text { mumm } \\
\left(\mathrm{ft}^{3} / \mathrm{s}\right)\end{array}$ & $\begin{array}{l}\text { Date of } \\
\text { maximum }\end{array}$ & $\begin{array}{c}\text { Mint } \\
\text { mum } \\
\left(\mathrm{ft}^{3} / \mathrm{s}\right)\end{array}$ & $\begin{array}{l}\text { Date of } \\
\text { minimum }\end{array}$ \\
\hline 06023500 & $\begin{array}{l}\text { Big Hole River near } \\
\text { Jackson }\end{array}$ & 44.0 & d & $1948-53$ & 52.1 & 938 & $05-29-48$ & 5 & $02-01-50$ \\
\hline 06024000 & $\begin{array}{l}\text { Miner Creek near } \\
\text { Jackson }\end{array}$ & 17.6 & d & $1948-53$ & 33.76 & 336 & $06-22-50$ & 3 & $01-31-50$ \\
\hline 06024450 & $\begin{array}{l}\text { Big Hole River below } \\
\text { Big Lake Creek, at } \\
\text { Wisdom }\end{array}$ & 575 & $d, t$ & May-Sept. 1988- & - & 4,300 & $06-07-91$ & 0 & $08-28-88$ \\
\hline 06024500 & $\begin{array}{l}\text { Trail Creek near } \\
\text { Wisdom }\end{array}$ & 71.4 & d & $1948-53,1966-72$ & 85.3 & 1,350 & $06-02-72$ & 1.6 & $11-09-69$ \\
\hline 06024580 & $\begin{array}{l}\text { Big Hole River near } \\
\text { Wise River }\end{array}$ & 1,611 & d, c & $\begin{array}{l}\text { June 1979-Sept. } \\
1981\end{array}$ & ${ }^{1} 888$ & 6,420 & $06-10-81$ & 80 & $01-28-80$ \\
\hline 06024590 & $\begin{array}{l}\text { Wise River near Wise } \\
\text { River }\end{array}$ & 214 & d & $1972-85$ & 183 & 2,730 & $06-16-74$ & 13 & $11-28-76$ \\
\hline 06025000 & $\begin{array}{l}\text { Big Hole River near } \\
\text { Dewey }\end{array}$ & 1,990 & d & $1910-13$ & 1,377 & 11,600 & $06-13-13$ & -- & -- \\
\hline 06025500 & $\begin{array}{l}\text { Big Hole River near } \\
\text { Melrose }\end{array}$ & 2,476 & $\begin{array}{l}d \\
s \\
\text { t }\end{array}$ & $\begin{array}{l}1923- \\
1956-57,1960-64 \\
1956-57,1960-64, \\
1977 .\end{array}$ & 1,118 & 23,000 & $06-14-27$ & 49 & $08-17-31$ \\
\hline
\end{tabular}

${ }^{1}$ Data for water year 1981.

from, and not within, the Big Hole Basin (pl. 1), samples collected at the station probably are indicative of arsenic concentrations within the basin. The concentration of total recoverable arsenic was $2 \mu \mathrm{g} / \mathrm{L}$ or less for all samples under flow conditions ranging from 128 to $4,330 \mathrm{ft}^{3} / \mathrm{s}$ (Knapton and Horpestad, 1987, p. 16), well below the maximum contaminant level of $50 \mu \mathrm{g} / \mathrm{L}$ arsenic established by the U.S. Environmental Protection Agency (1991) for treated drinking water.

Ground water in the Big Hole Basin is obtained primarily from Quaternary and Tertiary basin fill. Most wells are less than $125 \mathrm{ft}$ deep, and provide water for domestic and livestock use. Wells completed in Quaternary deposits produce yields comparable to most wells completed in shallow Tertiary sediments (table 11). Except for one 475$\mathrm{ft}$-deep well completed in Tertiary sediments in Wisdom (02S15W34CCCB01) that reportedly produces 250 $\mathrm{gal} / \mathrm{min}$, all wells used to compile table $11 \mathrm{yield} 50 \mathrm{gal} / \mathrm{min}$ or less. The low production rates, however, may be due more to the small casing diameters ( 6 in. or less) used for domestic and livestock wells, than to the limitations of the aquifers.

Table 11. Summary of data for yield and specific capacity of wells completed in selected hydrogeologic units in the Big Hole Basin, Montana

[Source: Dutton and others, 1995. Hydrogeologic units: Qal, Holocene and Pleistocene alluvial deposits; Ts, Tertiary sedimentary deposits and rocks. Abbreviations: $\mathrm{gal} / \mathrm{min}$, gallon per minute; (gal/min)/ft, gallon per minute per foot]

\begin{tabular}{|c|c|c|c|c|c|c|c|c|c|c|}
\hline \multirow{2}{*}{$\begin{array}{l}\text { Hydro- } \\
\text { goologle } \\
\text { unit }\end{array}$} & \multirow[b]{2}{*}{$\begin{array}{c}\text { Number of } \\
\text { wells }\end{array}$} & \multicolumn{4}{|c|}{ Yield (gal/min) } & \multirow[b]{2}{*}{$\begin{array}{c}\text { Number of } \\
\text { wells }\end{array}$} & \multicolumn{4}{|c|}{ Specific capacity $[(\mathrm{g} a \mid / \mathrm{m} / \mathrm{n}) / \mathrm{tt}]$} \\
\hline & & Mean & Modian & $\begin{array}{l}\text { Mint } \\
\text { mum }\end{array}$ & $\begin{array}{l}\text { Maxh- } \\
\text { mum }\end{array}$ & & Mean & Modian & $\begin{array}{l}\text { Mint- } \\
\text { mum }\end{array}$ & $\begin{array}{l}\text { Maxt } \\
\text { mum }\end{array}$ \\
\hline$\overline{\text { Qal }}$ & 10 & 11 & 10 & 2.4 & 20 & 7 & 2.4 & 2.0 & 1.0 & 5.0 \\
\hline Ts & 25 & 24 & 11 & 3.2 & 250 & 25 & 6.1 & 1.3 & .2 & 83 \\
\hline
\end{tabular}


A few domestic wells tap bedrock aquifers along the basin margins. Two wells completed in igneous intrusive rocks reportedly produce $8-12 \mathrm{gal} / \mathrm{min}$. One of these wells has a specific capacity of $0.1(\mathrm{gal} / \mathrm{min}) / \mathrm{ft}$; the other was not tested (Dutton and others, 1995).

Levings (1986, sheet 1) and Briar and others (in press) have compiled potentiometric-surface maps of the Big Hole Basin, each with a contour interval of $100 \mathrm{ft}$. Levings' (1986) map, at a scale of 1:170,000, is based on water levels measured in 1982. Briar and others' (in press) map, at a scale of 1:750,000, is based on water levels measured in 1991. Comparison between the two maps reveals no significant changes over time. Both maps indicate that ground water flows from the uplands toward the valley floor, then northward along the Big Hole River.

Basin-fill aquifers are recharged by precipitation and snowmelt, surplus irrigation water, leakage from irrigation canals, subsurface inflow from bedrock, and infiltration from the Big Hole River and tributary streams. The ground-water contribution area (fig. 2, pl. 1) is about $1,280 \mathrm{mi}^{2}$. Infiltration anywhere within this area could potentially recharge basin-fill aquifers in the Big Hole Basin. Well hydrographs indicate that most recharge occurs between early spring, when the ground thaws, and early summer, when streamflow decreases and evapotranspiration increases (Levings, 1986). The presence of Jackson Hot Springs (05S15W25CBBB) may indicate a source of geothermal water from bedrock. The spring discharges water with a temperature of $58{ }^{\circ} \mathrm{C}$ at a rate of $260 \mathrm{gal} / \mathrm{min}$ (Sonderegger and Bergantino, 1981). Ground water discharges from basin-fill aquifers by evapotranspiration, withdrawals from wells, and seepage to springs, seeps, and stream channels. Levings (1986) computed a simplified ground-water budget for the Big Hole Basin which assumes that all recharge comes from precipitation and discharge is 73 percent evapotranspiration and 27 percent leakage to stream channels.

Water levels were measured from 1982 through 1991 at a 205 -ft-deep well completed in Tertiary sediments near Wisdom (03S15W16DCCD01). Water levels in the well fluctuated between $20.22 \mathrm{ft}$ below land surface (recorded July 25-26, 1983) and $28.13 \mathrm{ft}$ below land surface (April 15-16, 1983). The complete water-level record and records from eight other wells that were monitored monthly in 1982-83 (Levings, 1986) are stored in the USGS WATSTORE database.

The quality of ground water throughout the basin is suitable for irrigation and domestic use, although large concentrations of iron in some areas may cause undesirable staining (Levings, 1986). The type and quality of ground water in the basin was determined on the basis of 48 samples analyzed for major ions and measured dissolved-solids concentrations, and 1 sample in which dissolved-solids concentrations were estimated from specific-conductance measurements. Ground water is a calcium sodium bicarbonate type in most of the basin, with a significant amount of magnesium in the south-central and southern areas. The concentration of dissolved solids is less than $250 \mathrm{mg} / \mathrm{L}$ except beneath the Tertiary pediment east of Wisdom, where dissolved-solids concentrations typically range from about 250 to $500 \mathrm{mg} / \mathrm{L}$ (Clark and Dutton, in press). Wells near Jackson Hot Springs produce a sodium-bicarbonate type water similar in composition to the hot spring water (Levings, 1986), which has a dissolved-solids concentration of $660 \mathrm{mg} / \mathrm{L}$ (Sonderegger and Bergantino, 1981).

\section{Selected References}

Black, G.A., 1983, Geology and geothermal system near Jackson, Beaverhead County, Montana: Bozeman, Montana State University, M.S. thesis, 111 p.

Briar, D.W., Lawlor, S.M., Stone, M.A.J., Parliman, D.J., Shaefer, J.L., and Kendy, Eloise, in press, Ground-water levels in intermontane basins of the Northern Rocky Mountains, Montana and Idaho: U.S. Geological Survey Hydrologic Investigations Atlas 738-B, 1 sheet, scale 1:750,000.

Brumbaugh, D.S., 1973, Structural analysis of the complexly deformed Big Hole area, Madison, Beaverhead, and Silver Bow Counties, Montana: Bloomington, Indiana University, Ph.D. dissertation, 96 p.

Clark, D.W., and Dutton, D.M., in press, Quality of ground water and surface water in intermontane basins of the Northern Rocky Mountains, Montana and Idaho: U.S. Geological Survey Hydrologic Investigations Atlas 738-C, 1 sheet, scale 1:750,000. 
Dutton, D.M., Lawlor, S.M., Briar, D.W., and Tresch, R.E., 1995, Hydrogeologic data for the Northern Rocky Mountains intermontane basins, Montana: U.S. Geological Survey Open-File Report 95-143, 94 p.

Hanneman, D.L., 1984a, Geologic map of the Wisdom quadrangle, Beaverhead County, Montana: U.S. Geological Survey Miscellaneous Field Studies Map MF-1695, scale 1:24,000.

1984b, Geologic map of the Mud Lake quadrangle, Beaverhead County, Montana: U.S. Geological Survey Miscellaneous Field Studies Map MF-1696, scale 1:24,000.

Hanneman, D.L., and Nichols, Ralph, 1981, Late Tertiary sedimentary rocks of the Big Hole basin, southwest Montana [abs.]: Geological Society of America (Rocky Mountain Section), Abstracts with Programs, v. 13, no. 4, p. 199.

Knapton, J.R., and Horpestad, A.A., 1987, Arsenic data for streams in the upper Missouri River basin, Montana and Wyoming: U.S. Geological Survey Open-File Report 87-124, 25 p.

Levings, J.F., 1986, Water resources of the Big Hole Basin, southwestern Montana: Montana Bureau of Mines and Geology Memoir 59, 72 p.

McCulloch, Robin, 1993, Montana mining directory 1992: Montana Bureau of Mines and Geology Bulletin 131, 76 p.

National Oceanic and Atmospheric Administration, 1992, Monthly normals of temperature, precipitation, and heating and cooling degree days, 1961-90, Montana: Asheville, N.C., Climatography of the United States no. 81, unpaged.

Perry, E.S., 1934, Physiography and ground-water supply in the Big Hole Basin, Montana: Montana Bureau of Mines and Geology Memoir 12, 18 p.

Ruppel, E.T., 1982, Cenozoic block uplifts in east-central Idaho and southwest Montana: U.S. Geological Survey Professional Paper 1224, 24 p.

1993. Cenozoic tectonic evolution of southwest Montana and east-central Idaho: Montana Bureau of Mines and Geology Memoir 65, 62 p.

Ruppel, E.T., O'Neill, J.M., and Lopez, D.A, 1993, Geologic map of the Dillon $1^{\circ} \times 2^{\circ}$ quadrangle, Idaho and Montana: U.S. Geological Survey Miscellaneous Investigations Series Map I-1803-H, scale 1:250,000.

Sonderegger, J.L., and Bergantino, R.N., 1981, Geothermal resources map of Montana: Montana Bureau of Mines and Geology Hydrogeologic Map 4, scale 1:1,000,000.

Thompson, G.R., Fields, R.W., and Alt, David, 1981, Tertiary paleoclimates, sedimentation patterns and uranium distribution in southwestern Montana, in Montana Geological Society Field Conference and Symposium Guidebook to Southwest Montana: [Billings, Mont.], Montana Geological Society, p. 105-109.

Tuck, L. K., Briar, D.W., and Clark, D.W., in press, Hydrogeology of the Northern Rocky Mountains intermontane basins, Montana and Idaho: U.S. Geological Survey Hydrologic Investigations Atlas 738-A, 2 sheets, scale 1:750,000.

U.S. Environmental Protection Agency, 1991, Maximum contaminant levels (subpart B of part 141, National interim primary drinking-water regulations): U.S. Code of Federal Regulations, Title 40, Parts 100 to 149, revised July 1, 1991, p. 585-588.

U.S. Geological Survey, issued annually, Water resources data, Montana: Helena, Mont., U.S. Geological Survey Water-Data Report.

U.S. Geological Survey, 1982, Water resources data, Montana, Water Year 1981, Volume 1. Hudson Bay and Missouri River basins: U.S. Geological Survey Water-Data Report MT-81-1, 647 p.

U.S. Soil Conservation Service, 1977, Average annual precipitation in Montana, based on 1941-1970 data: Bozeman, Mont. $13 \mathrm{p}$.

Wallace, C.A., Lidke, D.J., Elliot, J.E., Desmarais, N.R., Obradovich, J.D., Lopez, D.A., Zarske, S.E., Heise, B.A., Blaskowski, M.J., and Loen, J.S., 1992, Geologic map of the Anaconda-Pintlar Wilderness and contiguous roadless area, Granite, Deer Lodge, Beaverhead, and Ravalli Counties, western Montana: U.S. Geological Survey Miscellaneous Field Studies Map MF-1633-C, 2 sheets, scale 1:50,000; accompanying text $36 \mathrm{p}$. 


\section{Bitterroot Valley}

\section{Geography}

The Bitterroot Valley is an approximately north-south-trending intermontane basin averaging about 7 miles wide, and encompassing an area of about $430 \mathrm{mi}^{2}$. It is bounded by the Bitterroot Mountains on the west, the Clark Fork and the Missoula Valley on the north, the Sapphire Mountains on the east, and the Anaconda Range on the southeast (pl. 1). This intermontane basin extends southward about 60 miles along the Bitterroot River from its confluence with the Clark Fork.

The Bitterroot Valley contains two principal topographic features. In the center of the basin is the flood plain of the Bitterroot River, which generally is 1 to $2 \mathrm{mi}$ wide. Along the west and east sides of the basin are extensive high terraces or benches that range from 3 to 6 mi wide. These benches typically slope toward the flood plain at angles ranging from $4^{\circ}$ or $5^{\circ}$ near the basin margins, to less than $1^{\circ}$ near the flood plain. Terraces on the east side

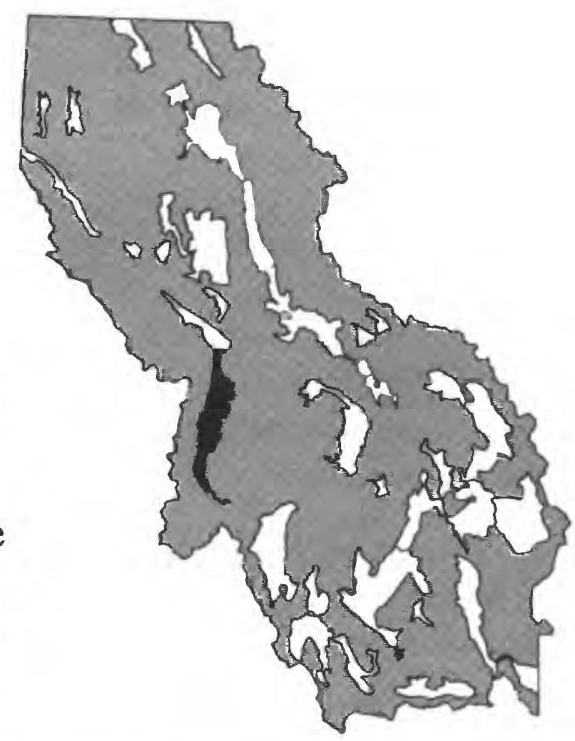
of the basin have smooth topography and generally end in 50- to 150-ft scarps, whereas terraces on the west side of the basin are dissected and merge gently with the flood plain. The Bitterroot Valley ranges in altitude from about $3,200 \mathrm{ft}$ where the Bitterroot River flows out of the basin, to about 5,500 ft on the highest terrace.

The climate of the Bitterroot Valley is typical of mid-elevation intermontane basins of the Northern Rocky Mountains west of the Continental Divide, with cold winters, mild summers, and light precipitation. On the basis of the 1961-90 period of record, the average annual precipitation at Stevensville (altitude 3,380 $\mathrm{ft}$ ) is 12.3 in., and the average annual temperature is $45.1^{\circ} \mathrm{F}$ (National Oceanic and Atmospheric Administration, 1992). The average last occurrence of $32^{\circ} \mathrm{F}$ is May 30, and the average first occurrence is September 10 (Natural Resources Conservation Service, U.S. Department of Agriculture, unpub. data., 1994). Mean monthly climatic data for Stevensville are plotted in figure 8. Precipitation generally increases to the south. For example, at Darby (altitude $3,880 \mathrm{ft}$ ), about $34 \mathrm{mi}$ south of Stevensville, the average annual precipitation is $15.8 \mathrm{in}$. The average temperature and length of the growing season, however, are about the same in Darby as in Stevensville (National Oceanic and Atmospheric Administration, 1992; Natural Resources Conservation Service, U.S. Department of Agriculture, unpub. data, 1994).

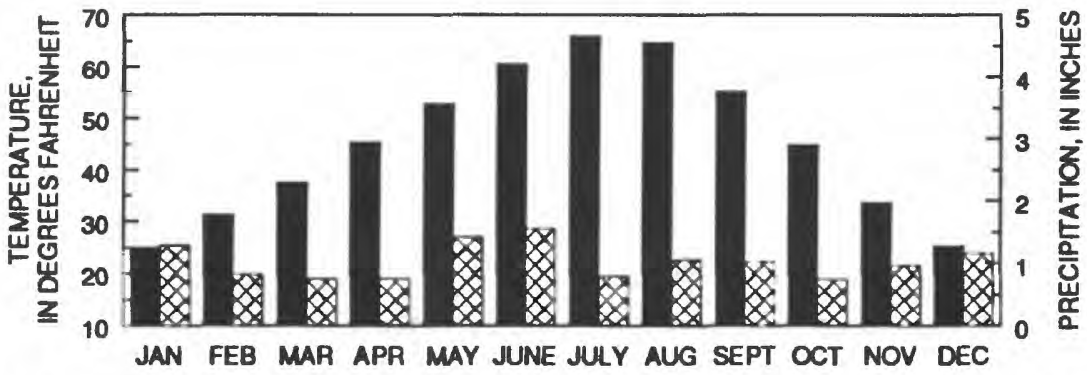

EXPLANATION

MEAN MONTHLY TEMPERATURE FOR 1961-90 PERIOD OF RECORD

$\bigotimes$

\section{MEAN MONTHLY PRECIPITATION FOR 1961-90 PERIOD OF RECORD}

Figure 8. Mean monthly precipitation and temperature at Stevensville, Mont. Data from National Oceanic and Atmospheric Administration (1992).

About 50,000 people reside in the Bitterroot Valley, including 2,746 in the unincorporated community of Lolo, 2,737 in the City of Hamilton, 1,221 in the Town of Stevensville, 625 in the Town of Darby, 624 in the unincorporated community of Victor, and 405 in the unincorporated community of Corvallis. The City of Missoula, 
which includes parts of both the Bitterroot and Missoula Valleys, has 42,918 residents (1990 census). Recently, the population of Ravalli County, which encompasses about three-fourths of the Bitterroot Valley, has increased at one of the fastest rates in Montana, nearly doubling from 14,400 in 1970 to 27,400 in 1992. Between 1990 and 1992 , the population grew by 9.7 percent, putting the county among the fastest growing areas in the nation (Great Falls Tribune, Feb. 8, 1994, p. 1B). Rapid population growth is not unprecedented in this area. The Bitterroot Valley was the first permanently settled area in the state. According to an early historical sketch, "The Bitterroot Valley has suffered through several programs of high pressure promotional land development," which resulted in the valley floor being subdivided into small tracts long before other Montana basins (U.S. Soil Conservation Service, 1947). In the 1960's, most farms were smaller than 50 acres (McMurtrey and others, 1972). In contrast with previous development growth cycles, the bench areas along the east and west sides of the basin are accommodating much of the recent population growth.

Land use in the Bitterroot Valley has long been dominated by irrigated agriculture. The first irrigation system in Montana was built in the 1840's by Jesuit missionaries to raise potatoes, wheat, oats, and garden vegetables in the Bitterroot Valley. In the ensuing years, hundreds of separate irrigation systems, from individually owned small diversions to major ditches serving thousands of acres, were dug in the gravelly subsoil. The principal crops were alfalfa and grass hay, sugar beets, peas, beans, potatoes, small grains, apples, cherries, and berries, much of which were processed locally. However, the orchards began to decline about 1930. The decreased productivity which precipitated the decline was caused in large part by waterlogging due to leaky canals, and soil leaching due to excessive springtime irrigation. Ironically, water shortages commonly occurred later in the season. Owing to these problems, grains, sugar beets, potatoes, and alfalfa gradually replaced most of the orchards. By 1950, 104,000 acres remained under irrigation--29,000 acres with diversions from the Bitterroot River, and 75,000 acres from tributary streams ([Montana] State Engineer's Office, 1958a; U.S. Soil Conservation Service, 1947). Today, hay and pasture and some apple orchards are the main irrigated crops. Dryland grains--primarily wheat and barley--are grown on the eastern terraces. The terraces also are used as rangeland (J.C. Eggen, Agricultural Stabilization and Conservation Service, oral commun., 1993).

Although the Bitterroot Valley is best known as an agricultural area, its economy has also benefitted significantly, albeit intermittently, from mining and timber harvesting. The lumber industry provided the impetus for the first major developments in the basin. By the 1940's, about 12 percent of the population depended on 20 local sawmills, while gold and silver were produced from eleven local mining districts (U.S. Soil Conservation Service, 1947). Today, gold and tin are placer-mined and underground-mined in the West Fork of the Bitterroot River drainage area, and gold exploration is ongoing in the West Fork and Bluejoint Creek drainage areas (McCulloch, 1993, p. 15, 49). Timber continues to be harvested from the Bitterroot and Sapphire Mountains.

\section{Geology}

The Bitterroot Valley is a structural basin formed initially during emplacement of the Idaho Batholith (fig. 4), either by the basin floor dropping down (McMurtrey and others, 1972) or by eastward transport of a major thrust plate (Hyndman and others, 1975). Gravity data indicate a distinct, relatively straight western basin margin, in contrast with an irregular eastern margin (Noble and others, 1982). Within the basin, lower Tertiary sediments have been deformed into a faulted syncline, whereas Pliocene sediments are relatively undisturbed (McMurtrey and others, 1972). According to gravity and magnetic data, Tertiary and Quatemary sediments attain a maximum thickness of more than 3,000 ft near Corvallis and Hamilton (Noble and others, 1982; Crosby, 1976).

Several investigators have examined the geology of the Bitterroot Valley (table 12). The geologic units described by previous investigators are summarized below. These geologic units are referenced to hydrogeologic units defined in this study (table 2) to provide a consistent regional framework. In the following discussion, the hydrogeologic-unit abbreviations are italicized. 
Table 12. Geologic and geophysical maps of the Bitterroot Valley, Montana

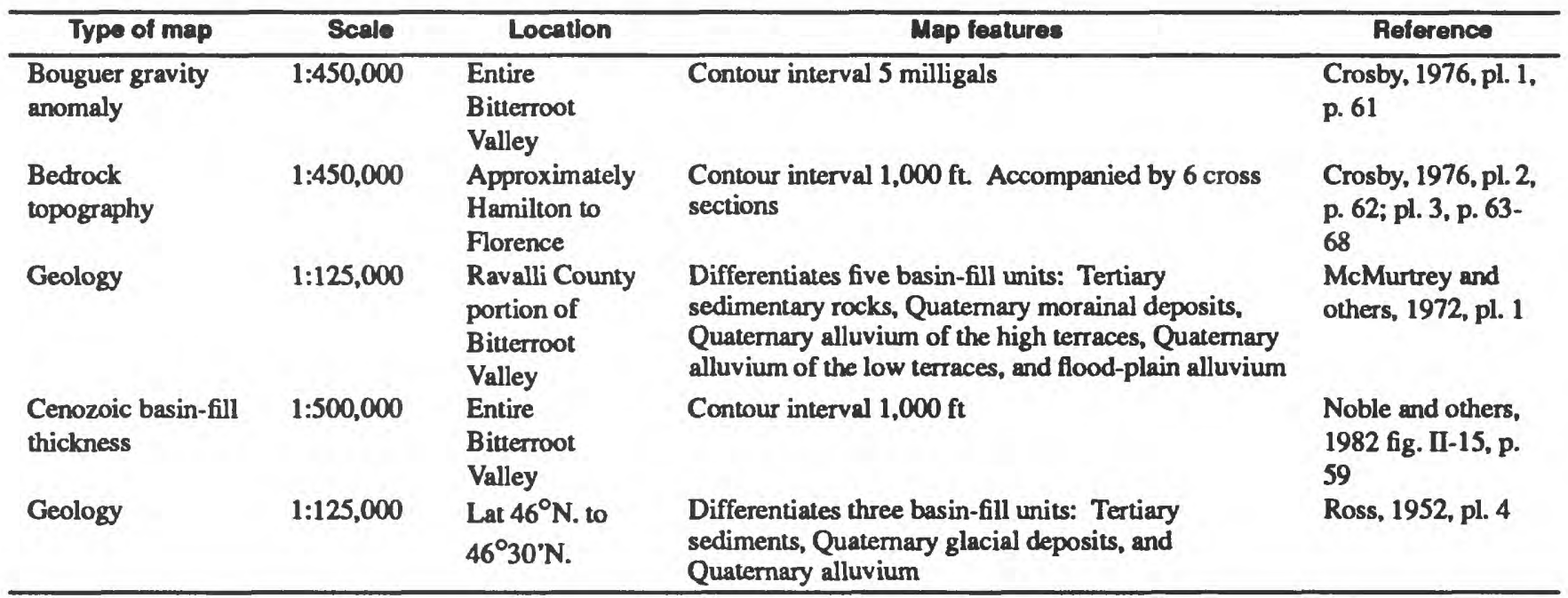

Metasedimentary, intrusive, metamorphic, and volcanic bedrock border the Bitterroot Valley. East of the basin, the Sapphire Mountains are composed mostly of metasedimentary rocks of the Middle Proterozoic Belt Supergroup (Yms) including quartzites, quartzitic and calcareous argillite, and argillaceous limestone. West and south of the basin, the Bitterroot, Anaconda and southern Sapphire Mountains are composed of Cretaceous granitic rocks (TKi) associated with the Idaho Batholith (fig. 4). These rocks are mostly gray quartz monzonite with some granodiorite and anorthite. Along the westem basin margin, the granitic rocks are bordered by gneiss which formed during batholith emplacement. The gneiss border averages about $2,000 \mathrm{ft}$ thick. Tertiary volcanic rocks (QTKe), ranging in composition from acidic to basic, crop out locally near fault zones along basin margins (McMurtrey and others, 1972).

Tertiary sediments (Ts) overlie bedrock throughout the basin and crop out on the eastern terraces. These unconsolidated to semiconsolidated deposits are dominantly brown and gray clay, ash, and silt interbedded with occasional lenses of poorly sorted sand and gravel. In outcrop, relatively coarse-grained, poorly sorted colluvial deposits along the basin margins grade into fine-grained alluvial-fan deposits, which themselves grade into silty, clayey flood-plain deposits toward the center of the basin. Interbedded in the flood-plain deposits are unconsolidated sand and gravel lenses deposited by the ancestral Bitterroot River (McMurtrey and others, 1972). Drillers commonly refer to a characteristic "blue clay" in logs of Tertiary sediments (Finstick, 1986; Uthman, 1988).

A veneer of Quaternary deposits overlies Tertiary sediments except on the high eastern terraces. Glacial till $(\mathrm{Qg})$ underlies many of the tributary valleys that emanate from the Bitterroot Mountains. These unsorted, unconsolidated deposits consist of boulders, cobbles, gravel, sand, silt, and a large amount of clay. Glacial outwash (Qal) forms alluvial fans on the west side of the basin consisting of angular to well-rounded boulders, cobbles, gravel, sand, and silt. Glacial-lakebed deposits $(Q g)$ of glacial Lake Missoula interfinger with glacial till and outwash and extend northward into the Missoula Valley. Outcrops of glacial-lakebed deposits are 40 to $50 \mathrm{ft}$ thick and consist of fine-grained, well-sorted, well-bedded sand interbedded with silt, clay, and some gravel. About $40 \mathrm{ft}$ of Quaternary alluvial-fan deposits (QTd) consisting of well-rounded gravel, sand, and silt mantles the terraces in most places. In general, the sorting increases and the average grain size decreases with distance from the mouths of tributary canyons. Holocene alluvium $(\mathrm{Qal})$ underlies the flood plain of the Bitterroot River and its major tributaries. Composed of reworked Tertiary and Pleistocene deposits, flood-plain alluvium is about $40 \mathrm{ft}$ thick beneath the Bitterroot River and is dominated by gravel and sand, with a small amount of silt and clay (McMurtrey and others, 1972). 


\section{Hydrology}

The major surface-water artery of the Bitterroot Valley is the Bitterroot River, which originates in the southem Bitterroot Mountains and flows northward through the basin to its confluence with the Clark Fork. About four times as many tributaries join the river from the Bitterroot Mountains as from the relatively arid Sapphire Mountains. Natural flows in the Bitterroot River and its tributaries typically peak in the spring, decline over the summer, and remain relatively stable through the winter. About 55 percent of the runoff in the river discharges in May and June in response to snowmelt and rainfall (McMurtrey and others, 1972). During the summer, irrigation withdrawals significantly reduce flow in the Bitterroot River and some of its tributaries; some stream reaches downstream from Hamilton routinely approach the minimum flows required to support fisheries (Nunnallce and Botz, 1976). However, a portion of the diverted water eventually drains back into the river system. Irrigation return flow to the Bitterroot River amounts to about 280,000 acre-ft during a normal year, and about 216,000 acre-ft during a dry year (U.S. Soil Conservation Service, 1947).

McMurtrey and others (1972) calculated water budgets for the Bitterroot River south of the Ravalli County line for 1938 through 1959. In an average year, 1,772,000 acre-ft flowed into the basin above Darby. Of this total, 37 percent entered from the south, 11 percent from the east, and 52 percent from the west. An average of 1,540,000 acre-ft/yr discharged from the Bitterroot River at Florence; thus an estimated 232,000 acre-ft/yr, or 13 percent of the total surface-water inflow was lost between Darby and Florence.

Streamflow data for gaging stations listed in table 13 are stored in the USGS WATSTORE database. Locations of the stations are shown on plate 1. In addition, the USGS has published monthend reservoir volume records for Painted Rocks Lake (station 12342000, drainage area $317 \mathrm{mi}^{2}$ ) since 1940 and Lake Como (station 12344500, drainage area $54.6 \mathrm{mi}^{2}$ ) since 1939. Data for years prior to 1961 are published in Water-Supply Papers; more recent data are in annual Water-Data Reports (U.S. Geological Survey, issued annually). Water-quality data were collected from Lake Como in 1956. Both lakes supply irrigation water to the Bitterroot Valley.

The quality of surface water in the Bitterroot Valley is influenced by the geology of the headwater areas. Streams draining the Bitterroot Mountains flow through terrains of igneous and metamorphic rocks, which are relatively resistant to dissolution. As a result, these streams have low concentrations of dissolved solids. For example, six streams draining the Bitterroot Mountains that were sampled in the fall of 1957 had dissolved-solids concentrations ranging from 11 to $21 \mathrm{mg} / \mathrm{L}$. In comparison, six streams draining the sedimentary and igneous Sapphire Mountains had dissolved-solids concentrations ranging from 57 to $113 \mathrm{mg} / \mathrm{L}$ (McMurtrey and others, 1972). Water in the Bitterroot River, which receives inflow from streams on both sides, as well as irrigation return flow, has dissolved-solids concentrations of about 50 to $100 \mathrm{mg} / \mathrm{L}$. Calcium, sodium, and bicarbonate are the major dissolved ions (McMurtrey and others, 1972; Clark and Dutton, in press).

Ground water is of great importance to the residents of the Bitterroot Valley, most of whom rely upon it for drinking water. About 8,000 wells, including several municipal-supply systems, pump ground water from the basin.

Quatemary alluvium is the most productive aquifer. Of the 3,900 wells completed in this unconfined aquifer, about 2,500, or 64 percent, have depths of $60 \mathrm{ft}$ or less (Montana Bureau of Mines and Geology, unpub. data, 1994). Drillers' logs indicate that the predominant lithology is coarse-grained sand and gravel; consequently, yield and specific-capacity values for these wells are relatively large (table 14). On the basis of 12 aquifer tests, McMurtrey and others (1972) calculated transmissivity values ranging from 2,000 to $38,000 \mathrm{ft}^{2} / \mathrm{d}$. However, Finstick (1986) and Uthman (1988) obtained somewhat lower values from specific-capacity data reported on drillers' logs. 
Table 13. Summary of data for U.S. Geological Survey streamflow-gaging stations in the Bitterroot Valley, Montana

[Type of data collected: $c$, water chemistry; d, discharge. Periods of record for stations that were being operated as of November 1994 are indicated by the first year of record followed by $a$ dash only. Abbreviations: $\mathrm{ft}^{3} / \mathrm{s}$, cubic feet per second. Symbol: $\cdots$, no dara]

\begin{tabular}{|c|c|c|c|c|c|c|c|c|c|}
\hline \multirow[b]{2}{*}{$\begin{array}{l}\text { Station } \\
\text { number }\end{array}$} & \multirow[b]{2}{*}{ Station name } & \multirow{2}{*}{$\begin{array}{l}\text { Drainage } \\
\text { area } \\
\text { (square } \\
\text { mlles) }\end{array}$} & \multirow{2}{*}{$\begin{array}{l}\text { Type } \\
\text { of data } \\
\text { col- } \\
\text { lected }\end{array}$} & \multirow{2}{*}{$\begin{array}{l}\text { Perlod of record } \\
\text { (calendar year) }\end{array}$} & \multicolumn{5}{|c|}{ Discharge for period of record } \\
\hline & & & & & $\begin{array}{c}\text { Mean } \\
\text { annual } \\
\left(\mathrm{ft}^{3} / \mathrm{s}\right)\end{array}$ & $\begin{array}{l}\text { Maxl } \\
\text { mum } \\
\left(f^{3} / s\right)\end{array}$ & $\begin{array}{l}\text { Date of } \\
\text { maximum }\end{array}$ & $\begin{array}{l}\text { Mint } \\
\text { mum } \\
\left(\mathrm{ft}^{3} / \mathrm{s}\right)\end{array}$ & $\begin{array}{l}\text { Date of } \\
\text { minimum }\end{array}$ \\
\hline 12342500 & $\begin{array}{l}\text { West Fork Bitlerroot } \\
\text { River near Conner }\end{array}$ & 317 & d & 1941- & 269 & 4,060 & $05-09-47$ & 0.2 & $11-25-52$ \\
\hline 12343000 & $\begin{array}{l}\text { West Fork Bitterroot } \\
\text { River near Darby }\end{array}$ & 552 & d & $\begin{array}{l}\text { 1910-17 } \\
\text { (no winter records) }\end{array}$ & -- & 6,730 & $06-17-17$ & 106 & 09-07-14 \\
\hline 12343400 & $\begin{array}{l}\text { East Fork Bitterroot } \\
\text { River near Conner }\end{array}$ & 381 & d & $1956-72$ & 293 & 4,000 & $06-02-72$ & 23 & $11-29-60$ \\
\hline 12343500 & $\begin{array}{l}\text { East Fork Bitterroot } \\
\text { River at Conner }\end{array}$ & 405 & d & $1910-16,1937-57$ & 257 & 3,760 & $05-29-48$ & 1.4 & $08-17-37$ \\
\hline 12344000 & $\begin{array}{l}\text { Bitterroot River near } \\
\text { Darby }\end{array}$ & 1,049 & $\begin{array}{l}\text { d } \\
\text { c }\end{array}$ & $\begin{array}{l}1937- \\
1956\end{array}$ & 878 & 11,500 & $05-09-47$ & 71 & 02-09-39 \\
\hline 12345000 & Rock Creek near Darby & 55.4 & d & $1946-53,1957-59$ & 149 & 1,580 & $06-17-50$ & $\mathbf{0}$ & $\begin{array}{l}\text { At times, } \\
\text { owing to } \\
\text { regulation }\end{array}$ \\
\hline 12345500 & $\begin{array}{l}\text { Rock Creek Canal near } \\
\text { Darby }\end{array}$ & -- & d & $\begin{array}{l}1946,1948-53 \text { (no } \\
\text { winter records) }\end{array}$ & -- & 407 & $08-03-52$ & 0 & At times \\
\hline 12345850 & $\begin{array}{l}\text { Sleeping Child Creek } \\
\text { near Hamilton }\end{array}$ & 65.2 & d & $\begin{array}{l}1973-77 \text { (no winter } \\
\text { records) } \\
1956\end{array}$ & -- & 825 & 05-14-76 & 5.2 & $11-04-74$ \\
\hline 12346000 & $\begin{array}{l}\text { Bitterroot River near } \\
\text { Grantsdale }\end{array}$ & 1.414 & d & $1902-07$ & 11,525 & 12,900 & 06-03-03 & 5.0 & 09-19-05 \\
\hline 12346500 & $\begin{array}{l}\text { Skalkaho Creek near } \\
\text { Hamilton }\end{array}$ & 87.8 & $\begin{array}{l}\text { d } \\
\text { c }\end{array}$ & $\begin{array}{l}1949-53,1957-79 \\
1956,1980\end{array}$ & 93.5 & 1,210 & $06-01-72$ & 10 & $04-02-53$ \\
\hline 12347000 & $\begin{array}{l}\text { Skalkaho Creek at } \\
\text { Brennan's ranch, } \\
\text { near Hamilton }\end{array}$ & 96.2 & d & $\begin{array}{l}1920-24 \text { (no winter } \\
\text { records) }\end{array}$ & - & 1,110 & $06-15-22$ & 14 & $03-26-24$ \\
\hline 12347500 & $\begin{array}{l}\text { Blodgett Creek near } \\
\text { Corvallis }\end{array}$ & 25.9 & $\begin{array}{l}\text { d } \\
\text { c }\end{array}$ & $\begin{array}{l}1947-69 \\
1957\end{array}$ & 70.5 & 836 & $05-16-49$ & 1.2 & $11-09-52$ \\
\hline 12348000 & $\begin{array}{l}\text { Blodgett Creek near } \\
\text { Hamilton }\end{array}$ & 28.3 & d & $1938-43$ & 233.5 & 678 & $05-26-42$ & .6 & $08-03-42$ \\
\hline 12348200 & $\begin{array}{l}\text { Bitterroot River near } \\
\text { Corvallis }\end{array}$ & 1,711 & $\begin{array}{l}\text { d } \\
\text { c }\end{array}$ & $\begin{array}{l}1959-63 \\
1959-63\end{array}$ & 1,414 & 12,800 & $06-04-60$ & 112 & 08-27-62 \\
\hline 12348500 & $\begin{array}{l}\text { Willow Creek near } \\
\text { Corvallis }\end{array}$ & 22.4 & $\begin{array}{l}\text { d } \\
\text { c }\end{array}$ & $\begin{array}{l}1920-24,1957-65 \\
1956\end{array}$ & 15.6 & 159 & 06-12-65 & ${ }^{3} 1.0$ & $01-04-61$ \\
\hline 12349000 & $\begin{array}{l}\text { Willow Creek at } \\
\text { Anfinson Ranch, } \\
\text { near Corvallis }\end{array}$ & 23.2 & d & $1938-43$ & 6.1 & 125 & $06-09-42$ & .1 & $09-11-38$ \\
\hline 12349500 & $\begin{array}{l}\text { Fred Burr Creek near } \\
\text { Victor }\end{array}$ & 17.7 & d & $1947-51$ & 52.3 & 23,100 & $405-28-48$ & 2.7 & $09-20-48$ \\
\hline 12350000 & Bear Creek near Victor & 26.8 & $\begin{array}{l}\text { d } \\
\text { c }\end{array}$ & $\begin{array}{l}1938-54,1957-59 \\
1957\end{array}$ & 66.0 & 1,340 & $06-16-50$ & .6 & $12-01-52$ \\
\hline 12350250 & $\begin{array}{l}\text { Bitterroot River at Bell } \\
\text { Crossing, near } \\
\text { Victor }\end{array}$ & 1,963 & d & $\begin{array}{l}\text { 1987. } \\
\text { (no winter records) }\end{array}$ & - & 11,300 & $06-06-91$ & 60 & $07-16-87$ \\
\hline 12350300 & Big Creek near Victor & 32.9 & c & 1957 & -- & -- & -- & -- & -- \\
\hline 12350500 & $\begin{array}{l}\text { Kootenai Creek near } \\
\text { Stevensville }\end{array}$ & 28.9 & $\begin{array}{l}\text { d } \\
\text { c }\end{array}$ & $\begin{array}{l}1949-53,1957-63 \\
1957\end{array}$ & 78.9 & 1,300 & $06-17-50$ & 32.0 & $11-30-52$ \\
\hline 12351000 & $\begin{array}{l}\text { Burnt Fork Bitterroot } \\
\text { River near } \\
\text { Stevensville }\end{array}$ & 74.0 & d & $\begin{array}{l}1920,1922-24, \\
1938-62 \\
1956\end{array}$ & 48.3 & 641 & $05-28-38$ & 32.0 & $03-11-48$ \\
\hline
\end{tabular}


Table 13. Summary of data for U.S. Geological Survey streamflow-gaging stations in the Bitterroot Valley, Montana (Continued)

\begin{tabular}{|c|c|c|c|c|c|c|c|c|c|}
\hline \multirow[b]{2}{*}{$\begin{array}{l}\text { Station } \\
\text { number }\end{array}$} & \multirow[b]{2}{*}{ Station name } & \multirow{2}{*}{$\begin{array}{c}\text { Drainage } \\
\text { area } \\
\text { (square } \\
\text { miles) }\end{array}$} & \multirow{2}{*}{$\begin{array}{l}\text { Type } \\
\text { of data } \\
\text { cot- } \\
\text { lected }\end{array}$} & \multirow[b]{2}{*}{$\begin{array}{l}\text { Perlod of record } \\
\text { (calendar year) }\end{array}$} & \multicolumn{5}{|c|}{ Discharge for period of record } \\
\hline & & & & & $\begin{array}{c}\text { Mean } \\
\text { annual } \\
\left(\mathrm{ft}^{3} / \mathrm{s}\right)\end{array}$ & $\begin{array}{l}\text { Maxt } \\
\text { mum } \\
\left(\mathrm{ft}^{3} / \mathrm{s}\right)\end{array}$ & $\begin{array}{c}\text { Date of } \\
\text { maximum }\end{array}$ & $\underset{\substack{\text { Mint- } \\
\text { mum } \\
\left(\mathrm{ft}^{3} / \mathrm{s}\right)}}{\text {. }}$ & $\begin{array}{l}\text { Date of } \\
\text { minimum }\end{array}$ \\
\hline 12351200 & $\begin{array}{l}\text { Bitterroot River near } \\
\text { Florence }\end{array}$ & 2,354 & $\begin{array}{l}d \\
c\end{array}$ & $\begin{array}{l}1957-65 \\
1956\end{array}$ & 2,336 & 20,300 & $06-09-64$ & 365 & $08-20-61$ \\
\hline 12351400 & $\begin{array}{l}\text { Eightmile Creek near } \\
\text { Florence }\end{array}$ & 20.6 & $\begin{array}{l}\text { d } \\
\text { c }\end{array}$ & $\begin{array}{l}1957-63 \\
1956\end{array}$ & 7.15 & 62 & 05-13-58 & 31.0 & $01-11-63$ \\
\hline 12351500 & Lolo Creek near Lolo & 231 & d & $\begin{array}{l}1911-15 \text { (few win- } \\
\text { ter records) }\end{array}$ & 5274 & 2,500 & $05-28-13$ & 33 & $12-21-11$ \\
\hline 12352000 & $\begin{array}{l}\text { Lolo Creek above } \\
\text { Sleeman Creek, near } \\
\text { Lolo }\end{array}$ & 250 & d & $1951-60$ & 215 & 2,430 & $05-24-56$ & 6.3 & $11-09-52$ \\
\hline 12352500 & $\begin{array}{l}\text { Bitterroot River near } \\
\text { Missoula }\end{array}$ & 2,814 & d & $\begin{array}{l}\text { 1898-1901, 1903- } \\
04,1989-\end{array}$ & 2,410 & 38,300 & $6-20-1899$ & 3300 & $02-09-94$ \\
\hline 12352980 & $\begin{array}{l}\text { Bitterroot River at } \\
\text { Maclay Bridge, } \\
\text { near Missoula }\end{array}$ & 2,850 & c & $1970-73$ & -- & -- & -- & -- & -- \\
\hline
\end{tabular}

${ }^{1}$ Data for 1903,1904 .

${ }^{2}$ Data for 1940, 1941, 1942.

${ }^{3}$ Lowest daily mean.

${ }^{4}$ Dam failed above station.

${ }^{5}$ Date for water year 1914.

Table 14. Summary of data for yield and specific capacity of wells completed in selected hydrogeologic units in the Bitterroot Valley, Montana

[Source: Dutton and others, 1995. Hydrogeologic unit: Qal, Holocene and Pleistocene alluvial deposits; QTd, Quaternary through Tertiary undifferentiated deposits; Ts, Tertiary sedimentary deposits and rocks; TKi, Tertiary to Cretaceous intrusive rocks (Idaho Batholith); Yms, Middle Proterozoic metasedimentary rocks. Abbreviations: gal/min, gallon per minute; (gal/min)/ft, gallon per minute per fool]

\begin{tabular}{|c|c|c|c|c|c|c|c|c|c|c|}
\hline \multirow{2}{*}{$\begin{array}{l}\text { Hydro } \\
\text { goologic } \\
\text { unit }\end{array}$} & \multirow[b]{2}{*}{$\begin{array}{c}\text { Number of } \\
\text { wells }\end{array}$} & \multicolumn{4}{|c|}{ Yield (gal $/ \mathrm{m} \mid \mathrm{n})$} & \multirow[b]{2}{*}{$\begin{array}{c}\text { Number of } \\
\text { wells }\end{array}$} & \multicolumn{4}{|c|}{ Speciflc capacily $[(g a l / m i n) / f t]$} \\
\hline & & Moan & Median & $\begin{array}{l}\text { Mint- } \\
\text { mum }\end{array}$ & $\begin{array}{l}\text { Maxt- } \\
\text { mum }\end{array}$ & & Mean & Median & $\begin{array}{l}\text { Mini- } \\
\text { mum }\end{array}$ & $\begin{array}{l}\text { Maxt- } \\
\text { mum }\end{array}$ \\
\hline Qal & 35 & 160 & 50 & 2.0 & 1,500 & 33 & 14 & 3.3 & 0.1 & 200 \\
\hline QTd & 29 & 71 & 10 & 2.0 & 900 & 26 & 3.1 & .6 & .2 & 40 \\
\hline Ts & 19 & 54 & 10 & 1.0 & 400 & 15 & 1.4 & .2 & .1 & 7.9 \\
\hline $\mathrm{TK}^{1}{ }^{1}$ & 4 & 13 & 7.5 & 2 & 35 & 3 & .3 & .2 & .1 & .6 \\
\hline $\mathrm{Yms}^{1}$ & 6 & 17 & 18 & 8.5 & 25 & 5 & .2 & .2 & .1 & .3 \\
\hline
\end{tabular}

IMay include wells completed along basin margins, outside the area of basin fill.

Because of poor sorting and a large proportion of fine-grained material, glacial till and glacial-lakebed deposits have low permeability. Yields from wells completed in these deposits average about $5 \mathrm{gal} / \mathrm{min}$ (Noble and others, 1982, p. 60). Specific-capacity values for wells completed in glacial deposits west of the Bitterroot River range from 7 to 55 (gal/min)/ft and average about 20 (gal/min)/ft (McMurtrey and others, 1972).

Wells that are completed in both Quaternary alluvium and Tertiary sediments are grouped under the hydrogeologic unit QTd in table 14. Most of these wells are located on the terraces, and are not highly productive. In contrast, a municipal-supply well for the Town of Hamilton (06N20W30DBCC01) produces $500 \mathrm{gal} / \mathrm{min}$ from permeable sand and gravel lenses in Quaternary and Tertiary deposits near the center of the basin. A 240-ft-deep irrigation well (05N20W18CBCD01) that produces $900 \mathrm{gal} / \mathrm{min}$ also taps both Quaternary and Tertiary deposits 
(Dutton and others, 1995). On the basis of specific-capacity data from drillers' logs, Finstick (1986) estimated transmissivity values ranging from 7.0 to $110 \mathrm{ft}^{2} / \mathrm{d}$ for 20 wells completed in both Quaternary and Tertiary deposits.

Most wells completed in Tertiary sediments are less than about $400 \mathrm{ft}$ deep. Of the approximately 1,900 wells completed in Tertiary sediments on the eastern terrace, 29 percent have depths of $60 \mathrm{ft}$ or less. Of the almost 2,300 wells completed on the western terrace, 47 percent have depths of $60 \mathrm{ft}$ or less (Montana Bureau of Mines and Geology, unpub. data, 1994). Production from wells completed in Tertiary sediments reflects the wide range of hydraulic characteristics of these heterogeneous deposits (table 14). In general, wells completed in aquifers underlying the high terraces tap fine-grained Tertiary sediments and are relatively unproductive. Although permeable lenses may be found throughout the Tertiary sediments, their density is apparently greater toward the center of the basin. McMurtrey and others (1972) performed aquifer tests on three wells in Tertiary sediments, from which they calculated transmissivities of 320,440 , and $1,500 \mathrm{ft}^{2} / \mathrm{d}$. Finstick (1986) estimated the transmissivity of Tertiary sediments from data reported on 142 drillers' logs, and obtained results ranging from 2.8 to $480 \mathrm{ft}^{2} / \mathrm{d}$, and averaging $64 \mathrm{ft}^{2} / \mathrm{d}$. Little is known about the hydraulic characteristics of Tertiary sediments at great depths. However, several aquifer tests of two deep test wells on the eastern terrace--a 2,723-ft well near Stevensville (09N19W06BAA) and a 1,110-ft-deep well near Corvallis (06N20W14BBB)--yielded specific-capacity values from 0.8 to 2.6 ( $(\mathrm{gal} / \mathrm{min}) / \mathrm{ft}$, transmissivity values from 160 to $1,500 \mathrm{ft}^{2} / \mathrm{d}$, and storage-coefficient values from 0.00005 to 0.14 . An estimated 50 to 90 percent of the water from each test well came from the upper 30 to 50 percent of the aquifer (Norbeck, 1980).

Bedrock that surrounds and floors the basin is not a major aquifer, although wells completed in bedrock may yield small amounts of water from fractures and weathered zones (McMurtrey and others, 1972). Transmissivities of bedrock range from 5.6 to $230 \mathrm{ft}^{2} / \mathrm{d}$ and average $60 \mathrm{ft}^{2} / \mathrm{d}$ for five wells, according to data reported on drillers' logs (Finstick, 1986).

Potentiometric-surface maps (table 15) indicate that ground water generally flows from the terraces toward the Bitterroot River flood plain, then northward paralleling the river. Ground water leaves the basin at Missoula. The hydraulic gradient is steepest along the western basin margin, and relatively flat beneath the Bitterroot River flood plain (McMurtrey and others, 1972).

Table 15. Potentiometric-surface maps of the Bitterroot Valley, Montana

\begin{tabular}{|c|c|c|c|c|}
\hline Location & $\begin{array}{l}\text { Dates water levels } \\
\text { were measured }\end{array}$ & Scale & $\begin{array}{c}\text { Contour } \\
\text { Interval in } \\
\text { foet }\end{array}$ & Reference \\
\hline Entire Bitterroot Valley & Summer 1991 & $1: 750,000$ & 100 & Briar and others, in press \\
\hline Lat $46^{\circ} 22^{\prime} 30^{\prime \prime} \mathrm{N}$. to $46^{\circ} 30^{\prime} \mathrm{N}$. & July 1984 & $1: 100,000$ & 100 & Finstick, 1986, fig. 6, p. 38 \\
\hline Lat $46^{\circ} 22^{\prime} 30^{\prime \prime} \mathrm{N}$. to $46^{\circ} 30^{\prime} \mathrm{N}$. & March 1985 & $1: 100,000$ & 100 & Finstick, 1986, fig. 7, p. 39 \\
\hline $\begin{array}{l}\text { Approximately Hamilton to } \\
\text { Florence }\end{array}$ & March 1958 & $1: 125,000$ & 25 & $\begin{array}{l}\text { McMurtrey and others, } 1972 \text {, } \\
\text { pl. } 1\end{array}$ \\
\hline Lat $46^{\circ} 15^{\prime} \mathrm{N}$. to $46^{\circ} 22^{\prime} 30^{\prime \prime} \mathrm{N}$. & September 1983 & $1: 90,000$ & 50 & Uthman, 1988 , fig. 4.2 , p. 53 \\
\hline
\end{tabular}

Sources of recharge to unconsolidated deposits include leakage from canals, surplus irrigation water, subsurface flow from surrounding bedrock, precipitation and snowmelt, and infiltration from tributary streams. Ground water discharges by evapotranspiration, withdrawals from wells, subsurface flow to the Missoula Valley, and seepage to springs, seeps, irrigation drains, and stream channels. The ground-water contribution area (fig. 2, pl. 1) is about $2,870 \mathrm{mi}^{2}$. Infiltration anywhere within this area potentially could recharge basin-fill aquifers in the Bitterroot Valley. However, most recharge comes from flood-irrigated fields and leaky canals (Finstick, 1986). The effects of irrigation on recharge were evident in June 1958, when near-record-high rainfall precluded the need for irrigation. Despite the large amount of precipitation, ground-water levels were lower than normal (McMurtrey and others, 1972). Geothermal gradients in four deep (957 to 2,530 ft) exploration wells gave no indication of hydrothermal water recharging aquifers in this basin (Leonard and Wood, 1980). 
A considerable volume of ground water may be stored in basin-fill deposits in the Bitterroot Valley. Assuming a uniform porosity of 20 percent and a uniform accessible depth of $400 \mathrm{ft}$, basin-fill deposits in the Bitterroot Valley store about 14 million acre-ft of available ground water (Crosby, 1976, p. 52-53). A more detailed analysis, accounting for different thicknesses and hydraulic properties of the various hydrogeologic units that comprise the basin fill, indicates that 21 million acre-ft are available (Boettcher and Gosling, 1977, p. 13). However, long-term pumping in excess of the rate of natural and irrigation-induced recharge would deplete the aquifers. In 1957-59, the volume of ground water in the basin fluctuated about 86,000 acre-ft because of natural and irrigation-induced processes; that is, each year about 86,000 acre-ft discharged from, and subsequently recharged to, the aquifer without causing any long-term change in storage (McMurtrey and others, 1972).

Water-level data for the wells listed in table 16 are stored in the USGS WATSTORE database. Water levels were measured in these wells at least once annually during the period of record. Water levels are generally highest in the spring and early summer due to snowmelt, rainfall, and infiltration from streams and irrigation canals, and water levels are generally lowest in late winter.

Table 16. Summary of water-level data for selected wells in the Bitterroot Valley, Montana

[Hydrogeologic unit: Qal, Holocene and Pleistocene alluvial deposits; Ts, Tertiary sedimentary deposits and rocks. Periods of record for observation wells that were being operated as on February 1995 are indicated by the first year of record followed by a dash only]

\begin{tabular}{|c|c|c|c|c|c|c|c|}
\hline \multirow[b]{2}{*}{ Location number } & \multirow{2}{*}{$\begin{array}{l}\text { Depth of well, } \\
\text { in feet below } \\
\text { land surface }\end{array}$} & \multirow{2}{*}{$\begin{array}{l}\text { Hydro- } \\
\text { geologic } \\
\text { unit }\end{array}$} & \multirow{2}{*}{$\begin{array}{l}\text { Perlod of } \\
\text { record }\end{array}$} & \multicolumn{4}{|c|}{ Water level, In feet below land surface } \\
\hline & & & & Highest & $\begin{array}{l}\text { Date of } \\
\text { highest }\end{array}$ & Lowest & $\begin{array}{l}\text { Date of } \\
\text { lowest }\end{array}$ \\
\hline 12N20W22ADAC01 & 53 & Qal & $1992-94$ & 3.23 & $05-28-93$ & 8.99 & $12-05-92$ \\
\hline 12N20W22ADACO2 & 48 & Qal & $1992-94$ & 2.87 & $05-22-93$ & 8.92 & $09-26-92$ \\
\hline 12N20W22ADAC03 & 52 & Qal & 1992- & 1.96 & $05-29-93$ & 8.43 & $02-08-94$ \\
\hline 10N20W13BBA 01 & 50.5 & Qal & 1959 - & 2.48 & $06-15-59$ & 8.04 & $02-14-77$ \\
\hline 09N20W12BBBB01 & 60.0 & Qal & $1955-75$ & 8.21 & $09-29-55$ & 20.75 & $03-29-73$ \\
\hline 09N20W21ADB 01 & 32.2 & Qal & $1955-80$ & 1.72 & $06-22-76$ & 30.91 & $02-21-79$ \\
\hline 09N20W21ADB 02 & 40.0 & Qal & $1976-82$ & 16.87 & $06-26-78$ & 34.01 & $03-28-77$ \\
\hline 08N20W19BAAD03 & 52.0 & Ts & $1957-92$ & 12.39 & $09-02-61$ & 19.76 & $03-29-73$ \\
\hline 08N19W07CBBD01 & 117 & Ts & $1956-92$ & 79.25 & $10-12-83$ & 104.14 & $09-09-92$ \\
\hline 07N20W32DDD 02 & 40.0 & Qal & $1972-91$ & 4.03 & $08-23-78$ & 13.21 & $04-07-81$ \\
\hline 06N21W02BA 01 & 84.0 & Ts & $1957-67$ & 41.48 & $09-03-65$ & 61.00 & $03-03-61$ \\
\hline 06N21 W11AABB01 & 20.0 & Qal & $1957-81$ & .74 & $06-10-80$ & 19.75 & $02-17-71$ \\
\hline 06N21 W26DBD 01 & 365 & Qal & $1957-67$ & 6.91 & $06-27-57$ & 23.03 & $05-06-58$ \\
\hline 06N20W19CCCCO2 & 40.0 & Qal & $1970-$ & 5.19 & $06-21-76$ & 17.86 & $04-26-77$ \\
\hline 06N20W19CC 01 & 20.0 & Qal & $1956-91$ & 3.06 & $06-24-71$ & 17.86 & $04-26-77$ \\
\hline $05 \mathrm{~N} 19 \mathrm{~W} 26 \mathrm{BC} 01$ & 52.0 & Qal & $1962-78$ & 28.06 & $05-21-75$ & 36.11 & $03-23-78$ \\
\hline
\end{tabular}

Most ground water in Quatemary alluvium is a calcium bicarbonate type with dissolved-solids concentrations of less than about $200 \mathrm{mg} / \mathrm{L}$. The concentration of dissolved solids is larger in Tertiary sediments than in Quaternary alluvium. Beneath terraces east of Florence and Stevensville, where ground water moves slowly through finegrained Tertiary sediments, dissolved-solids concentrations typically exceed $250 \mathrm{mg} / \mathrm{L}$ and the ground water is a sodium bicarbonate type (McMurtrey and others, 1972; Clark and Dutton, in press). In places, hard water and large amounts of iron from Tertiary sediments cause carbonate deposits and rust-colored stains (Finstick, 1986; Uthman, 1988).

In areas where the basin-fill aquifers are unconfined, they can easily become contaminated. For example, the alluvial aquifer $1 \mathrm{mi}$ south of Victor has been impacted by landfill leachate, resulting in contamination of several wells. The 55-acre site currently is being remediated (C.K. Blundell, Superfund Program, Montana Department of Environmental Quality, oral commun., 1995). 


\section{Selected References}

Barkman, P.E., 1984, A reconnaissance investigation of active tectonism in the Bitterroot Valley, western Montana: Missoula, University of Montana, M.S. thesis, 84 p.

Boettcher, AJ., and Gosling, A.W., 1977, Water resources of the Clark Fork basin upstream from St. Regis, Montana: Butte, Montana Bureau of Mines and Geology Bulletin 104, 28 p.

Briar, D.W., Lawlor, S.M., Stone, M.A.J., Parliman, DJ., Schaefer, J.L., and Kendy, Eloise, in press, Ground-water levels in the intermontane basins of the Northern Rocky Mountains, Montana and Idaho: U.S. Geological Survey Hydrologic Investigations Atlas 738-B, 1 sheet, scale 1:750,000.

Cartier, K.D.W., 1984, Sediment, channel morphology, and streamflow characteristics of the Bitterroot River drainage basin, southwestern Montana: Missoula, University of Montana, M.S. thesis, 191 p.

Clark, D.W., and Dutton, D.M., in press, Ground-water quality in the intermontane basins of the Northern Rocky Mountains, Montana and Idaho: U.S. Geological Survey Hydrologic Investigations Atlas 738-C, 1 sheet, scale 1:750,000.

Crosby, G.W., 1976, Geophysical study of the water bearing strata in Bitterroot Valley, Montana: Bozeman, Mont., Montana University Joint Water Resources Research Center Report 80, 68 p.

Dutton, D.M., Lawlor, S.M., Briar, D.W., and Tresch, R.E., 1995, Hydrogeologic data for the Northern Rocky Mountains intermontane basins, Montana: U.S. Geological Survey Open-File Report 95-143, 94 p.

Finstick, S.A., 1986, Hydrogeology of the Victor and Bing quadrangles, Bitterroot Valley, Montana: Missoula, University of Montana, M.S. thesis, 150 p.

Hoffman, J.D., 1980, Water use, groundwater conditions, and slope failure on benchlands in western Montana--The Darby slide example: Bozeman, Mont., Montana University Joint Water Resources Research Center Report 109, 48 p.

Hyndman, D.W., Talbot, J.L., and Chase, R.B., 1975, Boulder batholith--A result of emplacement of a block detached from the Idaho batholith infrastructure: Geology, v. 3, p. 401-404.

Lankston, R.W., 1975, A geophysical investigation in the Bitterroot Valley, western Montana: Missoula, University of Montana, Ph.D. dissertation, 112 p.

Leonard, R.B., and Wood, W.A., 1980, Geothermal gradients in the Missoula and Bitterroot Valleys, west-central Montana: U.S. Geological Survey Water-Resources Investigations Report 80-89, 15 p.

Manghnani, M.H., and Hower, John, 1962, Structural significance of a gravity profile in the Bitterroot valley, Ravalli County, Montana [abs.]: Geological Society of America Special Paper 68, p. 93.

McCulloch, Robin, 1993, Montana mining directory 1992: Montana Bureau of Mines and Geology Bulletin 131, 76 p.

McMurtrey, R.G., Konizeski, R.L., Johnson, M.V., and Bartells, J.H., 1972, Geology and water resources of the Bitterroot Valley, southwestern Montana, with a section on Chemical quality of water, by H.A. Swenson: U.S. Geological Survey WaterSupply Paper $1889,80 \mathrm{p}$.

[Montana] State Engineer's Office, 1958a, Water resources survey, Ravalli County, Montana--Part 1, History of land and water use on irrigated areas: Helena, Mont., State Engineer's Office, 81 p.

1958b, Water resources survey, Ravalli County, Montana--Part 2, Maps showing irrigated areas: Helena, Mont, State Engineer's Office, 31 p.

National Oceanic and Atmospheric Administration, 1992, Monthly normals of temperature, precipitation, and heating and cooling degree days, 1961-90, Montana: Asheville, N.C., Climatography of the United States no. 81, inpaged.

Noble, R.A., Bergantino, R.N., Patton, T.W., Sholes, B.C., Daniel, Faith, and Schofield, Judeykay, 1982, Occurrence and characteristics of ground water of Montana--Volume 2, The Rocky Mountain Region: Montana Bureau of Mines and Geology Open-File Report 99, 132 p.

Nolan, K.M., 1973, Flood hazard mapping in the Bitterroot Valley, Montana: Missoula, University of Montana, M.S. thesis, 56 p. 
Norbeck, P.M., 1980, Preliminary evaluation of deep aquifers in the Bitterroot and Missoula Valleys in westem Montana: Montana Bureau of Mines and Geology Open-File Report 46, variously paged.

Nunnallee, David, and Botz, M.K., 1976, Water quality inventory and management plan, lower Clark Fork River basin, Montana: Montana Department of Health and Environmental Sciences, 129 p.

Rorabaugh, M.I., 1963, Estimating changes in bank storage and ground-water contributions to streamflow: International Association of Scientific Hydrology, Publication no. 63, p. 432-441.

Rorabaugh, M.I., and Simons, W.D., 1966, Exploration of methods of relating ground water to surface water, Columbia River basin--Second phase: U.S. Geological Survey Open-File Report, 99 p.

Ross, C.P., 1952, The eastem front of the Bitterroot Range: U.S. Geological Survey Bulletin 974-E, p. 135-175.

Senger, J.A., 1975, A compilation and synthesis of existing water resource information on the Bitterroot drainage, Montana: Missoula, University of Montana, M.S. thesis, $191 \mathrm{p}$.

Sonderegger, J.L., and Bergantino, R.N., 1981, Geothermal resources map of Montana: Montana Bureau of Mines and Geology Hydrogeologic Map 4, scale 1:1,000,000.

Tuck, L. K., Briar, D.W., and Clark, D.W., in press, Geologic history and hydrogeologic units of intermontane basins in the Northern Rocky Mountains, Montana and Idaho: U.S. Geological Survey Hydrologic Investigations Atlas 738-A, 2 sheets, scale 1:750,000.

U.S. Geological Survey, issued annually, Water resources data, Montana: Helena, Montana, U.S. Geological Survey WaterData Report.

U.S. Soil Conservation Service, 1947, Reconnaissance conservation report on water control, use and disposal, Bitterroot River drainage basin, Ravalli County, Montana: U.S. Department Agriculture, Soil Conservation Service, Region 5, Lincoln, Nebraska, 53 p.

Uthman, William, 1988, Hydrogeology of the Hamilton North and Corvallis quadrangles, Bitterroot Valley, southwestern Montana: Missoula, University of Montana, M.S. thesis, 232 p.

Weber, W.M., 1972, Correlation of Pleistocene glaciation in the Bitterroot Range, Montana, with fluctuations of glacial Lake Missoula: Montana Bureau of Mines and Geology Memoir 42, 42 p. 


\section{Geography}

The Blackfoot-Clearwater Valley includes the lower Blackfoot River valley below the junction of State Highways 200 and 141, as well as the valleys of its major tributaries, the Clearwater River and Nevada Creek (pl. 1). The Blackfoot-Clearwater Valley is a northwest-trending intermontane basin about $460 \mathrm{mi}^{2}$ in area. It is bounded by the drainage divide between the Clearwater and the Swan Rivers on the northwest, the Swan Range on the east, the drainage divide between the Little Blackfoot River and Nevada Creek on the southeast, the Gamet Range on the southwest, and the Mission Range on the west. The intermontane basin ranges in altitude from about 3,600 ft where the Blackfoot River leaves the basin, to about $5,800 \mathrm{ft}$ in the glaciated mountain foothills.

Topographically, the Blackfoot-Clearwater Valley is relatively diverse.

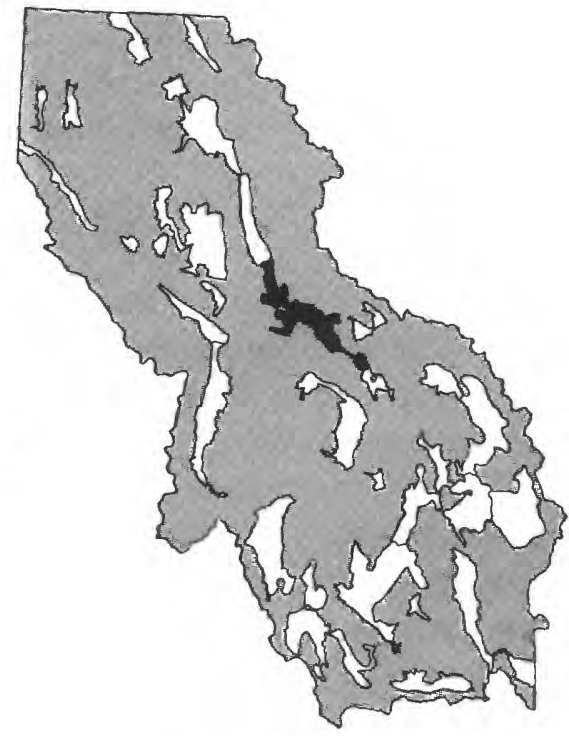
The lower Blackfoot and Clearwater River valleys were extensively glaciated, with glacial deposits extending onto the basin fioor from the surrounding mountains. The rolling hills of the basin flonr are interspersed with grasslands, sage, and timber. The Clearwater River flows southward through the Ushaped Clearwater River basin; its flood plain is not deeply incised. The sides of the lower Blackfoot River valley gently slope toward the hummocky, poorly drained center of the valley, which is dotted with lakes, ponds, and wetlands. In contrast, the upper Nevada Creek valley is wide and open, with distinct lateral pediments flanking the central flood plain.

The climate of the Blackfoot-Clearwater Valley is typical of mid-elevation intermontane basins of the Northern Rocky Mountains west of the Continental Divide, with cold, snowy winters and mild summers. On the basis of the 1961-90 period of record, the average annual precipitation at the Seeley Lake Ranger Station (altitude $4,100 \mathrm{ft}$ ) is $21.54 \mathrm{in}$., and the average annual temperature is $41.3^{\circ} \mathrm{F}$ (National Oceanic and Atmospheric Administration, 1992). The average last occurrence of $32^{\circ} \mathrm{F}$ is June 28 , and the average first occurrence is August 29 (Natural Resources Conservation Service, U.S. Department of Agriculture, unpub. data, 1994). Mean monthly climatic data for the Seeley Lake Ranger Station are plotted in figure 9.

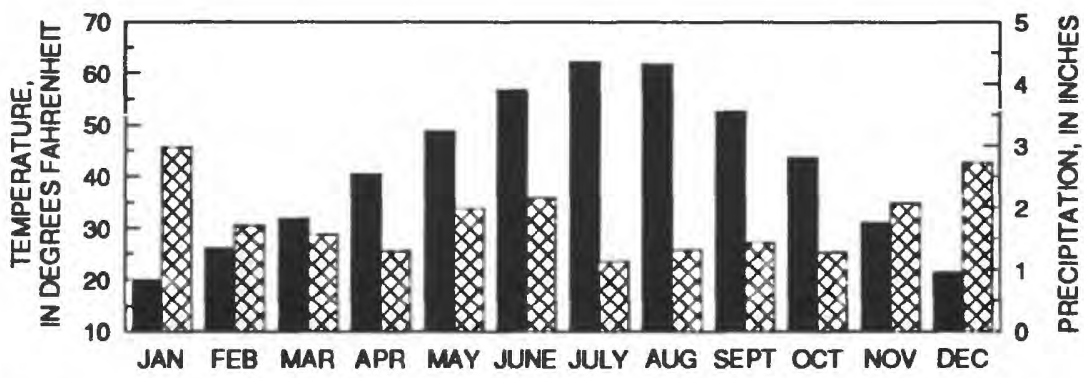

\section{EXPLANATION}

MEAN MONTHLY TENPERATURE FOR 1961-90 PERIOD OF RECORD 1961-90 PERIOD OF RECORD

Figure 9. Mean monthly precipitation and temperature at the Seeley Lake Ranger Station, Mont. Data from National Oceanic and Atmospheric Administration (1992).

Land uses include timber harvesting, livestock grazing, and irrigated and dryland pasture and grain production (J.C. Eggen, Agricultural Stabilization and Conservation Service, oral commun., 1993). Hard-rock mining and timber harvesting have been conducted in the headwater areas for more than 100 years. Barite is mined underground 
southeast of Greenough. Gold is placer-mined in several drainages, primarily south of the basin, and exploration is ongoing east of Helmville and in the upper reaches of the Blackfoot River drainage area (McCulloch, 1993). Residential development, while not a major land use, has increased in recent years. About 2,000 people reside in the Blackfoot-Clearwater Valley, including 798 in the unincorporated community of Seeley Lake (1990 census).

\section{Geology}

The Clearwater River valley occupies the southern tip of the eastern extension of the Rocky Mountain Trench (fig. 4), a zone of closely spaced, north-northwest-trending listric normal faults. The east-tilted crustal block underlying the basin downdropped at least 13,000 ft along a listric normal fault on the east side of the basin (Crosby, 1984). The most recent movement along this fault was probably post-Miocene (Mudge and others, 1982). Smaller downthrow has occurred along high-angle normal faults on the western side of the basin. The thickness of basin fill increases from less than $1,000 \mathrm{ft}$ at Seeley Lake to about 2,000 ft at Lake Alva, and continues to increase to the north, into the Swan Valley (Noble and others, 1982, p. 39-40). Structurally, the Blackfoot-Clearwater Valley is continuous with the Swan Valley, although a drainage divide separates the two hydrologically. Both the basin and the basinmarginal faults that define it are truncated on the south by the Lewis and Clark Line (fig. 4), a northwest-trending zone of high-angle normal, reverse, and right-lateral strike-slip faults (Mudge and others, 1982).

The lower Blackfoot River valley is bounded on the northwest by a normal fault. Several faults transect the basin and have upthrown bedrock "islands" in the Cenozoic basin fill between Seeley Lake and Ovando (Wallace, 1987; Mudge and others, 1982). Gravity data indicate that the deepest part of the basin is near Kleinschmidt Lake, where basin fill is more than 6,000 ft thick (Noble and others, 1982, p. 50). Structurally, the upper Nevada Creek valley is continuous with the Avon Valley, but a drainage divide separates the two hydrologically (Wallace and others, 1986; Wallace, 1987; Witkind and Weber, 1982).

Several investigators have examined the geology of the Blackfoot-Clearwater Valley. Witkind and Weber (1982) listed the USGS Open-File Reports of 1:24,000-scale and 1:62,500-scale geologic maps of the area. More generalized geologic and geophysical maps are listed in table 17. The geologic units described by previous investigators are summarized below. These geologic units are referenced to hydrogeologic units defined in this study (table 2) to provide a consistent regional framework. In the following discussion, the hydrogeologic-unit abbreviations are italicized.

Metasedimentary and extrusive bedrock borders the Blackfoot-Clearwater Valley. Metasedimentary rocks of the Middle Proterozoic Belt Supergroup $(\mathrm{Yms})$ surround most of the basin. These rocks include argillite, siltite, quartzite, limestone, and dolomite. Tertiary andesitic, basaltic, and latitic volcanic rocks (QTKe) border the west sides of the Nevada Creek and lower Blackfoot River valleys (Mudge and others, 1982; Wallace, 1987).

Tertiary sediments (TS) overlie bedrock throughout the basin, and crop out on broad, smooth-surfaced pediments flanking Nevada Creek. Pediments are commonly mantled with a veneer of Quaternary alluvium (QTd), giving them the appearance of alluvial fans. The Tertiary sediments consist primarily of light-gray, light-brown, brown, grayish-brown, and yellowish-brown deposits of semiconsolidated to consolidated clay, shale, siltstone, sandstone, and volcanic ash with minor amounts of conglomerate and marl (Witkind and Weber, 1982; Noble and others, 1982, p. 51).

At least three glaciers deposited Pleistocene glacial till $(Q g)$ throughout the basin north of the Blackfoot River. Heterogeneous, poorly sorted sand, gravel, pebbles, cobbles, and boulders in a sandy to clayey matrix compose the glacial till. On the basin floor, glacial till attains thicknesses exceeding $600 \mathrm{ft}$, whereas the foothills have only a veneer of till, which thins toward the mountains. Witkind and Weber (1982) provided detailed descriptions of 29 local glacial deposits and their geneses. 
Table 17. Geologic and geophysical maps of the Blackfoot-Clearwater Valley, Montana

\begin{tabular}{|c|c|c|c|c|}
\hline Type of map & Scale & Location & Map features & Reference \\
\hline $\begin{array}{l}\text { Aeromagnetic and } \\
\text { simplified } \\
\text { geology }\end{array}$ & $1: 250,000$ & $\begin{array}{l}\text { Entire Blackfoot- } \\
\text { Clearwater Valley }\end{array}$ & $\begin{array}{l}\text { Contour interval } 20 \text { gammas. All basin fill is } \\
\text { identified as undifferentiated Pliocene to } \\
\text { Oligocene lake and stream deposits }\end{array}$ & $\begin{array}{l}\text { Kleinkopf and Mudge, } \\
\text { 1972, pl. } 1\end{array}$ \\
\hline Bouguer gravity & $1: 250,000$ & $\begin{array}{l}\text { Entire Blackfoot- } \\
\text { Clearwater Valley }\end{array}$ & Contour interval 5 milligals & $\begin{array}{l}\text { Kleinkopf and Mudge, } \\
\text { 1972, pl. } 2\end{array}$ \\
\hline Geology & $1: 250,000$ & $\begin{array}{l}\text { Clearwater and northern } \\
\text { Blackfoot River } \\
\text { valleys }\end{array}$ & $\begin{array}{l}\text { Differentiates three basin-fill units: Tertiary } \\
\text { lake deposits, Quaternary glacial deposits, } \\
\text { and Quaternary alluvial and colluvial } \\
\text { deposits }\end{array}$ & $\begin{array}{l}\text { Mudge and others, } \\
1982\end{array}$ \\
\hline $\begin{array}{l}\text { Cenozoic basin- } \\
\text { fll thickness }\end{array}$ & $1: 500,000$ & $\begin{array}{l}\text { Clearwater and } \\
\text { Blackfoot River } \\
\text { valleys }\end{array}$ & Contour interval 1,000 feet & $\begin{array}{l}\text { Noble and others, } \\
1982 \text {, figs. II-10 } \\
\text { and II-13, p. } 40 \text { and } \\
50\end{array}$ \\
\hline Geology & $1: 250,000$ & $\begin{array}{l}\text { Nevada Creek and } \\
\text { southern Blackfoot } \\
\text { River valleys }\end{array}$ & $\begin{array}{l}\text { Differentiates two basin-fill units: Tertiary } \\
\text { sedimentary deposits and rocks, and } \\
\text { Quatemary surficial deposits }\end{array}$ & Wallace, 1987 \\
\hline Geology & $1: 250,000$ & $\begin{array}{l}\text { Nevada Creek and } \\
\text { southern Blackfoot } \\
\text { River valleys }\end{array}$ & $\begin{array}{l}\text { Differentiates } 4 \text { Tertiary and } 10 \text { Quaternary } \\
\text { basin-fill units }\end{array}$ & $\begin{array}{l}\text { Wallace and others, } \\
1986\end{array}$ \\
\hline Geology & $1: 125,000$ & $\begin{array}{l}\text { Entire Blackfoot- } \\
\text { Clearwater Valley }\end{array}$ & Differentiates about 20 basin-fill units & $\begin{array}{l}\text { Witkind and Weber, } \\
1982\end{array}$ \\
\hline
\end{tabular}

As glacial ice melted, streams and rivers carried huge loads of glacial debris, which settled out of suspension as unconsolidated, moderately sorted, glacial-outwash deposits of sand, gravel, pebbles, and cobbles (Qal). Glacial outwash occurs primarily in present-day stream and river channels, but in some areas, such as the terrace between Rock Creek and the North Fork of the Blackfoot River, it forms broad alluvial fans. Although the upper Nevada Creek drainage was not inundated by continental glaciers, meltwaters from alpine glaciers deposited large quantities of glacial outwash in several northeastern tributary flood plains (Witkind and Weber, 1982).

Holocene alluvium (Qal) overlies glacial outwash in some flood-plain areas and forms a few alluvial fans along basin margins. The most extensive deposits are at the confluence of Nevada Creek and the Blackfoot River, and extend at least $6 \mathrm{mi}$ up each drainage. These deposits consist of well-bedded, well-sorted silt, sand, gravel, pebbles, and some cobbles in a clayey matrix (Witkind and Weber, 1982). Along the Blackfoot River, the average thickness of alluvium is probably 80 to $100 \mathrm{ft}$ (Noble and others, 1982, p. 49).

\section{Hydrology}

Surface water is one of the most important natural resources in this area. The Blackfoot River is classified as a Class I trout stream by the Montana Department of Fish, Wildlife and Parks. Surface water from the river and its tributaries is used extensively for irrigation and for instream uses such as wildlife habitat, fishing, and boating. In addition, numerous lakes and wetlands provide valuable nesting sites for the area's abundant waterfowl.

The Blackfoot River flows toward the west from its headwaters near the Continental Divide to its confluence with the Clark Fork at Milltown. The Clearwater River and Nevada Creek are its major tributaries from the northwest and southeast, respectively.

Throughout the glaciated parts of the basin, lakes and wetlands fill potholes left by melting glacial ice blocks in poorly drained glacial till. For example, Kleinschmidt Lake and its associated wetland complex perch atop poorly permeable glacial till. In contrast, Lake Alva, Seeley Lake, and Salmon Lake are situated in glacial outwash along the Clearwater River and are probably hydraulically connected to ground water, as indicated by the permeable deposits and shallow water tables surrounding them. 
Streamflow data recorded for gaging stations listed in table 18 are stored in the USGS WATSTORE database. Locations of the stations are shown on plate 1. In addition, USGS has published records of monthend reservoir contents, in acre- $\mathrm{ft}$, of Nevada Lake (station 12336500, drainage area $145 \mathrm{mi}^{2}$ ) since 1939. The reservoir, which is used for irrigation and recreation, began storing water in 1938 (Shields and others, 1993). Data for years prior to 1961 are published in Water-Supply Papers; more recent data are in annual Water-Data Reports (U.S. Geological Survey, issued annually).

Table 18. Summary of data for U.S. Geological Survey streamflow-gaging stations in the Blackfoot-Clearwater Valley, Montana

[Type of data collected: c, chemistry; d, discharge. Periods of record for stations that were being operated as of November 1994 are indicated by the first year of record followed by a dash only. Abbreviations: $\mathrm{ft}^{3} / \mathrm{s}$, cubic feet per second. Symbol: --, no data]

\begin{tabular}{|c|c|c|c|c|c|c|c|c|c|}
\hline \multirow[b]{2}{*}{$\begin{array}{l}\text { Station } \\
\text { number }\end{array}$} & \multirow[b]{2}{*}{ Station name } & \multirow{2}{*}{$\begin{array}{l}\text { Drainage } \\
\text { area } \\
\text { (equare } \\
\text { miles) }\end{array}$} & \multirow{2}{*}{$\begin{array}{l}\text { Type } \\
\text { of data } \\
\text { cot- } \\
\text { lected }\end{array}$} & \multirow{2}{*}{$\begin{array}{l}\text { Period of record } \\
\text { (calendar year) }\end{array}$} & \multicolumn{5}{|c|}{ Discharge for period of record } \\
\hline & & & & & $\begin{array}{l}\text { Mean } \\
\text { annual } \\
\left(\mathrm{tt}^{3} / \mathrm{s}\right)\end{array}$ & $\begin{array}{l}\text { Maxk } \\
\text { mum } \\
\left(\mathrm{ft}^{3} / \mathrm{s}\right)\end{array}$ & $\begin{array}{l}\text { Date of } \\
\text { minimum }\end{array}$ & $\begin{array}{l}\text { Mini- } \\
\text { mum } \\
\left(\mathrm{tt}^{3} / \mathrm{s}\right)\end{array}$ & $\begin{array}{l}\text { Date of } \\
\text { maximum }\end{array}$ \\
\hline 12335000 & $\begin{array}{l}\text { Blackfoot River near } \\
\text { Helmville }\end{array}$ & 481 & d & $1940-53$ & 352 & 6,040 & $06-05-53$ & 50 & $01-03-50$ \\
\hline 12335500 & $\begin{array}{l}\text { Nevada Creek above } \\
\text { reservoir, near Finn }\end{array}$ & 116 & $\begin{array}{l}\text { d } \\
\text { c }\end{array}$ & $\begin{array}{l}1939- \\
1980\end{array}$ & 36.0 & 1,800 & $06-02-53$ & 12.0 & $08-20-44$ \\
\hline 12336000 & $\begin{array}{l}\text { Nevada Creek near } \\
\text { Finn }\end{array}$ & 144 & d & 1934-39 & 25.6 & 630 & $04-11-36$ & 4.6 & 09-18-37 \\
\hline 12337000 & $\begin{array}{l}\text { Nevada Creek near } \\
\text { Helmville }\end{array}$ & 165 & d & $\begin{array}{l}\text { 1946-49 (May- } \\
\text { Sept.) }\end{array}$ & -- & 470 & $05-22-48$ & 3.6 & $08-16-46$ \\
\hline 12337500 & $\begin{array}{l}\text { Douglas Creek near } \\
\text { Helmville }\end{array}$ & 84.8 & d & $\begin{array}{l}\text { 1946-47 (Apr.- } \\
\text { Sept.) }\end{array}$ &.- & 73 & $06-10-47$ & 1.2 & $09-05-46$ \\
\hline 12338000 & $\begin{array}{l}\text { North Fork Blackfoot } \\
\text { River near Ovando }\end{array}$ & 228 & d & $\begin{array}{l}1921-23 \text { (May- } \\
\text { Oct.) }\end{array}$ & -. & 2,900 & $06-05-22$ & - & -- \\
\hline 12338500 & $\begin{array}{l}\text { Blackfoot River near } \\
\text { Ovando }\end{array}$ & 1,274 & d & $1940-63$ & 855 & 14,600 & $06-04-53$ & 100 & $01-20-54$ \\
\hline 12338690 & $\begin{array}{l}\text { Monture Creek near } \\
\text { Ovando }\end{array}$ & 140 & d & $1973-83$ & 192 & 2,120 & $06-16-74$ & 20 & 01-05-77 \\
\hline 12339000 & $\begin{array}{l}\text { Blackfoot River at } \\
\text { Clearwater }\end{array}$ & 1,550 & d & $\begin{array}{l}\text { 1921-23 (May- } \\
\text { Nov.) }\end{array}$ & -- & 7,820 & $06-06-22$ & 410 & $11-13-22$ \\
\hline 12339450 & $\begin{array}{l}\text { Clearwater River near } \\
\text { Clearwater }\end{array}$ & 345 & d & $1974-92$ & 281 & 2,900 & $05-17-75$ & 16 & 09-07-88 \\
\hline 12339500 & $\begin{array}{l}\text { Clearwater River at } \\
\text { Clearwater }\end{array}$ & 391 & d & $\begin{array}{l}\text { 1921-23 (May- } \\
\text { Nov.) }\end{array}$ & .- & 2,400 & $05-26-22$ & 30 & $10-21-22$ \\
\hline 12339800 & $\begin{array}{l}\text { Blackfoot River near } \\
\text { Potomac }\end{array}$ & 2,046 & d & $1956-65$ & 1,496 & 17,500 & $06-10-64$ & 200 & $02-26-62$ \\
\hline 12340000 & $\begin{array}{l}\text { Blackfoot River near } \\
\text { Bonner }\end{array}$ & 2.290 & c & $\begin{array}{l}1898-1905 \\
\quad \text { (intermittent), } \\
1939- \\
1956-59,1985-\end{array}$ & 1,578 & 19,200 & $06-10-64$ & 156 & 02-02-89 \\
\hline
\end{tabular}

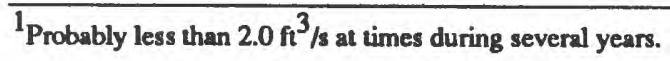

The quality of surface water in Nevada Creek and the Blackfoot River has been determined on the basis of limited sampling in which all major ions were analyzed. Analyses of two samples from Nevada Creek (gaging station 12335500) indicate a calcium bicarbonate type water with an average dissolved-solids concentration of 148 $\mathrm{mg} / \mathrm{L}$ (Clark and Dutton, in press). Five samples from the Blackfoot River near Bonner (station 12340000) indicate a calcium bicarbonate type water with an average dissolved-solids concentration of $113 \mathrm{mg} / \mathrm{L}$ (Shields and others, 1994).

The quality of the Blackfoot River has been affected by logging and hardrock mining in the headwater areas. Lambing (1991) statistically analyzed suspended-sediment and trace-element concentrations in the Blackfoot River near Bonner (station 12340000) throughout a wide range of hydrologic conditions during 1985-90. The median 
suspended-sediment concentration was $9 \mathrm{mg} / \mathrm{L}$ in the Blackfoot River, which supplies 43 percent of the average annual suspended-sediment load of the Clark Fork at Milltown. Trace-element concentrations exceeded aquatic-life criteria (U.S. Environmental Protection Agency, 1986) for total-recoverable copper, total-recoverable iron, and total-recoverable and dissolved lead during the reporting period. Based on a derived relation between suspendedsediment concentrations and total-recoverable trace-element concentrations, Lambing (1991) estimated that copper exceeded the aquatic-life criterion for chronic toxicity 24 percent of the time. Total-recoverable arsenic, iron, and zinc exceeded the criteria less than 2 percent of the time.

Moore and others (1991) measured metal concentrations in benthic biota, fish livers, water and fine-grained sediment along the Blackfoot River from its headwaters to its mouth. They concluded that although concentrations of most solute and particulate contaminants derived from mining activities decreased downstream, the most mobile metals, including cadmium, zinc, and copper, remained bioavailable throughout the river system.

Water in most lakes in the Clearwater drainage area is of good quality. However, Placid Lake is eutrophic because of land uses in the watershed which allow nutrients such as fertilizers to enter the lake. The nutrients increase biological activity, particularly algae blooms, which deplete oxygen levels and increase turbidity in the lake (Casne and others, 1975). Seeley Lake is moderately eutrophic, according to physical, biological, and chemical indicators (Cladouhos, 1968).

Ground water is an important resource in the Blackfoot-Clearwater Valley, where it provides domestic supplies for most residents. Quaternary alluvium and glacial-outwash are the primary aquifers. Ground water generally is accessible at shallow depths, and well yields typically range from 20 to $25 \mathrm{gal} / \mathrm{min}$ (Witkind and Weber, 1982; Noble and others, 1982, p. 48-51). Alluvial and glacial-outwash aquifers are unconfined everywhere in the basin except where occasional stringers of glacial outwash may be confined beneath poorly permeable glacial till. Yield and specific-capacity data for wells completed in Quaternary alluvium and glacial outwash in the BlackfootClearwater Valley are summarized in table 19.

Table 19. Summary of data for yield and specific capacity of wells completed in selected hydrogeologic units in the Blackfoot-Clearwater Valley, Montana

[Source: Dutton and others, 1995. Hydrogeologic unit: Qal, Holocene and Pleistocene alluvial deposits (includes glacia] outwash); QTd, Quatemary through Tertiary undifferentiated deposits. Abbreviations: gal/min, gallon per $\mathrm{minute}$; $(\mathrm{gal} / \mathrm{min}) / \mathrm{ft}$, gallon per minute per foot]

\begin{tabular}{|c|c|c|c|c|c|c|c|c|c|c|}
\hline \multirow{2}{*}{$\begin{array}{l}\text { Hydro- } \\
\text { geologlc } \\
\text { unit }\end{array}$} & \multirow[b]{2}{*}{$\begin{array}{c}\text { Number of } \\
\text { wells }\end{array}$} & \multicolumn{4}{|c|}{ Yield (gal/min) } & \multirow[b]{2}{*}{$\begin{array}{c}\text { Number of } \\
\text { wells }\end{array}$} & \multicolumn{4}{|c|}{ Specific capacity [(gal/min)/ft] } \\
\hline & & Mean & Median & $\begin{array}{l}\text { Mini- } \\
\text { mum }\end{array}$ & $\begin{array}{l}\text { Maxi- } \\
\text { mum }\end{array}$ & & Mean & Median & $\begin{array}{l}\text { Mini- } \\
\text { mum }\end{array}$ & $\begin{array}{l}\text { Maxl- } \\
\text { mum }\end{array}$ \\
\hline Qal & 7 & 32 & 25 & 10 & 50 & 6 & 2.8 & 2.2 & 0.8 & 6.3 \\
\hline QTd & 12 & 19 & 15 & 7.0 & 35 & 11 & 2.6 & 1.1 & .1 & 15 \\
\hline
\end{tabular}

Although glacial till is extensive, it is not a major aquifer in this basin. Wells completed in glacial till range in depth from 30 to more than $600 \mathrm{ft}$, and produce 5 to $17 \mathrm{gal} / \mathrm{min}$ (Noble and others, 1982, p. 48-51; Dutton and others, 1995), usually from discontinuous semi-confined to confined lenses of sand and gravel. Flowing wells are rare. In the flat area northeast of Kleinschmidt Lake, numerous wells have been drilled, but very few produce large yields from glacial till. Drainage through till-derived soils generally is poor (Witkind and Weber, 1982).

Tertiary sediments in the Blackfoot-Clearwater Valley are generally not permeable and, therefore, are not considered an important aquifer. Typically, wells completed in Tertiary sediments produce about $5 \mathrm{gal} / \mathrm{min}$ (Noble and others, 1982, p. 48-51). Wells completed in both Quaternary and Tertiary deposits yield an average of 19 gal/min (table 19). Permeable lenses within the Tertiary sediments are rare, and those that are encountered tend to be laterally discontinuous. On pediments in the upper Nevada Creek valley, for example, wells in close proximity are commonly finished at different depths and have different production capabilities. 
Large fractures in Tertiary volcanic rocks are capable of transmitting substantial quantities of ground water. For example, a well about 8 miles southwest of Helmville produces 3,000 gal/min (Noble and others, 1982 , p. 48-51). However, completing a successful well in volcanic rocks would depend on drilling through wellconnected, saturated fractures, the location of which would be extremely difficult to predict.

Water can also be obtained from fractures in Proterozoic bedrock. In comparison with volcanic rocks, metasedimentary Proterozoic bedrock generally has fewer and smaller fractures. However, wells completed in Proterozoic bedrock usually provide sufficient water for domestic use.

Little is known about ground-water flow in the Blackfoot-Clearwater Valley. However, a 1:750,000-scale potentiometric-surface map (Briar and others, in press) indicates that ground water generally flows from the uplands toward the flood plains, then parallel to the major streams. Dominant flow directions are northwest in the Nevada Creek valley, southeast in the Clearwater River Valley, and southwest in the lower Blackfoot River valley.

Basin-fill aquifers are recharged by precipitation and snowmelt, surplus irrigation water, leakage from irrigation canals, subsurface flow from bedrock, and infiltration from the Blackfoot River and tributary streams. The ground-water contribution area (fig. 2, pl. 1) is about $1,580 \mathrm{mi}^{2}$. Infiltration anywhere within this area could potentially recharge basin-fill aquifers in the Blackfoot-Clearwater Valley. Ground water discharges from the basinfill aquifers by evapotranspiration, withdrawals from wells, and seepage to springs, seeps, and stream channels. Some deep ground water might also discharge by subsurface flow to the Swan Valley.

Water levels measured in long-term monitoring well 15N12W36BCDD01 are stored in the USGS WATSTORE database. The 206-ft well is completed in Cenozoic basin fill. During the period September 1975 to October 1994, the water level in the well fluctuated between $95.79 \mathrm{ft}$ below land surface (April 26, 1991) and 126.72 $\mathrm{ft}$ below land surface (October 11, 1984).

The quality of ground water in the basin was determined on the basis of 20 samples analyzed for major ions and measured dissolved-solids concentrations. Ground water is a mixed-cation bicarbonate type with dissolvedsolids concentrations generally less than $250 \mathrm{mg} / \mathrm{L}$. Ground water in some Tertiary sediments has dissolved-solids concentrations of up to $500 \mathrm{mg} / \mathrm{L}$ (Clark and Dutton, in press), probably because of a long residence time.

\section{Selected References}

Boettcher, A.J., and Gosling, A.W., 1977, Water resources of the Clark Fork basin upstream from St. Regis, Montana: Montana Bureau of Mines and Geology Bulletin 104, 28 p.

Briar, D.W., Lawlor, S.M., Stone, M.A.J., Parliman, D.J., Schaefer, J.L., and Kendy, Eloise, in press, Ground-water levels in intermontane basins of the Northern Rocky Mountains, Montana and Idaho: U.S. Geological Survey Hydrologic Investigations Atlas 738-B, 1 sheet, scale 1:750,000.

Casne, E.W., Botz, M.K., and Pasichnyk, M.J., 1975, Water quality inventory and management plan, upper Clark Fork basin, Montana: Montana Department of Health and Environmental Sciences, 148 p.

Cladouhos, J.W., 1968, The water quality and cultural eutrophication of Seeley Lake, Montana: Missoula, University of Montana, M.S. thesis, 87 p.

Clark, D.W., and Dutton, D.M., in press, Quality of ground water and surface water in intermontane basins of the Northern Rocky Mountains, Montana and Idaho: U.S. Geological Survey Hydrologic Investigations Atlas 738-C, 1 sheet, scale 1:750,000.

Crosby, G.W., 1984, Structural-geophysical interpretation of Swan Valley, Montana: Montana Geological Society 1984 Field Conference, Northwestern Montana, p. 245-251.

Dutton, D.M., Lawlor, S.M., Briar, D.W., and Tresch, R.E., 1995, Hydrogeologic data for the Northern Rocky Mountains intermontane basins, Montana: U.S. Geological Survey Open-File Report 95-143, 94 p.

Kleinkopf, M.D., and Mudge, M.R., 1972, Aeromagnetic, Bouguer gravity, and generalized geologic studies of the Great FallsMission Range area, northwestern Montana: U.S. Geological Survey Professional Paper 726-A, 19 p.

Lambing, J.H., 1987, Water-quality data for the Clark Fork and selected tributaries from Deer Lodge to Milltown, Montana, March 1985 to June 1986: U.S. Geological Survey Open-File Report 87-110, 48 p. 
1988, Water-quality data (July 1986 through September 1987) and statistical summaries (March 1985 through September 1987) for the Clark Fork and selected tributaries from Deer Lodge to Missoula, Montana: U.S. Geological Survey OpenFile Report 88-308, 55 p.

1989, Water-quality data (October 1987 through September 1988) and statistical summaries (March 1985 through September 1988) for the Clark Fork and selected tributaries from Galen to Missoula, Montana: U.S. Geological Survey OpenFile Report 89-299, 51 p.

1990, Water-quality data (October 1988 through September 1989) and statistical summaries (March 1985 through September 1989) for the Clark Fork and selected tributaries from Galen to Missoula, Montana: U.S. Geological Survey OpenFile Report 90-168, 68 p.

1991, Water-quality and transport characteristics of suspended sediment and trace elements in streamflow of the upper Clark Fork basin from Galen to Missoula, Montana, 1985-1990: U.S. Geological Survey Water-Resources Investigations Report 91-4139,73 p.

McCulloch, Robin, 1993, Montana mining directory 1992: Montana Bureau of Mines and Geology Bulletin 131, 76 p.

Moore, J.N., Luoma, S.N., and Peters, Donald, 1991, Downstream effects of mine effluent on an intermontane riparian system: Canadian Journal of Fisheries and Aquatic Sciences, v. 48, no. 2, p. 222-232.

Mudge, M.R., Earhart, R.L., Whipple, J.W., and Harrison, J.E., 1982, Geologic and structure maps of the Choteau $1^{\circ} \times 2^{\circ}$ quadrangle, western Montana: Montana Bureau of Mines and Geology Montana Atlas 3-A, 1:250,000, 2 sheets.

National Oceanic and Atmospheric Administration, 1992, Monthly normals of temperature, precipitation, and heating and cooling degree days, 1961-90, Montana: Asheville, N.C., Climatography of the United States no. 81, unpaged.

Noble, R.A., Bergantino, R.N., Patton, T.W., Sholes, B.C., Daniel, Faith, and Schofield, Judeykay, 1982, Occurrence and characteristics of ground water of Montana--Volume 2, The Rocky Mountain Region: Montana Bureau of Mines and Geology Open-File Report 99, 132 p.

Shields, R.R., Knapton, J.R., White, M.K., Brosten, T.M., and Chambers, C.L., 1993, Water resources data, Montana, water year 1992: U.S. Geological Survey Water-Data Report MT-92-1, 534 p.

Shields, R.R., White, M.K., Brosten, T.M., and Chambers, C.L., 1994, Water resources data, Montana, water year 1993: U.S. Geological Survey Water-Data Report MT-93-1, 512 p.

Tuck, L.K., Briar, D.W., and Clark, D.W., in press, Geologic history and hydrogeologic units of intermontane basins of the Northern Rocky Mountains, Montana and Idaho: U.S. Geological Survey Hydrologic Investigations Atlas 738-A, 2 sheets, scale 1:750,000.

U.S. Environmental Protection Agency, 1986, Quality criteria for water 1986: Washington, D.C., Office of Water Regulations and Standards, EPA 440/5-86-001, unpaged.

U.S. Geological Survey, issued annually, Water resources data, Montana: Helena, Mont., U.S. Geological Survey Water-Data Report.

Wallace, C.A., 1987, Generalized geologic map of the Butte $1^{\circ} \times 2^{\circ}$ quadrangle, Montana: U.S. Geological Survey Miscellaneous Field Studies Map MF-1924, scale 1:250,000.

Wallace, C.A., Schmidt, R.G., Lidke, D.J., Waters, M.R., Elliott, J.E., French, A.B., Whipple, J.W., Zarske, S.E., Blaskowski, M.J., Heise, B.A., Yeoman, R.A., O'Neill, J.M., Lopez, D.A., Robinson, G.D., and Klepper, M.R., 1986, Preliminary geologic map of the Butte $1^{\circ} \times 2^{\circ}$ quadrangle, western Montana: U.S. Geological Survey Open-File Report 86-292, scale $1: 250,000$.

Weber, W.M., and Witkind, IJ., 1979, Reconnaissance geologic map of the northern two-thirds of the Avon quadrangle, Lewis and Clark and Powell Counties, Montana: U.S. Geological Survey Open-File Report 79-437, scale 1:62,500.

Wilke, K.R., 1979, Selected well inventory and chemical analyses of ground water, parts of Missoula and Powell Counties, Montana: U.S. Geological Survey Open-File Report 79-1491, 4 p., 2 tables.

Witkind, I.J., and Weber, W.M., 1982, Reconnaissance geologic map of the Big Fork-Avon environmental study area, Flathead, Lake, Lewis and Clark, Missoula, and Powell Counties, Montana: U.S. Geological Survey Miscellaneous Investigations Series Map I-1380, scale 1:125,000. 


\section{Boulder Valley}

\section{Geography}

The Boulder Valley is a north-northwest-trending intermontane basin about $124 \mathrm{mi}^{2}$ in area. It is bounded by Bull Mountain on the west and the Elkhorn Mountains on the east (pl. 1). From its headwaters near the Continental Divide, the Boulder River flows east toward the Town of Boulder, then southward through the basin, to the confluence with the Jefferson River near Cardwell. North of Boulder, the surrounding mountains rise abruptly from the alluvial plain, which is about $3 \mathrm{mi}$. wide. South of Boulder, the Boulder River meanders within a well-defined, sometimes swampy, flood plain about 0.5 to $1 \mathrm{mi}$. wide. Flanking the flood plain are large, grass- and sagecovered, dissected pediments and alluvial fans, which slope gently away from the mountains. The Boulder Valley ranges in altitude from about $4,300 \mathrm{ft}$ where the Boulder River flows out of the basin, to about $6,000 \mathrm{ft}$ on the highest pediment.

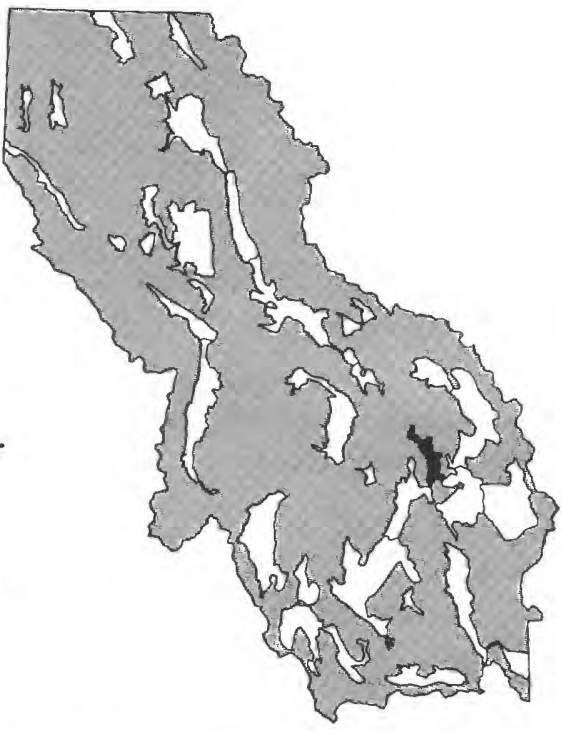

The climate of the Boulder Valley is typical of higher-elevation intermontane basins of the Northern Rocky Mountains east of the Continental Divide, with cold winters and mild summers. On the basis of the 1961-90 period of record, the average annual precipitation at Boulder (altitude $4,900 \mathrm{ft}$ above sea level) is $11.69 \mathrm{in}$., and the average annual temperature is $42.7^{\circ} \mathrm{F}$ (National Oceanic and Atmospheric Administration, 1992). The average last occurrence of $32^{\circ} \mathrm{F}$ is June 9, and the average first occurrence is September 7 (Natural Resources Conservation Service, U.S. Department of Agriculture, unpub. data, 1994). Mean monthly climatic data for Boulder are plotted on figure 10.

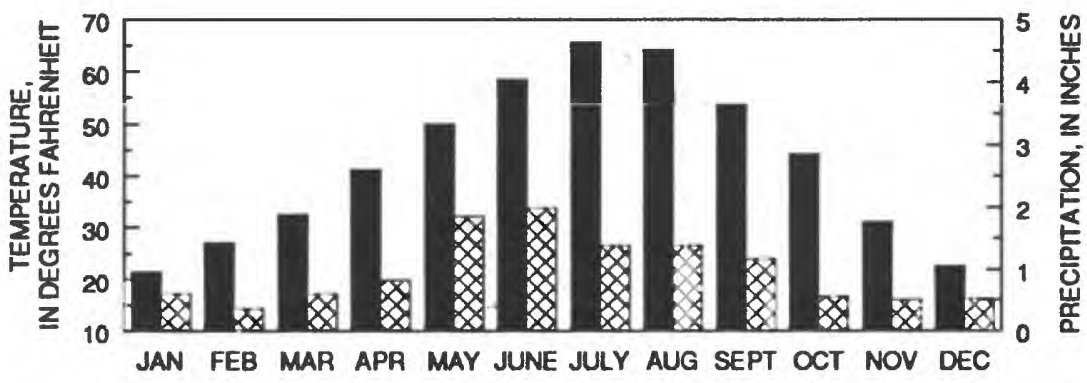

\section{EXPLANATION}

MEAN MONTHLY TEMPERATURE FOR 1961-90 PERIOD OF RECORD

$\triangle$ MEAN MONTHLY PRECIPITATION FOR 1961-90 PERЮD OF RECORD

Figure 10. Mean monthly precipitation and temperature at Boulder, Mont. Data from National Oceanic and Atmospheric Administration (1992).

Land uses include rangeland, and irrigated hay and pasture land. In addition, dryland small grains are grown to a limited extent on pediments (J.C. Eggen, Agricultural Stabilization and Conservation Service, oral commun., 1993). Subirrigation and surface-water diversions are used to irrigate the flood plain. Diversions from the Boulder River irrigate about 7,000 acres, while diversions from tributaries supply an additional 4,500 acres ([Montana] State Engineer's Office, 1956a). Recently completed wells on western pediments have allowed for some irrigated agriculture outside the flood plains. Mining is of historical importance in the mountains surrounding the Boulder Valley; current activity is limited to exploration for gold (McCulloch, 1993, p. 44). About 1,700 people reside in the Boulder Valley, including 1,316 in the Town of Boulder (1990 census). 


\section{Geology}

The ancestral Boulder Valley was probably delineated by erosional processes related to the Late Cretaceous to middle Eocene Laramide Orogeny (Fields and others, 1985; Lofgren, 1985). The ancestral Boulder Valley drained to the east, toward the present-day Western Three Forks Valley (Thompson and others, 1981). Westward transport began in about the late Miocene in response to uplift along the eastern margin of the basin (Pardee, 1950; Lofgren, 1985). Several poorly discernible faults with minor offset delineate the western basin margin. The Boulder Valley continued to subside until late Pliocene or early Pleistocene time, when present pediment surfaces developed. There is no evidence of late Pleistocene to Holocene faulting in the Boulder Valley (Lofgren, 1985). Gravity data indicate that the depth to bedrock is greatest in the central Boulder Valley, west of the Boulder River, where basin fill is more than 4,000 ft thick (Noble and others, 1982, p. 73-76).

Several investigators have mapped the geology of the Boulder Valley. Graduate students from Indiana University, including Parker (1961), Nelson (1962), Wilson (1962), Richard (1966), and Burfiend (1967) provided much of the early mapping and interpretations of local geologic features. Other geologic and geophysical maps of the basin are listed in table 20. The geologic units described by previous investigators are summarized below. These geologic units are referenced to hydrogeologic units defined in this study (table 2) to provide a consistent regional framework. In the following discussion, the hydrogeologic-unit abbreviations are italicized.

Table 20. Geologic and geophysical maps of the Boulder Valley, Montana

\begin{tabular}{|c|c|c|c|c|}
\hline Type of map & Scale & Location & Map features & Reference \\
\hline Aeromagnetic & $1: 250,000$ & Entire Boulder Valley & Contour intervals 20 and 100 gammas & $\begin{array}{l}\text { Johnson and others, } \\
1965\end{array}$ \\
\hline $\begin{array}{l}\text { Gravity, } \\
\text { magnetic, and } \\
\text { generalized } \\
\text { geology }\end{array}$ & $1: 62,500$ & $\begin{array}{l}\text { Central part of Boulder } \\
\text { Valley (north of lat } \\
46^{\circ} \mathrm{N} \text {. and east of long } \\
112^{\circ} \mathrm{W} \text {.) }\end{array}$ & $\begin{array}{l}\text { Gravity contour interval } 5 \text { milligals. Magnetic } \\
\text { contour interval } 20 \text { gammas. All basin fill } \\
\text { designated as Cenozoic deposits }\end{array}$ & $\begin{array}{l}\text { Kinoshita and } \\
\text { others, } 1965\end{array}$ \\
\hline $\begin{array}{l}\text { Cenozoic basin- } \\
\text { fill thickness }\end{array}$ & $1: 500,000$ & Entire Boulder Valley & Contour interval 1,000 feet & $\begin{array}{l}\text { Noble and others, } \\
1982 \text {, fig. II-19. } \\
\text { p. } 75\end{array}$ \\
\hline Geology & $1: 250,000$ & $\begin{array}{l}\text { Northwestern part of } \\
\text { basin (north of lat } \\
46^{\circ} \mathrm{N} \text {. and west of long } \\
112^{\circ} \mathrm{W} \text {.) }\end{array}$ & $\begin{array}{l}\text { Differentiates two basin-fill units: Tertiary } \\
\text { sedimentary deposits and rocks, and } \\
\text { Quatemary surficial deposits }\end{array}$ & Wallace, 1987 \\
\hline Geology & $1: 250,000$ & $\begin{array}{l}\text { Northwestem part of } \\
\text { basin (north of lat } \\
46^{\circ} \mathrm{N} \text {. and west of long } \\
112^{\circ} \mathrm{W} \text {.) }\end{array}$ & $\begin{array}{l}\text { Differentiates } 4 \text { Tertiary and } 10 \text { Quaternary } \\
\text { basin-fill units }\end{array}$ & $\begin{array}{l}\text { Wallace and others, } \\
1986\end{array}$ \\
\hline
\end{tabular}

Metasedimentary, sedimentary, volcanic and intrusive bedrock surround the basin. In the Elkhom Mountains, Precambrian through Mesozoic metasedimentary and sedimentary rocks are extensively faulted and folded. Argillaceous mudstone, shale, and sandstone of the Belt Supergroup ( $Y \mathrm{~ms}$ ) are overlain by interbedded phosphatic sandstone, quartzite, siltstone, mudstone, shale, and carbonate rocks of Paleozoic age (Pzls). Mississippian limestone forms broad ridges east of the Boulder Valley. Paleozoic and Mesozoic rocks (Mzsh)--primarily interbedded shale, mudstone, and sandstone--underlie the basin. West of the Boulder Valley, Bull Mountain is composed of Upper Cretaceous Elkhorn Mountains Volcanics (QTKe), which include tuffs, breccias, and flows ranging in composition from basalt to andesite. Intrusive rocks (TKi) in the area include diorite and diorite porphyry dikes and sills associated with the Elkhorn Mountains Volcanics, and the granodioritic Boulder Batholith (fig. 4) (Klepper and others, 1957; Wallace and others, 1986; Wallace, 1987). 
Tertiary sediments (Ts) in the Boulder Valley are part of the Renova and Sixmile Creek Formations of the Bozeman Group. The middle Eocene to lower Miocene Renova Formation is further subdivided into the contemporaneous Dunbar Creek and Climbing Arrow Members (Lofgren, 1985) (Dunbar Creek and Climbing Arrow Formations of Robinson, 1963). The Climbing Arrow Member, which crops out primarily on the eastern side of the basin, consists of about $600 \mathrm{ft}$ of montmorillonitic mudstone and siltstone, conglomerate, and sandstone. The Dunbar Creek Member, which crops out primarily on the westem side of the basin, consists of about $600 \mathrm{ft}$ of poorly consolidated tuffaceous siltstone with some pebble conglomerate, mudstone, and montmorillonitic siltstone. An unconformity separates the dominantly fine-grained Renova Formation from the more coarse-grained Sixmile Creek Formation. In the Boulder Valley, the middle to upper Miocene Sixmile Creek Formation consists of about $1.200 \mathrm{ft}$ of well-consolidated, coarse-grained, sand- and-gravel conglomerate that forms extensive cliffs and bluffs. West of the Boulder River, the conglomerate contains clasts of Elkhorn Mountains Volcanics, whereas Paleozoic carbonate rock fragments dominate outcrops east of the river. Late Pliocene to early Pleistocene pediment surfaces are capped by Pleistocene gravels (Lofgren, 1985).

Quaternary flood-plain alluvium (Qal) underlies the Boulder River flood plain. North of the Town of Boulder, alluvium spans the entire three-mile width of the basin and directly overlies granitic bedrock, whereas south of Boulder it is confined to a narrow flood plain, which in most places overlies Tertiary sediments. However, floodplain alluvium overlies Mississippian limestone near the center of the basin. The alluvium consists of gravel, sand, and some silt, and is typically about $50 \mathrm{ft}$ thick. In some areas, however, more than $100 \mathrm{ft}$ of alluvium overlie Tertiary sediments.

\section{Hydrology}

The Boulder River originates near the Continental Divide, west of Bull Mountain. It drains a terrane of volcanic and intrusive bedrock before entering the northwestern tip of the Boulder Valley. Numerous diversions from the river supply water for irrigated land, including about 3,500 acres upstream from the Town of Boulder (Shields and others, 1993). After traversing the length of the basin, the Boulder River leaves the Boulder Valley through a narrow bedrock gorge.

Streamflow data for gaging stations listed in table 21 are stored in the USGS WATSTORE database. Locations of the stations are shown on plate 1.

Table 21. Summary of data for U.S. Geological Survey streamflow-gaging stations in the Boulder Valley, Montana

[Type of data collected: $c$, water chemistry; d, discharge. Periods of record for stations that were being operated as of November 1994 are indicated by the first year of record followed by a dash only. Abbreviations: $\mathrm{ft}^{3} / \mathrm{s}$, cubic feet per second. Symbol: --, no data]

\begin{tabular}{|c|c|c|c|c|c|c|c|c|c|}
\hline \multirow[b]{2}{*}{$\begin{array}{l}\text { Station } \\
\text { number }\end{array}$} & \multirow[b]{2}{*}{ Station name } & \multirow{2}{*}{$\begin{array}{c}\text { Drainage } \\
\text { area } \\
\text { (square } \\
\text { miles) }\end{array}$} & \multirow{2}{*}{$\begin{array}{l}\text { Type } \\
\text { of data } \\
\text { cot- } \\
\text { lected }\end{array}$} & \multirow[b]{2}{*}{$\begin{array}{l}\text { Period of record } \\
\text { (calendar year) }\end{array}$} & \multicolumn{5}{|c|}{ Discharge for period of record } \\
\hline & & & & & $\begin{array}{l}\text { Mean } \\
\text { annual } \\
\left(\mathrm{ft}^{3} / \mathrm{s}\right)\end{array}$ & $\begin{array}{l}\text { Maxt- } \\
\text { mum } \\
\left(\mathrm{ft}^{3} / \mathrm{s}\right)\end{array}$ & $\begin{array}{l}\text { Date of } \\
\text { maximum }\end{array}$ & $\begin{array}{l}\text { Mint } \\
\text { mumm } \\
\left(\mathrm{ft}^{3} / \mathrm{s}\right)\end{array}$ & $\begin{array}{c}\text { Date of } \\
\text { minimum }\end{array}$ \\
\hline 06032500 & $\begin{array}{l}\text { Muskrat Creek near } \\
\text { Boulder }\end{array}$ & 6.09 & d & $1912-14$ & $1_{3.95}$ & 42 & $06-01-14$ & 0.8 & 04-01-14 \\
\hline 06033000 & $\begin{array}{l}\text { Boulder River near } \\
\text { Boulder }\end{array}$ & 381 & d & $\begin{array}{l}1929-32,1934-72, \\
1984\end{array}$ & 117 & 3.490 & $06-09-64$ & 0 & $07-15-31$ \\
\hline 06033500 & $\begin{array}{l}\text { North Fork Little } \\
\text { Boulder River near } \\
\text { Boulder }\end{array}$ & 18.8 & d & $1926-27$ & 8.47 & 77 & $06-09-27$ & -- & - \\
\hline 06033900 & $\begin{array}{l}\text { Boulder River near } \\
\text { Cardwell }\end{array}$ & -- & $c^{2}$ & 1986 & - & - & - & - & - \\
\hline
\end{tabular}

Data for water year 1913.

${ }^{2}$ Specific conductance, temperature, and concentration of total recoverable arsenic (Knapton and Horpestad, 1987). 
Little is known about the basic water quality of the Boulder River. One sample collected near Boulder on February 21, 1973 indicates that water in the Boulder River has a low concentration of dissolved solids, and is a moderately hard, calcium bicarbonate type (Braico and Botz, 1975).

Historical mining activities in the Boulder River drainage area have affected water quality in the Boulder River (Braico and Botz, 1975). Dissolved metals and suspended sediment enter the river, primarily from tributaries upstream of the Boulder Valley.

The concentration of total-recoverable arsenic measured in twelve samples collected near the mouth (gaging station 06033900 ) ranged from $6 \mu \mathrm{g} / \mathrm{L}$ to $38 \mu \mathrm{g} / \mathrm{L}$ during water-year 1986. The largest concentration coincided with the largest sampled flow $\left(646 \mathrm{ft}^{3} / \mathrm{s}\right)$, on May 27, 1986 (Knapton and Horpestad, 1987, p. 17). All arsenic concentrations were smaller than the maximum contaminant level of $50 \mu \mathrm{g} / \mathrm{L}$ arsenic established by the U.S. Environmental Protection Agency (1991) for treated drinking water.

Ground water is an important resource in the Boulder Valley, as all basin residents rely upon it for domesticwater supplies. However, little information is available about the aquifers in the Boulder Valley.

The primary aquifer is the unconsolidated Quaternary alluvium that underlies the flood plain of the Boulder River. Wells completed in this unconfined aquifer typically yield 10 to $50 \mathrm{gal} / \mathrm{min}$ for domestic and agricultural use. However, a 95-ft-deep irrigation well (04N03W01) completed in alluvium produces more than 1,000 gal/min (Noble and others, 1982, p. 73-76).

The heterogeneity of Tertiary sediments is evidenced by the large range of yield and specific-capacity values encountered in the Boulder Valley (table 22). Some irrigation wells recently completed in Tertiary sediments on the west side of the basin produce more than $1,000 \mathrm{gal} / \mathrm{min}$ with specific-capacity values as large as 57 (gal/min)/ $\mathrm{ft}$. However, in other parts of the basin, wells completed in Tertiary sediments produce only about $5 \mathrm{gal} / \mathrm{min}$. Depths of wells completed in Tertiary sediments range from about 50 to $400 \mathrm{ft}$. Ground water in Tertiary sediments is unconfined, or semiconfined by laterally discontinuous layers of fine-grained material.

Table 22. Summary of data for yield and specific capacity of wells completed in selected hydrogeologic units in the Boulder Valley, Montana

[Source: Dutton and others, 1995. Hydrogeologic unit: Ts. Tertiary sedimentary deposits and rocks; TKi, Teniary through Cretaceous intrusive rocks (Boulder Batholith). Abbreviations: gal/min, gallon per minute; (gal/min)/ft, gallon per minute per foot]

\begin{tabular}{|c|c|c|c|c|c|c|c|c|c|c|}
\hline \multirow{2}{*}{$\begin{array}{l}\text { Hydro- } \\
\text { geologle } \\
\text { unit }\end{array}$} & \multirow[b]{2}{*}{$\begin{array}{c}\text { Number of } \\
\text { wells }\end{array}$} & \multicolumn{4}{|c|}{ Yield (gal/min) } & \multirow[b]{2}{*}{$\begin{array}{c}\text { Number of } \\
\text { wells }\end{array}$} & \multicolumn{4}{|c|}{ Specific capracity $[(g a i / m i n) / f t]$} \\
\hline & & Mean & Median & $\begin{array}{l}\text { Mint } \\
\text { mum }\end{array}$ & $\begin{array}{l}\text { Maxi- } \\
\text { mum }\end{array}$ & & Mean & Median & $\begin{array}{l}\text { Mini- } \\
\text { mum }\end{array}$ & $\begin{array}{l}\text { Maxk- } \\
\text { mum }\end{array}$ \\
\hline Ts & 14 & 340 & 20 & 5.0 & 2,200 & 12 & 7.0 & 0.4 & 0.1 & 57 \\
\hline $\mathrm{TKi}^{1}$ & 12 & 180 & 28 & 3.0 & 1,500 & 8 & 5.6 & .6 & .1 & 40 \\
\hline
\end{tabular}

TMay include wells completed along basin margins, outside the area of basin fill.

Most wells in the northem part of the basin, near the Town of Boulder, are completed in granitic rocks of the Boulder Batholith which underlie about $50 \mathrm{ft}$ of alluvium. Some of the wells, which range from about 40 to $400 \mathrm{ft}$ deep, are capable of producing substantial quantities of water (table 22). However, because many are completed in both alluvium and granite, the contribution from the separate hydrogeologic units is unknown. For example, a 350 ft well (06N04W28DADD) produces $1,500 \mathrm{gal} / \mathrm{min}$ from sand and gravel between 18 and $116 \mathrm{ft}$ below land surface, and from granite between 140 and $350 \mathrm{ft}$ below land surface. Wells that are completed only in granite produce from about 3 to $20 \mathrm{gal} / \mathrm{min}$ (Montana Bureau of Mines and Geology, unpub. data, 1994).

Except for Mississippian limestone, the Mesozoic and Paleozoic sedimentary rocks that border and underlie the Boulder Valley generally do not yield useful quantities of ground water to wells. Where Mississippian limestone is saturated, however, it is potentially a useful aquifer because ground water can move easily through cavernous openings created by dissolution of carbonate minerals. A $170-\mathrm{ft}$ well that was drilled through alluvium to limestone 
in the center of the basin (04N02W30DADD) produces $900 \mathrm{gal} / \mathrm{min}$ with a specific capacity of 45 (gal/min)/ft. However, another well, located in the northern part of the basin (05N03W22CAAA) was completed in limestone at a depth of $390 \mathrm{ft}$, and produces about $12 \mathrm{gal} / \mathrm{min}$ with a specific capacity of $0.1(\mathrm{gal} / \mathrm{min}) / \mathrm{ft}$ (Dutton and others, 1995).

Fractures in Proterozoic metasedimentary bedrock can yield sufficient water for domestic use. A 215-ft-deep well near the Boulder River in the southern end of the basin (02N03W23DDBD) yields $18 \mathrm{gal} / \mathrm{min}$ (Dutton and others, 1995).

Little is known about ground-water movement in the Boulder Valley. However, a 1:750,000-scale potentiometric-surface map which includes the Boulder Valley (Briar and others, in press) indicates that ground water generally flows from the uplands toward the flood plain, then southward paralleling the Boulder River.

Basin-fill aquifers are recharged by precipitation and snowmelt, surplus irrigation water, leakage from irrigation canals, subsurface flow from bedrock, and infiltration from the Boulder River and tributary streams. The ground-water contribution area (fig. 2, pl. 1) is about $440 \mathrm{mi}^{2}$. Infiltration anywhere within this area could potentially recharge basin-fill aquifers in the Boulder Valley. Ground water discharges from basin-fill aquifers by evapotranspiration, withdrawals from wells, and seepage to springs, seeps, and stream channels.

The quality of ground water in the basin was determined on the basis of 14 samples analyzed for major ions and measured dissolved-solids concentrations, and 6 samples in which dissolved-solids concentrations were estimated from specific-conductance measurements. The quality of ground water varies throughout the Boulder Valley. In the northem part of the basin, where about $50 \mathrm{ft}$ of alluvium directly overlies bedrock, ground water is a calcium bicarbonate type with dissolved-solids concentrations of 250 to $500 \mathrm{mg} / \mathrm{L}$ (Clark and Dutton, in press). Water from Boulder Hot Springs (05N04W10CBA), which discharge from quartz monzonite at the edge of this area (Chadwick and Leonard, 1979), has an average dissolved-solids concentration of $420 \mathrm{mg} / \mathrm{L}$ (Sonderegger and Bergantino, 1981). Similar water quality typifies ground water within Tertiary sediments along the northeastern edge of the basin. Downgradient, where the basin fill is thickest, calcium and bicarbonate ions also dominate, but dissolved-solids concentrations are typically less than $250 \mathrm{mg} / \mathrm{L}$. Still farther downgradient, in the southern third of the basin, ground water is a mixed-sulfate type in which calcium, magnesium, and sodium may occur in any combination with sulfate, and the concentration of dissolved solids ranges from about 250 to $500 \mathrm{mg} / \mathrm{L}$ (Clark and Dutton, in press).

\section{Selected References}

Braico, R.D., and Botz, M.K., 1975, Water quality inventory and management plan, upper Missouri tributaries basin, Montana: Montana Department of Health and Environmental Sciences, 167 p.

Briar, D.W., Lawlor, S.M., Stone, M.A.J., Parliman, D.J., Schaefer, J.L., and Kendy, Eloise, in press, Ground-water levels in intermontane basins of the Northern Rocky Mountains, Montana and Idaho: U.S. Geological Survey Hydrologic Investigations Atlas 738-B, 1 sheet, scale 1:750,000.

Burfiend, W.J., 1967, A gravity investigation of the Tobacco Root Mountains, Jefferson basin, Boulder batholith, and adjacent areas of southwestern Montana: Bloomington, Indiana University, Ph.D. dissertation, $90 \mathrm{p}$.

Chadwick, R.A., and Leonard, R.B., 1979, Structural controls of hot-spring systems in southwestem Montana: U.S. Geological Survey Open-File Report 79-1333, 25 p.

Clark, D.W., and Dutton, D.M., in press, Quality of ground water and surface water in intermontane basins of the Northern Rocky Mountains, Montana and Idaho: U.S. Geological Survey Hydrologic Investigations Atlas 738-C, 1 sheet, scale $1: 750,000$.

Dutton, D.M., Lawlor, S.M., Briar, D.W., and Tresch, R.E., 1995, Hydrogeologic data for the Northem Rocky Mountains intermontane basins, Montana: U.S. Geological Survey Open-File Report 95-143, 94 p.

Fields, R.W., Tabrum, A.R., Rasmussen, D.L., and Nichols, Ralph, 1985, Cenozoic rocks of the intermontane basins of western Montana and eastem Idaho--A summary, in Flores, R.M., and Kaplan, S.S., eds., Cenozoic paleogeography of west-central United States: Denver, Colo., Rocky Mountain Section, Society of Economic Paleontologists and Mineralogists, p. 9-36. 
Johnson, R.W., Jr., Henderson, J.R., and Tyson, N.S., 1965, Aeromagnetic map of the Boulder batholith area, southwestern Montana: U.S. Geological Survey Geophysical Investigations Map GP-538, scale 1:250,000.

Kinoshita, W.T., Davis, W.E., and Robinson, G.D., 1965, Aeromagnetic, Bouguer gravity, and generalized geologic map of Toston and Radersburg quadrangles and part of the Devils Fence quadrangle, Gallatin, Broadwater and Jefferson Counties, Montana: U.S. Geological Survey Geophysical Investigations Map GP-496, 2 sheets, scale 1:62,500.

Klepper, M.R., Weeks, R.A., and Ruppel, E.T., 1957, Geology of the southern Elkhorn Mountains, Jefferson and Broadwater Counties, Montana: U.S. Geological Survey Professional Paper 292, 82 p.

Knapton, J.R., and Horpestad, A.A., 1987, Arsenic data for streams in the upper Missouri River basin, Montana and Wyoming: U.S. Geological Survey Open-File Report 87-124, 25 p.

Kuenzi, W.D., and Richard, B.H., 1969, Middle Tertiary unconformity, North Boulder and Jefferson basins, southwest Montana: Geological Society of America Bulletin, v. 80, p. 315-320.

Lofgren, D.L., 1985, Tertiary vertebrate paleontology, stratigraphy, and structure, North Boulder River basin, Jefferson County, Montana: Missoula, University of Montana, M.S. thesis, 113 p.

McCulloch, Robin, 1993, Montana mining directory 1992: Montana Bureau of Mines and Geology Bulletin 131, 76 p.

[Montana] State Engineer's Office, 1956a, Water resources survey, Jefferson County, Montana--Part 1, History of land and water use on irrigated areas: Helena, Mont., State Engineer's Office, 54 p.

1956b, Water resources survey, Jefferson County, Montana--Part 2, Maps showing irrigated areas: Helena, Mont., State Engineer's Office, 29 p.

National Oceanic and Atmospheric Administration, 1992, Monthly normals of temperature, precipitation, and heating and cooling degree days, 1961-90, Montana: Asheville, N.C., Climatography of the United States no. 81, unpaged.

Nelson, W.L., 1962, A seismic study of North Boulder Valley and other selected areas, Jefferson and Madison Counties, Montana: Bloomington, Indiana University, M.A. thesis, 33 p.

Noble, R.A., Bergantino, R.N., Patton, T.W., Sholes, B.C., Daniel, Faith, and Schofield, Judeykay, 1982, Occurrence and characteristics of ground water of Montana--Volume 2, The Rocky Mountain Region: Montana Bureau of Mines and Geology Open-File Report 99, 132 p.

Pardee, J.T., 1950, Late Cenozoic block faulting in western Montana: Geological Society of America Bulletin, v. 61, p. 356406.

Parker, J.S., 1961, A preliminary seismic investigation of Tertiary basin fill in the Jefferson Island Quadrangle, Montana: Bloomington, Indiana University, M.A. thesis, 35 p.

Richard, B.H., 1966, Geologic history of the intermontane basins of the Jefferson Island quadrangle, Montana: Bloomington, Indiana University, Ph.D. dissertation, 121 p.

Robinson, G.D., 1963, Geology of the Three Forks quadrangle, Montana: U.S. Geological Survey Professional Paper 370, $143 \mathrm{p}$.

Shields, R.R., Knapton, J.R., White, M.K., Brosten, T.M., and Chambers, C.L., 1993, Water resources data, Montana, water year 1992: U.S. Geological Survey Water-Data Report MT-92-1, p. 87.

Sonderegger, J.L., and Bergantino, R.N., 1981, Geothermal resources map of Montana: Montana Bureau of Mines and Geology Hydrogeologic Map 4, scale 1:1,000,000.

Thompson, G. R., Fields, R.W., and Alt, David, 1981, Tertiary paleoclimates, sedimentation patterns and uranium distribution in southwestern Montana, in Montana Geological Society Field Conference and Symposium Guidebook to Southwest Montana: [Billings, Mont.], Montana Geological Society, p. 105-109.

Tuck, L.K., Briar, D.W., and Clark, D.W., in press, Geologic history and hydrogeologic units of intermontane basins of the Northern Rocky Mountains, Montana and Idaho: U.S. Geological Survey Hydrologic Investigations Atlas 738-A, 2 sheets, scale 1:750,000.

U.S. Environmental Protection Agency, 1991, Maximum contaminant levels (subpart B of part 141, National primary drinkingwater regulations): U.S. Code of Federal Regulations, Title 40, Parts 100 to 149, revised July 1, 1991, p. 585-588.

U.S. Geological Survey, issued annually, Water resources data, Montana: Helena, Mont., U.S. Geological Survey Water-Data Report. 
Wallace, C.A., 1987, Generalized geologic map of the Butte $1^{\circ} \times 2^{\circ}$ quadrangle, Montana: U.S. Geological Survey Miscellaneous Field Studies Map MF-1924, scale 1:250,000.

Wallace, C.A., Schmidt, R.G., Lidke, D.J., Waters, M.R., Elliott, J.E., French, A.B., Whipple, J.W., Zarske, S.E., Blaskowski, M.J., Heise, B.A., Yeoman, R.A., O'Neill, J.M., Lopez, D.A., Robinson, G.D., and Klepper, M.R., 1986, Preliminary geologic map of the Butte $1^{\circ} \times 2^{\circ}$ quadrangle, western Montana: U.S. Geological Survey Open-File Report 86-292, scale $1: 250,000$.

Wilson, D.A., 1962, A seismic and gravity investigation of the North Boulder River and Jefferson River Valleys, Madison and Jefferson Counties, Montana: Bloomington, Indiana University, M.A. thesis, 43 p. 


\section{Camas Prairle Basin}

\section{Geography}

The Camas Prairie Basin is a north-trending intermontane basin in the western part of the Flathead Indian Reservation. This $40-\mathrm{mi}^{2}$ basin is surrounded by the Salish and Cabinet Mountains (pl. 1). South-flowing Camas Creek drains the basin. The broad, flat center of the basin is surrounded by moderately steep alluvial fans. In the northem end of the basin, delta-like benches and numerous ridges are oriented perpendicular to the general southward slope of the land. These ridges have been interpreted as giant ripple marks caused by catastrophic draining of glacial Lake Missoula (Pardee, 1942), or as ancient shorelines of glacial Lake Missoula (Alden, 1953). The Camas Prairie Basin ranges in altitude from about 2,800 ft where Camas Creek flows out of the basin, to about $3,600 \mathrm{ft}$ on the highest alluvial fan.

Because of the rainshadow effect of the Cabinet Mountains, the climate of the Camas Prairie Basin is somewhat drier than other lower-elevation

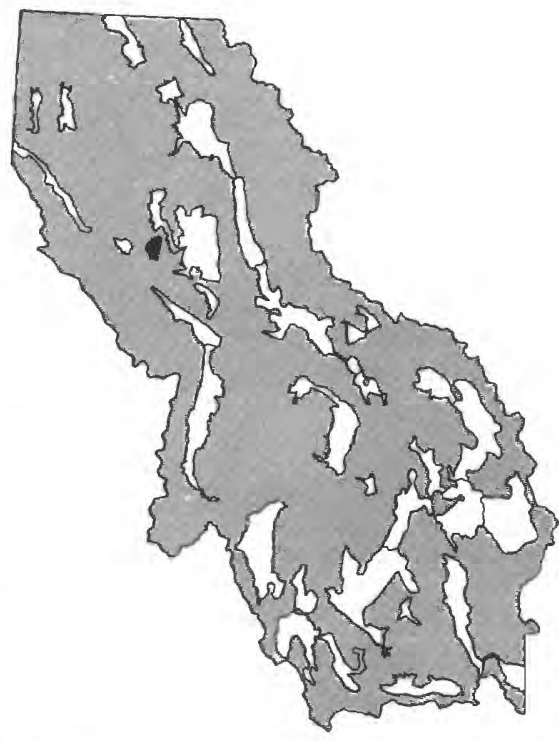
intermontane basins of the Northern Rocky Mountains west of the Continental Divide. The National Weather Service does not maintain a weather station in the Camas Prairie Basin. However, the climate is similar to that of Lonepine (altitude 2,880 ft), which is located in the Little Bitterroot Valley about 11 miles to the north. Mean monthly climatic data for Lonepine are plotted in figure 20 (see page 133), Little Bitterroot Valley.

Land uses in the Camas Prairie Basin include livestock grazing and irrigated hay and grain production. Dryland small grains are also grown to a limited extent (J.C. Eggen, Agricultural Stabilization and Conservation Service, oral commun., 1993). Surface water is not diverted for irrigation; rather, a few shallow dug wells provide irrigation water in the northem end of the basin, and the central basin is subirrigated. Dryland farming is practiced in the southem end of the basin, as well as on alluvial fans along the basin margin (S.E. Slagle, U.S. Geological Survey, oral commun., 1994). About 100 people reside in Camas Prairie Basin.

\section{Geology}

Like other intermontane basins in Montana, the Camas Prairie Basin is a graben. It is bounded by normal faults on the east and southwest. In addition, several northwest-trending normal faults transect the basin. Both bounding faults, as well as the basin itself, are truncated on the south by the Lewis and Clark Line (fig. 4), a northwest-trending zone of high-angle, normal, reverse, and right-lateral strike-slip faults (Harrison and others, 1986). About $700 \mathrm{ft}$ of sediment fills the intermontane basin (Slagle, 1988).

Little is known about the geology of Camas Prairie Basin. However, a few generalized geologic and geophysical maps are available (table 23). The geologic units described by previous investigators are summarized below. These geologic units are referenced to hydrogeologic units defined in this study (table 2) to provide a consistent regional framework. In the following discussion, the hydrogeologic-unit abbreviations are italicized.

Middle Proterozoic quartzite, siltite, and argillite of the Belt Supergroup (Yms) underlie and surround the basin. The folded and faulted bedrock is intruded by dioritic to gabbroic Proterozoic sills from less than 3 to $1,500 \mathrm{ft}$ thick. The metasedimentary bedrock has been metamorphosed as far as $600 \mathrm{ft}$ from the larger sills (Harrison and others, 1986).

Tertiary sediments (Ts) may overlie bedrock in the Camas Prairie Basin, but none are exposed at the surface. Slagle (1988) tentatively identified dark-tan to reddish-brown silt and fine-grained silty sand from 119 to $500 \mathrm{ft}$ below land surface in a test well (20N24W23CBAA) as Tertiary sediments, based primarily on their greater degree of consolidation than the overlying Quatemary alluvium. 
Table 23. Geologic and geophysical maps of the Camas Prairie Basin, Montana

\begin{tabular}{|c|c|c|c|c|}
\hline Type of map & Scale & Location & Map features & Reference \\
\hline Geology & $1: 250,000$ & Entire basin & $\begin{array}{l}\text { All basin fill is identified as undifferentiated } \\
\text { glacial, fluvioglacial (outwash) and flood } \\
\text { deposits. Includes a southwest-northeast } \\
\text { bedrock cross-section near Camas Prairie }\end{array}$ & Harrison and others, 1986 \\
\hline Aeromagnetic & $1: 250,000$ & Entire basin & Contour interval 10 gammas & Kleinkopf and others, 1972 \\
\hline Geology & $1: 300,000$ & Entire basin & $\begin{array}{l}\text { All basin fill is grouped as Quatemary alluvium. } \\
\text { Reported springs are located }\end{array}$ & $\begin{array}{l}\text { [Montana] State Engineer's } \\
\text { Office, 1969a }\end{array}$ \\
\hline Geology & $1: 500,000$ & Entire basin & $\begin{array}{l}\text { All basin fill is identified as Quaternary } \\
\text { alluvium }\end{array}$ & Slagle, 1992, fig. 2, p. 5 \\
\hline
\end{tabular}

The Camas Prairie Basin apparently was never covered by Pleistocene glaciers. No evidence such as glacial till or striations has been identified. Most of the basin is underlain by Quaternary alluvium (Qal) which grades from very coarse gravel, cobbles, and boulders in the north to lacustrine silt and clay in the south. In the center of the basin, sand and gravel interbed with silt and clay. Because most wells in the basin are less than $20 \mathrm{ft}$ deep, the thickness of the alluvium is unknown (Slagle, 1988).

\section{Hydrology}

Camas Creek originates in the mountains northwest of the Camas Prairie Basin and flows southward to its confluence with the Flathead River near Perma. The USGS measured discharge of Camas Creek near Hot Springs (gaging station 12388650, drainage area $4.46 \mathrm{mi}^{2}$; pl. 1) from 1982 to 1987 . Discharge ranged from a minimum of $0.06 \mathrm{ft}^{3} / \mathrm{s}$ on August 11, 1986 to a maximum of $32 \mathrm{ft}^{3} / \mathrm{s}$ on February 26,1986 . The mean annual flow was $1.24 \mathrm{ft}^{3} / \mathrm{s}$ over the period of record.

The quality of water in Camas Creek was determined on the basis of 16 samples from Camas Creek near Hot Springs (gaging station 12388650) which were collected from 1982 to 1985 . Analyses indicate a mixed-cation bicarbonate type water with an average dissolved-solids concentration of $68 \mathrm{mg} / \mathrm{L}$ (Clark and Dutton, in press).

Most of the ground water that is used in the Camas Prairie Basin is pumped from a few irrigation wells completed in the upper $10 \mathrm{ft}$ of Quatemary alluvium in the northern part of the basin. These wells, which are completed in coarse gravels, yield 500 to $600 \mathrm{gal} / \mathrm{min}$ and, according to drillers' logs, have specific-capacity values from 125 to 200 ( $\mathrm{gal} / \mathrm{min}) / \mathrm{ft}$. Test wells completed in the central part of the basin yield 5.4 to $80 \mathrm{gal} / \mathrm{min}$ and have specific-capacity values from 0.56 to 45 (gal/min)/ft. Slagle (1988) conducted an aquifer test in the south-central part of the basin. Results of the test indicate that the transmissivity of the upper $100 \mathrm{ft}$ of alluvium is about 10,200 to $11,700 \mathrm{ft}^{2} / \mathrm{d}$ and the storage coefficient is 0.017 .

Fractures in the Proterozoic bedrock that surrounds and underlies the basin can yield sufficient water for domestic use. The bedrock aquifer is used in areas around the basin margin where Quaternary deposits are unsaturated. Of 33 bedrock wells tested throughout the Flathead Indian Reservation, discharge rates ranged from 2.5 to $40 \mathrm{gal} / \mathrm{min}$ and averaged $9.5 \mathrm{gal} / \mathrm{min}$, and specific-capacity values ranged from 0.08 to 3.2 (gal $/ \mathrm{min}$ )/ft and averaged $0.73(\mathrm{gal} / \mathrm{min}) / \mathrm{ft}$ (Slagle, 1988). Proterozoic bedrock also is the source of geothermal water that discharges to springs, wells, and the basin-fill aquifer (Sonderegger and Bergantino, 1981).

A potentiometric-surface map (Slagle 1988, pl. 2), based on water levels measured from 1967 to 1984 indicates that ground water flows from the uplands toward the flood plain, then southward paralleling Camas Creek. The water table generally is within about $10 \mathrm{ft}$ of land surface. The fine-grained sediments that predominate at the southern, downgradient, end of the basin essentially dam the ground water that flows through the coarser material upgradient (S. E. Slagle, U.S. Geological Survey, oral commun., 1993). Water levels were reported to have declined 
around the turn of the century. Much of the basin was swampy before farming and timber harvesting altered hydrologic conditions (Perry, 1933).

Basin-fill aquifers are recharged by precipitation and snowmelt, subsurface flow from bedrock, and infiltration from Camas Creek and its tributaries. The ground-water contribution area (fig. 2, pl. 1) is about $110 \mathrm{mi}^{2}$. Infiltration anywhere within this area could potentially recharge basin-fill aquifers in the Camas Prairie Basin. The presence of Green Springs (20N24W33CBA) and a hot $\left(26.0^{\circ} \mathrm{C}\right)$ well $(19 \mathrm{~N} 24$ W04AADB) indicate subsurface inflow of geothermal water from bedrock. The spring discharges water with a temperature of $26.0^{\circ} \mathrm{C}$ at a rate of $80 \mathrm{gal} / \mathrm{min}$ from alluvium which overlies Proterozoic metasedimentary rocks (Slagle, 1988; Sonderegger and Bergantino, 1981).

Ground water discharges from basin fill by evapotranspiration, withdrawals from wells, and seepage to springs, seeps, and stream channels. Slagle (1988) estimated that about 1,300 acre-ft of ground water was pumped from shallow irrigation wells in 1980. In contrast, domestic ground-water use totalled about 23 acre-ft/yr. Synoptic streamflow measurements on February 15, 1984 indicate that Camas Creek gained about $0.7 \mathrm{ft}^{3} / \mathrm{s}(500 \mathrm{acre}-\mathrm{ft} / \mathrm{yr})$ when the effects of evapotranspiration and irrigation return flow were minimal (Slagle, 1988).

The quality of ground water in the Camas Prairie Basin was determined on the basis of eight samples analyzed for major ions and measured dissolved-solids concentrations, and two samples in which dissolved-solids concentrations were estimated from specific-conductance measurements. Ground water in the basin is a mixedcation bicarbonate type with dissolved-solids concentrations of less than $250 \mathrm{mg} / \mathrm{L}$ throughout the basin (Clark and Dutton, in press). Green Springs (20N24W33CBA) discharges water with a dissolved-solids concentration of about $280 \mathrm{mg} / \mathrm{L}$ (Sonderegger and Bergantino, 1981).

\section{Selected References}

Alden, W.C., 1953, Physiography and glacial geology of western Montana and adjacent areas: U.S. Geological Survey Professional Paper 231, 200 p.

Briar, D.W., Lawlor, S.M., Stone, M.A.J., Parliman, D.J., Schaefer, J.L., and Kendy, Eloise, in press, Ground-water levels in intermontane basins of the Northern Rocky Mountains, Montana and Idaho: U.S. Geological Survey Hydrologic Investigations Atlas 738-B, 1 sheet, scale 1:750,000.

Clark, D.W., and Dutton, D.M., in press, Quality of ground water and surface water in the intermontane basins of the Northern Rocky Mountains, Montana and Idaho: U.S. Geological Survey Hydrologic Investigations Atlas 738-C, 1 sheet, scale 1:750,000.

Dutton, D.M., Lawlor, S.M., Briar, D.W., and Tresch, R.E., 1995, Hydrogeologic data for the Northern Rocky Mountains intermontane basins, Montana: U.S. Geological Survey Open-File Report 95-143, 94 p.

Harrison, J.E., Griggs, A.B., and Wells, J.D., 1986, Geologic and structure maps of the Wallace $1^{\circ} \times 2^{\circ}$ quadrangle, Montana and Idaho: U.S. Geological Survey Miscellaneous Investigations Series Map I-1509, 2 sheets, scale 1:250,000.

Johns, W.M., McClernan, H.G., and Lawson, D.C., 1971, Geological reconnaissance and soil-sample investigation of the Ravalli-Dixon-Perma-Camas Prairie area, Sanders County, Montana: Montana Bureau of Mines and Geology Open-File Report 10,40 p.

Kleinkopf, M.D., Harrison, J.E., and Zartman, R.E., 1972, Aeromagnetic and geologic map of part of northwestern Montana and northern Idaho: U.S. Geological Survey Geophysical Investigations Map GP-830, scale 1:250,000.

Levings, G.W., and White, M.K., 1983, Selected annotated bibliography of ground-water resources, records of wells and springs, and availability of streamflow data on Indian reservations in Montana: U.S. Geological Survey Open-File Report $83-129,137 \mathrm{p}$.

Lister, J.C., 1981, The sedimentology of Camas Prairie Basin and its significance to the Lake Missoula floods: Missoula, University of Montana, M.S. thesis, $66 \mathrm{p}$.

[Montana] State Engineer's Office, 1969a, Water resources survey, Mineral and Sanders Counties, Montana--Part 1, History of land and water use on irrigated areas: Helena, Mont., State Engineer's Office, 62 p. 
1969b, Water resources survey, Mineral and Sanders Counties, Montana--Part 2, Maps showing irrigated areas: Helena, Mont., State Engineer's Office, 36 p.

National Oceanic and Atmospheric Administration, 1962, Monthly normals of temperature, precipitation, and heating and cooling degree days, 1931-60, Montana: Asheville, N.C., Climatography of the United States no. 81, unpaged.

Pardee, J.T., 1942, Unusual currents in glacial Lake Missoula, Mont.: Geological Society of America Bulletin, v. 53, no. 11, p. 1569-1599.

Perry, E.S., 1933, Shallow wells as a source of irrigation water in Frenchtown and Camas Prairie valleys, Montana: Montana Bureau of Mines and Geology Miscellaneous Contributions 5, 8 p.

Slagle, S.E., 1988, Geohydrology of the Flathead Indian Reservation, northwestern Montana: U.S. Geological Survey WaterResources Investigations Report 88-4142, 152 p. 1992, Irrigation-canal leakage in the Flathead Indian Reservation, northwestern Montana: U. S. Geological Survey WaterResources Investigations Report 92-4066, 77 p.

Sonderegger, J.L., and Bergantino, R.N., 1981, Geothermal resources map of Montana: Montana Bureau of Mines and Geology Hydrogeologic Măp 4, scale 1:1,000,000.

Tuck, L. K., Briar, D.W., and Clark, D.W., in press, Geologic history and hydrogeologic units of intermontane basins of the Northern Rocky Mountains, Montana and Idaho: U.S. Geological Survey Hydrologic Investigations Atlas 738-A, 2 sheets, scale 1:750,000.

U.S. Geological Survey, issued annually, Water resources data, Montana: Helena, Mont., U.S. Geological Survey Water-Data Report.

Wunder, Laura, 1974, Water use, surface water, and water rights on the Flathead Indian Reservation, Montana, a review: Missoula, University of Montana, M.S. thesis, 250 p. 


\title{
Centennlal Valley
}

\section{Geography}

The Centennial Valley is an east-trending intermontane basin in southwestern Montana. This $210-\mathrm{mi}^{2}$ basin is about 5 to $6 \mathrm{mi}$ wide and its floor is nearly level. It is bounded by the steep-sided Henrys Lake Mountains (Idaho) on the east, the Centennial Mountains on the south, the rolling hills of the Snowcrest Range on the northwest, and the southern Gravelly Range on the north. The Continental Divide extends from west to east along the ridge of the Centennial Mountains and bends northward into the Henrys Lake Mountains (pl. 1). The Centennial Valley drainage area extends westward from the Continental Divide about $40 \mathrm{mi}$ to Lima Reservoir. Within the intermontane basin, all streams drain westward, although their sluggish courses are interrupted by many ponds, marshes, and sloughs. The basin ranges in altitude from about $6,500 \mathrm{ft}$ at the Lima Reservoir, to about $8,200 \mathrm{ft}$ on the basin margins.

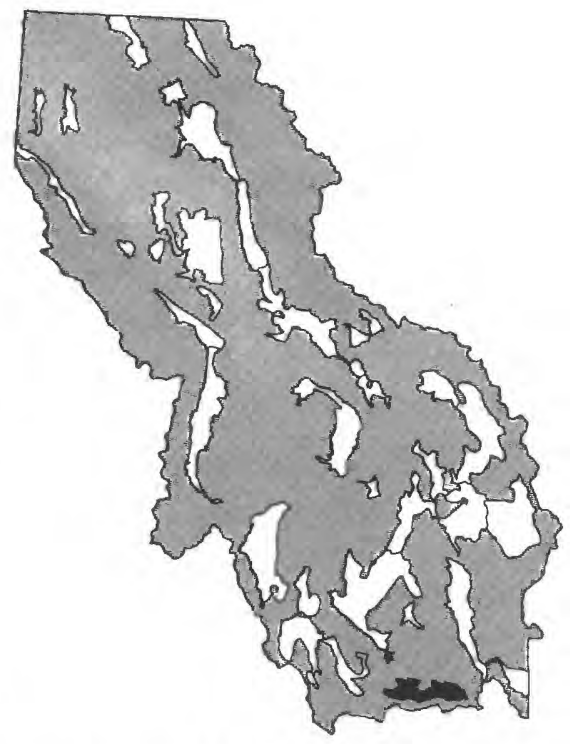

The climate of the Centennial Valley is typical of high-elevation intermontane basins of the Northern Rocky Mountains in southwestern Montana, with cold winters, mild summers, and sparse precipitation. On the basis of the 1961-90 period of record, the average annual temperature at Lakeview (altitude $6,710 \mathrm{ft}$ ) is $35.1^{\circ} \mathrm{F}$ and the average annual precipitation is 20.36 in. (National Oceanic and Atmospheric Administration, 1992). Lakeview is located on the southern basin margin; the central part of the basin averages 14 to 18 in. of precipitation annually (Sonderegger and others, 1982). At Lakeview, the average last occurrence of $32^{\circ} \mathrm{F}$ is on July 7 and the average first occurrence is on August 22 (Natural Resources Conservation Service, U.S. Department of Agriculture, unpub. data., 1994). Mean monthly climatic data for Lakeview are plotted in figure 11.

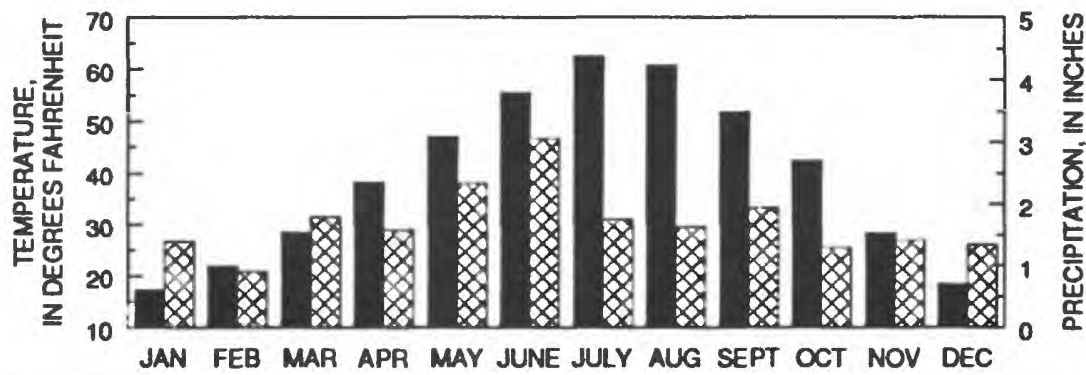

\author{
EXPLANATION \\ MEAN MONTHLY TEMPERATURE FOR \\ 1961-90 PERIOD OF RECORD \\ MEAN MONTHLY PRECIPITATION FOR \\ 1961-90 PERIOD OF RECORD
}

Figure 11. Mean monthly precipitation and temperature at Lakeview, Mont. Data from National Oceanic and Atmospheric Administration (1992).

In 1935, the 40,000-acre Red Rock Lakes National Wildlife Refuge was established to protect the trumpeter swan. The refuge, which is located in the eastern part of the basin, includes 14,000 acres of marsh and open water. The protected wetlands and adjacent uplands provide excellent habitat for many species of waterfowl, including Barrow's goldeneye, whistling swans, and sandhill cranes, moose, deer, elk, and antelope (Lane and others, 1967). Outside the refuge boundaries, livestock grazing is the primary land use.

Less than 100 people reside in the Centennial Valley (1990 census). Lakeview, as headquarters for the Red Rock Lakes National Wildlife Refuge, houses at least one winter resident. Access to Lakeview is by dirt road in the summer, and by snowmobile in the winter. 


\section{Geology}

The Centennial Valley intermontane basin developed as the result of a localized stress regime associated with the Yellowstone hot spot, superimposed on the regional Basin and Range extensional regime. The combined stresses have produced an active east-trending belt of seismicity (Stickney and Bartholomew, 1987; Stickney, 1993). Within this belt, the southern margin of the Centennial Valley is defined by a normal fault, along which the basin has been downthrown at least 10,000 ft. The fault has been active in Pleistocene and Holocene times, and continues to be one of the major active faults in Montana (Witkind, 1975; Sonderegger and others, 1982; Haller and others, 1993). The northem basin boundary is defined by several smaller normal faults. Numerous cross-basin faults have resulted in an irregularly shaped basin floor. Gravity data indicate that the deepest bedrock is more than $6,000 \mathrm{ft}$ below land surface in the east-central part of the basin (Sonderegger and others, 1982; Noble and others, 1982; Schofield, 1981).

Several investigators have examined the geology of the Centennial Valley (table 24). The geologic units described by previous investigators are summarized below. These geologic units are referenced to hydrogeologic units defined in this study (table 2) to provide a consistent regional framework. In the following discussion, the hydrogeologic-unit abbreviations are italicized.

Table 24. Geologic and geophysical maps of the Centennial Valley, Montana

\begin{tabular}{|c|c|c|c|c|}
\hline Type of map & Scalo & Location & Map foatures & Reference \\
\hline Geology & $1: 253,440$ & $\begin{array}{l}\text { Western part of } \\
\text { Centennial Valley }\end{array}$ & $\begin{array}{l}\text { Differentiates two basin-fill units: Tertiary } \\
\text { sedimentary rocks and Quatemary deposits }\end{array}$ & Klepper, 1950, pl. 16 \\
\hline $\begin{array}{l}\text { Cenozoic basin- } \\
\text { fill thickness }\end{array}$ & $1: 500,000$ & $\begin{array}{l}\text { Entire Centennial } \\
\text { Valley }\end{array}$ & Contour interval $3,000 \mathrm{ft}$. & $\begin{array}{l}\text { Noble and others, } \\
\text { 1982, fig. II- } 24 \text {, } \\
\text { p. } 91\end{array}$ \\
\hline Bouguer gravity & $1: 176,000$ & $\begin{array}{l}\text { Eastem half of } \\
\text { Centennial Valley }\end{array}$ & Contour interval 2 milligals & $\begin{array}{l}\text { Schofield, 1981, fig. 3, } \\
\text { p. } 278\end{array}$ \\
\hline $\begin{array}{l}\text { Basement } \\
\text { elevation }\end{array}$ & $1: 176,000$ & $\begin{array}{l}\text { Eastem half of } \\
\text { Centennial Valley }\end{array}$ & Contour interval $1,000 \mathrm{ft}$ & $\begin{array}{l}\text { Schofield, 1981, fig. } 4 \text {, } \\
\text { p. } 279\end{array}$ \\
\hline Geology & $1: 62,600$ & $\begin{array}{l}\text { Northeastern part of } \\
\text { Centennial Valley }\end{array}$ & $\begin{array}{l}\text { Differentiates } 20 \text { basin-fill units, including } \\
\text { sedimentary deposits and volcanic rocks }\end{array}$ & $\begin{array}{l}\text { Sonderegger and } \\
\text { others, 1982, pl. } 1\end{array}$ \\
\hline Bouguer gravity & $1: 62,600$ & $\begin{array}{l}\text { Northeastern part of } \\
\text { Centennial Valley }\end{array}$ & Contour interval 2 milligals & $\begin{array}{l}\text { Sonderegger and } \\
\text { others, 1982, pl. } 3\end{array}$ \\
\hline $\begin{array}{l}\text { Basement } \\
\text { elevation }\end{array}$ & $1: 62,500$ & $\begin{array}{l}\text { Northeastern part of } \\
\text { Centennial Valley }\end{array}$ & $\begin{array}{l}\text { Contour interval } 1,000 \mathrm{ft} \text {. Locates faults based } \\
\text { on gravity, mapping, and photo interpretation }\end{array}$ & $\begin{array}{l}\text { Sonderegger and } \\
\text { others, } 1982, \mathrm{pl} .4\end{array}$ \\
\hline Geology & $1: 62,500$ & $\begin{array}{l}\text { Along southem } \\
\text { margin of } \\
\text { Centennial Valley }\end{array}$ & $\begin{array}{l}\text { Detailed Quaternary geology of deposits } \\
\text { associated with basin-marginal fault }\end{array}$ & Witkind, 1975 \\
\hline Geology & $1: 62,500$ & $\begin{array}{l}\text { East of long } \\
1111^{\circ} 45^{\prime} \mathrm{W}\end{array}$ & Differentiates 14 sedimentary basin-fill units & Witkind, 1976 \\
\hline Geology & $1: 62,500$ & $\begin{array}{l}\text { Between long } 111^{\circ} 45^{\circ} \\
\text { W. and } 112^{\circ} \mathrm{W} \text {. }\end{array}$ & Differentiates nine Quaternary basin-fill units & $\begin{array}{l}\text { Witkind and Prostka, } \\
1980\end{array}$ \\
\hline
\end{tabular}

The Centennial Valley is surrounded by metamorphic, sedimentary, and volcanic bedrock. A fault divides the Centennial Mountains into an upthrown eastern half and downthrown western half. The eastern half is a Precambrian metamorphic block overlain by Paleozoic and lower Mesozoic rocks. The Precambrian rocks (KAm), including gneiss, gabbro, metagranodiorite, amphibolite, dolomite, quartzite, and mica schist, underlie basin fill in the vicinity of Upper Red Rock Lake (Witkind, 1976) and also are the core of the Henrys Lake Mountains and the Gravelly Range (Sonderegger and others, 1982). The Paleozoic rocks ( $P z l s)$ consist of silty, fossiliferous carbonates interbedded with minor amounts of shale and sandstone. The Mesozoic rocks (Mzsh) are primarily shale, siltstone, and sandstone, with minor amounts of carbonates (Sonderegger, 1981). These older rocks are overlain, in part, by Tertiary volcanic rocks (QTKe). The western half of the Centennial Mountains is composed of Cretaceous sandstone, limestone, and mudstone (Mzsh) overlain by Tertiary volcanic rocks (QTKe) (Honkala, 1960). The Snowcrest and Gravelly Ranges primarily consist of Paleozoic and Mesozoic sedimentary rocks similar to those in 
the Centennial Range (Klepper, 1950). Tertiary volcanic rocks (QTKe), probably of Pliocene age, floor part of the Centennial Valley (Lane and others, 1967). These volcanic rocks include porphyry, basalt, and ash-flow tuff (Witkind, 1976).

More than $6,000 \mathrm{ft}$ of Tertiary sediments (Ts) interbedded with volcanic and volcaniclastic rocks ( $Q T K e$ ) fill the Centennial Valley. The oldest, the Beaverhead Group of probable Late Cretaceous, Palcocene, and Eocene age, unconformably overlies Cretaceous sedimentary rocks in the westem part of the basin, and extends well into the foothills beyond the basin boundaries. The Beaverhead Group consists of about $2,500 \mathrm{ft}$ of silty sandstone with layers of well-rounded and subrounded cobbles and boulders (Sonderegger, 1981; Sonderegger and others, 1982). Continental clastic sediments of Eocene age may be present at depth (Honkala, 1960). However, the next youngest exposed rock is Oligocene basalt. The basalt is overlain by lower Miocene(?) fine- to medium-grained sandstone, limestone, and clay believed to be of continental origin. Although the Miocene sediments are not well-exposed, they comprise the bulk of the basin fill (Sonderegger and others, 1982).

More than $600 \mathrm{ft}$ of volcanic ash-flow tuffs of early Pleistocene age (QTKe) cover Tertiary sediments and adjacent bedrock along much of the Centennial Valley margin. These tuffs cover a large area, extending northward into the Madison River Valley (Sonderegger and others, 1982).

Quatemary basin-fill deposits of glacial and alluvial origin underlie most of the basin. At the base of the Centennial Mountains, terminal moraines of valley glaciers have coalesced, forming lobate deposits of morainal debris $(Q g)$ with knob-and-kettle topography. The unconsolidated to semiconsolidated, unsorted material ranges from clay to boulders. North of Red Rock Lakes, Pleistocene glacial lakebed deposits ( $Q g)$ crop out. These unconsolidated deposits consist primarily of silt and sand, with some pebbles. Emanating from canyon mouths at the edges of the basin are Quaternary alluvial-fan deposits (QTd) of unconsolidated, moderately sorted silt, sand, gravel, cobbles, and a few boulders. Along the northeastem basin margin, widespread dunes of unconsolidated, well-sorted sand (Qal) mantle bedrock. Streambeds are underlain by Holocene alluvium (Qal) consisting of unconsolidated fluvial deposits of silt, sand, and gravel (Witkind, 1976; Sonderegger and others, 1982). Because it is composed largely of reworked glacial lakebed deposits, the dominantly fine-grained alluvium is, in many places, difficult to distinguish from its glacial lakebed parent material $(\mathrm{Qg})$.

\section{Hydrology}

The Red Rock River begins in the Centennial Valley at Upper Red Rock Lake. Tributaries to the lake originate near the Continental Divide, and flow westward into the Centennial Valley. From Upper Red Rock Lake, the river flows through the Red Rock Lakes National Wildlife Refuge to Lower Red Rock Lake. Upper and Lower Red Rock Lakes are less than $8 \mathrm{ft}$ deep, and are rimmed by marshes (Sonderegger and others, 1982). Downstream from the refuge, the river meanders about $13 \mathrm{mi}$ to the Lima Reservoir, an irrigation project completed in 1902 . Downstream from the reservoir, the river flows through the Red Rock Valley for about 30 mi before entering Clark Canyon Reservoir.

Streamflow data for gaging stations listed in table 25 are stored in the USGS WATSTORE database. Locations of the stations are shown on plate 1. In addition, the USGS has published monthend reservoir volume records for Lima Reservoir (station 06012000 , drainage area $570 \mathrm{mi}^{2}$ ) since 1940. Data for years prior to 1961 are published in Water-Supply Papers; more recent data are in annual Water-Data Reports (U.S. Geological Survey, issued annually).

Lake-bottom sediments in the Red Rock Lakes National Wildlife Refuge are biologically fertile and have large concentrations of available calcium, magnesium, potassium, fluoride, and organic matter, but small concentrations of sodium and phosphorus. High winds easily suspend bottom sediment in shallow Upper Red Rock Lake (Paullin, 1973).

Although it is not extensively developed, ground water is an important resource in the Centennial Valley. Springs outnumber wells in the eastem part of the basin, where springs are used for livestock watering and irrigation. Springs also supply the warm water that keeps the Red Rock Lakes ice-free all year. Wells are used for livestock watering and for limited domestic and irrigation supplies (Sonderegger and others, 1982). 
Table 25. Summary of data for U.S. Geological Survey streamflow-gaging stations in the Centennial Valley, Montana

[Type of dats collected: d, discharge. Periods of record for stations that were being operated as of November 1994 are indicated by the first year of record followed by a dash only. Abbreviations: $\mathrm{ft}^{3} / \mathrm{s}$, cubic feet per second, e; estimated. Symbol: --, no data]

\begin{tabular}{|c|c|c|c|c|c|c|c|c|c|}
\hline \multirow[b]{2}{*}{$\begin{array}{l}\text { Station } \\
\text { number }\end{array}$} & \multirow[b]{2}{*}{ Station name } & \multirow{2}{*}{$\begin{array}{c}\text { Drainage } \\
\text { area } \\
\text { (square } \\
\text { miles) }\end{array}$} & \multirow{2}{*}{$\begin{array}{c}\text { Type } \\
\text { of data } \\
\text { col- } \\
\text { locted }\end{array}$} & \multirow[b]{2}{*}{$\begin{array}{l}\text { Perlod of record } \\
\text { (calendar year) }\end{array}$} & \multicolumn{5}{|c|}{ Discharge for period of record } \\
\hline & & & & & $\begin{array}{l}\text { Mean } \\
\text { annual } \\
\left(\mathrm{t}^{3} / \mathrm{s}\right)\end{array}$ & $\begin{array}{c}\text { Maxi- } \\
\text { mum } \\
\left(\mathrm{ft}^{3} / \mathrm{s}\right)\end{array}$ & $\begin{array}{l}\text { Date of } \\
\text { maximum }\end{array}$ & $\begin{array}{l}\text { Mint- } \\
\text { mum } \\
\left(\mathrm{ft}^{3} / \mathrm{s}\right)\end{array}$ & $\begin{array}{l}\text { Date of } \\
\text { minimum }\end{array}$ \\
\hline 06007000 & $\begin{array}{l}\text { Tom Creek near } \\
\text { Lakeview }\end{array}$ & 6.43 & d & $\begin{array}{l}\text { May 1-Sept. 30, } \\
1989\end{array}$ & -- & 13 & $05-18-89$ & 0 & Many days \\
\hline 06008000 & $\begin{array}{l}\text { Odell Creek above } \\
\text { Taft Ranch, near } \\
\text { Lakeview }\end{array}$ & 17.7 & d & $\begin{array}{l}\text { Sept. 1993- } \\
\text { (Apr.-Oct.) }\end{array}$ & -- & 112 & $05-08-94$ & 6.1 & $09-12-94$ \\
\hline 06010000 & $\begin{array}{l}\text { Red Rock River near } \\
\text { Lakeview }\end{array}$ & 237 & d & 1933-37 & 147.3 & 1,010 & $05-01-33$ & 0 & Al times \\
\hline 06010500 & $\begin{array}{l}\text { Red Rock River at } \\
\text { Metzel Fork, near } \\
\text { Monida }\end{array}$ & 264 & d & $1925-29$ & 129.7 & 586 & $05-17-27$ & 2.7 & $09-23-26$ \\
\hline 06010600 & $\begin{array}{l}\text { Red Rock River at } \\
\text { Brundage Bridge, } \\
\text { near Lakeview }\end{array}$ & 277 & d & $\begin{array}{l}\text { Oct. 1988-Sept. } \\
1989 \\
\text { (intermittent) }\end{array}$ & - & 350 & $05-11-89$ & 5.8 & $10-15-88$ \\
\hline 06011000 & $\begin{array}{l}\text { Red Rock River at } \\
\text { Kennedy Ranch, } \\
\text { near Lakeview }\end{array}$ & 323 & d & $\begin{array}{l}\text { 1936-67 (no winter } \\
\text { records after } \\
1942 \text { ) }\end{array}$ & ${ }^{2} 93.6$ & 1,360 & $04-30-52$ & 1.5 & $09-02-40$ \\
\hline 06011500 & $\begin{array}{l}\text { Red Rock River above } \\
\text { Lima Reservoir, } \\
\text { near Monida }\end{array}$ & 431 & d & $\begin{array}{l}\text { 1911,1914-18, } \\
\text { 1925, 1930 } \\
\text { (intermittent) }\end{array}$ & - & $1,200 \mathrm{e}$ & $04-26-14$ & .4 & $07-31-30$ \\
\hline 06012500 & $\begin{array}{l}\text { Red Rock River below } \\
\text { Lima Reservoir, } \\
\text { near Monida }\end{array}$ & 570 & d & $\begin{array}{r}1911-19,1925-69 \\
1974-82,1985-\end{array}$ & 143 & 2,500 & $05-15-33$ & 0 & $\begin{array}{l}\text { Oct.-Mar., } \\
\text { most years }\end{array}$ \\
\hline
\end{tabular}

Tata for water year 1935.

2 Data for water years 1936-42.

Most wells in the basin are completed in Quaternary deposits, including reworked glacial material and alluvial-fan deposits. Well depths range from about 30 to $200 \mathrm{ft}$. Reported yields from eleven wells completed in Quaternary alluvium range from 5.0 to $460 \mathrm{gal} / \mathrm{min}$, with a median value of $20 \mathrm{gal} / \mathrm{min}$. Specific-capacity values for seven of these wells range from 0.1 to $7.5(\mathrm{gal} / \mathrm{min}) / \mathrm{ft}$, with a median value of $2.0(\mathrm{gal} / \mathrm{min}) / \mathrm{ft}$ (Dutton and others, 1995). Estimates of the transmissivity of alluvial-fan deposits along the south side of the basin range from about 360 to $540 \mathrm{ft}^{2} / \mathrm{d}$ (Sonderegger and others, 1982).

Wells completed in the Pleistocene tuff along the northeastem basin margin generally do not have large yields. However, the tuff is capable of producing sufficient supplies for domestic and livestock use (Sonderegger and others, 1982; Dutton and others, 1995).

Little is known about ground-water movement in the Centennial Valley. However, a 1:750,000-scale potentiometric map which includes the Centennial Valley indicates that ground water generally flows from the uplands toward the central part of the basin, then westward paralleling the Red Rock River (Briar and others, in press).

Basin-fill aquifers in the Centennial Valley are recharged by precipitation and snowmelt, subsurface flow from bedrock (Sonderegger and others, 1982), and infiltration from streams. The ground-water contribution area (fig. 2, pl. 1) is about $560 \mathrm{mi}^{2}$. Infiltration anywhere within this area could potentially recharge basin-fill aquifers in the Centennial Valley. Ground water discharges from the basin-fill aquifers by evapotranspiration, withdrawals from wells, and seepage to springs, seeps, and stream channels. 
The presence of geothermal springs in the northeastern part of the Centennial Valley provides evidence for recharge to surficial basin-fill aquifers from bedrock aquifers. Similarities between the temperatures and chemistry of springs and water from shallow wells substantiate this hypothesis (Sonderegger and others, 1982). Seven springs located in 13S02W17 and 13S02W18 have a combined discharge of about $2,700 \mathrm{gal} / \mathrm{min}$ and an average temperature of $27^{\circ} \mathrm{C}$. Airborne heat-sensing imagery indicates another zone of warm water along the north side of Upper Red Rock Lake and the marshy channel that connects it to Lower Red Rock Lake. The springs issue from step faults along the southern margin of the Gravelly Range (Sonderegger, 1981).

The quality of ground water was determined on the basis of 36 samples analyzed for major ions and measured dissolved-solids concentrations, and 9 samples in which dissolved-solids concentrations were estimated from specific-conductance measurements. Ground water is consistently a calcium bicarbonate type throughout the basin. Dissolved-solids concentrations are typically less than $250 \mathrm{mg} / \mathrm{L}$ near the eastem basin margin, and range from about 250 to $500 \mathrm{mg} / \mathrm{L}$ throughout the rest of the basin (Clark and Dutton, in press).

Ground-water chemistry provides a basis for distinguishing deep-circulating water from shallow sources of water issuing from springs and wells. On the northeast side of the basin, ground water derived from shallow local flow systems has dissolved-solids concentrations of less than $100 \mathrm{mg} / \mathrm{L}$, whereas deep-circulating, warm ground water in the same area has dissolved-solids concentrations ranging from 128 to $510 \mathrm{mg} / \mathrm{L}$ and significantly larger proportions of sulfate and magnesium (Sonderegger, 1981).

\section{Selected References}

Bailey, J.P., 1977, Seismicity and contemporary tectonics of the Hebgen Lake-Centennial Valley, Montana, area: Salt Lake City, University of Utah, M.S. thesis, 115 p.

Briar, D.W., Lawlor, S.M., Stone, M.A.J., Parliman, D.J., Schaefer, J.L., and Kendy, Eloise, in press, Ground-water levels in intermontane basins of the Northern Rocky Mountains, Montana and Idaho: U.S. Geological Survey Hydrologic Investigations Atlas 738-B, 1 sheet, scale 1:750,000.

Clark, D.W., and Dutton, D.M., in press, Quality of ground water and surface water in intermontane basins of the Northern Rocky Mountains, Montana and Idaho: U.S. Geological Survey Hydrologic Investigations Atlas 738-C, 1 sheet, scale 1:750,000.

Dutton, D.M., Lawlor, S.M., Briar, D.W., and Tresch, R.E., 1995, Hydrogeologic data for the Northern Rocky Mountains intermontane basins, Montana: U.S. Geological Survey Open-File Report 95-143, 94 p.

Haller, K.M., Dart, R.L., and Stickney, M.C., 1993, A compilation of major active faults for parts of Montana and Idaho: Geological Society of America Abstracts with Programs, v. 25, no. 5, p. 46.

Honkala, F.S., 1949, Geology of the Centennial region, Beaverhead County, Montana: Ann Arbor, University of Michigan, Ph.D. dissertation, $145 \mathrm{p}$.

1960, Structure of the Centennial Mountains and vicinity, Beaverhead County, Montana, in Billings Geological Society 11th Annual Field Conference, September 7-10, 1960, Guidebook for West Yellowstone-Earthquake area: Billings, Mont., Billings Geological Society, p. 107-113.

Klepper, M.R., 1950, A geologic reconnaissance of parts of Beaverhead and Madison Counties, Montana: U.S. Geological Survey Bulletin 969-C, p. 54-85.

Lane, B.B., Hupp, Bill, and Walthall, B.H., 1967, First day geologic road log, West Yellowstone to Lima Reservoir, in Montana Geological Society 18th Annual Field Conference, August 9-12, 1967, Guidebook for Centennial Basin of Southwest Montana: Billings, Mont., Montana Geological Society, p. I-VI.

National Oceanic and Atmospheric Administration, 1992, Monthly normals of temperature, precipitation, and heating and cooling degree days, 1961-90, Montana: Asheville, N.C., Climatography of the United States no. 81, unpaged.

Noble, R.A., Bergantino, R.N., Patton, T.W., Sholes, B.C., Daniel, Faith, and Schofield, Judeykay, 1982, Occurrence and characteristics of ground water of Montana--Volume 2, The Rocky Mountain Region: Montana Bureau of Mines and Geology Open-File Report 99, 132 p.

Paullin, D.G., 1973, The ecology of submerged aquatic macrophytes of Red Rock Lakes National Wildlife Refuge, Montana: Missoula, University of Montana, M.S. thesis, $171 \mathrm{p}$. 
Schofield, J.D., 1980, A gravity and magnetic investigation of the eastern portion of the Centennial Valley, Beaverhead County, Montana: Butte, Montana College of Mineral Science and Technology, M.S. thesis, 94 p.

1981, Structure of the Centennial and Madison Valleys based on gravitational interpretation, in Montana Geological Society Field Conference and Symposium Guidebook to Southwest Montana: [Billings, Mont.], Montana Geological Society, p. 275-283.

Scholten, Robert, Keenmon, K.A., and Kupsch, W.O., 1955, Geology of the Lima region, southwestern Montana and adjacent Idaho: Bulletin of the Geological Society of America, v. 66, p. 345-404.

Sonderegger, J.L., 1981, Geology and geothermal resources of the eastern Centennial Valley, in Montana Geological Society Field Conference and Symposium Guidebook to Southwest Montana: [Billings, Mont.], Montana Geological Society, p. 357-363.

Sonderegger, J.L., and Schmidt, F.A., 1981, Geothermal resources in Montana: Montana Academy of Science Proceedings, v. 40, p. 50-62.

Sonderegger, J.L., Schofield, J.D., Berg, R.B., and Mannick, M.L, 1982, The upper Centennial Valley, Beaverhead and Madison Counties, Montana, with a section on The Madison Valley thermal springs, by G.J. Weinheimer: Montana Bureau of Mines and Geology Memoir 50, 53 p.

Stickney, M.C., 1993, Seismicity and focal mechanisms of the central Centennial Tectonic Belt, southwestern Montana and east-central Idaho [abs.]: Geological Society of America Abstracts with Programs, v. 25, no. 5, p. 151.

Stickney, M.C., and Bartholomew, M.J., 1987, Seismicity and late Quaternary faulting of the northern Basin and Range province, Montana and Idaho: Bulletin of the Seismological Society of America, v. 77, no. 5, p. 1602-1625.

Tuck, L. K., Briar, D.W., and Clark, D.W., in press, Geologic history and hydrogeologic units of intermontane basins of the Northern Rocky Mountains, Montana and Idaho: U.S. Geological Survey Hydrologic Investigations Atlas 738-A, 2 sheets, scale 1:750,000.

U.S. Geological Survey, issued annually, Water resources data, Montana: Helena, Mont., U.S. Geological Survey Water-Data Report.

Witkind, I.J., 1975, Geology of a strip along the Centennial fault, southwestern Montana and adjacent Idaho: U.S. Geological Survey Miscellaneous Investigations Map I-890, scale 1:62,500.

1976, Geologic map of the southern part of the Upper Red Rock Lake Quadrangle, southwestern Montana and adjacent Idaho: U.S. Geological Survey Miscellaneous Investigation Series Map I-943, scale 1:62,500.

Witkind, IJ., and Prostka, H.J., 1980, Geologic map of the southern part of the Lower Red Rock Lake quadrangle, Beaverhead and Madison Counties, Montana, and Clark County, Idaho: U.S. Geological Survey Miscellaneous Investigation Series Map I-1216, scale 1:62,500. 


\section{Gallatin Valley}

\section{Geography}

The Gallatin Valley is an approximately north-trending intermontane basin about $520 \mathrm{mi}^{2}$ in area. It is bounded by the Horseshoe Hills on the north, the Bridger Range on the east, the Gallatin and Madison Ranges on the south, and the Western Three Forks Valley on the west (pl. 1). This basin has at various times been referred to as all or part of "Three Forks valley" (Fields and others, 1985; Hanneman and Wideman, 1991), "Three Forks Basin" (Robinson, 1961; Davis and others, 1965), and "Gallatin Valley" (Alden, 1953; Hackett and others, 1960; Slagle, 1995a, b). For the purposes of this study the large intermontane basin bounded on the east by the Gallatin Range and on the west by the Tobacco Root Mountains has been divided into two areas: "Western Three Forks Valley" refers to that part of the intermontane basin west of the Madison Plateau, and "Gallatin Valley" refers to the portion east of and including the Madison Plateau (pl. 1).

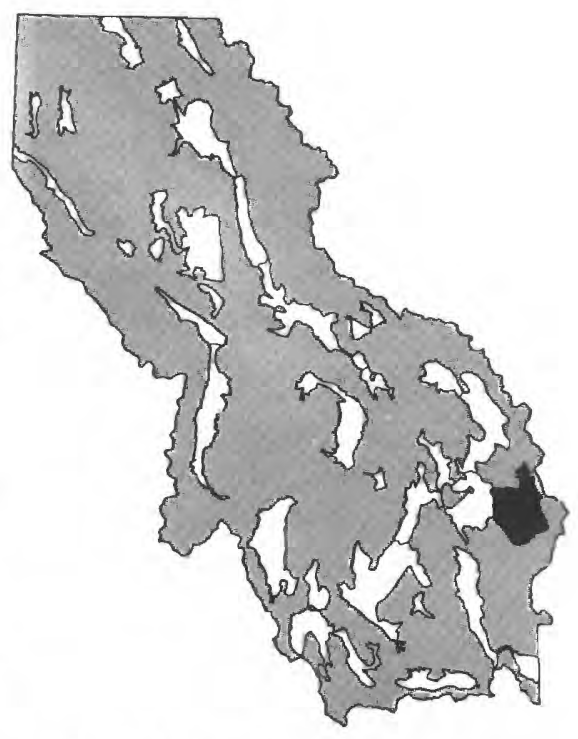

Topographically, the Gallatin Valley mainly consists of a central and eastem flood plain and a westem plateau. The flood plains of the Gallatin and East Gallatin Rivers merge at the center of the basin, creating a broad, level plain with an altitude of 4,100 to 4,500 ft. West of the flood plain, the Madison Plateau (also known as the Madison Bluffs and as the Camp Creek Hills) is a broad bench with an altitude of more than 5,000 ft that drains northeastward into the Gallatin River. Steep, 300- to 500-ft-high bluffs define the westerm edge of the Madison Plateau. Scattered along the eastem and southem basin margins are smaller benches, or terraces, some of which are mantled by alluvial fans. The Gallatin Valley ranges in altitude from about $4,100 \mathrm{ft}$ where the Gallatin River leaves the basin, to about $6,300 \mathrm{ft}$ at the southeastem mountain front.

The climate of the Gallatin Valley is typical of mid-elevation intermontane basins of the Northern Rocky Mountains east of the Continental Divide, with cold winters and mild summers. On the basis of the 1961-90 period of record, the average annual precipitation at the Belgrade Airport (altitude 4,450 ft) is $14.69 \mathrm{in}$., and the average annual temperature is $41.9^{\circ} \mathrm{F}$ (National Oceanic and Atmospheric Administration, 1992). The average last occurrence of $32^{\circ} \mathrm{F}$ is June 3 and the average first occurrence is September 13 (Natural Resources Conservation Service, U.S. Department of Agriculture, unpub. data., 1994). Mean monthly climatic data for the Belgrade Airport are plotted in figure 12. For comparison, the average annual precipitation at Bozeman (altitude 4,860 ft) is $19.2 \mathrm{in}$.,

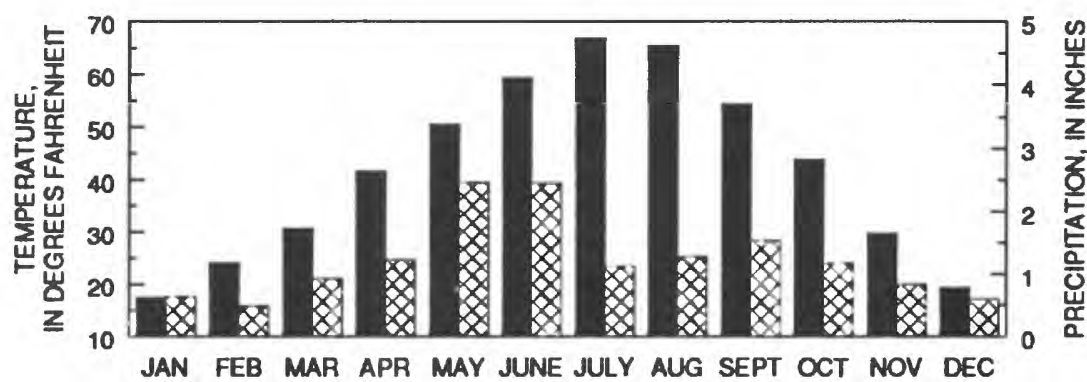

EXPLANATION

MEAN MONTHLY TEMPERATURE FOR 1961-90 PERIOD OF RECORD

$\bigotimes$ MEAN MONTHLY PRECIPITATION FOP 1961-90 PERIOD OF RECORD

Figure 12. Mean monthly precipitation and temperature at the Belgrade Airport, Mont. Data from National Oceanic and Atmospheric Administration (1992). 
and the average annual temperature is $44.2^{\circ} \mathrm{F}$ (National Oceanic and Atmospheric Administration, 1992). The growing season normally extends from May 27 to September 18 in Bozeman (Natural Resources Conservation Service, U.S. Department of Agriculture, unpub. data, 1994).

More than 40,000 people reside in the Gallatin Valley, including 22,660 in the City of Bozeman, 3,422 in the City of Belgrade, 1,034 in the Town of Manhattan, 603 in the combined unincorporated communities of Amsterdam and Church Hill, and 588 in the unincorporated community of Gallatin Gateway (1990 census). Over the past 40 years, the population of the area has grown significantly. Gallatin County grew from 21,902 residents in 1950 to 50,463 in 1990, while Bozeman grew from 11,325 to 22,660 (U.S. Department of Commerce, 1992).

Land use in the Gallatin Valley primarily is agricultural. On the Madison Plateau, irrigated seed potatoes are the principal crop; hay and grain production and rangeland are also important. On the intensively irrigated flood plain, hay and grains are the principal crops. The eastern benches are used primarily for rangeland and dryland grain production, with limited irrigated hay and grains (J.C. Eggen, Agricultural Stabilization and Conservation Service, oral commun., 1993). In recent years, numerous rural residential subdivisions have replaced agricultural land, particularly on the flood plain and the eastern benches. Most homes in these subdivisions have individual wells and septic systems (Slagle, 1995a). Parts of the mountainous drainage area contributing to the Gallatin Valley have been and continue to be logged. Much of the timber is processed locally at a sawmill in Belgrade. In addition, gold was placer-mined on a small scale in tributary streams to the Gallatin River from about 1880 to 1945 ([Montana] State Engineer's Office, 1953a).

\section{Geology}

Structurally, the Gallatin Valley, together with the Western Three Forks Valley, is an eastward-tilted graben. The northem, western, and southern basin boundaries are not flanked by obvious faults, and may be depositional contacts between Cenozoic basin fill and pre-Cenozoic bedrock. The eastern boundary of the Gallatin Valley is a series of steep normal faults along the fronts of the Bridger and Gallatin Ranges (Robinson, 1961). Gravity data indicate that more than $6,000 \mathrm{ft}$ of Cenozoic sediments fill the basin at its deepest part, east of Bozeman Hot Springs (Noble and others, 1982). Tertiary deformation is evidenced by several broad folds (Custer, 1991) and by possible faulting along the western margin of the Madison Plateau (Schneider, 1970b).

Several investigators have examined the geology of the Gallatin Valley (table 26). The geologic units described by previous investigators are summarized below. These geologic units are referenced to hydrogeologic units defined in this study (table 2) to provide a consistent regional framework. In the following discussion, the hydrogeologic-unit abbreviations are italicized.

Precambrian bedrock floors most of the basin. Archean metamorphic rocks $(K A m)$ border the basin along the southem Bridger Range front, and probably underlie the southem part of the basin. These crystalline rocks are mainly biotite gneiss, with some schist, quartzite, and marble. Rocks of the Middle Proterozoic Belt Supergroup (Yms) crop out in places in the Horseshoe Hills and the northem Bridger Range, and probably underlie the northern part of the basin. Although most formations of the Belt Supergroup consist of argillite and quartzite, the rocks that border this basin are primarily coarse-grained arkose and conglomerate with minor siltstone. Folded and faulted Paleozoic (Pzls) and Mesozoic (Mzsh) sedimentary rocks crop out sporadically along the northern, southern, and southeastern basin boundaries. Thick Tertiary sills (TKi) have intruded many older rocks surrounding the Gallatin Valley (Hackett and others, 1960; Robinson, 1961; Davis and others, 1965).

Tertiary sediments (Ts) of the Bozeman Group (Robinson, 1961) underlie the entire basin; where they are not exposed, they are covered by a veneer of Quaternary and/or Tertiary alluvium. In general, the Tertiary sediments exposed at the surface grade from moderately well-cemented fanglomerate along the southem and eastern basin margins, to finer-grained, tuffaceous siltstone and sandstone toward the center and western parts of the basin (Hackett and others, 1960). Eocene and Oligocene sediments, which are equivalent to the Renova Formation recognized in other basins (Fields and others, 1985), are not well-exposed in the Gallatin Valley. However, they 
Table 26. Geologic and geophysical maps of the Gallatin Valley, Montana

\begin{tabular}{|c|c|c|c|c|}
\hline Type of map & Scale & Location & Map features & Reference \\
\hline $\begin{array}{l}\text { Bouguer gravity } \\
\text { and generalized } \\
\text { geology }\end{array}$ & $1: 62,500$ & $\begin{array}{l}\text { Entire Gallatin } \\
\text { Valley }\end{array}$ & $\begin{array}{l}\text { Gravity contour interval } 5 \text { milligals. All basin fill } \\
\text { designated as Cenozoic basin deposits }\end{array}$ & $\begin{array}{l}\text { Davis and others, } 1965 \text {, } \\
\text { sheet } 1\end{array}$ \\
\hline Geology & $1: 63,360$ & $\begin{array}{l}\text { Entire Gallatin } \\
\text { Valley }\end{array}$ & $\begin{array}{l}\text { Differentiates five basin-fill units: Tertiary } \\
\text { lacustrine deposits, Tertiary fluviatile deposits, } \\
\text { Quatemary and Tertiary old alluvium, } \\
\text { Quatemary alluvial-fan deposits, and } \\
\text { Quatemary stream-laid alluvium }\end{array}$ & $\begin{array}{l}\text { Hackett and others, } \\
1960, \mathrm{pl} .2\end{array}$ \\
\hline Geology & $1: 31,680$ & $\begin{array}{l}\text { Dry Creek } \\
\text { drainage area }\end{array}$ & $\begin{array}{l}\text { Differentiates four basin-fill units: Tertiary } \\
\text { Renova Formation, Tertiary Sixmile Creek } \\
\text { Formation, Tertiary to Quatemary old fan and } \\
\text { pediment gravels, and Holocene stream } \\
\text { alluvium }\end{array}$ & $\begin{array}{l}\text { Hughes, 1981, pl. I, } \\
\text { p. } 112\end{array}$ \\
\hline
\end{tabular}

crop out extensively in the Western Three Forks Valley to the west. Because the Gallatin and Westem Three Forks Valleys compose one continuous structural basin, and the sediments that fill the basin dip to the east, it is likely that these fine-grained, dominantly lacustrine, tuffaceous sediments underlie younger Tertiary sediments in most, if not all, of the Gallatin Valley (Hackett and others, 1960; Robinson, 1961). Miocene to Pliocene sediments of the Madison Valley Formation underlie the Madison Plateau and crop out on the terrace east of Bozeman and in the Dry Creek drainage area (Hackett and others, 1960), where they correlate with the Sixmile Creek Formation (Hughes, 1981; Fields and others, 1985). The formation consists of three unconformable cyclic units. The basal portion of each unit is a fluviatile, cross-bedded, andesitic conglomerate with coarse-grained sandstone. This grades upward into sediments that vary laterally from lacustrine beach sands to laminated clays with tuffaceous claystone. The entire formation is rich in tuffaceous siltstone, and contains numerous ash beds ranging in thickness from 0.5 to $12 \mathrm{ft}$ (Schneider, 1970b).

As much as $150 \mathrm{ft}$ of older alluvium of Tertiary and/or Quatemary age (QTd) mantles Tertiary pediments along the Bridger and Gallatin Range fronts. Appearing much like modern alluvial fans, these deposits consist of poorly sorted rock fragments in a sand, silt, and clay matrix with some carbonate cement and various degrees of consolidation (Hackett and others, 1960, p. 40).

Quatemary deposits cover more than half of the basin. Alluvial-fan deposits (QTd), probably of late Pleistocene age, extend into the Gallatin Valley from the Bridger and Gallatin Range fronts and consist of a heterogenous mixture of coarse- and fine-grained sediments. Typically, grain sizes decrease toward the toes of the fans. Likewise, fan thicknesses decrease from more than $150 \mathrm{ft}$ at the heads to zero thickness at the toes of the fans (Hackett and others, 1960). The largest alluvial fan emanates from the Gallatin Range south of Bozeman and covers a 56- $\mathrm{mi}^{2}$ area (Custer, 1991). Quatemary flood-plain alluvium (Qal) underlies the Gallatin River and its major tributaries and extends across the large plain between the Gallatin and East Gallatin Rivers. Moderately sorted cobbles, pebbles, and gravel compose the majority of the deposit, but sand, silt, and clay are also present in places. The proportion of fine-grained material generally increases to the north, where at least the upper $20 \mathrm{ft}$ contain substantial silt and clay. Although it is difficult to distinguish Quatemary alluvium from the underlying Tertiary sediments in drill cuttings, estimates of the thickness of the alluvium range from $70 \mathrm{ft}$ near Bozeman Hot Springs to more than $800 \mathrm{ft}$ near Belgrade (Hackett and others, 1960). 


\section{Hydrology}

The Gallatin River and its tributaries drain the Gallatin Valley. The river originates in Yellowstone National Park and flows northward about $80 \mathrm{mi}$ through a bedrock canyon before entering the Gallatin Valley near Gallatin Gateway. From there, the river flows northward to the northern basin boundary, then westward to the northwest corner of the basin. After leaving the Gallatin Valley, the Gallatin River joins the Madison and Jefferson Rivers to form the Missouri River. The principal tributary to the Gallatin River, the East Gallatin River, originates in the Bridger Range, meanders northwesterly along the northern edge of the Gallatin Valley, and joins the mainstem about 2 mi north of Manhattan (pl. 1). Reservoirs on tributaries east of the basin provide municipal-supply water for the City of Bozeman. Within the basin, the Gallatin River is the major source of irrigation water (Parrett and Johnson, 1988; [Montana] State Engineer's Office, 1953a, 1953b). Diversions for irrigation have, on occasion. dewatered some sections of the river (Dunkle, 1955).

Streamflow data for gaging stations listed in table 27 are stored in the USGS WATSTORE database. Locations of these stations are shown on plate 1. Records of 40 additional stations operated from 1951 to 1954 are also available. Monthly and annual data for these stations are summarized in Hackett and others (1960).

Table 27. Summary of data for U.S. Geological Survey streamflow-gaging stations in the Gallatin Valley, Montana

[Type of data collected: $c$, water chemistry; d, discharge. Periods of record for stations that were being operated as of November 1994 are indicated by the first year of record followed by a dash only. Abbreviations: $\mathrm{ft}^{3} / \mathrm{s}$, cubic feet per second. Symbol: --, no data]

\begin{tabular}{|c|c|c|c|c|c|c|c|c|c|}
\hline \multirow[b]{2}{*}{$\begin{array}{l}\text { Station } \\
\text { number }\end{array}$} & \multirow[b]{2}{*}{ Station name } & \multirow{2}{*}{$\begin{array}{l}\text { Drainage } \\
\text { area } \\
\text { (square } \\
\text { miles) }\end{array}$} & \multirow{2}{*}{$\begin{array}{l}\text { Type } \\
\text { of date } \\
\text { col- } \\
\text { lected }\end{array}$} & \multirow[b]{2}{*}{$\begin{array}{l}\text { Perlod of record } \\
\text { (calendar year) }\end{array}$} & \multicolumn{5}{|c|}{ Discharge for period of record } \\
\hline & & & & & $\begin{array}{c}\text { Mean } \\
\text { annual } \\
\left(\mathrm{ft}^{3} / \mathrm{s}\right)\end{array}$ & $\begin{array}{l}\text { Maxi- } \\
\text { mum } \\
\left(\mathrm{ft}^{3} / \mathrm{s}\right)\end{array}$ & $\begin{array}{c}\text { Date of } \\
\text { maximum }\end{array}$ & $\begin{array}{l}\text { Mint- } \\
\text { mum } \\
\left(\mathrm{ft}^{3} / \mathrm{s}\right)\end{array}$ & $\begin{array}{l}\text { Dates of } \\
\text { minimum }\end{array}$ \\
\hline 06043500 & $\begin{array}{l}\text { Gallatin River near } \\
\text { Gallatin Gateway }\end{array}$ & 825 & c & $\begin{array}{l}1889-1894,1930- \\
81,1984- \\
1985-86\end{array}$ & 806 & 9,100 & $06-17-74$ & 117 & $01-19-35$ \\
\hline 06044000 & $\begin{array}{l}\text { Gallatin River near } \\
\text { Salesville }\end{array}$ & 833 & d & $\begin{array}{c}1895-1905,1910- \\
13,1921-23\end{array}$ & 958 & 10,000 & 06-20-1899 & - & -- \\
\hline 06048500 & $\begin{array}{l}\text { Bridger Creek near } \\
\text { Bozeman }\end{array}$ & 62.5 & d & $\begin{array}{l}1945-69,1971-72, \\
1987\end{array}$ & 36.6 & 902 & $06-03-53$ & .9 & $\begin{array}{l}\text { 03-23-53, } \\
08-30-54\end{array}$ \\
\hline 06050000 & $\begin{array}{l}\text { Hyalite Creek at } \\
\text { Hyalite Ranger } \\
\text { Station, near } \\
\text { Bozeman }\end{array}$ & 48.2 & d & $1895-1904,1934-$ & 66.3 & 956 & $06-14-1898$ & 5.0 & $01-27-61$ \\
\hline 06052500 & Gallatin River at Logan & 1,795 & $\begin{array}{l}d \\
c\end{array}$ & $\begin{array}{c}1893-1905,1928- \\
1951-52,1956-57 \\
1965,1979-86\end{array}$ & 1,065 & 9,840 & 06-21-1899 & 130 & $07-19-39$ \\
\hline
\end{tabular}

Hackett and others (1960, pl. 8) compiled monthly surface-water budgets for the Gallatin Valley from October 1951 to September 1953, accounting for surface-water inflow and outflow, precipitation, ground-water recharge and discharge, snowmelt, evapotranspiration, and storage changes in soil moisture and ground water. Net surface-water flow was into the basin from June through August 1952 and from May through September 1953; otherwise, net flow was out of the basin. Periods during which surface water recharged ground water generally coincided with the periods of net surface-water inflow to the basin, although peak recharge to the ground-water reservoir preceded peak gains in surface-water flow.

The quality of surface water in the Gallatin River was determined on the basis of 11 samples from the Gallatin River at Logan (gaging station 06052500). Analyses indicate a calcium-bicarbonate type water with an average dissolved-solids concentration of $246 \mathrm{mg} / \mathrm{L}$ (Clark and Dutton, in press).

As part of a reconnaissance survey of arsenic in the upper Missouri River basin, samples were collected from the Gallatin River near Gallatin Gateway and at Logan (gaging stations 06043500 and 06052500 ) twelve times 
from November 1985 to October 1986. The concentration of total-recoverable arsenic for both sites was consistently $2 \mu \mathrm{g} / \mathrm{L}$ or less (Knapton and Horpestad, 1987, p. 22-23). The U.S. Environmental Protection Agency (1991) has established a maximum contaminant level of $50 \mu \mathrm{g} / \mathrm{L}$ arsenic for treated drinking water.

The East Gallatin River flows through agricultural land for its entire length. Erosive stream banks, runoff from farmland, and effluent from the sewage treatment plant at Bozeman have contributed suspended and dissolved solids, nutrients, and coliform to the East Gallatin River (Braico and Botz, 1975; Adamsen, 1974).

Suspended sediment in the Gallatin River originates both within the Gallatin Valley and in the headwater drainage areas. In an investigation of sediment sources to the Gallatin River, Hsieh (1972) determined that the Taylor Fork was the main source of sediment to the Gallatin River mainstem, and bank erosion was the main source to the East Gallatin River. In the mainstem, a 60-percent increase in suspended-sediment load between Gallatin Gateway and Manhattan in May and June 1970 was attributed to bank erosion (Hsieh, 1972). Construction activities near Big Sky have also contributed significant suspended solids to the Gallatin River (Braico and Botz, 1975). Aasheim (1973) predicted potential impacts of logging the drainage of Porcupine Creek, a tributary to the Gallatin River, on suspended sediment loads in the river.

Ground water is an important resource in the Gallatin Valley. It provides drinking water for many residents, irrigation water for about 2,800 acres (Parrett and Johnson, 1988), and water for livestock.

Quaternary flood-plain alluvium generally is the most permeable material in the basin, and the most reliable source of ground water. Wells completed in flood-plain alluvium as deep as $260 \mathrm{ft}$ (Dutton and others, 1995) typically provide sufficient supplies for any intended use, including irrigation. Table 28 summarizes yield and specific-capacity values for selected wells completed in flood-plain alluvium. Based on 24 aquifer tests, transmissivity values range from 5,100 to $90,000 \mathrm{ft}^{2} / \mathrm{d}$, and average $27,000 \mathrm{ft}^{2} / \mathrm{d}$ for alluvium of the Gallatin and East Gallatin Rivers. Based on four multiple-well aquifer tests, storage coefficients range from 0.01 to 0.06 (Hackett and others, 1960).

Table 28. Summary of data for yield and specific capacity of wells completed in selected hydrogeologic units in the Gallatin Valley, Montana

[Source: Dutton and others, 1995. Hydrogeologic unit: Qal, Holocene and Pleistocene alluvial deposits; QTd, Quatemary through Tertiary undifferentiated deposits (primarily alluvial-fan deposits); Ts, Teniary sedimentary deposits and rocks. Abbreviations: gal/min, gallon per minute; (gal/min)/ft, gallon per minute per foot]

\begin{tabular}{|c|c|c|c|c|c|c|c|c|c|c|}
\hline \multirow{2}{*}{$\begin{array}{l}\text { Hydro- } \\
\text { geologic } \\
\text { unit }\end{array}$} & \multirow[b]{2}{*}{$\begin{array}{c}\text { Number of } \\
\text { wells }\end{array}$} & \multicolumn{4}{|c|}{ Yield (gal/min) } & \multirow[b]{2}{*}{$\begin{array}{c}\text { Number of } \\
\text { wells }\end{array}$} & \multicolumn{4}{|c|}{ Specific capacity [(gal/min)/ft] } \\
\hline & & Mean & Median & $\begin{array}{l}\text { Minl- } \\
\text { mum }\end{array}$ & $\begin{array}{l}\text { Maxl- } \\
\text { mum }\end{array}$ & & Mean & Median & $\begin{array}{l}\text { Mini- } \\
\text { mum }\end{array}$ & $\begin{array}{l}\text { Maxl- } \\
\text { mum }\end{array}$ \\
\hline Qal & 18 & 270 & 38 & 5.0 & 1,500 & 15 & 11 & 5.1 & 0.5 & 45 \\
\hline QTd & 11 & 165 & 20 & 3.0 & 1,600 & 10 & 4.5 & .6 & .1 & 38 \\
\hline Ts & 41 & 700 & 500 & 5.7 & 2,800 & 39 & 9.1 & 5.7 & .1 & 59 \\
\hline
\end{tabular}

Quatemary and Tertiary alluvial-fan deposits $(Q T d)$ have a wide range of hydraulic characteristics, indicating they can provide sufficient supplies for domestic and livestock use, and in some places, for irrigation. Table 28 summarizes yield and specific-capacity values for selected wells 60 to $305 \mathrm{ft}$ deep completed in alluvial fans. Hackett and others (1960) calculated transmissivity values ranging from 600 to $8,700 \mathrm{ft}^{2} / \mathrm{d}$ from aquifer tests of eight wells completed in these deposits.

Until the 1960's, it was not known that Tertiary sediments beneath the Gallatin Valley could produce large yields suitable for irrigation supply. East of the Madison Plateau, wells completed in Tertiary sediments typically have low production capabilities. Specific-capacity values for 16 wells completed in Tertiary sediments east of the Madison Plateau range from 0.2 to $47.6(\mathrm{gal} / \mathrm{min}) / \mathrm{ft}$ with a median value of $0.78(\mathrm{gal} / \mathrm{min}) / \mathrm{ft}$ (Slagle, 1995a); transmissivity values determined from four aquifer tests range from 40 to 2,300 $\mathrm{ft}^{2} / \mathrm{d}$ (Hackett and others, 1960, table 12). Recently, as housing has expanded onto the benches east of Bozeman, many landowners there have drilled dry or poorly producing wells. However, wells drilled deep into the Madison Plateau tap a permeable zone capable of 
yiclding as much as $2,800 \mathrm{gal} / \mathrm{min}$ to 16 -in. irrigation wells. These wells are typically about 200 to more than 500 ft dcep, with well depths increasing to the south. Specific-capacity values estimated from drillers' logs of 14 irrigation wells on the Madison Plateau range from 6.2 to $59(\mathrm{gal} / \mathrm{min}) / \mathrm{ft}$, with a median value of 17.5 (gal $/ \mathrm{min}) / \mathrm{ft}$ (Dutton and others, 1995). Hackett and others (1960) calculated a transmissivity value of 3,500 $\mathrm{ft}^{2} / \mathrm{d} \mathrm{for} \mathrm{a} 225$ - $\mathrm{ft}$ well on the Madison Plateau (01N03E33DD), but considered the value to be an exception, rather than an indication of an important aquifer. Table 28 summarizes yield and specific-capacity values for selected wells completed in Tertiary sediments, combining data from the Madison Plateau with the rest of the Gallatin Valley.

Basin-fill aquifers are unconfined throughout the Gallatin Valley, except where they may be locally confined or semi-confined by fine-grained material. For example, in 1931, ground water entered an 800-ft oil-exploration well (01S04E01BAD) at a depth of $400 \mathrm{ft}$ and rose to $20 \mathrm{ft}$ below land surface (Montana Board of Oil and Gas Conservation, unpub. data, 1990).

Bedrock is not an important aquifer in the Gallatin Valley. Most of the bedrock that surrounds the basin has low permeability and therefore does not transmit ground water readily. One exception might be the Mississippian limestone that borders the basin in a few places. Where limestone is below the water table, it could potentially be a useful aquifer because ground water might flow through cavemous openings created by dissolution of carbonate minerals. However, a 165-ft well completed in Mississippian limestone in Logan (02N02E35ADDA01) has a reported yield of only $4.5 \mathrm{gal} / \mathrm{min}$, and a specific capacity of 0.1 (gal/min)/ft (Dutton and others, 1995).

Considerable ground-water data are available for the Gallatin Valley. Water levels measured in the wells listed in table 29 are stored in the USGS WATSTORE database. Records of periodic water levels measured in other wells over shorter time frames have been documented by Murdock (1926), Hackett and others (1960), Earth Scicnce Services, Inc. (1978), and Slagle (1995b).

Table 29. Summary of water-level data for selected wells in the Gallatin Valley, Montana

[Hydrogeologic unit: Qal, Holocene and Pleistocene alluvial deposits. Periods of record for observation wells that were being operated as of February 1995 are indicated by the first year of record followed by a dash only]

\begin{tabular}{|c|c|c|c|c|c|c|c|}
\hline \multirow[b]{2}{*}{ Location number } & \multirow{2}{*}{$\begin{array}{l}\text { Depth of well, } \\
\text { In feet below } \\
\text { land surface }\end{array}$} & \multirow{2}{*}{$\begin{array}{l}\text { Hydro- } \\
\text { geologle } \\
\text { unit }\end{array}$} & \multirow{2}{*}{$\begin{array}{c}\text { Perlod of } \\
\text { record }\end{array}$} & \multicolumn{4}{|c|}{ Water level, In feot below land surface } \\
\hline & & & & Hilghest & $\begin{array}{l}\text { Date of } \\
\text { highest }\end{array}$ & Loweat & $\begin{array}{l}\text { Date of } \\
\text { lowest }\end{array}$ \\
\hline 01N04E25DCDD01 & 101 & Qal & 1951- & 5.92 & 08-06-52 & 16.91 & $05-04-94$ \\
\hline 01S04E25AAA 03 & 50.5 & Qal & $1953-75$ & 5 & $07-19-74$ & 19.84 & 04-24-74 \\
\hline 02S04E13CCBC01 & 11.0 & Qal & $1947-93$ & 2.54 & $06-27-52$ & 10.40 & $02-20-71$ \\
\hline
\end{tabular}

Water levels in the basin range from more than $450 \mathrm{ft}$ below the surface of the Madison Plateau, to a few feet below the surface of the Gallatin River flood plain (Dutton and others, 1995; Hackett and others, 1960, pl. 6). Potentiometric-surface maps of the Gallatin Valley (table 30) indicate that ground water generally flows from the uplands toward the flood plain, then approximately parallel to the Gallatin River. Ground water exits the basin at Logan, where numerous springs issue from alluvium as ground water flow is constricted by a narrow bedrock canyon.

Typically, ground-water levels rise from spring through mid-summer, peak in June or July, and gradually recede until about April, when snowmelt and seepage from runoff-swollen streams begin to recharge the basin-fill aquifers. In most parts of the flood plain, water levels fluctuate seasonally. The greatest fluctuation occurred near Belgrade in 1953, where water levels rose more than $40 \mathrm{ft}$ between April 1 and August 1 (Hackett and others, 1960, pl. 7 and 9).

Irrigation practices strongly influence water levels in the basin. The Gallatin Valley was one of the first areas in Montana to be extensively irrigated. The first irrigation ditches were completed in 1864 ([Montana] State Engineer's Office, 1953a). By the 1910's, irrigators routinely experienced late-season water shortages. Meanwhile, surplus irrigation water from early in the season accumulated in the downgradient end of the basin, raising water 
Table 30. Potentiometric-surface maps of the Gallatin Valley, Montana

\begin{tabular}{|c|c|c|c|c|}
\hline Location & $\begin{array}{l}\text { Dates water } \\
\text { levels were } \\
\text { moasured }\end{array}$ & Scale & $\begin{array}{c}\text { Contour } \\
\text { Interval in } \\
\text { foet }\end{array}$ & Relerence \\
\hline Primarily the flood plain & Aug.-Sept. 1977 & $1: 170,000$ & 40 & $\begin{array}{l}\text { Earth Science Services, Inc., } \\
1978\end{array}$ \\
\hline Primarily the flood plain & Apr. 1, 1953 & $1: 126,720$ & 40 & Hackett and others, $1960, \mathrm{pl} .5$ \\
\hline Primarily the flood plain & Aug. 1,1953 & $1: 126,720$ & 40 & Hackett and others, $1960, \mathrm{pl} .5$ \\
\hline $\begin{array}{l}\text { Between Gallatin and East Gallatin } \\
\text { Rivers north of Belgrade }\end{array}$ & Summer 1919(?) & $1: 76,000$ & 10 & Murdock, 1926, fig. 6, p. 13 \\
\hline Entire Gallatin Valley & Aug. 2-4, 1993 & $1: 100,000$ & 50 & Slagle, 1995a, sheet 1, fig. 2 \\
\hline
\end{tabular}

levels an estimated $50 \mathrm{ft}$ or more near Belgrade. Several swampy areas developed, the largest of which extended from the Gallatin River to the East Gallatin River north of Belgrade. The area comprised about 15,000 acres that were too waterlogged to farm without artificial drainage (Murdock, 1926). Subsequently, successful drainage projects increased the productive land base. However, the problem of late-season water shortages remained--of the 97,000 acres irrigated in the 1930's, 74,000 acres experienced shortages every year (Debler and Robertson, 1937). Nor was the waterlogging problem solved. In 1953, it was reported that "the waste of water on higher areas, and seepage from the too numerous ditches" had turned many once-productive valley bottoms into pasture, at best ([Montana] State Engineer's Office, 1953a). Currently, there are few water-logged areas because seepage has been reduced, drainage has been improved, and the amount of irrigated land has decreased from 107,261 acres in 1952 to about 96,200 acres in 1985 (Slagle, 1995a).

Comprehensive records of water levels in wells in the Gallatin Valley begin in about the 1950's. Hackett and others (1960) conducted the most detailed study of ground water in the Gallatin Valley to date. Periodic water-level measurements in more than 100 wells from 1951 to 1953, plus measurements in some additional wells from 1947 to 1954, provided the basis for the first potentiometric-surface map of the entire valley floor (table 30).

The Montana Department of Natural Resources and Conservation monitored water levels in Tertiary sediments beneath the Madison Plateau from 1986 to 1993. The network consisted of 21 wells, 18 of which were deep irrigation wells. Water levels were measured in about March, May, August, and November. Prompted by a shortage of available surface water, landowners began drilling deep irrigation wells in the Madison Plateau in the early 1960's. After the successful completion of about 20 large-capacity wells, which supplement canal water diverted from the Gallatin River and ground water pumped up from a few wells near the Madison River, the plateau developed into a prosperous seed-potato producing area.

In 1978, the U.S. Environmental Protection Agency funded a study of the Gallatin Valley in which water levels in 76 of the wells that Hackett and others (1960) measured in 1951-53 were remeasured to document changes that had occurred in the intervening years. Water levels had decreased somewhat, most significantly near Belgrade. However, this was attributed to an abnormally low supply of irrigation water in 1977, temporarily resulting in reduced aquifer recharge from canal seepage and surplus irrigation water. No long-term trends were observed (Earth Science Services, Inc., 1978).

In recent years, rapid population growth in the Gallatin Valley has prompted the development of numerous rural subdivisions. Because of the consequent increase in ground-water use and potential for changes in groundwater levels and chemical quality, the USGS, in cooperation with the Montana Bureau of Mines and Geology, conducted an appraisal of the 1992-93 hydrologic conditions in the basin (Slagle, 1995a, 1995b). Although no longterm water-level trends were detected, short-term effects of irrigation on aquifer recharge were evident. Because the growing season in 1993 was exceptionally cool and wet, most farmers and ranchers did not irrigate. In areas that were usually irrigated, ground-water levels declined by as much as $12 \mathrm{ft}$. Conversely, in dryland farming and grazing areas, water levels rose as much as $21 \mathrm{ft}$ in response to above-normal precipitation.

The relative importance of irrigation water in recharging basin-fill aquifers is evidenced by the water table rising to maximum altitudes during periods of intense irrigation rather than during periods of great precipitation 
(Brustkern, 1977; Slagle, 1995a). For this reason, large-scale land-use changes from irrigated agriculture to residential subdivisions may result in a lowering of the water table. A computerized ground-water flow model of the alluvial fan area west of Bozeman also predicts this result (Brustkem, 1977).

Basin-fill aquifers in the Gallatin Valley also are recharged by precipitation and snowmelt, subsurface flow from bedrock, and infiltration from the Gallatin River and its tributaries. The ground-water contribution area (fig. $2, \mathrm{pl}$. 1) is about $1,000 \mathrm{mi}^{2}$. Infiltration anywhere within this area could potentially recharge aquifers in the Gallatin Valley. Ground water discharges from the basin-fill aquifers by evapotranspiration, withdrawals from wells, and seepage to springs, seeps, irrigation drains, and stream channels.

The presence of Bozeman Hot Springs near the center of the basin (02S04E14DDBA) indicates subsurface flow of geothermal water from Archean bedrock (Chadwick and Leonard, 1979). The springs discharge water with a temperature of $55^{\circ} \mathrm{C}$ at a rate of $74 \mathrm{gal} / \mathrm{min}$. A 685-ft flowing geothermal well at the same location produces 1,000 $\mathrm{gal} / \mathrm{min}$ of $55^{\circ} \mathrm{C}$ water (Sonderegger and Bergantino, 1981).

Ground-water quality in the Gallatin Valley correlates relatively well with geology. The quality of ground water in the basin was determined on the basis of 39 samples analyzed for major ions and measured dissolved-solids concentrations, and 41 samples in which dissolved-solids concentrations were estimated from specific-conductance measurements. Wells completed in flood-plain alluvium typically have calcium bicarbonate water with less than $250 \mathrm{mg} / \mathrm{L}$ dissolved solids. Water in Tertiary sediments beneath pediments and aliuvial fans has similar major-ion chemistry, but has dissolved-solids concentrations as large as $500 \mathrm{mg} / \mathrm{L}$. Many of the largest dissolved-solids concentrations are associated with low-yielding domestic wells. Beneath the Madison Plateau, wells completed in Tertiary sediments have mixed-bicarbonate type water in which calcium, magnesium, and sodium may be present in similar proportions, and dissolved-solids concentrations range from about 250 to $500 \mathrm{mg} / \mathrm{L}$ (Clark and Dutton, in press).

In 1978, 17 of the wells that Hackett and others (1960) sampled in 1951-53 were resampled to document any changes that may have occurred in the intervening years. On the average, dissolved-solids concentrations had increased $30 \mathrm{mg} / \mathrm{L}$, from 229 to $259 \mathrm{mg} / \mathrm{L}$ throughout the basin (Earth Science Services, Inc., 1978). In 1993, nitrate concentrations in ground-water samples from 43 wells ranged from 0.1 to $4.5 \mathrm{mg} / \mathrm{L}$ as $\mathrm{N}$. The distribution of nitrate concentrations in ground water suggests the possibility that urban development may have affected ground-water quality. Most of the larger concentrations coincided with densely developed rural subdivisions north-northwest of Bozeman (01S05E), in an area of concentrated septic tanks and probable lawn fertilizer application (Slagle, 1995a). The U.S. Environmental Protection Agency (1991) has established a maximum contaminant level of $10 \mathrm{mg} / \mathrm{L}$ nitrate as $\mathrm{N}$ for treated drinking waters.

Radon is a naturally-occurring isotope formed by the radioactive decay of uranium, which is present to some extent in nearly all rocks. Sixteen wells sampled for radon in the Gallatin Valley had concentrations of radon ranging from 170 to $1,565 \mathrm{pCi} / \mathrm{L}$ (Slagle, 1995a). Although it is safe to drink water containing radon, when the water is exposed to the air, it can release airborne radon which, when inhaled, poses a risk of lung cancer. Therefore, the EPA has proposed that the concentration of radon in public water supplies not exceed $300 \mathrm{pCi} / \mathrm{L}$ (picocuries per liter) (Clark and Briar, 1993).

\section{Selected References}

Aasheim, R.J., 1973, Assessing potential impacts of logging and road construction on the soil and water resources in a semiprimitive area: Bozeman, Montana State University, M.S. thesis, 135 p.

Adamsen, FJ., 1974, Phosphorus, sediment, and water interactions in the Gallatin River of southwestern Montana: Bozeman, Montana State University, M.S. thesis, 79 p.

Alden, W.C., 1953, Physiography and glacial geology of western Montana and adjacent areas: U.S.Geological Survey Professional Paper 231, 200 p.

Boyd, D.W., 1968, Simulation via time-partitioned linear programming--a ground and surface water allocation model for the Gallatin Valley of Montana: Bozeman, Montana University Joint Water Resources Research Center Report 10, 217 p. 
Braico, R.D., and Botz, M.K., 1975, Water quality inventory and management plan, upper Missouri tributaries basin, Montana: Montana Department of Health and Environmental Sciences, $167 \mathrm{p}$.

Briar, D.W., Lawlor, S.M., Stone, M.A.J., Parliman, D.J., Schaefer, J.L., and Kendy, Eloise, in press, Ground-water levels in intermontane basins of the Northern Rocky Mountains, Montana and Idaho: U.S. Geological Survey Hydrologic Investigations Atlas 738-B, 1 sheet, scale 1:750,000.

Brustkem, R.L., 1977, The impact of land use change on the ground water resources of the Bozeman, Montana area: Bozeman, Montana University Joint Water Resources Research Center Report 88, 20 p.

Chadwick, R.A. and Leonard, R.B., 1979, Structural controls of hot-spring systems in southwestern Montana: U.S. Geological Survey Open-File Report 79-1333, 25 p.

Clark, D.W., and Briar, D.W., 1993, Radon in ground water of western Montana: U.S. Geological Survey Water Fact Sheet, Open-File Report 93-64, 1 sheet.

Clark, D.W., and Dutton, D.M., in press, Quality of ground water and surface water in intermontane basins of the Northern Rocky Mountains, Montana and Idaho: U.S. Geological Survey Hydrologic Investigations Atlas 738-C, 1 sheet, scale 1:750,000.

Custer, S.G., 1991, Ground-water potential in the Bozeman-fan subarea, Gallatin County, Montana: Report to the Montana Department of Natural Resources and Conservation, Water Development Bureau, 141 p.

Davis, W.E., Kinoshita, W.T., and Robinson, G.D., 1965, Bouguer gravity, aeromagnetic, and generalized geologic map of the eastern part of the Three Forks basin, Broadwater, Madison, and Gallatin Counties, Montana: U.S. Geological Survey Geophysical Investigations Map GP-498, 2 sheets, scale 1:62,500.

Debler, E.B., and Robertson, R.R., 1937, Report on Gallatin Valley investigations, Montana: Bureau of Reclamation Open-File Report, 129 p.

Dunkle, F. H., Jr., 1955, A survey of water uses of the West Gallatin River, Gallatin County, Montana: Montana Academy of Sciences [Proceedings], v. 15, p. 31-39.

Dutton, D.M., Lawlor, S.M., Briar, D.W., and Tresch, R.E., 1995, Hydrogeologic data for the Northern Rocky Mountains intermontane basins, Montana: U.S. Geological Survey Open-File Report 95-143, 94 p.

Earth Science Services, Inc., 1978, Ground water levels and ground water chemistry, Gallatin Valley, Montana, 1977: prepared for Blue Ribbons of the Big Sky Country Areawide Planning Organization, Bozeman, Mont., 62 p.

Ehlke, T.A., and Soltero, R.A., 1969, Microbiological pollution studies on the East Gallatin River and its tributaries: Montana Academy of Sciences [Proceedings], v. 29, p. 97-113.

Fields, R.W., Rasmussen, D.L., Tabrum, A.R., and Nichols, Ralph, 1985, Cenozoic rocks of the intermontane basins of western Montana and eastern Idaho--A summary, in Flores, R.M., and Kaplan, S.S., eds., Cenozoic paleogeography of west-central United States: Society of Economic Paleontologists and Mineralogists, Rocky Mountain Section, Denver, Colo., p. 9-36.

Glancy, P.A., 1964, Cenozoic geology of the southeastern part of the Gallatin Valley, Montana: Bozeman, Montana State University, M.S. thesis, $67 \mathrm{p}$.

Griffith, E.F., 1982, Environmental geology of the southeast margin of the Gallatin Valley, Gallatin County, Montana: Bozeman, Montana State University, M.S. thesis, $116 \mathrm{p}$.

Hackett, O.M., Visher, F.N., McMurtrey, R.G., and Steinhilber, W.L., 1960, Geology and ground-water resources of the Gallatin Valley, Gallatin County, Montana, with a section on Surface-water resources by Frank Stermitz and F.C. Boner, and a section on Chemical quality of the water by R.A. Krieger: U.S. Geological Survey Water-Supply Paper 1482, 282 p.

Hanneman, D.L., and Wideman, C.J., 1991, Sequence stratigraphy of Cenozoic continental rocks, southwestern Montana: Geological Society of America Bulletin, v. 103, p. 1335-1345.

Hsieh, Y. P., 1972, A source study of the suspended solids in the Gallatin River: Bozeman, Montana State University, M.S. thesis, $96 \mathrm{p}$.

Hughes, G.C., 1981, Tertiary stratigraphy and depositional history of the Dry Creek Valley, Montana, in Montana Geological Society Field Conference and Symposium Guidebook to Southwest Montana: [Billings, Mont.], Montana Geological Society, p. 111-119.

Knapton, J.R., and Horpestad, A.A., 1987, Arsenic data for streams in the upper Missouri River basin, Montana and Wyoming: U.S. Geological Survey Open-File Report 87-124, 25 p. 
Mifflin, M.D., 1963, Geology of a part of the southern margin of the Gallatin Valley, southwest Montana: Bozeman, Montana State University, M.S. thesis, 111 p.

[Montana] State Engineer's Office, 1953a, Water resources survey, Gallatin County, Montana--Part 1, History of land and water use on irrigated areas: Helena, Mont., State Engineer's Office, 62 p.

1953b, Water resources survey, Gallatin County, Montana--Part 2, Maps showing irrigated areas: Helena, Mont., State Engineer's Office, $53 \mathrm{p}$.

Murdock, H.E., 1926, Irrigation and drainage problems in the Gallatin Valley: Montana University Agricultural Engineering Station Bulletin 195, $36 \mathrm{p}$.

National Oceanic and Atmospheric Administration, 1992, Monthly normals of temperature, precipitation, and heating and cooling degree days, 1961-90, Montana: Asheville, N.C., Climatography of the United States no. 81, unpaged.

Noble, R.A., Bergantino, R.N., Patton, T.W., Sholes, B.C., Daniel, Faith, and Schofield, Judeykay, 1982, Occurrence and characteristics of ground water of Montana--Volume 2, The Rocky Mountain Region: Montana Bureau of Mines and Geology Open-File Report 99, 132 p.

Parrett, Charles, and Johnson, D.R., 1988, Estimation of surface withdrawals for irrigation and irrigated acreage, 1985, Gallatin County, Montana, in Proceedings of the Symposium on Water-Use Data for Water Resources Management: Bethesda, Md., American Water Resources Association, p. 641-647.

Robinson, G.D., 1961, Origin and development of the Three Forks basin, Montana: Geological Society of America Bulletin, v. 72, p. 1,003-1,014.

Schneider, G.B., 1970a, Cenozoic geology of the Madison Bluffs area, Gallatin County, Montana: Bozeman, Montana State University, M.S. thesis, $56 \mathrm{p}$.

1970b, Cenozoic stratigraphy of the Madison Bluffs area, Gallatin County, Montana [abs.]: Geological Society of America Abstracts with Programs, v. 2, p. 348.

Slagle, S.E., 1995a, Geohydrologic conditions and land use in the Gallatin Valley, southwestern Montana, 1992-93: U.S. Geological Survey Water-Resources Investigations Report 95-4034, 2 sheets, scale 1:100,000.

1995b, Records of water levels in monitoring wells in the Gallatin Valley, southwestern Montana, 1947-93: U.S. Geological Survey Open-File Report 94-536, 41p.

Soltero, R.A., 1968, Chemical and physical findings from pollution studies on the East Gallatin River and its tributaries: Bozeman, Montana State University, M.S. thesis, 111 p.

Sonderegger, J.L., and Bergantino, R.N., 1981, Geothermal resources map of Montana: Montana Bureau of Mines and Geology Hydrogeologic Map 4, scale 1:1,000,000.

Tuck, L. K., Briar, D.W., and Clark, D.W., in press, Geologic history and hydrogeologic units of intermontane basins of the Northern Rocky Mountains, Montana and Idaho: U.S. Geological Survey Hydrologic Investigations Atlas 738-A, 2 sheets, scale 1:750,000.

U.S. Department of Commerce, 1992, 1990 census of population and housing, population and housing unit counts, Montana: Bureau of the Census CPH-2-28, variously paged.

U.S. Environmental Protection Agency, 1991, Maximum contaminant levels (subpart B of part 141, National primary drinkingwater regulations): U.S. Code of Federal Regulations, Tiule 40, Parts 100 to 149, revised July 1, 1991, p. 585-588.

U.S. Geological Survey, issued annually, Water resources data, Montana: Helena, Mont., U.S. Geological Survey Water-Data Report.

Van Voast, W.A., 1972, Hydrology of the West Fork drainage of the Gallatin River, southwestem Montana, prior to commercial recreational development: Montana Bureau of Mines and Geology Special Publication 57, 19 p.

Wantland, Dart, 1951, Second phase of geophysical investigations in connection with U.S. Geological Survey ground-water studies in the Gallatin River valley, Montana: Bureau of Reclamation, Engineering Geology Branch, Geology Report G-121, 29 p. 


\section{Grasshopper Valley}

\section{Geography}

The Grasshopper Valley is an approximately north-trending intermontane basin in southwestern Montana. The $120-\mathrm{mi}^{2}$ basin is bounded by the Big Hole Divide on the west, the Pioneer Mountains on the north and east, Henneberry Ridge on the southeast, and the drainage divide between Grasshopper Creek and Horse Prairie Creek on the south (pl. 1). Grasshopper Creek originates in the Pioneer Mountains and flows south toward the central Grasshopper Valley. The creek then bends southeastward and leaves the basin through a narrow bedrock constriction. The flood plain is about one mile across at its widest in the northern part of the basin. Willows and cottonwoods along the creek contrast with the grass- and sage-covered range that characterizes the rest of the Grasshopper Valley. Except for the narrow flood plain and a few incised terraces in the northeast, most of the basin terrain consists of smoothly undulating pediments, which continue southward into the

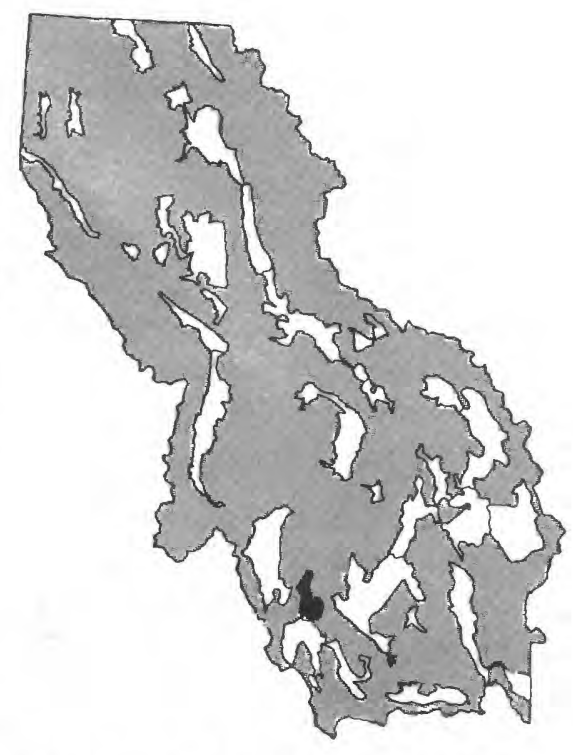
Horse Prairie Valley. Steep, rugged, forested mountains flank the eastem, northem, and western basin margins. This mountainous wall is unbroken except by the grassy, rounded Big Hole Pass southwest of Polaris. The Grasshopper Valley ranges in altitude from about $5,800 \mathrm{ft}$ where Grasshopper Creek flows out of the southeastem edge of the basin, to about $7,700 \mathrm{ft}$ on the highest terrace.

The climate of the Grasshopper Valley is typical of higher-elevation intermontane basins in southwestern Montana, with very cold winters and mild summers. A climate station maintained by the National Weather Service in Polaris recorded precipitation and snowfall from June 1949 through June 1958. On the basis of the 1949-58 period of record, the average annual precipitation at Polaris (elevation 6,710 ft) is $11.00 \mathrm{in}$. (National Oceanic and Atmospheric Administration, issued annually). Average monthly precipitation data for Polaris are plotted in figure 13. The climate station did not record temperature. The nearest temperature-recording climate stations are in Dillon (fig. 6) and Jackson.

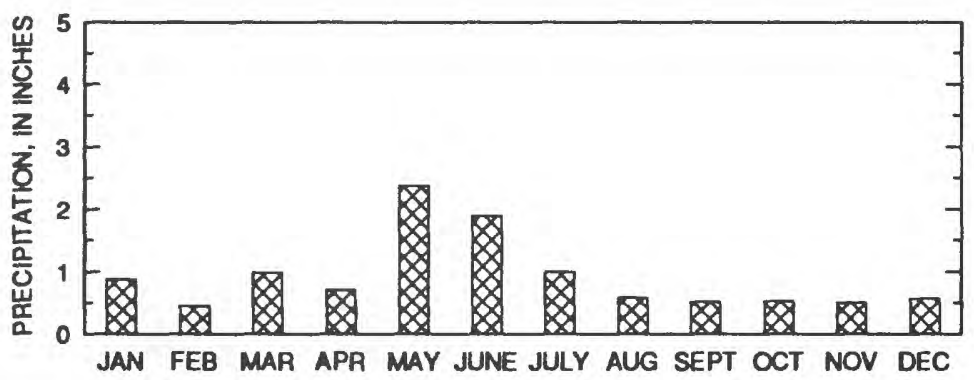

EXPLANATION FOR 194958 PERIOD OF RECORD

Figure 13. Mean monthly precipitation at Polaris, Mont. Data from National Oceanic and Atmospheric Administration (issued annually).

Land in the Grasshopper Valley, most of which is administered by the Bureau of Land Management and the U.S. Forest Service, primarily is used as rangeland (J.C. Eggen, Agricultural Stabilization and Conservation Service, oral commun., 1993). In addition, canals divert surface water from Grasshopper Creek and several of its tributaries to flood-irrigated pastures on the valley bottom. About 100 people reside in the Grasshopper Valley (1990 census). 


\section{Geology}

The Grasshopper Valley formed by downdropping along essentially normal faults on the east and west basin margins. Gravity data suggest that about $12,000 \mathrm{ft}$ of sediment fill the basin at its deepest point, near the southern end (Ruppel, 1993, p. 23).

Few detailed geologic data are available for the Grasshopper Valley. A map of the "Bannack-Grayling area" (Lowell, 1965) identifies all deposits in the Grasshopper Valley as "hill wash." The generalized basin geology is shown in a 1:250,000-scale map (Ruppel and others, 1993), which differentiates three basin-fill units: Tertiary valley-fill deposits, Quatemary till, and Quaternary alluvial-fan deposits. The geologic units described by previous investigators are summarized below. These geologic units are referenced to hydrogeologic units defined in this study (table 2) to provide a consistent regional framework. In the following discussion, the hydrogeologic-unit abbreviations are italicized.

Bedrock that surrounds and floors the Grasshopper Valley is predominantly metasedimentary, carbonate, and igneous intrusive rocks. Metasedimentary rocks of the Middle Proterozoic Belt Supergroup (Yms) border the basin intermittently along the east and compose the Big Hole Divide. These rocks consist of quartzite, argillite, and siltite with minor amounts of conglomerate. The Proterozoic rocks are folded and faulted and, in places, intruded by Cretaceous and early Tertiary plutonic rocks (TKi) (Ruppel and others, 1993). Paleozoic sedimentary rocks (Pzls), consisting largely of Mississippian limestone, adjoin the southeastem basin margin (Lowell, 1965). Late Cretaceous granodiorite, tonalite, and quartz diorite (TKi) compose the Pioneer Mountains (Ruppel and others, 1993).

Tertiary sediments (Ts) consisting of tuff, tuffaceous sedimentary rocks, conglomeratic sandstone, and shale fill the basin (Ruppel, 1993, p. 23). These sediments belong to the Renova Formation and the overlying Sixmile Creek Formation of the Bozeman Group, although it is difficult to distinguish the two formations in this basin. Tertiary sediments crop out on pediments in the southern part of the basin and continue, uninterrupted, into the Horse Prairie Valley to the south. Tertiary pediments in the northern and central parts of the basin largely are covered by glacial deposits (Ruppel and others, 1993).

Quaternary deposits in the basin include glacial till and outwash, and alluvium. A dissected terrace of Pleistocene glacial till $(\mathrm{Qg})$ extends from the Pioneer Mountains into the northern part of the Grasshopper Valley. Deposits of till also fill some tributary valleys along the western side of the basin. The till is composed of an unsorted mixture of boulders, cobbles, pebbles, and sand deposited by alpine glaciers. A veneer of glacial outwash (Qal) conceals Tertiary deposits throughout most of the basin. The poorly sorted, bouldery gravel and sand deposits form alluvial fans, emanating primarily from tributaries to the northern half of the basin (Ruppel and others, 1993). Holocene alluvium consisting of gravel, sand, silt, and clay underlies the flood plains of Grasshopper Creek and its major tributaries.

\section{Hydrology}

Grasshopper Creek is a tributary to the Beaverhead River below Clark Canyon Reservoir. The USGS streamflow-gaging station nearest to the Grasshopper Valley was station 06015500 (drainage area $348 \mathrm{mi}^{2}$ ), located on Grasshopper Creek about $15 \mathrm{mi}$ downstream from the basin margin and 1.25 mi upstream from the confluence with the Beaverhead River (pl. 1). Daily or monthly streamflow measurements were recorded at this station from 1921 to 1929,1930 to 1933,1945 to 1953 , and 1955 to 1961 . Over the period of record, discharge ranged from a minimum of no flow briefly during the summers of 1930 and 1931 when all flow was diverted for irrigation, to a maximum of $1,870 \mathrm{ft}^{3} / \mathrm{s}$ on March 24,1956 . The mean annual discharge at the station for the period of record is $51.6 \mathrm{ft}^{3} / \mathrm{s}$ (U.S. Geological Survey, 1961, p. 31).

Little is known about the quality of surface water in the Grasshopper Valley. However, Grasshopper Creek near Dillon (gaging station 06015500) was sampled for arsenic once during low flow $\left(29 \mathrm{ft}^{3} / \mathrm{s}\right.$ on November 13 , 1985 ) and once during high flow ( $140 \mathrm{f} 3 / \mathrm{s}$ on May 28,1986$)$. The concentration of total recoverable arsenic was 3 
$\mu \mathrm{g} / \mathrm{L}$ at low flow and $6 \mu \mathrm{g} / \mathrm{L}$ at high flow (Knapton and Horpestad, 1987, p. 14). Both samples had concentrations well below the maximum contaminant level of $50 \mu \mathrm{g} / \mathrm{L}$ arsenic established by the U.S. Environmental Protection Agency (1991) for treated drinking water.

Ground water is an important local resource, because all basin residents rely on it for domestic supplies. Also, many wells provide water for livestock use. However, very little is known about the hydraulic characteristics of the aquifers underlying the Grasshopper Valley.

Six wells completed in Quaternary alluvium, four of which also tap Tertiary sediments beneath alluvial fans, have reported yields ranging from 9.2 to $24 \mathrm{gal} / \mathrm{min}$, with a median value of $14.5 \mathrm{gal} / \mathrm{min}$. Specific-capacity values for five of these wells range from 0.4 to $1.3(\mathrm{gal} / \mathrm{min}) / \mathrm{ft}$, with a median value of $0.7(\mathrm{gal} / \mathrm{min}) / \mathrm{ft}$. These wells range in depth from about 40 to $130 \mathrm{ft}$, with the deeper wells completed in Tertiary sediments that underlie alluvial fans. Ground-water levels in Quaternary alluvium are typically less than $30 \mathrm{ft}$ beneath the land surface, except in alluvial fans along the basin margins, where depth to water may exceed $100 \mathrm{ft}$ (Dutton and others, 1995).

Eleven wells completed in Tertiary sediments range in depth from less than 100 to more than $500 \mathrm{ft}$. Yields from these wells range from 10 to $120 \mathrm{gal} / \mathrm{min}$, reflecting the heterogeneity of the Tertiary deposits. The median yield is $25 \mathrm{gal} / \mathrm{min}$. Specific-capacity values for nine of these wells range from 0.1 to 13 ( $\mathrm{gal} / \mathrm{min}) / \mathrm{ft}$, with a median value of 0.7 ( $\mathrm{gal} / \mathrm{min}) / \mathrm{ft}$. Ground-water levels in these wells range from above land surface to more than $400 \mathrm{ft}$ below land surface. In some areas, particularly near the mouth of Buffalo Creek, depths to ground water vary widely between nearby wells--another indication of the heterogeneous nature of the Tertiary sediments (Dutton and others, 1995).

Fractures in bedrock surrounding the Grasshopper Valley may yield sufficient quantities of water to supply domestic and stock wells in some places. One well (04S12S29CCCA01) completed in igneous intrusive rocks has a reported yield of $12 \mathrm{gal} / \mathrm{min}$ with a specific capacity of 2.4 (gal/min)/ft (Dutton and others, 1995).

Little is known about ground-water movement in the Grasshopper Valley. However, a 1:750,000-scale potentiometric-surface map which includes the Grasshopper Valley (Briar and others, in press) indicates that ground water generally flows from the basin margins toward the flood plain, then southeastward along Grasshopper Creek.

Basin-fill aquifers are recharged by precipitation and snowmelt, surplus irrigation water, subsurface inflow from surrounding bedrock, and infiltration from tributary streams and from Grasshopper Creek. The ground-water contribution area, which includes the surrounding mountains (fig. 2, pl. 1), is about $280 \mathrm{mi}^{2}$. Infiltration anywhere within this area could potentially recharge aquifers in the Grasshopper Valley. Ground water discharges from the basin-fill aquifers by evapotranspiration, seepage to springs, seeps, and stream channels, and a small quantity as withdrawals from wells. In addition, there may be some deep flow of ground water through Tertiary sediments between Grasshopper and Horse Prairie Valleys.

The quality of ground water in the basin was determined on the basis of 4 samples analyzed for major ions and measured dissolved-solids concentrations, and 9 samples in which dissolved-solids concentrations were estimated from specific-conductance measurements. Within the glacial-outwash deposits that cover the northern and central parts of the basin, ground water is a calcium bicarbonate type with dissolved-solids concentrations of less than $250 \mathrm{mg} / \mathrm{L}$. Tertiary sediments beneath the eastern part of the basin have a sodium bicarbonate type water with dissolved-solids concentrations as high as $500 \mathrm{mg} / \mathrm{L}$ (Clark and Dutton, in press).

\section{Selected References}

Briar, D.W., Lawlor, S.M., Stone, M.A.J., Parliman, D.J., Schaefer, J.L., and Kendy, Eloise, in press, Ground-water levels in intermontane basins of the Northern Rocky Mountains, Montana and Idaho: U.S. Geological Survey Hydrologic Investigations Atlas 738-B, 1 sheet, scale 1:750,000.

Clark, D.W., and Dutton, D.M., in press, Quality of ground water and surface water in intermontane basins of the Northern Rocky Mountains, Montana and Idaho: U.S. Geological Survey Hydrologic Investigations Atlas 738-C, 1 sheet, scale 1:750,000. 
Dutton, D.M., Lawlor, S.M., Briar, D.W., and Tresch, R.E., 1995, Hydrogeologic data for the Northern Rocky Mountains intermontane basins, Montana: U.S. Geological Survey Open-File Report 95-143, 94 p.

Knapton, J.R., and Horpestad, A.A., 1987, Arsenic data for streams in the upper Missouri River basin, Montana and Wyoming: U.S. Geological Survey Open-File Report 87-124, 25 p.

Lowell, W.R., 1965, Geologic map of the Bannack-Grayling area, Beaverhead County, Montana: U.S. Geological Survey Miscellaneous Geologic Investigations Map I-433, scale 1:31,680.

National Oceanic and Atmospheric Administration, issued annually, Climatological data annual summary, Montana: Asheville, N.C., National Climatic Data Center.

Ruppel, E.T., 1993, Cenozoic tectonic evolution of southwest Montana and east-central Idaho: Montana Bureau of Mines and Geology Memoir 65, 62 p.

Ruppel, E.T., O'Neill, J.M., and Lopez, D.A., 1993, Geologic map of the Dillon $1^{\circ} \times 2^{\circ}$ quadrangle, Idaho and Montana: U.S. Geological Survey Miscellaneous Investigations Series Map I-1803-H, scale 1:250,000.

Tuck, L.K., Briar, D.W., and Clark, D.W., in press, Geologic history and hydrogeologic units of intermontane basins of the Northern Rocky Mountains, Montana and Idaho: U.S. Geological Survey Hydrologic Investigations Atlas 738-A, 2 sheets, scale 1:750,000.

U.S. Environmental Protection Agency, 1991, Maximum contaminant levels (subpart B of part 141, National interim primary drinking-water regulations): U.S. Code of Federal Regulations, Title 40, Parts 100 to 149, revised July 1, 1991, p. 585-588.

U.S. Geological Survey, issued annually, Water resources data, Montana: Helena, Mont., U.S. Geological Survey Water-Data Report.

1961, Surface water records of Montana, 1961: Helena, Mont., 281 p. 


\section{Helena Valley}

\section{Geography}

The Helena Valley is a northwest-trending, $150-\mathrm{mi}^{2}$, oval-shaped basin located just east of the Continental Divide. In the western half of the Helena Valley, unconsolidated sediments of Quaternary age form a gently sloping alluvial plain. The alluvial plain is flanked by alluvial fans that descend from the Elkhorn Mountains to the south, the Scratchgravel Hills to the west, and the Big Belt Mountains to the north. The eastern half of the Helena Valley is a Tertiary pediment characterized by flat-topped benches and low, rolling hills that rise toward the east, merging with the Spokane Hills. Southwest of the Spokane Hills, a low topographic divide separates the Helena Valley from the Townsend Valley (pl. 1). The basin ranges in altitude from about $3,600 \mathrm{ft}$ at Lake Helena, to about $5,000 \mathrm{ft}$ on the highest pediment.

The climate of the Helena Valley is typical of mid-elevation intermontane basins of the Northern Rocky Mountains east of the Continental

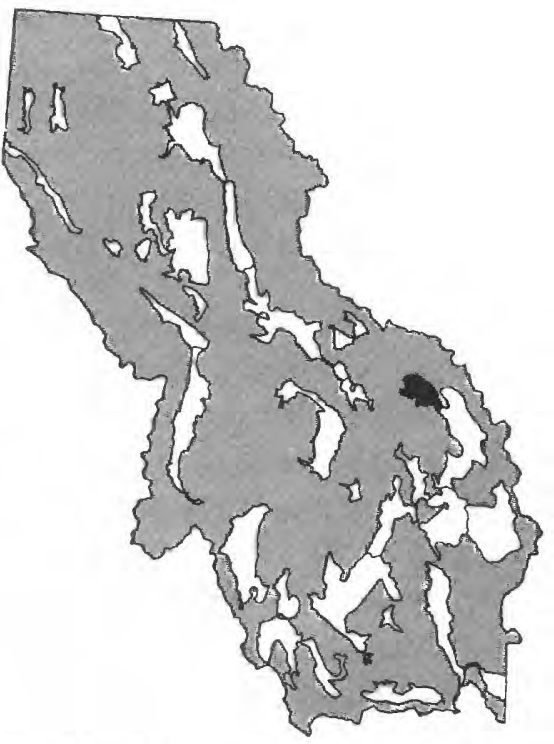
Divide, with cold winters, mild summers, and little precipitation. On the basis of the 1961-90 period of record, the average annual temperature at the Helena Regional Airport in the south-central part of the basin (altitude 3,830 ft) is $44.0^{\circ} \mathrm{F}$ and the average annual precipitation is $11.6 \mathrm{in}$. (National Oceanic and Atmospheric Administration, 1992). The average last occurrence of $32^{\circ} \mathrm{F}$ is May 18, and the average first occurrence is September 20 (Natural Resources Conservation Service, U.S. Department of Agriculture, unpub. data, 1994). Mean monthly climatic data for Helena are plotted in figure 14. Average annual precipitation at high altitudes in the drainage basin can exceed 30 in. (U.S. Soil Conservation Service, 1977).
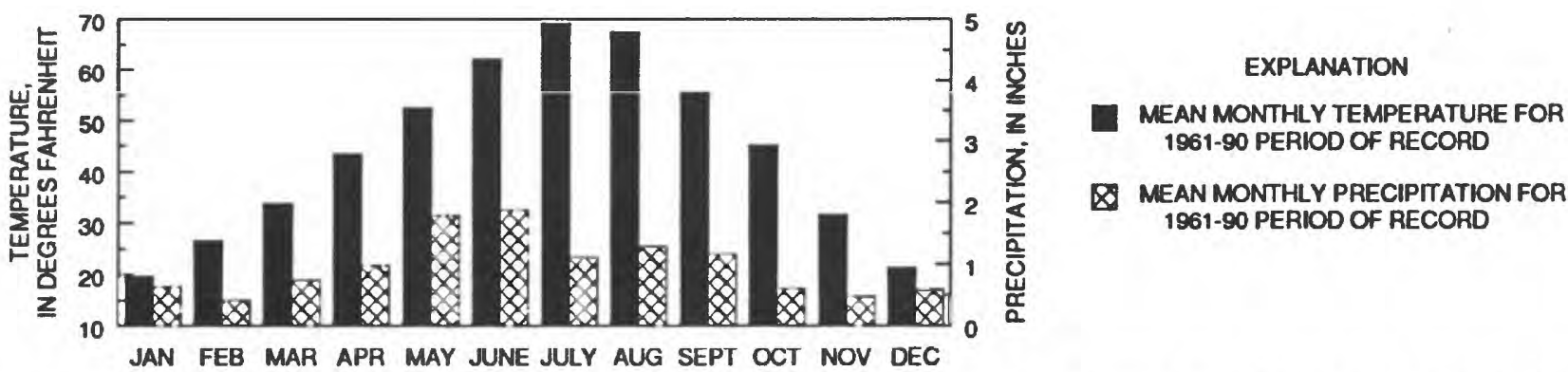

Figure 14. Mean monthly precipitation and temperature at the Helena Regional Airport, Mont. Data from National Oceanic and Atmospheric Administration (1992).

About 40,000 people reside in the Helena Valley, including 24,609 in the City of Helena and 1,538 in the Town of East Helena (1990 census). As the State capital, much of the local economy depends on State and Federal government.

Land uses in the Helena Valley include irrigated hay and pasture farming, livestock grazing, and residential development. Dryland small grains are grown on the east side of the basin (J.C. Eggen, Agricultural Stabilization and Conservation Service, oral commun., 1993). During the 1970's, as economic activity and State government expanded, the Helena Valley experienced rapid population growth which prompted the subdivision of agricultural land into one- to twenty-acre parcels. As a result, land use in the valley is distributed in an irregular patchwork of single-family dwellings, ranchettes, subdivisions, and trailer courts interspersed with small farms and hay fields. 
The Helena Valley Irrigation District manages the distribution of irrigation water diverted from the Missouri River at Canyon Ferry Dam. Water is pumped to the Helena Valley Regulating Reservoir (pl. 1), from which it flows into a canal that circles clockwise around the alluvial plain. After completing the circuit, any water that does not evaporate, infiltrate, or discharge to distributary canals flows into the northeast end of Lake Helena, and then into the Missouri River. Diversions from streams and withdrawals from wells also supply irrigation water. An estimated 17,600 acres are irrigated (Briar and Madison, 1992).

The mountains surrounding the Helena Valley have been mined since placer gold was discovered near Helena in 1864. Recently, gold and silver were extracted from a mine in the Tenmile Creek drainage and lead, silver, gold, and zinc are extracted from a mine in the Prickly Pear drainage. Both mines use(d) open-pit and cyanide heapleaching methods to extract ore. In addition, exploration is ongoing for three proposed placer gold mines northwest of Helena (McCulloch, 1993, p. 1, 7, 45). Along with mining came the construction and operation of numerous smelters. Of these, only a lead smelter in East Helena remains. The U.S. Environmental Protection Agency has designated the smelter a Priority Site under the Comprehensive Environmental Response Compensation and Liability Act of 1980 (CERCLA), and is currently overseeing efforts to remediate soil and ground-water contamination in East Helena.

\section{Geology}

The Helena Valley is a northwest-trending half-graben, controlled by strike-slip and extensional faulting. The intermontane basin is situated at the southeastern end of the Lewis and Clark Line (fig. 4), a northwest-trending zone of high-angle normal, reverse, and right-lateral strike-slip faults (Wallace and others, 1990). Basin-marginal faults, as well as several cross-cutting normal faults, are potentially active. On October 18, 1935, displacement on the southwestern fault resulted in a 6.25-magnitude earthquake which caused extensive damage to buildings in Helena (Schmidt, 1986). The Helena Valley intermontane basin is filled with about 5,500 (Davis and others, 1963) to 6,000 (Noble and others, 1982) $\mathrm{ft}$ of Cenozoic sediments at its deepest point, immediately north of Lake Helena.

Several investigators have examined the geology of the Helena Valley (table 31). The geologic units described by previous investigators are summarized below. These geologic units are referenced to hydrogeologic units defined in this study (table 2) to provide a consistent regional framework. In the following discussion, the hydrogeologic-unit abbreviations are italicized.

The Helena Valley is surrounded by folded and fractured sedimentary, metamorphic, and igneous bedrock. Metasedimentary rocks of the Middle Proterozoic Belt Supergroup ( $Y \mathrm{~ms}$ ) border the basin on the north and east, and intermittently on the south and west. Argillite and quartzite characterize most of the formations in the supergroup adjacent to the basin. However, dolomite and limestone border the basin on the southwest. Paleozoic sedimentary rocks $(P z l s)$ consisting chiefly of limestone, with some shale and quartzite, border the basin on the south of Helena. Cretaceous plutonic rocks (TKi), including syenodiorite (in the Scratchgravel Hills), diorite, granodiorite, and granite, intrude the older rocks. Upper Cretaceous andesites and tuffs (QTKe) border the basin on the southeast and Tertiary rhyolite (QTKe) crops out locally in basin fill southeast of Helena (Lorenz and Swenson, 1951; Knopf, 1963; Noble and others, 1982).

Tertiary sediments (Ts) crop out in the eastem half of the basin and on a bench southwest of East Helena and underlie surficial deposits in the western half of the basin. These sediments are moderately indurated, poorly sorted, tan to brown, micaceous, sandy siltstone, lacustrine ash, clay, and volcaniclastic units with laterally discontinuous sandy-pebble and cobble-gravel interbeds and lenses. These deposits, which are as much as $6,000 \mathrm{ft}$ thick, probably are equivalent to the Renova and Sixmile Creek Formations of the Bozeman Group. In the center of the basin, Tertiary sediments are generally coarse-grained and are difficult to distinguish from the overlying Quaternary alluvium (Briar and Madison, 1992). 
Table 31. Geologic and geophysical maps of the Helena Valley, Montana

\begin{tabular}{|c|c|c|c|c|}
\hline Type of map & Scale & Location & Map features & Reference \\
\hline Geology & $1: 131,000$ & $\begin{array}{l}\text { West of long } \\
111^{\circ} 51^{\prime} \mathrm{W} \text {. }\end{array}$ & $\begin{array}{l}\text { Differentiates three basin-fill units: Tertiary } \\
\text { sediments, Tertiary to Quatemary pediments, } \\
\text { and Quaternary alluvium }\end{array}$ & $\begin{array}{l}\text { Briar and Madison, } \\
1992, \text { fig. } 5, \text { p. } 12\end{array}$ \\
\hline Aeromagnetic & $1: 62,500$ & $\begin{array}{l}\text { East of long } \\
112^{\circ} \mathrm{W} \text {. }\end{array}$ & Contour intervals 20,100 and 500 gammas & $\begin{array}{l}\text { Davis and others, } 1963 \text {, } \\
\text { sheet } 2\end{array}$ \\
\hline Aeromagnetic & $1: 250,000$ & $\begin{array}{l}\text { South of Lake } \\
\text { Helena }\end{array}$ & Contour intervals 20 and 100 gammas & $\begin{array}{l}\text { Johnson and others, } \\
1965\end{array}$ \\
\hline Geology & $1: 48,000$ & $\begin{array}{l}\text { Southwestem } \\
\text { edge of Helena } \\
\text { Valley }\end{array}$ & $\begin{array}{l}\text { Differentiates three Quaternary basin-fill units: } \\
\text { morainal deposits, high-level gravel, and } \\
\text { alluvium }\end{array}$ & Knopf, 1963 \\
\hline $\begin{array}{l}\text { Depth to top of } \\
\text { fine-grained } \\
\text { material }\end{array}$ & $1: 48,000$ & $\begin{array}{l}\text { North and west of } \\
\text { East Helena }\end{array}$ & Contour interval $20 \mathrm{ft}$ & $\begin{array}{l}\text { Moreland and Leonard, } \\
1980, \mathrm{pl} .2\end{array}$ \\
\hline $\begin{array}{l}\text { Cenozoic basin- } \\
\text { fill thickness }\end{array}$ & $1: 500,000$ & $\begin{array}{l}\text { North and west of } \\
\text { East Helena }\end{array}$ & Contour interval $1,000 \mathrm{ft}$. & $\begin{array}{l}\text { Noble and others, } 1982 \text {, } \\
\text { fig. II-14, p. } 53\end{array}$ \\
\hline Bouguer gravity & $1: 316,800$ & $\begin{array}{l}\text { North and west of } \\
\text { East Helena }\end{array}$ & Contour interval 2 milligals & $\begin{array}{l}\text { Renick, } 1965 \text {, fig. } 2 \text {. } \\
\text { p. } 220\end{array}$ \\
\hline Geology & $1: 48,000$ & $\begin{array}{l}\text { West of long } \\
111^{\circ} 45^{\prime} \mathrm{W} \text {. }\end{array}$ & Differentiates eleven basin-fill units & $\begin{array}{l}\text { Schmidh, 1986, pls. } 1 \\
\text { and } 2\end{array}$ \\
\hline Geology & $1: 25,000$ & $\begin{array}{l}\text { City of Helena and } \\
\text { vicinity }\end{array}$ & $\begin{array}{l}\text { Differentiates seven basin-fill units. Locates } \\
\text { buildings damaged in } 1935 \text { earthquake }\end{array}$ & Schmidt, 1986, pl. 3 \\
\hline
\end{tabular}

Pleistocene lag deposits (QTd) as much as $15 \mathrm{ft}$ thick mantle Tertiary pediments and pre-Tertiary bedrock along the western basin margins. Typically, these deposits consist of subrounded to subangular, pebble-to-cobble gravel in a light brown, poorly sorted, unstratified sand and silt matrix (Stickney, 1987).

Quaternary alluvium (Qal) as much as $100 \mathrm{ft}$ thick overlies Tertiary sediments in the west half of the basin. The alluvium includes unconsolidated stream-channel, alluvial-plain, terrace, and fan deposits. Along the southern and western basin margins, the deposits are coarse-grained, moderately sorted, and well-rounded to subrounded cobbles, gravel, and sand with some silt and clay. Near Lake Helena, the material becomes better sorted and finer grained (Briar and Madison, 1992). Although silt and clay layers are abundant, down-hole gamma-ray geophysical logs indicate they are not laterally continuous (Moreland and Leonard, 1980).

\section{Hydrology}

Surface water enters the Helena Valley principally from Prickly Pear, Tenmile, and Silver Creeks (pl. 1) and from irrigation canals supplied from the Missouri River. All surface water in the Helena Valley flows toward Lake Helena, which is backwater from Hauser Dam on the Missouri River. Hauser Lake was impounded in 1907. In 
1945, a dam and control works separated Hauser Lake from Lake Helena in order to regulate the two reservoirs independently (Shields and others, 1994, p. 358-359).

Streamflow data for gaging stations listed in table 32 are stored in the USGS WATSTORE database. Locations of the stations are shown on plate 1. In addition, Briar and Madison (1992) estimated monthly and annual mean streamflow for the principal streams in the basin. Records of monthend contents, in acre-ft, for the Helena Valley Reservoir (gaging station 06058600), Lake Helena (gaging station 06064500 , drainage area $610 \mathrm{mi}^{2}$ ), and Hauser Lake (gaging station 06065000 , drainage area $16,876 \mathrm{mi}^{2}$ ) are reported in annual USGS Water-Data Reports (U.S. Geological Survey, issued annually).

Table 32. Summary of data for U.S. Geological Survey streamflow-gaging stations in the Helena Valley, Montana

\begin{tabular}{|c|c|c|c|c|c|c|c|c|c|}
\hline \multirow[b]{2}{*}{$\begin{array}{l}\text { Station } \\
\text { number }\end{array}$} & \multirow[b]{2}{*}{ Station name } & \multirow{2}{*}{$\begin{array}{l}\text { Drainage } \\
\text { area } \\
\text { (equare } \\
\text { milles) }\end{array}$} & \multirow{2}{*}{$\begin{array}{l}\text { Type } \\
\text { of data } \\
\text { col- } \\
\text { lected }\end{array}$} & \multirow{2}{*}{$\begin{array}{l}\text { Period of record } \\
\text { (calendar year) }\end{array}$} & \multicolumn{5}{|c|}{ Diecharge for perlod of record } \\
\hline & & & & & $\begin{array}{l}\text { Mean } \\
\text { annual } \\
\left(\mathrm{ft}^{3} / \mathrm{s}\right)\end{array}$ & $\begin{array}{l}\text { Maxi- } \\
\text { mum } \\
\left(\mathrm{ft}^{3} / \mathrm{s}\right)\end{array}$ & $\begin{array}{l}\text { Dete of } \\
\text { maxl- } \\
\text { mum }\end{array}$ & $\begin{array}{l}\text { Mini- } \\
\text { mum } \\
\left(\mathrm{ft}^{3} / \mathrm{s}\right)\end{array}$ & $\begin{array}{l}\text { Date of } \\
\text { mini- } \\
\text { mum }\end{array}$ \\
\hline 06061900 & $\begin{array}{l}\text { McClellan Creek near } \\
\text { East Helena }\end{array}$ & 33.2 & $\begin{array}{l}\mathrm{g} \\
\mathrm{d}\end{array}$ & $\begin{array}{l}1960-75 \\
1989-90 \text {, Apr.- } \\
\text { Sept. }\end{array}$ & -- & 390 & $06-08-64$ & 2.8 & $08-25-61$ \\
\hline 06062000 & $\begin{array}{l}\text { Prickly Pear Creek at } \\
\text { East Helena }\end{array}$ & 251 & c,d & $1908-13$ & 67.5 & 535 & $06-19-09$ & - & -- \\
\hline 06062500 & $\begin{array}{l}\text { Tenmile Creek near } \\
\text { Rimini }\end{array}$ & 32.7 & d & 1914- & 17.3 & 3,290 & $05-22-81$ & 0 & $08-31-31$ \\
\hline 06063000 & $\begin{array}{l}\text { Tenmile Creek near } \\
\text { Helena }\end{array}$ & 102 & $\begin{array}{l}\text { d } \\
\text { c }\end{array}$ & $\begin{array}{l}1908-54 \\
1948,1950-51\end{array}$ & 27.2 & 995 & $05-28-17$ & 0 & At times \\
\hline 06063500 & $\begin{array}{l}\text { Sevenmile Creek at } \\
\text { Birdseye }\end{array}$ & 31.9 & d & $1908-13$ & 7.60 & 76 & $06-09-09$ & .1 & $07-30-10$ \\
\hline 06065500 & $\begin{array}{l}\text { Missouri River } \\
\text { below Hauser } \\
\text { Dam, near Helena }\end{array}$ & 16,876 & d & $1922-42$ & 4,115 & 33,300 & $06-15-27$ & 280 & 03-03-38 \\
\hline
\end{tabular}

Surface water in the Helena Valley is generally a calcium bicarbonate type with relatively low concentrations of dissolved solids. Analyses of eleven samples from McClellan Creek near East Helena (gaging station 06061900), eleven samples from Prickly Pear Creek at East Helena (gaging station 06062000), and one sample from Tenmile Creek near Helena (gaging station 06063000 ) indicate calcium bicarbonate type water with average dissolved-solids concentrations of 77,50 , and $188 \mathrm{mg} / \mathrm{L}$, respectively. McClellan Creek, which drains the Elkhom Mountains south of East Helena, generally has a larger proportion of sulfate than Tenmile and Prickly Pear Creeks (Clark and Dutton, in press). Below East Helena, Prickly Pear Creek is affected by elevated concentrations of nutrients, suspended solids, and metals, thermal modifications, flow alteration, siltation, flow and other habitat alterations, and un-ionized ammonia. Probable causes include municipal-waste discharges, urban runoff, irrigated crop production, livestock grazing, pasture farming, subsurface mining, dredge mining, channelization, road construction, and domestic wastewater lagoon discharges (Montana Department of Health and Environmental Sciences, 1994).

Elevated levels of arsenic have been found in the Missouri River, which is used to irrigate crops in the Helena Valley. The source of arsenic in the Missouri River is the tributary Madison River that receives inflow of arsenicenriched geothermal water from Yellowstone National Park. From 1985 to 1987, the concentration of total recoverable arsenic in the Missouri River below Canyon Ferry Dam, near Helena (gaging station 06058502) ranged from 22 to $34 \mu \mathrm{g} / \mathrm{L}$ (Knapton and Brosten, 1987; Knapton and Horpestad, 1987). The U.S. Environmental Protection Agency (1991) has established a maximum contaminant level of $50 \mu \mathrm{g} / \mathrm{L}$ arsenic for treated drinking water. 
Ground water is an important resource in the Helena Valley. It is the sole source of domestic-water supply for about 13,000 residents and supplies water for irrigation and livestock (Briar and Madison, 1992).

Two ground-water regimes are present in the Helena Valley intermontane basin. In the west half of the basin, Quaternary alluvium and the upper few hundred feet of Tertiary sediments comprise a dependable alluvial aquifer. In the east half, poorly permeable Tertiary sediments comprise the only available aquifer. Bedrock aquifers surround the basin and are hydraulically connected to adjacent basin fill.

The upper few hundred feet of sediment in the west half of the basin is complexly stratified, such that the lateral discontinuity of the many fine-grained layers allows hydraulic interconnection between coarse-grained water-yielding zones. Therefore, Quaternary and shallow Tertiary deposits together function as a single alluvial aquifer (Briar and Madison, 1992). Specific-capacity values for 12 wells in this aquifer range from 0.2 to 33 ( $\mathrm{gal} / \mathrm{min}) / \mathrm{ft}$ with a median value of 1.6 ( $\mathrm{gal} / \mathrm{min}) / \mathrm{ft}$ (Dutton and others, 1995). Results of five aquifer tests indicate that the transmissivity of the water-yielding zones is on the order of $10,000 \mathrm{ft}^{2} / \mathrm{d}$ (Moreland and Leonard, 1980). However, the overall transmissivity of the alluvial aquifer is lower, reflecting the presence of numerous fine-grained layers. The vertical hydraulic conductivity is probably 1-3 orders of magnitude less than that in the horizontal direction (Briar and Madison, 1992).

Minimum depths to ground water in the alluvial aquifer are generally less than $10 \mathrm{ft}$ from land surface within 3 to $4 \mathrm{mi}$ south and west of Lake Helena, and increase away from the lake. Depths to water typically fluctuate 2 to $15 \mathrm{ft}$ annually (Moreland and Leonard, 1980). Water levels generally are lowest in early spring, rise during the irrigation season, and then recede throughout the fall and winter. Near the land surface, ground water may be unconfined. At depth, fine-grained layers locally confine or semi-confine water-yielding zones (Moreland and Leonard, 1980; Briar and Madison, 1992).

Little is known about the hydraulic characteristics of basin fill below a depth of a few hundred feet because the abundance of water in the shallow parts of the aquifer has generally made deeper drilling unnecessary. However, a 478-ft well recently was drilled near East Helena. The well is screened in selected intervals of a 103-ft, semiconsolidated to well-consolidated arkosic sandstone. This permeable sandstone is confined beneath $110 \mathrm{ft}$ of tight brown clay which underlies $265 \mathrm{ft}$ of poorly sorted sandy, silty alluvium. After the well was pumped at a rate of $700 \mathrm{gal} / \mathrm{min}$ for 24.5 hours, the water level dropped from a static level of $55 \mathrm{ft}$ to $231 \mathrm{ft}$ below land surface. Transmissivity and hydraulic conductivity values of $600 \mathrm{ft}^{2} / \mathrm{d}$ and $12 \mathrm{ft} / \mathrm{d}$, respectively, were calculated from data collected during this test (David Donahue, PRC-Environmental Management, Inc., oral commun., 1994). Other deep (greater than $300 \mathrm{ft}$ ) wells drilled into Tertiary sediments beneath the alluvial plain have had a wide range of yields, depending upon whether permeable layers were penetrated. At least two deep wells produce flowing water, but several others were dry (Lorenz and Swenson, 1951).

Tertiary sediments beneath the pediment in the eastern half of the basin may yield supplies of water sufficient for domestic and limited livestock needs (Lorenz and Swenson, 1951). Little is known about these sediments, but additional wells to accommodate ongoing residential expansion eastward from Helena are being drilled with increasing frequency.

Most wells completed in bedrock aquifers that surround the Helena Valley produce enough water for domestic use; however, well yields are variable. Some wells drilled into bedrock produce little to no water and some wells that penetrate fracture zones yield more than $100 \mathrm{gal} / \mathrm{min}$ (J.N. Thamke, U.S. Geological Survey. oral commun., 1994). A recent increase in residential development in the mountains near Helena has prompted concern about the quantity and quality of ground water.

Potentiometric-surface maps of the west half of the Helena Valley (table 33) depict ground-water flow from the southern, western, and northern margins of the basin toward Lake Helena. Tertiary sediments on the east side of the basin are relatively impermeable, as evidenced by potentiometric-surface lines that are nearly perpendicular to the boundary between the alluvium and the Tertiary sediments. Hydraulic gradients are steepest along the southern and western basin margins, and flattest south and west of Lake Helena. Seasonal fluctuations in water levels do not alter the general flow pattern. 
Table 33. Potentiometric-surface maps of the Helena Valley, Montana

\begin{tabular}{lcccc}
\hline Location & $\begin{array}{c}\text { Dates water lovels } \\
\text { were measured }\end{array}$ & Scale & $\begin{array}{c}\text { Contour } \\
\text { interval in } \\
\text { foet }\end{array}$ & Reference \\
\hline $\begin{array}{l}\text { North and west of East Helena } \\
\text { North and west of East Helena }\end{array}$ & $\begin{array}{c}\text { March to April 1991 } \\
\text { April and August } \\
1948\end{array}$ & $1: 48,000$ & 20 & $\begin{array}{c}\text { Briar and Madison, 1992, pl. 1 } \\
\text { Lorenz and Swenson, 1951, pl. 3 }\end{array}$ \\
North and west of East Helena & $1976-79$ & $1: 48,000$ & 5 & $\begin{array}{c}\text { Moreland and Leonard, 1980, pl. 1 (depth } \\
\text { to water table) } \\
\text { Wilke and Coffin, 1973, fig. 3 } \\
\text { Wilke and Johnson, 1978 (depth to water } \\
\text { table) }\end{array}$ \\
\hline
\end{tabular}

Vertical hydraulic gradients delineate two zones of vertical ground-water flow in the Quatemary and Tertiary aquifer. Within about 4 mi of Lake Helena, ground-water flows upward; in the southern and western parts of the aquifer, it flows downward (Briar and Madison, 1992).

Sources of recharge to basin-fill aquifers include precipitation, leakage from canals, surplus irrigation water, subsurface flow from surrounding bedrock, and infiltration of streamflow. The ground-water contribution area (fig. 2, pl. 1), is about $610 \mathrm{mi}^{2}$. Infiltration anywhere within this area potentially could recharge basin-fill aquifers. Although previous investigators (Wilke and Coffin, 1973; Lorenz and Swenson, 1951) have attributed most of the recharge to surplus irrigation water, Briar and Madison (1992) found that subsurface flow from bedrock may account for as much as $\mathbf{4 5}$ percent of the recharge to the alluvial aquifer. Together, surplus irrigation water and leakage from canals contribute an additional 39 percent of the recharge. Infiltration of streamflow provides about 15 percent, and the contribution from precipitation is negligible (Briar and Madison, 1992).

Ground water discharges from the basin-fill aquifer to wells, streams, irrigation drains, and Lake Helena. Of these components, Lake Helena receives about 57 percent and streams and drains receive about $\mathbf{4 1}$ percent of the discharge. [In this calculation, evapotranspiration was accounted for in the recharge components of the water budget (Briar and Madison, 1992)].

Water-level data for the wells listed in table 34 are stored in the USGS WATSTORE database. Water levels were measured in these wells at least once annually during the period of record. Many of the record-high water levels correspond with a record flood that inundated the Helena Valley in 1981.

From about 1900 to 1950 , more than 8,000 acres of formerly productive land became waterlogged in the topographically low parts of the Helena Valley. The water-table rise was caused by seepage from irrigation canals and infiltration from flood-irrigated fields (Lorenz and Swenson, 1951). Several irrigation drains were installed beginning in 1958, in part to accommodate irrigation water imported from the Missouri River. When the drainage system was completed in the 1960 's, the water table once again dropped below the land surface in the affected areas.

With few exceptions, ground water in the Helena Valley is of suitable quality for most uses and is a hard, calcium bicarbonate type (Wilke and Coffin, 1973). Dissolved-solids concentrations in more than 200 wells sampled from 1971 to 1990 ranged from 85 to $1,250 \mathrm{mg} / \mathrm{L}$, and had a median value of $286 \mathrm{mg} / \mathrm{L}$. Major-ion concentrations in ground water are smallest near losing reaches of streams and along the western and southern basin margins. Concentrations increase somewhat downgradient as ground water dissolves aquifer material (Briar and Madison, 1992).

Because it is shallow, unconfined, and relatively permeable, the Helena valley-fill aquifer system is susceptible to contamination from surface and near-surface sources. Documented sources of local contamination 
Table 34. Summary of water-level data for selected wells in the Helena Valley, Montana

[Hydrogeologic unit: Qal, Holocene and Pleistocene alluvial deposits; Ts, Tertiary sedimentary deposits and rocks; TKi, Tentiary through Cretaceous intrusive rocks. Symbol: -, no data. Periods of record for observation wells that were being operated as of February 1995 are indicated by the first year of record followed by a dash only]

\begin{tabular}{|c|c|c|c|c|c|c|c|}
\hline \multirow[b]{2}{*}{ Location number } & \multirow{2}{*}{$\begin{array}{c}\text { Depth of } \\
\text { well, in feet } \\
\text { below land } \\
\text { surface }\end{array}$} & \multirow{2}{*}{$\begin{array}{l}\text { Hydro- } \\
\text { geologic } \\
\text { unlt }\end{array}$} & \multirow{2}{*}{$\begin{array}{l}\text { Perlod of } \\
\text { record }\end{array}$} & \multicolumn{4}{|c|}{ Water level, in feet below or above $(t)$ land surface } \\
\hline & & & & Highest & $\begin{array}{l}\text { Date of } \\
\text { highest }\end{array}$ & Lowest & $\begin{array}{l}\text { Date of } \\
\text { lowest }\end{array}$ \\
\hline 11N03W22BBCB01 & 195 & Qal & 1979-91 & +54.57 & $10-11-84$ & +39.98 & 08-21-91 \\
\hline 11N03W30BBBC01 & 127 & Qal & $1979-90$ & 30.41 & 09-30-87 & 48.49 & $12-20-88$ \\
\hline 11N03W30DADA01 & 44.0 & Qal & 1978-93 & +1.17 & $08-28-79$ & 6.23 & $05-10-90$ \\
\hline 10N04W02CBAA01 & 110 & TKi & 1976- & 12.18 & $06-21-81$ & 39.40 & $03-02-93$ \\
\hline 10N04W10DDDA01 & 22.8 & Qal & 1978-93 & 1.86 & 07-05-90 & 8.55 & $12-20-88$ \\
\hline 10N03W03BACB01 & 64.8 & Qal & 1978- & .01 & 06-02-81 & 4.08 & 04-08-92 \\
\hline 10N03W05CCDD01 & 23 & Qal & 1978- & 1.98 & $06-02-81$ & 12.74 & 08-17-92 \\
\hline 10N03W09ACCC01 & 64.5 & Qal & 1978- & .69 & $07-10-79$ & 3.53 & $11-08-90$ \\
\hline 10N03W11DDCC01 & 39.6 & Qal & $1978-$ & 8.31 & $06-02-81$ & 27.17 & $04-13-91$ \\
\hline 10N03W15DDCA01 & 326 & Qal & $1990-92$ & 5.62 & 09-01-90 & 12.75 & $05-12-92$ \\
\hline 10N03W15DDDD02 & -- & Qal & $1981-83$ & 6.13 & $11-05-81$ & 8.85 & $05-25-82$ \\
\hline 10N03W17ACAD01 & 28.2 & Qal & $1978-$ & 14.10 & $12-06-78$ & 23.14 & $04-11-79$ \\
\hline 10N03W22AAAA01 & 23.3 & Qal & 1978- & 5.57 & $06-02-81$ & 17.87 & $05-17-91$ \\
\hline 10N02W18DDCD01 & 70.0 & Ts & 1981- & 44.93 & $08-20-90$ & 59.52 & $04-08-92$ \\
\hline
\end{tabular}

include three landfills, spilled and leaked fuel, sewage lagoons, industrial spills and leaks, and septic systems (V.M. Drake, Supervisor, Lewis and Clark County Water Quality Protection District, oral commun., 1995). Some areas with large densities of private septic systems correlate with large concentrations of nitrate in ground water (Wilke and Coffin, 1973; Briar and Madison, 1992). However, no evidence exists for long-term regional changes in ground-water quality (Moreland and Leonard, 1980; Briar and Madison, 1992).

Use of Missouri River water to irrigate crops in the basin has raised concerns that the irrigation water may have locally contaminated basin-fill aquifers with arsenic. However, recent analyses indicate arsenic concentrations of less than $5 \mu \mathrm{g} / \mathrm{L}$ in nine wells that are completed beneath irrigated fields within about 3 mi of Lake Helena (L.K. Tuck, U.S. Geological Survey, written commun., 1995).

\section{Selected References}

Briar, D.W., and Madison, J.P., 1992, Hydrogeology of the Helena valley-fill aquifer system, west-central Montana: U.S. Geological Survey Water-Resources Investigations Report 92-4023, 92 p.

Briar, D.W., Lawlor, S.M., Stone, M.A.J., Parliman, D.J., Schaefer, J.L., and Kendy, Eloise, in press, Ground-water levels in intermontane basins of the Northern Rocky Mountains, Montana and Idaho: U.S. Geological Survey Hydrologic Investigations Atlas, 738-B, 1 sheet, scale 1:750,000.

Clark, D.W., and Dutton, D.M., in press, Quality of ground water and surface water in intermontane basins of the Northern Rocky Mountains, Montana and Idaho: U.S. Geological Survey Hydrologic Investigations Atlas 738-C, 1 sheet, scale 1:750,000.

Davis, W.E., Kinoshita, W.T., and Smedes, H.W., 1963, Bouguer gravity, aeromagnetic and generalized geologic map of East Helena and Canyon Ferry quadrangles and part of the Diamond City quadrangle, Lewis and Clark, Broadwater and Jefferson Counties, Montana: U.S. Geological Survey Investigation Map GP-444, 3 sheets, scale 1:250,000.

Duton, D.M., Lawlor, S.M., Briar, D.W., and Tresch, R.E., 1995, Hydrogeologic data for the Northern Rocky Mountains intermontane basins, Montana: U.S. Geological Survey Open-File Report 95-143, 94 p.

Freidline, R.A., Smith, R.B., and Blackwell, D.D., 1976, Seismicity and contemporary tectonics of the Helena, Montana area: Bulletin of the Seismological Society of America, v. 66, no. 1, p. 81-95.

Johnson, R.W., Jr., Henderson, J.R., and Tyson, N.S., 1965, Aeromagnetic map of the Boulder batholith area, southwestern Montana: U.S. Geological Survey Geophysical Investigations Map GP-538, scale 1:250,000. 
Knapton, J.R., and Brosten, T.M., 1987, Supplemental arsenic data for selected streams in the Missouri River basin, Montana, 1987: U.S. Geological Survey Open-File Report 87-697, 14 p.

Knapton, J.R., and Horpestad, A.A., 1987, Arsenic data for streams in the upper Missouri River basin, Montana and Wyoming: U.S. Geological Survey Open-File Report 87-124, 25 p.

Knopf, Adolph, 1913, Ore deposits of the Helena mining region, Montana: U.S. Geological Survey Bulletin 527, 143 p. 1963, Geology of the northern part of the Boulder Bathylith and adjacent area, Montana: U.S. Geological Survey Miscellaneous Geologic Investigations Map 1-381, scale 1:48,000.

Lorenz, H.W., and Swenson, F.A., 1951, Geology and ground-water resources of the Helena Valley, Montana, with a section on Chemical quality of the water, by H.A. Swenson: U.S. Geological Survey Circular 83, 68 p.

McCulloch, Robin, 1993, Montana mining directory 1992: Montana Bureau of Mines and Geology Bulletin 131, 76 p.

Montana Department of Health and Environmental Sciences, 1994, Montana water quality, 1994: Helena, Water Quality Bureau, Montana 305(b) Report, 159 p.

[Montana] State Engineer's Office, 1957a, Water resources survey, Lewis and Clark County, Montana--Part 1, History of land and water use on irrigated areas: Helena, Mont., State Engineer's Office, 59 p.

1957b, Water resources survey, Lewis and Clark County, Montana--Part 2, Maps showing irrigated areas: Helena, Mont. State Engineer's Office, 43 p.

Moreland, J.A., and Leonard, R.B., 1980, Evaluation of shallow aquifers in the Helena Valley, Lewis and Clark County, Montana: U.S. Geological Survey Water-Resources Investigations Open-File Report 80-1102, 24 p.

Moreland, J.A., Leonard, R.B., Reed, T.E., Clausen, R.O., and Wood, W.A., 1979, Hydrologic data from selected wells in the Helena Valley, Lewis and Clark County, Montana: U.S. Geological Survey Open-File Report 79-1676, 54 p.

National Oceanic and Atmospheric Administration, 1992, Monthly normals of temperature, precipitation, and heating and cooling degree days, 1961-90, Montana: Asheville, N.C., Climatography of the United States no. 81, unpaged.

Noble, R.A., Bergantino, R.N., Patton, T.W., Sholes, B.C., Daniel, Faith, and Schofield, Judeykay, 1982, Occurrence and characteristics of ground water of Montana--Volume 2, The Rocky Mountain Region: Montana Bureau of Mines and Geology Open-File Report 99, 132 p.

Renick, Howard, Jr., 1965, A gravity survey of the Boulder batholith and the Prickly Pear Valley near Helena, Montana: The Compass of Sigma Gamma Epsilon, v. 42, no. 4, p. 217-224.

Schmidt, R.G., 1986, Geology, earthquake hazards and land use in the Helena area, Montana--A review: U.S. Geological Survey Professional Paper 1316, 64 p.

Schmidt, R.G., Loen, J.S., Wallace, C.A., and Mehnert, H.M., 1994, Geology of the Elliston region, Powell and Lewis and Clark Counties, Montana: U.S. Geological Survey Bulletin 2045, 25 p.

Shields, R.R., White, M.K., Brosten, T.M., and Chambers, C.L., 1994, Water resources data, Montana, water year 1993: U.S. Geological Survey Water-Data Report MT-93-1, 512 p.

Stickney, M.C., 1987, Quaternary geologic map of the Helena Valley, Montana: Montana Bureau of Mines and Geology Geologic Map 46, scale 1:50,000.

Tuck, L.K., Briar, D.W., and Clark, D.W., in press, Geologic history and hydrogeologic units of the intermontane basins of the Northern Rocky Mountains, Montana and Idaho: U.S. Geological Survey Hydrologic Investigations Atlas 738-A, 2 sheets, scale 1:750,000.

U.S. Environmental Protection Agency, 1991, Maximum contaminant levels (subpart B of part 141, National primary drinkingwater regulations): U.S. Code of Federal Regulations, Title 40, parts 100 to 149, revised July 1, 1991, p. 585-588.

U.S. Geological Survey, issued annually, Water resources data, Montana: Helena, Mont., U.S. Geological Survey Water-Data Report.

U.S. Soil Conservation Service, 1977, Average annual precipitation in Montana, based on 1941-70 data: Bozeman, Mont., 13 p.

Wallace, C.A., Lidke, D.J., and Schmidt, R.G., 1990, Faults of the central part of the Lewis and Clark Line and fragmentation of the Late Cretaceous foreland basin in west-central Montana: Geological Society of America Bulletin, v. 102, p. 10211037.

Wilke, K.R., and Coffin, D.L, 1973, Appraisal of the quality of ground water in the Helena Valley, Montana: U.S. Geological Survey Water-Resources Investigations Report 32-73, 31 p.

Wilke, K.R., and Johnson, M.V., 1978, Maps showing depth to water table, September 1976, and areas inundated by the June 1975 flood, Helena Valley, Lewis and Clark County, Montana: U.S. Geological Survey Open-File Report 78-110, 2 sheets, scale 1:48,000. 


\section{Horse Prairle Valley}

\section{Geography}

The Horse Prairie Valley as defined in this study is a $290-\mathrm{mi}^{2}$, intermontane basin in southwestem Montana. In map view, the basin is horseshoeshaped, with the curve of the horseshoe facing north. The Maiden Peak Spur, a north-trending mountainous ridge, separates the two limbs of the horseshoe. The basin is bounded by the Tendoy Mountains on the east and the Bitterroot Range on the west (pl. 1). The northern basin boundary is the drainage divide between Grasshopper Creek and Horse Prairie Creek and the southern boundary is the drainage divide between Sheep Creek and Horse Prairie Creek. Horse Prairie Creek flows northward along the west limb of the horseshoe, bends to the east, and joins Medicine Lodge Creek, which flows northward along the east limb. In the north-trending limbs, flood plains of Horse Prairie and Medicine Lodge Creeks are about $0.5 \mathrm{mi}$ wide, and are flanked by pediments which gently slope from near the mountaintops toward

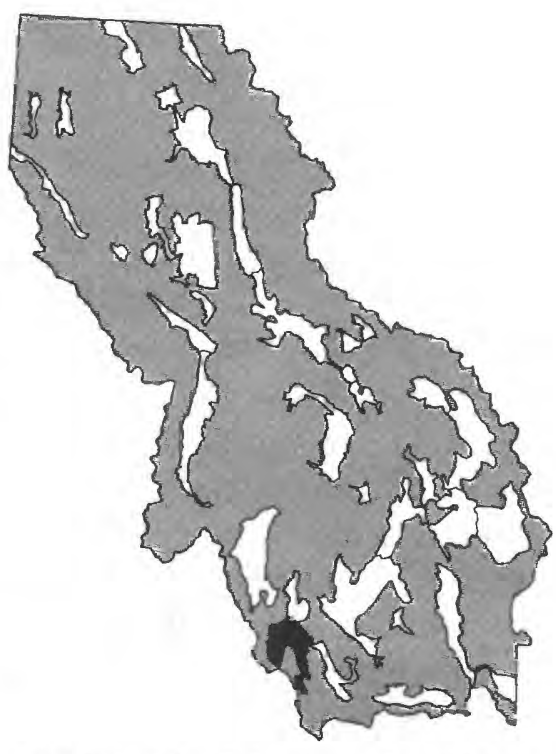
the flood plains. In contrast, the flood plain of the eastward-flowing reach of Horse Prairie Creek is more than $4 \mathrm{mi}$ wide. Mountains rise abruptly from the south side of the east-trending flood plain, whereas the undulating pediment north of the flood plain continues northward into the Grasshopper Valley. The Horse Prairie Valley ranges in altitude from about 5,600 ft where Horse Prairie Creek flows out of the northeast comer of the basin, to about $8,000 \mathrm{ft}$ on the highest pediment.

The climate of the Horse Prairie Valley is typical of higher-elevation intermontane basins in southwest Montana, with very cold, dry winters and mild summers. On the basis of the 1961-90 period of record, the average annual precipitation $4 \mathrm{mi}$ northeast of Grant (altitude 5,840 ft) is $9.59 \mathrm{in}$. (National Oceanic and Atmospheric Administration, 1992). Mean monthly precipitation data for the Grant 4NE station are plotted in figure 15 . The National Weather Service does not measure temperature in the Horse Prairie Valley. The nearest temperaturerecording climate stations are in Dillon (fig. 6) and Jackson (fig. 7).

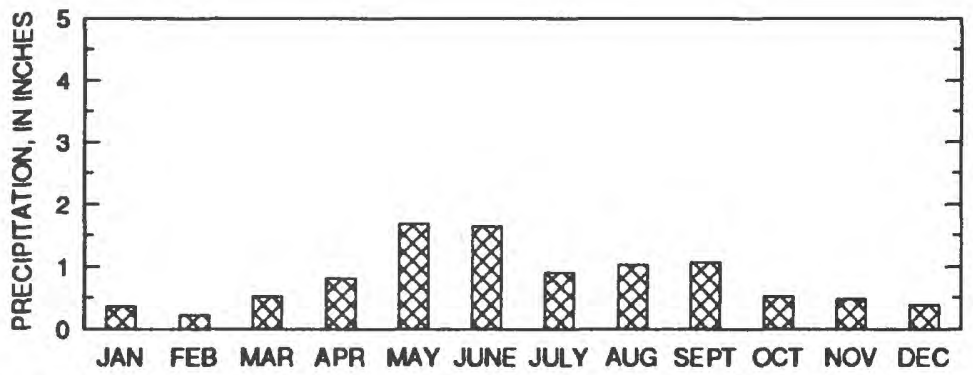

EXPLANATION

MEAN MONTHLY PRECIPITATION FOR 1961-90 PERIOD OF RECORD

Figure 15. Mean monthly precipitation 4 miles northeast of Grant, Mont. Data from National Oceanic and Atmospheric Administration (1992).

Land uses include flood-irrigated hay and pasture farming on some flood plains, and livestock grazing throughout the basin (J.C. Eggen, Agricultural Stabilization and Conservation Service, oral commun., 1993). Numerous surface-water diversions provide water for flood irrigation. Ground water is used for stock and domestic supplies. Small coal mines operated intermittently in the Medicine Lodge Creek area from 1919 to 1950 (M'Gonigle, 1993). About 100 people reside in the Horse Prairie Valley (1990 census), with most residents sparsely populating the flood-plain areas. The southeastern part of the basin is uninhabited. 


\section{Geology}

The Horse Prairie Valley formed by Tertiary extension along normal faults (M'Gonigle and others, 1991). Most offset relative to the Bitterroot Range occurred after the Oligocene epoch. Prior to Miocene time, the ancestral Horse Prairie Valley was more or less continuous with the Lemhi Valley, Idaho, to the west (Thompson and others, 1981). Continued seismic activity is evidenced by north-striking faults that disrupt stream courses, truncate the heads of young alluvial fans, and are associated with recent landslides in the southern part of the Horse Prairie Valley (Ruppel, 1993). The eastward flowing reach of Horse Prairie Creek parallels a fault zone along which the northern part of the basin has been offset about $3 \mathrm{mi}$ from the southern part (Ruppel, 1993). Tertiary basin fill in the Medicine Lodge Creek area dips to the northeast (M'Gonigle and others, 1991; M'Gonigle, 1993).

The maximum depth of the Horse Prairie Valley is uncertain. M'Gonigle and others (1991) estimated the basin contains as much as 17,000 ft of Eocene to Miocene volcanic and sedimentary rocks. The only drillhole known to have penetrated pre-Tertiary bedrock did so at a depth of $6,395 \mathrm{ft}$ below land surface. This 1979 oil exploration drillhole was located at 10S12W27DD, about $2 \mathrm{mi}$ west of Medicine Lodge Creek (Montana Board of Oil and Gas Conservation, unpub. data, 1990). Gravity data indicate that about $6,000 \mathrm{ft}$ of basin fill underlie the northward-flowing reach of Horse Prairie Creek (Ruppel, 1993).

The geology of the Horse Prairie Valley has never been mapped in detail (Ruppel, 1993). At a scale of 1:500,000, Ross and others (1955) compiled the only geologic map that covers the entire basin. More detailed maps of selected parts of the basin are listed in table 35. The geologic units described by previous investigators are summarized below. These geologic units are referenced to hydrogeologic units defined in this study (table 2) to provide a consistent regional framework. In the following discussion, the hydrogeologic-unit abbreviations are italicized.

Table 35. Geologic maps of the Horse Prairie Valley, Montana

\begin{tabular}{|c|c|c|c|c|}
\hline $\begin{array}{l}\text { Type of } \\
\text { map }\end{array}$ & Scale & Location & Map features & Reference \\
\hline Geology & $1: 31,680$ & $\begin{array}{l}\text { Northeastem part of Horse Prairie } \\
\text { Valley }\end{array}$ & $\begin{array}{l}\text { Emphasizes bedrock geology northeast } \\
\text { of Horse Prairie Valley. Includes a } \\
\text { geologic section }\end{array}$ & Lowell, 1965 \\
\hline Geology & $1: 24,000$ & $\begin{array}{l}\text { Medicine Lodge Peak quadrangle } \\
\text { (lat } 44^{\circ} 45^{\circ} \mathrm{N} \text {. to } 44^{\circ} 52^{\prime} 30^{\prime \prime} \mathrm{N} \text {., } \\
\text { long } 113^{\circ} \mathrm{W} \text {. to } 113^{\circ} 07^{\prime} 30^{\prime \prime} \mathrm{W} \text {.) }\end{array}$ & $\begin{array}{l}\text { Differentiates } 8 \text { Tertiary and } 8 \\
\text { Quatemary sedimentary basin-fill } \\
\text { units. Includes an east-west geologic } \\
\text { section from Maiden Peak Spur to } \\
\text { Medicine Lodge Creek }\end{array}$ & M'Gonigle, 1993 \\
\hline Geology & $1: 24,000$ & $\begin{array}{l}\text { Hansen Ranch quadrangle (lat } \\
44^{\circ} 52^{\circ} 30^{\circ} \mathrm{N} \text {. to } 45^{\circ} \mathrm{N} \text {., long } \\
113^{\circ} \mathrm{W} \text {, to } 113^{\circ} 07^{\circ} 30^{\circ} \mathrm{W} \text {.) }\end{array}$ & $\begin{array}{l}\text { Differentiates } 9 \text { Tertiary and } 8 \\
\text { Quatemary basin-fill units }\end{array}$ & M'Gonigle and others, 1991 \\
\hline Geology & $1: 500,000$ & Entire Horse Prairie Valley & $\begin{array}{l}\text { Differentiates two basin-fill units: } \\
\text { Tertiary sediments and Quaternary } \\
\text { alluvium }\end{array}$ & Ross and others, 1955 \\
\hline Geology & $1: 250,000$ & North of lat $45^{\circ} \mathrm{N}$. & $\begin{array}{l}\text { Differentiates three basin-fill units: } \\
\text { Tertiary valley-fill deposits, } \\
\text { Quaternary alluvial-fan deposits, and } \\
\text { Quaternary alluvium }\end{array}$ & Ruppel and others, 1993 \\
\hline Geology & $1: 126,720$ & Medicine Lodge Creek valley & $\begin{array}{l}\text { Differentiates } 9 \text { Tertiary and } 5 \\
\text { Quaternary basin-fill units }\end{array}$ & $\begin{array}{l}\text { Scholten and others, } 1955 \text {, } \\
\text { pl. } 1\end{array}$ \\
\hline
\end{tabular}

Metamorphic, sedimentary, and igneous bedrock surround the Horse Prairie Valley. The Bitterroot Range is composed of metasedimentary rocks of the Middle Proterozoic Belt Supergroup (Yms) (Ross and others, 1955). Archean gneiss (KAm) underlies basin fill (M'Gonigle and others, 1991; Ruppel, 1993). Metasedimentary rocks of the Belt Supergroup (Yms), Paleozoic carbonate and clastic rocks ( $P z l s)$, including extensive outcrops of 
Mississippian limestone, and Mesozoic clastic and carbonate rocks (Mzsh) border the basin in places, including the Tendoy Mountains (Ross and others, 1955; Lowell, 1965; M'Gonigle, 1993). In the Maiden Peak Spur south of Grant, plutonic rocks of probable Tertiary age (TKi) intrude Archean gneiss (KAm) (M'Gonigle and others, 1991). Along the north end of the Maiden Peak Spur, the Eocene Challis Volcanics (QTKe) consisting of tuff, breccia, and andesitic to basaltic flows border the basin (M'Gonigle and others, 1991). Tertiary volcanic rocks (QTKe) also crop out on small hills which protrude from basin fill near the north end of the basin (Ross and others, 1955).

Tertiary basin fill includes volcanic (QTKe) and sedimentary deposits and rocks (Ts). The Beaverhead Group, which is in part Late Cretaceous in age, accumulated in many ancestral intermontane basins of southwestern Montana, including Horse Prairie Valley, during the later stages of the Laramide Orogeny. The Beaverhead Group consists of several thousand feet of poorly to well consolidated, complexly interfingering conglomerate with subordinate sandstone and limestone (Ryder and Scholten, 1973; Lowell, 1965). Unconformably overlying the Beaverhead Group are white and pink tuff and andesite agglomerate and flows which are cut by andesite dikes and overlain by interbedded tuff, basalt, rhyolite, and volcaniclastic deposits (Lowell, 1965). In the Medicine Lodge Creek area, the volcanic rocks thin to the south (M'Gonigle, 1993). Most basin fill in the Horse Prairie Valley consists of several thousand feet of Eocene(?), Oligocene, and Miocene deposits of lakes, swamps, flood plains, and alluvial fans which Scholten and others (1955) designated informally as the "Medicine Lodge beds." M'Gonigle and others (1991) described seven Tertiary sedimentary units overlying volcanic rocks in the Medicine Lodge Creek area. These are a basal conglomeratic sandstone; Eocene(?) to Oligocene shale with limestone, tuff, and sandstone; Oligocene(?) to Miocene(?) erosion-resistant conglomerate with sandstone and diamictite; Oligocene(?) to Miocene(?) shale and sandstone with localized coal beds; Oligocene(?) to Miocene tuffaceous shale with limestone, conglomeratic sandstone, and mudstone; Miocene(?) interbedded sandstone, shale, and mudstone with localized coal stringers; and Miocene(?) boulder conglomerate and sandstone. Coal beds contained in Tertiary sediments in the Medicine Lodge Creek area are as much as about $7 \mathrm{ft}$ thick, but have limited economic potential because of high ash and sulfur content and complex structural relations (Dyni and Schell, 1982). The Tertiary deposits crop out on broad, dissected pediments which extend from the mountain fronts to the flood plains. In the southem parts of the basin, Tertiary pediments extend beyond the basin boundary, almost to the mountaintops (Tuck and others, in press).

Quaternary deposits include gravel veneer on Tertiary pediments (QTd) and flood-plain alluvium (Qal). As much as $30 \mathrm{ft}$ of unconsolidated, poorly sorted boulders, cobbles, and pebbles in a sandy matrix locally overlie pediments and grade into alluvial fans in the Medicine Lodge Creek area (M'Gonigle and others, 1991). An unknown thickness of mostly unconsolidated sand, silt, and gravel underlie the flood plains of Horse Prairie Creek, Medicine Lodge Creek, and their major tributaries (M'Gonigle and others, 1991; Lowell, 1965).

\section{Hydrology}

Horse Prairie Creek originates in the Bitterroot Range, flows north past its confluence with Bloody Dick Creek, then bends east and joins Medicine Lodge Creek, which originates in the Tendoy Mountains (pl. 1). After draining the Horse Prairie Valley, Horse Prairie Creek flows east a short distance across a narrow flood plain incised in bedrock. Horse Prairie Creek and the Red Rock River join to form the Beaverhead River at the Clark Canyon Reservoir, which was constructed in 1964 for irrigation, flood control, and recreation. The USGS has published monthend reservoir contents (in acre-ft) for the Clark Canyon Reservoir (gaging station 06015300, drainage area $2,321 \mathrm{mi}^{2}$ ) in annual Water-Data Reports since 1964 (U.S. Geological Survey, issued annually). Records of daily elevations are maintained in files at the Montana District office in Helena.

Streamflow data for gaging station 06015000 (pl. 1), Horse Prairie Creek near Grant (drainage area $325 \mathrm{mi}^{2}$ ), are stored in the USGS WATSTORE database. Over the period of record from 1946 to 1953, discharge at the station ranged from a minimum of $12 \mathrm{ft}^{3} / \mathrm{s}$ on November 26,1952 to a maximum of $1,360 \mathrm{ft}^{3} / \mathrm{s}$ on June 2,1953 . The mean annual discharge was $109 \mathrm{ft}^{3} / \mathrm{s}$.

Ground water is an important resource in the Horse Prairie Valley, as it provides domestic water for nearly all the basin residents. Quaternary alluvial deposits and Tertiary sedimentary deposits and rocks are the major aquifers. Ground water might also be available in some bedrock units, but no wells now tap bedrock in the vicinity of the 
basin. Little is known about the hydrogeology of the Horse Prairie Valley. However, yield and specific-capacity data for some wells are summarized in table 36.

Table 36. Summary of data for yield and specific capacity of wells completed in selected hydrogeologic units in the Horse Prairie Valley, Montana

[Source: Dutuon and others, 1995. Hydrogeologic units: Qal, Holocene and Pleistocene alluvial deposits; Ts, Tertiary sedimentary deposits and rocks. Abbreviations: gal/min, gallon per minute; (gal/min)/ft, gallon per minute per foot]

\begin{tabular}{|c|c|c|c|c|c|c|c|c|c|c|}
\hline \multirow{2}{*}{$\begin{array}{l}\text { Hydro- } \\
\text { geologic } \\
\text { unit }\end{array}$} & \multirow[b]{2}{*}{$\begin{array}{c}\text { Number of } \\
\text { wells }\end{array}$} & \multicolumn{4}{|c|}{ Yield (gal/min) } & \multirow[b]{2}{*}{$\begin{array}{c}\text { Number of } \\
\text { wells }\end{array}$} & \multicolumn{4}{|c|}{ Specific capacity [(gal/min)/ft] } \\
\hline & & Mean & Median & $\begin{array}{l}\text { Minf- } \\
\text { mum }\end{array}$ & $\begin{array}{l}\text { Maxi- } \\
\text { mum }\end{array}$ & & Mean & Median & $\begin{array}{l}\text { Mini- } \\
\text { mum }\end{array}$ & $\begin{array}{l}\text { Maxt } \\
\text { mum }\end{array}$ \\
\hline Qal & 4 & 30 & 32 & 12 & 45 & 3 & 3.0 & 2.0 & 0.7 & 6.3 \\
\hline Ts & 19 & 27 & 25 & 5.0 & 90 & 18 & 2.3 & .7 & .2 & 15 \\
\hline
\end{tabular}

Wells completed in Quaternary alluvium range in depth from about 30 to $80 \mathrm{ft}$ and can produce more than 10 $\mathrm{gal} / \mathrm{min}$ with relatively small drawdowns (Dutton and others, 1995). Ground-water levels in Quaternary alluvium are near the land surface, despite the arid climate. The high water levels may be attributed, at least in part, to floodirrigation practices. In areas that have converted to sprinkler irrigation, some residents report declining water levels. However, alluvium in the southern part of the Medicine Lodge Creek valley, where flood irrigation is not practiced, is often waterlogged.

Wells completed in Tertiary sedimentary deposits and rocks range in depth from less than 40 to more than 400 $\mathrm{ft}$. These wells have a wide range of production capabilities, reflecting the heterogeneity of the Tertiary deposits (table 36). Ground-water levels in Tertiary deposits increase from less than $100 \mathrm{ft}$ below land surface near the flood plains, to about $300 \mathrm{ft}$ beneath Tertiary pediment surfaces along the northem edge of the basin (Dutton and others, 1995).

Little is known about ground-water flow in the Horse Prairie Valley. However, a 1:750,000-scale potentiometric-surface map which includes the Horse Prairie Valley (Briar and others, in press) indicates that ground water generally flows from the uplands toward the flood plains, then eastward paralleling Horse Prairie Creek.

Basin-fill aquifers are recharged by precipitation and snowmelt, surplus irrigation water, leakage from irrigation canals, subsurface flow from surrounding bedrock, and infiltration from tributary streams. The groundwater contribution area (fig. 2, pl. 1) is about $700 \mathrm{mi}^{2}$. Infiltration anywhere within this area could potentially recharge basin-fill aquifers in the Horse Prairie Valley. Ground water discharges from the basin-fill aquifers by evapotranspiration, withdrawals from wells, and seepage to springs, seeps, and stream channels. In addition, there might be some deep subsurface flow between Grasshopper Valley and Horse Prairie Valley.

Ground-water quality is a concern for many residents of the Horse Prairie Valley. Some well-owners use water softeners and other treatment systems to improve the unpleasant taste and staining caused by large quantities of iron and sulfate in their water. The quality of ground water in the basin was determined on the basis of seven samples analyzed for major ions and measured dissolved-solids concentrations, and eight samples in which dissolved-solids concentrations were estimated from specific-conductance measurements. In general, the ground water is a calcium sodium bicarbonate type in the western half of the basin, and a mixed-cation sulfate type in the eastern half. The concentration of dissolved solids is less than $250 \mathrm{mg} / \mathrm{L}$ beneath the flood plain of Horse Prairie Creek, more than $500 \mathrm{mg} / \mathrm{L}$ in the Medicine Lodge Creek area, and about 250 to $500 \mathrm{mg} / \mathrm{L}$ in Tertiary deposits in the northem and western parts of the basin (Clark and Dutton, in press).

\section{Selected References}

Briar, D.W., Lawlor, S.M., Stone, M.A.J., Parliman, D.J., Schaerfer, J.L., and Kendy, Eloise, in press, Ground-water levels in intermontane basins of the Northern Rocky Mountains, Montana and Idaho: U.S. Geological Survey Hydrologic Investigations Atlas 738-B, 1 sheet, scale 1:750,000. 
Clark, D.W., and Dutton, D.M., in press, Quality of ground water and surface water in intermontane basins of the Northem Rocky Mountains, Montana and Idaho: U.S. Geological Survey Hydrologic Investigations Aulas 738-C, 1 sheet, scale 1:750,000.

Dutton, D.M., Lawlor, S.M., Briar, D.W., and Tresch, R.E., 1995, Hydrogeologic data for the Northern Rocky Mountains intermontane basins, Montana: U.S. Geological Survey Open-File Report 95-143, 94 p.

Dyni, J.R., and Schell, E.M., 1982, Tertiary coals in the Medicine Lodge Creek Valley, Beaverhead County, Montana: Montana Bureau of Mines and Geology Geologic Map 29, 18 p., 3 sheets, scale 1:37,000.

Kellogg, K.S., 1993, Style of Cenozoic extensional deformation in the central Beaverhead Mountains, Idaho-Montana [abs.]: Geological Society of America Abstracts with Programs, v. 25, no. 5, p. 61.

Lowell, W.R., 1965, Geologic map of the Bannack-Grayling area, Beaverhead County, Montana: U.S. Geological Survey Miscellaneous Geological Investigations Map I-433, scale 1:31,680.

M'Gonigle, J.W., 1965, Structure of the Maiden-Peak area, Montana-Idaho: University Park, Pa., The Pennsylvania State University, Ph.D. dissertation, $146 \mathrm{p}$.

1993, Geologic map of the Medicine Lodge Peak quadrangle, Beaverhead County, southwest Montana: U.S. Geological Survey Geologic Quadrangle map GQ-1724, scale 1:24,000.

M'Gonigle, J.W., Kirschbaum, M.A., and Weaver, J.N., 1991, Geologic map of the Hansen Ranch quadrangle, Beaverhead County, southwest Montana: U.S. Geological Survey Geologic Quadrangle Map GQ-1704, scale 1:24,000.

National Oceanic and Atmospheric Administration, 1992, Monthly normals of temperature, precipitation, and heating and cooling degree days, 1961-90, Montana: Asheville, N.C., Climatography of the United States no. 81, unpaged.

Ross, C.P., Andrews, D.A., and Witkind, I.J., 1955, Geologic map of Montana: U.S. Geological Survey, 2 sheets, scale $1: 500,000$.

Ruppel, E.T., 1978, The Medicine Lodge thrust system: U.S. Geological Survey Professional Paper 1031, 23 p. 1993. Cenozoic tectonic evolution of southwest Montana and east-central Idaho: Montana Bureau of Mines and Geology Memoir 65, $62 \mathrm{p}$.

Ruppel, E.T., O'Neill, J.M., and Lopez, D.A, 1993, Geologic map of the Dillon $1^{\circ} \times 2^{\circ}$ quadrangle, Idaho and Montana: U.S. Geological Survey Miscellaneous Investigations Series Map I-1803-H, scale 1:250,000.

Ryder, R.T., and Scholten, Robert, 1973, Syntectonic conglomerates in southwest Montana--Their nature, origin and significance: Geological Society of America Bulletin, v. 84, p. 773-796.

Scholten, Robert, Keenmon, K.A., and Kupsch, W.O., 1955, Geology of the Lima region, southwestem Montana and adjacent parts of Idaho: Geological Society of America Bulletin, v. 66, p. 345-404.

Scholten, Robert, 1981, Horse Prairie fault zone in southwest Montana--Its role in sedimentation and tectogenesis [abs.]: Geological Society of America Abstracts with Programs, v. 13, no. 4, p. 225.

Shields, R.R., Knapton, J.R., White, M.K., Brosten, T.M., and Chambers, C.L., 1993, Water resources data, Montana, water year 1992: U.S. Geological Survey Water-Data Report MT-92-1, 534 p.

Thompson, G.R., Fields, R.W., and Alt, David, 1981, Tertiary paleoclimates, sedimentation patterns and uranium distribution in southwestern Montana, in Montana Geological Society Field Conference and Symposium Guidebook to Southwest Montana: [Billings, Mont.], Montana Geological Society, p. 105-109.

Tuck, L.K., Briar, D.W., and Clark, D.W., in press, Geologic history and hydrogeologic units of the intermontane basins of the Northern Rocky Mountains, Montana and Idaho: U.S. Geological Survey Hydrologic Investigations Atlas 738-A, 2 sheets, scale $1: 750,000$.

U.S. Geological Survey, issued annually, Water resources data, Montana: Helena, Mont., U.S. Geological Survey Water-Data Report. 


\section{Jefferson River Valley}

\section{Geography}

The Jefferson River Valley is a north-northeast-trending intermontane basin in southwestem Montana. The $260-\mathrm{mi}^{2}$ basin is bounded by the Highland Mountains on the west, the Continental Divide on the northwest, Bull Mountain on the north, the London Hills on the northeast, and the Tobacco Root Mountains on the east (pl. 1). The southern basin boundary is arbitrarily defined as the confluence of the Big Hole and Beaverhead Riversthe point at which the Jefferson River begins-although the structural basin actually continues southward into the Beaverhead Valley. The intermontane basin as defined in this study includes the valley of Whitetail Creek, a northern tributary to the Jefferson River. In the southern half of the Jefferson River Valley, the flood plain follows a northeastward route to the eastern basin margin. Alluvial fans slope gently from the face of the Tobacco Root Mountains toward the flood plain. This geometry is mirrored in the northern

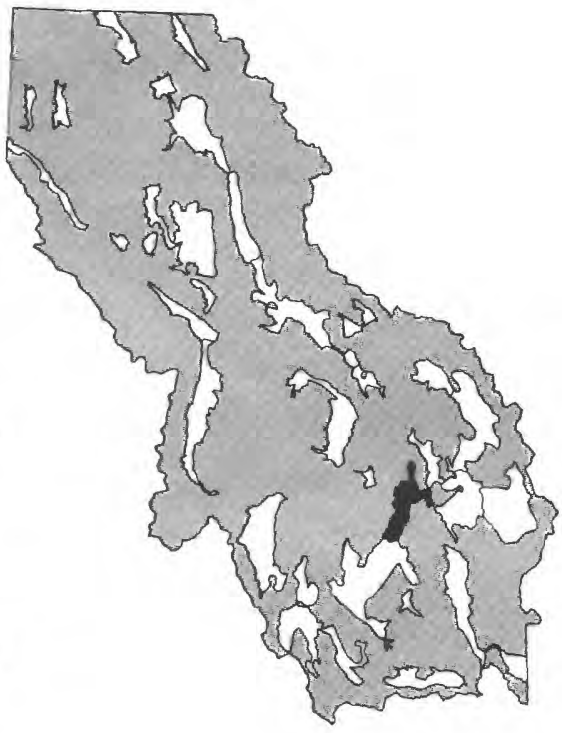
part of the basin, where the river bends to the north and alluvial fans emanate from the Highland Mountains. South of Whitehall, the river bends to the east and flows through a narrower valley, which is flanked by gently sloping alluvial fans. North of the Jefferson River, the Whitetail Creek flood plain is also flanked by gently sloping alluvial fans. In some areas, terraces flanking the flood plain are as high as $100 \mathrm{ft}$ above the river. The Jefferson River Valley ranges in altitude from about $4,300 \mathrm{ft}$ where the Jefferson River leaves the basin, to about $5,800 \mathrm{ft}$ on the highest alluvial fan.

The climate of the Jefferson River Valley is typical of mid-elevation intermontane basins of the Northem Rocky Mountains east of the Continental Divide, with cold winters and mild summers. On the basis of the 1961-90 period of record, the average annual precipitation at Twin Bridges (altitude 4,620 ft) is $9.73 \mathrm{in}$., and the average annual temperature is $43.1^{\circ} \mathrm{F}$ (National Oceanic and Atmospheric Administration, 1992). The average last occurrence of $32^{\circ} \mathrm{F}$ is June 14 and the average first occurrence is August 31 (Natural Resources Conservation Service, U.S. Department of Agriculture, unpub. data, 1994). Mean monthly climatic data for Twin Bridges are plotted in figure 16.

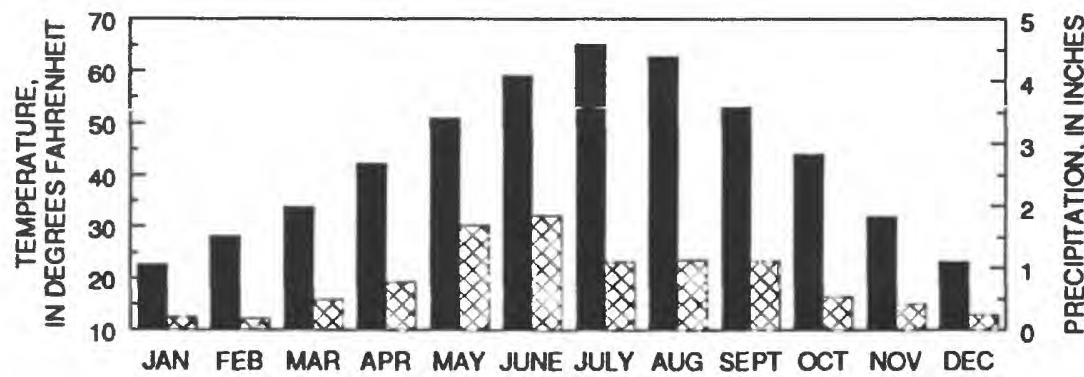

\section{EXPLANATION}

MEAN MONTHLY TEMPERATURE FOR 1961-90 PERIOD OF RECORD

Q MEAN MONTHLY PRECIPITATION FOR 1961-90 PERIOD OF RECORD

Figure 16. Mean monthly precipitation and temperature at Twin Bridges, Mont. Data from National Oceanic and Atmospheric Administration (1992).

Land uses primarily are rangeland and irrigated pastures. In addition, dryland small grains are grown to a limited extent on alluvial fans west of Cardwell and south of Whitehall (J.C. Eggen, Agricultural Stabilization and Conservation Service, oral commun., 1993). About 3,000 people reside in the Jefferson River Valley, including 1,067 in the Town of Whitehall, 374 in the Town of Twin Bridges, and 76 in the unincorporated community of Cardwell (1990 census). 
The mountains surrounding the basin have been extensively mined. A large open-pit cyanide-heap-leach gold and silver mine operates at the southern end of Bull Mountain north of Whitehall and an open-cut placer gold operation recently closed in the Highland Mountains. Limestone is quarried in the Pipestone Creek drainage and an open-pit chlorite mine operates intermittently at the basin margin south of Silver Star (McCulloch, 1992, p. 30; 1993, p. 4, 21, 24).

\section{Geology}

The Jefferson River Valley formed by Cenozoic faulting and by doming of the Boulder Batholith (fig. 4). Faults bound the east and west sides of the basin, and cross-cut the basin in several places (Ruppel, 1993). The Jefferson River Valley was probably continuous with the Western Three Forks Valley to the east until late Tertiary time, when uplift of the London Hills separated the two basins (Aram, 1981, p. 291). Continued seismic activity is evidenced by young fault scarps and the disruption of present drainages (Jorgensen, 1990; Bartholomew and others, 1990; Ruppel, 1993).

Little agreement exists regarding the depth of the Jefferson River Valley. According to gravity data, the maximum depth is $4,900 \mathrm{ft}$, but seismic data indicate a depth of $11,000 \mathrm{ft}$ (Ruppel, 1993, p. 24-27). Other estimates are in the range of 6,000 ft to 7,000 ft (Noble and others, 1982, p. 77; Burfiend, 1967). The deepest drillhole in the basin was completed in 1951 for oil exploration. The hole, located at 03S05W18DB, penetrated $835 \mathrm{ft}$ of clay, shale, gravel, and sand without reaching bedrock (Montana Board of Oil and Gas Conservation, unpub. data, 1990). Another oil-exploration drillhole located just south of the Jefferson River Valley, about 4 mi southeast of Twin Bridges, penetrated the contact between Tertiary sediments and Archean metamorphic rocks at a depth of about 2,160 ft below land surface (Ruppel, 1993, p. 27).

Numerous investigators have examined the geology of the Jefferson River Valley (table 37). Graduate students from Indiana University, including Parker (1961), Wilson (1962), Reshkin (1963), Richard (1966), Burfiend (1967), and Vane (1972), provided much of the early mapping and interpretations of local geological features. Kuenzi and Fields (1971) provided the first detailed description of basin fill in the Jefferson River Valley; their often-cited paper became the basis for a unified interpretation of Cenozoic events in southwestem Montana. Bedrock geology was most recently described by Ruppel and others (1993). The geologic units described by previous investigators are summarized below. These geologic units are referenced to hydrogeologic units defined in this study (table 2) to provide a consistent regional framework. In the following discussion, the hydrogeologicunit abbreviations are italicized.

A diverse assemblage of bedrock surrounds the Jefferson River Valley. Archean and Early Proterozoic gneiss and schist $(\mathrm{KAm})$ outcrop extensively in the Tobacco Root and Highland Mountains. Conglomerate, breccia, arkose, shale, siltstone, and sandstone of the Middle Proterozoic Belt Supergroup ( $Y m s$ ) border the basin intermittently in the Tobacco Root and southern Bull Mountains. Paleozoic rocks ( $P$ z $l s$ ), including interbedded carbonate rocks, phosphatic sandstone, quartzite, siltstone, mudstone, and shale, unconformably overlie the Proterozoic rocks. Mississippian limestone adjoins the basin intermittently along the east side. The Middle Proterozoic and Paleozoic metasedimentary and sedimentary rocks are extensively folded and faulted. Upper Cretaceous Elkhom Mountains Volcanics (QTKe), which range in composition from andesite to latite, crop out along the northem basin margin. The Cretaceous Boulder Batholith and associated granodioritic intrusive rocks (TKi) compose the bulk of the Highland Mountains (Kuenzi and Fields, 1971; Ruppel and others, 1993).

It is uncertain what type of bedrock underlies basin fill in the Jefferson River Valley. According to Ruppel (1993, p. 27), Archean metamorphic rocks (KAm) floor almost the entire basin. Kuenzi and Fields (1971), however, suggest that the Proterozoic Belt Supergroup (Yms) and Cretaceous intrusive rocks underlie at least the northeastem area. Thompson and others (1981) concluded that igneous rocks of the Elkhom Mountains Volcanics (QTKe) and Boulder Batholith (TKi) floor the basin. 
Table 37. Geologic and geophysical maps of the Jefferson River Valley, Montana

\begin{tabular}{|c|c|c|c|c|}
\hline Type of map & Scale & Location & Map features & Reference \\
\hline Geology & $1: 394,000$ & $\begin{array}{l}\text { Entire Jefferson } \\
\text { River Valley }\end{array}$ & Differentiates five "sequences" of Cenozoic basin fill & $\begin{array}{l}\text { Hanneman and } \\
\text { Wideman, } 1991 \text {, } \\
\text { fig. } 5\end{array}$ \\
\hline Bouguer gravity & $1: 335,000$ & $\begin{array}{l}\text { Entire Jefferson } \\
\text { River Valley }\end{array}$ & Contour interval 5 milligals & $\begin{array}{l}\text { Hanneman and } \\
\text { Wideman, 1991, } \\
\text { fig. } 7\end{array}$ \\
\hline Geology & $1: 36,200$ & $\begin{array}{l}\text { Entire Jefferson } \\
\text { River Valley }\end{array}$ & $\begin{array}{l}\text { Differentiates five basin-fill units: the Dunbar Creek, } \\
\text { Climbing Arrow, and Bone Basin Members of the } \\
\text { Tertiary Renova Formation; the Tertiary Sixmile } \\
\text { Creek Formation; and Quaternary deposits. Includes } \\
\text { three geologic cross sections }\end{array}$ & $\begin{array}{l}\text { Kuenzi and Fields, } \\
\text { 1971, fig. } 3\end{array}$ \\
\hline $\begin{array}{l}\text { Cenozoic basin } \\
\text { fill isopach }\end{array}$ & $1: 500,000$ & $\begin{array}{l}\text { Entire Jefferson } \\
\text { River Valley }\end{array}$ & Contour interval 3,000 feet & $\begin{array}{l}\text { Noble and others, } \\
\text { 1982, fig. II-20, } \\
\text { p. } 78\end{array}$ \\
\hline Principal faults & $1: 500,000$ & $\begin{array}{l}\text { Entire Jefferson } \\
\text { River Valley }\end{array}$ & $\begin{array}{l}\text { Shows inferred direction and distance of extension, and } \\
\text { locations of oil exploration drillholes }\end{array}$ & $\begin{array}{l}\text { Ruppel, } 1993 \text {, } \\
\text { sheet } 1\end{array}$ \\
\hline Geology & $1: 126,720$ & $\begin{array}{l}\text { Eastern margin of } \\
\text { the Jefferson } \\
\text { River Valley }\end{array}$ & Illustrates complex structural relations & $\begin{array}{l}\text { Ruppel, 1993, } \\
\text { fig. 11, p. } 17\end{array}$ \\
\hline Gravity & $1: 845,000$ & $\begin{array}{l}\text { Entire Jefferson } \\
\text { River Valley }\end{array}$ & Contour interval 10 milligals & $\begin{array}{l}\text { Ruppel, } 1993, \text { fig. } \\
\text { 17, p. } 26\end{array}$ \\
\hline Geology & $1: 250,000$ & $\begin{array}{l}\text { Entire Jefferson } \\
\text { River Valley }\end{array}$ & $\begin{array}{l}\text { Differentiates four basin-fill units: Pliocene to Eocene } \\
\text { basin fill, Tertiary and Quatemary pediment and } \\
\text { alluvial gravels, Quatemary alluvial-fan deposits, and } \\
\text { Quatemary alluvium }\end{array}$ & $\begin{array}{l}\text { Ruppel and others, } \\
1993\end{array}$ \\
\hline
\end{tabular}

Tertiary sediments (TS) in the Jefferson River Valley belong to the dominantly fine-grained Renova Formation and the overlying coarse-grained Sixmile Creek Formation of the Bozeman Group. In the Jefferson River Valley, the Renova Formation is of Early to Middle Oligocene age. The formation, which crops out primarily on the western side of the basin, consists of about 3,500 ft (Kuenzi and Fields, 1971; Suttner and others, 1981) of interbedded micritic and oolitic limestone, montmorillonitic mudstone, and vitric siltstone with lesser amounts of vitric arenite, arkose, conglomerate, and coal typical of relatively humid flood plain, pond, and low-gradient stream channel environments. Outcrops are light-colored, and form dissected benches and badlands. The upper Miocene to upper Pliocene Sixmile Creek Formation consists of about 2,400 ft of conglomerate and medium- to coarse-grained sand with lesser amounts of vitric arenite, vitric siltstone, montmorillonitic mudstone, and calcareous mudstone typical of relatively arid, high-energy ephemeral and perennial stream-channel environments. Renova Formation beds dip about $6^{\circ}$ to $45^{\circ}$ to the east, with the greatest dips located near the western basin margin. Sixmile Creek Formation beds also dip to the east, but at lower angles (Kuenzi and Fields, 1971; Ruppel, 1993).

Quatemary deposits, including pediment gravels ( $Q T d)$, alluvial-fan deposits ( $Q T d)$, and flood-plain alluvium (Qal), unconformably overlie Tertiary sediments in the Jefferson River Valley. Pediment gravels, including unconsolidated, deeply weathered, angular-to-rounded pebbles, cobbles, small boulders, and eolian silt, locally veneer Tertiary pediments along the west side of the basin. Alluvial-fan deposits consisting of poorly sorted silty sand and gravel extend from the mountain fronts to the Jefferson River flood plain and cover most of the basin. Distinguishing between these large Quatemary fans and surficial pediment gravels can be difficult, due to the fanlike aspect of the pediments. Alluvial deposits consisting of silt, sand, and gravel extend along channels and flood plains of the Jefferson River and its major tributaries. The geologic contact between Quaternary deposits and the 
underlying, similarly textured Tertiary Sixmile Creek Formation is difficult to distinguish. Therefore, thickness of the Quaternary deposits is unknown (Ruppel and others, 1993; Kuenzi and Fields, 1971).

\section{Hydrology}

The Big Hole, Beaverhead, and Ruby Rivers form the Jefferson River near Twin Bridges. The river flows through the Jefferson River Valley where it is joined by several tributaries from the east and west and by Whitetail Creek and the Boulder River from the north. The Jefferson, Gallatin, and Madison Rivers form the Missouri River near Three Forks. Flow in the Jefferson River is regulated by the Clark Canyon and Ruby River Reservoirs and by diversions for irrigation of more than 300,000 acres (Shields and others, 1993). Minimum discharges are recorded during late summer. Late-season irrigation water shortages often occur, and the concurrent dewatering potentially decreases fish populations in the Jefferson River (Missouri River Basin Commission, 1981).

Streamflow data for gaging stations listed in table 38 are stored in the USGS WATSTORE database. Locations of the stations are shown on plate 1 .

Table 38. Summary of data for U.S. Geological Survey streamflow-gaging stations in the Jefferson River Valley, Montana

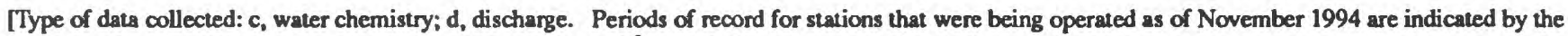
first year of record followed by a dash only. Abbreviations: $\mathrm{ft}^{3} / \mathrm{s}$, cubic feet per second. Symbol: --, no data]

\begin{tabular}{|c|c|c|c|c|c|c|c|c|c|}
\hline \multirow[b]{2}{*}{$\begin{array}{l}\text { Station } \\
\text { number }\end{array}$} & \multirow[b]{2}{*}{ Station name } & \multirow[b]{2}{*}{$\begin{array}{c}\text { Drainage } \\
\text { area } \\
\text { (equare } \\
\text { miles) }\end{array}$} & \multirow{2}{*}{$\begin{array}{l}\text { Type } \\
\text { of } \\
\text { data } \\
\text { cot- } \\
\text { locted }\end{array}$} & \multirow[b]{2}{*}{$\begin{array}{l}\text { Period of record } \\
\text { (calendar year) }\end{array}$} & \multicolumn{5}{|c|}{ Discharge for period of record } \\
\hline & & & & & $\begin{array}{l}\text { Mean } \\
\text { annual } \\
\left(\mathrm{ft}^{3} / \mathrm{s}\right)\end{array}$ & $\begin{array}{l}\text { Maxi- } \\
\text { mum } \\
\left(\mathrm{ft}^{3} / \mathrm{s}\right)\end{array}$ & $\begin{array}{l}\text { Date of } \\
\text { maximum }\end{array}$ & $\begin{array}{l}\text { Mint- } \\
\text { mum } \\
\left(\mathrm{ft}^{3} / \mathrm{s}\right)\end{array}$ & $\begin{array}{c}\text { Date of } \\
\text { minimum }\end{array}$ \\
\hline 06026500 & $\begin{array}{l}\text { Jefferson River near } \\
\text { Twin Bridges }\end{array}$ & 7,632 & $\bar{d}$ & $\begin{array}{c}1940-43,1957-72 \\
1994 \\
1957-62,1965-72\end{array}$ & 2,014 & 16,500 & $06-10-64$ & 82 & $08-17-66$ \\
\hline 06027000 & $\begin{array}{l}\text { Jefferson River near } \\
\text { Silver Star }\end{array}$ & 7,683 & d & $1910-16,1920-39$ & 1,714 & 20,300 & $06-15-27$ & 50 & 09-04-37 \\
\hline 06027200 & $\begin{array}{l}\text { Jefferson River at } \\
\text { Silver Star }\end{array}$ & 7,683 & $\begin{array}{l}d \\
c\end{array}$ & $\begin{array}{l}1940-43,1957-74 \\
1973-74\end{array}$ & 1,961 & 16,500 & $06-10-64$ & 82 & $08-17-66$ \\
\hline 06027500 & $\begin{array}{l}\text { Bell Creek near } \\
\text { Waterloo }\end{array}$ & 5.63 & d & $1941-42$ & 13.7 & 55 & $06-07-42$ & 4.6 & $\begin{array}{c}\text { Several } \\
\text { days each } \\
\text { year }\end{array}$ \\
\hline 06028000 & $\begin{array}{l}\text { Big Pipestone Creek } \\
\text { near Whitehall }\end{array}$ & 108 & d & $1910-11$ & 15.3 & 87 & $06-09-11$ & .5 & $\begin{array}{l}\text { Several } \\
\text { days in } \\
\text { Aug. and } \\
\text { Sept. } 1911\end{array}$ \\
\hline 06028500 & $\begin{array}{l}\text { Little Pipestone Creek } \\
\text { near Whitehall }\end{array}$ & 30.7 & d & $1935-40$ & 3.4 & 175 & $07-01-38$ & .5 & $\begin{array}{c}\text { Several } \\
\text { days }\end{array}$ \\
\hline 06028700 & $\begin{array}{l}\text { Big Pipestone Creek at } \\
\text { Whitehall }\end{array}$ & -- & c & 1986 & - & - & - & -- & - \\
\hline 06029000 & $\begin{array}{l}\text { Whitetail Creek near } \\
\text { Whitehall }\end{array}$ & 30.8 & d & $\begin{array}{l}\text { 1949-53, 1955-58, } \\
\text { 1959-68 (no } \\
\text { winter records } \\
\text { after 1951) }\end{array}$ & -- & 126 & $05-18-51$ & .2 & $01-27-57$ \\
\hline
\end{tabular}

The quality of water in the Jefferson River near Twin Bridges (gaging station 06026500) was determined on the basis of 253 samples. Analyses indicate a calcium bicarbonate type water with an average dissolved-solids concentration of $213 \mathrm{mg} / \mathrm{L}$ (Clark and Dutton, in press).

As part of a reconnaissance survey of arsenic in the upper Missouri River basin, water samples were collected from the Jefferson River near Three Forks (gaging station 06036650) and analyzed for arsenic twelve times under 
various hydrologic conditions from November 1985 to October 1986. Although the station is located downstream from, and not within, the Jefferson River Valley (pl. 1), samples collected at the station are indicative of arsenic concentrations within the basin. The concentration of total recoverable arsenic was $10 \mu \mathrm{g} / \mathrm{L}$ or less during each sampling period, under flow conditions ranging from 665 to $6,820 \mathrm{ft}^{3} / \mathrm{s}$ (Knapton and Horpestad, 1987, p. 18), well below the maximum contaminant level of $50 \mu \mathrm{g} / \mathrm{L}$ established by the U.S. Environmental Protection Agency (1991) for treated drinking water. As part of the same study, Big Pipestone Creek at Whitehall (gaging station 06028700) was sampled for arsenic on November 14, 1985 and May 27, 1986. The concentration of total recoverable arsenic was $5 \mu \mathrm{g} / \mathrm{L}$ for both samples (Knapton and Horpestad, 1987, p. 16).

Ground water is an important resource in the Jefferson Valley, as residents rely on it for all domestic supplies. However, little is known about the aquifers that contain this resource. The primary aquifer in the basin is the unconsolidated Quatemary alluvium that underlies the flood plain of the Jefferson River and its major tributaries. Wells completed in Quaternary alluvium can produce about 20 to $500 \mathrm{gal} / \mathrm{min}$ for domestic, public-supply, or agricultural use (table 39). A municipal-supply well for Whitehall that is completed in Quaternary alluvium produces $450 \mathrm{gal} / \mathrm{min}$. Well depths are generally about 60 to $100 \mathrm{ft}$ (Montana Bureau of Mines and Geology, unpub. data, 1993), and most ground water in Quaternary alluvium is unconfined.

Table 39. Summary of data for yield and specific capacity of wells completed in selected hydrogeologic units in the Jefferson River Valley, Montana

[Source: Dutton and others, 1995. Hydrogeologic unit: Qal, Holocene and Pleistocene alluvial deposits; Ts, Tertiary sedimentary deposits and rocks. Abbreviations: $\mathrm{gal} / \mathrm{min}, \mathrm{gallon}$ per minute; ( $\mathrm{gal} / \mathrm{min}) / \mathrm{ft}$, gallon per minute per foot]

\begin{tabular}{|c|c|c|c|c|c|c|c|c|c|c|}
\hline \multirow{2}{*}{$\begin{array}{l}\text { Hydro- } \\
\text { geologle } \\
\text { unit }\end{array}$} & \multirow{2}{*}{$\begin{array}{l}\text { Number } \\
\text { of wells }\end{array}$} & \multicolumn{4}{|c|}{ Vield (gal/min) } & \multirow{2}{*}{$\begin{array}{l}\text { Number } \\
\text { of wells }\end{array}$} & \multicolumn{4}{|c|}{ Specific capacity [(gal/min)/ft] } \\
\hline & & Mean & Medlan & $\begin{array}{l}\text { Mini- } \\
\text { mum }\end{array}$ & $\begin{array}{l}\text { Maxi- } \\
\text { mum }\end{array}$ & & Mean & Median & $\begin{array}{l}\text { Mini- } \\
\text { mum }\end{array}$ & $\begin{array}{l}\text { Maxi- } \\
\text { mum }\end{array}$ \\
\hline Qal & 7 & 150 & 25 & 20 & 500 & 7 & 35 & 1.2 & 0.3 & 225 \\
\hline Ts & 9 & 28 & 25 & 8.0 & 60 & 7 & 1.4 & 1.3 & .6 & 2.5 \\
\hline
\end{tabular}

Few wells have been completed in Tertiary sediments beneath alluvial fans and pediments, which are largely undeveloped. Because of the large proportion of fine-grained material in Tertiary sediments, these deposits generally do not yield large quantities of ground water to wells (table 39). According to the driller's log, one 180$\mathrm{ft}, 6$-in.-diameter well produced $60 \mathrm{gal} / \mathrm{min}$. However, the water level in the well, which was perforated through 80 $\mathrm{ft}$ of "hard clay with gravel", dropped $106 \mathrm{ft}$ during two hours of pumping, resulting in a specific-capacity value of 0.57 (gal.min)/ft. Depths of wells completed in Tertiary sediments in the Jefferson River Valley range from about 50 to $400 \mathrm{ft}$ (Montana Bureau of Mines and Geology, unpub. data, 1993). Ground water in Tertiary sediments is unconfined or semiconfined by laterally discontinuous layers of fine-grained material.

Limited records are available for wells completed in bedrock beneath Cenozoic sediments in the Jefferson River Valley. According to one driller's $\log$, a 139-ft well on the west side of the basin (02SO6W12CCBC) was completed in $32 \mathrm{ft}$ of clayey basin fill and $7 \mathrm{ft}$ of fractured granite and reportedly produces $8 \mathrm{gal} / \mathrm{min}$ with a specific capacity of 2.1 (gal/min)/ft (Dutton and others, 1995). Except for Mississippian limestone, the Paleozoic and Mesozoic sedimentary rocks that surround and underlie parts of the Jefferson River Valley probably cannot yield large quantities of ground water to wells. Where Mississippian limestone is below the water table, however, it might be an adequate aquifer because ground water potentially could flow through cavernous openings created by dissolution of carbonate minerals. Fractures within the Proterozoic and Archean bedrock also might yield adequate water for domestic use.

Little is known about ground-water flow in the Jefferson River Valley. However, a 1:750,000-scale potentiometric-surface map which includes the Jefferson River Valley (Briar and others, in press) indicates that ground water generally flows from the uplands toward the flood plain, then parallels the Jefferson River. 
Basin-fill aquifers in the Jefferson River Valley are recharged by precipitation and snowmelt, surplus irrigation water, leakage from irrigation canals, subsurface flow from surrounding bedrock, subsurface flow from the Beaverhead Valley, and infiltration from tributary streams. The ground-water contribution area (fig. 2, pl. 1) is about $860 \mathrm{mi}^{2}$. Infiltration anywhere within this area could potentially recharge basin-fill aquifers in the Jefferson River Valley. Ground water discharges from basin-fill aquifers by evapotranspiration, withdrawals from wells, and seepage to springs, seeps, irrigation drains, and stream channels.

Subsurface recharge from bedrock is evidenced by geothermal springs. Renova, Pipestone, and Silver Star Hot Springs discharge from normal faults along the basin margins (Chadwick and Leonard, 1979). Renova Hot Springs (01N04W32DBC) discharge water with a temperature of $50^{\circ} \mathrm{C}$ at a rate of $40 \mathrm{gal} / \mathrm{min}$ from the eastern edge of the basin (pl. 1); Pipestone Hot Springs (02N05W28BDDD) discharge water with a temperature of $57^{\circ} \mathrm{C}$ at a rate of $250 \mathrm{gal} / \mathrm{min}$ from the northwestem edge; and Silver Star Hot Springs (02S06W01CCBA) discharge water with a temperature of $72^{\circ} \mathrm{C}$ at a rate of $40 \mathrm{gal} / \mathrm{min}$ from the western edge of the basin (Sonderegger and Bergantino, 1981).

The quality of ground water in the basin was determined on the basis of 10 samples analyzed for major ions and measured dissolved-solids concentrations, and 7 samples in which dissolved-solids concentrations were estimated from specific-conductance measurements. In general, water from flood-plain alluvium is a calcium bicarbonate type with a dissolved-solids concentration of less than $250 \mathrm{mg} / \mathrm{L}$ (Clark and Dutton, in press). In some areas, water from alluvial flood-plain deposits has a large concentration of iron (Noble and others, 1982, p. 79). Alluvial-fan deposits and Tertiary sediments contain more mineralized ground water and have dissolved-solids concentrations ranging from 250 to $500 \mathrm{mg} / \mathrm{L}$. On the eastem side of the basin, ground water in alluvial-fan deposits and Tertiary sediments derived from the Tobacco Root Mountains dominantly is a calcium bicarbonate type. In contrast, ground water west of the Jefferson River contains-more magnesium, sodium, and sulfate (Clark and Dutton, in press). Pipestone Hot Springs and Silver Star Hot Springs discharge water with dissolved-solids concentrations of $340 \mathrm{mg} / \mathrm{L}$ and $610 \mathrm{mg} / \mathrm{L}$, respectively (Sonderegger and Bergantino, 1981).

\section{Selected References}

Abdul-Malik, M.M., 1977, A geophysical investigation of the Silver Star area of Madison County, southwestern Montana: Butte, Montana College of Mineral Science and Technology, M.S. thesis, 100 p.

Aram, R.B., 1981, Geologic history of Lewis and Clark Caverns, Montana, in Montana Geological Society Field Conference and Symposium Guidebook to Southwest Montana: [Billings, Mont.], Montana Geological Society, p. 285-300.

Axelrod, R.B., 1984, Tertiary facies and depositional environments, northern Jefferson basin, southwest Montana [abs.]: Geological Society of America Abstracts with Programs, v. 16, no. 4, p. 214.

Bartholomew, M.J., Stickney, M.C., and Wilde, E.M., 1990, Late Quaternary faults and seismicity in the Jefferson basin, in Quaternary geology of the western Madison Range, Madison valley, Tobacco Root Range, and Jefferson valley, Rocky Mountain Friends of the Pleistocene, August 15-19, 1990, Fieldtrip Guidebook: Indianapolis, Indiana University at Indianapolis, Department of Geology, p. 238-244.

Briar, D.W., Lawlor, S.M., Stone, M.A.J., Parliman, D.J., Shaefer, J.L., and Kendy, Eloise, in press, Ground-water levels in intermontane basins of the Northern Rocky Mountains, Montana and Idaho: U.S. Geological Survey Hydrologic Investigations Atlas 738-B, 1 sheet, scale 1:750,000.

Burfiend, W.J., 1967, A gravity investigation of the Tobacco Root Mountains, Jefferson basin, Boulder batholith, and adjacent areas in southwestern Montana: Bloomington, Indiana University, Ph.D. dissertation, 90 p.

Burnsvold, L.D., 1989, A seismic reflection study of the Jefferson basin, southwest Montana: Butte, Montana College of Mineral Science and Technology, M.S. thesis, 45 p.

Chadwick, R.A., and Leonard, R.B., 1979, Structural controls of hot-spring systems in southwestem Montana: U.S. Geological Survey Open-File Report 79-1333, 25 p.

Clark, D.W., and Dutton, D.M., in press, Quality of ground water and surface water in intermontane basins of the Northern Rocky Mountains, Montana and Idaho: U.S. Geological Survey Hydrologic Investigations Atlas 738-C, 1 sheet, scale 1:750,000. 
Deeds, J.F., and White, W.N., 1927, Water power and irrigation in the Jefferson River basin, Montana: U.S. Geological Survey Water Supply Paper 580-B, p. 41-116.

Dutton, D.M., Lawlor, S.M., Briar, D.W., and Tresch, R.E., 1995, Hydrogeologic data for the Northern Rocky Mountains intermontane basins, Montana: U.S. Geological Survey Open-File Report 95-143, 94 p.

Fields, R.W., and Petkewich, R.M., 1967, Tertiary stratigraphy and geologic history of the upper Jefferson, Ruby, lower Beaverhead, and lower Big Hole River valleys, in Montana Geological Society, 18th Annual Field Conference, Guidebook for Centennial Basin of Southwest Montana: Billings, Mont., Montana Geological Society, p. 71-77.

Hanneman, D.L., and Wideman, C.J., 1991, Sequence stratigraphy of Cenozoic continental rocks, southwestern Montana: Geological Society of America Bulletin, v. 103, p. 1,335-1,345.

Johnson, R.W., Jr., Henderson, J.R., and Tyson, N.S., 1965, Aeromagnetic map of the Boulder batholith area, southwestern Montana: U.S. Geological Survey Geophysical Investigations Map GP-538, scale 1:250,000.

Jorgensen, D.W., 1990, Hydraulic adjustment of the Jefferson River, MT to uplift, in Quaternary geology of the western Madison Range, Madison valley, Tobacco Root Range, and Jefferson valley, Rocky Mountain Friends of the Pleistocene, August 15-19, 1990, Fieldtrip Guidebook: Indianapolis, Indiana University at Indianapolis, Department of Geology, p. 245-257.

Knapton, J.R., and Horpestad, A.A., 1987, Arsenic data for streams in the upper Missouri River basin, Montana and Wyoming: U.S. Geological Survey Open-File Report 87-124, 25 p.

Kuenzi, W.D., 1966, Tertiary stratigraphy of the Jefferson River Basin, Montana: Missoula, University of Montana, Ph.D. dissertation, 293 p.

Kuenzi, W.D., and R.W. Fields, 1971, Tertiary stratigraphy, structure and geologic history, Jefferson Basin, Montana: Geological Society of America Bulletin, v. 82, p. 3,374-3,394.

Kuenzi, W.D., and Richard, B.H., 1969, Middle Tertiary unconformity, North Boulder and Jefferson basins, southwest Montana: Geological Society of America Bulletin, v. 80, p. 315-320.

McCulloch, Robin, 1992, Montana mining directory 1991, Montana Bureau of Mines and Geology Bulletin 130, 136 p. 1993, Montana mining directory 1992, Montana Bureau of Mines and Geology Bulletin 131, $76 \mathrm{p}$.

Missouri River Basin Commission, 1981, Upper Missouri River basin level B study report and environmental impact statement: Omaha, Nebraska, 186 p.

[Montana] State Engineer's Office, 1954a, Water resources survey, Madison County, Montana--Part 1, History of land and water use on irrigated areas: Helena, Mont., State Engineer's Office, 68 p.

1954b, Water resources survey, Madison County, Montana--Part 2, Maps showing irrigated areas: Helena, Mont., State Engineer's Office, $62 \mathrm{p}$.

1956a, Water resources survey, Jefferson County, Montana--Part 1, History of land and water use on irrigated areas: Helena, Mont., State Engineer's Office, 54 p.

1956b, Water resources survey, Jefferson County, Montana--Part 2, Maps showing irrigated areas: Helena, Mont., State Engineer's Office, $29 \mathrm{p}$.

National Oceanic and Atmospheric Administration, 1992, Monthly normals of temperature, precipitation, and heating and cooling degree days, 1961-90, Montana: Asheville, N.C., Climatography of the United States no. 81, unpaged.

Noble, R.A., Bergantino, R.N., Patton, T.W., Sholes, B.C., Daniel, Faith, and Schofield, Judeykay, 1982, Occurrence and characteristics of ground water of Montana--Volume 2, The Rocky Mountain Region: Montana Bureau of Mines and Geology Open-File Report 99, 132 p.

O'Haire, D.P., 1978, Geology and hydrology of hot springs in the Jefferson valley, Montana: Bozeman, Montana State University, M.S. thesis, 100 p.

Parker, J.S., 1961, A preliminary seismic investigation of Tertiary basin fill in the Jefferson Island Quadrangle, Montana: Bloomington, Indiana University, M.A. thesis, 35 p.

Rasmussen, D.L., and Fields, R.W., 1983, Structural and depositional history, Jefferson and Beaverhead basins, southwestern Montana [abs.]: American Association of Petroleum Geologists Bulletin, v. 67, no. 8, p. 1352.

Reshkin, Mark, 1963, Geomorphic history of the Jefferson basin, Jefferson, Madison and Silver Bow Counties, Montana: Bloomington, Indiana University, Ph.D. dissertation, 146 p. 
Richard, B.H., 1966, Geologic history of the intermontane basins of the Jefferson Island quadrangle, Montana: Bloomington, Indiana University, Ph.D. dissertation, $121 \mathrm{p}$.

Ruppel, E.T., 1993, Cenozoic tectonic evolution of southwest Montana and east-central Idaho: Montana Bureau of Mines and Geology Memoir 65, 62 p.

Ruppel, E.T., O’Neill, J.M., and Lopez, D.A., 1993, Geologic map of the Dillon $1^{\circ} \times 2^{\circ}$ quadrangle, Idaho and Montana: U.S. Geological Survey Miscellaneous Investigations Series Map I-1803-H, scale 1:250,000.

Schmidt, C.J., and Hendrix, T.E., 1981, Tectonic controls for thrust belt and Rocky Mountain foreland structures in the northern Tobacco Root Mountains--Jefferson Canyon area, southwestern Montana, in Montana Geological Society Field Conference and Symposium Guidebook to Southwest Montana: [Billings, Mont.], Montana Geological Society, p. 167-180.

Shields, R.R., Knapton, J.R., White, M.K., Brosten, T.M., and Chambers, C.L., 1993, Water resources data, Montana, water year 1992: U.S. Geological Survey Water-Data Report MT-92-1, p. 90.

Sonderegger, J. L., and Bergantino, R. N., 1981, Geothermal resources map of Montana: Montana Bureau of Mines and Geology Hydrogeologic Map 4, scale 1:1,000,000.

Suttner, L.J., Schwartz, R.K., James, W.C., 1981, Late Mesozoic to early Cenozoic foreland sedimentation in southwest Montana, in Montana Geological Society Field Conference and Symposium Guidebook to Southwest Montana: [Billings, Mont.], Montana Geological Society, p. 93-103.

Thompson, G.R., Fields, R.W., and Alt, David, 1981, Tertiary paleoclimates, sedimentation patterns and uranium distribution in southwestern Montana, in Montana Geological Society Field Conference and Symposium Guidebook to Southwest Montana: [Billings, Mont.], Montana Geological Society, p. 105-109.

Tuck, L.K., Briar, D.W., and Clark, D.W., in press, Geologic history and hydrogeologic units of intermontane basins of the Northern Rocky Mountains, Montana and Idaho: U.S. Geological Survey Hydrologic Investigations Atlas 738-A, 2 sheets, scale 1:750,000.

U.S. Geological Survey, issued annually, Water resources data, Montana: Helena, Mont., U.S. Geological Survey Water-Data Report.

U.S. Environmental Protection Agency, 1991, Maximum contaminant levels (subpart B of part 141, National primary drinkingwater regulations): U.S. Code of Federal Regulations, Title 40, Parts 100 to 149, revised July 1, 1991, p. 585-588.

Vane, Gregg, 1972, A seismic reflection investigation of the Jefferson River Basin, Jefferson, Madison, and Silver Bow Counties, Montana: Bloomington, Indiana University, M.S. thesis, 38 p.

Vice, D.H., 1982, A review of the thermal infrared imagery for the Jefferson River survey, southwestern Montana: Montana Bureau of Mines and Geology Open-File Report 98, 18 p.

Wilson, D.A., 1962, A seismic and gravity investigation of the North Boulder River and Jefferson River valleys, Madison and Jefferson Counties, Montana: Bloomington, Indiana University, M.A. thesis, 43 p. 


\section{Geography}

The Jocko River Valley is a northwest-trending intermontane basin in the southern part of the Flathead Indian Reservation. The $60-\mathrm{mi}^{2}$ basin is bounded by the Mission Range on the east and the Reservation Divide mountains on the south and west (pl. 1). The Jocko River drains the basin. Steep-sided mountains mantled with glacial till rise abruptly from the edges of the basin. The Jocko River Valley ranges in altitude from about $2,800 \mathrm{ft}$ where the Jocko River flows out of the basin, to about 4,600 ft along the southem basin margin.

Two alluvial fans dominate the basin topography. The southem fan emerges from a terminal alpine glacial moraine in the mountains south of the basin and slopes to the north; State Highway 200 traverses its western side. The Jocko River alluvial fan originates on the eastemmost edge of the basin, where the Jocko River emerges from the mountains. About 2 mi south of

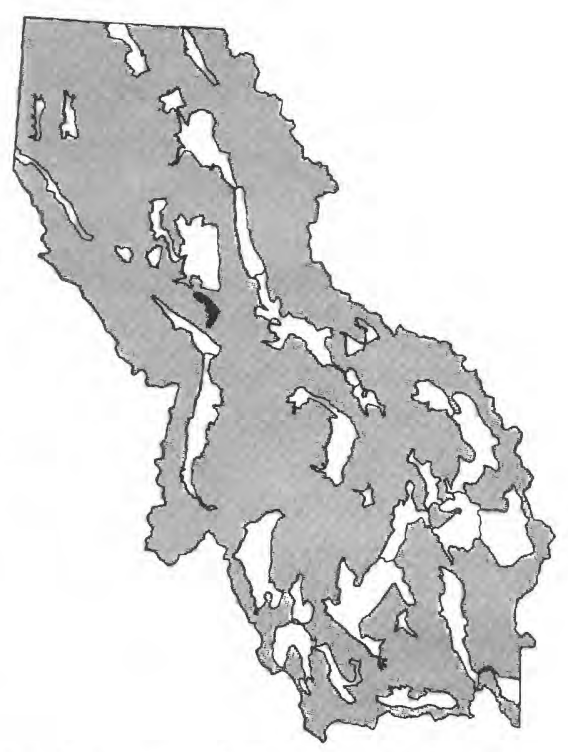
Arlee, the Jocko River fan intercepts the southem fan and the basin surface slopes more gently to the northwest. Whereas the southerm fan is not deeply eroded, the Jocko River has incised more than $100 \mathrm{ft}$ into the Jocko River fan, creating a series of narrow terraces along the river.

The National Weather Service does not maintain a weather station in the Jocko River Valley, but monitors precipitation and temperature at St. Ignatius about $6 \mathrm{mi}$ north of the basin. The climate is typical of lower-elevation intermontane basins of the Northern Rocky Mountains west of the Continental Divide. On the basis of the 1961-90 period of record, the average annual precipitation at St. Ignatius (altitude 2,900 ft) is $16.66 \mathrm{in}$., and the average annual temperature is $45.8^{\circ} \mathrm{F}$ (National Oceanic and Atmospheric Administration, 1992). The average last occurrence of $32^{\circ} \mathrm{F}$ is May 22, and the average first occurrence is September 17 (Natural Resources Conservation Service, U.S. Department of Agriculture, unpub. data, 1994). Mean monthly climatic data for St. Ignatius are plotted in figure 23. Precipitation increases along the edges of the basin; with the front of the Mission Range receiving about 20 in. per year (U.S. Soil Conservation Service, 1977).

Land uses include rangeland and irrigated hay and grain production. In addition, dryland small grains are grown to a limited extent on upper reaches of alluvial fans (J.C. Eggen, Agricultural Stabilization and Conservation Service, oral commun., 1993). The Flathead Agency Irrigation Division manages an elaborate network of distribution canals that divert water from the Jocko River and its tributaries to irrigable land in the Jocko River drainage area. In 1985, the amount of surface water diverted for irrigation was reduced in order to maintain instream flows (Thompson and others, 1989). About 2,000 people reside in Jocko River Valley, including 489 in the unincorporated community of Arlee and 73 in the unincorporated community of Evaro (1990 census).

\section{Geology}

The Jocko River Valley is bounded by high-angle normal faults, and cross-cut by at least two major normal faults (Harrison and others, 1986). Readily visible fault scarps indicate late Quatemary activity along the base of the Mission Range (Ostenaa and others, 1993). On the basis of well logs, Slagle (1988) and Thompson (1988) concluded that most of the bedrock floor of the basin is less than $500 \mathrm{ft}$ below land surface and that basin fill attains its maximum thickness of more than $500 \mathrm{ft}$ in an area 4 to $6 \mathrm{mi}$ southeast of Arlee.

Several investigators have examined the geology of the Jocko Valley (table 40). The geologic units described by previous investigators are summarized below. These geologic units are referenced to hydrogeologic units defined in this study (table 2) to provide a consistent regional framework. In the following discussion, the hydrogeologic-unit abbreviations are italicized. 
Table 40. Geologic maps of the Jocko River Valley, Montana

\begin{tabular}{|c|c|c|c|c|}
\hline Type of map & Scale & Location & Map features & Reference \\
\hline Geology & $1: 250,000$ & $\begin{array}{l}\text { Entire Jocko } \\
\text { River Valley }\end{array}$ & $\begin{array}{l}\text { Differentiates four basin-fill units: Pleistocene } \\
\text { glacial deposits, Pleistocene lake sediments, } \\
\text { Holocene landslide deposits, and Holocene } \\
\text { alluvium }\end{array}$ & $\begin{array}{l}\text { Harrison and others, } \\
1986\end{array}$ \\
\hline Geology & $1: 126,720$ & $\begin{array}{l}\text { Entire Jocko } \\
\text { River Valley }\end{array}$ & $\begin{array}{l}\text { All basin fill is identified as Quaternary to } \\
\text { Tertiary valley-fill deposits. Depth to bedrock } \\
\text { is designated at } 11 \text { locations }\end{array}$ & Slagle, 1988, pl. 1 \\
\hline
\end{tabular}

Metasedimentary rocks of the Middle Proterozoic Belt Supergroup ( $Y \mathrm{~ms}$ ) surround and floor the basin. Around most of the basin, these rocks consist of siltite, argillite, and quartzite; rocks that border the basin on the east and northwest also contain significant amounts of dolomite and limestone. The Proterozoic bedrock is extensively folded and faulted (Harrison and others, 1986; Mudge and others, 1982).

Although few Tertiary sediments (Ts) are exposed at the surface, they are inferred from well logs and seismic refraction surveys to overlie bedrock in much of the basin (Slagle, 1988; Makepeace, 1989) and possibly to form terraces along the northem basin margins (Slagle, 1988; Thompson, 1988, p. 28). The composition varies, but is dominantly clay, indicating a lacustrine origin. In places, Tertiary sediments have also been described as red gravel and sandstone, cemented gravel with dark-brown and yellow silt, and partially cemented gravel and friable gray sandstone with minor lignite (Alden, 1953; Slagle, 1988).

Terminal moraines from several alpine glaciers extend to the edges of the basin from surrounding mountains. The moraines are composed of glacial till $(Q g)$--an unsorted mixture of gravel- to boulder-sized clasts in a silty clay matrix (Thompson, 1988).

Pleistocene glacial Lake Missoula inundated the Jocko River Valley at least 40 times (Chambers, 1984), leaving glacial-lakebed deposits $(Q g)$ which consist of buff-to-lavender, varved, silty clay with a few lenses of sand and occasional gravel seams. Erosion has removed most glacial-lakebed deposits from the basin. However, remnants are exposed in the northern area and drillers' logs indicate that fluvially reworked glacial-lakebed deposits are present in the lower part of the Jocko River alluvial fan (Harrison and others, 1986; Thompson, 1988).

The Quaternary alluvium (Qal) that forms the alluvial fan in the southem part of the basin is composed primarily of reworked glacial till and glacial-lakebed deposits. The surface of the fan is strewn with boulders up to $14 \mathrm{ft}$ in diameter. Beneath the surface, the alluvium is dominantly gravel and tan silt. In contrast, outcrops at the head of the fan, near Evaro, display thick beds of gravel, cobbles, and boulders, which were possibly deposited during catastrophic draining of glacial Lake Missoula (Thompson, 1988).

The Jocko River fan consists of silt, sand, gravel, cobbles, and boulders typical of braided glacial outwash. Grain size generally decreases toward the northwest, where silty alluvium grades into glacial-lakebed deposits. Throughout the alluvial fan, silt accounts for more than 50 percent of the matrix. The head of the Jocko River fan overlies and probably interfingers with the foot of the southern alluvial fan (Thompson, 1988; Makepeace, 1989).

\section{Hydrology}

The Jocko River originates in the southern part of the Mission Range and flows northwest through the Jocko River Valley. After leaving the intermontane basin through a narrow bedrock valley, the river flows to its confluence with the Flathead River near Dixon. Several small tributaries to the Jocko River drain the southem part of the basin. More than $60 \mathrm{mi}$ of irrigation canals inodify the surface-water drainage. As part of the irrigation system, water has been stored in Upper Jocko Lake (gaging station 12380000, drainage area $2.99 \mathrm{mi}^{2}$ ) since 1967 and in Lower Jocko 
Lake (gaging station 12380500 , drainage area $7.39 \mathrm{mi}^{2}$ ) since 1939 . Natural drainage is further modified by transmountain diversions that take water from the Clearwater River drainage to Upper Jocko Lake in the Jocko River drainage, and from Lower Jocko Lake in the Jocko River drainage to St. Mary's Lake in the Mission Valley drainage (Shields and others, 1993).

Streamflow data for gaging stations listed in table 41 are stored in the USGS WATSTORE database. Locations of the stations are shown on plate 1. In addition, the USGS has published monthend reservoir volume records for Upper and Lower Jocko Lakes in annual Water-Data Reports since 1968 (U.S. Geological Survey, issued annually). Discharge data are also available for several stations that were measured during the 1900's and 1910's to help plan the construction of the irrigation system.

Table 41. Summary of data for U.S. Geological Survey streamflow-gaging stations in the Jocko River Valley, Montana

[Type of data collected: c, water chemistry; d, discharge; s, suspended sediment. Periods of record for stations that were being operated as of November 1994 are indicated by the first year of record followed by a dash only. Abbreviations: $\mathrm{ft}^{3} / \mathrm{s}$, cubic feet per second. Symbol: --, no data]

\begin{tabular}{|c|c|c|c|c|c|c|c|c|c|}
\hline \multirow[b]{2}{*}{$\begin{array}{l}\text { Station } \\
\text { number }\end{array}$} & \multirow[b]{2}{*}{ Station name } & \multirow{2}{*}{$\begin{array}{c}\text { Drainage } \\
\text { area } \\
\text { (square } \\
\text { milles) }\end{array}$} & \multirow{2}{*}{$\begin{array}{l}\text { Type } \\
\text { of } \\
\text { data } \\
\text { col- } \\
\text { lected }\end{array}$} & \multirow[b]{2}{*}{$\begin{array}{l}\text { Perlod of record } \\
\text { (calendar year) }\end{array}$} & \multicolumn{5}{|c|}{ Discharge for perlod of record } \\
\hline & & & & & $\begin{array}{c}\text { Mean } \\
\text { annual } \\
\left(\mathrm{ft}^{3} / \mathrm{s}\right)\end{array}$ & $\begin{array}{l}\text { Maxl- } \\
\text { mum } \\
\left(\mathrm{ft}^{3} / \mathrm{s}\right)\end{array}$ & $\begin{array}{l}\text { Date of } \\
\text { maxlmum }\end{array}$ & $\begin{array}{l}\text { Mint- } \\
\text { mum } \\
\left(\mathrm{ft}^{3} / \mathrm{s}\right)\end{array}$ & $\begin{array}{l}\text { Date of } \\
\text { minimum }\end{array}$ \\
\hline 12381400 & $\begin{array}{l}\text { South Fork Jocko } \\
\text { River near Arlee }\end{array}$ & 56.0 & $\begin{array}{l}\mathrm{d} \\
\mathrm{c}\end{array}$ & $\begin{array}{l}1982- \\
1983-86\end{array}$ & 53.4 & 596 & $05-10-89$ & $T_{2.0}$ & 02-04-89 \\
\hline 12383500 & $\begin{array}{l}\text { Big Knife Creek near } \\
\text { Arlee }\end{array}$ & 6.88 & $\begin{array}{l}\text { d } \\
\text { c }\end{array}$ & $\begin{array}{l}1910-16,1982- \\
1983-85\end{array}$ & 10.0 & 78 & $06-30-16$ & 1.3 & 02-04-89 \\
\hline 12387450 & $\begin{array}{l}\text { Valley Creek near } \\
\text { Arlee }\end{array}$ & 15.3 & d & $\begin{array}{l}1982 \text { - (seasonal } \\
\text { records only) } \\
1983-85 \text { (seasonal } \\
\text { records only) }\end{array}$ & -- & 96 & $05-19-91$ & ${ }^{15.5}$ & 04-01-88 \\
\hline 12388200 & Jocko River at Dixon & 380 & $\begin{array}{c}d \\
c, s\end{array}$ & $\begin{array}{l}1990- \\
1987-1992\end{array}$ & 190 & 1,130 & $05-19-91$ & 194 & $02-24-93$ \\
\hline
\end{tabular}

Towest daily mean.

Surface-water quality has been determined for two streams in the Jocko River Valley. Analyses of 15 samples from Big Knife Creek near Arlee (gaging station 12383500) indicate a calcium bicarbonate type water with an average dissolved-solids concentration of $104 \mathrm{mg} / \mathrm{L}$. Analyses of 31 samples from the Jocko River at Dixon (gaging station 12388200) also indicate a calcium bicarbonate type water, but with a slightly higher average dissolved-solids concentration of $127 \mathrm{mg} / \mathrm{L}$ and a slightly higher ratio of magnesium to calcium than Big Knife Creek (Clark and Dutton, in press). Irrigation return flows carry sediment and dissolved salts into the river and, on occasion, pesticides have caused fish kills in the Jocko River below Arlee (Nunnallee and Botz, 1976).

Ground water is an important resource in the Jocko River Valley. The basin-fill aquifer provides domestic water for all basin residents (Makepeace, 1989).

The primary aquifer is unconsolidated Quaternary alluvium underlying the Jocko River alluvial fan. Well yields of as much as $400 \mathrm{gal} / \mathrm{min}$ and specific-capacity values of more than 20 ( $\mathrm{gal} / \mathrm{min}) / \mathrm{ft}$ have been reported for wells completed in this aquifer (Slagle, 1988). The average hydraulic conductivity determined from four slug tests and one aquifer test near Arlee was $7.0 \mathrm{ft} / \mathrm{d}$ (Slagle, 1992). On the basis of specific-capacity data reported by drillers, Thompson (1988) estimated that the average hydraulic conductivity of the fan material is $270 \mathrm{ft} / \mathrm{d}$. Makepeace (1989) analyzed an aquifer test for a well east of Arlee and about $0.4 \mathrm{mi}$ north of the Jocko River that penetrates the entire $307 \mathrm{ft}$ of alluvial-fan material. Although the test indicated a horizontal hydraulic conductivity of $53 \mathrm{ft} / \mathrm{d}$, hydraulic conductivity values ranging from 75 to $1,800 \mathrm{ft} / \mathrm{d}$ were required to calibrate a two-dimensional numerical ground-water flow model of the alluvial fan. Specific yiclds of 0.1 to 0.25 were input to calibrate a transient model 
(Makepeace, 1989). The upper part of the Jocko River alluvial fan is unconfined; however, north of Arlee, silty material in the aquifer confines or semi-confines ground water (Thompson, 1988).

Quatemary alluvium in the southem fan also transmits ground water, but low-permeability material separates laterally discontinuous permeable zones, rendering alluvium in the southem fan less productive than alluvium in the Jocko River fan. The western margin of the southern fan is the most productive, with specific capacity values as large as 9.5 (gal/min)/ft and hydraulic conductivity values as large as $670 \mathrm{ft} / \mathrm{d}$ and averaging $230 \mathrm{ft} / \mathrm{d}$. In the center and eastern part of the southern fan, the average hydraulic conductivity is about $80 \mathrm{ft} / \mathrm{d}$. Ground water is unconfined in the southern alluvial fan (Thompson, 1988).

Glacial-lakebed deposits and glacial till are not productive aquifers in the Jocko River Valley. Where terminal moraine deposits have been reworked near the basin margins, they potentially could yield sufficient water for domestic wells; however, these deposits commonly are unsaturated. Discontinuous, coarse-grained lenses within glacial-lakebed deposits can yield water to wells but these scarce lenses cannot be located prior to drilling. In the northem part of the basin, silty glacial-lakebed deposits confine the underlying alluvium (Thompson, 1988).

Few wells in the Jocko River Valley are completed in Tertiary sediments. Tertiary sediments generally underlie productive Quatemary aquifers and are relatively impermeable. On the basis of a reported specific capacity of 0.04 ( $\mathrm{gal} / \mathrm{min}) / \mathrm{ft}$, Thompson (1988) computed a hydraulic conductivity of $0.46 \mathrm{ft} / \mathrm{d}$ for one well.

Fractures within the Proterozoic bedrock that surrounds and underlies the basin can yield sufficient water for domestic use. Of 33 bedrock wells tested throughout the Flathead Indian Reservation, yields ranged from 2.5 to 40 $\mathrm{gal} / \mathrm{min}$ and averaged $9.5 \mathrm{gal} / \mathrm{min}$; specific-capacity values ranged from 0.08 to $3.2(\mathrm{gal} / \mathrm{min}) / \mathrm{ft}$ and averaged 0.73 (gal/min)/ft (Slagle, 1988).

Potentiometric-surface maps (table 42) indicate that ground water generally flows northward through the southern alluvial fan. At the Jocko River fan, the hydraulic gradient decreases and the ground-water flow direction becomes more northwesterly, parallel to the Jocko River (Makepeace, 1989; Slagle, 1988; Thompson, 1988). The map by Slagle (1988) indicated a larger component of flow from the northwestern basin margin toward the Jocko River than the maps by Makepeace (1989) and Thompson (1988) suggest.

Table 42. Potentiometric-surface maps of the Jocko River Valley, Montana

\begin{tabular}{llcl}
\hline $\begin{array}{c}\text { Dates water levels } \\
\text { were measured }\end{array}$ & Scale & $\begin{array}{c}\text { Contour } \\
\text { Interval } \\
\text { (feet) }\end{array}$ & \multicolumn{1}{c}{ Reforence } \\
\hline $1949-1988$ & $1: 58,000$ & 50 & Thompson, 1988, fig. 12, p. 41 \\
1967-1984 & $1: 126,720$ & 100 & Slagle, 1988, pl. 2 \\
January and July 1988 & $1: 225,000$ & 25 & Thompson and others, 1989, fig. 2, p. 698 \\
July 1988 & $1: 50,000$ & 25 & Makepeace, 1989, fig. 16, p. 38 \\
March 1989 & $1: 50,000$ & 25 & Makepeace, 1989, fig. 17, p. 39 \\
\hline
\end{tabular}

The water table is about 10 to $50 \mathrm{ft}$ below land surface in the southem part of the basin, and $150 \mathrm{ft}$ below land surface where the two major alluvial fans coalesce. At the northwestem end of the basin, along the Jocko River, the water table intersects the land surface. Water levels in wells completed in the Jocko River fan fluctuate up to $30 \mathrm{ft}$ annually, rising from April through June and then declining through March. During the 1980's, the region recorded below-average precipitation. Simultaneously, diversions of surface water to irrigation canals were reduced in order to maintain instream flows. Responding to diminished recharge from precipitation and leaky canals, the water table declined, causing many wells to go dry (Thompson and others, 1989; Makepeace, 1989).

Water levels measured in long-term monitoring well 16N19W08ACBD01 are stored in the USGS WATSTORE database. The $307-\mathrm{ft}$ well is completed in Pleistocene fluvial deposits. During the period of record from July 1990 to Oct. 7, 1994, the water level in the well has fluctuated between $138.74 \mathrm{ft}$ below land surface (July 22, 1993) and $188.29 \mathrm{ft}$ below land surface (Apr. 5, 1994). 
Basin-fill aquifers are recharged by precipitation and snowmelt, surplus irrigation water, leakage from canals, subsurface flow from bedrock, and infiltration from the Jocko River and tributary streams. The ground-water contribution area (fig. 2, pl. 1) is about $330 \mathrm{mi}^{2}$. Infiltration anywhere within this area could potentially recharge basin-fill aquifers in the Jocko River Valley. Ground water discharges from the basin-fill aquifers by evapotranspiration, withdrawals from wells, and seepage to springs, seeps, irrigation drains, and stream channels.

Several components of the ground-water budget have been examined (Slagle, 1988; 1992). Irrigation canals modify the natural drainage system considerably and also recharge basin-fill aquifers. Slagle (1992) used seepage meters, tracer tests, water-temperature profiles, and aquifer tests to determine leakage rates from unlined canals in different hydrogeologic units throughout the Flathead Reservation. Average leakage rates were $0.001 \mathrm{ft} / \mathrm{d}$ in bedrock, $0.0013 \mathrm{ft} / \mathrm{d}$ in glacial-lakebed deposits, $0.0012 \mathrm{ft} / \mathrm{d}$ in glacial till, and $0.0023 \mathrm{ft} / \mathrm{d}$ in alluvium. Recharge from bedrock may be indicated by a water temperature of $18.0^{\circ} \mathrm{C}$ in a well at $18 \mathrm{~N} 20 \mathrm{~W} 32 \mathrm{CBDA}$ (Slagle, 1988). Slagle (1988) also estimated that withdrawals from wells accounted for about 500 to 840 acre-ft of ground-water discharge from the Jocko River Valley in 1980.

Makepeace (1989) computed a water budget for the Jocko River alluvial fan. Although the exact quantities of flow are poorly constrained, it is evident that underflow from the southern alluvial fan is an important source of recharge to the Jocko River alluvial-fan aquifer.

Interaction between ground water and surface water accounts for a significant component of the ground-water budget. Synoptic streamflow measurements by Slagle (1988) on February 13, 1984 indicate that the Jocko River gained about $46 \mathrm{ft}^{3} / \mathrm{s}$ when the effects of evapotranspiration and irrigation return flow were minimal. In contrast, the river loses about 50 percent of its flow to ground water at the head of the Jocko River alluvial fan, within the first $3 \mathrm{mi}$ of the river entering the basin. The amount of seepage from the river to the aquifer, as well as the length of river from which seepage occurs, decreases with receding river stage following spring runoff (Makepeace, 1989; Thompson and others, 1989).

The quality of ground water in the basin was determined on the basis of eight samples analyzed for major ions and measured dissolved-solids concentrations. Throughout the basin, ground water is a calcium bicarbonate type with dissolved-solids concentrations of less than $250 \mathrm{mg} / \mathrm{L}$ (Clark and Dutton, in press).

\section{Selected References}

Alden, W.C., 1953, Physiography and glacial geology of western Montana and adjacent areas: U.S. Geological Survey Professional Paper 231, 200 p.

Briar, D.W., Lawlor, S.M., Stone, M.A.J., Parliman, D.J., Schaefer, J.L., and Kendy, Eloise, in press, Ground-water levels in intermontane basins of the Northern Rocky Mountains, Montana and Idaho: U.S. Geological Survey Hydrologic Investigations Atlas 738-B, 1 sheet, scale 1:750,000.

Chambers, R.L., 1984, Sedimentary evidence for multiple glacial Lakes Missoula, in Northwest Montana and Adjacent Canada, Montana Geological Society 1984 Field Conference and Symposium: [Billings, Mont.], Montana Geological Society, p. 189-199.

Clark, D.W., and Dutton, D.M., in press, Quality of ground water and surface water in intermontane basins of the Northern Rocky Mountains, Montana and Idaho: U.S. Geological Survey Hydrologic Investigations Atlas 738-C, 1 sheet, scale 1:750,000.

Curry, R.R., Lister, J.C., and Stoffel, Keith, 1977, Glacial history of Flathead Valley and Lakes Missoula floods, in Glacial geology of Flathead Valley and catastrophic drainage of glacial Lakes Missoula: Rocky Mountain Section, Geological Society of America 30th Annual Meeting Field Guide No. 4, p. 14-38.

Dutton, D.M., Lawlor, S.M., Briar, D.W., and Tresch, R.E., 1995, Hydrogeologic data for the Northern Rocky Mountains intermontane basins, Montana: U.S. Geological Survey Open-File Report 95-143, 94 p.

Harrison, J.E., Griggs, A.B, and Wells, J.D., 1986, Geologic and structure maps of the Wallace $1^{\circ} \times 2^{\circ}$ quadrangle: U.S. Geological Survey Miscellaneous Investigation Series Map I-1509, 2 sheets, scale 1:250,000. 
Levings, G.W., and White, M.K., 1983, Selected annotated bibliography of ground-water resources, records of wells and springs, and availability of streamflow data on Indian reservations in Montana: U.S. Geological Survey Open-File Report 83-129, $137 \mathrm{p}$.

Makepeace, S.V., 1989, Simulation of ground water flow in a coarse grained alluvial aquifer in the Jocko Valley, Flathead Indian Reservation, Montana: Missoula, University of Montana, M.S. thesis, 155 p.

[Montana] State Engineer's Office, 1963a, Water resources survey, Lake County, Montana--Part 1, History of land and water use on irrigated areas: Helena, Mont., State Engineer's Office, 53 p.

1963b, Water resources survey, Lake County, Montana--Part 2, Maps showing irrigated areas: Helena, Mont., State Engineer's Office, $32 \mathrm{p}$.

Morrison-Maierle, Inc. and James M. Montgomery, Consulting Engineers, Inc., 1977, Lakes and streams water quality study, Flathead drainage, Montana: [Helena, Mont.], Morrison-Maierle, Inc., variously paged.

Mudge, M.R., Earhart, R.L., Whipple, J.W., and Harrison, J.E., 1982, Geologic and structure maps of the Choteau $1^{\circ} \times 2^{\circ}$ quadrangle, northwestern Montana: U.S. Geological Survey Miscellaneous Investigations Series Map I-1300, 2 sheets, scale $1: 250,000$.

National Oceanic and Atmospheric Administration, 1992, Monthly normals of temperature, precipitation, and heating and cooling degree days, 1961-90, Montana: Asheville, N.C., Climatography of the United States no. 81, unpaged.

Noble, R.A., Bergantino, R.N., Patton, T.W., Sholes, B.C., Daniel, Faith, and Schofield, Judeykay, 1982, Occurrence and characteristics of ground water of Montana--Volume 2, The Rocky Mountain Region: Montana Bureau of Mines and Geology Open-File Report 99, 132 p.

Nunnallee, David, and Botz, M.K., 1976, Water quality inventory and management plan, lower Clark Fork River basin, Montana: Montana Department of Health and Environmental Sciences, $129 \mathrm{p}$.

Ostenaa, D.A., Klinger, R.E., and Levish, D.R., 1993, Holocene faulting on the Mission fault, northwest Montana [abs.]: Geological Society of America Abstracts with Programs, v. 25, no. 5, p. 130.

Shields, R.R., Knapton, J.R., White, M.K., Brosten, T.M., and Chambers, C.L., 1993, Water resources data, Montana, water year 1992: U.S. Geological Survey Water-Data Report MT-92-1, 534 p.

Slagle, S.E., 1988, Geohydrology of the Flathead Indian Reservation, northwestern Montana: U.S. Geological Survey WaterResources Investigations Report 88-4142, 152 p.

1992, Irrigation-canal leakage in the Flathead Indian Reservation, northwestern Montana: U.S. Geological Survey WaterResources Investigations Report 92-4066, 77 p.

Thompson, W.R., 1988, Hydrogeology of the Jocko Valley, west-central Montana: Missoula, University of Montana, M.S. thesis, $120 \mathrm{p}$.

Thompson, W.R., Makepeace, Seth, and Woessner, W.W., 1989, Recharge/discharge relationships in a coarse-grained alluvial aquifer, in Woessner, W.W., and Potts, D.F., eds., Symposium on Headwaters Hydrology, 1989, Proceedings: Bethesda, Md., American Water Resources Association, p. 695-703.

Tuck, L.K., Briar, D.W., and Clark, D.W., in press, Geologic history and hydrogeologic units of intermontane basins of the Northern Rocky Mountains, Montana and Idaho: U.S. Geological Survey Hydrologic Investigations Atlas 738-A, 2 sheets, scale $1: 750,000$.

U.S. Geological Survey, issued annually, Water resources data, Montana: Helena, Mont., U.S. Geological Survey Water-Data Report.

U.S. Soil Conservation Service, 1977, Average annual precipitation in Montana, based on 1941-1970 data: Bozeman, Montana, $13 \mathrm{p}$.

Wunder, Laura, 1974, Water use, surface water, and water rights on the Flathead Indian Reservation, Montana, a review: Missoula, University of Montana, M.S. thesis, 250 p. 


\section{Kalispell Valley}

\section{Geography}

The Kalispell Valley is a north-northwest trending intermontane basin in northwestem Montana. The $490-\mathrm{mi}^{2}$ basin is bounded by Flathead Lake on the south, the Salish Mountains on the west, Stryker Ridge on the northwest, the Whitefish Range on the north, and the Swan Range on the east (pl. 1). The Kalispell Valley ranges in altitude from about $2,900 \mathrm{ft}$ at Flathead Lake to about $5,200 \mathrm{ft}$ on the highest terrace.

The southwestward-flowing Flathead River is the principal stream in the Kalispell Valley. The Stillwater and Whitefish Rivers flow southward across the basin, joining the Flathead River near Kalispell. The flood plains and terraces of these rivers are the principal topographic features of the Kalispell Valley. North of Kalispell, the narrow flood plain of the Flathead River is flanked by low terraces. South of Kalispell, the Flathead River meanders past numerous oxbows within a 6-mi-wide flood plain. The river discharges into Flathead Lake (pl. 1).

Glacially sculpted terraces flank the flood plains. The terrace between the Flathead River and the Swan Range to the east has a hummocky surface typical of kame and kettle topography, grading northward to swell-and-swale features. The terrace between the Whitefish and Stillwater Rivers grades from swell-and-swale topography in the south to rolling sand hills in the north. Glacial scouring left narrow, distinct, south-trending ridges on the hills between Whitefish Lake and the Stillwater River. The glaciated terrain northwest of Kalispell is marked by kames, kettles, and drumlins (Konizeski and others, 1968).

The modified Pacific maritime climate of the Kalispell Valley is typical of low-elevation intermontane basins of the Northern Rocky Mountains west of the Continental Divide. On the basis of the 1961-90 period of record, the average annual precipitation at Kalispell (altitude 2,970 ft) is $16.51 \mathrm{in}$., and the average annual temperature is $42.4^{\circ} \mathrm{F}$ (National Oceanic and Atmospheric Administration, 1992). The average last occurrence of $32^{\circ} \mathrm{F}$ is June 2 and the average first occurrence is September 12 (Natural Resources Conservation Service, U.S. Department of Agriculture, unpub. data, 1994). Mean monthly climatic data for Kalispell are plotted in figure 17. Flathead Lake moderates

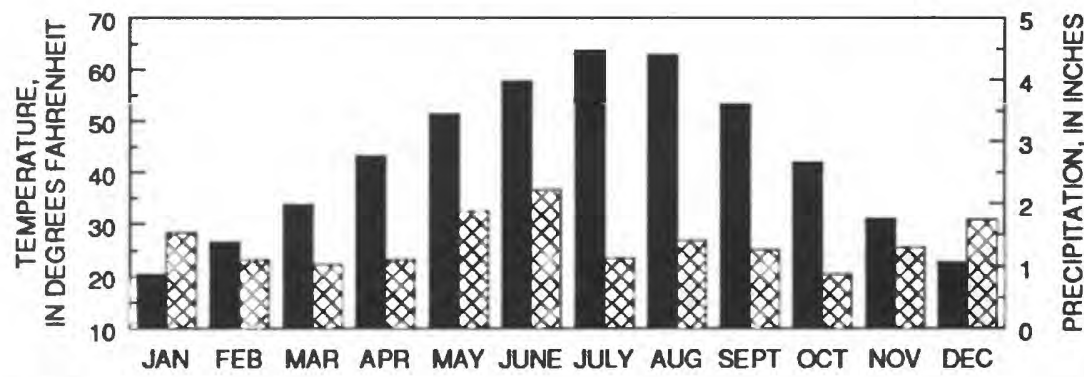

EXPLANATION

MEAN MONTHLY TEMPERATURE FOR 1961-90 PERIOD OF RECORD

$\bigotimes$
MEAN MONTHLY PRECIPITATION FOR 1961-90 PERIOD OF RECORD

Figure 17. Mean monthly precipitation and temperature at Kalispell, Mont. Data from National Oceanic and Atmospheric Administration (1992).

the climate locally, resulting in cooler summers, warmer winters, longer growing seasons, and more precipitation within several miles of the shoreline. At the north end of the Kalispell Valley, Olney (altitude 3,170 $\mathrm{ft}$ ) had an average annual precipitation of 23.04 in. and an average annual temperature of $41.2^{\circ} \mathrm{F}$ during the $1961-90$ period of record (National Oceanic and Atmospheric Administration, 1992). The average potential growing season in Olney 
extends from July 4 to August 24--considerably shorter than the lower-elevation areas in the southern part of the basin (Natural Resources Conservation Service, U.S. Department of Agriculture, unpub. data, 1994).

About 50,000 people reside in the Kalispell Valley, including 11,917 in the City of Kalispell; 4,368 in the City of Whitefish; 2,921 in the City of Columbia Falls; 1,461 in the unincorporated community of Big Fork; and 735 in the unincorporated community of Somers (1990 census). The population of the Kalispell Valley has grown considerably in the 1980's and 1990's.

Both surface- and ground-water resources are critical to the residents of the Kalispell Valley. Most people depend on municipal, community, or private wells to supply their drinking water. However, the City of Kalispell supplements its municipal water supply from wells with spring water. The City of Columbia Falls has abandoned its two shallow supply wells, primarily because of insufficient production, and is now changing from temporary surface-water sources to deep ground-water sources (C.M. Tesmer, Columbia Falls Public Works Director, oral commun., 1994). Surface water supplies municipal water to the City of Whitefish. A few large-capacity wells scattered throughout the basin produce water for irrigation but the vast majority of irrigation water is provided by surface-water diversions.

Land uses include irrigated and dryland agriculture, silviculture, and residential development. The Kalispell Valley produces sprinkler-irrigated grain, pasture, and hay (Nunnallee and others, 1976); livestock and dairy products; and some dryland grain. Sweet cherries are cultivated near Flathead Lake. Mint is an important crop near Kalispell. Timber has been harvested and processed throughout the basin and numerous Christmas tree farms are located east and south of Kalispell (J.C. Eggen, Agricultural Stabilization and Conservation Service, oral commun., 1993). Residential subdivisions are rapidly replacing irrigated agriculture as the dominant land use in the Kalispell Valley. This change in land use may eventually decrease the demand for surface-water diversions; however, in recent years these developments have substantially increased private well withdrawals and septic-system density. A large aluminum-reduction plant in Columbia Falls obtains process water from several large-capacity wells and discharges wastewater to percolation ponds on the plant premises.

\section{Geology}

The Kalispell Valley intermontane basin occupies the southern extension of the thousand-mile-long Rocky Mountain Trench (fig. 4) of late Paleocene to Eocene age (Harrison and others, 1992). The Kalispell Valley is bounded by normal faults on the east and west sides, and cross-cut by numerous faults, resulting in an irregularly shaped basin floor. Gravity data indicate that Bigfork is near the northern end of a north-northwest-trending horst (uplifted crustal block) which separates the grabens (downdropped crustal blocks) on which Flathead Lake and Echo Lake are approximately centered. According to Noble and others (1982), these grabens each contain about 2,000 ft of Cenozoic deposits--considerably less than the 4,800 ft reported by Konizeski and others (1968). A graben north of Creston and Kalispell contains about 4,000 ft of basin fill at its deepest point near LaSalle (Noble and others, 1982, p. 36; Harrison and others, 1992).

Several investigators have examined the geology of the Kalispell Valley (table 43). The geologic units described by previous investigators are summarized below. These geologic units are referenced to hydrogeologic units defined in this study (table 2) to provide a consistent regional framework. In the following discussion, the hydrogeologic-unit abbreviations are italicized.

Metasedimentary rocks of the Middle Proterozoic Belt Supergroup (Yms) surround the basin. These rocks include limestone, dolomite, siltite, quartzite, and argillite (Harrison and others, 1992).

Although no Tertiary sediments (Ts) crop out in the Kalispell Valley, this basin, like others in the Rocky Mountain Trench, contains hundreds to thousands of feet of Tertiary sediments beneath its glacial and alluvial veneer. A 1984 oil exploration well located in T. 31 N., R. 21 W., sec. 26, NW1/4 NE1/4 SE1/4 penetrated the Helena Formation at a depth of 1,695 ft. Overlying the bedrock are Tertiary sediments described as lignite, clay, and argillaceous, sandy siltstone from $1,695 \mathrm{ft}$ to $1,120 \mathrm{ft}$, overlain by peat, clay, and some sand from $1,120 \mathrm{ft}$ to $600 \mathrm{ft}$. 
Table 43. Geologic and geophysical maps of the Kalispell Valley, Montana

\begin{tabular}{|c|c|c|c|c|}
\hline Type of map & Scale & Location & Map features & Reference \\
\hline Geology & $1: 46,500$ & $\begin{array}{l}\text { Northwest of } \\
\text { Whitefish }\end{array}$ & Differentiates five Quaternary units & $\begin{array}{l}\text { Coffin and others, } 1971 \text {. } \\
\text { pl. } 1 \text { (south half) }\end{array}$ \\
\hline Geology & $1: 250,000$ & $\begin{array}{l}\text { Entire Kalispell } \\
\text { Valley }\end{array}$ & $\begin{array}{l}\text { Differentiates four basin-fill units: } \\
\text { Pleistocene lake sediments, Pleistocene } \\
\text { glacial and fluvioglacial (outwash) } \\
\text { deposits, Holocene landslide deposits, and } \\
\text { Holocene alluvial deposits. Includes an } \\
\text { east-west bedrock geologic section } \\
\text { through Whitefish Lake }\end{array}$ & $\begin{array}{l}\text { Harrison and others, } \\
1992\end{array}$ \\
\hline Geology & $1: 126,720$ & $\begin{array}{l}\text { Entire Kalispell } \\
\text { Valley }\end{array}$ & $\begin{array}{l}\text { Differentiates three Quaternary basin-fill } \\
\text { units: glacial deposits, glacial silt, and } \\
\text { alluvium. Includes an east-west bedrock } \\
\text { geologic section through Whitefish Lake }\end{array}$ & Johns, 1970, pl. 2 \\
\hline Geology & $1: 68,500$ & $\begin{array}{l}\text { Entire Kalispell } \\
\text { Valley }\end{array}$ & Differentiates six Quaternary basin-fill units & $\begin{array}{l}\text { Konizeski and others, } \\
\text { 1968, pl. } 1\end{array}$ \\
\hline $\begin{array}{l}\text { Cenozoic basin fill } \\
\text { isopach }\end{array}$ & $1: 500,000$ & $\begin{array}{l}\text { Entire Kalispell } \\
\text { Valley }\end{array}$ & Contour interval 1,000 feet & $\begin{array}{l}\text { Noble and others, } 1982 \text {, } \\
\text { fig. II-9, p. } 37\end{array}$ \\
\hline
\end{tabular}

The upper $600 \mathrm{ft}$ of material at the site are reported to be Pleistocene glacial deposits (Montana Board of Oil and Gas Conservation, unpub. data, 1990; Harrison and others, 1992).

About 600 to $1,000 \mathrm{ft}$ of Quatemary glacial deposits and alluvium overlie the Tertiary deposits (Noble and Stanford, 1986). At the base of these materials are well-sorted, poorly bedded sand, gravel, cobbles and boulders of glacial outwash $(\mathrm{Qal})$ interbedded with and underlying discontinuous lenses of fine-grained glacial till and glacial-lakebed deposits $(Q g)$. In the north-central and western parts of the basin, glacial till is clayey and bouldery, whereas along the eastern basin margin it is more sandy and gravelly. In the southem part of the basin, the glaciallakebed deposits are more than $600 \mathrm{ft}$ thick. Glacial Lake Missoula deposited well-bedded, sometimes varved, sand and silt which interfinger with, and are locally overlain by as much as $75 \mathrm{ft}$ of, late Wisconsinan to Holocene dune sand on the lower terraces. In the deltaic area south of Kalispell, Holocene flood-plain alluvium ( $\mathrm{Qal}$ ) consists of sandy silt. Beneath the flood plains of the major rivers and tributaries to the north, the alluvium is more gravelly (Konizeski and others, 1968).

\section{Hydrology}

The Whitefish, Stillwater, Flathead, and Swan Rivers drain the Kalispell Valley. The Whitefish River flows into Whitefish Lake from the north, then flows southward from the lake at a gradient of about $2 \mathrm{ft} / \mathrm{mi}$ to its confluence with the Stillwater River on the northeastem outskirts of Kalispell. The Stillwater River enters the basin from the northwest and flows south-southeastward at a gradient of about $2 \mathrm{ft} / \mathrm{mi}$ to its confluence with the Flathead River about a mile southeast of Kalispell. The Flathead River enters the basin from the east near Columbia Falls, and flows south-southwestward toward Kalispell at an average gradient of about $6 \mathrm{f} / \mathrm{mi}$. About one-third of its flow--the contribution from the South Fork of the Flathead River--has been regulated by Hungry Horse Reservoir since 1951. Below Kalispell, the Flathead River meanders across its delta to Flathead Lake at a reduced gradient of about $1 \mathrm{ft} / \mathrm{mi}$. The Swan River enters the southeastem comer of the basin, through which it traverses for about $8 \mathrm{mi}$ before emptying into Flathead Lake. Sixteen tributary streams enter the Kalispell Valley from the mountains; however, most of their flow either infiltrates directly into basin fill, or is diverted for irrigation (Konizeski and others, 1968).

The Kalispell Valley contains more than 40 lakes. Flathead Lake, at 126,000 acres, is the largest natural freshwater lake in the westem United States (Montana Department of Health and Environmental Sciences, 1994). 
Its natural storage capacity is increased by Kerr Dam, which was constructed in 1938. Echo Lake is the largest of more than thirty, primarily spring-fed, pothole lakes in the kame-and-kettle area on the east side of the basin. Whitefish Lake, on the northwest basin boundary, is naturally impounded behind a glacial moraine (Konizeski and others, 1968).

Streamflow data for gaging stations listed in table 44 are stored in the USGS WATSTORE database. Locations of the stations are shown on plate 1. In addition, USGS has published daily elevation records for Flathead Lake at Somers (gaging station 12371500 , drainage area $7,086 \mathrm{mi}^{2}$ ) since 1900 . Data for years prior to 1961 are published in Water-Supply Papers; more recent data are in annual Water-Data Reports (U.S. Geological Survey, issued annually).

Table 44. Summary of data for U.S. Geological Survey streamflow-gaging stations in the Kalispell Valley, Montana

[Type of data collected: $c$, water chemistry; $d$, discharge; $m$, microbiological; $s$, suspended sediment; $t$, temperature. Periods of record for stations that were being operated as of November 1994 are indicated by the first year of record followed by a dash only. Abbreviations: $\mathrm{ft}^{3} / \mathrm{s}$, cubic feet per second. Symbol: --, no data]

\begin{tabular}{|c|c|c|c|c|c|c|c|c|c|}
\hline \multirow[b]{2}{*}{$\begin{array}{l}\text { Station } \\
\text { number }\end{array}$} & \multirow[b]{2}{*}{ Station name } & \multirow{2}{*}{$\begin{array}{l}\text { Drainage } \\
\text { area } \\
\text { (square } \\
\text { miles) }\end{array}$} & \multirow{2}{*}{$\begin{array}{c}\text { Type } \\
\text { of } \\
\text { data } \\
\text { col- } \\
\text { lected }\end{array}$} & \multirow[b]{2}{*}{$\begin{array}{l}\text { Perlod of record } \\
\text { (calendar year) }\end{array}$} & \multicolumn{5}{|c|}{ Discharge for period of record } \\
\hline & & & & & $\begin{array}{l}\text { Mean } \\
\text { annual } \\
\left(\mathrm{ft}^{3} / \mathrm{s}\right)\end{array}$ & $\begin{array}{l}\text { Maxl- } \\
\text { mum } \\
\left(\mathrm{ft}^{3} / \mathrm{s}\right)\end{array}$ & $\begin{array}{l}\text { Date of } \\
\text { maxl- } \\
\text { mum }\end{array}$ & $\begin{array}{l}\text { Mini- } \\
\text { mum } \\
\left(\mathrm{ft}^{3} / \mathrm{s}\right)\end{array}$ & $\begin{array}{l}\text { Date of } \\
\text { mini- } \\
\text { mum }\end{array}$ \\
\hline 12363000 & $\begin{array}{l}\text { Flathead River at } \\
\text { Columbia Falls }\end{array}$ & 4,464 & $\begin{array}{c}\text { c, d, m, } \\
s, t\end{array}$ & $1922-23,1928-$ & 9,626 & 176,000 & 06-09-64 & 798 & $12-08-29$ \\
\hline 12363500 & $\begin{array}{l}\text { Flathead River near } \\
\text { Kalispell }\end{array}$ & - & c & $1968-69$ & -. & - & -- & - & -- \\
\hline 12365000 & $\begin{array}{l}\text { Stillwater River near } \\
\text { Whitefish }\end{array}$ & 524 & $\begin{array}{l}\text { d } \\
\text { c }\end{array}$ & $\begin{array}{l}1930-50,1986- \\
1977-83\end{array}$ & 338 & 4,330 & $05-26-48$ & 2.9 & $08-18-92$ \\
\hline 12365500 & $\begin{array}{l}\text { Stillwater River near } \\
\text { Kalispell }\end{array}$ & ${ }^{1537}$ & d & $\begin{array}{c}1907,1922, \\
1928-31\end{array}$ & 2192 & 2,750 & $05-22-22$ & 26 & $11-11-29$ \\
\hline 12366000 & $\begin{array}{l}\text { Whitefish River near } \\
\text { Kalispell }\end{array}$ & 170 & c & $\begin{array}{l}1928,1929-1950 \\
1963-64,1986- \\
1977-1983\end{array}$ & 190 & 1,580 & $06-24-74$ & 4.5 & $10-18-34$ \\
\hline 12367500 & $\begin{array}{l}\text { Ashley Creek near } \\
\text { Kalispell }\end{array}$ & 195 & c, d & $\begin{array}{c}1931-50,1969- \\
70,1972-74\end{array}$ & 30.8 & 749 & $05-27-48$ & 0 & At times \\
\hline 12369000 & $\begin{array}{l}\text { Flathead River near } \\
\text { Bigfork }\end{array}$ & - & c & $1969-71$ & -- & -- & -- & -- & -- \\
\hline 12370000 & $\begin{array}{l}\text { Swan River near } \\
\text { Bigfork }\end{array}$ & 671 & d & ${ }^{3} 1910-11,1922$ & 1,158 & 8,890 & $06-20-74$ & 193 & $01-26-30$ \\
\hline
\end{tabular}

In contrast to other major streams in the study area, the dissolved-solids concentration and chemical composition of the Flathead River changes little as the river flows out of the North Fork Flathead Valley through the Kalispell Valley. The dissolved-solids concentration remains less than $100 \mathrm{mg} / \mathrm{L}$ and calcium and bicarbonate are the dominant ions, thereby indicating that the largest tributaries contribute water of similar chemical composition.

Increased residential development has raised concem about surface-water contamination. Under natural conditions, Flathead Lake is oligotrophic, or nutrient-poor, and produces small amounts of algae. However, the lake is becoming eutrophic due to increased nutrient loads (Montana Department of Health and Environmental Sciences, 1994, p. 28). The leading source of phosphorus in Flathead Lake is atmospheric deposition of dust and smoke (Montana Department of Health and Environmental Sciences, 1994, p. 26). Another source of nutrients to the lake is the Flathead River. In urban areas north of Kalispell, nitrate and phosphorus discharge to the river from the 
unconfined alluvial aquifer (Stanford and others, 1983; Noble and Stanford, 1986). Recent monitoring indicates that the amounts of nutrients and algae are increasing in Flathead Lake. Apparently, a phosphorus detergent ban and improvements to all of the municipal wastewater-treatment plants in the Flathead Lake drainage basin have been unable to offset increased phosphorus loading from private septic tanks and other sources (Montana Department of Health and Environmental Sciences, 1994, p. 24).

Other water bodies in the basin also have eutrophication problems, exacerbated by domestic sewage from nearby homes. Several smaller lakes, including Echo Lake, as well as the Whitefish River and Ashley Creek are among those affected (Nunnallee and others, 1976). Whitefish Lake also has low dissolved-oxygen concentrations and rising phosphorus concentrations indicative of cultural eutrophication (N.M. Butler, University of Montana Flathead Lake Biological Station, written commun., 1994).

Other water-quality concerns in the basin include increased sedimentation, temperature, and nutrients in streams because of grazing and logging practices; large fluctuations in the temperature of Flathead River due to Hungry Horse Dam operations; and inadequate dilution of wastewater discharges due to irrigation withdrawals from the Whitefish and Stillwater Rivers and Ashley Creek (Nunnallee and others, 1976). Ashley Creek, the most severely impacted stream in the basin, is affected by siltation, thermal modification, habitat alteration, nutrients, and pathogens due to channelization, removal of riparian vegetation, farming practices, feedlot management, and problems with nutrients due to municipal point sources, septic tanks, and dryland crop production (Montana Department of Health and Environmental Sciences, 1994).

Ground water is an important resource in the Kalispell Valley, as thousands of residents rely on it for domestic supplies. Konizeski and others (1968) categorized four principal types of aquifers in the basin: Holocene floodplain aquifers, Pleistocene perched aquifers, Pleistocene confined aquifers, and the Precambrian bedrock aquifer.

Holocene flood-plain aquifers include the deltaic-sand aquifer south of Kalispell and the alluvial-gravel aquifer underlying the flood plains of the Flathead and Whitefish Rivers north of Kalispell. Hydraulic characteristics of both are listed in table 45 .

Table 45. Hydraulic characteristics of selected aquifers in the Kalispell Valley, Montana

[Abbreviations: $\mathrm{ft}^{2} / \mathrm{d}$, fool squared per day; (gal/min)/ft, gallon per minute per foot; gal/min, gallon per minute. Symbol: --, no data]

\begin{tabular}{|c|c|c|c|c|c|}
\hline $\begin{array}{l}\text { Aquifer description } \\
\text { (Konlzeskl and others, 1968) }\end{array}$ & $\begin{array}{l}\text { Specific } \\
\text { yield or } \\
\text { torage } \\
\text { coefficient }\end{array}$ & $\begin{array}{l}\text { Thickness } \\
\text { (feet) }\end{array}$ & $\begin{array}{l}\text { Transmissivity } \\
\left(\mathrm{ft}^{2} / \mathrm{day}\right)\end{array}$ & $\begin{array}{c}\text { Speciflc } \\
\text { capacity } \\
{[(g a l / m i n) / f t]}\end{array}$ & $\begin{array}{l}\text { Yield to wells } \\
\text { (gal/min) }\end{array}$ \\
\hline $\begin{array}{l}\text { Holocene deltaic sand south of } \\
\text { Kalispell }\end{array}$ & 10.27 & ${ }^{1} 100-200$ & $\begin{array}{c}21,000 \\
{ }_{1} 1-3,700\end{array}$ & - & -- \\
\hline $\begin{array}{l}\text { Holocene alluvial gravel north } \\
\text { of Kalispell }\end{array}$ & ${ }^{2} 0.2$ & $\begin{array}{c}28 \text { average } \\
1_{28-30}\end{array}$ & $\begin{array}{l}2,150,000 \text { average } \\
1_{120,000-240,000}\end{array}$ & ${ }^{2} 260-640$ & ${ }^{2}$ More than 1,500 \\
\hline $\begin{array}{l}\text { Pleistocene perched glacial } \\
\text { outwash northwest of } \\
\text { Kalispell }\end{array}$ & - & ${ }^{2} 70$ & 276,000 & ${ }^{2} 6-92$ & $270-200$ \\
\hline $\begin{array}{l}\text { Pleistocene confined glacial } \\
\text { outwash underlying entire } \\
\text { basin }\end{array}$ & ${ }^{2} 0.00087$ & $\begin{array}{c}2 \text { more than } \\
364\end{array}$ & $248-510$ & ${ }^{2} 0.04-32$ & $\begin{array}{l}21-1,500 \text { pumped, } \\
1-225 \text { flowing }\end{array}$ \\
\hline Precambrian bedrock & $\begin{array}{l}{ }^{3} 0.0000153 \\
{ }^{4} 0.003-0.3\end{array}$ & - & $\begin{array}{c}{ }^{3} 4,650-8,130 \\
{ }^{4} 1,600\end{array}$ & $\begin{array}{l}{ }^{2} 0.2 \text { average } \\
50.1-2.0\end{array}$ & $\begin{array}{l}29 \text { average } \\
510-50\end{array}$ \\
\hline
\end{tabular}

\footnotetext{
TSource: Noble and Stanford (1986)

2Source: Konizeski and others (1968)

${ }^{3}$ Source: Spratt and Associates (1990)

4Source: Newman (1981), as cited in Sprat and Associates (1990)

${ }^{5}$ Source: Dutton and others (1995)
} 
The Holocene deltaic-sand aquifer south of Kalispell is not an important source of water because it is much less permeable and has more dissolved constituents than the underlying confined aquifer. Stage fluctuations of ten feet in Flathead Lake due to releases from Kerr Dam annually reverse the hydraulic gradient in the deltaic-sand aquifer within one-half mile of affected surface-water bodies, including Flathead Lake, the Flathead River, and associated sloughs and oxbows. During May and June, when the lake level is highest, lake water recharges the aquifer, during mid-November, when the lake level declines below the water table, ground water reverses its flow direction and begins to discharge to the lake. Precipitation and evapotranspiration also directly affect storage in the deltaic-sand aquifer (Noble and Stanford, 1986).

The Holocene alluvial-gravel aquifer north of Kalispell is an important source of water and once provided much of the municipal supply for Kalispell. However, the susceptibility of this aquifer to contamination has, in recent years, prompted a shift to reliance on underlying, confined aquifers. Most of the recharge to the alluvialgravel aquifer occurs in April, May, and June from snowmelt and spring showers. Significant interaction between ground water and surface water occurs along the east side of the alluvial-gravel aquifer in response to stage fluctuations in the Flathead River following releases from Hungry Horse Reservoir. In most of the aquifer, groundwater flow approximately parallels the direction of streamflow. Ground water discharges from the alluvial-gravel aquifer to surface water near the confluence of the Flathead and Stillwater Rivers (Konizeski and others, 1968; Noble and Stanford, 1986).

Three types of Pleistocene perched aquifers are separated from the underlying confined aquifers by clay, till, or cemented gravel. These are the laterally discontinuous, low-permeability, dune and lacustrine sand aquifers on the tops of terraces; a gravelly, glacial-outwash aquifer northwest of Kalispell; and a glacial-drift aquifer in the pothole lake area in the eastern part of the basin. Of these three types, the glacial-outwash aquifer northwest of Kalispell is the most important source of water. Its hydraulic characteristics are summarized in table 45 . The glacial-outwash aquifer is recharged primarily by seepage from streams and it discharges largely to irrigation wells. The sand aquifers are not used much in comparison to the underlying Pleistocene artesian aquifer. The glacial-drift aquifer is not used much despite its favorable hydraulic properties because it is located in an area with plentiful surface water (Konizeski and others, 1968).

Two Pleistocene confined aquifers are separated by 10 to $400 \mathrm{ft}$ of till and/or 20 to $600 \mathrm{ft}$ of lacustrine silt. Both are composed of sand and gravel. The shallower of the two is present locally near Creston and is not laterally extensive. It is about $60 \mathrm{ft}$ thick and has a specific capacity of 0.3 to 0.5 ( $\mathrm{gal} / \mathrm{min}) / \mathrm{ft}$.

The deep Pleistocene confined aquifer consists of glacial outwash and underlies the entire basin. As the principal aquifer in the Kalispell Valley, the deep Pleistocene confined aquifer supplies municipal water for the City of Kalispell, irrigation water for hundreds of acres, and domestic water for many, if not most, basin residents. Its hydraulic characteristics are summarized in table 45 . Within the deep Pleistocene confined aquifer, ground water generally flows from the edges of the basin toward the Flathead and Whitefish Rivers, where it discharges into floodplain alluvium. The aquifer is recharged by precipitation and runoff near the basin margins and by subsurface flow from the surrounding mountains. Ground water discharges from the aquifer by withdrawals from wells and seepage into adjacent aquifers (Konizeski and others, 1968).

The Precambrian bedrock aquifer is an important source of water near outcrops and other areas where overlying basin fill is either thin or not productive. The bedrock aquifer is confined where it underlies glacial deposits of low permeability; elsewhere, it is unconfined. Wells completed in bedrock yield about 0.5 to $30 \mathrm{gal} / \mathrm{min}$ (Konizeski and others, 1968). Selected hydraulic characteristics of the bedrock aquifer are summarized in table 45.

The ground-water contribution area for the Kalispell Valley (fig. 2, pl. 1) is about $1,370 \mathrm{mi}^{2}$. Infiltration anywhere within this area could potentially recharge basin-fill aquifers.

Several investigators have compiled potentiometric-surface maps of all or part of the Kalispell Valley. Table 46 lists some of the available maps, along with the water-level measurement dates and contour intervals. In addition, Coffin and others (1971, pl. 2, scale 1:86,400) plotted, but did not contour, water levels in wells northwest of Whitefish. 
Table 46. Potentiometric-surface maps of aquifers in the Kalispell Valley, Montana

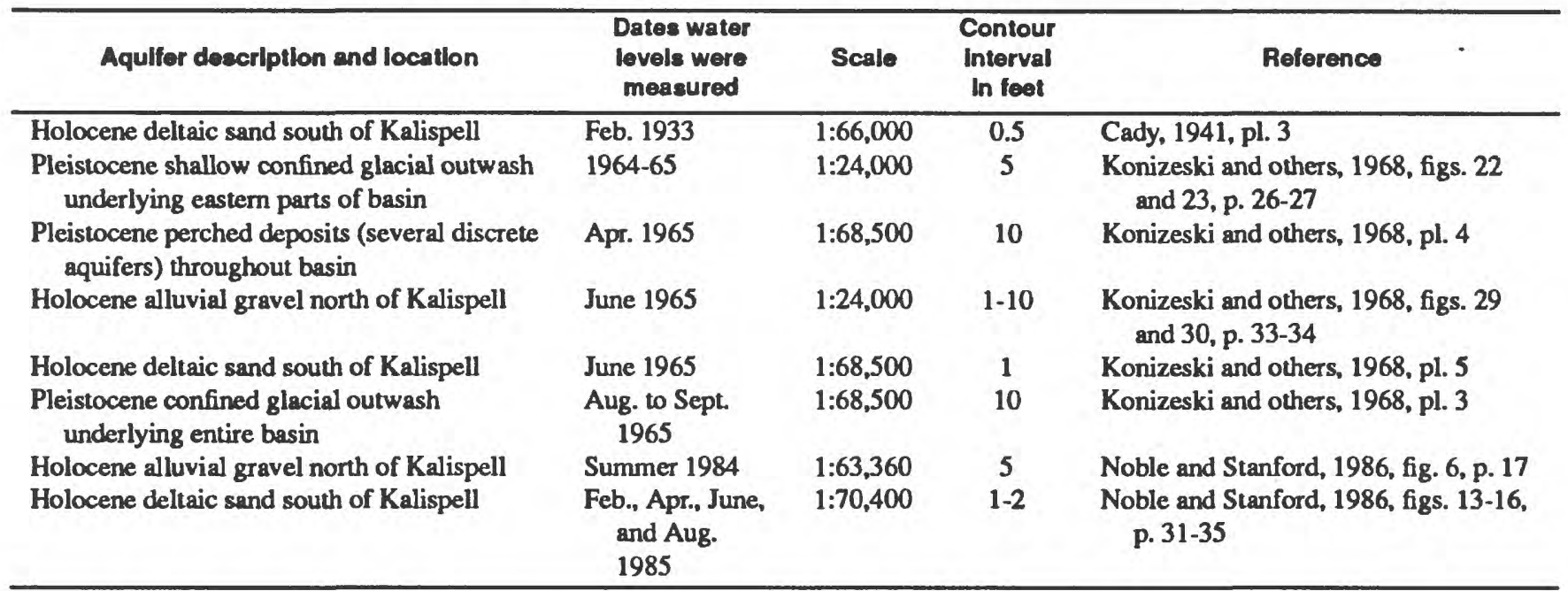

Water-level data for wells listed in table 47 are stored in the USGS WATSTORE database. Water levels were measured in these wells at least annually.

Table 47. Summary of water-level data for selected wells in the Kalispell Valley, Montana

[Hydrogeologic unit: Qal, Holocene and Pleistocene alluvial deposits; Qg. Pleistocene glacial deposits. Periods of record for observation wells that were being operated as of February 1995 are indicated by the first year of record followed by a dash only]

\begin{tabular}{|c|c|c|c|c|c|c|c|}
\hline \multirow{2}{*}{ Location number } & \multirow{2}{*}{$\begin{array}{l}\text { Depth of } \\
\text { well, in feet } \\
\text { below land } \\
\text { surface }\end{array}$} & \multirow{2}{*}{$\begin{array}{l}\text { Hydro- } \\
\text { geologic } \\
\text { unit }\end{array}$} & \multirow{2}{*}{$\begin{array}{l}\text { Perlod of } \\
\text { record }\end{array}$} & \multicolumn{4}{|c|}{$\begin{array}{c}\text { Water level, in feet below or above (t) land } \\
\text { surface }\end{array}$} \\
\hline & & & & Highest & $\begin{array}{l}\text { Date(s) of } \\
\text { highest }\end{array}$ & Lowest & $\begin{array}{l}\text { Date of } \\
\text { lowest }\end{array}$ \\
\hline 29N22W08ADDD01 & 211 & $\mathrm{Qg}$ & $1964-91$ & 173.90 & $07-17-64$ & 210.89 & $07-28-78$ \\
\hline 29N22W14BBDD01 & 220 & Q8 & 1964- & 104.85 & $10-06-64$ & 149.12 & $08-10-89$ \\
\hline 29N22W26BCBC01 & 313 & Qg & $1976-91$ & 134.87 & $04-27-77$ & 154.9 & 08-09-79 \\
\hline 29N22W27CABA01 & 390 & $\mathrm{Qg}$ & $1976-82$ & 140.98 & $03-11-77$ & 193.99 & 08-09-79 \\
\hline 29N22W28ACCC01 & 200 & Q8 & 1965- & 144.90 & $08-25-65$ & 178.84 & $09-10-85$ \\
\hline 29N22W28DDDD01 & 180 & Qg & $1965-91$ & 129.64 & $06-10-80$ & 170.58 & $08-18-77$ \\
\hline 29N22W35DDDA01 & 400 & Qg & $1976-82$ & 120.99 & $03-11-77$ & 148.06 & $07-14-77$ \\
\hline 29N22W36BCBD01 & 452 & Q8 & 1976- & 125.43 & $06-10-81$ & 144.75 & $09-12-94$ \\
\hline 29N21W17CCDB01 & 6.8 & Qg & $1964-82$ & +.92 & $04-02-79$ & 4.75 & $03-12-80$ \\
\hline $29 \mathrm{~N} 21 \mathrm{~W} 20 \mathrm{CCCC} 01$ & 278 & $Q_{8}$ & 1963- & 100.00 & $\begin{array}{l}07-01-64 \\
06-28-65\end{array}$ & 113.85 & $09-21-90$ \\
\hline 29N21W33CCC 01 & 9.4 & Qal & $1963-77$ & 5.00 & $06-30-76$ & 6.91 & $11-17-76$ \\
\hline 29N20W18AAD 01 & 20.0 & Qg & $1963-91$ & 14.27 & $08-16-91$ & 19.36 & $02-15-78$ \\
\hline 29N20W29BD 01 & 152 & Qg & $1963-81$ & 19.88 & $11-17-69$ & 39.24 & $06-11-75$ \\
\hline 28N21W03AB 01 & 9.4 & Qal & $1963-82$ & +.70 & $06-11-64$ & 6.01 & $12-03-63$ \\
\hline 28N20W14CCCBO2 & 140 & $\mathrm{Qg}$ & $1994-$ & +15.35 & $06-07-94$ & +11.66 & $09-12-94$ \\
\hline $28 \mathrm{~N} 20 \mathrm{~W} 14 \mathrm{CCCC} 03$ & 40 & $\mathrm{Qg}$ & $1994-$ & 3.30 & $06-14-94$ & 6.22 & $08-10-94$ \\
\hline 28N20W14CCCCO4 & 14.5 & $\mathrm{Qg}$ & 1994- & 4.01 & $06-14-94$ & 8.17 & $08-10-94$ \\
\hline $27 N 20 W 17 C C 01$ & 9.6 & Qal & $1963-82$ & 1.79 & $04-02-79$ & 5.32 & $09-22-77$ \\
\hline
\end{tabular}

Ground-water quality differs between the various aquifers in the Kalispell Valley. Water in the deltaic-sand aquifer is a calcium magnesium bicarbonate to sodium bicarbonate type (Noble and Stanford, 1986) with an average dissolved-solids concentration of about $340 \mathrm{mg} / \mathrm{L}$ (Konizeski and others, 1968). The relatively large concentrations of dissolved solids, including iron, magnesium, and sodium, have been attributed to the long residence time of the 
water in the aquifer, during which naturally occurring minerals dissolve from aquifer material (Noble and Stanford, 1986).

The alluvial-gravel aquifer that underlies the flood plains north of Kalispell has a calcium bicarbonate type water with dissolved-solids concentrations of less than $200 \mathrm{mg} / \mathrm{L}$ (Konizeski and others, 1968). This near-surface, coarse-grained aquifer has been affected by contamination from urban areas that overlie it. For example, fecal coliform, an indicator of possible septic-tank effluent, was detected in nearly every well sampled by Noble and Stanford (1986, p. 44). In the 1960's, phenol contamination resulted from dumping waste glue into a shallow pit (Konizeski and others, 1968). Spratt (1980), Stanford (1984) and King (1988) have examined more recent urban impacts on this aquifer.

Ground water in the perched Pleistocene aquifers is a calcium bicarbonate type with dissolved-solids concentrations ranging from about 200 to $800 \mathrm{mg} / \mathrm{L}$. Nitrate concentrations ranging from 5.3 to $292 \mathrm{mg} / \mathrm{L}$ as $\mathrm{NO}_{3}$ indicate widespread contamination from livestock waste, septic-tank effluent, and/or fertilizers in these aquifers (Konizeski and others, 1968).

The confined Pleistocene glacial-outwash aquifer has a calcium magnesium bicarbonate type water with an average dissolved-solids concentration of about $200 \mathrm{mg} / \mathrm{L}$. Although some wells have relatively large concentrations of iron and fluoride, the water in this aquifer generally is of acceptable quality for drinking water (Konizeski and others, 1968).

\section{Selected References}

Bauman, B.J., 1985, Soil suitability for on-site sewage treatment in the Flathead Valley, Montana; soil permeability, variability, and groundwater contamination: Bozeman, Montana State University, Ph.D. dissertation, 221 p.

Briar, D. W., Lawlor, S.M., Stone, M.A.J., Parliman, D.J., Shaefer, J.L., and Kendy, Eloise, in press, Ground-water levels in the intermontane basins of the Northern Rocky Mountains, Montana and Idaho: U.S. Geological Survey Hydrologic Investigations Atlas 738-B, 1 sheet, scale 1:750,000.

Brietkrietz, Alex, 1966, Basic water data report no. 3, Kalispell Valley, Montana: Montana Bureau of Mines and Geology Bulletin 53, 25 p.

Cady, R.C., 1941, Effect upon ground-water levels of proposed surface-water storage in Flathead Lake, Montana: U.S. Geological Survey Water-Supply Paper 849-B, p. 59-81.

Cary, L.E., 1989, Trends in selected water-quality characteristics, Flathead River at Flathead, British Columbia, and at Columbia Falls, Montana, water years 1975-86: U.S. Geological Survey Water-Resources Investigations Report 89-4054, 14 p.

Clark, D.W., and Dutton, D.M., in press, Quality of ground water and surface water in intermontane basins of the Northern Rocky Mountains, Montana and Idaho: U.S. Geological Survey Hydrologic Investigations Atlas 738-C, 1 sheet, scale 1:750,000.

Coffin, D.L., Brietkrietz, Alex, and McMurtrey, R.G., 1971, Surficial geology and water resources of the Tobacco and upper Stillwater River valleys, northwestern Montana: Montana Bureau of Mines and Geology Bulletin 81, 48 p.

Decker, G.L., 1969, Preliminary report on the geology, geochemistry, and sedimentology of Flathead Lake, northwestern Montana: Missoula, University of Montana, M.S. thesis, 91 p.

Dutton, D.M., Lawlor, S.M., Briar, D.W., and Tresch, R.E., 1995, Hydrogeologic data for the Northern Rocky Mountains intermontane basins, Montana: U.S. Geological Survey Open-File Report 95-143, 94 p.

Harrison, J.E., Cressman, E.R., and Whipple, J.W., 1992, Geologic and structure maps of the Kalispell $1^{\circ} \times 2^{\circ}$ quadrangle, Montana, and Alberta and British Columbia: U.S. Geological Survey Miscellaneous Investigations Series Map I-2267, 2 sheets, scale 1:250,000.

Johns, W.M., Smith, A.G., Barnes, W.C., Gilmour, E.H., and Page, W.D., 1963, Progress Report 5, Geologic investigations in the Kootenai-Flathead area, northwest Montana, western Flathead County and part of Lincoln County: Montana Bureau of Mines and Geology Bulletin 36, 68 p.

Johns, W.M., 1970, Geology and mineral deposits of Lincoln and Flathead Counties, Montana: Montana Bureau of Mines and Geology Bulletin 79, 182 p.

Joyce, M.J., 1980, Stratigraphy, clay mineralogy and pesticide analysis of Flathead Lake sediments, Flathead Lake, Montana: Missoula, University of Montana, M.S. thesis, 86 p. 
King, J.B., 1988, Hydrogeologic analysis of septic system nutrient attenuation efficiencies in the Evergreen area, Montana: Montana Bureau of Mines and Geology Open-File Report 205, 81 p.

Kogan, Jerry, 1980, A seismic sub-bottom profiling study of recent sedimentation in Flathead Lake, Montana: Missoula, University of Montana, M.S. thesis, $98 \mathrm{p}$.

Konizeski, R.L., Brietkrietz, Alex, and McMurtrey, R.G., 1968, Geology and ground water resources of the Kalispell Valley, northwestern Montana: Montana Bureau of Mines and Geology Bulletin 68, 42 p.

McDonald, C.C., 1946, Effects of storage in Flathead Lake, Montana, on ground-water levels: U.S. Geological Survey OpenFile Report, 7 p.

Montana Department of Health and Environmental Sciences, 1994, Montana Water Quality, 1994: Helena, Water Quality Bureau, Montana 305(b) Report, 159 p.

[Montana] State Engineer's Office, 1965a, Water resources survey, Flathead and Lincoln Counties, Montana--Part 1, History of land and water use on irrigated areas: Helena, Mont., State Engineer's Office, 56 p.

1965b, Water resources survey, Flathead and Lincoln Counties, Montana--Part 2, Maps showing irrigated areas: Helena, Mont., State Engineer's Office, 26 p.

Morrison-Maierle, Inc. and James M. Montgomery, Consulting Engineers, Inc., 1977, Lakes and streams water quality study, Flathead drainage, Montana: [Helena, Mont.], Morrison-Maierle, Inc., variously paged.

Mudge, M.R., Earhart, R.L., Whipple, J.W., and Harrison, J.E., 1982, Geologic and structure maps of the Choteau $1^{\circ} \times 2^{\circ}$ quadrangle, northwestern Montana: U.S. Geological Survey Miscellaneous Investigations Series Map I-1300, 2 sheets, scale 1:250,000.

National Oceanic and Atmospheric Administration, 1992, Monthly normals of temperature, precipitation, and heating and cooling degree days, 1961-90, Montana: Asheville, N.C., Climatography of the United States no. 81, unpaged.

Noble, R.A., Bergantino, R.N., Patton, T.W., Sholes, Brenda, Daniel, Faith, and Schofield, Judeykay, 1982, Occurrence and characteristics of ground water in Montana--Volume 2, The Rocky Mountain Region: Montana Bureau of Mines and Geology Open-File Report 99, 132 p.

Noble, R.A., and Stanford, J.A., 1986, Ground-water resources and water quality of the unconfined aquifers in the Kalispell Valley, Montana: Montana Bureau of Mines and Geology Open-File Report 177, 112 p.

Nunnallee, David, Botz, M.K., and Willems, D.G., 1976, Water quality inventory and management plan, Flathead drainage basin, Montana: Montana Department of Health and Environmental Sciences, 114 p.

Sahinen, U.M., Johns, W.M., and Lawson, D.C., 1965, Geochemical reconnaissance stream-sampling in Flathead and Lincoln Counties, Montana: Montana Bureau of Mines and Geology Bulletin 48, 16 p.

1967, Geochemical investigations in Lincoln and Flathead Counties, Montana: Montana Bureau of Mines and Geology Bulletin 61, 18 p.

Sonstelie, L.C., 1967, A study of the water quality of the Flathead River: Missoula, University of Montana, M.S. thesis, 72 p.

Spratt, M.M., 1980, Urban impacts on a gravel unconfined aquifer in the Evergreen area near Kalispell, Montana: Flathead drainage 208 project, 92 p.

Spratt and Associates, 1990, Review and analysis of Somers municipal well pump test report and data March 13-16, 1990: Kalispell, Montana, consulting report prepared for Flathead Lake Protection Association, Lakeside, Montana, 21 p.

Stanford, J.A., 1984, Land use and groundwater quality in western Montana--the impact on nutrient budgets for surface waters: Bozeman, Montana Water Resources Research Center, Montana State University, Research Project Technical Completion Report 41, 33 p.

Stanford, J.A., Stuart, T.J., and Ellist, B.K., 1983, Limnology of Flathead Lake--Final Report: Helena, Mont., U.S. Environmental Protection Agency, Flathead River Basin Environmental Impact Study, 65 p.

Stickney, M.C., 1980, Seismicity and gravity studies of faulting in the Kalispell Valley, northwest Montana: Missoula, University of Montana, M.S. thesis, $82 \mathrm{p}$.

1978, Seismicity and faulting of central western Montana: Northwest Geology, v. 7, p. 1-8.

Tuck, L.K., Briar, D.W., and Clark, D.W., in press, Geologic history and hydrogeologic units of intermontane basins of the Northern Rocky Mountains, Montana and Idaho: U.S. Geological Survey Hydrologic Investigations Allas 738-A, 2 sheets, scale 1:750,000.

U.S. Geological Survey, issued annually, Water resources data, Montana: Helena, Mont., U.S. Geological Survey Water-Data Report.

1955, Compilation of records of surface waters of the United States through September 1950: U.S. Geological Survey Water-Supply Paper 1316, 592 p. 


\title{
Lake Creek Valley
}

\section{Geography}

The Lake Creek Valley is an approximately north-trending intermontane basin in northwestern Montana. The $53 \mathrm{mi}^{2}$ basin is bounded by the Purcell Mountains on the north and the Cabinet Mountains on the east, south and west (pl. 1). Lake Creek flows northward through the basin, and joins the westward-flowing Kootenai River one mile southeast of Troy. In the northern half of the basin, steep-sided terraces flank the Lake Creck flood plain. Hummocky glacial drift extends from nearly vertical mountains to nearly horizontal terraces. In the southern half of the basin, hummocky, dissected hills extend from the mountain front to the flood plain. The Lake Creek Valley ranges in altitude from about $2,000 \mathrm{ft}$ where the Kootenai River leaves the basin, to about $4,400 \mathrm{ft}$ along the basin margin.

The climate of the Lake Creek Valley is typical of lower-elevation intermontane basins of the Northern Rocky Mountains west of the Continental

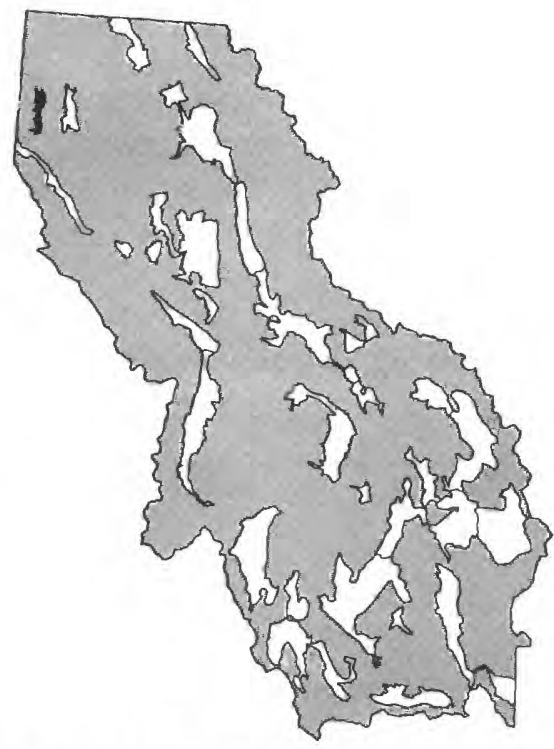
Divide, with relatively warm summers and cool, humid winters. On the basis of the 1961-90 period of record, the average annual precipitation at Troy (altitude $1,930 \mathrm{ft}$ ) is $25.18 \mathrm{in}$, and the average annual temperature is $45.6^{\circ} \mathrm{F}$ (National Oceanic and Atmospheric Administration, 1992). The average last occurrence of $32^{\circ} \mathrm{F}$ is May 29 , and the average first occurrence is September 16 (Natural Resources Conservation Service, U.S. Department of Agriculture, unpub. data, 1994). Mean monthly climatic data for Troy are plotted in figure 18.

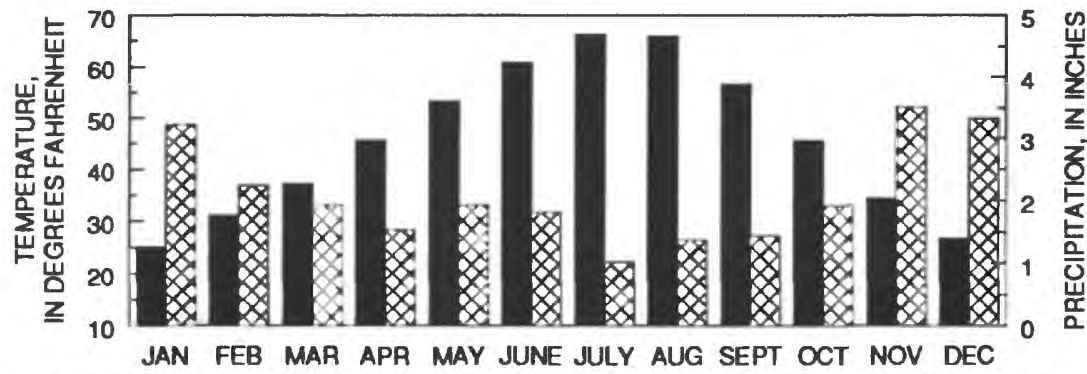

\author{
EXPLANATION \\ MEAN MONTHLY TEMPERATURE FOR \\ 1961-90 PERIOD OF RECORD \\ MEAN MONTHLY PRECIPITATION FOR \\ 1961-90 PERIOD OF RECORD
}

Figure 18. Mean monthly precipitation and temperature at Troy, Mont. Data from National Oceanic and Atmospheric Administration (1992).

The primary land uses in the Lake Creek Valley are timber harvesting, lumber processing, and livestock grazing. Irrigated hay and pasture are also produced to a limited extent (J.C. Eggen, Agricultural Stabilization and Conservation Service, oral commun., 1993). About 2,000 people reside in the Lake Creck Valley, including 953 in the City of Troy (1990 census). Gold and other minerals historically were mined from the mountains surrounding the basin (Gibson, 1948; Levings and others, 1984). Copper and silver are extracted from an underground mine near the southern end of the Lake Creek Valley (McCulloch, 1993, p. 10).

\section{Geology}

The Lake Creck Valley basin was formed by Cenozoic extension, which continues to be active (Levings and others, 1984). The basin is bounded on the east by a listric normal fault and on the west by numerous crosscutting 
faults. The depth of the bedrock floor of the basin is unknown. The deepest well (31N33W29DCCC) is $400 \mathrm{ft}$ deep and does not penetrate bedrock (Montana Bureau of Mines and Geology, unpub. data, 1991).

Several investigators have examined the geology of the Lake Creek Valley (table 48). The geologic units described by previous investigators are summarized below. These geologic units are referenced to hydrogeologic units defined in this study (table 2) to provide a consistent regional framework. In the following discussion, the hydrogeologic-unit abbreviations are italicized.

Table 48. Geologic and geophysical maps of the Lake Creek Valley, Montana

\begin{tabular}{|c|c|c|c|c|}
\hline Type of map & Scale & Location & Map features & Roference \\
\hline Geology & $1: 125,000$ & $\begin{array}{l}\text { Entire Lake } \\
\text { Creek valley }\end{array}$ & $\begin{array}{l}\text { Differentiates two Quatemary basin-fill units. } \\
\text { Indicates mines, prospects, and placers. Includes } \\
\text { several bedrock sections }\end{array}$ & Gibson, 1948, pl. 1 \\
\hline Geology & $1: 250,000$ & $\begin{array}{l}\text { Entire Lake } \\
\text { Creek valley }\end{array}$ & $\begin{array}{l}\text { Differentiates four basin-fill units: Pleistocene lake } \\
\text { sediments, Pleistocene glacial and fluvioglacial } \\
\text { (outwash) deposits, Holocene landslide deposits, } \\
\text { and Holocene alluvial deposits. Includes an east- } \\
\text { west bedrock geologic section through Bull Lake }\end{array}$ & $\begin{array}{l}\text { Harrison and others, } \\
1992\end{array}$ \\
\hline Geology & $1: 126,720$ & $\begin{array}{l}\text { Entire Lake } \\
\text { Creek valley }\end{array}$ & $\begin{array}{l}\text { Differentiates two Quaternary basin-fill units. } \\
\text { Includes an east-west bedrock section through the } \\
\text { Lake Creek Valley }\end{array}$ & Johns, 1970 , pl. 1 \\
\hline $\begin{array}{l}\text { Aeromagnetic } \\
\text { and } \\
\text { generalized } \\
\text { geology }\end{array}$ & $1: 250,000$ & $\begin{array}{l}\text { Entire Lake } \\
\text { Creek valley }\end{array}$ & $\begin{array}{l}\text { Contour interval } 10 \text { and } 20 \text { gammas. All basin fill } \\
\text { designated as Quatemary surficial deposits }\end{array}$ & $\begin{array}{l}\text { Kleinkopf and others, } \\
1972\end{array}$ \\
\hline
\end{tabular}

The basin is almost completely surrounded by Middle Proterozoic bedrock of the Belt Supergroup (Yms). The argillite, quartzite, sandstone, and dolomite which compose the Belt Supergroup are folded and faulted, and locally intruded by a Cretaceous granitic pluton (TKi) and associated metadiorite dikes and sills (Harrison and others, 1992).

Tertiary sediments overlie bedrock in most of the intermontane basins of the Northern Rocky Mountains. However, no Tertiary deposits crop out in the Lake Creek Valley, and drillers' logs do not indicate their presence in the subsurface.

Quatemary deposits in the Lake Creek Valley include Pleistocene glacial drift and glacial-lakebed deposits $(Q g)$, and Holocene flood-plain alluvium (Qal). Pleistocene glacial drift is a heterogeneous mixture of sand, silt, and clay interbedded with discontinuous gravel and cobble zones. More than $\mathbf{4 0 0} \mathrm{ft}$ of glacial drift underlies the hummocky hills along the edges of the basin, into which it extends from the adjacent mountain slopes (Levings and others, 1984).

Pleistocene glacial-lakebed deposits underlie terraces adjacent to the Lake Creek flood plain in the northem half of the basin. Two-hundred-foot cliffs have resulted from Lake Creek cutting down into the terraces. The cliffs expose buff, laminated layers of clay and silt with lenses of gravel and scattered dropstones (Harrison and others, 1992). Drillers' logs indicate that discontinuous layers of glacial-lakebed deposits and glacial drift interfinger in the subsurface throughout the basin.

Holocene alluvium consisting primarily of well-sorted sand and gravel underlies the flood plains of Lake Creek and its major tributaries. Its thickness is unknown, but is likely to be on the order of a few tens of feet (Harrison and others, 1992; Levings and others, 1984). 


\section{Hydrology}

Surface water in the Lake Creek Valley drains to Lake Creek, the Kootenai River, and several lakes. Lake Creek, a tributary to the Kootenai River, drains most of the basin. Lake Creek originates at the north end of Bull Lake and flows northward. The Kootenai River flows from east to west through the northern part of the basin. Since 1972, flow in the river has been regulated by Lake Koocanusa, which is impounded by Libby Dam about 35 mi upstream from Troy. At 1,250 acres, Bull Lake is the largest of several lakes in the basin. Other lakes up to 75 acres in area fill potholes left by melting glacial ice blocks (Levings and others, 1984).

Streamflow data for gaging stations listed in table 49 are stored in the USGS WATSTORE database. Locations of the stations are shown on plate 1. In addition, the USGS measured the water quality and stage of Bull Lake and other, smaller, lakes as part of a basin study in 1980-81 (Levings and others, 1984).

Table 49. Summary of data for U.S. Geological Survey streamflow-gaging stations in the Lake Creek Valley, Montana

[Type of data collected: $c$, water chemistry; d, discharge. Periods of record for stations that were being operated as of November 1994 are indicated by the first year of record followed by a dash only. Abbreviations: $f^{3} / s$, cubic feet per second. Symbol: --, no data]

\begin{tabular}{|c|c|c|c|c|c|c|c|c|c|}
\hline \multirow[b]{2}{*}{$\begin{array}{l}\text { Station } \\
\text { number }\end{array}$} & \multirow[b]{2}{*}{ Station name } & \multirow{2}{*}{$\begin{array}{c}\text { Drainage } \\
\text { area } \\
\text { (square } \\
\text { miles) }\end{array}$} & \multirow{2}{*}{$\begin{array}{c}\text { Type } \\
\text { of } \\
\text { data col- } \\
\text { lected }\end{array}$} & \multirow{2}{*}{$\begin{array}{l}\text { Perlod of record } \\
\text { (calendar year) }\end{array}$} & \multicolumn{5}{|c|}{ Discharge for period of record } \\
\hline & & & & & $\begin{array}{l}\text { Mean } \\
\text { annual } \\
\left(\mathrm{ft}^{3} / \mathrm{s}\right)\end{array}$ & $\begin{array}{l}\text { Maxi- } \\
\text { mum } \\
\left(\mathrm{ft}^{3} / \mathrm{s}\right)\end{array}$ & $\begin{array}{l}\text { Date of } \\
\text { maximum }\end{array}$ & $\begin{array}{l}\text { Mini- } \\
\text { mum } \\
\left(\mathrm{ft}^{3} / \mathrm{s}\right)\end{array}$ & $\begin{array}{l}\text { Date of } \\
\text { minimum }\end{array}$ \\
\hline 12303400 & Ross Creek near Troy & 23.8 & c & $1971,1976-78$ & 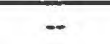 & $\cdots$ & -- & - & $\ldots$ \\
\hline 12303430 & Stanley Creek near Troy & 12.8 & c & $1976-78$ & - & -- & -- & - & -- \\
\hline 12303490 & Lake Creek near Troy & 188 & c & $1976-78$ & - & -. & -- & - & -- \\
\hline 12303500 & Lake Creek at Troy & 210 & d & $1945-57,1982-$ & 430 & 3,820 & $11-25-90$ & 2.0 & $09-01-47$ \\
\hline 12304000 & Callahan Creek at Troy & 85.8 & d & $\begin{array}{l}\text { 1911-12, 1914- } \\
16 \text { (Apr.-Oct.) }\end{array}$ & - & 1,680 & $05-23-13$ & 12 & $10-29-11$ \\
\hline
\end{tabular}

Water in Lake Creek and its sampled tributaries is a calcium bicarbonate type with dissolved-solids concentrations of less than $100 \mathrm{mg} / \mathrm{L}$ (Levings and others, 1984; Clark and Dutton, in press). A short period of large concentrations of total suspended solids in Lake Creek resulted in a fish kill in 1991 (Montana Department of Health and Environmental Sciences, 1992). Mill tailings along headwater streambanks contribute siltation and possibly dissolved metals, which limit the ability of Lake Creek to support aquatic life and cold-water fisheries (Montana Department of Health and Environmental Sciences, 1994).

Ground water is an important resource in the Lake Creek Valley, as all residents rely upon it for drinking-water supplies. Two wells supply municipal water for the City of Troy. The remainder of the basin residents depend on private wells.

Very few wells are completed in Quaternary alluvium in the Lake Creek Valley because the alluvium is generally shallow and close to surface water. However, wells that are completed in alluvium are reliable producers because of the permeability of the deposits and their proximity to recharge sources.

Interbedded Pleistocene glacial-lakebed deposits and glacial drift compose the primary aquifer in the Lake Creek Valley. Discontinuous permeable zones produce water, whereas silt and clay lenses act as local confining layers. The heterogeneous nature of the Pleistocene deposits results in a fairly wide range of yields from wells completed in this basin. Fifteen wells have reported yields ranging from 0.2 to $50 \mathrm{gal} / \mathrm{min}$ with a median value of $15 \mathrm{gal} / \mathrm{min}$. Specific-capacity values of seven of these wells range from 0.4 to $30(\mathrm{gal} / \mathrm{min}) / \mathrm{ft}$ with a median value of $3.0(\mathrm{gal} / \mathrm{min}) / \mathrm{ft}$ (Dutton and others, 1995). Water levels and water quality commonly differ significantly between nearby wells (Levings and others, 1984). Most wells in the basin are completed at depths of about $105 \mathrm{fo} 150 \mathrm{ft}$ below land surface. Another, possibly perched, laterally discontinuous water-bearing zone produces water from about 65 to $80 \mathrm{ft}$ below land surface (M.A.J. Stone, U.S. Geological Survey, written commun., 1992).

Because of the great thickness of the surficial Quaternary deposits, no wells are completed in the Proterozoic bedrock that underlies them. Therefore, little is known about the hydraulic characteristics of the bedrock. Bedrock wells outside the basin might be expected to produce sufficient water for domestic use. However, a 262-ft dry hole 
was drilled into bedrock near the edge of the basin (32N34W26CDCA) (Edwin Pluger, landowner, oral commun., 1992).

Potentiometric-surface maps indicate that, in general, ground water flows from the uplands toward the flood plains, then northward along Lake Creek and westward along the Kootenai River (Briar and others, in press; Levings and others, 1984, pl. 1). However, local flow directions may vary considerably, due to heterogeneities in aquifer materials.

Basin-fill aquifers are recharged by precipitation and snowmelt, infiltration from streams and possibly lakes, and probably subsurface flow from surrounding mountains. The ground-water contribution area (fig. 2, pl. 1) is about $360 \mathrm{mi}^{2}$, about one-eighth of which is located in Idaho (not shown on plate 1). Infiltration anywhere within this area could potentially recharge basin-fill aquifers in the Lake Creek Valley. Ground water discharges from basin-fill aquifers by evapotranspiration, withdrawals from wells, and seepage to springs, seeps, stream channels, and lakes.

Water-level data for wells listed in table 50 are stored in the USGS WATSTORE database. Water levels were measured in these wells at least annually.

Table 50. Summary of water-level data for selected wells in the Lake Creek Valley, Montana

[Hydrogeologic unit: Qal, Holocene through Pleistocene alluvial deposits; Qg. Pleistocene glacial deposits. Periods of record for observation wells that were being operated as of February 1995 are indicated by the first year of record followed by a dash only]

\begin{tabular}{|c|c|c|c|c|c|c|c|}
\hline \multirow{2}{*}{ Location number } & \multirow{2}{*}{$\begin{array}{l}\text { Depth of } \\
\text { well, in feet } \\
\text { below land } \\
\text { surface }\end{array}$} & \multirow{2}{*}{$\begin{array}{l}\text { Hydro- } \\
\text { geologic } \\
\text { unit }\end{array}$} & \multirow{2}{*}{$\begin{array}{l}\text { Period of } \\
\text { record }\end{array}$} & \multicolumn{4}{|c|}{$\begin{array}{c}\text { Water level, in feet below or above }(+) \text { land } \\
\text { surface }\end{array}$} \\
\hline & & & & Highest & $\begin{array}{l}\text { Date of } \\
\text { highest }\end{array}$ & Lowest & $\begin{array}{l}\text { Date of } \\
\text { lowest }\end{array}$ \\
\hline 31 N33W28ACA 01 & 313 & $\mathrm{Qg}$ & $1973-76$ & 83.12 & $06-05-74$ & 87.95 & $02-05-75$ \\
\hline 31N33W29DCCC02 & 45.0 & $\mathrm{Qg}$ & $1980-91$ & 32.77 & $08-25-82$ & 33.85 & $07-17-80$ \\
\hline 30N33W05ABAB01 & 187 & $\mathrm{Qg}$ & $1980-$ & +25.06 & $05-19-82$ & +17.58 & $09-07-94$ \\
\hline 30N33W05ABAB02 & 17.5 & Qal & $1980-85$ & 4.23 & $05-19-82$ & 7.23 & $10-10-84$ \\
\hline 30N33W30DAAD01 & 42.7 & $\mathrm{Qg}$ & 1980 & 8.02 & $05-19-82$ & 10.73 & $10-04-88$ \\
\hline $30 \mathrm{~N} 33 \mathrm{~W} 30 \mathrm{DAADO} 2$ & 22.7 & $\mathrm{Qg}$ & 1980 & 6.88 & $05-19-82$ & 9.67 & $10-04-88$ \\
\hline 30N33W30DCAD01 & 138 & $\mathrm{Qg}$ & $1980-82$ & 8.13 & $06-09-81$ & 11.05 & $11-19-81$ \\
\hline $30 \mathrm{~N} 33 \mathrm{~W} 30 \mathrm{DCAD} 02$ & 13.0 & Qal & $1980-82$ & 4.97 & $12-11-80$ & 6.31 & $08-12-81$ \\
\hline 28N33W09BAAA01 & 37.8 & $\mathrm{Qg}$ & $1980-82$ & 5.76 & $02-24-82$ & 16.34 & $09-09-81$ \\
\hline 28N33W09BADC01 & 36.0 & $\mathrm{Qg}$ & $1980-82$ & 9.26 & $02-24-82$ & 24.72 & 09-09-81 \\
\hline
\end{tabular}

The quality of ground water in the basin was determined on the basis of 27 samples analyzed for major ions and measured dissolved-solids concentrations and 5 samples in which dissolved-solids concentrations were estimated from specific-conductance measurements. Ground water is typically a calcium bicarbonate type with dissolved-solids concentrations of less than $250 \mathrm{mg} / \mathrm{L}$ throughout the basin (Clark and Dutton, in press). The ground water is soft to moderately hard, with generally low concentrations of nitrates and trace metals (Levings and others, 1984).

\section{Selected References}

Briar, D.W., Lawlor, S.M., Stone, M.A.J., Parliman, D.J., Schaefer, J.L., and Kendy, Eloise, in press, Ground-water levels in intermontane basins of the Northern Rocky Mountains, Montana and Idaho: U.S. Geological Survey Hydrologic Investigations Atlas 738-B, 1 sheet, scale 1:750,000.

Clark, D.W., and Dutton, D.M., in press, Quality of ground water and surface water in intermontane basins of the Northern Rocky Mountains, Montana and Idaho: U.S. Geological Survey Hydrologic Investigations Atlas 738-C, 1 sheet, scale 1:750,000. 
Dutton, D.M., Lawlor, S.M., Briar, D.W., and Tresch, R.E., 1995, Hydrogeologic data for the Northem Rocky Mountains intermontane basins, Montana: U.S. Geological Survey Open-File Report 95-143, 94 p.

Gibson, Russell, 1948, Geology and ore deposits of the Libby quadrangle, Montana, with sections on Pleistocene glaciation, by W.C. Alden, and Physiography, by J.T. Pardee: U.S. Geological Survey Bulletin 956, 131 p.

Harrison, J.E., Cressman, E.R., and Whipple, J.W., 1992, Geologic and structure maps of part of the Kalispell $1^{\circ} \times 2^{\circ}$ quadrangle, Montana, and Alberta and British Columbia: U.S. Geological Survey Miscellaneous Investigations Series Map I-2267, 2 sheets, scale 1:250,000.

Johns, W.M., 1959, Progress report on geologic investigations in the Kootenai-Flathead area, northwest Montana: Montana Bureau of Mines and Geology Bulletin 12,56 p. 1970, Geology and mineral deposits of Lincoln and Flathead Counties, Montana: Montana Bureau of Mines and Geology Bulletin 79, $182 \mathrm{p}$.

Kleinkopf, M.D., Harrison, J.E., and Zartman, R.E., 1972, Aeromagnetic and geologic map of part of northwestern Montana and northern Idaho: U.S. Geological Survey Geophysical Investigations Map GP-830, scale 1:250,000.

Levings, G.W., Ferreira, R.F., and Lambing, J.H., 1984, Water resources of Lake Creek Valley, northwestern Montana: Montana Bureau of Mines and Geology Memoir 56, 81 p.

McCulloch, Robin, 1993, Montana mining directory 1992, Montana Bureau of Mines and Geology Bulletin 131, 76 p.

Montana Department of Health and Environmental Sciences, 1992, Montana Water Quality 1992: Helena, Water Quality Bureau, Montana 305(b) Report, p. 21. 1994, Montana Water Quality 1994: Helena, Water Quality Bureau, Montana 305(b) Report, p. 159.

[Montana] State Engineer's Office, 1965a, Water resources survey, Flathead and Lincoln Counties, Montana--Part 1, History of land and water use on irrigated areas: Helena, Mont., State Engineer's Office, $56 \mathrm{p}$. 1965b, Water resources survey, Flathead and Lincoln Counties, Montana--Part 2, Maps showing irrigated areas: Helena, Mont., State Engineer's Office, 26 p.

National Oceanic and Atmospheric Administration, 1992, Monthly normals of temperature, precipitation, and heating and cooling degree days, 1961-90, Montana: Asheville, N.C., Climatography of the United States no. 81, unpaged.

Tuck, L.K., Briar, D.W., and Clark, D.W., in press, Geologic history and hydrogeologic units of intermontane basins of the Northern Rocky Mountains, Montana and Idaho: U.S. Geological Survey Hydrologic Investigations Atlas 738-A, 2 sheets, scale 1:750,000.

U.S. Geological Survey, issued annually, Water resources data, Montana: Helena, Mont., U.S. Geological Survey Water-Data Report. 


\section{Libby Creek Valley}

\section{Geography}

The Libby Creek Valley is a north-northwest-trending intermontane basin in northwestern Montana. The $87-\mathrm{mi}^{2}$ basin is bounded by the Purcell Mountains on the north and the Cabinet Mountains on the east, south, and west (pl. 1). Libby Creek flows northward through the basin, and joins the westward-flowing Kootenai River at Libby. Steep-sided terraces of silty glacial-lakebed deposits flank the flood plains of both rivers. A distinct terrace northeast of Libby abruptly rises $300 \mathrm{ft}$ above the city. Hummocky glacial drift extends from the terraces to the mountains, breaking the contact between the nearly horizontal terraces and the nearly vertical mountains. The Libby Creek Valley ranges in altitude from about $2,000 \mathrm{ft}$ where the Kootenai River flows out of the basin, to about $4,000 \mathrm{ft}$ on the highest glacial drift.

The climate of the Libby Creek Valley is typical of lower-elevation intermontane basins of the Northern Rocky Mountains west of the Conti-

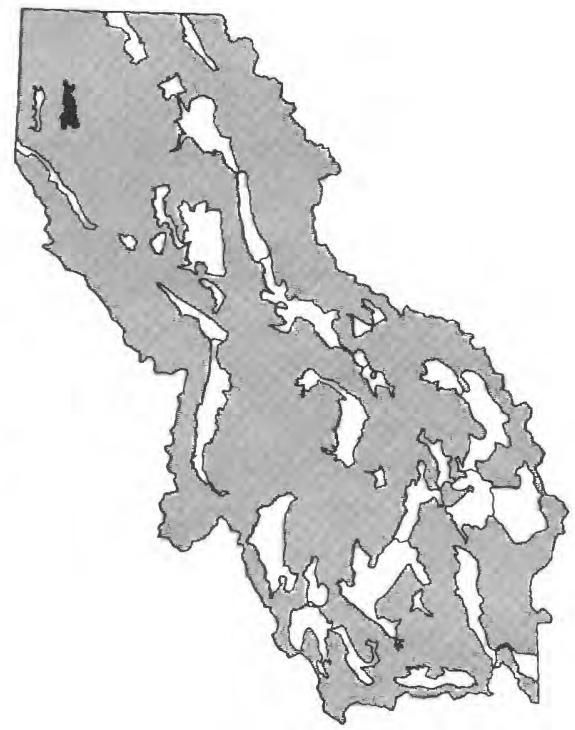
nental Divide, with relatively warm summers and cool, humid winters. On the basis of the 1961-90 period of record, the average annual precipitation at the Libby Ranger Station 1 mi northeast of Libby (altitude 2,100 ft) is 18.45 in., and the average annual temperature is $46.2^{\circ} \mathrm{F}$ (National Oceanic and Atmospheric Administration, 1992). The average last occurrence of $32^{\circ} \mathrm{F}$ is June 7 , and the average first occurrence is September 8 (Natural Resources Conservation Service, U.S. Department of Agriculture, unpub. data, 1994). Mean monthly climatic data for the Libby Ranger Station are plotted in figure 19.

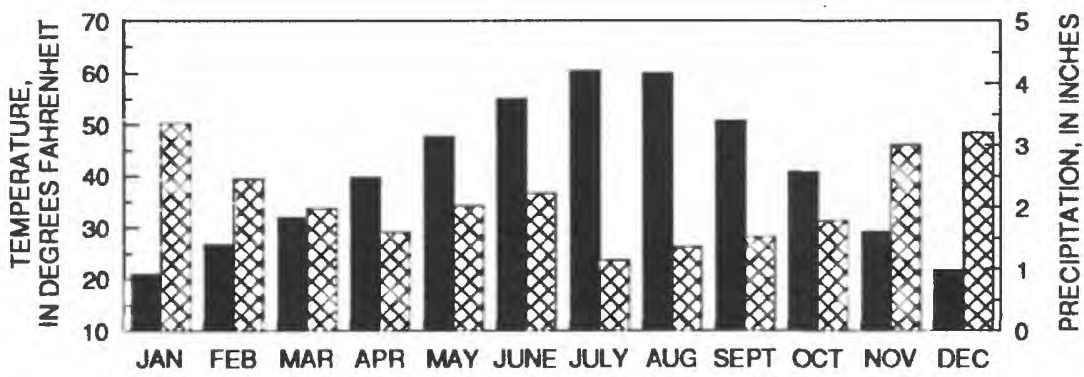

EXPLANATION

MEAN MONTHLY TEMPERATURE FOR 1961-90 PERIOD OF RECORD

区
MEAN MONTHLY PRECIPITATION FOR 1961-90 PERIOD OF RECORD

Figure 19. Mean monthly precipitation and temperature at the Libby Ranger Station, Mont. Data from National Oceanic and Atmospheric Administration (1992).

About 9,000 people reside in the Libby Creek Valley, including 2,532 in the City of Libby (1990 census). The basin population increased 64 percent from 1960 to 1970 when it grew from 7,300 to 12,045 residents (Boettcher and Wilke, 1978).

Timber harvesting and livestock grazing are the primary land uses in the Libby Creek Valley. Irrigated hay and pasture are also produced to a limited extent (J.C. Eggen, Agricultural Stabilization and Conservation Service, oral commun., 1993).

Gold and other minerals have been mined from the mountains surrounding the basin. In addition, several placer claims have heen worked, with varying levels of success, in Libby Creek and its tributaries (Gibson, 1948). Exploration and permitting are underway for copper, silver, and gold mines in the headwaters areas of Libby and Flower Creeks, and for a gold, lead, zinc, and silver mine in the Big Cherry Creek drainage area (McCulloch, 1993, p. 7, 45-6). 


\section{Geology}

The Libby Creek Valley formed by Cenozoic extension along normal faults on the east and west basin margins. The depth of the bedrock floor of the basin is unknown. According to the driller's log, the deepest well in the center of the basin (30N31 W15CAAA) is $576 \mathrm{ft}$ deep and does not penetrate bedrock (Montana Bureau of Mines and Geology, unpub. data, 1993).

Several investigators have examined the geology of the Libby Creek Valley (table 51). The geologic units described by previous investigators are summarized below. These geologic units are referenced to hydrogeologic units defined in this study (table 2) to provide a consistent regional framework. In the following discussion, the hydrogeologic-unit abbreviations are italicized.

Table 51. Geologic and geophysical maps of the Libby Creek Valley, Montana

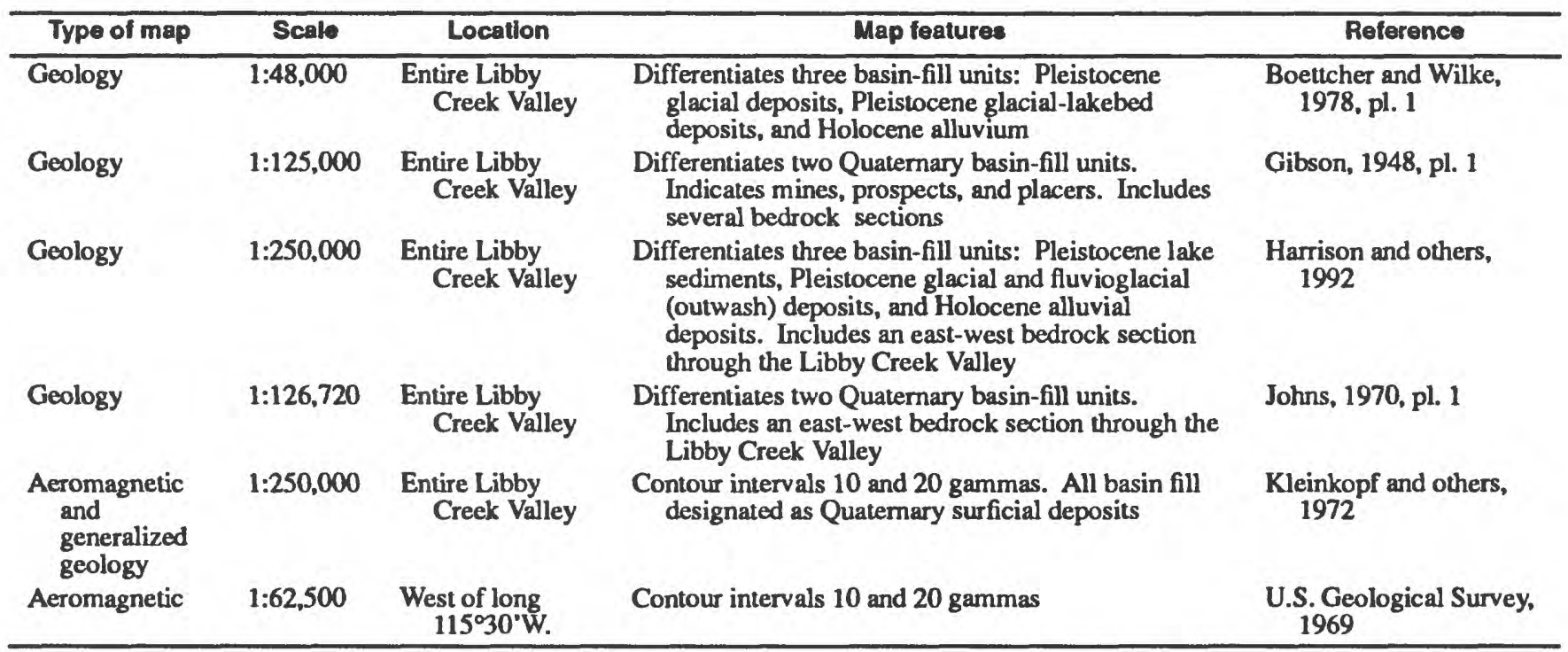

Middle Proterozoic bedrock of the Belt Supergroup (Yms) almost completely surrounds the basin. The argillite, quartzite, and siltite rocks are folded, faulted, and fractured in a generally north-northwestern trend (Harrison and others, 1992).

Tertiary sediments $(T s)$ overlie bedrock in most of the intermontane basins of the Northern Rocky Mountains. However, Tertiary sediments do not crop out in the Lake Creek Valley and drillers' logs do not indicate their presence in the subsurface (Montana Bureau of Mines and Geology, unpub. data, 1993).

Quaternary deposits in Libby Creek Valley include glacial drift $(Q g)$, glacial-lakebed deposits $(Q g)$, and alluvial deposits (Qal). More than $500 \mathrm{ft}$ of Pleistocene glacial drift, a heterogeneous mixture of boulders, gravel, sand, silt, and clay, probably overlies Proterozoic bedrock in most of the basin. Glacial drift mantles the hummocky hills along the edges of the basin, into which it extends from the adjacent mountain slopes (Boettcher and Wilke, 1978).

Pleistocene glacial-lakebed deposits from glacial Lake Kootenai underlie terraces adjacent to low-elevation flood plains. The glacial-lakebed deposits, which drillers' logs indicate are more than $600 \mathrm{ft}$ thick, consist primarily of clay, silt, and fine-grained sand. East of Libby, a 300-ft cliff has resulted from Libby Creek and the Kootenai River cutting down into glacial-lakebed deposits (Boettcher and Wilke, 1978).

Drillers' logs indicate that more than $100 \mathrm{ft}$ of Holocene alluvial deposits consisting of well-sorted silt, sand, gravel, and cobbles underlies the flood plains of Libby Creek and the Kootenai River, and lesser thicknesses fill tributary valleys. In the vicinity of Libby, a clayey deposit from about 40 to $60 \mathrm{ft}$ below land surface separates shallow alluvium from deeper alluvium (Montana Bureau of Mines and Geology, unpub. data, 1993). 


\section{Hydrology}

Big Cherry Creek and Libby Creek flow into the Libby Creek Valley from the southwest and south, respectively, and drain most of the basin. Big Cherry Creek joins Libby Creek about 2 mi south of Libby. A reservoir on Flower Creek (a tributary to Libby Creek) supplies municipal water for the City of Libby and adjacent subdivisions west of town. Just east of Libby, the Libby River joins the Kootenai River, which flows from east to west through the northem part of the Libby Creek Valley. Since 1972, flow in the Kootenai River has been regulated by Lake Koocanusa, which is impounded by Libby Dam about 11 mi east of Libby.

Streamflow data for gaging stations listed in table 52 are stored in the USGS WATSTORE database. Locations of the stations are shown on plate 1 . In addition, USGS has published reservoir elevation records for Lake Koocanusa near Libby (gaging station 12301920 , drainage area $8,985 \mathrm{mi}^{2}$ ) in annual Water-Data Reports since storage began in March 1972 (U.S. Gcological Survey, issued annually).

Table 52. Summary of data for U.S. Geological Survey streamflow-gaging stations in the Libby Creek Valley, Montana

[Type of data collected: $c$, water chemistry; $d$, discharge. Abbreviations: $\mathrm{ft}^{3} / \mathrm{s}$, cubic feet per second]

\begin{tabular}{|c|c|c|c|c|c|c|c|c|c|}
\hline \multirow[b]{2}{*}{$\begin{array}{l}\text { Station } \\
\text { number }\end{array}$} & \multirow[b]{2}{*}{ Station name } & \multirow{2}{*}{$\begin{array}{c}\text { Drainage } \\
\text { area } \\
\text { (square } \\
\text { miles) }\end{array}$} & \multirow{2}{*}{$\begin{array}{l}\text { Type } \\
\text { of } \\
\text { deta } \\
\text { col- } \\
\text { locted }\end{array}$} & \multirow[b]{2}{*}{$\begin{array}{l}\text { Period of record } \\
\text { (calendar year) }\end{array}$} & \multicolumn{5}{|c|}{ Diecharge for period of record } \\
\hline & & & & & $\begin{array}{c}\text { Mean } \\
\text { annual } \\
\left(t^{3} / s\right)\end{array}$ & $\begin{array}{l}\text { Maxi- } \\
\text { mum } \\
\left(f^{3} / s\right)\end{array}$ & $\begin{array}{l}\text { Date of } \\
\text { maximum }\end{array}$ & 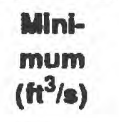 & $\begin{array}{l}\text { Date of } \\
\text { minimum }\end{array}$ \\
\hline 12302500 & $\begin{array}{l}\text { Granite Creek near } \\
\text { Libby }\end{array}$ & 23.6 & d & $\begin{array}{l}1933,1936-43 \\
1958-59,1960- \\
69\end{array}$ & 69.5 & 1,960 & $04-18-38$ & $\mathbf{0}$ & $01-04-33$ \\
\hline 12303000 & $\begin{array}{l}\text { Kootenai River at } \\
\text { Libby }\end{array}$ & 10,240 & $\begin{array}{l}\text { d } \\
\text { c }\end{array}$ & $\begin{array}{l}1910-91 \\
1968-73,1978\end{array}$ & 12,110 & 121,000 & $06-21-16$ & 895 & 01-11-30 \\
\hline 12303100 & $\begin{array}{l}\text { Flower Creek near } \\
\text { Libby }\end{array}$ & 11.1 & d & $1960-1992$ & 26.0 & 709 & 01-16-74 & 3.1 & $11-20-79$ \\
\hline
\end{tabular}

Surface-water quality in Libby Creek and the Kootenai River has been measured occasionally. Three samples collected from Libby Creek in September 1972 had dissolved-solids concentrations ranging from 80 to $90 \mathrm{mg} / \mathrm{L}$. The concentration of dissolved solids in the Kootenai River at Libby (gaging station 12303000) ranges from about 100 to $250 \mathrm{mg} / \mathrm{L}$ (Boettcher and Wilke, 1978).

The construction of Libby Dam to impound Lake Koocanusa has affected the quality of water in the Kootenai River downstream from the dam. For example, from 1972 to about 1976, before power generators were installed on the dam, nitrogen supersaturation resulted from water cascading down the spillway and entrapping air. The increased pressure caused atmospheric nitrogen to dissolve in the water, increasing nitrogen concentrations to levels intolerable to fish. Major fish kills were reported for at least ten miles below Libby Dam and symptoms of nitrogen poisoning were observed as far downstream as Troy (Nunnallee and Botz, 1974). More recently, flow alteration and resulting thermal modifications downstream from the dam limit the ability of the Kootenai River to support aquatic life, including cold-water fisheries (Montana Department of Health and Environmental Sciences, 1994).

Ground water is an important resource in the Libby Creek Valley. All residents outside Libby and its westem suburbs rely on private wells and springs for drinking-water supplies.

Wells completed in Quaternary alluvial deposits can produce more than $500 \mathrm{gal} / \mathrm{min}$ (Boettcher and Wilke, 1978). Beneath the flood plain near Libby, a 20 -ft-thick clayey layer locally separates the shallow (less than about $40 \mathrm{ft}$ below land surface) from the deep (more than about $60 \mathrm{ft}$ below land surface) alluvial aquifer. However, the deep aquifer has been impacted by contamination from surface sources (J. C. Harris, U.S. Environmental Protection Agency, oral commun,. 1995), indicating the clayey layer does not prevent vertical flow between the aquifers. Specific capacity and yield data for wells completed in Quaternary alluvium are summarized in table 53. 
Table 53. Summary of data for yield and specific capacity of wells completed in selected hydrogeologic units in the Libby Creek Valley, Montana

[Source: Dutton and others, 1995. Hydrogeologic units: Qal, Holocene and Pleistocene alluvial deposits; Qg, Pleistocene glacial deposits. Abbreviations: $\mathrm{gal} / \mathrm{min}$, gallon per minute; (gal/min)/ft, gallon per minute per foot]

\begin{tabular}{cccccccccccccc}
\hline \multirow{2}{*}{$\begin{array}{c}\text { Hydro- } \\
\text { geologic } \\
\text { unit }\end{array}$} & $\begin{array}{c}\text { Number } \\
\text { of wells }\end{array}$ & Mean & Median & $\begin{array}{c}\text { Mini- } \\
\text { mum }\end{array}$ & $\begin{array}{l}\text { Maxl- } \\
\text { mum }\end{array}$ & & $\begin{array}{c}\text { Number } \\
\text { of wells }\end{array}$ & Mean & Median & $\begin{array}{c}\text { Mini- } \\
\text { mum }\end{array}$ & $\begin{array}{c}\text { Maxi- } \\
\text { mum }\end{array}$ \\
\hline Qal & 16 & 35 & 10 & 2.0 & 360 & 14 & 3.2 & 1.0 & 0.1 & 18 \\
Qg & 16 & 15 & 10 & 3.0 & 45 & & 9 & 1.0 & .5 & .1 & 2.5 \\
\hline
\end{tabular}

Interbedded Pleistocene glacial drift and glacial-lakebed deposits yield water to wells from discontinuous, possibly perched, zones. In table $53, \mathrm{Qg}$ includes both glacial drift and glacial-lakebed deposits. Drillers' logs indicate that wells in glacial drift can produce as much as $45 \mathrm{gal} / \mathrm{min}$, whereas wells finished in glacial-lakebed deposits typically have smaller yields. Scattered gravel lenses within glacial-lakebed deposits provide adequate water for domestic use, but are not laterally extensive. Therefore, specific-capacity values for wells finished in glacial-lakebed deposits commonly are less than 1.0 (gal/min)/ft (Montana Bureau of Mines and Geology, unpub. data, 1994).

The Proterozoic bedrock that surrounds and underlies the basin generally is not a prolific aquifer, although in places it can yield sufficient water to wells for domestic use. Because of the great thickness of surficial Quaternary deposits, bedrock wells are located only along the basin margins. Typically, bedrock wells in the area produce less than $10 \mathrm{gal} / \mathrm{min}$ (Montana Bureau of Mines and Geology, unpub. data, 1994).

A 1:48,000-scale potentiometric-surface map of the Libby Creek Valley was compiled from water levels measured in the summer of 1972 (Boettcher and Wilke, 1978). This map indicates that ground water generally flows from the uplands toward the flood plains, then north, paralleling Libby Creek and west, paralleling the Kootenai River.

Basin-fill aquifers are recharged by precipitation and snowmelt, surplus irrigation water, subsurface flow from bedrock, and infiltration from tributary streams. The ground-water contribution area (fig. 2, pl. 1) is about $410 \mathrm{mi}^{2}$. Infiltration anywhere within this area could potentially recharge basin-fill aquifers in the Libby Creek Valley. Ground water discharges from basin-fill aquifers by evapotranspiration, withdrawals from wells, and seepage to springs, the Kootenai River, and the lower reaches of tributary streams.

Water levels measured in long-term monitoring well 31 N31 W33CCBB01 are stored in the USGS WATSTORE database. The 40-ft well is completed in Quaternary alluvial deposits. During the period of record from September 1972 to April 1989, the water level in the well fluctuated between $6.95 \mathrm{ft}$ below land surface (June 7,1974 ) and $13.77 \mathrm{ft}$ below land surface (Feb. 2, 1973).

The quality of ground water in the basin was determined on the basis of 67 samples analyzed for major ions and measured dissolved-solids concentrations and 32 samples in which dissolved-solids concentrations were estimated from specific-conductance measurements. Ground water is typically a calcium bicarbonate type throughout the basin. The concentration of dissolved solids is less than $250 \mathrm{mg} / \mathrm{L}$ everywhere except in the glacial deposits northeast of Libby where dissolved-solids concentrations range from about 250 to $500 \mathrm{mg} / \mathrm{L}$ (Clark and Dutton, in press).

Elevated concentrations of nitrate have been detected in ground water in some areas with private wells and septic tanks. A 1963-64 epidemic of infectious hepatitis among residents of rural subdivisions south of Libby prompted a basin-wide hydrogeological investigation. The water-quality analyses from that study showed that nitrate levels above the background concentrations of $1.5 \mathrm{mg} / \mathrm{L}$ were common in shallow wells, particularly south of Libby where the hepatitis outbreak had occurred. The study concluded that untreated sewage effluent from percolation pits was largely responsible for the elevated nitrate concentrations. In response to the study, the South Libby Flats Water and Sewer District was established to design municipal water and sewage systems for the area south of Libby (Boettcher and Wilke, 1978). The District drilled a test well and proposed a public water supply and 
sewer system to serve the rural community. Local support to fund the proposed system was not obtained and the South Libby Flats Water and Sewer District disbanded. Most residents have deepened their private wells to at least $60 \mathrm{ft}$. However, some residents continue to rely on shallow alluvial wells. Although septic tanks have replaced most of the percolation pits which previously allowed untreated sewage to enter the shallow aquifer directly (J.W. Peterson, Lincoln County Dept. of Environmental Health, oral commun., 1994), concentrations of nitrate ranging from 3.9 to $9.0 \mathrm{mg} / \mathrm{L}$ as $\mathrm{N}$ persist in at least three wells (U.S. Geological Survey, unpub. data, 1991). The U.S. Environmental Protection Agency (1991) has established a maximum contaminant level of $10 \mathrm{mg} / \mathrm{L}$ nitrate as $\mathrm{N}$ for treated drinking water.

East of Libby, water quality in the alluvial aquifer has been affected by dense nonaqueous phase liquid (DNAPL) contamination as a result of historical wood treating processes. Under the Comprehensive Environmental Response Compensation and Liability Act of 1980 (CERCLA), in situ and extractive bioremediation techniques are being used to treat the aquifer (Jim Davidson, Champion International, oral commun., 1991). The effort to investigate and remediate the CERCLA site has produced numerous technical documents which are available from the U.S. Environmental Protection Agency.

\section{Selected References}

Boettcher, A.J., and Wilke, K.R., 1978, Ground-water resources in the Libby area, northwestern Montana: Montana Bureau of Mines and Geology Bulletin 106, 36 p.

Clark, D.W., and Dutton, D.M., in press, Quality of ground water and surface water in intermontane basins of the Northern Rocky Mountains, Montana and Idaho: U.S. Geological Survey Hydrologic Investigations Atlas 738-C, 1 shcet, scale 1:750,000.

Dutton, D.M., Lawlor, S.M., Briar, D.W., and Tresch, R.E., 1995, Hydrogeologic data for the Northern Rocky Mountains intermontane basins, Montana: U.S. Geological Survey Open-File Report 95-143, 94 p.

Gibson, Russell, 1948, Geology and ore deposits of the Libby quadrangle, Montana, with sections on Pleistocene glaciation, by W.C. Alden, and Physiography, by J.T. Pardee: U.S. Geological Survey Bulletin 956, 131 p.

Harrison, J.E., Cressman, E.R., and Whipple, J.W., 1992, Geologic and structure maps of the Kalispell $1^{\circ} \times 2^{\circ}$ quadrangle, Montana, and Alberta and British Columbia: U.S. Geological Survey Miscellaneous Investigations Series Map I-2267, 2 sheets, scale 1:250,000.

Johns, W.M., 1959, Progress report on geologic investigations in the Kootenai-Flathead area, northwest Montana: Montana Bureau of Mines and Geology Bulletin 12, $56 \mathrm{p}$. 1970, Geology and mineral deposits of Lincoln and Flathead Counties, Montana: Montana Bureau of Mines and Geology Bulletin 79, $182 \mathrm{p}$.

Kleinkopf, M.D., Harrison, J.E., and Zartman, R.E., 1972, Aeromagnetic and geologic map of part of northwestern Montana and northern Idaho: U.S. Geological Survey Geophysical Investigations Map GP-830, scale 1:250,000.

McCulloch, Robin, 1993, Montana mining directory 1992: Montana Bureau of Mines and Geology Bulletin 131, $76 \mathrm{p.}$

Montana Department of Health and Environmental Sciences, 1994, Montana Water Quality, 1994: Helena, Water Quality Bureau, Montana 305(b) Report, 159 p.

[Montana] State Engineer's Office, 1965a, Water resources survey, Flathead and Lincoln Counties, Montana--Part 1, History of land and water use on irrigated areas: Helena, Mont., State Engineer's Office, 56 p.

1965b, Water resources survey, Flathead and Lincoln Counties, Montana--Part 2, Maps showing irrigated areas: Helena, Mont., State Engineer's Office, 26 p.

National Oceanic and Atmospheric Administration, 1992, Monthly normals of temperature, precipitation, and heating and cooling degree days, 1961-90, Montana: Asheville, N.C., Climatography of the United States no. 81, unpaged.

Nunnallee, David, and Botz, M.K., 1974, Water quality inventory and management plan, Kootenai River basin, Montana: Montana Department of Health and Environmental Sciences, 49 p.

Tuck, L.K., Briar, D.W., and Clark, D.W., in press, Geologic history and hydrogeologic units of intermontane basins of the Northern Rocky Mountains, Montana and Idaho: U.S. Geological Survey Hydrologic Investigations Atlas 738-A, 2 sheets, scale 1:750,000.

U.S. Environmental Protection Agency, 1991, Maximum contaminant levels (subpart B of part 141, National primary drinkingwater regulations): U.S. Code of Federal Regulations, Title 40, Parts 100 to 149, revised, July 1, 1991, p. 585-588.

U.S. Geological Survey, 1969, Aeromagnetic map of the Libby and Mt. Pend Oreille quadrangles, Lincoln and Sanders Counties, Montana and Bonner County, Idaho: U.S. Geological Survey Geophysical Investigations Map GP-682, scale $1: 62,500$.

issued annually, Water Resources Data, Montana: Helena, Mont., U.S. Geological Survey Water-Data Report. 


\section{Little Bitterroot Valley}

\section{Geography}

The Little Bitterroot Valley, a north-northwest-trending intermontane basin in the western part of the Flathead Indian Reservation, is bounded by the Salish Mountains on the east and the Cabinet Mountains on the west (pl. 1). The $110-\mathrm{mi}^{2}$ basin narrows from about $5 \mathrm{mi}$ wide in the north to about $1 \mathrm{mi}$ wide in the south. The Little Bitterroot River flows southeastward through the basin for about $30 \mathrm{mi}$, from below Hubbart Reservoir to the Flathead River. North of Lonepine, the topography is characterized by undulating hills formed on eroded silty deposits. To the south, the undulating topography grades to a relatively level surface. Broad, low, alluvial fans slope off the mountain fronts. The Little Bitterroot Valley ranges in altitude from about $2,600 \mathrm{ft}$ where the Little Bitterroot River flows out of the basin to about $3,500 \mathrm{ft}$ on the highest alluvial fan.

Because of a rainshadow effect of the Cabinet Mountains, the climate

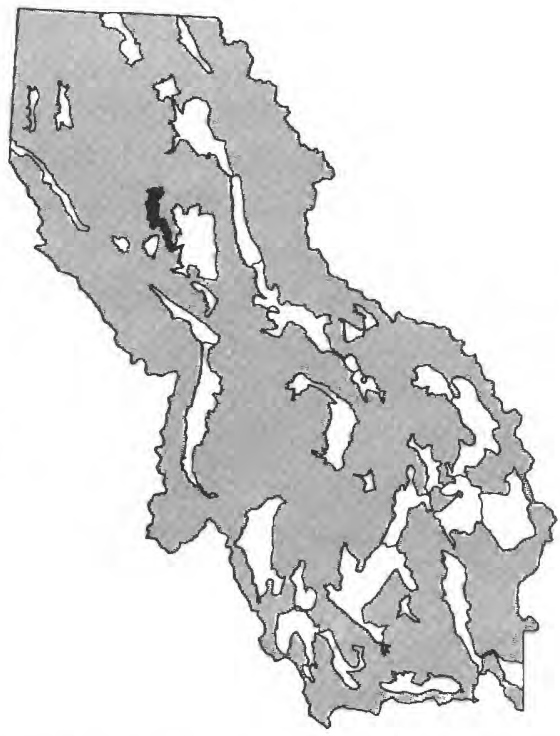
of the Little Bitterroot Valley is somewhat drier than other lower-elevation intermontane basins of the Northern Rocky Mountains west of the Continental Divide. On the basis of the 1931-60 period of record, the average annual precipitation one mile west-northwest of Lonepine (altitude 2,880 ft) is $11.46 \mathrm{in}$., and the average annual temperature is $45.3^{\circ} \mathrm{F}$ (National Oceanic and Atmospheric Administration, 1962). The average last occurrence of $32^{\circ} \mathrm{F}$ is May 25 and the average first occurrence is September 18 (Natural Resources Conservation Service, U.S. Department of Agriculture, unpub. data, 1994). Mean monthly climatic data for the Lonepine 1 WNW station are plotted in figure 20. Hot Springs, which is close to the mountains, receives about 14 in. of precipitation annually (U.S. Soil Conservation Service, 1977).

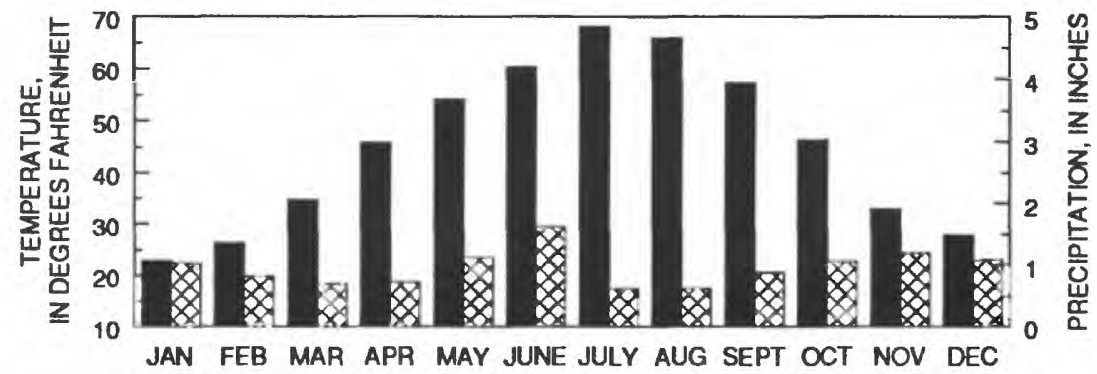

EXPLANATION

MEAN MONTHLY TEMPERATURE FOR 1931-60 PERIOD OF RECORD

$\bigotimes$ MEAN MONTHLY PRECIPITATION FOR 1931-60 PERIOD OF RECORD

Figure 20. Mean monthly precipitation and temperature at Lonepine, Mont. Data from National Oceanic and Atmospheric Administration (1962).

Land uses include rangeland and irrigated hay and grain production. In addition, dryland small grains are grown to a limited extent on alluvial fans (J.C. Eggen, Agricultural Stabilization and Conservation Service, oral commun., 1993). The Flathead Agency Irrigation Division manages an elaborate network of distribution canals that divert water from the Little Bitterroot River and its tributaries to about 6,000 acres of irrigable land, primarily between Lonepine and Hot Springs. Irrigation wells produce water for an additional 3,000 to 3,500 acres, primarily at elevations below 2,780 ft along the Little Bitterroot River. Donovan (1985a) documented the history of water development and use in the Little Bitterroot Valley. About 1,000 people reside in the Little Bitterroot Valley, including 411 in the Town of Hot Springs (1990 census). 


\section{Geology}

The Little Bitterroot Valley is bounded and cross-cut by normal faults (Donovan, 1985a; Harrison and others, 1986). Gravity and seismic-refraction data and well logs indicate that about $7 \mathrm{mi}$ east of Hot Springs, the maximum thickness of the basin fill is about 1,000 ft (Slagle, 1988). However, Noble and others (1982) reported a maximum thickness of more than 2,000 ft about 6 mi south of Lonepine, based on gravity data. Most of the basin is less than $200 \mathrm{ft}$ deep (Slagle, 1988).

Several investigators have examined the geology of the Little Bitterroot Valley (table 54). The geologic units described by previous investigators are summarized below. These geologic units are referenced to hydrogeologic units defined in this study (table 2) to provide a consistent regional framework. In the following discussion, the hydrogeologic-unit abbreviations are italicized.

Table 54. Geologic and geophysical maps of the Little Bitterroot Valley, Montana

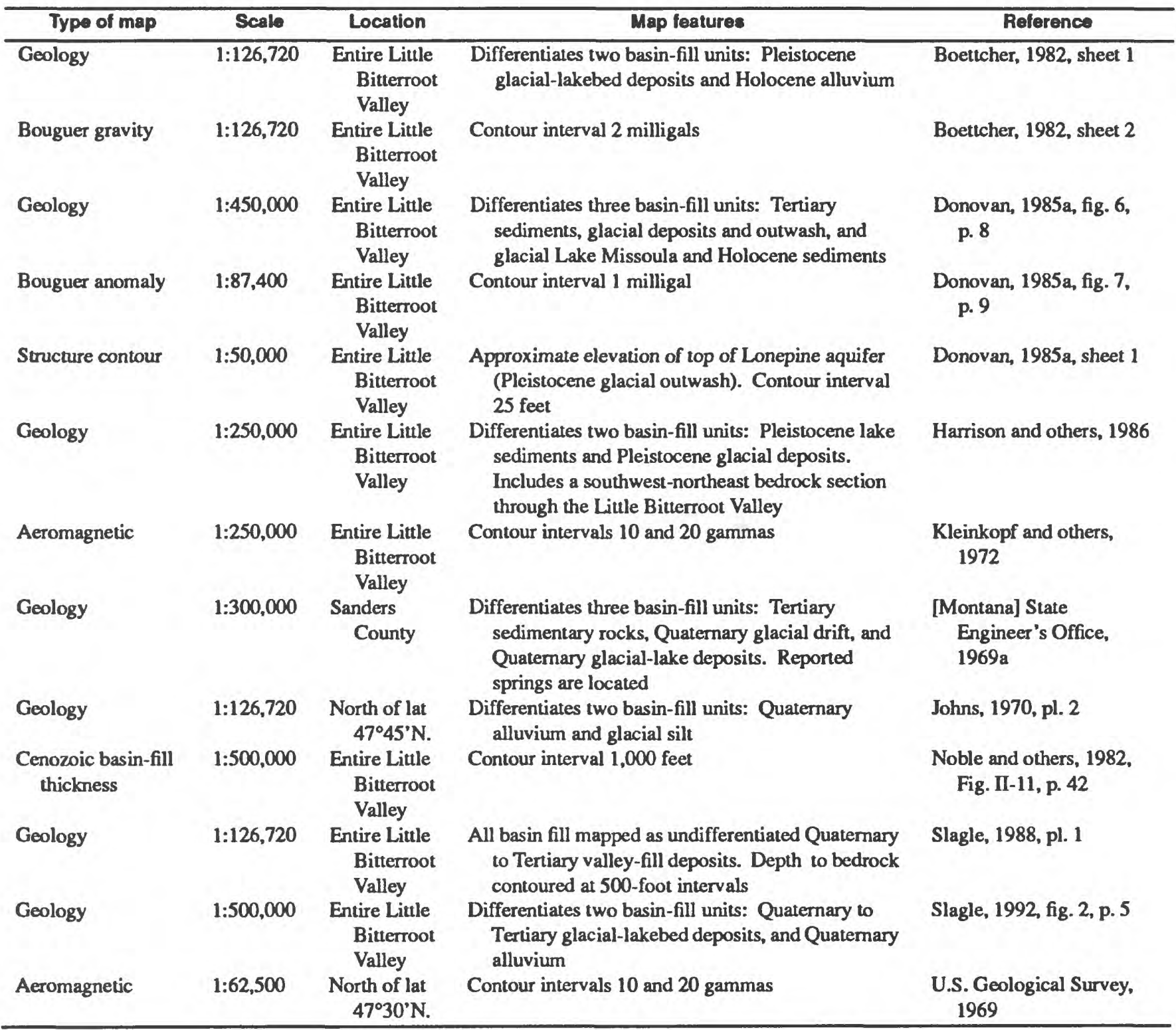


Metasedimentary rocks of the Middle Proterozoic Belt Supergroup (Yms) consisting of quartzite and quartzitic argillite surround the basin. Proterozoic hornblende-diorite dikes and sills as thick as $1,500 \mathrm{ft}$ locally intrude the metasedimentary bedrock, which has been metamorphosed as far as $600 \mathrm{ft}$ from the largest sills (Harrison and others, 1986; Donovan, 1985a). Tertiary pyroclastic volcanic rocks (QTKe), including rhyolite, tuff, volcaniclastic conglomerate, and volcanic ash, border the basin near Niarada (Donovan, 1985a).

Tertiary sediments (Ts) do not crop out, but are inferred from well logs to overlie bedrock everywhere except in the Camp Aqua area. Loosely cemented, very fine-grained gray sandstone; gray, brown, blue, or green clay; and tan or brown siltstone characterize the partially consolidated sediments. Stringers of low-grade coal are present locally (Slagle, 1988; Boettcher, 1982; Donovan, 1985a).

Pleistocene glacial outwash (Qal) ranging in thickness from about 10 to $60 \mathrm{ft}$ overlies Proterozoic and Tertiary rocks and sediments, but does not crop out. Drillers' logs describe the glacial outwash as very clean sand and gravel. Generally, the grain size and overall thickness of these deposits decrease to the south, although the thickness varies considerably over short distances (Slagle, 1988; Donovan, 1985a). Meinzer (1917) regarded these deposits as ancestral Flathead River alluvium.

Pleistocene deposits from glacial Lake Missoula $(Q g)$ overlie glacial outwash throughout the basin. The glacial-lakebed deposits consist of buff-to-lavender, varved, silty clay with a few lenses of sand and occasional gravel seams (Harrison and others, 1986) and range in thickness from zero to more than $300 \mathrm{ft}$ (Noble and others, 1982; Slagle, 1988).

Holocene alluvium (Qal) underlies the flood plains of the Little Bitterroot River on the eastern side of the basin, as well as several tributary flood plains along the basin margins. The alluvium is less than $100 \mathrm{ft}$ thick everywhere except in the northeast part of the basin along State Highway 28, where its thickness exceeds $400 \mathrm{ft}$. The composition of alluvium from different tributaries varies, but generally is composed of sand and gravel with varying amounts of boulders, cobbles, silt, and occasionally clay. In contrast, alluvium within the flood plain of the Little Bitterroot River south of Lonepine contains a large proportion of reworked glacial Lake Missoula silt (Donovan, 1985a).

\section{Hydrology}

The Little Bitterroot River originates at Little Bitterroot Lake in the Salish Mountains, and flows southeast through the Little Bitterroot Valley to its confluence with the Flathead River. Natural drainage to the Little Bitterroot River is modified by an elaborate irrigation system. Canals deliver irrigation water from four upland reservoirs to valley croplands, and additional canals divert from the Little Bitterroot River and its tributaries. Some of the water used to irrigate the Little Bitterroot Valley originates outside the drainage basin. For example, water is diverted from the Thompson Creek drainage and stored in the Upper Dry Fork Reservoir near Lonepine for application in the Little Bitterroot drainage (Donovan, 1985a).

Streamflow data for gaging stations listed in table 55 are stored in the USGS WATSTORE database. Locations of the stations are shown on plate 1. In addition, the monthend usable contents of the four irrigationwater reservoirs have been published in Water-Supply Papers and Water-Data Reports regularly since 1940. Data for years prior to 1961 are published in Water-Supply Papers; more recent data are in annual Water-Data Reports (U.S. Geological Survey, issued annually). These are Little Bitterroot Lake (gaging station 12372500, drainage area $31.8 \mathrm{mi}^{2}$ ) and Hubbart Reservoir (gaging station 12373500 , drainage area $114 \mathrm{mi}^{2}$ ) on the Little Bitterroot River, and Upper Dry Fork Reservoir (gaging station 12375000, drainage area $8.53 \mathrm{mi}^{2}$ ) and Dry Fork Reservoir (gaging station 12375500 , drainage area $17.8 \mathrm{mi}^{2}$ ) on Dry Fork Creek.

Surface-water quality has been measured for two streams. Analyses of 16 samples from Mill Creek (gaging station 12374250) indicate a calcium sodium bicarbonate type water with an average dissolved-solids concentration of $34 \mathrm{mg} / \mathrm{L}$. Downstream, 31 samples from the Little Bitterroot River near Perma (gaging station 12375800) 
Table 55. Summary of data for U.S. Geological Survey streamflow-gaging stations in the Little Bitterroot Valley, Montana

[Type of data collected: $c$, water chemistry; d, discharge; s, suspended sediment. Periods of record for stations that were being operated as of November 1994 are indicated by the first year of record followed by a dash only. Abbreviations: $\mathrm{ft}^{3} / \mathrm{s}$, cubic feet per second. Symbol: --, no data]

\begin{tabular}{|c|c|c|c|c|c|c|c|c|c|}
\hline \multirow[b]{2}{*}{$\begin{array}{l}\text { Station } \\
\text { number }\end{array}$} & \multirow[b]{2}{*}{ Station name } & \multirow{2}{*}{$\begin{array}{l}\text { Drainage } \\
\text { area } \\
\text { (square } \\
\text { miles) }\end{array}$} & \multirow{2}{*}{$\begin{array}{c}\text { Type } \\
\text { of } \\
\text { data } \\
\text { col- } \\
\text { lected }\end{array}$} & \multirow[b]{2}{*}{$\begin{array}{l}\text { Period of record } \\
\text { (calendar year) }\end{array}$} & \multicolumn{5}{|c|}{ Discharge for period of record } \\
\hline & & & & & $\begin{array}{l}\text { Mean } \\
\text { annual } \\
\left(f t^{3 / 8}\right)\end{array}$ & $\begin{array}{l}\text { Maxt- } \\
\text { mum } \\
\left(\mathrm{ft}^{3} / 8\right)\end{array}$ & $\begin{array}{l}\text { Date of } \\
\text { maximum }\end{array}$ & $\begin{array}{l}\text { Mini- } \\
\text { mum } \\
\left(\mathrm{ft}^{3} / 8\right)\end{array}$ & $\begin{array}{l}\text { Date of } \\
\text { minimum }\end{array}$ \\
\hline 12373000 & $\begin{array}{l}\text { Little Bitterroot River } \\
\text { near Marion }\end{array}$ & 31.8 & d & $1910-16$ & 17.7 & 53 & $04-27-16$ & 0 & $01-19-15$ \\
\hline 12374000 & $\begin{array}{l}\text { Little Bitterroot River } \\
\text { near Hubbart }\end{array}$ & 134 & d & $\begin{array}{l}\text { 1909-16, } \\
\text { (intermittent) }\end{array}$ & -- & 340 & $05-06-16$ & 1.4 & $10-20-14$ \\
\hline 12374250 & $\begin{array}{l}\text { Mill Creek above } \\
\text { Bassoo Creek, near } \\
\text { Niarada }\end{array}$ & 19.6 & $\begin{array}{l}\text { d } \\
\text { c }\end{array}$ & $\begin{array}{l}1982- \\
1983-85\end{array}$ & 7.26 & 113 & $05-20-91$ & .85 & $01-06-88$ \\
\hline 12374500 & $\begin{array}{l}\text { Little Bitterroot River } \\
\text { near Niarada }\end{array}$ & 223 & d & $\begin{array}{c}1908-09,1916-17, \\
\text { (intermittent) }\end{array}$ & -- & 412 & $05-07-16$ & 3.0 & $08-28-17$ \\
\hline 12374800 & $\begin{array}{l}\text { Cromwell Creek near } \\
\text { Niarada }\end{array}$ & 14.3 & $\begin{array}{l}\text { d } \\
\text { c }\end{array}$ & $\begin{array}{l}21982-89 \\
1983-1985\end{array}$ & .66 & 14 & 03-04-86 & $\mathbf{0}$ & $\begin{array}{l}\text { At times } \\
\text { most } \\
\text { years }\end{array}$ \\
\hline 12375800 & $\begin{array}{l}\text { Little Bitterroot near } \\
\text { Perma }\end{array}$ & 585 & $c, s$ & $1987-92$ & -- & -- & -- & - & -- \\
\hline
\end{tabular}

${ }^{1}$ Data for water years 1915 and 1916.

${ }^{2}$ No winter reconds for $1987-1989$.

indicate a sodium bicarbonate type water with an average dissolved-solids concentration of $138 \mathrm{mg} / \mathrm{L}$. The downstream increase in sodium and dissolved solids probably results from inflows of ground water associated with geothermal activity (Clark and Dutton, in press).

The Little Bitterroot River is turbid and carries heavy sediment loads. Turbidity is generally highest during the summer when irrigation return flows contribute suspended sediment to seasonally low streamflows (Nunnallee and Botz, 1976).

Ground water is an important resource in the Little Bitterroot Valley. The basin-fill aquifer system provides domestic water for all rural residents. The municipal supply for Hot Springs and the adjacent area combines surfaceand ground-water sources (Boettcher, 1982).

Shallow unconfined aquifers composed of Holocene alluvium are located primarily along the Little Bitterroot River north of Lonepine and in tributary valleys along the basin margins. Along the Little Bitterroot River west of Niarada, where the river emerges from the mountains, wells completed in a bouldery gravel lens that is at least 72 $\mathrm{ft}$ thick, yield as much as $500 \mathrm{gal} / \mathrm{min}$. South of Lonepine, silt and clay limit production from Little Bitterroot River flood-plain alluvium. Along the basin margins, wells and small springs in alluvium yield sufficient water for domestic and livestock use. In tributary valleys on the east side of the basin, south of Lonepine, some wells completed in alluvium are capable of producing several hundreds of gallons per minute from depths of less than 100 $\mathrm{ft}$ (Donovan, 1985a).

Pleistocene glacial-lakebed deposits do not yield usable quantities of water to wells. Typically, wells are drilled through the glacial-lakebed deposits to tap the underlying glacial outwash.

Pleistocene glacial outwash is the primary aquifer in the Little Bitterroot Valley (Donovan, 1985a). Most wells completed in this aquifer are between 200 and $300 \mathrm{ft}$ deep and some produce more than $800 \mathrm{gal} / \mathrm{min}$. Specificcapacity values range from 100 to more than 200 ( $\mathrm{gal} / \mathrm{min}$ )/ft and transmissivity values range from 27,000 to $134,000 \mathrm{ft}^{2} / \mathrm{d}$. The aquifer, which is confined beneath glacial-lakebed deposits, has a storage coefficient of about 0.0003 , resulting in rapid and extensive drawdown in response to pumping. Drawdown from irrigation ranges from 
2 to $20 \mathrm{ft}$ in most years. Although this is small compared to the total thickness of the aquifer ( 60 to $200 \mathrm{ft}$ ), it is enough to stop or significantly reduce discharge from flowing wells. Because numerous ranchers rely on these wells, the allocation of ground water from this aquifer has been a concern. To assist planners with future allocations, Donovan (1985a) developed a transient two-dimensional numerical ground-water flow model of the glacial-outwash aquifer.

Few wells tap Tertiary sediments in the Little Bitterroot Valley. Generally, Tertiary sediments underlie productive Pleistocene or Holocene aquifers, which are more reliable. Typically, wells completed in Tertiary sediments yield less than $15 \mathrm{gal} / \mathrm{min}$ (Dutton and others, 1995; Slagle, 1988). Two test wells completed in Tertiary sediments reportedly have transmissivity values of 3.2 to $18 \mathrm{ft}^{2} / \mathrm{d}$ and specific-capacity values of about 0.1 (gal/min)/ft (Slagle, 1988).

Although local Tertiary volcanic rocks are somewhat porous, little data are available regarding their hydraulic characteristics (Boettcher, 1982). A few wells north of Niarada produce from fractured or altered zones in the volcanic rocks (Donovan, 1985a).

Wells completed in fractures in Proterozoic bedrock can yield adequate water supplies for domestic use. Typically, the bedrock aquifer is used only in areas around the basin margin and near bedrock outcrops, where Quaternary deposits are thin or absent. Of 33 bedrock wells tested throughout the Flathead Indian Reservation, discharge rates ranged from 2.5 to $40 \mathrm{gal} / \mathrm{min}$ and averaged $9.5 \mathrm{gal} / \mathrm{min}$; specific-capacity values ranged from 0.08 to $3.2(\mathrm{gal} / \mathrm{min}) / \mathrm{ft}$ and averaged $0.73(\mathrm{gal} / \mathrm{min}) / \mathrm{ft}$ (Slagle, 1988). Aquifer tests indicate that the transmissivity of the bedrock fracture system in the Camas area typically ranges from about 700 to $1,300 \mathrm{ft}^{2} / \mathrm{d}$ (Gary, 1982).

Potentiometric-surface maps of the Little Bitterroot Valley (table 56) indicate that ground water generally flows from the uplands toward the center of the basin, then southeastward toward the Flathead River. Water levels in glacial outwash decline during the irrigation season, particularly in dry years (Donovan, 1985a).

Table 56. Potentiometric-surface maps of the Little Bitterroot Valley, Montana

\begin{tabular}{lllll}
\hline \multicolumn{1}{c}{ Location } & \multicolumn{1}{c}{$\begin{array}{c}\text { Dates water levels } \\
\text { were measured }\end{array}$} & \multicolumn{1}{c}{ Scale } & $\begin{array}{c}\text { Contour Interval } \\
\text { In feet }\end{array}$ & \multicolumn{1}{c}{ Reference } \\
\hline Entire Little Bitterroot Valley & Summers of 1974-76 & $1: 126,720$ & 10,40 , and 50 & Boettcher, 1982, sheet 3 \\
Entire Little Bitterroot Valley & Oct. 17, 1981 & $1: 50,000$ & 5 & Donovan, 1985, sheet 1 \\
Entire Little Bitterroot Valley & $1967-1984$ & $1: 126,720$ & 25,50 , and 100 & Slagle, 1988, pl.2 \\
\hline
\end{tabular}

Basin-fill aquifers are recharged by precipitation and snowmelt, leakage of water from irrigation canals, subsurface flow from surrounding bedrock and from the alluvial valley between Niarada and Elmo, geothermal water in the Hot Springs and Camp Aqua areas, and infiltration from tributary streams. The ground-water contribution area (fig. 2, pl. 1) is about $580 \mathrm{mi}^{2}$. Infiltration anywhere within this area could potentially recharge basin-fill aquifers in the Little Bitterroot Valley. Ground water discharges from basin-fill aquifers by evapotranspiration, withdrawal from pumped and flowing wells, subsurface flow to the Mission Valley, and seepage to springs, seeps, irrigation drains, and stream channels.

Several components of the water budget have been estimated. Direct precipitation and leakage from irrigation canals account for only a small proportion of recharge to basin-fill aquifers because poorly permeable glaciallakebed deposits impede infiltration to the underlying aquifer. Geothermal water from fractured bedrock recharges confined glacial-lakebed deposits in the Camp Aqua area at an estimated rate of about 1,600 acre-ft/yr (1,000 $\mathrm{gal} / \mathrm{min}$ ) (Donovan, 1985a). Domestic wells withdrew about 340 acre-ft of ground water, and irrigation wells pumped about 6,300 acre-ft from aquifers in the Little Bitterroot Valley in 1980 (Slagle, 1988). Subsurface flow from the Little Bitterroot Valley to the Mission Valley accounts for an estimated 610 acre-ft/yr (Slagle, 1988). Discharge to the Little Bitterroot River accounts for about 11,400 acre-ft/yr, according to synoptic streamflow measurements on February 13 to 15, 1984 (Slagle, 1988). Bocttcher (1982) estimated withdrawals from irrigation 
wells and surface-water infiltration to ground water in the combined areas of the Mission Valley and the Little Bitterroot Valley.

Proterozoic bedrock discharges geothermal water to springs, wells, and basin-fill aquifers. In the Hot Springs area, about $75 \mathrm{gal} / \mathrm{min}$ flows from springs, and geothermal wells yield about 50 to $115 \mathrm{gal} / \mathrm{min}$. The source of geothermal water in the Hot Springs area is apparently about 300 to $400 \mathrm{ft}$ below land surface (Gary, 1982). The warmest spring water in the area is $49^{\circ} \mathrm{C}$, whereas well water ranges from 14 to $51^{\circ} \mathrm{C}$. In the Camp Aqua area, geothermal water discharges from bedrock into glacial outwash at a depth of about 240 to $300 \mathrm{ft}$. Wells completed in the Camp Aqua area yield water with temperatures ranging from 13 to $52^{\circ} \mathrm{C}$. A 1,002-ft-deep well completed in fractured bedrock flows about $650 \mathrm{gal} / \mathrm{min}$ (Donovan, 1985a).

Water-level data for wells listed in table 57 are stored in the USGS WATSTORE database. In this table, Qal indicates either Holocene alluvium or Pleistocene glacial outwash.

Table 57. Summary of water-level data for selected wells in the Little Bitterroot Valley, Montana

[Hydrogeologic unit: Qal, Holocene and Pleistocene alluvial deposits. Periods of record for observation wells that were being operated as of February 1995 are indicated by the first year of record followed by a dash only]

\begin{tabular}{|c|c|c|c|c|c|c|c|}
\hline \multirow[b]{2}{*}{ Location number } & \multirow{2}{*}{$\begin{array}{l}\text { Depth of well, } \\
\text { In feet below } \\
\text { land surface }\end{array}$} & \multirow{2}{*}{$\begin{array}{l}\text { Hydro- } \\
\text { geologic } \\
\text { unit }\end{array}$} & \multirow{2}{*}{$\begin{array}{l}\text { Perlod of } \\
\text { record }\end{array}$} & \multicolumn{4}{|c|}{ Water level, in feet below or above $(+)$ land surface } \\
\hline & & & & Highest & $\begin{array}{c}\text { Date(s) of } \\
\text { highest }\end{array}$ & Lowest & $\begin{array}{l}\text { Date of } \\
\text { lowest }\end{array}$ \\
\hline 24N23W21BCDA01 & 250 & Qal & 1975 & 31.10 & $10-09-80$ & 39.51 & $04-11-94$ \\
\hline 23N24W27CDDD01 & 184.0 & Qal & $1967-$ & 21.60 & $05-18-67$ & 36.46 & $07-19-94$ \\
\hline 23N24W34ADAA01 & 377 & Qal & 1943- & 102.72 & $04-10-81$ & 118.72 & $10-07-94$ \\
\hline 21N24W01CCC 01 & 185 & Qal & 1973-77 & 1.13 & $07-01-75$ & 6.38 & $01-15-75$ \\
\hline 20N22W30DADD01 & 155 & Qal & 1969- & +1.90 & $\begin{array}{l}\text { Several } \\
\text { times } \\
1972-82\end{array}$ & 7.63 & $01-25-95$ \\
\hline
\end{tabular}

The quality of ground water in the basin was determined on the basis of 57 samples analyzed for major ions and measured dissolved-solids concentrations, and 4 samples in which dissolved-solids concentrations were estimated from specific-conductance measurements. Ground water in the basin ranges from a mixed-cation bicarbonate to a sodium bicarbonate type, with dissolved-solids concentrations ranging from less than $250 \mathrm{mg} / \mathrm{L}$ to almost $500 \mathrm{mg} / \mathrm{L}$. In general, the concentrations of sodium and dissolved solids increase downstream toward areas of geothermal activity (Clark and Dutton, in press). The geothermal water also has elevated concentrations of lithium, boron, chloride, fluoride, and arsenic (Donovan, 1985a). Downgradient from the geothermal areas, recharge from surface-water tributaries dilutes dissolved constituents in ground water.

\section{Selected References}

Boettcher, A.J., 1982, Ground-water resources in the central part of the Flathead Indian Reservation, northwestern Montana: Montana Bureau of Mines and Geology Memoir 48, 28 p.

Briar, D.W., 1987, Water resource analysis of the Sullivan Flats area near Niarada, Flathead Indian Reservation, Montana: Missoula, University of Montana, M.S. thesis, 184 p.

Briar, D.W., Lawlor, S.M., Stone, M.A.J., Parliman, D.J., Schaefer, J.L., and Kendy, Eloise, in press, Ground-water levels in intermontane basins of the Northern Rocky Mountains, Montana and Idaho: U.S. Geological Survey Hydrologic Investigations Atlas 738-B, 1 sheet, scale 1:750,000.

Clark, D.W., and Dutton, D.M., in press, Quality of ground water and surface water in intermontane basins of the Northern Rocky Mountains, Montana and Idaho: U.S. Geological Survey Hydrologic Investigations Atlas 738-C, 1 sheet, scale 1:750,000. 
Curry, R.R., Lister, J.C., and Stoffel, Keith, 1977, Glacial history of Flathead Valley and Lakes Missoula floods in Glacial geology of Flathead Valley and catastrophic drainage of glacial Lakes Missoula: Rocky Mountain Section, Geological Society of America 30th Annual Meeting Field Guide No. 4, p. 14-38.

Donovan, J.J., 1985a, Hydrogeology and geothermal resources of the Litule Bitterroot valley, northwestern Montana: Montana Bureau of Mines and Geology Memoir 58,60 p.

1985b, Hydrogeologic test data for the Lonepine aquifer, Little Bitterroot valley, northwestern Montana: Montana Bureau of Mines and Geology Open-File Report 162, 10 p.

Donovan, J.J., Wideman, C.J., and Sonderegger, J.L, 1980, Geochemical evaluation of shallow dilution of geothermal water in the Little Bitterroot River, Montana: Geothermal Resources Council Transactions, v. 4, p. 157-160.

Donovan, JJ., and Sonderegger, John, 1981, Drilling report of Camp Aqua geothermal test well \#1, Hot Springs, Montana: Montana Bureau of Mines and Geology Open-File Report 80, 42 p.

Dutton, D.M., Lawlor, S.M., Briar, D.W., and Tresch, R.E., 1995, Hydrogeologic data for the Northern Rocky Mountains intermontane basins, Montana: U.S. Geological Survey Open-File Report 95-143, 94 p.

Gary, S.D., 1982, Geothermal investigation of the Camas Hot Springs area for the Confederated Salish and Kootenai Tribes of the Flathead Indian Reservation: Report to the Bureau of Indian Affairs, $22 \mathrm{p}$.

Harrison, J.E., Griggs, A.B, and Wells, J.D., 1986, Geologic and structure maps of the Wallace $1^{\circ} \times 2^{\circ}$ quadrangle: U.S. Geological Survey Miscellaneous Investigation Series Map I-1509, 2 sheets, scale 1:250,000.

Hawe, R.G., 1974, A telluric current survey over two known geothermal areas: Missoula, University of Montana, M.S. thesis, $45 \mathrm{p}$.

Johns, W.M., 1970, Geology and mineral deposits of Lincoln and Flathead Counties, Montana: Montana Bureau of Mines and Geology Bulletin 79, 182 p.

Johns, W.M., McClernan, H.G., and Lawson, D.C., 1971, Geological reconnaissance and soil-sample investigation of the Ravalli-Dixon-Perma-Camas Prairie area, Sanders County, Montana: Montana Bureau of Mines and Geology Open-File Report 10,73 p.

Kleinkopf, M.D., Harrison, J.E., and Zartman, R.E., 1972, Aeromagnetic and geologic map of part of northwestern Montana and northern Idaho: U.S. Geological Survey Geophysical Investigations Map GP-830, scale 1:250,000.

LaPoint, DJ., 1971, Geology and geophysics of the southwestern Flathead Lake region, Montana: Missoula, University of Montana, M.S. thesis, $110 \mathrm{p}$.

1973, Gravity survey and geology of the Flathead Lake region, Montana: Northwest Geology, v. 2, p. 13-20.

Levings, G.W., and White, M.K., 1983, Selected annotated bibliography of ground-water resources, records of wells and springs, and availability of streamflow data on Indian reservations in Montana: U.S. Geological Survey Open-File Report $83-129,137 \mathrm{p}$.

Meinzer, O.E., 1917, Artesian water for irrigation in the Little Bitterroot valley, Montana: U.S. Geological Survey Water-Supply Paper 400-B, p. 9-37.

[Montana] State Engineer's Office, 1969a, Water resources survey, Mineral and Sanders Counties, Montana--Part 1, History of land and water use on irrigated areas: Helena, Mont., State Engineer's Office, 62 p.

1969b, Water resources survey, Mineral and Sanders Counties, Montana--Part 2, Maps showing irrigated areas: Helena, Mont., State Engineer's Office, 36 p.

Morrison-Maierle, Inc. and James M. Montgomery, Consulting Engineers, Inc., 1977, Lakes and streams water quality study, Flathead drainage, Montana: [Helena, Mont.], Morrison-Maierle, Inc., variously paged.

National Oceanic and Atmospheric Administration, 1962, Monthly normals of temperature, precipitation, and heating and cooling degree days, 1931-60, Montana: Asheville, N.C., Climatography of the United States no. 81, unpaged.

Noble, R.A., Bergantino, R.N., Patton, T.W., Sholes, B.C., Daniel, Faith, and Schofield, Judeykay, 1982, Occurrence and characteristics of ground water of Montana--Volume 2, The Rocky Mountain Region: Montana Bureau of Mines and Geology Open-File Report 99, 132 p.

Nunnallee, David, and Botz, M.K., 1976, Water quality inventory and management plan, lower Clark River basin, Montana: Montana Department of Health and Environmental Sciences, 129 p. 
Sahinen, U.M., Johns, W.M., and Lawson, D.C., 1965, Geochemical reconnaissance stream-sampling in Flathead and Lincoln counties, Montana: Montana Bureau of Mines and Geology Bulletin 48, $16 \mathrm{p}$.

Slagle, S.E., 1988, Geohydrology of the Flathead Indian Reservation, Northwestern Montana: U.S. Geological Survey WaterResources Investigations Report 88-4142, $152 \mathrm{p}$.

1992, Irrigation-canal leakage in the Flathead Indian Reservation, northwestern Montana: U.S. Geological Survey WaterResources Investigations Report 92-4066, 77 p.

Tuck, L.K., Briar, D.W., and Clark, D.W., in press, Geologic history and hydrogeologic units of intermontane basins of the Northern Rocky Mountains, Montana and Idaho: U.S. Geological Survey Hydrologic Investigations Atlas 738-A, 2 sheets, scale 1:750,000.

U.S. Geological Survey, 1969, Aeromagnetic map of the Hubbart Reservoir-Hot Springs area, Sanders, Flathead, and Lake Counties, Montana: U.S. Geological Survey Geophysical Investigations Map GP-687, scale 1:62,500. issued annually, Water resources data, Montana: Helena, Mont., U.S. Geological Survey Water-Data Report.

U.S. Soil Conservation Service, 1977, Average annual precipitation in Montana, based on 1941-1970 data: Bozeman, Montana, 13 p.

Wunder, Laura, 1974, Water use, surface water, and water rights on the Flathead Indian Reservation, Montana, a review: Missoula, University of Montana, M.S. thesis, $250 \mathrm{p}$. 


\section{Lower Clark Fork Valley}

\section{Geography}

The Lower Clark Fork Valley is an elongate, northwest-trending intermontane basin in northwestern Montana. The $190 \mathrm{mi}^{2} \mathrm{U}$-shaped valley is bounded by the steep flanks of the Cabinet Mountains on the northeast, the Coeur D'Alene Mountains on the southwest, and the Idaho-Montana border on the northwest (pl. 1). Although the intermontane basin continues westward into Idaho, the State border defines the northwestern boundary of this study area. The 52-mi-long Lower Clark Fork Valley ranges in width from about 0.2 to $2 \mathrm{mi}$. A series of reservoirs on the Clark Fork of the Columbia River submerge the flood plain. Therefore, topographically the lowest dry land in the basin is a fairly level terrace, the surface of which is more than one hundred feet above the reservoir stage. Tributaries to the Clark Fork descend from hanging valleys to the main terrace. The Lower Clark Fork Valley ranges in altitude from about $2,100 \mathrm{ft}$ where the Clark Fork leaves the basin to about $4,100 \mathrm{ft}$ where basin fill extends onto lower mountain slopes.

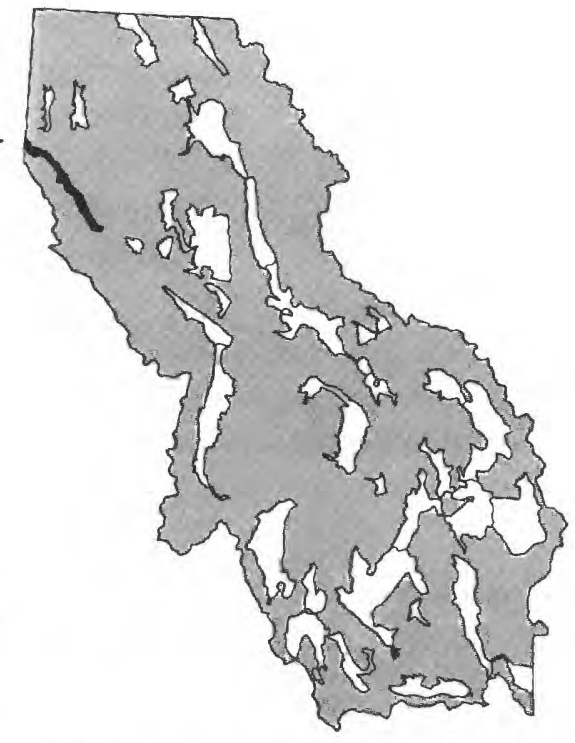

The climate of the Lower Clark Fork Valley is typical of lower-elevation intermontane basins of the Northem Rocky Mountains west of the Continental Divide, with relatively warm summers and cool, humid winters. The moderating, humidifying effect of Pacific maritime air masses is pronounced in this basin because of its low altitude and northwesterly trend which exposes it to coastal weather patterns. On the basis of the 1961-90 period of record, the average annual precipitation at the Trout Creek Ranger Station in Trout Creek (altitude 2,360 ft) is $29.72 \mathrm{in}$., and the average annual temperature is $45.6^{\circ} \mathrm{F}$ (National Oceanic and Atmospheric Administration, 1992). The average last occurrence of $32^{\circ} \mathrm{F}$ is June 13, and the average first occurrence is September 5 (Natural Resources Conservation Service, U.S. Department of Agriculture, unpub. data, 1994). Mean monthly climatic data for the Trout Creek Ranger Station are plotted in figure 21. Downstream to the northwest, near the Idaho border, a weather station $2 \mathrm{mi}$ northwest of Heron (station Heron $2 \mathrm{NW}$, altitude 2,240 ft) received more precipitation (average $33.86 \mathrm{in}$.) and had slightly cooler temperatures (average $44.3^{\circ} \mathrm{F}$ ) during the same period of record. The average frost-free period at the Heron 2 NW station extends from June 4 to September 12. Upstream to the southeast, Thompson Falls receives less precipitation and has warmer temperatures and a longer frost-free period (National Oceanic and Atmospheric Administration, 1992; Natural Resources Conservation Service, U.S. Department of Agriculture, unpub. data, 1994).

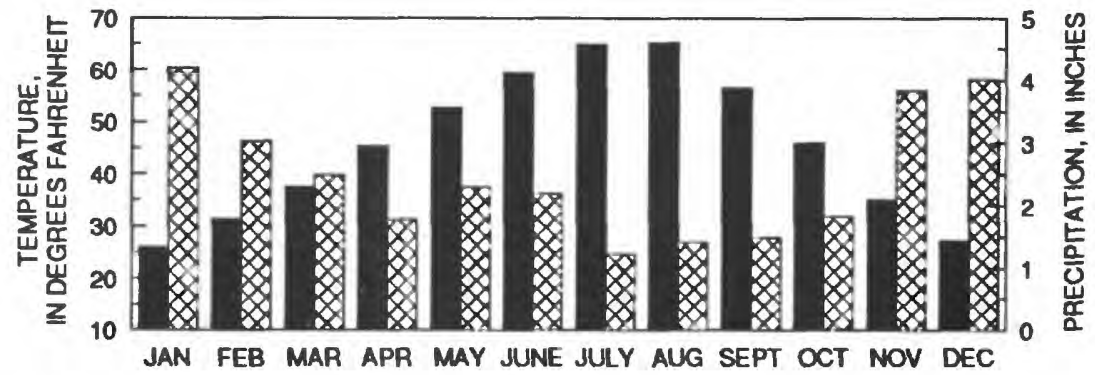

EXPLANATION

MEAN MONTHLY TEMPERATURE FOR 1961-90 PERIOD OF RECORD

区

MEAN MONTHLY PRECIPITATION FOR 1961-90 PERIOD OF RECORD

Figure 21. Mean monthly precipitation and temperature at the Trout Creek Ranger Station, Mont. Data from National Oceanic and Atmospheric Administration (1992). 
Land uses in the Lower Clark Fork Valley include timber harvesting, livestock grazing, and irrigated hay and pasture farming (J.C. Eggen, Agricultural Stabilization and Conservation Service, oral commun., 1993). Diversions from the Clark Fork between Plains and the Montana-Idaho border irrigate about 19,000 acres (Shields and others, 1993, p. 507; Harenberg and others, 1992, p. 56). The basin is heavily forested, especially in the northwestern half. Scattered forest clearings in the southeastern half are used for pastures and some residential development. About 4,000 people reside in the Lower Clark Fork Valley, including 1,319 in the City of Thompson Falls, 186 in the unincorporated community of Noxon, 167 in the unincorporated community of Trout Creek, and 58 in the unincorporated community of Heron (1990 census).

Mining is a major land use in the mountains surrounding the Lower Clark Fork Valley. In the Cabinet Mountains, gold is mined east of Trout Creek. Exploration and permitting are in progress for proposed silver and copper mines northeast of Noxon. In the Couer D'Alene Mountains, exploration is in progress for copper and silver west of Trout Creek, and for reopening old lead and zinc mines west of Thompson Falls. In addition, a smelter and refinery has processed antimony southwest of Thompson Falls since 1967 (McCulloch, 1993, p. 9, 10, 20, 49, 50).

\section{Geology}

The Lower Clark Fork Valley occupies a zone of steeply dipping faults that roughly parallel the basin. Displacement on the fault zone is primarily strike-slip, in contrast to the normal faulting that formed other basins in the study area. This fault zone probably originated during the Proterozoic eon, and seismic activity renewed during the Eocene epoch (Harrison and others, 1986;1992). The maximum depth to the bedrock floor of the Lower Clark Fork Valley is unknown, but numerous wells penetrate bedrock within 200 to $300 \mathrm{ft}$ of the land surface (Montana Bureau of Mines and Geology, unpub. data, 1993).

Several investigators have examined the geology of the Lower Clark Fork Valley (table 58). The geologic units described by previous investigators are summarized below. These geologic units are referenced to hydrogeologic units defined in this study (table 2) to provide a consistent regional framework. In the following discussion, the hydrogeologic-unit abbreviations are italicized.

Most of the bedrock that surrounds the basin consists of metasedimentary rocks--primarily quartzite, argillite, dolomite, and siltite of the Middle Proterozoic Belt Supergroup (Yms). East of the community of Trout Creek, a Cretaceous felsic pluton (TKi) borders the basin (Harrison and others, 1986; 1992).

Whereas Tertiary sediments $(T s)$ overlie bedrock in most intermontane basins of the Northern Rocky Mountains, there is no evidence of their presence in the Lower Clark Fork Valley. Numerous wells in the basin penetrate bedrock within a few hundred feet of the surface, having been drilled through only glacial deposits. Therefore, it is possible that Quaternary deposits directly overlie Proterozoic bedrock everywhere in this intermontane basin.

Quaternary deposits in the Lower Clark Fork Valley resulted from Pleistocene glaciation, followed by Holocene downcutting and alluvial deposition. Pleistocene glaciers scoured the faces of the surrounding mountains, carving a U-shaped basin and tributary valleys. As the glaciers melted, they filled the basin with glacial till $(Q g)$-an unsorted, heterogeneous mixture of sand, gravel, cobbles, and boulders in a silty clay matrix. Meltwaters from periodic glacial recessions deposited thick beds of glacial outwash (Qal) consisting of sand and gravel, which interfinger with the till. The alternating flooding and draining of glacial Lake Missoula deposited glacial-lakebed $(Q g)$ and flood deposits $(Q a l)$. Buff to lavender, varved clayey and silty glacial-lakebed deposits underlie erosional remnants within several Clark Fork meanders. Gravel deposits from torrential draining of Glacial Lake Missoula crop out at the mouths of some tributary valleys (Harrison and others, 1986). Subsurface discontinuous lenses of the various Pleistocene deposits interfinger throughout the basin.

Holocene alluvium (Qal) composed primarily of sand and gravel underlies the Clark Fork flood plain. However, most of the alluvium that was once exposed at the surface is now fiooded beneath the series of lakes that span the length of the basin. A few higher-elevation alluvial terraces crop out in the northwestern part of the basin and near the mouths of tributary valleys (Johns, 1970; Harrison and others, 1986; 1992). 
Table 58. Geologic and geophysical maps of the Lower Clark Fork Valley, Montana

\begin{tabular}{|c|c|c|c|c|}
\hline Type of map & Scale & Location & Map foaturee & Relerence \\
\hline Geology & $1: 125,000$ & $\begin{array}{l}\text { Downstream from } \\
\text { Noxon }\end{array}$ & $\begin{array}{l}\text { Differentiates two Quaternary basin-fill units: } \\
\text { glacial deposits and alluvial deposits. Indicates } \\
\text { mines, prospects, and placers }\end{array}$ & Gibson, 1948, pl. 1 \\
\hline Geology & $1: 250,000$ & $\begin{array}{l}\text { Upstream from } \\
\text { Noxon }\end{array}$ & $\begin{array}{l}\text { Differentiates three Quaternary basin-fill units: } \\
\text { glacial deposits, glacial-lakebed deposits, and } \\
\text { alluvial deposits. Includes southwest-northeast } \\
\text { bedrock geologic section through center of basin }\end{array}$ & $\begin{array}{l}\text { Harrison and others, } \\
1992\end{array}$ \\
\hline Geology & $1: 250,000$ & $\begin{array}{l}\text { Downstream from } \\
\text { Noxon }\end{array}$ & $\begin{array}{l}\text { Differentiates two Quaternary basin-fill units: } \\
\text { glacial deposits and alluvial deposits }\end{array}$ & $\begin{array}{l}\text { Harrison and others, } \\
1986\end{array}$ \\
\hline Geology & $1: 126,720$ & $\begin{array}{l}\text { Downstream from } \\
\text { Noxon }\end{array}$ & $\begin{array}{l}\text { Differentiates two Quaternary basin-fill units: } \\
\text { glacial deposits and alluvial deposits }\end{array}$ & Johns, 1970, pl. 1 \\
\hline Aeromagnetic & $1: 125,000$ & $\begin{array}{l}\text { Downstream from } \\
\text { Heron }\end{array}$ & Contour interval 10 gammas. & $\begin{array}{l}\text { King and others, } 1970 \text {, } \\
\text { pl. } 1\end{array}$ \\
\hline $\begin{array}{l}\text { Aeromagnetic } \\
\text { and } \\
\text { generalized } \\
\text { geology }\end{array}$ & $1: 250,000$ & $\begin{array}{l}\text { Entire Lower Clark } \\
\text { Fork Valley }\end{array}$ & $\begin{array}{l}\text { Contour interval } 20 \text { gammas. All basin fill } \\
\text { designated as Quatemary surficial deposits }\end{array}$ & $\begin{array}{l}\text { Kleinkopf and others, } \\
1972\end{array}$ \\
\hline Geology & $1: 300,000$ & $\begin{array}{l}\text { Entire Lower Clark } \\
\text { Fork Valley }\end{array}$ & $\begin{array}{l}\text { Differentiates three basin-fill units: Tertiary to } \\
\text { Quatemary terrace deposits, Quaternary } \\
\text { glacial-lake deposits, and Quaternary alluvium. } \\
\text { Reported springs are located }\end{array}$ & $\begin{array}{l}\text { [Montana] State } \\
\text { Engineer's Office, } \\
\text { 1969a }\end{array}$ \\
\hline Aeromagnetic & $1: 62,500$ & $\begin{array}{l}\text { Trout Creek } \\
\text { quadrangle (lat } \\
47^{\circ} 30^{\prime} \mathrm{N} \text {. to } \\
48^{\circ} \mathrm{N} \text {., long } \\
115^{\circ} 30^{\circ} \mathrm{W} \text {. to } \\
116^{\circ} \mathrm{W} \text {.) }\end{array}$ & Contour intervals 10 and 20 gammas & $\begin{array}{l}\text { U.S. Geological } \\
\text { Survey, 1969a }\end{array}$ \\
\hline Aeromagnetic & $1: 62,500$ & $\begin{array}{l}\text { Thompson Falls } \\
\text { quadrangle (lat } \\
47^{\circ} 30^{\prime} \mathrm{N} \text {. to } \\
48^{\circ} \mathrm{N} \text {., long } \\
115^{\circ} \mathrm{W} \text {. to } \\
115^{\circ} 30^{\prime} \mathrm{W} \text {.) }\end{array}$ & Contour intervals 10 and 20 gammas & $\begin{array}{l}\text { U.S. Geological } \\
\text { Survey, 1969b }\end{array}$ \\
\hline
\end{tabular}

\section{Hydrology}

The Clark Fork flows northwestward through the basin. Within the basin, river flow is regulated by Cabinet Gorge Dam, which has impounded the Cabinet Gorge Reservoir since 1952; Noxon Rapids Dam, which has impounded the Noxon Reservoir since 1959; and a hydroelectric dam in Thompson Falls, which has impounded the Thompson Falls Reservoir since 1915 (Harenberg and others, 1992; Shields and others, 1993). Upstream from the basin, the Clark Fork is regulated by Flathead Lake and Hungry Horse Reservoir.

Streamflow data for gaging stations listed in table 59 are stored in the USGS WATSTORE database. Locations of the stations are shown on plate 1. In addition, the USGS has published monthend reservoir volume records for the Thompson Falls Reservoir (gaging station 12390000, drainage area 20,968 $\mathrm{mi}^{2}$ ) and the Noxon Rapids Reservoir (gaging station 12391300, drainage area 21,833 mi²) since 1939 and 1959, respectively. Data for years prior to 1961 are published in Water-Supply Papers; more recent data are in annual Water-Data Reports (U.S. Geological Survey, issued annually).

The quality of surface water in the Clark Fork was determined on the basis of 16 samples from the Clark Fork at Whitehorse Rapids, near Cabinet, Idaho (gaging station 12392000). Analyses indicate a calcium bicarbonate type water with an average dissolved-solids concentration of about $100 \mathrm{mg} / \mathrm{L}$ (Clark and Dutton, in press). 
Table 59. Summary of data for U.S. Geological Survey streamflow-gaging stations in the Lower Clark Fork Valley, Montana and Idaho

[Type of data collected: $c$, water chemistry; d, discharge. Periods of record for stations that were being operated as on November 1994 are indicated by the first year of record followed by a dash only. Abbreviations: $\mathrm{ft}^{3} / \mathrm{s}$, cubic feet per second. Symbol: --, no data]

\begin{tabular}{|c|c|c|c|c|c|c|c|c|c|}
\hline \multirow[b]{2}{*}{$\begin{array}{l}\text { Station } \\
\text { number }\end{array}$} & \multirow[b]{2}{*}{ Station name } & \multirow{2}{*}{$\begin{array}{c}\text { Drainage } \\
\text { area } \\
\text { (square } \\
\text { miles) }\end{array}$} & \multirow{2}{*}{$\begin{array}{l}\text { Type } \\
\text { of } \\
\text { data } \\
\text { col- } \\
\text { locted }\end{array}$} & \multirow[b]{2}{*}{$\begin{array}{l}\text { Perlod of record } \\
\text { (calendar year) }\end{array}$} & \multicolumn{5}{|c|}{ Discharge for period of record } \\
\hline & & & & & $\begin{array}{c}\text { Mean } \\
\text { annual } \\
\left(\mathrm{ft}^{3} / \mathrm{s}\right)\end{array}$ & $\begin{array}{l}\text { Maxi- } \\
\text { mum } \\
\left(f^{3} / s\right)\end{array}$ & $\begin{array}{l}\text { Date of } \\
\text { maximum }\end{array}$ & $\begin{array}{l}\text { Mini- } \\
\text { mum } \\
\left(f^{3} / s\right)\end{array}$ & $\begin{array}{l}\text { Date of } \\
\text { minimum }\end{array}$ \\
\hline 12390500 & $\begin{array}{l}\text { Prospect Creek near } \\
\text { Thompson Falls }\end{array}$ & 145 & d & $\begin{array}{l}1911-16 \\
\text { (intermittent) }\end{array}$ & - & 1,860 & $05-29-13$ & -- & -- \\
\hline 12390700 & $\begin{array}{l}\text { Prospect Creek at } \\
\text { Thompson Falls }\end{array}$ & 182 & d & $1956-$ & 237 & 5,490 & $01-16-74$ & 24 & $01-04-88$ \\
\hline 12391000 & $\begin{array}{l}\text { Clark Fork at } \\
\text { Thompson Falls }\end{array}$ & 21,113 & $\begin{array}{l}\text { d } \\
\text { c }\end{array}$ & $\begin{array}{l}1951-59 \\
1963,1969-73\end{array}$ & 21,920 & 109,000 & $05-26-56$ & 495 & $09-01-58$ \\
\hline 12391400 & $\begin{array}{l}\text { Clark Fork below } \\
\text { Noxon Rapids } \\
\text { Dam, near Noxon }\end{array}$ & 21,833 & d & $1960-$ & 20,070 & 125,000 & $06-12-64$ & 60 & $01-29-89$ \\
\hline 12391500 & Bull River near Heron & -- & c & 1971 & -- & -- & -- & -- & -- \\
\hline 12391550 & Bull River near Noxon & 139 & $\begin{array}{l}\text { d } \\
\text { c }\end{array}$ & $\begin{array}{l}1972-82 \\
1977-79\end{array}$ & 389 & 3,890 & $01-16-74$ & 29 & $12-04-72$ \\
\hline 12392000 & $\begin{array}{l}\text { Clark Fork at } \\
\text { Whitehorse } \\
\text { Rapids, near } \\
\text { Cabinet, Idaho }\end{array}$ & 22,073 & $\begin{array}{l}\text { d } \\
\text { c }\end{array}$ & $\begin{array}{l}1928- \\
1984-\end{array}$ & 21,960 & 153,000 & $05-29-48$ & 270 & $08-12-52$ \\
\hline
\end{tabular}

Ground water is an important resource in the Lower Clark Fork Valley. The basin-fill aquifer system provides domestic water for almost all basin residents, including municipal supplies for Thompson Falls, Trout Creek, Noxon, and Heron. Aquifers comprising this system include glacial deposits which are underlain and surrounded by bedrock.

Glacial deposits largely consist of poorly permeable silt and clay. However, enough layers of permeable sand and gravel interfinger with the fine-grained sediments that most domestic wells are successfully completed in the glacial deposits. Depths of wells completed in glacial deposits in the Lower Clark Fork Valley range from about 60 to $400 \mathrm{ft}$ (Dutton and others, 1995). Yield and specific-capacity data for wells completed in glacial deposits in the Lower Clark Fork Valley are summarized in table 60. In this table, Qg refers to undifferentiated glacial deposits, including till, outwash and flood deposits, and possibly glacial-lakebed deposits. Water-producing zones are unconfined throughout the Lower Clark Fork Valley, except where they may be locally confined or semi-confined by fine-grained glacial-lakebed and till deposits.

Table 60. Summary of data for yield and specific capacity of wells completed in selected hydrogeologic units in the Lower Clark Fork Valley Montana

[Source: Dutton and others, 1995. Hydrogeologic units: Qg, Pleistocene glacial deposits; Yms; Middle Proterozoic metasedimentary rocks. Abbreviations: gal/min, gallon per minute; (gal/min)/ft, gallon per minute per foot]

\begin{tabular}{|c|c|c|c|c|c|c|c|c|c|c|}
\hline \multirow{2}{*}{$\begin{array}{l}\text { Hydro- } \\
\text { geologic } \\
\text { unit }\end{array}$} & \multirow{2}{*}{$\begin{array}{l}\text { Number } \\
\text { of wells }\end{array}$} & \multicolumn{4}{|c|}{ Yield (gal/min) } & \multirow{2}{*}{$\begin{array}{l}\text { Number } \\
\text { of wells }\end{array}$} & \multicolumn{4}{|c|}{ Specific capacity [(gal/min)/ft] } \\
\hline & & Mean & Median & $\begin{array}{l}\text { Mini- } \\
\text { mum }\end{array}$ & $\begin{array}{l}\text { Maxi- } \\
\text { mum }\end{array}$ & & Mean & Median & $\begin{array}{l}\text { Mini- } \\
\text { mum }\end{array}$ & $\begin{array}{l}\text { Maxi- } \\
\text { mum }\end{array}$ \\
\hline $\mathrm{Qg}$ & 24 & 120 & 30 & 7 & 1,500 & 20 & 36 & 2.7 & 0.4 & 470 \\
\hline$Y m s^{1}$ & 4 & 19 & 20 & 5 & 30 & 3 & 1.5 & .4 & .3 & 3.8 \\
\hline
\end{tabular}

${ }^{1}$ May include wells completed along basin margin, outside area of basin fill. 
Most wells within about one-half mile of the Clark Fork tap glacial till and glacial-lakebed deposits, and are completed in highly transmissive gravels at the approximate altitude of the reservoir. The gravels probably represent widespread glacial outwash or deposits of torrential glacial Lake Missoula floods. Static water levels in these wells correlate to reservoir stages. A similarity between ground-water and surface-water quality in the area is further indication that ground water in the gravels is hydraulically connected to the river.

In the few places in which drillers did not encounter saturated, permeable basin fill, Middle Proterozoic bedrock underlying the basin typically provides sufficient water for domestic use. Bedrock wells for which yield and specific capacity values are summarized in table 60 range in depth from about 170 to $300 \mathrm{ft}$ (Dutton and others, 1995).

Little is known about ground-water flow in the Lower Clark Fork Valley. However, a 1:750,000-scale potentiometric-surface map which includes the Lower Clark Fork Valley (Briar and others, in press) indicates that in the southeastern half of the basin ground water generally flows from the uplands toward the Clark Fork, then northwestward, approximately parallel to the river. In the northwestern part of the basin ground-water levels are nearly identical to the reservoir stage, making it difficult to determine the local direction of ground-water flow. During periods when the reservoir stage is above the water table, the direction of ground-water flow is away from the river.

Basin-fill aquifers are recharged by precipitation and snowmelt, surplus irrigation water, subsurface flow from bedrock, and infiltration from the Clark Fork and tributary streams. The ground-water contribution area (fig. 2, pl. 1) is about $1,170 \mathrm{mi}^{2}$. Infiltration anywhere within this area could potentially recharge basin-fill aquifers in the Lower Clark Fork Valley. The presence of warm water at a fish hatchery near Heron and in a nearby well $\left(20.0^{\circ} \mathrm{C}\right.$ at 27N35W24DADA01) (Dutton and others, 1995) indicates that geothermal water from bedrock locally recharges the glacial aquifer. Ground water discharges from basin-fill aquifers by evapotranspiration, withdrawals from wells, and seepage to springs, seeps, and the Clark Fork.

Water levels measured in monitoring well 28N33W09BDDB01 are stored in the USGS WATSTORE database. This 43.6- $\mathrm{ft}$ well is completed in Pleistocene glacial deposits. During the period of record from July 1980 to August 1982, the water level in the well fluctuated between $10.42 \mathrm{ft}$ below land surface (May 19, 1992) and 21.09 ft below land surface (Sept. 9, 1981).

The quality of ground water in the basin was determined on the basis of 5 samples analyzed for major ions and measured dissolved-solids concentrations and 19 samples in which dissolved-solids concentrations were estimated from specific-conductance measurements. Ground water is typically a calcium bicarbonate type with dissolved-solids concentrations of less than $250 \mathrm{mg} / \mathrm{L}$ throughout the basin (Clark and Dutton, in press).

\section{Selected References}

Briar, D.W., Lawlor, S.M., Stone, M.A.J., Parliman, D.J., Schaefer, J.L., and Kendy, Eloise, in press, Ground-water levels in intermontane basins of the Northern Rocky Mountains, Montana and Idaho: U.S. Geological Survey Hydrologic Investigations Atlas 738-B, 1 sheet, scale 1:750,000.

Clark, D.W., and Dutton, D.M., in press, Quality of ground water and surface water in intermontane basins of the Northern Rocky Mountains, Montana and Idaho: U.S. Geological Survey Hydrologic Investigations Atlas 738-C, 1 sheet, scale 1:750,000.

Dutton, D.M., Lawlor, S.M., Briar, D.W., and Tresch, R.E., 1995, Hydrogeologic data for the Northern Rocky Mountains intermontane basins, Montana: U.S. Geological Survey Open-File Report 95-143, 94 p.

Gibson, Russell, 1948, Geology and ore deposits of the Libby quadrangle, Montana, with sections on Pleistocene glaciation, by W.C. Alden, and Physiography, by J.T. Pardee: U.S. Geological Survey Bulletin 956, 131 p.

Harenberg, W.A., Jones, M.L., O'Dell, I., Brennan, T.S., and Lehmann, A.K., 1992, Water resources data, Idaho, water year 1991: U.S. Geological Survey Water-Data Report ID-91-2, v. 2, 357 p.

Harrison, J.E., Griggs, A.B, and Wells, J.D., 1986, Geologic and structure maps of the Wallace $1^{\circ} \times 2^{\circ}$ quadrangle: U.S. Geological Survey Miscellaneous Investigation Series Map I-1509, 2 sheets, scale 1:250,000. 
Harrison, J.E., Cressman, E.R., and Whipple, J.W., 1992, Geologic and structure maps of the Kalispell $1^{\circ} \times 2^{\circ}$ quadrangle, Montana, and Alberta and British Columbia: U.S. Geological Survey Miscellaneous Investigations Series Map I-2267, 2 sheets, scale 1:250,000.

Johns, W.M., 1970, Geology and mineral deposits of Lincoln and Flathead Counties, Montana: Montana Bureau of Mines and Geology Bulletin 79, 182 p.

King, E.R., Harrison, J.E., and Griggs, A.B., 1970, Geologic implications of aeromagnetic data in the Pend Oreille area, Idaho and Montana: U.S. Geological Survey Professional Paper 646D, 17 p.

Kleinkopf, M.D., Harrison, J.E., and Zartman, R.E., 1972, Aeromagnetic and geologic map of part of northwestern Montana and northern Idaho: U.S. Geological Survey Geophysical Investigations Map GP-830, scale 1:250,000.

McCulloch, Robin, 1993, Montana mining directory 1992, Montana Bureau of Mines and Geology Bulletin 131, 76 p.

[Montana] State Engineer's Office, 1969a, Water resources survey, Mineral and Sanders Counties, Montana--Part 1, History of land and water use on irrigated areas: Helena, Mont., State Engineer's Office, 62 p. 1969b, Water resources survey, Mineral and Sanders Counties, Montana--Part 2, Maps showing irrigated areas: Helena, Mont., State Engineer's Office, 36 p.

National Oceanic and Atmospheric Administration, 1992, Monthly normals of temperature, precipitation, and heating and cooling degree days, 1961-90, Montana: Asheville, N.C., Climatography of the United States no. 81, unpaged.

Shields, R.R., Knapton, J.R., White, M.K., Brosten, T.M., and Chambers, C.L., 1993, Water resources data, Montana, water year 1992: U.S. Geological Survey Water-Data Report MT-92-1, 534 p.

Tuck, L.K., Briar, D.W., and Clark, D.W., in press, Geologic history and hydrogeologic units of intermontane basins of the Northern Rocky Mountains, Montana and Idaho: U.S. Geological Survey Hydrologic Investigations Atlas 738-A, 2 sheets, scale 1:750,000.

U.S. Geological Survey, issued annually, Water resources data, Montana: Helena, Mont: U.S. Geological Survey Water-Data Report.

1969a, Aeromagnetic map of the Trout Creek quadrangle, Sanders and Lincoln Counties, Montana: U.S. Geological Survey Geophysical Investigations Map GP-685, scale 1:62,500.

1969 b, Aeromagnetic map of the Thompson Falls quadrangle, Lincoln and Sanders Counties, Montana: U.S. Geological Survey Geophysical Investigations Map GP-686, scale 1:62,500. 


\title{
Madison River Valley
}

\section{Geography}

The Madison River Valley is a north-trending intermontane basin in southwestem Montana. The $350-\mathrm{mi}^{2}$ basin is bounded by the Madison Range on the east, the Continental Divide at Raynolds Pass on the south, the Gravelly Range on the west, the Tobacco Root Mountains on the northwest, and Ennis Lake on the north. Well-defined fluvial terraces flank both sides of the Madison River flood plain and large, partly coaleascing alluvial fans slope from the mountain fronts to the fluvial terraces. Alluvial fans on the eastern side of the basin are larger than those on the west. Many tributaries are entrenched in their alluvial fans on both sides of the basin (Hall, 1990; Hadley, 1980). The basin ranges in altitude from about 4,800 ft at Ennis Lake, to about 7,600 ft on the highest alluvial fan.

The climate of the Madison River Valley is typical of high-elevation intermontane basins of the Northern Rocky Mountains east of the Continental

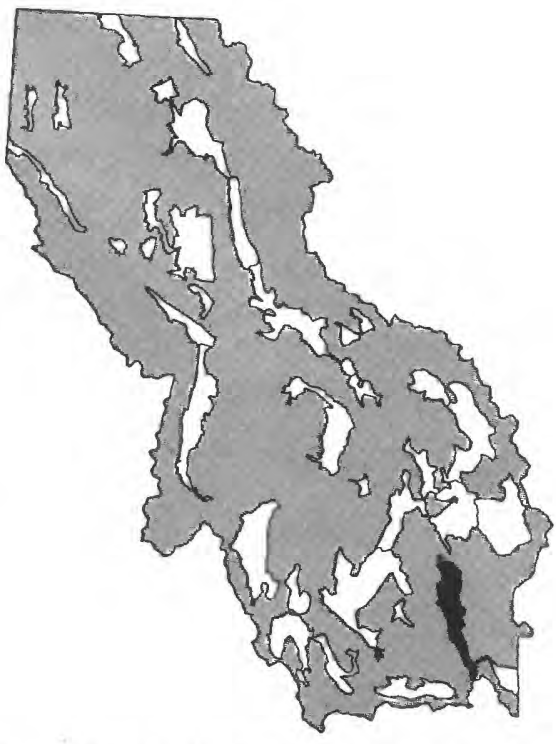
Divide, with cold winters and mild summers. On the basis of the 1961-90 period of record, the average annual precipitation at Ennis (altitude 4,950 ft) is 13.26 in. and the average annual temperature is $43.6^{\circ} \mathrm{F}$ (National Oceanic and Atmospheric Administration, 1992). The average last occurrence of $32^{\circ} \mathrm{F}$ is June 7 and the average first occurrence is September 9 (Natural Resources Conservation Service of the U.S. Department of Agriculture, unpub. data, 1994). Mean monthly climatic data for Ennis are plotted in figure 22.

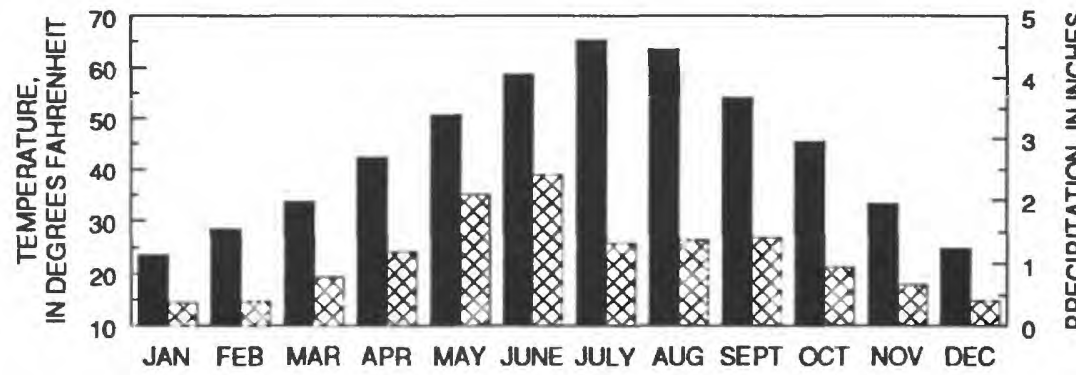

\author{
EXPLANATION \\ MEAN MONTHLY TEMPERATURE FOR \\ 1961-90 PEROD OF RECORD \\ 叉 \\ MEAN MONTHLY PRECIPITATION FOR \\ 1961-90 PERID OF RECORD
}

Figure 22. Mean monthly precipitation and temperature at Ennis, Mont. Data from National Oceanic and Atmospheric Administration (1992).

The Madison River Valley is used primarily as rangeland. A few irrigation diversions, mostly from tributary streams, provide water for limited irrigated hay and pasture farming. In addition, dryland small grains are grown to a very limited extent on some benches. About 1,700 people reside in the Madison River Valley, including 773 in the Town of Ennis (1990 census). Recently, an increasing amount of agricultural land is being converted to rural residential subdivisions (J.C. Eggen, Agricultural Stabilization and Conservation Service, oral commun., 1993). Mining is historically an important land use of the mountains surrounding the Madison River Valley. Currently, two open-pit mines produce talc from the Gravelly Range southwest of Ennis (McCulloch, 1993, p. 33-34).

\section{Geology}

Cenozoic extension has downdropped the bedrock floor of the basin more than $26,000 \mathrm{ft}$ along basin-marginal normal faults, including as much as $400 \mathrm{ft}$ since early Pleistocene time (Locke and Schneider, 1990, p. 6; Hadley, 
1980, p. 105). Gravity data suggest that 9,000 to $15,000 \mathrm{ft}$ of Cenozoic deposits fill the deepest parts of the basin near the eastern margin (Schofield, 1981, p. 282; Noble and others, 1982, p. 84; Rasmussen and Fields, 1983). Geologic and geophysical logs of oil exploration wells (07S01E18DA and 08S01E27CC) indicate the contact between Tertiary sediments and the underlying Archean metamorphic rocks is 7,254 and 5,918 $\mathrm{ft}$ below land surface, respectively (Montana Board of Oil and Gas Conservation, unpub. data, 1990). Within the basin, Tertiary sediments generally dip gently toward the valley axis (Kellogg, 1993).

Several investigators have examined the geology of the Madison River Valley (table 61). The geologic units described by previous investigators are summarized below. These geologic units are referenced to hydrogeologic units defined in this study (table 2) to provide a consistent regional framework. In the following discussion, the hydrogeologic-unit abbreviations are italicized.

Table 61. Geologic and geophysical maps of the Madison River Valley, Montana

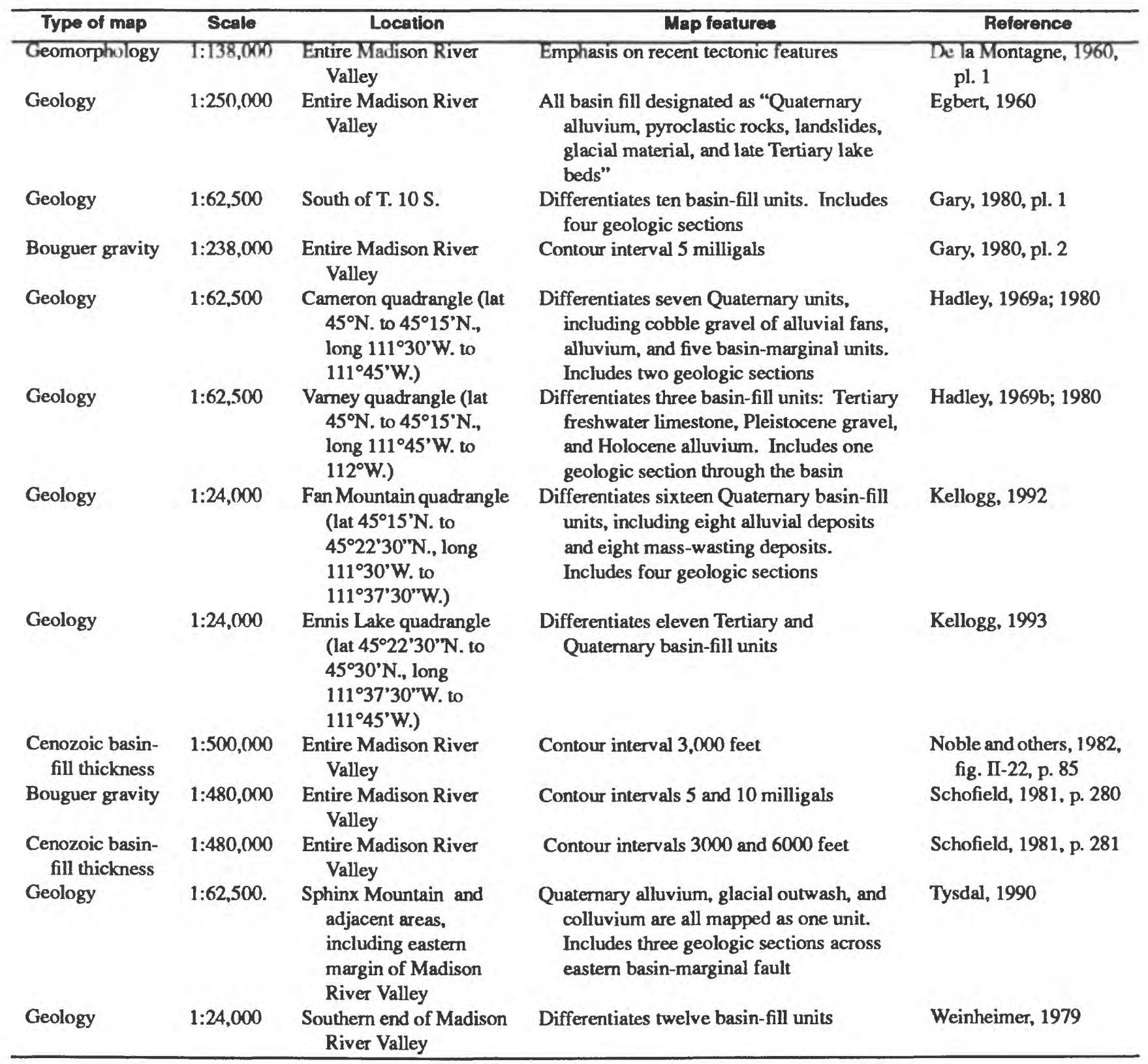


Metamorphic, sedimentary, and igneous bedrock surrounds the basin. Archean gneiss, dolomitic marble, schist, and quartzite $(\mathrm{KAm})$ underlic basin fill and border the basin on the southeast, west, and north. Paleozoic limestone $\left(P_{z} l s\right)$ and Mesozoic shale, conglomerate, and other sedimentary rocks (Mzsh) border the basin on the northeast. Tertiary granite (TKi) forms the Tobacco Root Mountains to the northwest. Tertiary and Quatemary extrusive igneous rocks ( $Q T K e$ ), including basalt and tuff, border the basin on the south and crop out locally within the basin.

Perhaps as much as $15,000 \mathrm{ft}$ (Schofield, 1981, p. 282) of Tertiary sediments (Ts) reflect both open- and closed-basin depositional sequences (Hadley, 1980). In the northem part of the basin, Tertiary deposits include conglomerates and gravels interbedded with tuffaceous and fine-grained sediments and some sand. In the southern part of the basin, similar Tertiary deposits are interbedded with basalt and tuff (Noble and others, 1982, p. 84; Sonderegger and others, 1982). In the low hills west of Varney, an extensive fresh-water limestone approximately $15 \mathrm{ft}$ thick crops out (Hadley, 1980, p. 91). The highest terrace east of Cameron is underlain by Tertiary fanglomerate beneath about $150 \mathrm{ft}$ of gravel of latest Tertiary to earliest Pleistocene age (Schneider, 1990).

Quaternary glacial and alluvial deposits locally overlie Tertiary sediments (Hadley, 1969a). Pleistocene colluvial and alluvial cobbles and gravel (QTd) underlie alluvial fans, benches, and slopes along range fronts. Pleistocene glacial deposits $(Q g)$, including moraine and outwash, partially extend into the basin from some tributary valleys, particularly in the southern portion of the basin. Holocene alluvium (Qal) underlies flood plains of the Madison River and its major tributaries.

\section{Hydrology}

The Madison River originates in Yellowstone National Park and traverses the upper Madison River Valley, through Hebgen and Earthquake Lakes, to the Madison River Valley. Within the basin, the river flows northward and empties into Ennis Lake. Its flow is regulated by Hebgen Lake, which was constructed for power generation in 1915.

Streamflow data for gaging stations listed in table 62 are stored in the USGS WATSTORE database. Locations of the stations are shown on plate 1. In addition, the Helena office of the USGS maintains records of daily volume and elevation for Hebgen Lake (gaging station 06038000 , drainage area $904 \mathrm{mi}^{2}$ ) and Ennis Lake (gaging station 06040500 , drainage area $2,181 \mathrm{mi}^{2}$ ) dating back to 1936 . Monthend contents, in acre-ft, are published in annual Water-Data Reports. Data for years prior to 1961 are published in Water-Supply Papers; more recent data are in Water-Data Reports (U.S. Geological Survey, issued annually). Water impounded in Ennis and Hebgen Lakes is used for recreation and power generation (Shields and others, 1993, p. 377-378).

The chemical composition of water in the Madison River changes as it flows downstream. In the upper Madison River, which originates in Yellowstone National Park, the average dissolved-solids concentration is 213 $\mathrm{mg} / \mathrm{L}$ and sodium ions are essentially the only significant cation. The source of the sodium ions is geothermal water, which has sodium as the only cation and chloride and bicarbonate as the predominant anions. Weathering of volcanic rocks, which contain little soluble calcium carbonate minerals, may also contribute to the relatively large sodium concentrations. Three downstream sites on the Madison River generally have progressively smaller percentages of sodium and chloride as flow in the river mixes with tributaries whose water contains calcium and bicarbonate in greater proportions. For example, analyses of two samples from Jack Creek indicate a calcium bicarbonate type water with an average dissolved-solids concentration of $97 \mathrm{mg} / \mathrm{L}$. Downstream, 15 samples from below Ennis (gaging station 06041000) indicate a mixed-cation bicarbonate type water with an average dissolvedsolids concentration of $190 \mathrm{mg} / \mathrm{L}$ (Clark and Dutton, in press).

Sediment eroded from the West Fork of the Madison River drainage area changes the mainstem water from clear to turbid during spring runoff. Lisle (1972) identified historical sheep grazing practices as the main cause of erosion. 
Table 62. Summary of data for U.S. Geological Survey streamflow-gaging stations in the Madison River Valley, Montana [Type of data collected: c, water chemistry; d, discharge; $\mathrm{l}$, temperature. Periods of record for stations that were being operated as of November 1994 are indicated by the first year of record followed by a dash only. Abbreviations: $\mathrm{f}^{3} / \mathrm{s}$, cubic feet per second. Symbol: --, no data]

\begin{tabular}{|c|c|c|c|c|c|c|c|c|c|}
\hline \multirow[b]{2}{*}{$\begin{array}{l}\text { Station } \\
\text { Number }\end{array}$} & \multirow[b]{2}{*}{ Station name } & \multirow{2}{*}{$\begin{array}{l}\text { Drainage } \\
\text { area } \\
\text { (square } \\
\text { miles) }\end{array}$} & \multirow{2}{*}{$\begin{array}{l}\text { Type } \\
\text { of data } \\
\text { col- } \\
\text { lected }\end{array}$} & \multirow[b]{2}{*}{$\begin{array}{l}\text { Perlod of record } \\
\text { (calendar year) }\end{array}$} & \multicolumn{5}{|c|}{ Discharge for perlod of record } \\
\hline & & & & & $\begin{array}{l}\text { Mean } \\
\text { annual } \\
\left(\mathrm{ft}^{3} / \mathrm{s}\right)\end{array}$ & $\begin{array}{l}\text { Maxi- } \\
\text { mum } \\
\left(\mathrm{ft}^{3} / \mathrm{s}\right)\end{array}$ & $\begin{array}{c}\text { Date of } \\
\text { maximum }\end{array}$ & $\begin{array}{l}\text { Mini- } \\
\text { mum } \\
\left(\mathrm{ft}^{3} / \mathrm{s}\right)\end{array}$ & $\begin{array}{l}\text { Date of } \\
\text { minimum }\end{array}$ \\
\hline 06038500 & $\begin{array}{l}\text { Madison River below } \\
\text { Hebgen Lake, near } \\
\text { Grayling }\end{array}$ & 905 & $\begin{array}{l}\mathrm{d} \\
\mathrm{c}\end{array}$ & $\begin{array}{l}1909- \\
1985-88,1990\end{array}$ & 1,003 & 10,200 & $08-17-59$ & 5.0 & $05-09-60$ \\
\hline 06038800 & $\begin{array}{l}\text { Madison River at } \\
\text { Kirby Ranch, near } \\
\text { Cameron }\end{array}$ & 1,065 & d & $\begin{array}{l}\text { 1959-63, 1978- } \\
\text { (seasonal records) } \\
1960\end{array}$ & 1,117 & 5,030 & $05-31-93$ & 139 & 09.01 .59 \\
\hline 06039000 & $\begin{array}{l}\text { West Fork Madison } \\
\text { River near } \\
\text { Lakeview }\end{array}$ & 11.9 & d & Apr.-Sept. 1936 & -- & 254 & $05-05-36$ & 0 & $\begin{array}{l}\text { Several } \\
\text { dates }\end{array}$ \\
\hline 06039200 & $\begin{array}{l}\text { West Fork Madison } \\
\text { River near } \\
\text { Cameron }\end{array}$ & 220 & d & $\begin{array}{l}1959,1961,1965- \\
67 \\
1986,1988\end{array}$ & 91.85 & 743 & $05-25-67$ & 21 & $01-07-67$ \\
\hline 06039500 & $\begin{array}{l}\text { Madison River at } \\
\text { Lyon }\end{array}$ & 1,346 & d & $1928-32$ & 1,093 & 3,360 & 08-13-29 & 255 & $03-24-30$ \\
\hline 06040000 & $\begin{array}{l}\text { Madison River near } \\
\text { Cameron }\end{array}$ & 1,669 & $\begin{array}{l}\text { d } \\
\text { c }\end{array}$ & $\begin{array}{l}1951-63,1968-70 \\
1988, \text { Apr.-Aug. } \\
1993\end{array}$ & 1,432 & 8,830 & $06-11-70$ & 275 & 08-31-59 \\
\hline 06040010 & $\begin{array}{l}\text { Blaine Spring Creek } \\
\text { near Cameron }\end{array}$ & 3.42 & d & $\begin{array}{l}\text { Aug. 1971-June } \\
\quad 1972\end{array}$ & -- & 37 & $02-23-72$ & 14 & $\begin{array}{l}\text { Many days } \\
\text { in June } 1972\end{array}$ \\
\hline 06040300 & Jack Creek near Ennis & 51.5 & c & $\begin{array}{l}\text { 1973-86, 1991-92 } \\
\text { (seasonal } \\
\text { records) } \\
1980\end{array}$ & 47.0 & 555 & $06-14-74$ & 5.0 & 03-07-75 \\
\hline 06040400 & $\begin{array}{l}\text { Meadow Creek near } \\
\text { McAllister }\end{array}$ & - & c & 1986 & -- & -- & - & - & - \\
\hline 06041000 & $\begin{array}{l}\text { Madison River below } \\
\text { Ennis Lake, near } \\
\text { McAllister }\end{array}$ & 2,186 & $\begin{array}{l}d \\
c, t\end{array}$ & $\begin{array}{l}1901- \\
1971-73,1977 .\end{array}$ & 1,748 & 9,950 & $06-12-70$ & ${ }^{1210}$ & $08-25-59$ \\
\hline
\end{tabular}

${ }^{1}$ Lowest daily mean.

Madison River water has high concentrations of arsenic due to the inflow of naturally enriched geothermal water from Yellowstone National Park. The concentration of total recoverable arsenic in the Madison River below Hebgen Dam (gaging station 06038500) ranged from 78 to $240 \mu \mathrm{g} / \mathrm{L}$ from 1985 to 1994. Downstream from the confluence with the West Fork of the Madison River, the concentration of total recoverable arsenic in the Madison River near Cameron (gaging station 06040000) ranged from 56 to $140 \mu \mathrm{g} / \mathrm{L}$ in 1988 and 1993-94. Below Ennis Lake (gaging station 06041000), total recoverable arsenic ranged from 35 to $120 \mu \mathrm{g} / \mathrm{L}$ from 1985 to 1994 . In general, high arsenic concentrations were recorded during low flows in the summer of 1994 and low values corresponded with high flows in the spring of 1993 (Knapton and Brosten, 1987, 1989; Knapton and Horpestad, 1987; U.S. Geological Survey, unpub. data, 1994). The U.S. Environmental Protection Agency (1991) has established a maximum contaminant level of $50 \mu \mathrm{g} / \mathrm{L}$ arsenic for treated drinking water.

Ground water is an important resource in the Madison River Valley, as the basin-fill aquifer system provides domestic water for nearly all basin residents. The Town of Ennis, for example, obtains water from three municipalsupply wells completed in basin fill. In recent years, new subdivisions throughout the basin have increased the reliance on private wells and septic tanks.

Drillers' logs indicate that coarse-grained alluvium and glacial outwash are the primary aquifers in the basin. Yield and specific-capacity data for wells completed in alluvium and glacial outwash are summarized in table 63. 
Table 63. Summary of data for yield and specific capacity of wells completed in selected hydrogeologic units in the Madison River Valley, Montana

[Source: Dutton and others, 1995. Hydrogeologic units: Qal, Holocene and Pleistocene alluvial deposits (includes glacial outwash); Ts, Tertiary sedimentary deposits and rocks. Abbreviations: gal/min, gallon per minute; (gal/min)/ft, gallon per minute per foot]

\begin{tabular}{ccccccccccccccc}
\hline \multirow{2}{*}{$\begin{array}{c}\text { Hydro } \\
\text { geologic } \\
\text { unit }\end{array}$} & $\begin{array}{c}\text { Number } \\
\text { of wells }\end{array}$ & Mean & Median & $\begin{array}{c}\text { Mini- } \\
\text { mum }\end{array}$ & $\begin{array}{c}\text { Maxi- } \\
\text { mum }\end{array}$ & & \multicolumn{2}{c}{$\begin{array}{c}\text { Number } \\
\text { of wells }\end{array}$} & Mean & Medlan & $\begin{array}{c}\text { Mini- } \\
\text { mum }\end{array}$ & $\begin{array}{c}\text { Maxi- } \\
\text { mum }\end{array}$ \\
\hline Qal & 17 & 52 & 30 & 8.0 & 400 & & 16 & 2.3 & 1.6 & 0.4 & 8.0 \\
Ts & 29 & 61 & 15 & .8 & 700 & & 22 & 5.9 & .4 & .1 & 100 \\
\hline
\end{tabular}

Sparse data on Tertiary basin fill suggest that these deposits are relatively impermeable because of a large percentage of fine-grained sediments and volcanic material. Generally, wells completed in Tertiary sediments range from 100 to $250 \mathrm{ft}$ deep (Montana Bureau of Mines and Geology, unpub. data, 1991). Transmissivity of Tertiary sediments at 11S01E04 was estimated to be $911 \mathrm{ft}^{2} / \mathrm{d}$ (Noble and others, 1982, p. 86). Table 63 indicates that wells completed in Tertiary sediments have larger mean yield and specific-capacity values than wells completed in Quaternary alluvium. While the numbers reported are not incorrect, it should be pointed out that three Tertiary wells, each of which produce at least $200 \mathrm{gal} / \mathrm{min}$, skew the statistics. These three wells may not represent typical Tertiary wells in the Madison River Valley because they are perforated through long intervals (more than $70 \mathrm{ft}$ ) and the perforations likely intersect some permeable Quaternary alluvium as well as Tertiary sediments.

The hydraulic characteristics of bedrock beneath and marginal to the Madison River Valley vary considerably. Limestone bedrock can be a reliable source of ground water. A spring issuing from Paleozoic limestone (07S02W13CAC01) discharges 15,300 gal/min (U.S. Geological Survey, unpub. data, 1991). Fractures in igneous and metamorphic rocks also can yield water to a few wells. One well completed in volcanic bedrock produces 15 $\mathrm{gal} / \mathrm{min}$; two wells completed in metasedimentary bedrock produce $2 \mathrm{gal} / \mathrm{min}$ and $75 \mathrm{gal} / \mathrm{min}$ (Dutton and others, 1995).

Little is known about ground-water flow in the Madison River Valley. However, a 1:750,000-scale potentiometric-surface map (Briar and others, in press) indicates that ground water generally flows toward the center of the valley from mountain ranges and terraces on both the east and the west sides, then northward, paralleling the Madison River.

Recharge to basin fill is primarily from precipitation and from losing streams as they flow out of the surrounding mountains and into the more permeable basin fill (Noble and others, 1982, p. 86). Surplus irrigation water and leaky canals also recharge underlying aquifers. The ground-water contribution area (fig. 2, pl. 1) is about $1,180 \mathrm{mi}^{2}$. Infiltration anywhere within this area could potentially recharge basin-fill aquifers in the Madison River Valley. Subsurface inflow from bedrock is evidenced by geothermal water issuing from basin fill at Ennis Hot Springs (05S01 W28DCAD) about $1.5 \mathrm{mi}$ north of Ennis. A range-front fault $1.2 \mathrm{mi}$ west of the spring may be the source of the geothermal water (Chadwick and Leonard, 1979). The water with a temperature of $83^{\circ} \mathrm{C}$ discharges at a rate of $19 \mathrm{gal} / \mathrm{min}$ (Leonard and Wood, 1988). Ground water discharges from basin fill by evapotranspiration, withdrawals from wells, and seepage to springs, seeps, irrigation drains, and stream channels.

The quality of ground water in the basin was determined on the basis of 27 samples analyzed for major ions and measured dissolved-solids concentrations and 23 samples in which dissolved-solids concentrations were estimated from specific-conductance measurements. Ground water in the Madison River Valley is a calcium bicarbonate type. In general, the concentration of dissolved solids increases from less than $250 \mathrm{mg} / \mathrm{L}$ in the southern and central parts of the basin to about 250 to $500 \mathrm{mg} / \mathrm{L}$, primarily on the benches north of Cameron (Clark and Dutton, in press). Geothermal water issuing from Ennis Hot Springs has a dissolved-solids concentration ranging from 992 to $1,030 \mathrm{mg} / \mathrm{L}$ (Leonard and Wood, 1988). 
Use of Madison River water to irrigate crops in the basin has raised concerns that the irrigation water may have elevated the concentration of arsenic in basin-fill aquifers. However, recent analyses indicate that arsenic concentrations as high as $140 \mu \mathrm{g} / \mathrm{L}$ occur primarily in wells that are hydraulically connected to the river or to irrigation canals, rather than in wells that are completed beneath irrigated ficlds (L.K. Tuck, U.S. Geological Survey, oral commun., 1995).

\section{Selected References}

Briar, D.W., Lawlor, S.M., Stone, M.A.J., Parliman, D.J., Schaefer, J.L., and Kendy, Eloise, in press, Ground-water levels in intermontane basins of the Northern Rocky Mountains, Montana and Idaho: U.S. Geological Survey Hydrologic Investigations Atlas 738-B, 1 sheet, scale 1:750,000.

Chadwick, R.A., and Leonard, R.B., 1979, Structural controls of hot-spring systems in southwestern Montana: U.S. Geological Survey Open-File Report 79-1333, 25 p.

Christopherson, K.R., Senterfit, T.M., Lewis, Vernon, and Dalati, Moutaz, 1979, Telluric profiles and location map for the Broadwater Hot Springs area, Montana: U.S. Geological Survey Open-File Report 79-1670, 5 p.

Clark, D.W., and Dutton, D.M., in press, Quality of ground water and surface water in intermontane basins of the Northern Rocky Mountains, Montana and Idaho: U.S. Geological Survey Hydrologic Investigations Atlas 738-C, 1 sheet, scale 1:750,000.

De la Montagne, John, 1960, Geomorphic problems in the Madison Valley, in Billings Geological Society 11th Annual Field Conference, September 7-10, 1960, Guidebook for West Yellowstone-Earthquake area: Billings, Mont., Billings Geological Society, p. 165-190.

Dutton, D.M., Lawlor, S.M., Briar, D.W., and Tresch, R.E., 1995, Hydrogeologic data for the Northern Rocky Mountains intermontane basins, Montana: U.S. Geological Survey Open-File Report 95-143, 94 p.

Egbert, R.L., 1960, Geologic map of the Madison Valley-Hebgen Lake, in Billings Geological Society 11th Annual Field Conference, September 7-10, 1960, Guidebook for West Yellowstone-Earthquake area: Billings, Mont., Billings Geological Society, scale 1:250,000.

Gary, S.D., 1980, Quaternary geology and geophysics of the upper Madison Valley: Missoula, University of Montana, M.S. thesis, $76 \mathrm{p}$.

Grabb, R.E., 1977, Geology for land use planning, Jack Creek basin, Madison County, Montana: Bozeman, Montana State University, M.S. thesis, $90 \mathrm{p}$.

Hadley, J.B., 1969a, Geologic map of the Cameron quadrangle, Madison County, Montana: U.S. Geological Survey Geologic Quadrangle Map GQ-813, scale 1:62,500.

1969b, Geologic map of the Varney quadrangle, Madison County, Montana: U.S. Geological Survey Geologic Quadrangle Map GQ-814, scale 1:62,500.

1980, Geology of Varney and Cameron quadrangles, Madison County, Montana: U.S. Geological Survey Bulletin 1459, $108 \mathrm{p}$.

Hall, R.D., ed., 1990, Quatemary geology of the western Madison Range, Madison valley, Tobacco Root Range, and Jefferson valley, Rocky Mountain Friends of the Pleistocene, August 15-19, 1990, Fieldtrip Guidebook: Indianapolis, Indiana University at Indianapolis, Department of Geology, $309 \mathrm{p}$.

Haller, K.M., Dart, R.L., and Stickney, M.C., 1993, A compilation of major active faults for parts of Montana and Idaho: Geological Society of America Abstracts with Programs, v. 25, no. 5, p. 46.

Kellogg, K.S., 1992, Geologic map of the Fan Mountain quadrangle, Madison County, Montana: U.S. Geological Survey Geologic Quadrangle Map GQ-1706, scale 1:24,000.

1993, Geologic map of the Ennis Lake quadrangle, Madison County, Montana: U.S. Geological Survey Geologic Quadrangle Map GQ-1729, scale 1:24,000.

Knapton, J.R., and Brosten, T.M., 1987, Supplemental arsenic data for selected streams in the Missouri River basin, Montana, 1987: U.S. Geological Survey Open-File Report 87-697, 14 p.

1989, Arsenic and chloride data for five stream sites in the Madison River drainage, Montana, 1988: U.S. Geological Survey Open-File Report 88-722, 12 p. 
Knapton, J.R., and Horpestad, A.A., 1987, Arsenic data for streams in the upper Missouri River basin, Montana and Wyoming: U.S. Geological Survey Open-File Report 87-124, 25 p.

Leonard, R.B., and Wood, W.A., 1980, Supplemental data from the Ennis and other thermal-spring areas, southwest Montana: U.S. Geological Survey Open-File Report 80-1182, 79 p.

1988, Evaluation of a hydrothermal anomaly near Ennis, Montana: U.S. Geological Survey Professional Paper 1044-K, $53 \mathrm{p}$.

Lisle, T.E., 1972, Sediment yield and hydrodynamic implications, West Fork of the Madison River, Montana: Missoula, University of Montana, M.S. thesis, 81 p.

Locke, W.W., and Schneider, N.P., 1990, General geology and geomorphology of the Madison Range and valley, southwest Montana, in Quaternary geology of the western Madison Range, Madison valley, Tobacco Root Range, and Jefferson valley, Rocky Mountain Friends of the Pleistocene, August 15-19, 1990, Fieldtrip Guidebook: Indianapolis, Indiana University at Indianapolis, Department of Geology, p. 1-23.

Long, C.L., and Senterfit, R.M., 1979, Audio-magnetotelluric data log and station-location map for the Ennis Hot Springs area, Montana: U.S. Geological Survey Open-File Report 79-1308, 7 p.

Lundstrom, S.C., 1986, Soil stratigraphy and scarp morphology studies applied to the Quaternary geology of the southern Madison valley, Montana: Arcata, California, Humboldt State University, M.S. thesis, 53 p.

McCulloch, Robin, 1993, Montana mining directory 1992, Montana Bureau of Mines and Geology Bulletin 131, $76 \mathrm{p}$.

[Montana] State Engineer's Office, 1954a, Water resources survey, Madison County, Montana--Part 1, History of land and water use on irrigated areas: Helena, Mont., State Engineer's Office, $68 \mathrm{p}$.

1954b, Water resources survey, Madison County, Montana--Part 2, Maps showing irrigated areas: Helena, Mont., State Engineer's Office, 62 p.

National Oceanic and Atmospheric Administration, 1992, Monthly normals of temperature, precipitation, and heating and cooling degree days, 1961-90, Montana: Asheville, N.C., Climatography of the United States no. 81, unpaged.

Noble, R.A., Bergantino, R.N., Patton, T.W., Sholes, B.C., Daniel, Faith, and Schofield, Judeykay, 1982, Occurrence and characteristics of ground water of Montana--Volume 2, The Rocky Mountain Region: Montana Bureau of Mines and Geology Open-File Report 99, 132 p.

Rasmussen, D.L., and Fields, R.W., 1983, Structural and depositional history, Jefferson and Madison basins, southwestern Montana [abs.]: American Association of Petroleum Geologists Bulletin, v. 67, p. 1,352.

Ruppel, E.T., 1993, Cenozoic tectonic evolution of southwest Montana and east-central Idaho: Montana Bureau of Mines and Geology Memoir 65, 62 p.

Schneider, N.P., 1990, Terrace geomorphology of the central Madison Valley, in Quaternary geology of the western Madison Range, Madison valley, Tobacco Root Range, and Jefferson valley, Rocky Mountain Friends of the Pleistocene, August 15-19, 1990, Fieldtrip Guidebook: Indianapolis, Indiana University at Indianapolis, Department of Geology, p. 24-50.

Schofield, J.D., 1981, Structure of the Centennial and Madison valleys based upon gravitational interpretation, in Montana Geological Society Field Conference and Symposium Guidebook to Southwest Montana: [Billings, Mont.], Montana Geological Society, p. 275-284.

Senterfit, R.M., 1980, Principal facts for a gravity survey of the Ennis, Montana geothermal area: U.S. Geological Survey Open-File Report 80-98, 8 p.

Shields, R.S., Knapton, J.R., White, M.K., Brosten, T.M., and Chambers, C.L., 1993, Water resources data, Montana, water year 1992: Helena, Mont., U.S. Geological Survey Water-Data Report MT-92-1, 534 p.

Sonderegger, J.L., Schofield, J.D., Berg, R.B., and Mannick, M.L., 1982. The upper Centennial Valley, Beaverhead and Madison Counties, Montana, with a section on The Madison Valley thermal springs, by G.J. Weinheimer: Montana Bureau of Mines and Geology Memoir 50, 53 p.

Tuck, L.K., Briar, D.W., and Clark, D.W., in press, Geologic history and hydrogeologic units of intermontane basins of the Northern Rocky Mountains, Montana and Idaho: U.S. Geological Survey Hydrologic Investigations Atlas 738-A, 2 sheets, scale $1: 750,000$.

Tysdal, R.G., 1990, Geologic map of the Sphinx Mountain quadrangle and adjacent parts of the Cameron, Cliff Lake and Hebgen Dam quadrangles, Montana: U.S. Geological Survey Miscellaneous Geologic Investigations Map I-1815, scale $1: 62,500$. 
U.S. Environmental Protection Agency, 1991, Maximum contaminant levels (subpart B of part 141, National primary drinkingwater regulations): U.S. Code of Federal Regulations, Title 40, Parts 100 to 149, revised July 1, 1991, p. 585-588.

U.S. Geological Survey, issued annually, Water resources data, Montana: Helena, Montana, U.S. Geological Survey WaterData Report.

Weinheimer, G.J., 1979, The geology and geothermal potential of the upper Madison valley between Wolf Creek and the Missouri Flats, Madison County, Montana: Bozeman, Montana State University, M.S. thesis, 107 p. 


\section{Mission Valley}

\section{Geography}

The Mission Valley is an approximately north-trending, rectangularshaped intermontane basin in the north-central part of the Flathead Indian

Reservation. The $490-\mathrm{mi}^{2}$ basin is bounded by the Salish Mountains on the west, Flathead Lake on the north, and the Mission Range on the east (pl. 1); on the south, the basin is bounded by the Lewis and Clark Line (fig. 4). The basin is about $30 \mathrm{mi}$ long and about $17 \mathrm{mi}$ across. Its surface is relatively level, although some topographic features are notable.

Immediately south of Flathead Lake, a terminal moraine forms a smooth, prominent hill. The land surface gradually slopes southward from this moraine, to an approximately east-trending recessional moraine that ends north of Post Creek. Unlike the northern moraine, this southem moraine has hummocky, swell-and-swale topography, with numerous lakes and ponds that fill "kettles" left by melting glacial ice, and pingo

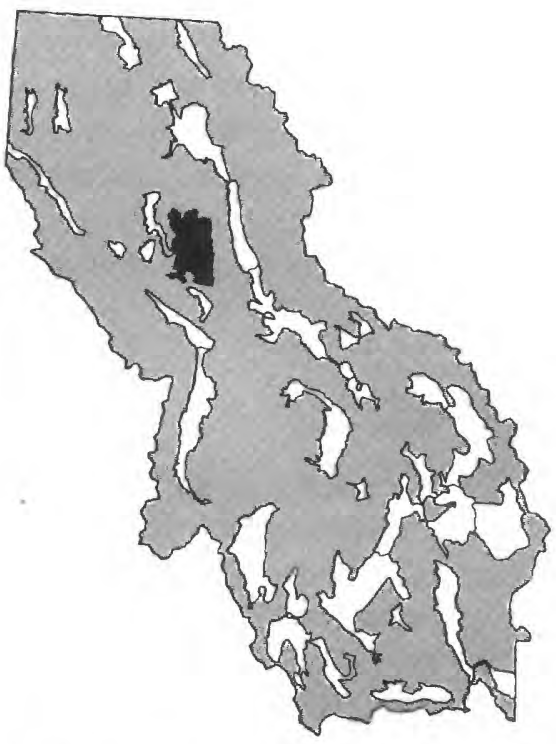
scars that resulted from Pleistocene permafrost action (Levish and others, 1993). The large area between the two moraines is covered by an undulating ground moraine. Just north of Post Creek, the land surface slopes down more than $100 \mathrm{ft}$. Along the westem side of the basin, the flood plain of the Flathead River is incised into a smooth, level terrace about 2 to $5 \mathrm{mi}$ wide. The Mission Valley ranges in altitude from about 2,600 ft where the Flathead River leaves the basin to about $4,300 \mathrm{ft}$ where basin fill extends up lower mountain slopes.

The climate of the Mission Valley is typical of lower-elevation intermontane basins of the Northem Rocky Mountains west of the Continental Divide, with warm summers and relatively cool, humid winters. The climate of St. Ignatius is typical of most of the Mission Valley. On the basis of the 1961-90 period of record, the average annual precipitation at St. Ignatius (altitude $2,900 \mathrm{ft}$ ) is $16.66 \mathrm{in}$. and the average annual temperature is $45.8^{\circ} \mathrm{F}$ (National Oceanic and Atmospheric Administration, 1992). The average last occurrence of $32^{\circ} \mathrm{F}$ is May 22 , and the average first occurrence is September 17. Mean monthly climatic data for St. Ignatius are plotted in fig. 23. Polson (altitude $2,990 \mathrm{ft}$ ) has a milder climate than St. Ignatius because of the moderating effect of Flathead Lake. The average potential growing season in Polson extends from May 11 to September 26 (Natural Resources Conservation Service, U.S. Department of Agriculture, unpub. data, 1994). Precipitation increases along the edges of the basin; the Mission Range front receives about 20 in. per year (U.S. Soil Conservation Service, 1977).

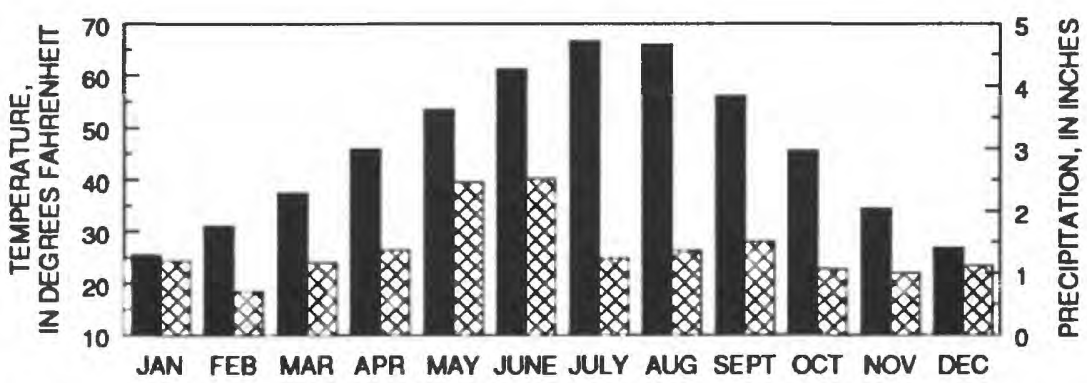

EXPLANATION

MEAN MONTHLY TEMPERATURE FOR 1961.90 PEAIOD OF RECORD

X MEAN MONTHLY PRECIPITATION FOR 1961-90 PERIOD OF RECORD

Figure 23. Mean monthly precipitation and temperature at St. lgnatius, Mont. Data from National Oceanic and Atmospheric Administration (1992). 
Land uses include irrigated hay pastures and seed-potato farms, rangeland, residential development, and some dryland small-grain production. The Flathead Agency Irrigation Division manages an elaborate network of distribution canals that divert water from the Flathead River and its tributaries to about 100,000 acres of irrigable land. Sweet cherry and apple orchards are prevalent near Flathead Lake, although residential subdivisions are rapidly displacing agriculture as the dominant land use in the Polson area (J.C. Eggen, Agricultural Stabilization and Conservation Service, oral commun., 1993; Slagle, 1992). About 16,000 people reside in the Mission Valley, including 3,291 in the City of Polson, 1,547 in the City of Ronan, 1,298 in the unincorporated community of Pablo, 778 in the Town of St. Ingatius, 358 in the unincorporated community of Charlo, 170 in the unincorporated community of Dixon, and 87 in the unincorporated community of Ravalli (1990 census).

\section{Geology}

The Mission Valley intermontane basin occupies the southernmost extension of the thousand-mile-long Rocky Mountain Trench, a zone of closely-spaced normal faults (fig. 4). Displacement along the high-angle normal fault at the base of the Mission Range is about $15,000 \mathrm{ft}$, including as much as $56 \mathrm{ft}$ during late Quaternary time (Ostenaa and others, 1993). The fault and the Mission Valley are truncated on the south by the Lewis and Clark Line, (fig. 4) a northwest-trending zone of high-angle normal, reverse, and right-lateral, strike-slip faults (Harrison and others, 1986).

Gravity, seismic-refraction, and well-log data indicate that the bedrock floor of the basin is highly irregular, with slopes of 1,000 to 1,300 feet per mile in places. Estimates of the maximum thickness of basin fill range from about 3,500 ft (Boettcher, 1982) to 4,000 ft (Noble and others, 1982, p. 41-44). The western part of the Mission Valley, through which the Flathead River flows, structurally is a separate fault-bounded basin with a maximum depth to bedrock of 3,000 ft (Noble and others, 1982).

Several investigators have examined the geology of the Mission Valley (table 64). The geologic units described by previous investigators are summarized below. These geologic units are referenced to hydrogeologic units defined in this study (table 2) to provide a consistent regional framework. In the following discussion, the hydrogeologic-unit abbreviations are italicized.

Metasedimentary bedrock of the Middle Proterozoic Belt Supergroup ( $Y \mathrm{~ms}$ ) surrounds the basin. These rocks primarily are siltite, argillite, and quartzite. However, the rocks that border the basin on the southwest and probably floor much of the basin, also include significant dolomite and limestone. The Proterozoic bedrock is extensively folded and faulted (Harrison and others, 1986).

Although no Tertiary sediments (Ts) crop out in the Mission Valley, this intermontane basin, like others in the Rocky Mountain Trench, probably contains hundreds to thousands of feet of Tertiary sediments beneath a veneer of Quaternary deposits. Tertiary sediments observed in drill cuttings from the Kalispell Valley to the north and the Little Bitterroot Valley to the west are characterized as unconsolidated to poorly consolidated sandstone, siltstone, clay and lignite (Slagle, 1988; Montana Board of Oil and Gas Conservation, unpub. data, 1990). Slagle (1988) tentatively identified Tertiary sediments in the Mission Valley in cuttings from well 22N21W28DDDD.

About 200 to $400 \mathrm{ft}$ of Quaternary glacial and alluvial deposits overlie bedrock and the inferred Tertiary deposits. Pleistocene glacial till $(Q g)$ comprises the northem and southem moraines, as well as the material underlying the intervening plain. In general, gravel, cobbles, and boulders in a clay matrix characterize the glacial till (Slagle, 1988). However, discontinuous stringers of well-sorted, coarse-grained glacial outwash locally are interbedded with the till, particularly northeast of Ronan (S.E. Slagle, U.S. Geological Survey, oral commun., 1993). The northern moraine also contains well-sorted, fine-grained sand and gravel typical of reworked glacial till or lacustrine sand deposited in shallow standing water (Slagle, 1988).

More than $500 \mathrm{ft}$ of Pleistocene glacial lakebed-deposits $(\mathrm{Qg})$ associated with glacial Lake Missoula and related glacial lakes underlie much of the nearly level terrace on the western side of the basin. These deposits consist of varved to massive, whitish-tan to light-tan silt and clay with occasional small lenses of sand and gravel. In most of the basin, glacial-lakebed deposits overlie glacial till. However, the area around White Earth Creek was never glaciated; there, glacial-lakebed deposits overlie fluvial sand and gravel (Boettcher, 1982; Slagle, 1988). 
Table 64. Geologic and geophysical maps of the Mission Valley, Montana

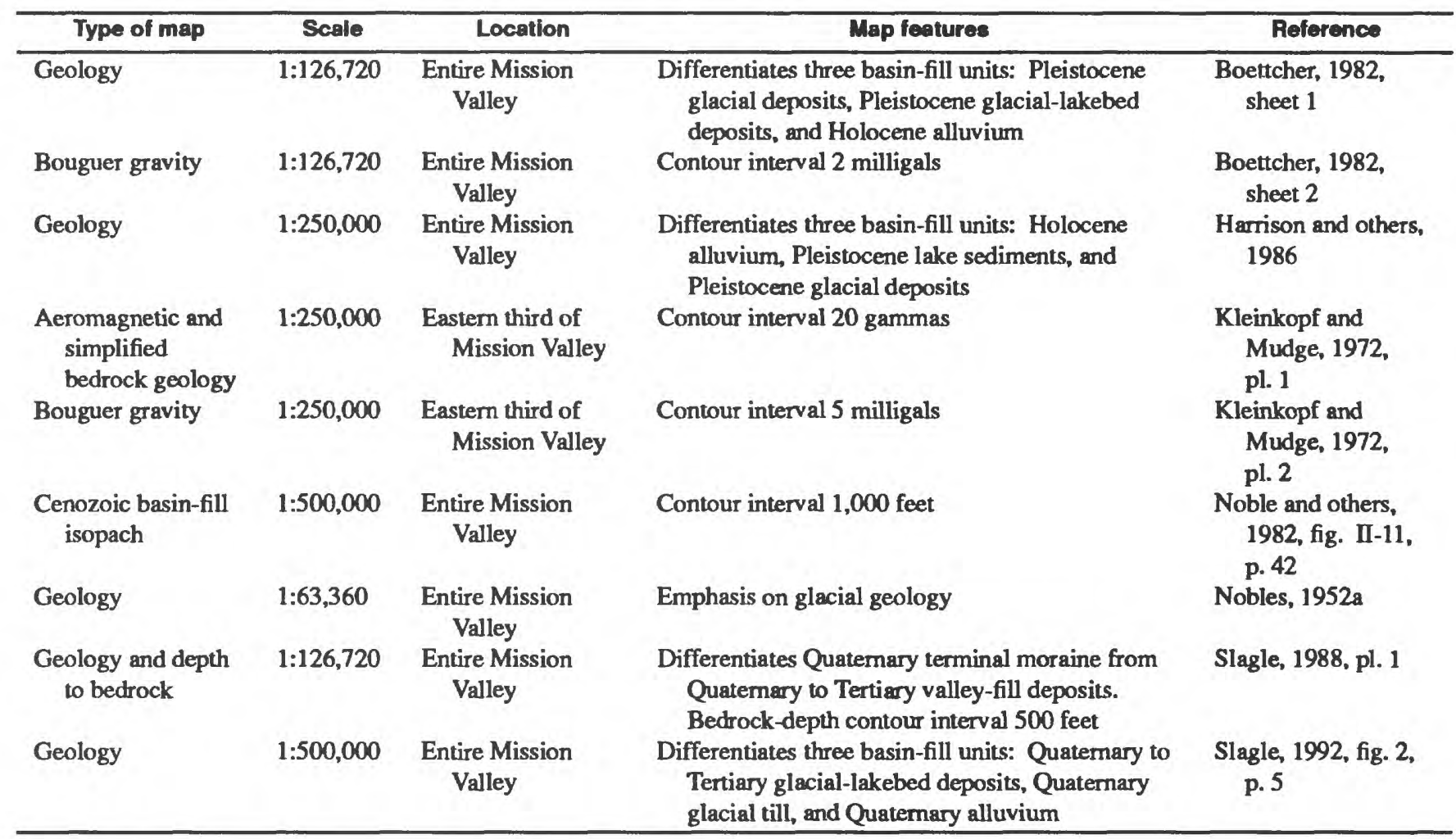

Holocene alluvium underlies the flood plain of the Flathead River (Harrison and others, 1986) and some areas adjacent to Flathead Lake (Slagle, 1992). It consists of well-sorted gravel, sand, silt, and clay.

\section{Hydrology}

The Flathead River flows westward from Flathead Lake at Polson, bends southward near its confluence with White Earth Creek, and meanders southward across the western side of the basin. The Mission Valley drainage system is poorly developed, complicated by numerous lakes and altered by an elaborate system of irrigation canals. The lakes and many smaller ponds fill kettles in the hummocky glacial topography. One of the largest lakes, Ninepipe Reservoir, and its associated wetlands are managed as a National Wildlife Refuge. A group of eight reservoirs is managed for irrigation. All are supplied from creeks and canals within the Mission Valley drainage basin, except for St. Mary's Lake, which receives water diverted from the Jocko River (Shields and others, 1993).

Streamflow data for gaging stations listed in table 65 are stored in the USGS WATSTORE database. Locations of these stations are shown on plate 1. Additional discharge data are available for several streamflowgaging stations that were measured during the 1900's and 1910's to help plan the construction of the irrigation system, and additional water-quality data are available for several stations that were sampled from 1983 to 1985 . Also, the USGS has published daily lake elevations for Flathead Lake at Somers (gaging station 12371500, drainage area $7,086 \mathrm{mi}^{2}$ ) since 1900 , and monthend combined usable contents, in acre-ft, of the eight irrigation reservoirs since 1939. Data for years prior to 1961 are published in Water-Supply Papers; more recent data are in annual WaterData Reports (U.S. Geological Survey, issued annually).

The quality of surface water in the Mission Valley has been measured on numerous occasions at several sites. Analyses of 49 samples from South Crow Creek near Ronan (gaging station 12375900) indicate a calcium bicarbonate type water with an average dissolved-solids concentration of about $49 \mathrm{mg} / \mathrm{L}$. Analyses of 94 samples from Mission Creek at the National Bison Range, at Moiese (gaging station 12379600) indicate a calcium 
bicarbonate type water with an average dissolved-solids concentration of $68 \mathrm{mg} / \mathrm{L}$. The general quality of the Flathead River remains stable between Columbia Falls in the Kalispell Valley (gaging station 12363000) and Perma (gaging station 12388700). Both stations have a calcium bicarbonate type water with average dissolved-solids concentrations between 90 and $100 \mathrm{mg} / \mathrm{L}$ (Clark and Dutton, in press).

Table 65. Summary of data for U.S. Geological Survey streamflow-gaging stations in the Mission Valley, Montana

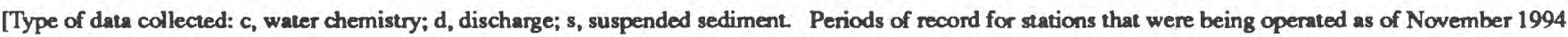
are indicated by the first year of record followed by a dash only. Abbreviations: $\mathrm{ft}^{3} / \mathrm{s}$, cubic feet per second. Symbol: --, no data; <, less than]

\begin{tabular}{|c|c|c|c|c|c|c|c|c|c|}
\hline \multirow[b]{2}{*}{$\begin{array}{l}\text { Station } \\
\text { number }\end{array}$} & \multirow[b]{2}{*}{ Station name } & \multirow{2}{*}{$\begin{array}{l}\text { Drainage } \\
\text { area } \\
\text { (square } \\
\text { miles) }\end{array}$} & \multirow{2}{*}{$\begin{array}{l}\text { Type } \\
\text { of } \\
\text { data } \\
\text { col- } \\
\text { lected }\end{array}$} & \multirow[b]{2}{*}{$\begin{array}{l}\text { Period of record } \\
\text { (calendar year) }\end{array}$} & \multicolumn{5}{|c|}{ Discharge for period of record } \\
\hline & & & & & $\begin{array}{l}\text { Mean } \\
\text { annual } \\
\left(f^{3} / s\right)\end{array}$ & $\begin{array}{l}\text { Maxi- } \\
\left(f^{3} / s\right)\end{array}$ & $\begin{array}{l}\text { Date of } \\
\text { maximum }\end{array}$ & $\underset{\left(f^{3} / s\right)}{\text { Mini- }}$ & $\begin{array}{l}\text { Date of } \\
\text { minimum }\end{array}$ \\
\hline 12371100 & $\begin{array}{l}\text { Hell Roaring Creek } \\
\text { near Polson }\end{array}$ & 6.41 & d & $1917-32$ & 6.64 & 104 & $06-09-17$ & 0 & $11-22,12-22$ \\
\hline 12371550 & $\begin{array}{l}\text { Flathead Lake at } \\
\text { Polson }\end{array}$ & 7,086 & c & $1969-71$ & - & - & - & -- & - \\
\hline 12372000 & $\begin{array}{l}\text { Flathead River near } \\
\text { Polson }\end{array}$ & 7,096 & $\begin{array}{l}\text { d } \\
\text { c }\end{array}$ & $\begin{array}{l}1907- \\
1977-83\end{array}$ & 11,540 & 82,800 & $05-29-28$ & $<5.0$ & $04-13-38$ \\
\hline 12375900 & $\begin{array}{l}\text { South Crow Creek } \\
\text { near Ronan }\end{array}$ & 7.57 & $\begin{array}{l}\mathrm{d} \\
\mathrm{c}\end{array}$ & $\begin{array}{l}1982- \\
1983-85\end{array}$ & 20.3 & 312 & $06-30-91$ & $1 / 4.4$ & $02-17-93$ \\
\hline 12376900 & $\begin{array}{l}\text { Crow Creek at mouth, } \\
\text { near Ronan, }\end{array}$ & -- & c, s & $1987-92$ & - & -- & - & - & - \\
\hline 12377150 & $\begin{array}{l}\text { Mission Creek above } \\
\text { reservoir, near St. } \\
\text { Ignatius }\end{array}$ & 12.4 & d & $1982-$ & 48.5 & 892 & $06-30-91$ & 5.9 & $02-18-85$ \\
\hline 12379600 & $\begin{array}{l}\text { Mission Creek at } \\
\text { National Bison } \\
\text { Range, at Moiese }\end{array}$ & 236 & c, s & $1987-92$ & -- & $\cdots$ & - & -- & -- \\
\hline 12388200 & Jocko River at Dixon & 380 & $\begin{array}{c}\mathrm{d} \\
\mathrm{c}, \mathrm{s}\end{array}$ & $\begin{array}{l}1990- \\
1987-92\end{array}$ & 190 & 1,130 & $05-19-91$ & ${ }^{1} 94$ & $02-24-93$ \\
\hline 12388400 & $\begin{array}{l}\text { Revais Creek below } \\
\text { West Fork, near } \\
\text { Dixon }\end{array}$ & 23.4 & $\begin{array}{l}\mathrm{d} \\
\mathrm{c}\end{array}$ & $\begin{array}{l}1982- \\
1983-85,1991-92\end{array}$ & 16.5 & 277 & $05-18-91$ & ${ }^{1} 2.5$ & $02-04-89$ \\
\hline 12388700 & $\begin{array}{l}\text { Flathead River at } \\
\text { Perma }\end{array}$ & 8,795 & $\begin{array}{c}\mathrm{d} \\
\mathrm{c}, \mathrm{s}\end{array}$ & $\begin{array}{l}1983- \\
1971-73,1984-92\end{array}$ & 11,190 & 44,600 & $07-03-91$ & 12,670 & $05-29-84$ \\
\hline
\end{tabular}

${ }^{1}$ Loweat daily mean

Agricultural practices affect water quality in some Mission Valley streams. For example, increased turbidity and sedimentation have resulted from irrigation retum flow in several streams, including Crow Creek and Post Creek (Nunnallee and Botz, 1976).

Ground water is an important resource in the Mission Valley. The urban areas depend partly or entirely on ground water for domestic supply and rural residents rely entirely on ground water (Noble and others, 1982, p. 4144).

Holocene alluvium is tapped primarily for domestic wells. Many alluvial wells are more than $100 \mathrm{ft}$ deep (Slagle, 1988). Few wells producing more than $300 \mathrm{gal} / \mathrm{min}$ are completed in flood-plain alluvium because nearby surface water is readily available (Boettcher, 1982). On the basis of eight aquifer tests using four wells, the transmissivity of Holocene alluvium ranges from 87 to $45,600 \mathrm{ft}^{2} / \mathrm{d}$ and averages $10,700 \mathrm{ft}^{2} / \mathrm{d}$. Specific-capacity values range from 1.2 to 81 (gal/min)/ft (Slagle, 1988).

Because they are very fine-grained, Pleistocene glacial-lakebed deposits do not readily yield water to wells. Using aquifer tests, Slagle (1992) determined hydraulic conductivity values ranging from 0.04 to $0.75 \mathrm{ft} / \mathrm{d}$ and averaging $0.11 \mathrm{ft} / \mathrm{d}$ in near-surface glacial-lakebed deposits about 3 mi east of Moiese. 
The principal aquifer in the Mission Valley is a heterogeneous mixture of glacially deposited material, varying in composition from poorly sorted clay till to well-sorted sand-and-gravel outwash, collectively known as Pleistocene glacial drift. Hydraulic characteristics of the drift vary considerably, reflecting its heterogeneous composition. On the basis of 11 aquifer tests and 2 specific capacity tests, the transmissivity ranges from 42 to $43,600 \mathrm{ft}^{2} / \mathrm{d}$ and averages $16,200 \mathrm{ft}^{2} / \mathrm{d}$. The larger values represent glacial outwash, while the smaller values represent glacial till. Hydraulic conductivity of near-surface glacial till determined from aquifer and tracer tests near Charlo ranges from 0.002 to $0.80 \mathrm{ft} / \mathrm{d}$ and average $0.21 \mathrm{ft} / \mathrm{d}$ (Slagle, 1992). Specific capacity of glacial drift ranges from about 0.14 to 25 (gal/min)/ft (Boettcher, 1982). Large-capacity wells are completed in glacial outwash in four general areas: (1) White Earth Creek, (2) northwest of Polson, (3) between Pablo and Ronan, and (4) the southeastern edge of the basin. In contrast, an approximately $50-\mathrm{mi}^{2}$ area west of Ronan apparently lacks sufficient permeability to supply domestic wells (Slagle, 1988). In most other areas of the basin, wells completed in glacial drift are capable of at least providing domestic supplies. Well depths in glacial drift range from about $50 \mathrm{ft}$ to more than $\mathbf{4 0 0} \mathrm{ft}$. Glacial aquifers are confined everywhere in the Mission Valley except along the Mission Range front. Flowing wells exist in the White Earth Creek, Post Creek, and Ronan areas where glacial-lakebed deposits or finegrained glacial till overlie saturated permeable zones (Boettcher, 1982, fig. 4, p. 8).

No wells are known to be completed in Tertiary deposits in the Mission Valley. Adequate yields from the overlying Quaternary deposits generally preclude the need to drill beneath this surficial aquifer.

Fractures within the Proterozoic bedrock that surrounds and floors the basin can yield adequate water for domestic use. Typically, the bedrock aquifer is only used in areas around the basin margin and near bedrock outcrops, where Quaternary deposits are thin or absent. Of 33 bedrock wells tested throughout the Flathead Indian Reservation, discharge rates ranged from 2.5 to $40 \mathrm{gal} / \mathrm{min}$ and averaged $9.5 \mathrm{gal} / \mathrm{min}$; specific-capacity values ranged from 0.08 to $3.2(\mathrm{gal} / \mathrm{min}) / \mathrm{ft}$ and averaged $0.73(\mathrm{gal} / \mathrm{min}) / \mathrm{ft}$ (Slagle, 1988).

Potentiometric-surface maps of the Mission Valley (table 66) indicate that ground water generally flows westward from the Mission Mountain front, toward the Flathead River. Southwest of Ronan, ground-water flow also has a strong southward component. Near Polson, ground water flows northward toward Flathead Lake. In that area, high ground-water levels result in persistent seeps, frost heave, poor soil drainage, waterlogged areas, and susceptibility to ground-water contamination (Kennett and Curry, 1981).

Table 66. Potentiometric-surface maps of the Mission Valley, Montana

\begin{tabular}{lllll}
\hline \multicolumn{1}{c}{ Location } & $\begin{array}{c}\text { Dates water lovels } \\
\text { were measured }\end{array}$ & \multicolumn{1}{c}{ Scale } & $\begin{array}{c}\text { Contour interval } \\
\text { In feet }\end{array}$ & Reference \\
\hline Entire Mission Valley & Summers of 1974-76 & $1: 126,720$ & 10,40 , and 50 & Boettcher, 1982, sheet 3 \\
Entire Mission Valley & $1967-1984$ & $1: 126,720$ & 25,50 , and 100 & Slagle, 1988, pl. 2 \\
\hline
\end{tabular}

Basin-fill aquifers are recharged by precipitation and snowmelt, surplus irrigation water, leakage from irrigation canals, subsurface flow from the Little Bitterroot Valley and from surrounding bedrock, and infiltration from tributary streams. The ground-water contribution area (fig. 2, pl. 1) is about $840 \mathrm{mi}^{2}$. Infiltration anywhere within this area could potentially recharge basin-fill aquifers in the Mission Valley. Ground water discharges from the basin-fill aquifers by evapotranspiration, withdrawals from wells, subsurface flow near Moiese, and seepage to springs, seeps, irrigation drains, and the Flathead River.

Several components of the basin-wide water budget have been quantified. Leakage of water from irrigation canals significantly recharge basin-fill aquifers, causing ground-water levels to be highest during the growing season. Slagle (1992) used seepage meters, tracer tests, water-temperature profiles, and aquifer and slug tests to determine leakage rates from unlined canals in different hydrogeologic units throughout the Flathead Reservation. Average leakage rates were $0.001 \mathrm{ft} / \mathrm{d}$ in bedrock, $0.0013 \mathrm{ft} / \mathrm{d}$ in glacial-lakebed deposits, $0.0012 \mathrm{ft} / \mathrm{d}$ in glacial till, and $0.0023 \mathrm{ft} / \mathrm{d}$ in alluvium. About 610 acre- $\mathrm{ft} / \mathrm{yr}$ recharges basin-fill aquifers in the Mission Valley as subsurface flow from basin-fill aquifers in the adjoining Little Bitterroot Valley (Slagle, 1988). Boettcher (1982) reported municipal-supply water use in 1976 by Charlo ( 85 acre-ft from ground water, estimated), Pablo (100 acre-ft from 
ground water), Polson (46 acre-ft from ground water and 1,028 acre-ft from surface water), Ronan (15 acre-ft from ground water and 131 acre-ft from surface water, both estimated), Round Butte (134 acre-ft from ground water), and St. Ignatius (503 acre-ft from ground water and surface water, combined). Slagle (1988) estimated that about 5,800 acre-ft of ground water was pumped from domestic, municipal-supply, and irrigation wells in the Mission Valley in 1980. Boettcher (1982) also provided estimates of withdrawals from irrigation wells and surface-water infiltration to ground water in the combined areas of the Mission Valley and the Little Bitterroot Valley.

Ground-water discharge to the Flathead River was estimated on the basis of synoptic streamflow measurements on April 8, 1977, when flow from Flathead Lake was constant and effects of evapotranspiration and irrigation retum flow were minimal. During that low-flow period, the Flathead River gained about $360 \mathrm{ft}^{3} / \mathrm{s}$ from ground water between Polson and Dixon (Boettcher, 1982). Records from streamflow-gaging stations, supplemented by low-flow measurements during February 13 to 15, 1984 approximately concur, indicating that the same stretch of the Flathead River gained about $330 \mathrm{ft}^{3} / \mathrm{s}$ (Slagle, 1988). Discharge by subsurface flow from basinfill aquifers near Moiese is an estimated 7,400 acre-ft/yr (Slagle, 1988).

Water-level data for wells listed in table 67 are stored in the USGS WATSTORE database. Water levels were measured in these wells at least annually In general, long-term water levels appear to be fairly stable (Slagle, 1988), although declines of as much as $36 \mathrm{ft}$ were evident in the Polson area during the 1970's (Boettcher, 1982).

Table 67. Summary of water-level data for selected wells in the Mission Valley, Montana

[Hydrogeologic unit: Qg, Pleistocene glacial deposits]

\begin{tabular}{|c|c|c|c|c|c|c|c|}
\hline \multirow{2}{*}{ Location number } & \multirow{2}{*}{$\begin{array}{l}\text { Depth of } \\
\text { well, In feet } \\
\text { below land } \\
\text { curface }\end{array}$} & \multirow{2}{*}{$\begin{array}{l}\text { Hydro- } \\
\text { geologic } \\
\text { unil }\end{array}$} & \multirow{2}{*}{$\begin{array}{l}\text { Period of } \\
\text { record }\end{array}$} & \multicolumn{4}{|c|}{$\begin{array}{c}\text { Water level, In feel below or above }(t) \text { land } \\
\text { eurface }\end{array}$} \\
\hline & & & & Highest & $\begin{array}{l}\text { Date of } \\
\text { highest }\end{array}$ & Lowest & $\begin{array}{l}\text { Date of } \\
\text { lowest }\end{array}$ \\
\hline 21N20W14ACB 01 & 12.0 & $\mathrm{Qg}$ & $1974-94$ & 2.57 & $08-14-75$ & 7.86 & $08-01-91$ \\
\hline 21N20W24CAAA02 & 290 & $Q g$ & $1974-94$ & +1.00 & $10-22-74$ & 60.00 & $07-07-94$ \\
\hline 20N20W26CCBD01 & 200 & $\mathrm{Qg}$ & $1967-90$ & 142.62 & $11-18-81$ & 168.05 & $07-13-88$ \\
\hline 19N20W35AAA 01 & 54.0 & $Q g$ & $1967-94$ & 29.97 & $07-08-85$ & 48.39 & $07-18-89$ \\
\hline 18N20W14DBDC01 & 30.0 & $\mathrm{Qg}$ & $1974-94$ & 11.10 & $07-10-74$ & 16.10 & 04-04-88 \\
\hline
\end{tabular}

The quality of ground water in the basin was determined on the basis of 65 samples analyzed for major ions and measured dissolved-solids concentrations and 4 samples in which dissolved-solids concentrations were estimated from specific-conductance measurements. Along the Mission Range front, extending about 5 mi west of the front, ground water is a calcium bicarbonate type with dissolved-solids concentrations of less than $50 \mathrm{mg} / \mathrm{L}$. Downgradient, the sodium and dissolved-solids concentrations increase. In the southwestem part of the basin, ground water is a sodium bicarbonate type with dissolved-solids concentrations ranging from 250 to $500 \mathrm{mg} / \mathrm{L}$ and occasionally exceeding $500 \mathrm{mg} / \mathrm{L}$. One well in the southwest (20N20W30DCD) has a sulfate concentration of 360 $\mathrm{mg} / \mathrm{L}$. In the central and westem areas, ground water is a mixed-cation bicarbonate type with dissolved-solids concentrations generally exceeding $250 \mathrm{mg} / \mathrm{L}$ (Clark and Dutton, in press; Slagle, 1988). Only minor changes in ground-water quality in the vicinity of irrigation canals result from leakage from the canals (Slagle, 1992).

\section{Selected References}

Boettcher, A.J., 1982, Ground-water resources in the central part of the Flathead Indian Reservation, northwestern Montana: Montana Bureau of Mines and Geology Memoir 48, 28 p.

Briar, D.W., Lawlor, S.M., Stone, M.A.J., Parliman, D.J., Schaefer, J.L., and Kendy, Eloise, in press, Ground-water levels in intermontane basins of the Northern Rocky Mountains, Montana and Idaho: U.S. Geological Survey Hydrologic Investigations Atlas 738-B, 1 sheet, scale 1:750,000. 
Clark, D.W., and Dutton, D.M., in press, Quality of ground water and surface water in intermontane basins of the Northem Rocky Mountains, Montana and Idaho: U.S. Geological Survey Hydrologic Investigations Atlas 738-C, 1 sheet, scale 1:750,000.

Curry, R.R., Lister, J.C., and Stoffel, Keith, 1977, Glacial history of Flathead Valley and Lakes Missoula floods, in Glacial geology of Flathead Valley and catastrophic drainage of glacial Lakes Missoula: Rocky Mountain Section, Geological Society of America 30th Annual Meeting Field Guide 4, p. 14-38.

Decker, G.L., 1969, Preliminary report on the geology, geochemistry, and sedimentology of Flathead Lake, northwestem Montana: Missoula, University of Montana, M.S. thesis, 91 p.

Dutton, D.M., Lawlor, S.M., Briar, D.W., and Tresch, R.E., 1995, Hydrogeologic data for the Northern Rocky Mountains intermontane basins, Montana: U.S. Geological Survey Open-File Report 95-143, 94 p.

Harrison, J.E., Griggs, A.B, and Wells, J.D., 1986, Geologic and structure maps of the Wallace $1^{\circ} \times 2^{\circ}$ quadrangle: U.S. Geological Survey Miscellaneous Investigation Series Map I-1509, 2 sheets, scale 1:250,000.

Johns, W.M., McClernan, H.G., and Lawson, D.C., 1971, Geological reconnaissance and soil-sample investigation of the Ravalli-Dixon-Perma-Camas Prairie area, Sanders County, Montana: Montana Bureau of Mines and Geology Open-File Report 10,73 p.

Joyce, M.J., 1980, Stratigraphy, clay mineralogy and pesticide analysis of Flathead Lake sediments, Flathead Lake, Montana: Missoula, University of Montana, M.S. thesis, 86 p.

Kennett, G.A., and Curry, R.R., 1981, Investigations of high groundwater in Polson terminal moraine: Montana Water Resources Research Center Report 116, Bozeman, Mont., 34 p.

Kleinkopf, M.D., and Mudge, M.R., 1972, Aeromagnetic, Bouguer gravity, and generalized geologic studies of the Great FallsMission Range area, northwestem Montana: U.S. Geological Survey Professional Paper 726-A, 19 p.

Kogan, Jerry, 1980, A seismic sub-bottom profiling study of recent sedimentation in Flathead Lake, Montana: Missoula, University of Montana, M.S. thesis, 98 p.

LaPoint, DJ., 1971, Geology and geophysics of the southwestern Flathead Lake region, Montana: Missoula, University of Montana, M.S. thesis, $110 \mathrm{p}$. 1973, Gravity survey and geology of the Flathead Lake region, Montana: Northwest Geology, v. 2, p. 13-20.

Levings, G.W., and White, M.K., 1983, Selected annotated bibliography of ground-water resources, records of wells and springs, and availability of streamflow data on Indian reservations in Montana: U.S. Geological Survey Open-File Report 83-129, 137 p.

Levish, D.R., Klinger, R.E., and Ostenaa, D.A., 1993, Pingo scars in the Mission Valley, northwest Montana--implications for paleoclimate and the Flathead lobe of the Cordilleran ice sheet [abs.]: Geological Society of America Abstracts with Programs, v. 25, no. 5, p. 69.

[Montana] State Engineer's Office, 1963a, Water resources survey, Lake County, Montana--Part 1, History of land and water use on irrigated areas: Helena, Mont., State Engineer's Office, 53 p.

1963b, Water resources survey, Lake County, Montana--Part 2, Maps showing irrigated areas: Helena, Mont., State Engineer's Office, 32 p.

Morrison-Maierle, Inc. and James M. Montgomery, Consulting Engineers, Inc., 1977, Lakes and streams water quality study, Flathead drainage, Montana: [Helena, Mont.], Morrison-Maierle, Inc., variously paged.

National Oceanic and Atmospheric Administration, 1992, Monthly normals of temperature, precipitation, and heating and cooling degree days, 1961-90, Montana: Asheville, N.C., Climatography of the United States no. 81, unpaged.

Noble, R.A., Bergantino, R.N., Patton, T.W., Sholes, B.C., Daniel, Faith, and Schofield, Judeykay, 1982, Occurrence and characteristics of ground water of Montana--Volume 2, The Rocky Mountain Region: Montana Bureau of Mines and Geology Open-File Report 99, 132 p.

Nobles, L.H., 1952a, Glacial geology of the Mission Valley, western Montana: Cambridge, Massachusetts, Harvard University, Ph.D. dissertation, 123 p.

1952b, Glacial sequence in the Mission Valley, western Montana [abs.]: Geological Society of America Bulletin, v. 63, p. 1,286 . 
Nunnallee, David, and Botz, M.K., 1976, Water quality inventory and management plan, lower Clark Fork River basin, Montana: Montana Department of Health and Environmental Sciences, 129 p.

Ostenaa, D.A., Klinger, R.E., and Levish, D.R., 1993, Holocene faulting on the Mission fault, northwest Montana [abs.]: Geological Society of America Abstracts with Programs, v. 25, no. 5, p. 130.

Shields, R.R., Knapton, J.R., White, M.K., Brosten, T.M., and Chambers, C.L., 1993, Water resources data, Montana, water year 1992: U.S. Geological Survey Water-Data Report MT-92-1, 534 p.

Silverman, Arnold, 1972, A geologic, geochemical, and sedimentologic study of Flathead Lake, Montana: Bozeman, Mont. Montana University Joint Water Resources Research Center Report 21, 48 p.

Slagle, S.E., 1988, Geohydrology of the Flathead Indian Reservation, northwestern Montana: U.S. Geological Survey WaterResources Investigations Report 88-4142, 152 p. 1992, Irrigation-canal leakage in the Flathead Indian Reservation, northwestern Montana: U.S. Geological Survey WaterResources Investigations Report 92-4066, 77 p.

Smith, D.G., 1977, Glacial geology of the Big Arm Region of Flathead Lake, in Glacial geology of Flathead Valley and catastrophic drainage of Glacial Lake Missoula: Rocky Mountain Section, 30th Annual Meeting, Geological Society of America Field Guide no. 4, p. 1-13.

Tuck, L.K., Briar, D.W., and Clark, D.W., in press, Geologic history and hydrogeologic units of intermontane basins of the Northem Rocky Mountains, Montana and Idaho: U.S. Geological Survey Hydrologic Investigations Atlas 738-A, 2 sheets, scale 1:750,000.

U.S. Geological Survey, issued annually, Water resources data, Montana: Helena, Mont., U.S. Geological Survey Water-Data Report.

U.S. Soil Conservation Service, 1977, Average annual precipitation in Montana, based on 1941-1970 data: Bozeman, Montana, $13 \mathrm{p}$.

Wold, R.J., 1982, Seismic reflection study of Flathead Lake, Montana: U.S. Geological Survey Miscellaneous Field Studies. Map MF-1433, scale 1:117,000.

Wunder, Laura, 1974, Water use, surface water, and water rights on the Flathead Indian Reservation, Montana, a review: Missoula, University of Montana, M.S. thesis, $250 \mathrm{p}$. 


\title{
Missoula Valley
}

\section{Geography}

The Missoula Valley is a west-northwest-trending, wedge-shaped intermontane basin in northwestern Montana. The $170-\mathrm{mi}^{2}$ basin is bounded by the Reservation Divide on the northeast, the Bitterroot Valley on the south, and the Bitterroot Mountains on the southwest (pl. 1). McMurtrey and others (1965, p. 6-8) identified four topographic features of the Missoula Valley: (1) the Clark Fork flood plain; (2) the low terrace, which borders the Clark Fork flood plain on the northeast; (3) the high terrace which slopes southwestward toward the low terrace; and (4) the "north-side" bedrock ridge, which borders the high terrace on the northeast and parallels the northeastern basin boundary. The Missoula Valley ranges in altitude from about $3,000 \mathrm{ft}$ where the Clark Fork leaves the basin, to about $4,400 \mathrm{ft}$ on the highest terrace.

The climate of the Missoula Valley is typical of lower-elevation intermontane basins of the Northem Rocky Mountains west of the Continental

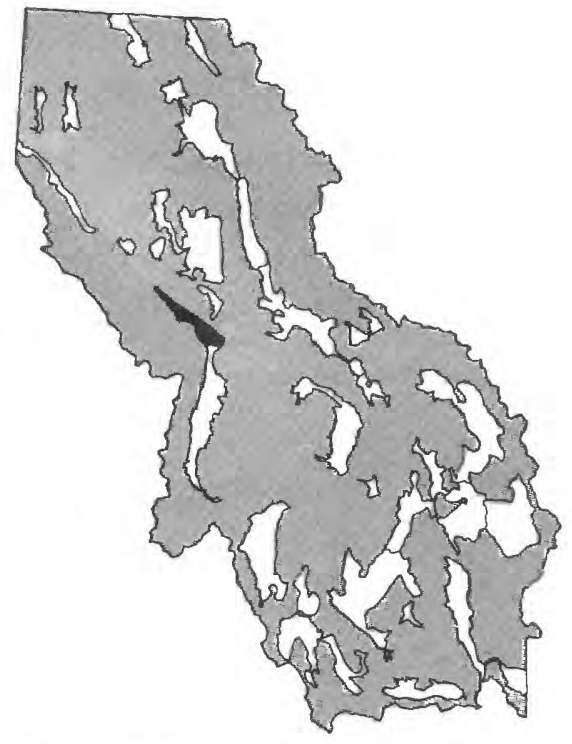
Divide, with warm summers and cool, humid winters. On the basis of the 1961-90 period of record, the average annual precipitation at the Missoula Airport (altitude 3,200 ft) is $13.24 \mathrm{in}$. and the average annual temperature is $44.3^{\circ} \mathrm{F}$ (National Oceanic and Atmospheric Administration, 1992). The average last occurrence of $32^{\circ} \mathrm{F}$ is May 27 and the average first occurrence is September 18 (Natural Resources Conservation Service, U.S. Department of Agriculture, unpub. data, 1994). Mean monthly climatic data for the Missoula Airport are plotted in figure 24.

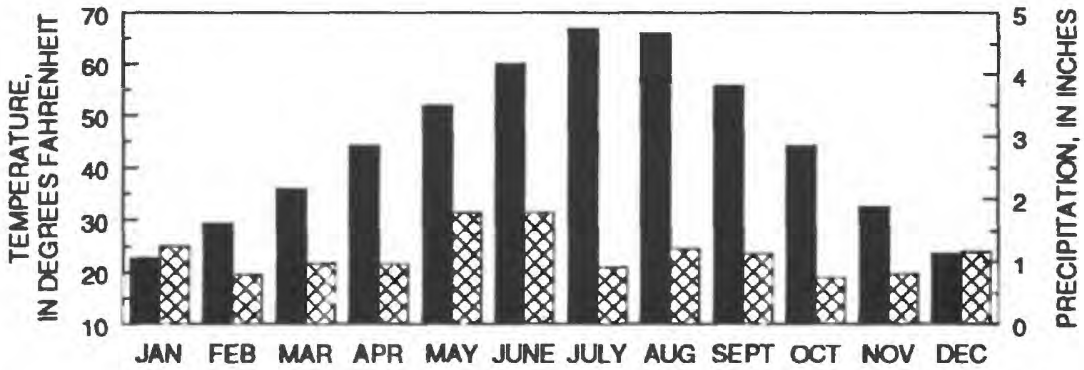

\author{
EXPLANATION \\ MEAN MONTHLY TEMPERATURE FOR \\ 1961-90 PERIOD OF RECORD \\ Q MEAN MONTHLY PRECIPITATION FOR \\ 1961-90 PERIOD OF RECORD
}

Figure 24. Mean monthly precipitation and temperature at the Missoula Airport, Mont. Data from National Oceanic and Atmospheric Administration (1992).

About 47,000 people reside in the Missoula Valley, including 354 in the Town of Alberton, and 323 in the unincorporated community of Frenchtown. The City of Missoula, which includes parts of both the Missoula Valley and the Bitterroot Valley, has 42,918 residents (1990 census).

Land uses include rangeland, urban and other residential development, irrigated pastures, and lumber processing. Dryland small grains are grown to a limited extent on terraces (J.C. Eggen, Agricultural Stabilization and Conservation Service, oral commun., 1993). Mining is historically important in the mountains surrounding the Missoula Valley. Currently, gold is placer-mined in the Ninemile Creek drainage area (McCulloch, 1993, p. 12, 17, 47).

\section{Geology}

The Missoula Valley was a regional topographic low as early as the Late Cretaceous; however, the normal faulting that created the present-day structural basin did not begin until Tertiary time (McMurtrey and others, 1965. 
p. 16-17). The bedrock floor of the intermontane basin has dropped down relative to the Reservation Divide along a high-angle fault (Harrison and others, 1986). This fault is part of the Lewis and Clark Line (fig. 4), a northwesttrending zone of high-angle normal, reverse, and right-lateral strike-slip faults (Wallace and others, 1990).

Several investigators have examined the geology of the Missoula Valley (table 68). The geologic units described by previous investigators are summarized below. These geologic units are referenced to hydrogeologic units defined in this study (table 2) to provide a consistent regional framework. In the following discussion, the hydrogeologic-unit abbreviations are italicized.

Table 68. Geologic and geophysical maps of the Missoula Valley, Montana

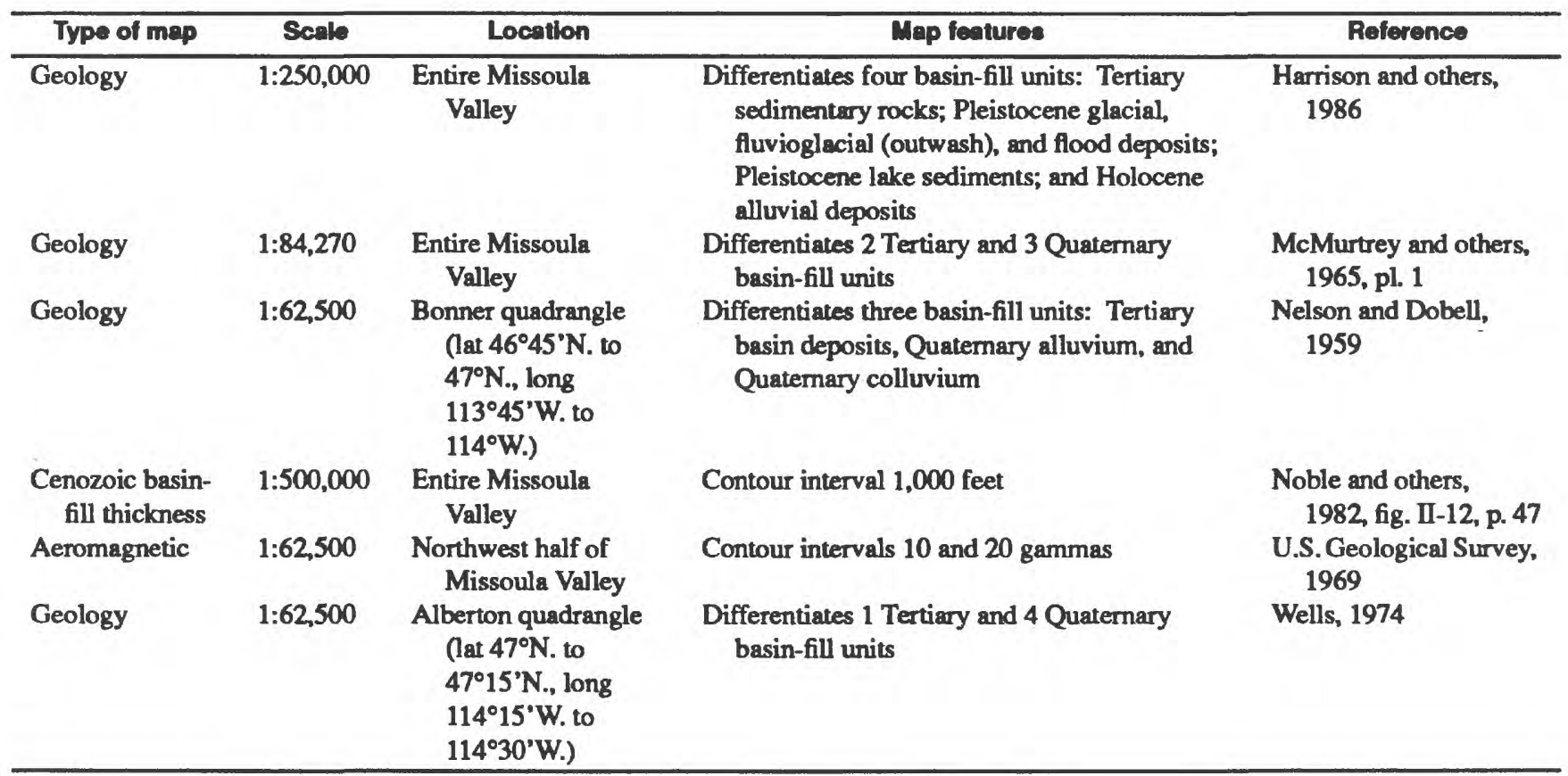

Bedrock surrounding the basin consists of Precambrian metasedimentary rocks and Cambrian sedimentary rocks. Metasedimentary rocks of the Middle Proterozoic Belt Supergroup ( $Y m s$ ) are primarily quartzite, siltite, and argillite, with some limestone and dolomite. Cambrian sedimentary rocks ( $P$ zls), which border the basin intermittently along the southwest side, include primarily carbonate and argillaceous rocks. More than $3,000 \mathrm{ft}$ of Cenozoic basin fill overlie the bedrock floor (Noble and others, 1982).

Tertiary deposits (Ts) include Oligocene(?) alluvial deposits and Pliocene(?) channel deposits (McMurtrey and others, 1965). The older deposits, which crop out on the high terrace adjacent to the mountain front, consist of semi- to well-consolidated conglomerate interbedded with incompetent beds of shale, coal, and some volcanic ash. The younger Tertiary deposits crop out on the high terrace adjacent to the low terrace and consist of well-bedded, well-sorted, unconsolidated sand and gravel. Strata that underlie the high terrace generally dip to the northeast (McMurtrey and others, 1965).

Strata that underlie the low terrace are approximately level. In ascending order, Tertiary deposits are overlain by about $25 \mathrm{ft}$ of Pleistocene glacial deposits $(\mathrm{Qg})$ consisting primarily of gravel; about $140 \mathrm{ft}$ of Pleistocene glaciofluvial deposits (Qal), which are mainly sand, but also include interbedded clay, silt, and gravel; and about $115 \mathrm{ft}$ of Pleistocene glacial-lakebed deposits $(Q g)$ consisting of unconsolidated, varved clay and silt deposited by glacial Lake Missoula. Less than $100 \mathrm{ft}$ of Holocene alluvium and reworked glacial-lakebed deposits (Qal) underlies the Clark Fork flood plain (McMurtrey and others, 1965). 


\section{Hydrology}

The southern edge of the Missoula Valley intermontane basin is defined by the confluence of the northwardflowing Bitterroot River with the northwestward-flowing Clark Fork at Missoula. The basin is drained by Ninemile Creek from the northwest and the Clark Fork from the southeast. The two coalesce and exit the basin to the west at Alberton.

Streamflow data for gaging stations listed in table 69 are stored in the USGS WATSTORE database. Locations of the stations are shown on plate 1.

Table 69. Summary of data for U.S. Geological Survey streamflow-gaging stations in the Missoula Valley, Montana

[Type of data collected: $c$, water chemistry; $d$, discharge; $m$, microbiological; s, suspended sediment. Periods of record for stations that were being operated as on November 1994 are included by the first year of record followed by a dash only. Abbreviations: $\mathrm{ft}^{3} / \mathrm{s}$, cubic feet per second. Symbol: --, no data]

\begin{tabular}{|c|c|c|c|c|c|c|c|c|c|}
\hline \multirow[b]{2}{*}{$\begin{array}{l}\text { Station } \\
\text { number }\end{array}$} & \multirow[b]{2}{*}{ Station name } & \multirow{2}{*}{$\begin{array}{c}\text { Drainage } \\
\text { area } \\
\text { (equare } \\
\text { miles) }\end{array}$} & \multirow{2}{*}{$\begin{array}{l}\text { Type } \\
\text { of } \\
\text { dats } \\
\text { cot- } \\
\text { locted }\end{array}$} & \multirow[b]{2}{*}{$\begin{array}{l}\text { Perlod of record } \\
\text { (callendar year) }\end{array}$} & \multicolumn{5}{|c|}{ Discharge for perlod of record } \\
\hline & & & & & $\begin{array}{c}\text { Mean } \\
\text { annual } \\
\left(t^{3} / s\right)\end{array}$ & $\begin{array}{l}\text { Maxt- } \\
\text { mum } \\
\left(f^{3} / s\right)\end{array}$ & $\begin{array}{c}\text { Date of } \\
\text { maximum }\end{array}$ & $\begin{array}{l}\text { Mint } \\
\text { mum } \\
\left(\mathrm{tt}^{3} / \mathrm{a}\right)\end{array}$ & $\begin{array}{c}\text { Dale of } \\
\text { minimum }\end{array}$ \\
\hline 12340500 & $\begin{array}{l}\text { Clark Fork above } \\
\text { Missoula }\end{array}$ & 5,999 & $\begin{array}{c}\mathrm{d} \\
\mathrm{c}, \mathrm{s}\end{array}$ & $\begin{array}{l}1929- \\
1969-71,1977-83, \\
1986-\end{array}$ & 2,932 & 32,300 & $06-21-75$ & 115 & $10-25-43$ \\
\hline 12341000 & $\begin{array}{l}\text { Rattlesnake Creek at } \\
\text { Missoula }\end{array}$ & 79.7 & d & $\begin{array}{r}1899-1900 \\
1958-67\end{array}$ & 110 & 2,050 & $06-18-1899$ & .10 & $02-24-64$ \\
\hline 12341500 & $\begin{array}{l}\text { Clark Fork at } \\
\text { Missoula }\end{array}$ & 6,084 & d & $1898-1907$ & 3,353 & 36,400 & 06-20-1899 & 455 & $02-17-00$ \\
\hline 12352500 & $\begin{array}{l}\text { Bitterroot River near } \\
\text { Missoula }\end{array}$ & 2,814 & d & $\begin{array}{l}\text { 1898-1901, } \\
1903-04,1989-\end{array}$ & 2,410 & 38,300 & 06-20-1899 & $1_{300}$ & 02-09-94 \\
\hline 12352980 & $\begin{array}{l}\text { Bitterroot River at } \\
\text { Maclay Bridge, } \\
\text { near Missoula }\end{array}$ & 2,850 & c & $1970-73$ & - & - & - & - & - \\
\hline 12353000 & $\begin{array}{l}\text { Clark Fork below } \\
\text { Missoula }\end{array}$ & 9,003 & $\begin{array}{c}\mathrm{d} \\
\mathrm{c}, \mathrm{m}, \mathrm{s}\end{array}$ & $\begin{array}{l}1929- \\
1960-64,1977 .\end{array}$ & 5,323 & 52,800 & $05-23-48$ & 388 & 01-18-33 \\
\hline 12353280 & $\begin{array}{l}\text { Ninemile Creek near } \\
\text { Huson }\end{array}$ & 170 & $c, d$ & $1973-1983$ & 132 & 1,700 & 01-16-74 & 9.4 & $12-23-74$ \\
\hline
\end{tabular}

${ }^{1}$ Lowest daily mean.

The quality of surface water in the Clark Fork below Missoula (gaging station 12353000) was determined on the basis of 101 samples. Analyses indicate that water in the river is a calcium bicarbonate type with an average dissolved-solids concentration of $107 \mathrm{mg} / \mathrm{L}$ (Clark and Dutton, in press).

Several sites affected by mining-related contaminants are located upstream from the Missoula Valley along the Clark Fork and some of its tributaries between Butte and Milltown. Mine tailings from these sources have contributed elevated concentrations of trace metals to the Clark Fork (Lambing, 1991). However, inflow from the Bitterroot and Blackfoot Rivers dilutes these constituents in the Clark Fork below Missoula.

Nutrient loading leads to algae blooms in the Clark Fork during the warm seasons. Recently, phosphorus detergents have been banned and industrial waste-treatment processes have been improved in an attempt to alleviate the problem (Montana Department of Health and Environmental Sciences, 1992).

Ninemile Creek sometimes has elevated concentrations of suspended sediment. Erosion due to road building, dredge mining, and logging have caused increased sedimentation in the creek (Nunnallee and Botz, 1976).

Ground water is an important resource in the Missoula Valley, as the basin-fill aquifer system provides drinking water for nearly all residents. Wells also provide process water for a large paper mill south of Frenchtown, and irrigation water for thousands of acres throughout the basin. Basin fill in the southern part of the valley (above 
Ninemile Creek) probably contains about 8 million acre-ft of water in storage that is available to wells, including about 1.75 million acre- $\mathrm{ft}$ in the upper $200 \mathrm{ft}$ of saturated material (McMurtrey and others, 1965, p. 28-30).

Permeable Quatemary sand-and-gravel deposits underlying the City of Missoula have been designated a Sole-Source Aquifer by the U.S. Environmental Protection Agency. Annually, more than 9.7 billion gallons of water are pumped from the sand-and-gravel aquifer (Woessner, 1988, p. 1). Reported yields from wells completed in this aquifer are as large as $2,300 \mathrm{gal} / \mathrm{min}$, with very little drawdown, as indicated by specific-capacity values as large as $1,500(\mathrm{gal} / \mathrm{min}) / \mathrm{ft}$ (table 70). The largest consumer is Mountain Water Company, whose thirty-two largecapacity municipal-supply wells provide Missoula area residents with up to 46 million gallons of water per day (Sherry Devlin, The Missoulian, July 17, 1991, p. A-1). South of Frenchtown, twelve large-capacity wells supply process water for the production of linerboard (cardboard) (Larry Weeks, Stone Container, oral communication, 1993).

Table 70. Summary of data for yield and specific capacity of wells completed in selected hydrogeologic units in the Missoula Valley, Montana

[Source: Dutton and others, 1995. Hydrogeologic unit: Qa], Holocene and Pleistocene alluvial deposits; Qg, Pleistocene glacial deposits (includes glacial-lakebed deposits); Ts, Tertiary sedimentary deposits and rocks; Yms, Middle Proterozoic metasedimentary rocks.

Abbreviations: gal/min, gallon per minute; (gal/min)/ft, gallon per minute per foot]

\begin{tabular}{|c|c|c|c|c|c|c|c|c|c|c|}
\hline \multirow{2}{*}{$\begin{array}{l}\text { Hydro- } \\
\text { geologic } \\
\text { unit }\end{array}$} & \multirow{2}{*}{$\begin{array}{l}\text { Number } \\
\text { of wells }\end{array}$} & \multicolumn{4}{|c|}{ Yield (gal/min) } & \multirow{2}{*}{$\begin{array}{l}\text { Number } \\
\text { of welle }\end{array}$} & \multicolumn{4}{|c|}{ Speclile capacity [(gal/min)/ft] } \\
\hline & & Mean & Median & $\begin{array}{l}\text { Mint- } \\
\text { mum }\end{array}$ & $\begin{array}{l}\text { Maxi- } \\
\text { mum }\end{array}$ & & Mean & Median & $\begin{array}{l}\text { Mint- } \\
\text { mum }\end{array}$ & $\begin{array}{l}\text { Maxt- } \\
\text { mum }\end{array}$ \\
\hline Qal & 320 & 540 & 94 & 5.0 & 2,300 & 28 & 89 & 9.2 & 0.2 & 1,500 \\
\hline Qg & 5 & 12 & 10 & 2.5 & 25 & 5 & 3.2 & 2.0 & .6 & 6.3 \\
\hline Ts & 13 & 13 & 10 & 1.0 & 40 & 11 & 1.1 & .5 & .1 & 5 \\
\hline$Y_{m s}{ }^{1}$ & 8 & 8.2 & 8.5 & 3.0 & 15.0 & 6 & .4 & .2 & .1 & 1.3 \\
\hline
\end{tabular}

${ }^{1}$ May include wells completed along basin margins, outside the area of basin fill.

Table 71 compares hydraulic characteristics for wells completed in the Missoula Valley from three published reports and two unpublished M.S. theses. Woessner (1988) divided the sand-and-gravel aquifer into Units 1,2, and 3, which roughly correspond to (1) Holocene alluvium, (2) Pleistocene glacial-lakebed deposits, and (3) Pleistocene glaciofluvial and glacial deposits and Pliocene channel deposits described by McMurtrey and others (1965). Unit 4 represents older Tertiary deposits.

Pleistocene glacial-lakebed deposits generally do not yield large quantities of water to wells, because of the poor water-transmitting abilities of the clay and silt that comprise the deposits. Therefore, few wells are completed in glacial-lake deposits. However, in a few places, laterally discontinuous interbeds of permeable material supply a small amount of water to domestic wells.

Wells completed in Tertiary sediments are used for domestic and livestock water (Noble and others, 1982, p. 48); wells completed in bedrock are used for domestic water. Increased residential development on terraces has recently raised concem about limited ground-water supplies from Tertiary deposits (Barclay, 1986). Many residents who rely on ground water from Tertiary deposits or bedrock report inadequate supplies for domestic use. Little is known about the hydraulic characteristics of Tertiary sediments at great depths. However, analysis of aquifer tests of several depth intervals in two deep exploration wells on the northeast side of the basin--a 2,515-ft-deep well near Huson (15N21 W17CCC) and a 2,907-ft-deep well near DeSmet (14N20W24ADB)--gave specific-capacity values from 0.04 to 0.09 (gal/min)/ft, transmissivity values from 0.7 to $20 \mathrm{ft}^{2} / \mathrm{d}$, and storage-coefficient values from 0.0001 to 0.37 . An estimated 50 to 90 per cent of the water from each hole came from the upper 30 to 50 percent of the aquifer (Norbeck, 1980). 
Table 71. Hydraulic characteristics of aquifer units in the Missoula Valley, Montana

[Abbreviations: $\mathrm{ft} / \mathrm{d},\left(\mathrm{ft}^{3} / \mathrm{d}\right) / \mathrm{ft}^{2}$ or feet per day; gal/min, gallon per minute. Symbol: --, no data]

\begin{tabular}{|c|c|c|c|c|c|c|c|}
\hline \multirow{2}{*}{$\begin{array}{c}\text { Aquifer } \\
\text { unit } \\
\text { (Woesener, } \\
\text { 1988) }\end{array}$} & \multirow{2}{*}{ Porosity } & \multirow{2}{*}{$\begin{array}{l}\text { Specific } \\
\text { yleld or } \\
\text { storage } \\
\text { coefficient }\end{array}$} & \multirow{2}{*}{$\begin{array}{l}\text { Thicknese } \\
\text { (feet) }\end{array}$} & \multirow{2}{*}{$\begin{array}{l}\text { Horizontal hydraulic } \\
\text { conductivity (ft/d) }\end{array}$} & \multirow{2}{*}{$\begin{array}{l}\text { Vertical hydraulic } \\
\text { conductivity (fid) }\end{array}$} & \multicolumn{2}{|c|}{$\begin{array}{l}\text { Yield to wells } \\
\text { (gal/min) }\end{array}$} \\
\hline & & & & & & Average & Maximum \\
\hline Unit 1 & ${ }^{2} 0.2$ & 20.12 & $\begin{array}{l}210-30 \\
{ }^{3} 10-35\end{array}$ & ${ }^{2} 1,380$ & - & - & - \\
\hline Unit 2 & -- & - & $\begin{array}{l}240 \\
490\end{array}$ & 227 & - & -- & - \\
\hline Unit 3 & ${ }^{2} 0.20$ & ${ }^{2} 0.10$ & $\begin{array}{l}{ }^{2} 50-150 \\
{ }^{3} 125-140\end{array}$ & $\begin{array}{c}2380-3,417 \\
{ }^{4} 1,550-18,000\end{array}$ & $\begin{array}{r}2130-280 \\
443 ; 2,700\end{array}$ & 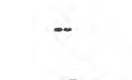 & ${ }^{2} 7000$ \\
\hline Unit 4 & - & - & $\begin{array}{c}2,500-3,500 \\
5,000\end{array}$ & - & - & ${ }^{2} 25$ & $1_{40}$ \\
\hline Bedrock & -- & ${ }^{6} 0.004$ & - & ${ }^{6} 0.11-0.72$ & - & $2_{1}$ & ${ }^{2} 17$ \\
\hline \multicolumn{8}{|c|}{${ }^{1}$ See text for correlation between aquifer units (Woessner, 1988) and geologic units (McMurtrey and others, 1965). } \\
\hline \multicolumn{8}{|c|}{ 'Basod an aquifer tests, permeameter tests, and drillers' logs of wells in and near the City of Missoula (Woessner, 1988, p. 13 and 28). } \\
\hline \multicolumn{8}{|c|}{ 'Based on drillers' logs of wells throughout the basin (McMurtrey and others, 1965, p. 13). } \\
\hline \multicolumn{8}{|c|}{${ }^{4}$ Based on aquifer tests near the southeast odge of the basin (Miller, 1991, p. 44). } \\
\hline \multicolumn{8}{|c|}{${ }^{5}$ Based an gravity profiles of the entire basin (Noble and others, 1982, p. 48). } \\
\hline
\end{tabular}

Potentiometric-surface maps of the Missoula Valley (table 72) indicate that ground water generally flows from the uplands toward the flood plain, then northwestward, paralleling the Clark Fork or southeastward, paralleling Ninemile Creek. Most ground-water movement occurs within about 200 feet of the land surface. Radiocarbon ages of as much as 18,000 years for deeper water indicate that, at depth, ground water is almost stagnant (Konizeski and Alt, 1972).

Table 72. Potentiometric-surface maps of the Missoula Valley, Montana

\begin{tabular}{|c|c|c|c|c|}
\hline Location & $\begin{array}{l}\text { Dates water levels were } \\
\text { measured }\end{array}$ & Scale & $\begin{array}{l}\text { Contour } \\
\text { interval } \\
\text { In feat }\end{array}$ & Reference \\
\hline Entire Missoula Valley & Summer 1991 & $1: 750,000$ & 100 & Briar and others, in press \\
\hline $\begin{array}{l}\text { East and north of the Bitterroot } \\
\text { River }\end{array}$ & $\begin{array}{l}\text { Feb. 1986, July } 1986, \\
\text { and Jan. } 1987\end{array}$ & $1: 79,200$ & 5 & Miller, 1991, p. 31-33 \\
\hline Southeast of Huson & Oct. 1962 & $1: 84,500$ & 20 & McMurtrey and others, 1965, pl. 3 \\
\hline East of the Bitterroot River & Mar., June, and Oct. 1986 & $1: 70,400$ & 5 & Woessner, 1988, p. 63-65 \\
\hline
\end{tabular}

Basin-fill aquifers are recharged by precipitation, leakage from canals, surplus irrigation water, subsurface flow from the Bitterroot Valley and from bedrock, and infiltration from tributary streams and from the Clark Fork above Lavalle Creek (McMurtrey and others, 1965). The ground-water contribution area (fig. 2, pl. 1) is about 600 $\mathrm{mi}^{2}$. Infiltration anywhere within this area could potentially recharge basin-fill aquifers in the Missoula Valley. Because evapotranspiration almost equals precipitation, infiltration from surface water is far more important than direct precipitation in recharging the aquifer (Konizeski and Alt, 1972). Geothermal gradients in two deep (2,338 and 2,700 ft) exploration wells give no evidence of hydrothermal water recharging basin-fill aquifers (Leonard and Wood, 1980). Ground water discharges from basin-fill aquifers by evapotranspiration, withdrawals from wells, and seepage into irrigation drains, the Clark Fork, and the lower reaches of tributary streams.

Water-level data for wells listed in table 73 are stored in the USGS WATSTORE database. Water levels were measured in these wells at least annually. Water-table altitudes in the sand-and-gravel aquifer underlying Missoula have been decreasing since 1983, either because of increased pumping (to substitute for Missoula's other, former 
municipal water source, Rattlesnake Creek, which was found to contain giardiasis bacteria); or decreased flows in the Clark Fork (which recharges the aquifer); or both (Woessner, 1988, p. 57; Miller, 1991, p. 40).

Table 73. Summary of water-level data for selected wells in the Missoula Valley, Montana

[Hydrogeologic unit: Qal, Holocene and Pleistocene alluvial deposits; Ts, Tertiary sedimentary deposits and rocks]

\begin{tabular}{|c|c|c|c|c|c|c|c|}
\hline \multirow[b]{2}{*}{ Locatlon number } & \multirow{2}{*}{$\begin{array}{c}\text { Depth of } \\
\text { well, in feet } \\
\text { below land } \\
\text { surfece }\end{array}$} & \multirow{2}{*}{$\begin{array}{l}\text { Hydro- } \\
\text { geologle } \\
\text { unit }\end{array}$} & \multirow{2}{*}{$\begin{array}{l}\text { Perlod of } \\
\text { record }\end{array}$} & \multicolumn{4}{|c|}{ Water level, in feet below land surface } \\
\hline & & & & Highest & $\begin{array}{l}\text { Date of } \\
\text { hlghest }\end{array}$ & Lowest & $\begin{array}{l}\text { Date of } \\
\text { lowest }\end{array}$ \\
\hline 14N21 W24DBA 01 & 33.4 & Qal & $1958-81$ & 7.48 & $07-30-59$ & 30.24 & $03-01-62$ \\
\hline 14N21 W25ABCCO1 & 23 & Qal & $1971-91$ & 8.22 & $06-08-72$ & 17.19 & $01-20-72$ \\
\hline 14N21W25BCAC01 & 51.0 & Qal & $1971-91$ & 4.32 & $06-08-72$ & 13.80 & 04-10-81 \\
\hline 14N21 W25CADD01 & 30 & Qal & 1971-82 & 5.24 & $06-08-72$ & 14.07 & $04-10-81$ \\
\hline 14N21W25CBA 01 & 152 & Ts & $1971-82$ & 7.51 & 11-04-75 & 24.76 & 04-10-81 \\
\hline 14N21W25CBA 02 & 20 & Ts & 1971-82 & 2.01 & $06-08-72$ & 12.60 & $04-10-81$ \\
\hline 14N21W25CCDA01 & 128.5 & Qal & $1971-82$ & 13.16 & $11-04-75$ & 34.39 & 04-10-81 \\
\hline 13N20W14ACCA01 & 35.5 & Qal & $1959-84$ & 8.08 & $06-20-74$ & 21.14 & $05-01-61$ \\
\hline 13N19W29DADD01 & 84.4 & Qal & $1958-92$ & 37.38 & $06-26-72$ & 55.86 & $09-09-92$ \\
\hline 13N19W30BDA 01 & 122 & Qal & $1959-82$ & 22.21 & 06-10-80 & 31.22 & $\begin{array}{l}07-08-59 \\
02-15-78\end{array}$ \\
\hline
\end{tabular}

Ground-water quality throughout the basin is suitable for domestic, irrigation, and industrial uses, based on McMurtrey and others (1965, p. 31), who sampled water from 21 wells. Results of other studies generally concur. On the basis of 26 samples analyzed for major ions and measured dissolved-solids concentrations and 27 samples in which dissolved-solids concentrations were estimated from specific-conductance measurements, Clark and Dutton (in press) describe ground water as typically a calcium bicarbonate type with dissolved-solids concentrations of less than $250 \mathrm{mg} / \mathrm{L}$ throughout the basin. On the basis of 96 wells sampled in the City of Missoula area in spring 1987. Woessner (1988) concluded that ground water in the sand-and-gravel aquifer is a calcium bicarbonate type. The dissolved-solids concentration ranged from 240 to $358 \mathrm{mg} / \mathrm{L}$ and $\mathrm{pH}$ ranged from 6.8 to 8.5 . Chloride concentrations generally were less than $10 \mathrm{mg} / \mathrm{L}$ and sulfate concentrations generally were less than $30 \mathrm{mg} / \mathrm{L}$. Noble and others (1982) described the ground-water quality in the alluvial deposits as moderately hard, with dissolved-solids concentrations averaging $175 \mathrm{mg} / \mathrm{L}$; by contrast, the dissolved-solids concentration in Tertiary deposits averaged $300 \mathrm{mg} / \mathrm{L}$.

Some land-use practices have impacted the quality of ground water in the basin fill. Nutrients and microorganisms from septic-tank waste, for example, have degraded ground-water quality locally (Ver Hey and Woessner, 1988). Elevated concentrations of chloride in ground water near Missoula storm drains during spring thaws probably result from winter road-salt application (W.W. Woessner, University of Montana, oral commun., 1993). Mining-related contaminants which enter the Clark Fork upstream from the Missoula Valley could potentially degrade ground-water quality where the Clark Fork recharges the basin-fill aquifer near Missoula (W.W. Woessner, University of Montana, oral commun., 1993).

Recognizing the importance of the basin-fill, the City of Missoula established a Water Quality Protection District in accordance with U.S. Environmental Protection Agency guidelines. In addition, the Mountain Water Company has commissioned the development of a draft wellhead protection plan for the 32 municipal wells that serve Missoula.

\section{Selected References}

Barclay, B.A., 1986, A ground-water evaluation of the Ninemile valley in Missoula County, western Montana: Missoula, University of Montana, Senior thesis, $80 \mathrm{p}$.

Bayuk, D.S., 1989, Hydrogeology of the Lower Hayes Creek drainage basin, western Montana: Missoula, University of Montana, M.S. thesis, $230 \mathrm{p}$. 
Boettcher, A.J., and Gosling, A.W., 1977, Water resources of the Clark Fork basin upstream from St. Regis, Montana: Montana Bureau of Mines and Geology Bulletin 104, 28 p.

Briar, D.W., Lawlor, S.M., Stone, M.A.J, Parliman, D.J., Schaefer, J.L., and Kendy, Eloise, in press, Ground-water levels in intermontane basins of the Northern Rocky Mountains, Montana and Idaho: U.S. Geological Survey Hydrologic Investigations Atlas 738-B, 1 sheet, scale 1:750,000.

Brietkrietz, Alex, 1964, Basic water data report no. 1, Missoula Valley, Montana: Montana Bureau of Mines and Geology Bulletin 37,43 p.

Clark, D.W., and Dutton, D.M., in press, Quality of ground water and surface water in intermontane basins of the Northern Rocky Mountains, Montana and Idaho: U.S. Geological Survey Hydrologic Investigations Atlas 738-C, 1 sheet, scale $1: 750,000$.

Clark, K.W., 1986, Interaction between the Clark Fork River and Missoula Aquifer, Missoula County, Montana: Missoula, University of Montana, M.S. thesis, $157 \mathrm{p}$.

Dutton, D.M., Lawlor, S.M., Briar, D.W., and Tresch, R.E., 1995, Hydrogeologic data for the Northern Rocky Mountains intermontane basins, Montana: U.S. Geological Survey Open-File Report 95-143, 94 p.

Eakins, G.R., and Honkala, F.S., 1952, Cenozoic history of Missoula Valley, Missoula County, Montana: Geological Society of America Bulletin, v. 63, no. 12, part 2, 1,361 p.

Fabrick, D.P., 1941, Area analysis--Bitterroot-Missoula area, Montana--Preliminary statement: National Resources Planning Board Report, 104 p.

Fields, R.W., 1981, A summary geologic report on the Missoula/Bitterroot drilling project, Missoula/Bitterroot basins, Montana: U.S. Department of Energy, Bendix Field Engineering Corporation, Open-File Report GJBX-7(81), 49 p.

Geldon, A.L., 1979, Hydrogeology and water resources of the Missoula basin, Montana: Missoula, University of Montana, M.S. thesis, $114 \mathrm{p}$.

Harrison, J.E., Griggs, A.B, and Wells, J.D., 1986, Geologic and structure maps of the Wallace $1^{\circ} \times 2^{\circ}$ quadrangle: U.S. Geological Survey Miscellaneous Investigation Series Map I-1509, 2 sheets, scale 1:250,000.

Hydrometrics, 1984, Evaluation of potential for increased groundwater production from wells for the City of Missoula: Missoula, Mont., unpublished consulting report to Mountain Water Company, 49 p.

Konizeski, R.L., and Alt, David, 1972, The age and circulation of ground water in the Missoula Valley, Montana: Bozeman, Mont., Montana University Joint Water Resources Research Center Report 24, 59 p.

Lambing, J.H., 1991, Water-quality and transport characteristics of suspended sediment and trace elements in streamflow of the upper Clark Fork basin from Galen to Missoula, Montana, 1985-90: U. S. Geological Survey Water-Resources Investigations Report 91 4139, 73 p.

Leonard, R.B., and Wood, W.A., 1980, Geothermal gradients in the Missoula and Bitterroot Valleys, west-central Montana: U.S. Geological Survey Water-Resources Investigations Report 80-89, 15 p.

McCulloch, Robin, 1993, Montana mining directory 1992, Montana Bureau of Mines and Geology Bulletin 131, 76 p.

McMurtrey, R.G., Konizeski, R.L., and Brietkrietz, Alex, 1965, Geology and ground-water resources of the Missoula Basin, Montana: Montana Bureau of Mines and Geology Bulletin 47, 35 p.

Miller, R.D., 1991, A numerical flow model of the Missoula Aquifer--Interpretation of aquifer properties and river interaction: Missoula, University of Montana, M.S. thesis, $275 \mathrm{p}$.

Montana Department of Health and Environmental Sciences, 1992, Montana water quality, 1992: Helena, Water Quality Bureau, Montana 305(b) Report, 42 p.

[Montana] State Engineer's Office, 1960a, Water resources survey, Missoula County, Montana--Part 1, History of land and water use on irrigated areas: Helena, Mont., State Engineer's Office, 53 p. 1960b, Water resources survey, Missoula County, Montana--Part 2, Maps showing irrigated areas: Helena, Mont., State Engineer's Office, 39 p.

National Oceanic and Atmospheric Administration, 1992, Monthly normals of temperature, precipitation, and heating and cooling degree days, 1961-90, Montana: Asheville, N.C., Climatography of the United States no. 81, unpaged.

Nelson, W.H., and Dobell, J.P., 1959, Geologic map and cross sections of the Bonner quadrangle, Montana: U.S. Geological Survey Miscellaneous Geological Investigations Map I-296, scale 1:62,500.

Noble, R.A., Bergantino, R.N., Patton, T.W., Sholes, B.C., Daniel, Faith, and Schofield, Judeykay, 1982, Occurrence and characteristics of ground water of Montana--Volume 2, The Rocky Mountain Region: Montana Bureau of Mines and Geology Open-File Report 99, 132 p.

Norbeck, P.M., 1980, Preliminary evaluation of deep aquifers in the Bitterroot and Missoula Valleys in westem Montana: Montana Bureau of Mines and Geology Open-File Report 46, 15 p. 
Nunnallee, David, and Botz, M.K., 1976, Water quality inventory and management plan, lower Clark Fork River basin, Montana: Montana Department of Health and Environmental Sciences, 129 p.

Pardee, J.T., 1942, Unusual currents in glacial Lake Missoula: Geological Society of America Bulletin, v. 53, p. 1569-1600.

Parrett, Charles, 1981, Potential effects of urbanization on peak flows in Rattlesnake Creek, Missoula County, Montana: U.S. Geological Survey Water-Resources Investigations Report 81-34, 18 p.

Perry, E.S., 1933, Shallow wells as a source of irrigation water in Frenchtown and Camas Prairie Valleys, Montana: Montana Bureau of Mines and Geology Miscellaneous Contributions 5, 8 p.

Perry, W.M., 1989, Migration and degradation of dissolved gasoline in a highly transmissive, unconfined, gravel and cobble aquifer-A study of the Champion Missoula sawmill spill, Missoula, Montana: Missoula, University of Montana, MS thesis, 222 p.

Popoff, M.A., 1985, A case study of the hydrogeology and ground-water contamination of Milltown Valley, Montana: Missoula, University of Montana, M.S. thesis, 166 p.

Pottinger, M.H., 1988, The source, fate and movement of herbicides in an unconfined, sand and gravel aquifer in Missoula, Montana: Missoula, University of Montana, M.S. thesis, 172 p.

Sheriff, S.D., Woessner, W.W., Sartor, L.C., Carlson, G.J., and Popoff, M.A., 1984, Quest for bedrock in Milltown, Montana-Hydrogeologic implications of a geophysical study [abs.] in Abstracts, 13th Annual Rocky Mountain Ground-Water Conference, Great Falls, Montana, April 8-11, 1984: Montana Bureau of Mines and Geology Special Publication 91, p. 10.

Tuck, L.K., Briar, D.W., and Clark, D.W., in press, Geologic history and hydrogeologic units of intermontane basins of the Northern Rocky Mountains, Montana and Idaho: U.S. Geological Survey Hydrologic Investigations Atlas 738-A, 2 sheets, scale $1: 750,000$.

U.S. Geological Survey, issued annually, Water resources data, Montana: Helena, Mont., U.S. Geological Survey Water-Data Report.

1969, Aeromagnetic map of the Plains, Perma, Superior and Tarkio quadrangles, Sanders, Mineral and Missoula Counties, Montana: U.S. Geological Survey Geophysical Investigations Map GP-691, scale 1:62,500.

Vanderpoel, W.I., III, 1978, A reconnaissance of the late Tertiary and Quaternary geology, geomorphology and contemporary surface hydrology of the Rattlesnake Creek: Missoula, University of Montana, M.S. thesis, 85 p.

Ver Hey, M.E., and Woessner, W.W., 1988, Documentation of the degree of waste treatment provided by septic system, vadose zone and aquifer in intermountain soils underlain by sand and gravel, in On-Site Wastewater Treatment, National Symposium on Individual and Small Community Sewage Systems, 5th, Chicago, Ill., 1987, Proceedings: St. Joseph, Mich., American Society of Agricultural Engineers Publication 10-87, p. 77-86.

Wallace, C.A., Lidke, D.J., and Schmidt, R.G., 1990, Faults of the central part of the Lewis and Clark Line and fragmentation of the Late Cretaceous foreland basin in west-central Montana: Geological Society of America Bulletin, v. 102, p. 1,0211,037 .

Wells, J.D., 1974, Geologic map of the Alberton Quadrangle, Missoula, Sanders, and Mineral Counties, Montana: U.S. Geological Survey Geological Quadrangle Map GQ-1157, scale 1:62,500.

Wilke, K.R., 1979, Selected well inventory and chemical analyses of ground water, parts of Missoula and Powell Counties, Montana: U.S.Geological Survey Open-File Report 79-1491, 4 p., 2 tables.

Woessner, W.W., 1988, Missoula Valley Aquifer study--Hydrogeology of the eastern portion of the Missoula Aquifer, Missoula County, Montana: Prepared for the Water Development Bureau, Montana Department of Natural Resources and Conservation, Helena, Mont., Volume 1, 127 p.; Volume 2 (Appendices), 292 p.

Woessner, W.W., and Ver Hey, M.E., 1988, Water quality management options for a coarse alluvial western mountain valley aquifer impacted by septic system wastes, in On-Site Wastewater Treatment, National Symposium on Individual and Small Community Sewage Systems, 5th, Chicago, Ill., 1987, Proceedings: St. Joseph, Mich., American Society of Agricultural Engineers Publication 10-87, p. 87-99.

Wogsland, K.L., 1988, The effect of urban storm water injection by Class V wells on the Missoula Aquifer, Missoula, Montana: Missoula, University of Montana, M.S. thesis, 133 p. 


\section{Plains Valley}

\section{Geography}

The Plains Valley is a northwest-trending intermontane basin in northwestern Montana. The $30-\mathrm{mi}^{2}$ basin is bounded by the Coeur D'Alene Mountains on the southwest and the Cabinet Mountains on the northeast (pl. 1). The Clark Fork of the Columbia River flows northwestward through the basin; the Town of Plains is located on the flood plain along a river meander. Surrounding the flood plain are hummocky terraces which comprise the remainder of the intermontane basin. The Plains Valley ranges in altitude from about $2,500 \mathrm{ft}$ where the Clark Fork leaves the basin, to about $3,400 \mathrm{ft}$ on the highest terrace.

The climate of the Plains Valley is typical of lower-elevation intermontane basins of the Northern Rocky Mountains west of the Continental Divide, with warm summers and cool, humid winters. The National Weather Service does not maintain a weather station in the Plains Valley. The nearest weather

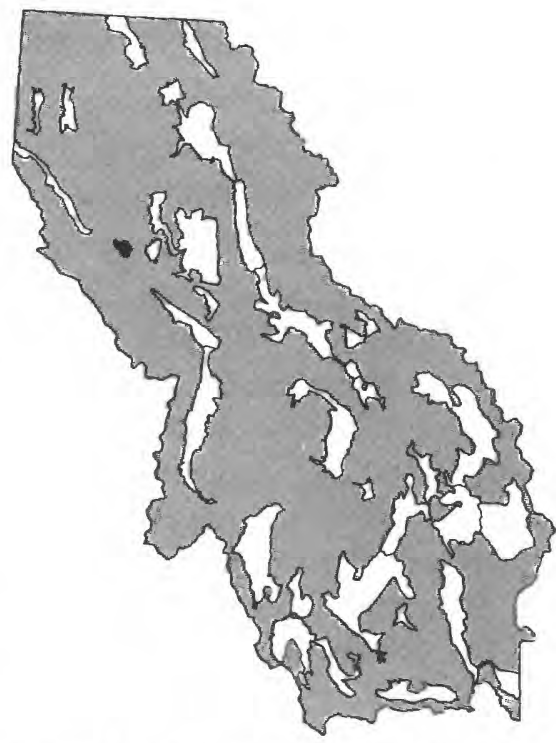
station is in Thompson Falls (altitude 2,440 ft), which is located along the Clark Fork 23 mi northwest of Plains.

Land uses include rangeland; irrigated hay, pasture, and small-grain production; residential development; and some dryland small-grain production. Timber is harvested from the basin and the surrounding mountains (J.C. Eggen, Agricultural Stabilization and Conservation Service, oral commun., 1993). About 2,000 people reside in the Plains Valley, including 992 in the Town of Plains (1990 census). In recent years, the conversion from agricultural land to subdivision developments has increased the density of private wells and septic systems.

\section{Geology}

The Plains Valley is bounded on the east by a thrust fault, and on the south by a right-lateral fault zone (Harrison and others, 1986). Several investigators have examined the geology of the Plains Valley (table 74). The geologic units described by previous investigators are summarized below. These geologic units are referenced to hydrogeologic units defined in this study (table 2) to provide a consistent regional framework. In the following discussion, the hydrogeologic-unit abbreviations are italicized.

Table 74. Geologic and geophysical maps of the Plains Valley, Montana

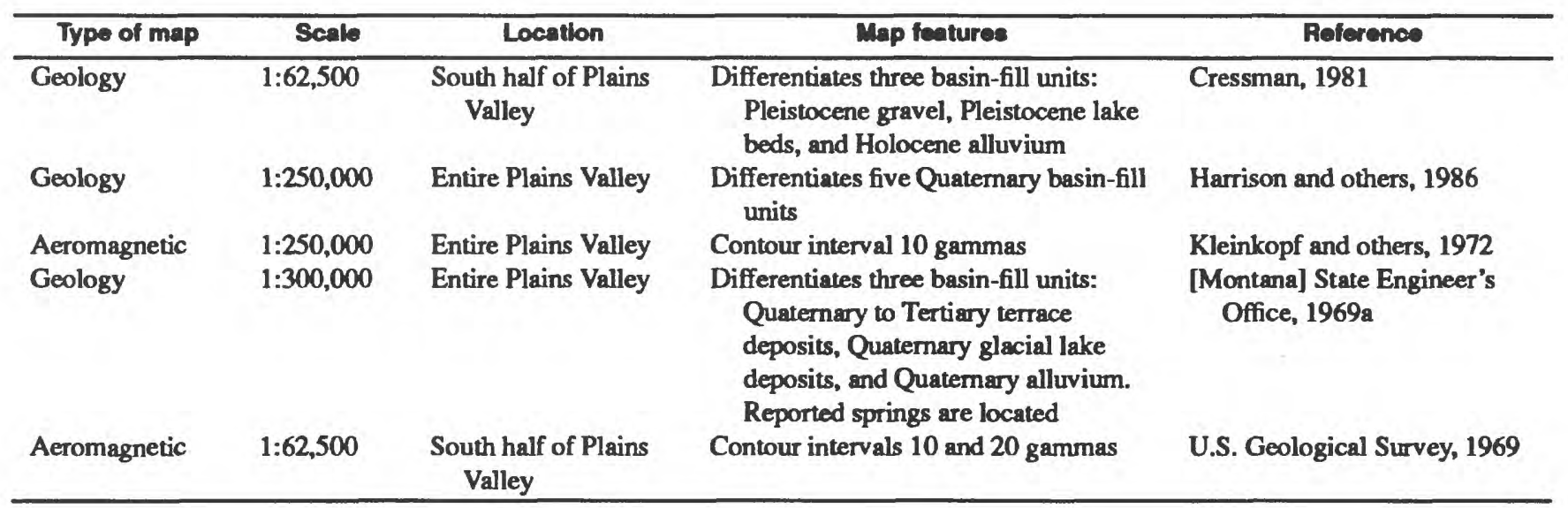


Metasedimentary bedrock, primarily quartzite and argillite of the Middle Proterozoic Belt Supergroup (Yms), surround the basin. Locally, Proterozoic mafic sills and dikes have intruded the metasedimentary rocks.

Tertiary sediments $(T s)$ do not crop out in the Plains Valley. Whereas Tertiary sediments overlie bedrock in most intermontane basins of the Northern Rocky Mountains, there is no evidence of pre-Quaternary deposits in the Plains Valley. Therefore, Quaternary deposits may directly overlie Proterozoic bedrock in this intermontane basin.

Quaternary deposits in the Plains Valley resulted from Pleistocene glaciation, followed by Holocene downcutting and alluvial deposition. Pleistocene glacial till, outwash, lakebed, and flood deposits $(Q g)$, including gravel deposits related to catastrophic emptying of glacial Lake Missoula, underlie terraces in hanging tributary valleys along the Clark Fork. For example, the tributary valley that enters Plains Valley from the northeast at Highway 28, filled with Pleistocene gravel when glacial Lake Missoula flooded, which scoured out bedrock to form Rainbow Lake, depositing gravel, pebbles, and boulders in the drainage below (Alt and Hyndman, 1986, p. 101). The U-shaped tributary valley of Lynch Creek, north of Plains, is underlain by about two hundred feet of glacial till. North of Plains, Pleistocene glacial-lakebed deposits consist of laminated silt with occasional gravel lenses. Holocene alluvium $(\mathrm{Qal}$ ) consisting of laterally discontinuous layers of gravel, sand, silt, and clay underlies the Clark Fork flood plain.

\section{Hydrology}

The Clark Fork is the principal stream in the Plains Valley. Flow in the Clark Fork is partly regulated by Hungry Horse Reservoir and Flathead Lake. Surface-water data recorded at the Clark Fork near Plains (gaging station 12389000 , drainage area $\left.19,958 \mathrm{mi}^{2}\right)(\mathrm{pl} .1$ ), are stored in the USGS WATSTORE database. Daily streamflow measurements have been recorded at this station since 1910. Water temperatures were recorded from 1969 to 1977 . During the period of record, discharge has ranged from a minimum of $3,200 \mathrm{ft}^{3} / \mathrm{s}$ on December 10 , 1940 , to a maximum of $134,000 \mathrm{ft}^{3} / \mathrm{s}$ on June 5,1948 , with a mean annual discharge 0 $19,620 \mathrm{ft}^{3} / \mathrm{s}$.

Ground water is an important resource in the Plains Valley, as wells and springs provide drinking water for all basin residents. However, little is known about the basin-fill aquifer that contains this resource. Most wells in the basin are completed in Quaternary deposits. Holocene alluvium, which in Plains Valley largely consists of reworked glacial deposits, is heterogeneous, but generally is a fairly reliable source of ground water (table 75). In most places, the alluvium is productive, but in some places, it is fine-grained and yields little water to wells. Pleistocene glacial-lakebed deposits are not known to yield water to wells in this basin. Wells completed in interbeds of glacial outwash within Pleistocene glacial deposits $(\mathrm{Qg}$, table 75$)$ are capable of producing sufficient quantities of water for domestic or stock use, but the locations of these beds are difficult to predict prior to drilling. Although the glacial outwash that resulted from the catastrophic draining of glacial Lake Missoula is permeable, most is perched on terraces, and is not sufficiently saturated to be a reliable source of ground water. Likewise, glacial till underlying the tributary valley of Lynch Creek is essentially unsaturated (Montana Bureau of Mines and Geology, unpub. data, 1991).

Table 75. Summary of data for yield and specific capacity of wells completed in selected hydrogeologic units in the Plains Valley, Montana

[Source: Dutton and others, 1995. Hydrogeologic unit: Qal, Holocene and Pleistocene alluvial deposits; Qg. Pleistocene glacial deposits; Yms, Middle Proterozoic metasedimentary rocks. Abbreviations: gal/min, gallon per minute; (gal/min)/fh, gallon per minute per foot]

\begin{tabular}{|c|c|c|c|c|c|c|c|c|c|c|}
\hline \multirow{2}{*}{$\begin{array}{l}\text { Hydro- } \\
\text { geologic } \\
\text { unit }\end{array}$} & \multirow[b]{2}{*}{$\begin{array}{l}\text { Number } \\
\text { of wella }\end{array}$} & \multicolumn{4}{|c|}{ Vield (gal/min) } & \multirow[b]{2}{*}{$\begin{array}{l}\text { Number } \\
\text { of wells }\end{array}$} & \multicolumn{4}{|c|}{ Speciflc capacity [(gal/min)/fi] } \\
\hline & & Mean & Medlan & $\begin{array}{l}\text { Mint- } \\
\text { mum }\end{array}$ & $\begin{array}{l}\text { Maxi- } \\
\text { mum }\end{array}$ & & Mean & Median & $\begin{array}{l}\text { Mini- } \\
\text { mum }\end{array}$ & $\begin{array}{l}\text { Maxi- } \\
\text { mum }\end{array}$ \\
\hline Qal & 6 & 280 & 220 & 10 & 600 & 6 & 26 & 9.7 & 0.3 & 100 \\
\hline Qg & 5 & 18 & 20 & 4.8 & 30 & 5 & 3.3 & 2.5 & .3 & 6.8 \\
\hline $\mathrm{Yms}^{1}$ & 8 & 13 & 8.5 & 1.0 & 30 & 6 & 1.9 & .8 & .1 & 7.0 \\
\hline
\end{tabular}

${ }^{1}$ May include wells completed along besin margins, outside the area of basin fill. 
Fractures in bedrock yield sufficient quantities of water to supply some domestic wells along the margins of the basin and in areas where the overlying glacial deposits are unsaturated (table 75). The Town of Plains obtains municipal-supply water from a series of springs, which probably issue from a bedrock source, southeast of town (Dutton and others, 1995).

Little is known about ground-water flow in the Plains Valley. However, a 1:750,000-scale potentiometricsurface map which includes the Plains Valley (Briar and others, in press) indicates that ground water generally flows from the uplands toward the flood plain, then northwestward, paralleling the Clark Fork.

Basin-fill aquifers are recharged by precipitation and snowmelt, surplus irrigation water, leakage from irrigation canals, subsurface inflow from bedrock, and infiltration from surface water. The ground-water contribution area (fig. 2, pl. 1) is about $220 \mathrm{mi}^{2}$. Infiltration anywhere within this area could potentially recharge basin-fill aquifers in the Plains Valley. Ground water discharges from basin-fill aquifers by evapotranspiration, withdrawals from wells, and seepage to springs, seeps, and stream channels.

The quality of ground water in the basin was determined on the basis of 3 samples analyzed for major ions and measured dissolved-solids concentrations and 14 samples in which dissolved-solids concentrations were estimated from specific-conductance measurements. Ground water is consistently a mixed-cation bicarbonate type throughout the basin. Dissolved-solids concentrations are less than $250 \mathrm{mg} / \mathrm{L}$ (Clark and Dutton, in press).

\section{Selected References}

Alt, David, and Hyndman, D.W., 1986, Roadside Geology of Montana: Missoula, Mont., Mountain Press Publishing Company, $427 \mathrm{p}$.

Briar, D.W., Lawlor, S.M., Stone, M.A.J., Parliman, D.J., Schaefer, J.L., and Kendy, Eloise, in press, Ground-water levels in intermontane basins of the Northern Rocky Mountains, Montana and Idaho: U.S. Geological Survey Hydrologic Investigations Atlas 738-B, 1 sheet, scale 1:750,000.

Clark, D.W., and Dutton, D.M., in press, Quality of ground water and surface water in intermontane basins of the Northern Rocky Mountains, Montana and Idaho: U.S. Geological Survey Hydrologic Investigations Atlas 738-C, 1 sheet, scale 1:750,000.

Cressman, E.R., 1981, Geologic map of parts of the Plains and Perma quadrangles, western Montana: U.S. Geological Survey Open-File Report 81-785, scale 1:62,500.

Dutton, D.M., Lawlor, S.M., Briar, D.W., and Tresch, R.E., 1995, Hydrogeologic data for the Northem Rocky Mountains intermontane basins, Montana: U.S. Geological Survey Open-File Report 95-143, 94 p.

Harrison, J.E., Griggs, A.B, and Wells, J.D., 1986, Geologic and structure maps of the Wallace $1^{\circ} \times 2^{\circ}$ quadrangle. U.S. Geological Survey Miscellaneous Investigation Series Map I-1509, 2 sheets, scale 1:250,000.

Kleinkopf, M.D., Harrison, J.E., and Zartman, R.E., 1972, Aeromagnetic and geologic map of parts of northwestern Montana and northern Idaho: U.S. Geological Survey Geophysical Investigations Map GP-830, scale 1:250,000.

[Montana] State Engineer's Office, 1969a, Water resources survey, Mineral and Sanders Counties, Montana--Part 1, History of land and water use on irrigated areas: Helena, Mont., State Engineer's Office, 62 p.

$1969 \mathrm{~b}$, Water resources survey, Mineral and Sanders Counties, Montana--Part 2, Maps showing irrigated areas in colors designating the sources of supply: Helena, Mont., State Engineer's Office, $36 \mathbf{p}$.

National Oceanic and Atmospheric Administration, 1992, Monthly normals of temperature, precipitation, and heating and cooling degree days, 1961-90, Montana: Asheville, N.C., Climatography of the United States no. 81, unpaged.

Tuck, L.K., Briar, D.W., and Clark, D.W., in press, Geologic history and hydrogeologic units of intermontane basins of the Northem Rocky Mountains, Montana and Idaho: U.S. Geological Survey Hydrologic Investigations Atlas 738-A, 2 sheets, scale 1:750,000.

U.S. Geological Survey, issued annually, Water resources data, Montana: Helena, Mont., U.S. Geological Survey Water-Data Report.

1969, Aeromagnetic map of the Plains, Perma, Superior and Tarkio Quadrangles, Sanders, Mineral and Missoula Counties, Montana: U.S. Geological Survey Geophysical Investigations Map GP-691, scale 1:62,500. 
The Red Rock Valley is a north-northwest-trending intermontane basin in southwestern Montana. The $160-\mathrm{mi}^{2}$ basin is bounded by the Tendoy Mountains on the west, Clark Canyon Reservoir on the north, and a series of hills and mountains on the east and south (pl. 1). The Red Rock Valley averages about $5 \mathrm{mi}$ wide, with an average altitude of about $5,700 \mathrm{ft}$ (Scholten and others, 1955). The topography of the basin is characterized by the approximately 1-mi-wide flood plain of the Red Rock River which is bounded by large alluvial fans sloping off the adjacent highlands. The Tendoy Mountain front along the western edge of the valley is steep and strikingly linear, with several deeply incised drainages that cross the front into the basin (Johnson, 1981a, 1981b). The eastern basin margin is less distinct. Sage Creek heads in the hills east of the Red Rock Valley and enters the main part of the basin near Dell. Cottonwoods and willows line the stream banks of the Red Rock River and its major tribu-

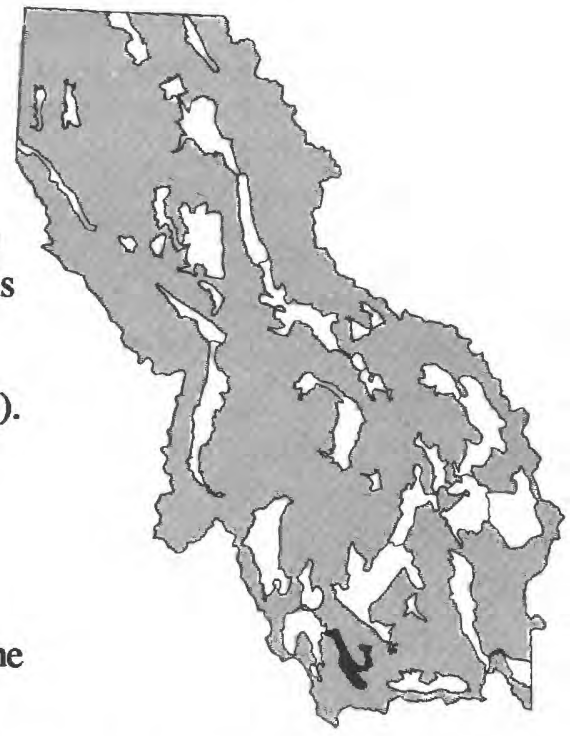
taries; otherwise, the basin is mostly grass and sage-covered rangeland. The Red Rock Valley ranges in altitude from about 5,500 ft where the Red Rock River flows out of the basin, to about 7,200 ft on the highest alluvial fan.

The climate of the Red Rock Valley is typical of high-elevation intermontane basins of southwestem Montana, with cold winters and mild summers. On the basis of the 1961-90 period of record, the average annual precipitation at Lima (altitude $6,270 \mathrm{ft}$ ) is $12.19 \mathrm{in}$., and the average annual temperature is $39.3^{\circ} \mathrm{F}$ (National Oceanic and Atmospheric Administration, 1992). The average last occurrence of $32^{\circ} \mathrm{F}$ is June 26 and the average first occurrence is August 29 (Natural Resources Conservation Service, U.S. Department of Agriculture, unpub. data, 1994). Figure 25 shows mean monthly climatic data for Lima.
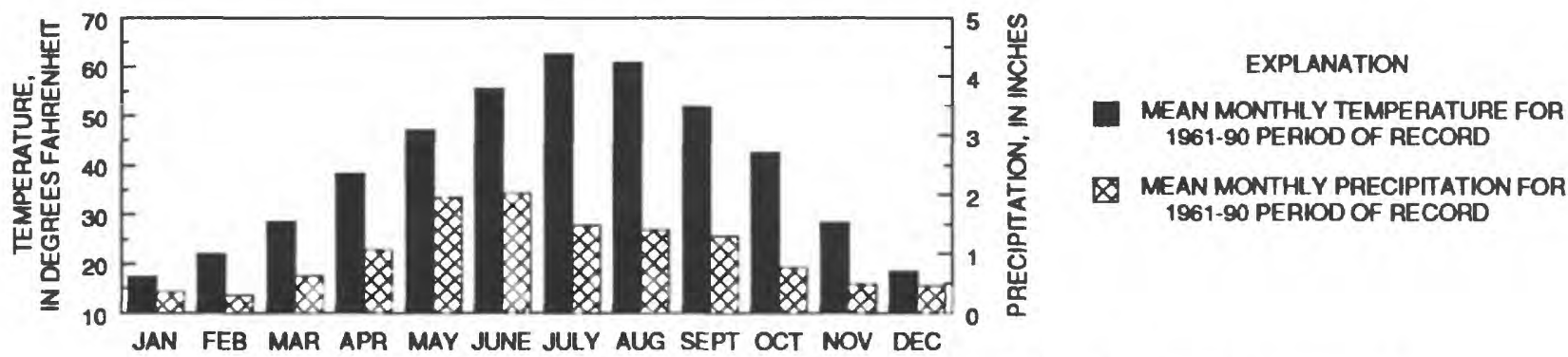

Figure 25. Mean monthly precipitation and temperature at Lima, Mont. Data from National Oceanic and Atmospheric Administration (1992).

Ranching is the principal livelihood in the Red Rock Valley and the area primarily is used for livestock grazing and irrigated hay. Gold and other minerals historically were mined in the mountains surrounding the basin (J.C. Eggen, Agricultural Stabilization and Conservation Service, oral commun., 1993). Currently, exploration for gold and copper is ongoing in the Sage Creek drainage basin (McCulloch, 1993, p. 47). About 500 people reside in the Red Rock Valley, including 265 people in the Town of Lima (1990 census).

\section{Geology}

The Red Rock Valley formed as the bedrock floor of the basin dropped down along several normal faults along the eastern front of the Tendoy Range. Scarps along this fault zone offset modern alluvial fans, indicating Tertiary through Holocene movement (Johnson, 1981a, 1981b; Haller and others, 1993). Vertical displacement along the 
zone is at least $500 \mathrm{ft}$ (Scholten and others, 1955), and probably as much as 3,000 ft (Pardee, 1950, p. 377; Johnson, 1981a, 1981b). Subsidence has also occurred along a series of faults on the northeastem side of the basin (Johnson, 1981a, 1981b; Scholten and others, 1955).

Several investigators have examined the geology of the Red Rock Valley (table 76). The geologic units described by previous investigators are summarized below. These geologic units are referenced to hydrogeologic units defined in this study (table 2) to provide a consistent regional framework. In the following discussion, the hydrogeologic-unit abbreviations are italicized.

Table 76. Geologic and geophysical maps of the Red Rock Valley, Montana

\begin{tabular}{|c|c|c|c|c|}
\hline Type of map & Scale & Location & Map features & Reference \\
\hline Geology & $1: 328,000$ & $\begin{array}{l}\text { Entire Red Rock } \\
\text { Valley }\end{array}$ & $\begin{array}{l}\text { Emphasis on Beaverhead Group. All basin fill } \\
\text { grouped as undifferentiated Tertiary deposits } \\
\text { and Quaternary alluvium }\end{array}$ & $\begin{array}{l}\text { Haley and Perry, } 1991 \text {, } \\
\text { fig. 1., p. } 2\end{array}$ \\
\hline Geology & $1: 63,360$ & $\begin{array}{l}\text { Southwestern part } \\
\text { of Red Rock } \\
\text { Valley }\end{array}$ & $\begin{array}{l}\text { Emphasis on basin-marginal fault. All basin fill } \\
\text { grouped as Tertiary basin sediments and } \\
\text { Holocene alluvium }\end{array}$ & Johnson, 1981a, pl. 2 \\
\hline Residual gravity & $1: 200,000$ & $\begin{array}{l}\text { Entire Red Rock } \\
\text { Valley }\end{array}$ & $\begin{array}{l}\text { Contour interval } 1 \text { milligals. Delineates anomaly } \\
\text { resulting from Red Rock Valley. Created by } \\
\text { subtracting Bouguer gravity data (Johnson, } \\
\text { 1981a, plate 1) from inferred regional } \\
\text { (statewide) Bouguer anomaly }\end{array}$ & $\begin{array}{l}\text { Johnson, } 1981 \mathrm{a}, \text { fig. } 6 \text {, } \\
\text { p. } 24\end{array}$ \\
\hline Geology & $1: 126,720$ & $\begin{array}{l}\text { Southwestern part } \\
\text { of Red Rock } \\
\text { Valley }\end{array}$ & $\begin{array}{l}\text { Emphasis on basin-marginal fault. All basin fill } \\
\text { grouped as Tertiary basin sediments and } \\
\text { Holocene alluvium }\end{array}$ & $\begin{array}{l}\text { Johnson, } 1981 \text { b, pl. } 1 \text {, } \\
\text { p. } 246\end{array}$ \\
\hline Geology & $1: 253,440$ & $\begin{array}{l}\text { Entire Red Rock } \\
\text { Valley }\end{array}$ & $\begin{array}{l}\text { Emphasis on Beaverhead Group. All basin fill } \\
\text { grouped as undifferentiated Tertiary deposits } \\
\text { and Quaternary alluvium }\end{array}$ & $\begin{array}{l}\text { Ryder and Scholten, } \\
1973\end{array}$ \\
\hline Geology & $1: 126,720$ & $\begin{array}{l}\text { Entire Red Rock } \\
\text { Valley }\end{array}$ & $\begin{array}{l}\text { Differentiates } 9 \text { Tertiary and } 5 \text { Quaternary basin- } \\
\text { fill units }\end{array}$ & $\begin{array}{l}\text { Scholten and others, } \\
\text { 1955, pl. } 1\end{array}$ \\
\hline
\end{tabular}

Pre-Tertiary bedrock is exposed in the eastem headwaters area of Sage Creek and along the western and northwestern basin boundaries. The Sage Creek area, and probably most of the rest of the Red Rock Valley, is floored with Precambrian metamorphic rocks $(K A m)$, primarily orthogneiss and schist (Scholten and others, 1955). Along the northwestem basin margin, Mississippian limestone ( $\left.P_{2} l s\right)$ forms prominent cliffs. The Mississippian rocks include $700 \mathrm{ft}$ to more than $1,700 \mathrm{ft}$ of dark-gray to bluish-gray, fine-grained, thin-bedded to massive limestone with large solution cavities near the top. Locally, the limestone contains chert layers and nodules, limestone breccia, and some calcareous shale (Scholten and others, 1955).

The Beaverhead Group (Ts) of probable Late Cretaceous to early Tertiary age borders the Red Rock Valley on the east, south, and southwest, and probably overlies bedrock in much of the basin as well. Outcrops appear mostly as rolling hills and some cliffs. This group consists of as much as 15,000 ft (Ryder and Scholten, 1973) of reddish, poorly consolidated, poorly sorted, well-rounded, poorly bedded to well-bedded, pebble and boulder conglomerate with boulders up to $12 \mathrm{ft}$ in diameter in a sparse, sandy, silty matrix. Clasts within the conglomerate are mostly quartzite and limestone, but locally include chert pebbles. The Beaverhead Group also includes lesser amounts of sandstone and fresh-water limestone. The Beaverhead Group is thought to unconformably overlie Cretaceous shales (Mzsh), which are not exposed locally (Scholten and others, 1955; Ryder and Scholten, 1973; Haley and Perry, 1991).

Tertiary basin fill (Ts) represents deposition of sediments derived mostly from local sources. More than 2,400 ft of poorly exposed Eocene and Oligocene sediments probably underlie Miocene sediments within the Red Rock 
Valley. The Cook Ranch Formation of Oligocene age crops out alongside flood-plain alluvium in the Sage Creek Valley and consists of $125 \mathrm{ft}$ to more than $1,000 \mathrm{ft}$ of mostly white and light-gray clay and tuff, with some sandstone and conglomerate, grading northward into tuff and acidic breccia. The Blacktail Deer Creek Formation of Miocene age crops out northeast of Lima. It consists of more than $2,000 \mathrm{ft}$ of light-gray and tan, poorly sorted, thin- to medium-bedded clay, feldspathic sandstone, fine-grained conglomerate, tuff, travertine limestone, limestone breccia, chert, and some lignite, interbedded with basalt flows. The formation outcrops primarily where limestone or volcanic rocks (QTKe) support cliffs and hills (Scholten and others, 1955).

Quaternary deposits include terrace gravels and alluvial fans (QTd) along the west side of the basin and alluvial deposits (Qal) along flood plains. The alluvial-fan material mainly consists of well-sorted, well-rounded pebbles. Younger, smaller alluvial fans are being deposited above the older fans (Scholten and others, 1955; Johnson, 1981a, 1981b).

\section{Hydrology}

The Red Rock River originates near the Continental Divide east of the Centennial Valley, enters the Red Rock Valley near Lima, and flows north-northwestward toward Clark Canyon Reservoir. Sage Creek and Big Sheep Creek are major tributaries to the Red Rock River from the east and west, respectively. The confluence of the Red Rock River and Horse Prairie Creek at Clark Canyon Reservoir marks the headwaters of the Beaverhead River (pl. 1). Flow in the Red Rock River has been regulated by Lima Reservoir in the Centennial Valley since 1902. Canals divert water from major tributaries to hay fields on the Red Rock River flood plain.

Streamflow data for gaging stations listed in table 77 are stored in the USGS WATSTORE database. Locations of these stations are shown on plate 1. In addition, USGS has published monthend volume records for Clark Canyon Reservoir (gaging station 06015300 , drainage area 2,321 $\mathrm{mi}^{2}$ ) and Lima Reservoir (gaging station 06012000 , drainage area $570 \mathrm{mi}^{2}$ ) since 1964 and 1940, respectively. Data for years prior to 1961 are published in Water-Supply Papers; more recent data are in annual Water-Data Reports (U.S. Geological Survey, issued annually).

Little is known about the quality of surface water in the Red Rock Valley. However, one water sample collected from the Red Rock River near Dell in September 1972 was a calcium bicarbonate type with moderate sulfate, sodium, magnesium, and chloride concentrations classified as very hard (Braico and Botz, 1975). Periodic turbidity measurements along the Red Rock River in 1972-73 indicate that turbidity increased significantly during low flow (Braico and Botz, 1975).

Ground water is not as extensively developed in the Red Rock Valley as in other basins. However, a few domestic and livestock wells are completed in Quaternary and Tertiary basin fill. Sixteen wells completed in Quaternary and Tertiary basin fill have measured or reported yields ranging from 6 to $60 \mathrm{gal} / \mathrm{min}$ (Dutton and others, 1995). Drillers' logs indicate that wells on alluvial fans range in depth from about 80 to $800 \mathrm{ft}$, whereas most wells on the Red Rock River flood plain are less than $\mathbf{4 0} \mathrm{ft}$ deep (Montana Bureau of Mines and Geology, unpub. data, 1994). Specific-capacity values for 15 wells in the Red Rock Valley range from 0.3 to 13 (gal/min)/ft, reflecting the heterogeneity of basin-fill deposits (Dutton and others, 1995).

At least two wells (11S10W34CCAC01 and 10S10W29DCCC01) are completed in Mississippian limestone near the westem basin margin. Well yields from limestone depend upon the degree of secondary permeability that forms as a result of faulting, fracturing, and dissolution. Although the reported yields for these 2 wells are only 10 and $15 \mathrm{gal} / \mathrm{min}$, the specific capacity for one well is 5.0 ( $\mathrm{gal} / \mathrm{min}) / \mathrm{ft}$ (Dutton and others, 1995). The other well reportedly was bailed for 3 hours at $15 \mathrm{gal} / \mathrm{min}$ with no drawdown, suggesting the limestone is very permeable (Levings, 1985, p. 3).

Little is known about ground-water flow in the Red Rock Valley. However, a 1:750,000-scale potentiometricsurface map which includes the Red Rock Valley (Briar and others, in press) indicates that ground water generally flows from the uplands toward the flood plain, then north-northwest, paralleling the Red Rock River. 
Table 77. Summary of data for U.S. Geological Survey streamflow-gaging stations in the Red Rock Valley, Montana [Type of data collected: d, discharge; s, suspended sediment. Periods of record for stations that were being operated as on November 1994 are indicated by the first year of record followed by a dash only. Abbreviations: $\mathrm{ft}^{3} / \mathrm{s}$, cubic feet per second. Symbol: --, no data]

\begin{tabular}{|c|c|c|c|c|c|c|c|c|c|}
\hline \multirow[b]{2}{*}{$\begin{array}{l}\text { Station } \\
\text { number }\end{array}$} & \multirow[b]{2}{*}{ Station name } & \multirow{2}{*}{$\begin{array}{l}\text { Drainage } \\
\text { area } \\
\text { (square } \\
\text { mlles) }\end{array}$} & \multirow{2}{*}{$\begin{array}{l}\text { Type } \\
\text { of data } \\
\text { col- } \\
\text { lected }\end{array}$} & \multirow[b]{2}{*}{$\begin{array}{l}\text { Period of record } \\
\text { (calondar year) }\end{array}$} & \multicolumn{5}{|c|}{ Discharge for perlod of record } \\
\hline & & & & & $\begin{array}{l}\text { Mean } \\
\text { annual } \\
\left(\mathrm{H}^{3} / \mathrm{s}\right)\end{array}$ & $\begin{array}{l}\text { Maxt } \\
\text { mum } \\
\left(\mathrm{tt}^{3} / \mathrm{s}\right)\end{array}$ & $\begin{array}{c}\text { Date of } \\
\text { maximum }\end{array}$ & $\begin{array}{l}\text { Mint- } \\
\text { mum } \\
\left(\mathrm{ft}^{3} / \mathrm{s}\right)\end{array}$ & $\begin{array}{l}\text { Date of } \\
\text { minimum }\end{array}$ \\
\hline 06012500 & $\begin{array}{l}\text { Red Rock River below } \\
\text { Lima Reservoir, } \\
\text { near Monida }\end{array}$ & 570 & d & $\begin{array}{l}\text { 1911-18, } 1919, \\
1925-69,1974-82, \\
1985-\end{array}$ & 143 & 2,500 & $05-15-33$ & ${ }^{1} 0$ & Many days \\
\hline 06013000 & $\begin{array}{l}\text { Red Rock River at } \\
\text { Lima }\end{array}$ & 602 & d & $1907-11$ & 170.7 & 936 & $04-11-10$ & 14 & $\begin{array}{c}\text { At times } \\
\text { during } \\
01-11 \text { and } \\
03-11\end{array}$ \\
\hline 06013500 & $\begin{array}{l}\text { Big Sheep Creek } \\
\text { below Muddy } \\
\text { Creek, near Dell }\end{array}$ & 278 & d & $\begin{array}{l}1936,1946-53 \\
1961-76,1976-79 \\
1977-79\end{array}$ & 65.0 & 909 & $04-18-52$ & 26 & $05-11-36$ \\
\hline 06014000 & $\begin{array}{l}\text { Red Rock River near } \\
\text { Dell }\end{array}$ & 1,421 & d & $\begin{array}{l}1942-67 \text { (no winter } \\
\text { records) }\end{array}$ & - & 1,480 & $06-09-44$ & 0 & $05-16-61$ \\
\hline 06014500 & $\begin{array}{l}\text { Red Rock River at } \\
\text { Red Rock }\end{array}$ & 1,548 & d & $\begin{array}{l}1890,1950-52 \\
1974-83\end{array}$ & 238 & 1,130 & $05-16-75$ & 4.0 & $05-24-51$ \\
\hline
\end{tabular}

${ }^{1_{\text {Loweat daily mean. }}}$

Basin-fill aquifers are recharged by precipitation and snowmelt, surplus irrigation water, leakage of water from irrigation canals, subsurface flow from bedrock, and infiltration from tributary streams and the Red Rock River. The ground-water contribution area for the basin, (fig. 2, pl. 1) is about $1,000 \mathrm{mi}^{2}$. Infiltration anywhere within this area potentially could recharge basin-fill aquifers in the Red Rock Valley. Ground water discharges from basin-fill aquifers by evapotranspiration, subsurface flow to the Clark Canyon Reservoir, withdrawals from wells, and seepage to springs, seeps, and stream channels.

The quality of ground water in the basin was determined on the basis of nine samples analyzed for major ions and measured dissolved-solids concentrations and three samples in which dissolved-solids concentrations were estimated from specific-conductance measurements. Ground water primarily is a calcium bicarbonate type with dissolved-solids concentrations ranging from about 250 to $500 \mathrm{mg} / \mathrm{L}$ throughout the basin (Clark and Dutton, in press).

\section{Selected References}

Braico, R.D., and Botz, M.K., 1975, Water quality inventory and management plan, upper Missouri tributaries basin, Montana: Helena, Mont, Montana Department of Health and Environmental Sciences, 167 p.

Briar, D.W., Lawlor, S.M., Stone, M.A.J., Parliman, D.J., Schaefer, J.L., and Kendy, Eloise, in press, Ground-water levels in intermontane basins of the Northern Rocky Mountains, Montana and Idaho: U.S. Geological Survey Hydrologic Investigations Atlas 738-B, 1 sheet, scale 1:750,000.

Clark, D.W., and Dutton, D.M., in press, Quality of ground water and surface water in intermontane basins of the Northern Rocky Mountains, Montana and Idaho: U.S. Geological Survey Hydrologic Investigations Atlas 738-C, 1 sheet, scale 1:750,000.

Dutton, D.M., Lawlor, S.M., Briar, D.W., and Tresch, R.E., 1995, Hydrogeologic data for the Northern Rocky Mountains intermontane basins, Montana: U.S. Geological Survey Open-File Report 95-143, 94 p.

Haley, J.C., and Perry, WJ., Jr., 1991, The Red Butte Conglomerate--A thrust-belt-derived conglomerate of the Beaverhead Group, southwestern Montana: U.S. Geological Survey Bulletin 1945, 19 p. 
Haller, K.M., Dart, R.L., and Stickney, M.C., 1993, A compilation of major active faults for parts of Montana and Idaho [abs.]: Geological Society of America Abstracts with Programs, v. 25, no. 5, p. 46.

Johnson, P.P., 1981a, Geology of the Red Rock fault and adjacent Red Rock Valley, Beaverhead County, Montana: Missoula, University of Montana, M.S. thesis, 88 p.

$1981 \mathrm{~b}$, Geology along the Red Rock fault and adjacent Red Rock Basin, Beaverhead County, Montana, in Montana Geological Society Field Conference and Symposium Guidebook to Southwest Montana: [Billings, Mont.], Montana Geological Society, p. 245-251.

Klepper, M.R., 1950, A geologic reconnaissance of parts of Beaverhead and Madison Counties, Montana: U.S. Geological Survey Bulletin 969-C, p. 54-85.

Levings, J.F., 1985, Hydrogeologic data related to the potential for stock-water development on federally owned rangeland near Dillon, Montana: U.S. Geological Survey Open-File Report 85-170, 22 p.

McCulloch, Robin, 1993, Montana mining directory 1992: Montana Bureau of Mines and Geology Bulletin 131, 76 p.

National Oceanic and Atmospheric Administration, 1992, Monthly normals of temperature, precipitation, and heating and cooling degree days, 1961-90, Montana: Asheville, N.C., Climatography of the United States no. 81, unpaged.

Pardee, J.T., 1950, Late Cenozoic block-faulting in western Montana: Geological Society of America Bulletin, v. 61, p. 359406.

Ryder, R.T., and Scholten, Robert, 1973, Syntectonic conglomerates in southwestern Montana--Their nature, origin, and tectonic significance: Geological Society of America Bulletin, v. 84, p. 773-796.

Scholten, Robert, Keenmon, K.A., and Kupsch, W.O., 1955, Geology of the Lima region, southwestern Montana and adjacent Idaho: Bulletin of the Geological Society of America, v. 66, p. 345-404.

Tuck, L.K., Briar, D.W., and Clark, D.W., in press, Geologic history and hydrogeologic units of intermontane basins of the Northern Rocky Mountains, Montana and Idaho: U.S. Geological Survey Hydrologic Investigations Atlas 738-A, 2 sheets, scale 1:750,000.

U.S. Geological Survey, issued annually, Water resources data, Montana: Helena, Mont., U.S. Geoogical Survey Water-Data Report. 


\section{Swan Valley}

\section{Geography}

The Swan Valley is an approximately 40 -mi-long, north-northwesttrending intermontane basin averaging about $6 \mathrm{mi}$ in width, with a total area of about $240 \mathrm{mi}^{2}$. It is bounded by the Mission Range on the west, Swan Lake on the north, and the Swan Range on the east (pl. 1). The subtle topographic divide between the Swan and the Clearwater River drainages forms the southem basin boundary. The Swan River flows from south to north through the U-shaped Swan Valley into Swan Lake. The flood plain of the river is not deeply incised into the basin fill. The glaciated edges of the basin slope gently downward toward the hummocky, poorly drained valley floor, which is dotted with lakes, ponds, and wetlands. The Swan Valley ranges in altitude from about 3,190 ft at Swan Lake, to about 5,500 ft in the glaciated mountain foothills.

The climate of the Swan Valley is typical of mid-elevation intermontane basins of the Northern Rocky Mountains west of the Continental Divide,

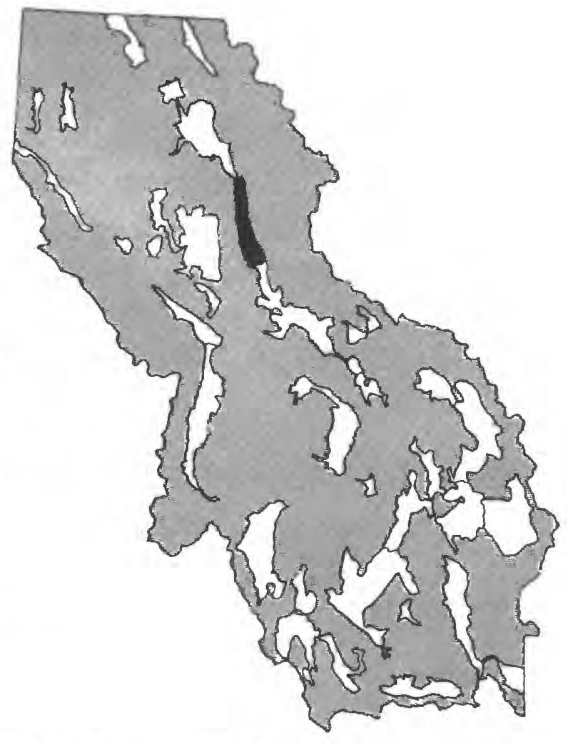
with mild summers and cold, humid winters. On the basis of the 1961-90 period of record, the average annual precipitation at Swan Lake (altitude 3,190 ft) is 28.43 in. and the average annual temperature is $42^{\circ} \mathrm{F}$ (National Oceanic and Atmospheric Administration, 1992). The average last occurrence of $32^{\circ} \mathrm{F}$ is June 18 and the average first occurrence is August 31 (Natural Resources Conservation Service, U.S. Department of Agriculture, unpub. data, 1994). Mean monthly climatic data for Swan Lake are plotted in figure 26.

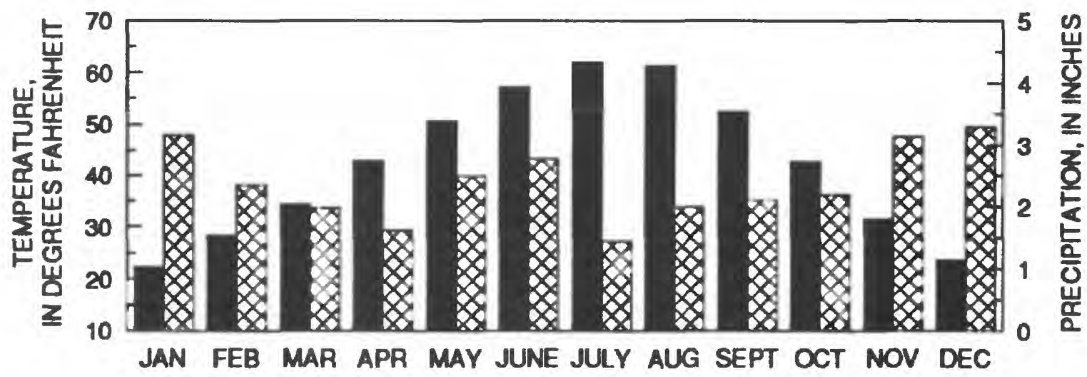

EXPLANATION

MEAN MONTHLY TEMPERATURE FOR 1861-90 PERIOD OF RECORD

区 1961-90 PERIOD OF RECORD

Flgure 26. Mean monthly precipitation and temperature at Swan Lake, Mont. Data from National Oceanic and Atmospheric Administration (1992).

Land uses in the Swan Valley include timber harvesting and limited livestock grazing, irrigated hay and pasture farming, and residential development. About 800 people reside in the Swan Valley, including 81 in the unincorporated community of Condon, and 60 in the unincorporated community of Swan Lake (1990 census). Vacation homes for summer and winter recreation are common. Residential development, while not yet a major land use, has increased significantly in recent years (J.C. Eggen, Agricultural Stabilization and Conservation Service, oral commun., 1993). Diversions from tributaries to Swan Lake irrigate about 200 acres ([Montana] State Engineer's Office, 1963a). The valley floor, which was once heavily forested, is now a patchwork of forested and cleared parcels.

\section{Geology}

The Swan Valley occupies the southem tip of the eastern extension of the Rocky Mountain Trench, a zone of closely-spaced normal faults (fig. 4). The crustal block underlying the Swan Valley downdropped at least 13,000 ft along a fault on the eastern basin margin, (Crosby, 1984). Lesser downthrow movement has occurred along the west 
side of the basin. The thickness of sediments filling the basin averages about $5,000 \mathrm{ft}$; the maximum thickness is 6,500 to 6,800 ft near Salmon Prairie (Noble and others, 1982, p. 39-40; Crosby, 1984). The structural basin is continuous with that of the Clearwater River Valley (a part of the Blackfoot Valley described in this report), although a drainage divide separates the two hydraulically.

Several investigators have examined the geology of the Swan Valley. Witkind and Weber (1982) list the USGS Open-File Reports of 1:24,000-scale geologic quadrangle maps of the area. Other geologic and geophysical maps are listed in table 78. The geologic units described by previous investigators are summarized below. These geologic units are referenced to hydrogeologic units defined in this study (table 2 ) to provide a consistent regional framework. In the following discussion, the hydrogeologic-unit abbreviations are italicized.

Table 78. Geologic and geophysical maps of the Swan Valley, Montana

\begin{tabular}{|c|c|c|c|c|}
\hline Type of map & Scale & Location & Map features & Reference \\
\hline Bouguer gravity & $1: 360,000$ & $\begin{array}{l}\text { Entire Swan } \\
\text { Valley }\end{array}$ & Contour interval 1 milligal & Crosby, 1984, pl. 1 \\
\hline Geology & $1: 126,720$ & $\begin{array}{l}\text { Northern part of } \\
\text { Swan Valley }\end{array}$ & $\begin{array}{l}\text { Differentiates two basin-fill units: glacial } \\
\text { moraine and alluvium }\end{array}$ & Johns, $1970, \mathrm{pl} .3$ \\
\hline $\begin{array}{l}\text { Aeromagnetic and } \\
\text { simplified bedrock } \\
\text { geology }\end{array}$ & $1: 250,000$ & $\begin{array}{c}\text { Entire Swan } \\
\text { Valley }\end{array}$ & Contour interval 20 gammas & $\begin{array}{l}\text { Kleinkopf and Mudge, } \\
\text { 1972, pl. } 1\end{array}$ \\
\hline Geology & $1: 250,000$ & $\begin{array}{c}\text { Entire Swan } \\
\text { Valley }\end{array}$ & $\begin{array}{l}\text { All basin fill is mapped as undifferentiated } \\
\text { Quatemary glacial deposits. Includes an } \\
\text { east-west geologic section }\end{array}$ & Mudge and others, 1982 \\
\hline $\begin{array}{l}\text { Cenozoic basin-fill } \\
\text { thickness }\end{array}$ & $1: 500,000$ & $\begin{array}{l}\text { Entire Swan } \\
\text { Valley }\end{array}$ & Contour interval 1,000 feet & $\begin{array}{l}\text { Noble and others, } 1982 \text {, } \\
\text { fig. II-10, p. } 40\end{array}$ \\
\hline
\end{tabular}

Metasedimentary rocks of the Middle Proterozoic Belt Supergroup (Yms) surround the basin. These rocks primarily consist of argillite, siltite, and quartzite to the northeast and southwest of the basin, and limestone and dolomite to the northwest and southeast (Mudge and others, 1982).

Although no Tertiary sediments (Ts) are exposed in the Swan Valley, this basin, like others in the Rocky Mountain Trench, probably contains thousands of feet of Tertiary sediments beneath its glacial and alluvial veneer (Crosby, 1984; Noble and others, 1982, p. 39-40). However, no wells are known to penetrate Tertiary sediments in this basin.

Quaternary deposits in the Swan Valley include glacial till $(Q g)$, glacial outwash (Qal), and flood-plain alluvium (Qal). The thickness of Quaternary deposits is unknown. The deepest well in the basin, located east of Condon, near the eastem basin margin (20N16W04D), penetrates glacial deposits throughout its entire 425-ft depth (Montana Bureau of Mines and Geology, unpub. data, 1991). Pleistocene glacial till covers most of the basin. On the valley floor, the till is a light-brown, brown, and reddish-brown, unsorted, unconsolidated to partly consolidated mixture of gravel- to boulder-sized clasts in a sandy matrix. On the foothills, the till is similar, except the reddish color is absent and the matrix is silty, clayey and more compact than on the valley floor. Pleistocene glacial outwash crops out at the mouths of a few tributaries and in small, isolated areas where glacial meltwater was channelled by ice. The glacial outwash consists of light-gray and light- to dark-brown, moderately sorted, unconsolidated silt, sand, gravel, pebbles, and cobbles. Holocene alluvium underlies the flood plain of the Swan River and commonly overlies glacial outwash deposits. It consists of light-brown, brown, and brownish-gray, well-bedded, well-sorted, unconsolidated silt, sand, gravel, pebbles, and some cobbles in a clayey matrix (Witkind and Weber, 1982). Although it is difficult to differentiate alluvium from the underlying glacial deposits, drillers' logs indicate that Holocene alluvium generally is less than about $20 \mathrm{ft}$ thick along the Swan River. 


\section{Hydrology}

The Swan River is the principal stream in the Swan Valley. The river flows north-northwestward through the basin, and into Swan Lake. North of the lake, the Swan River flows through the southeastern part of the Kalispell Valley for about $8 \mathrm{mi}$ before emptying into Flathead Lake. Streams flowing from the east flank of the Mission Range and the west flank of the Swan Range are tributary to the Swan River.

Numerous lakes, ponds, and wetlands fill potholes left by melting glacial ice in the poorly drained glacial till throughout the basin. For example, in the southern part of the basin, Holland and Lindbergh Lakes are perched on top of glacial till in the foothills of the Swan and Mission Ranges, respectively.

Streamflow data for gaging stations listed in table 79 are stored in the USGS WATSTORE database. Locations of the stations are shown on plate 1. Data for years prior to 1961 are published in Water-Supply Papers; more recent data are in annual Water-Data Reports (U.S. Geological Survey, issued annually).

Table 79. Summary of data for U.S. Geological Survey streamflow-gaging stations in the Swan Valley, Montana

[Type of data collected: d, discharge. Periods of record for stations that were being operated as of November 1994 are indicated by the first year of record followed by a dash only. Abbreviations: $\mathrm{ft}^{3} / \mathrm{s}$, cubic feet per second]

\begin{tabular}{|c|c|c|c|c|c|c|c|c|c|}
\hline \multirow[b]{2}{*}{$\begin{array}{l}\text { Station } \\
\text { number }\end{array}$} & \multirow[b]{2}{*}{ Station name } & \multirow{2}{*}{$\begin{array}{c}\text { Drainage } \\
\text { area } \\
\text { (equare } \\
\text { miles) }\end{array}$} & \multirow{2}{*}{$\begin{array}{l}\text { Type } \\
\text { of data } \\
\text { cot- } \\
\text { lected }\end{array}$} & \multirow[b]{2}{*}{$\begin{array}{l}\text { Period of record } \\
\text { (calendar year) }\end{array}$} & \multicolumn{5}{|c|}{ Discharge for perlod of record } \\
\hline & & & & & $\begin{array}{l}\text { Mean } \\
\text { annual } \\
\left(\mathrm{f}^{3} / \mathrm{a}\right)\end{array}$ & $\begin{array}{l}\text { Maxt- } \\
\text { mum } \\
\left(t^{3} / s\right)\end{array}$ & $\begin{array}{l}\text { Date of } \\
\text { maximum }\end{array}$ & $\begin{array}{l}\text { Mint- } \\
\text { mum } \\
\left(\mathrm{f}^{3} / \mathrm{s}\right)\end{array}$ & $\begin{array}{l}\text { Dats of } \\
\text { minimum }\end{array}$ \\
\hline 12369200 & $\begin{array}{l}\text { Swan River near } \\
\text { Condon }\end{array}$ & 69.1 & d & $1972-92$ & 159 & 1,540 & $06-18-74$ & 17 & 09-09-88 \\
\hline 12370000 & $\begin{array}{l}\text { Swan River near } \\
\text { Bigfork }\end{array}$ & 671 & d & $1910-11,1922-$ & 1,158 & 8,890 & $06-20-74$ & 193 & $01-26-30$ \\
\hline
\end{tabular}

Ground water is an important resource in the Swan Valley, as the basin-fill aquifer system provides domestic water for most residents. In the past, many residents relied on springs and streams for domestic supply, but in the last decade most have replaced surface-water sources with wells.

Quatemary deposits comprise the major aquifer in the Swan Valley. Numerous old, shallow (less than $20 \mathrm{ft}$ ) wells along the Swan River withdraw water from Holocene alluvium. Except for a few wells in Condon, nearly all the wells in the Swan River flood plain are less than $100 \mathrm{ft}$ deep and most are less than $60 \mathrm{ft}$ deep (Montana Bureau of Mines and Geology, unpub. data, 1991). Most of these wells probably withdraw water from the underlying Pleistocene glacial outwash, as well as from Holocene alluvium. Because of shallow water levels and high permeability, the combined alluvial and glacial-outwash deposits compose a reliable aquifer. Yield and specificcapacity data for wells completed in Quaternary deposits are summarized in table 80. Some wells near the river are flowing, possibly indicating confined conditions beneath layers of fine-grained material.

Wells in the central part of the valley withdraw water primarily from sandy Pleistocene glacial till within 100 $\mathrm{ft}$ of land surface. The yields of wells completed in the till typically are sufficient for domestic use. Neighboring wells commonly are completed at different depths and have different water levels, indicating that the productive parts of the aquifer probably are laterally discontinuous, semi-confined permeable zones within the till.

Nearby wells completed in clayey till along the basin margins also exhibit different completion depths and water levels. The clayey till deposits generally are less permeable than the sandy till in the central part of the basin and permeable lenses commonly do not lie near the surface. Wells located along basin margins typically are more than $100 \mathrm{ft}$ deep; a few are more than $400 \mathrm{ft}$ deep. Most, but not all, yield sufficient water for domestic use. The yield and specific-capacity data summarized for Quaternary glacial deposits $(Q g)$ in table 80 combines data for clayey and sandy till. 
Table 80. Summary of data for yield and specific capacity of wells completed in selected hydrogeologic units in the Swan Valley, Montana

[Source: Dutton and others, 1995. Hydrogeologic unit: Qal, Holocene and Pleistocene alluvial deposits; Qg, Pleistocene glacial deposits. Abbreviations: gal/min, gallon per minute; (gal/min)/ft, gallon per minute per foot]

\begin{tabular}{|c|c|c|c|c|c|c|c|c|c|c|}
\hline \multirow{2}{*}{$\begin{array}{l}\text { Hydro- } \\
\text { geologic } \\
\text { unit }\end{array}$} & \multirow[b]{2}{*}{$\begin{array}{c}\text { Number of } \\
\text { wells }\end{array}$} & \multicolumn{4}{|c|}{ Ylold (gal/min) } & \multirow[b]{2}{*}{$\begin{array}{c}\text { Number of } \\
\text { wells }\end{array}$} & \multicolumn{4}{|c|}{ Speciflc capacily [(gal/min)/ft] } \\
\hline & & Mean & Median & $\begin{array}{l}\text { Mink } \\
\text { mum }\end{array}$ & $\begin{array}{l}\text { Maxl- } \\
\text { mum }\end{array}$ & & Mean & Median & $\begin{array}{l}\text { Mint- } \\
\text { mum }\end{array}$ & $\begin{array}{l}\text { Maxi- } \\
\text { mum }\end{array}$ \\
\hline Qal & 3 & 16 & 12 & 12 & 25 & 3 & 2.6 & 1.2 & 0.4 & 6.3 \\
\hline $\mathrm{Qg}$ & 21 & 27 & 14 & .3 & 100 & 14 & 1.6 & .7 & .1 & 8.7 \\
\hline
\end{tabular}

A few wells along the basin margins are completed in Proterozoic bedrock. These wells typically produce about 1 to $20 \mathrm{gal} / \mathrm{min}$ (Montana Bureau of Mines and Geology, unpub. data, 1991).

Little is known about ground-water flow in the Swan Valley. However, a 1:750,000-scale potentiometricsurface map which includes the Swan Valley (Briar and others, in press) indicates that ground water generally flows from the uplands toward the center of the basin, then north-northwestward, parallel to the Swan River.

Basin-fill aquifers are recharged by precipitation and snowmelt, infiltration from surface water, subsurface flow from bedrock, and possibly deep subsurface flow from beneath the Clearwater River Valley. The practices of sprinkler irrigation and subirrigation, as opposed to flood irrigation, may preclude significant aquifer recharge from surplus irrigation water (Nunnallee and others, 1976). The ground-water contribution area for the intermontane basin (fig. 2, pl. 1) is about $640 \mathrm{mi}^{2}$. Infiltration anywhere within this area potentially could recharge basin-fill aquifers in the Swan Valley. For example, precipitation that falls on the Mission Range might move through the relatively porous, east-dipping Helena Formation and discharge to basin-fill aquifers in the Swan Valley. Ground water discharges from the basin-fill aquifers by evapotranspiration, pumpage from wells, and seepage into springs, seeps, and stream channels.

A considerable volume of ground water may be stored in basin fill in the Swan Valley. Crosby (1984) estimated that 129 million acre-ft of water may be stored in the combined basins of the Swan Valley and the Clearwater River Valley, assuming that $336-\mathrm{mi}^{2}$ of sediment with a porosity of 19 percent fill the basin to a depth of $0.6 \mathrm{mi}$ below land surface. Of this volume, 15.5 million acre- $\mathrm{ft}$ may be accessible for pumping.

The quality of ground water in the basin was determined on the basis of 8 samples analyzed for major ions and measured dissolved-solids concentrations and 15 samples in which dissolved-solids concentrations were estimated from specific-conductance measurements. Ground water typically is a calcium bicarbonate type with dissolved-solids concentrations of less than $250 \mathrm{mg} / \mathrm{L}$ throughout the basin (Wilke, 1979; Clark and Dutton, in press).

\section{Selected References}

Briar, D.W., Lawlor, S.M., Stone, M.A.J., Parliman, D.J., Schaefer, J.L., and Kendy, Eloise, in press, Ground-water levels in intermontane basins of the Northern Rocky Mountains, Montana and Idaho: U.S. Geological Survey Hydrologic Investigations Atlas 738-B, 1 sheet, scale 1:750,000.

Clark, D.W., and Dutton, D.M., in press, Quality of ground water and surface water in intermontane basins of the Northern Rocky Mountains, Montana and Idaho: U.S. Geological Survey Hydrologic Investigations Atlas 738-C, 1 sheet, scale 1:750,000.

Crosby, G.W., 1984, Structural-geophysical interpretation of Swan Valley, Montana, in Northwestern Montana and adjacent Canada, Montana Geological Society 1984 Field Conference and Symposium: [Billings, Mont.], Montana Geological Society, p. 245-251.

Dutton, D.M., Lawlor, S.M., Briar, D.W., and Tresch, R.E., 1995, Hydrogeologic data for the Northern Rocky Mountains intermontane basins, Montana: U.S. Geological Survey Open-File Report 95-143, 94 p. 
Johns, W.M., 1970, Geology and mineral deposits of Lincoln and Flathead Counties, Montana: Montana Bureau of Mines and Geology Bulletin 79, 182 p.

Kleinkopf, M.D., and Mudge, M.R., 1972, Aeromagnetic, Bouguer gravity, and generalized geologic studies of the Great FallsMission Range area, northwestern Montana: U.S. Geological Survey Professional Paper 726-A, 19 p.

[Montana] State Engineer's Office, 1963a, Water resources survey, Lake County, Montana--Part 1, History of land and water use on irrigated areas: Helena, Mont., State Engineer's Office, 53 p.

1963b, Water resources survey, Lake County, Montana--Part 2, Maps showing irrigated areas: Helena, Mont., State Engineer's Office, $32 \mathrm{p}$.

Morrison-Maierle, Inc. and James M. Montgomery, Consulting Engineers, Inc., 1977, Lakes and streams water quality study, Flathead drainage, Montana: [Helena, Mont.] Morrison-Maierle, Inc., variously paged.

Mudge, M.R., Earhart, R.L, Whipple, J.W., and Harrison, J.E., 1982, Geologic and structure maps of the Choteau $1^{\circ} \times 2^{\circ}$ quadrangle, northwestem Montana: U.S. Geological Survey Miscellaneous Investigations Series Map I-1300, 2 sheets, scale $1: 250,000$.

National Oceanic and Atmospheric Administration, 1992, Monthly normals of temperature, precipitation, and heating and cooling degree days, 1961-90, Montana: Asheville, N.C., Climatography of the United States no. 81, unpaged.

Noble, R.A., Bergantino, R.N., Patton, T.W., Sholes, B.C., Daniel, Faith, and Schofield, Judeykay, 1982, Occurrence and characteristics of ground water of Montana--Volume 2, The Rocky Mountain Region: Montana Bureau of Mines and Geology Open-File Report 99, 132 p.

Nunnallee, David, Botz, M.K., and Willems, D.G., 1976, Water quality inventory and management plan, Flathead drainage basin, Montana: Montana Department of Health and Environmental Sciences, 114 p.

Tuck, L. K., Briar, D.W., and Clark, D.W., in press, Geologic history and hydrogeologic units of intermontane basins of the Northern Rocky Mountains, Montana and Idaho: U.S. Geological Survey Hydrologic Investigations Atlas 738-A, 2 sheets, scale 1:750,000.

U.S. Geological Survey, issued annually, Water resources data, Montana: Helena, Mont., U.S. Geological Survey Water-Data Report.

Wilke, K.R., 1979, Selected well inventory and chemical analyses of ground water, parts of Missoula and Powell Counties, Montana: U.S. Geological Survey Open-File Report 79-1491, 4 p., 2 tables.

Witkind, I.J., and Weber, W.M., 1982, Reconnaissance geologic map of the Big Fork-Avon environmental study area, Flathead, Lake, Lewis and Clark, Missoula, and Powell Counties, Montana: U.S. Geological Survey Miscellaneous Investigations Series Map I-1380, scale 1:125,000. 


\section{Tobacco Valley}

\section{Geography}

The Tobacco Valley is a northwest-trending intermontane basin in northwestern Montana. The $160-\mathrm{mi}^{2}$ basin is bounded by the Salish Mountains on the southwest, the Purcell Mountains on the west, and the steep western face of the Whitefish Range on the east. The southeastern boundary is defined by a recessional glacial moraine that divides the drainages of the Tobacco and Stillwater Rivers (Coffin and others, 1971). Although the structural basin continues northward into Canada, the international border forms the northern boundary of the Tobacco Valley described in this study (pl. 1).

The Tobacco Valley is about $10 \mathrm{mi}$ wide near the United States-Canada border, narrows to about $4 \mathrm{mi}$ wide near Eureka, and widens to about $10 \mathrm{mi}$ wide near Fortine. The Tobacco River flows from its headwaters southeast of the basin, northwestward through the basin, to Lake Koocanusa on the Kootenai River. The flood plain of the Tobacco River is about 1 mi wide

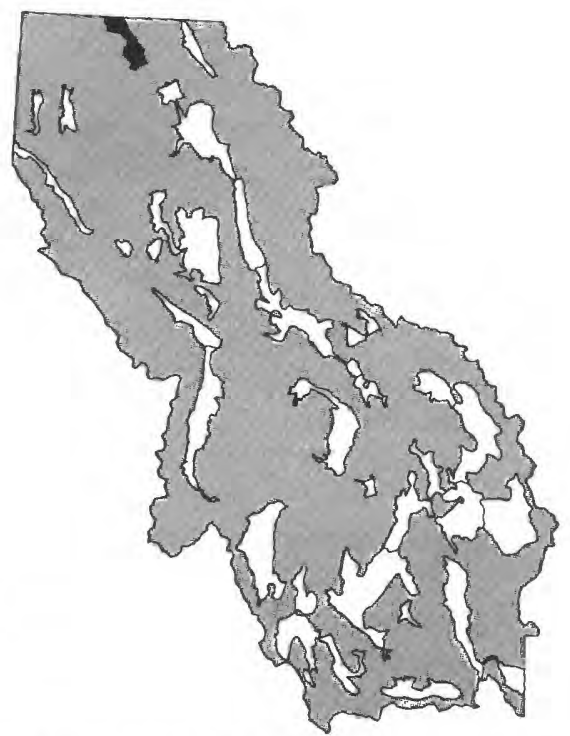
and is incised 200 to $300 \mathrm{ft}$ into the surrounding glaciated terraces. Glacial features dominate the basin topography. The Tobacco Plains north of Eureka and east of Lake Koocanusa (pl. 1) are a glacial terrace which is nearly level except for isolated drumlin hills and kettle lakes 20 to $100 \mathrm{ft}$ deep. The lack of relief in the Tobacco Plains contrasts with the hummocky topography that typifies the rest of the basin (Coffin and others, 1971). The Tobacco Valley ranges in altitude from about $2,400 \mathrm{ft}$ where the Tobacco River enters Lake Koocanusa, to about $4,400 \mathrm{ft}$ on the highest glacial terrace.

The temperature of the Tobacco Valley is typical of low-elevation intermontane basins of the Northern Rocky Mountains west of the Continental Divide, with cold winters and mild summers. However, the mountains to the west of the Tobacco Valley protect the basin from much of the maritime moisture that affects other basins in western Montana. On the basis of the 1961-90 period of record, the average annual precipitation at the Eureka Ranger Station (altitude $2,530 \mathrm{ft}$ ) is $14.49 \mathrm{in}$., and the average annual temperature is $44.9^{\circ} \mathrm{F}$ (National Oceanic and Atmospheric Administration, 1992). The average last occurrence of $32^{\circ} \mathrm{F}$ is May 27 and the average first occurrence is September 14 (Natural Resources Conservation Service, U.S. Department of Agriculture, unpub. data, 1994). Mean monthly climatic data for the Eureka Ranger Station in Eureka are plotted in figure 27.

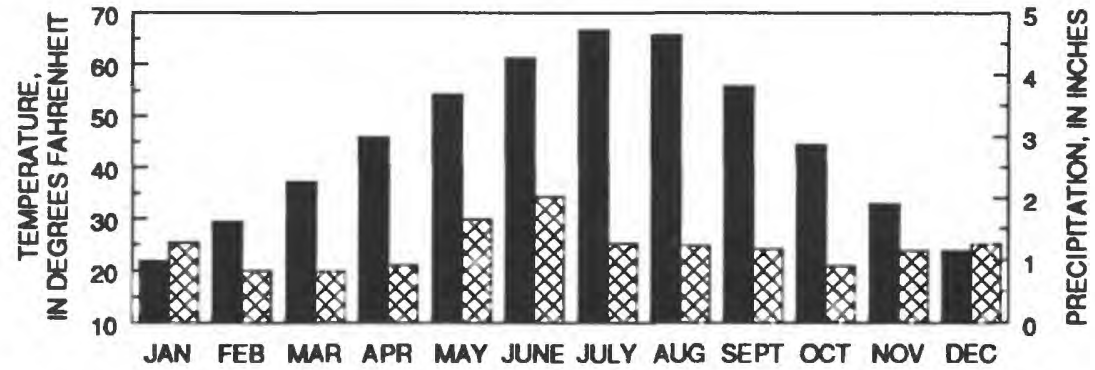

EXPLANATION

NEAN MONTHLY TEMPERATURE FOR 1961-SO PERIOD OF RECORD

Q

MEAN MONTHLY PRECIPITATION FOR 1961-90 PERIOD OF RECORD

Flgure 27. Mean monthly precipitation and temperature at the Eureka Ranger Station, Mont. Data from National Oceanic and Atmospheric Administration (1992).

The primary land use is timber harvesting; rangeland and irrigated hay and pastures are of secondary importance (J.C. Eggen, Agricultural Stabilization and Conservation Service, oral commun., 1993). About 3,000 people reside in the Tobacco Valley, including 1,043 in the Town of Eureka (1990 census). Three major lumber 
mills and several small family lumber mills, log-cabin-building companies, and pole mills process timber in the basin. Upstream from Eureka, where forests dominate the landscape, silviculture is the principal land use. Pockets of grassland within the forests are used as livestock range. Small towns are located along the Tobacco River Valley at the confluences of major tributary valleys. Hay pastures are farmed on flood plains near the towns. The fields upstream from Eureka are mostly subirrigated, although some flood- and sprinkler-irrigated crops are also cultivated. On the Tobacco Plains north of Eureka, which have more open native grassland and less timber than the upstream areas, land uses include limited dryland farming on the terraces and irrigated pastures on the flood plains. Diversions from the Tobacco River irrigate about 4,500 acres of cropland (Shields and others, 1993, p. 391). Surface-water diversions also supply municipal water for Fortine and most of Eureka. The remainder of the area residents rely on private wells and springs for domestic-water supplies (Coffin and others, 1971).

\section{Geology}

The Tobacco Valley basin occupies the southern extension of the thousand-mile-long Rocky Mountain Trench (fig. 4), a zone of closely spaced normal faults (Harrison and others, 1992). Late Paleocene to Eocene extension along these faults caused crustal blocks to drop down at least $4,000 \mathrm{ft}$ relative to the surrounding terrane, resulting in a series of subparallel basins, including the Tobacco Valley (Coffin and others, 1971).

Several investigators have examined the geology of the Tobacco Valley (table 81). The geologic units described by previous investigators are summarized below. These geologic units are referenced to hydrogeologic units defined in this study (table 2) to provide a consistent regional framework. In the following discussion, the hydrogeologic-unit abbreviations are italicized.

Table 81. Geologic and geophysical maps of the Tobacco Valley, Montana

\begin{tabular}{|c|c|c|c|c|}
\hline Type of map & Scale & Location & Map leatures & Reforence \\
\hline Geology & $1: 96,000$ & $\begin{array}{l}\text { Tobacco Plains } \\
\text { area north } \\
\text { of Eureka }\end{array}$ & Differentiates five Quatemary basin-fill units & $\begin{array}{l}\text { Coffin, 1970, fig. 2, p. L4 } \\
\text { L5 }\end{array}$ \\
\hline Geology & $1: 86,400$ & $\begin{array}{l}\text { Entire Tobacco } \\
\text { Valley }\end{array}$ & $\begin{array}{l}\text { Differentiates five Quatemary basin-fill units. } \\
\text { Includes two east-west geologic sections north of } \\
\text { Eureka }\end{array}$ & $\begin{array}{l}\text { Coffin and others, } 1971 \text {, } \\
\text { pl. } 1 \text { (North Haif) }\end{array}$ \\
\hline Geology & $1: 250,000$ & $\begin{array}{l}\text { Entire Tobscco } \\
\text { Valley }\end{array}$ & $\begin{array}{l}\text { Differentiates three basin-fill units: Pleistocene } \\
\text { glacial and outwash deposits, Pleistocene lake } \\
\text { sediments, and Holocene alluvial deposits. } \\
\text { Includes an east-west bedrock section through Bull } \\
\text { Lake }\end{array}$ & Harrison and others, 1992 \\
\hline Geology & $1: 126,720$ & $\begin{array}{l}\text { Entire Tobacco } \\
\text { Valley }\end{array}$ & $\begin{array}{l}\text { Differentiates two basin-fill units: glacial deposits } \\
\text { and alluvium }\end{array}$ & Johns, 1970, pl. 1 and 2 \\
\hline
\end{tabular}

Middle Proterozoic metasedimentary bedrock of the Belt Supergroup ( $Y m s$ ) surrounds the Tobacco Valley south of the United States-Canada border. The argillite, quartzite, sandstone, and dolomite are extensively folded and faulted (Harrison and others, 1992).

As the basin subsided, debris from the surrounding mountains filled the Tobacco Valley. Although Tertiary sediments (Ts) are not exposed at the surface, they probably overlie bedrock almost everywhere in the basin. On the basis of gravity measurements, Tertiary sediments may be as thick as 3,000 ft (Coffin and others, 1971; Noble and others, 1982). If the lithology of Tertiary basin fill in the Tobacco Valley is analogous to that of other basins in the Rocky Mountain Trench, then it probably consists of Oligocene conglomerate, sandstone, siltstone, marlstone, oil shale and coal (Harrison and others, 1992) and Miocene lacustrine deposits (Coffin and others, 1971). 
During Pleistocene time, a heterogeneous mixture of interfingering glacial till $(Q g)$, glacial-lakebed deposits $(Q g)$, glacial outwash $(Q a l)$, and deltaic deposits (Qal), were deposited unconformably on the Tertiary basin fill (Coffin and others, 1971). Glacial till forms southeast-trending drumlins at least $200 \mathrm{ft}$ thick and underlies and interfingers with other Quaternary deposits throughout the basin. Unsorted clay, silt, sand, gravel, and boulders compose the till, with an increasing percentage of large clasts near bedrock outcrops. More than $300 \mathrm{ft}$ of glaciallakebed deposits underlie terraces that flank the Tobacco River downstream from Eureka and underlie surficial deposits at altitudes below $2,650 \mathrm{ft}$. These glacial-lakebed deposits consist of buff-colored, varved, clayey silt and very fine-grained sand. Glacial outwash consisting of poorly sorted sand and gravel was deposited during periods of glacial retreat, when debris-choked tributaries transported the material onto flood plains. As the heavier materials dropped out of suspension, the dominant grain sizes of the glacial outwash decreased and the sorting improved downstream. Glacial-outwash deposits below an altitude of $2,700 \mathrm{ft}$ terminate in smooth, rounded slopes. Sandy deltaic deposits underlie these slopes and interfinger with glacial outwash and glacial-lakebed deposits (Coffin and others, 1971). The maximum thickness of Pleistocene deposits is unknown. The deepest well in the basin (36N26W07CB) penetrated $560 \mathrm{ft}$ of unconsolidated, gravel, sand, and clay about $1.5 \mathrm{mi}$ northeast of Eureka without reaching bedrock (Montana Bureau of Mines and Geology, unpub. data, 1991).

After the final glacial recession, the glacial lakes drained and the Kootenai River entrenched 200 to $300 \mathrm{ft}$ into glacial-lakebed deposits (Coffin, 1970). Holocene alluvium consisting primarily of well-sorted sand and gravel partly filled the resulting valley, where it remains in narrow bands along the Tobacco River and its major tributaries, and beneath Lake Koocanusa. The alluvium is at least $50 \mathrm{ft}$ thick in the Kootenai River Valley (Coffin and others, 1971).

\section{Hydrology}

The Tobacco River flows from its tributary headwaters in the Salish Mountains and the Whitefish Range, northwestward through the Tobacco Valley. It joins Lake Koocanusa about six miles northwest of Eureka. Libby Dam has impounded Lake Koocanusa on the Kootenai River since 1972.

Numerous lakes fill potholes left by melting glacial ice throughout the basin. Lakes on the Tobacco Plains are all ground-water fed except for Sophie Lake, which receives its inflow from an ephemeral stream. Most lakes south of Eureka also receive surface inflow. Glen Lake, southeast of Eureka, is a natural lake enlarged by a dam to increase storage for irrigation. Average lake levels have risen since the 1920 's, possibly in response to increased runoff caused by timber harvesting (Coffin and others, 1971).

Streamflow data for gaging stations listed in table 82 are stored in the USGS WATSTORE database. Locations of the stations are shown on plate 1. In addition, the USGS has published daily reservoir elevation records of Lake Koocanusa, near Libby (gaging station 12301920, drainage area approximately 8,985 $\mathrm{mi}^{2}$ ) in annual Water-Data Reports since March 1972 (U.S. Geological Survey, issued annually).

The quality of water in the Tobacco River near Eureka (gaging station 12301300) was determined on the basis of 45 samples. Analyses indicate the river has a calcium bicarbonate type water with an average dissolved-solids concentration of about $116 \mathrm{mg} / \mathrm{L}$ (Clark and Dutton, in press). The dissolved-solids concentration decreases during spring runoff because of dilution from snowmelt (Coffin and others, 1971). Although most surface water in the basin supports biological activity, some wetlands near Eureka are biologically sterile because deposits of glacial rock flour inhibit growth (Reichmuth, 1986).

Hydrogeology of the basin fill is complex, because of the interfingering of discontinuous alluvial, deltaic, glacial-outwash, glacial-lakebed, and glacial-till deposits. Flowing wells are common, as are wells completed in perched aquifers. Well depths in the basin range from less than 30 to more than $500 \mathrm{ft}$ (Montana Bureau of Mines and Geology, unpub. data, 1991). Many of the shallowest wells, with depths of less than about $50 \mathrm{ft}$, are completed in flood-plain alluvium. The sand and gravel that composes the alluvium is permeable, and has an estimated transmissivity as large as $67,000 \mathrm{ft}^{2} / \mathrm{d}$. Wells completed in alluvium yield 5 to $25 \mathrm{gal} / \mathrm{min}$ with very little drawdown (Coffin and others, 1971). 
Table 82. Summary of data for U.S. Geological Survey streamflow-gaging stations in the Tobacco Valley, Montana

[Type of data collected: $c$, water chemistry; d, dischange. Periods of record for stations that were being operated as of November 1994 are indicated by the first year of record followed by the a dash only. Abbreviations: $\mathrm{ft}^{3} / \mathrm{s}$, cubic feet per second. Symbol: --, no data]

\begin{tabular}{|c|c|c|c|c|c|c|c|c|c|}
\hline \multirow[b]{2}{*}{$\begin{array}{l}\text { Station } \\
\text { number }\end{array}$} & \multirow[b]{2}{*}{ Station name } & \multirow{2}{*}{$\begin{array}{l}\text { Drainege } \\
\text { area } \\
\text { (square } \\
\text { miles) }\end{array}$} & \multirow{2}{*}{$\begin{array}{l}\text { Type } \\
\text { of data } \\
\text { col- } \\
\text { locted }\end{array}$} & \multirow{2}{*}{$\begin{array}{l}\text { Perlod of record } \\
\text { (calendar year) }\end{array}$} & \multicolumn{5}{|c|}{ Dlecharge for period of record } \\
\hline & & & & & $\begin{array}{l}\text { Mean } \\
\text { annual } \\
\left(t^{3} / s\right)\end{array}$ & $\begin{array}{l}\text { Maxt- } \\
\text { mum } \\
\left(\mathrm{ft}^{3} / \mathrm{s}\right)\end{array}$ & $\begin{array}{l}\text { Dalo of } \\
\text { maximum }\end{array}$ & $\begin{array}{l}\text { Mint- } \\
\text { mum } \\
\left(t^{3} / s\right)\end{array}$ & $\begin{array}{l}\text { Dale of } \\
\text { minimum }\end{array}$ \\
\hline 12300000 & $\begin{array}{l}\text { Kootenay River at } \\
\text { Newgate, British } \\
\text { Columbia }\end{array}$ & 7,660 & $\begin{array}{l}\text { d } \\
\text { c }\end{array}$ & $\begin{array}{l}1930-72 \\
1949,1965\end{array}$ & 10,520 & 98,200 & $05-28-48$ & 994 & $02-07-36$ \\
\hline 12300110 & $\begin{array}{l}\text { Lake Koocanusa at } \\
\text { International } \\
\text { Boundary }\end{array}$ & - & c & $1972-$ & - & - & - & - & -- \\
\hline 12300200 & $\begin{array}{l}\text { Young Creek near } \\
\text { Rexford }\end{array}$ & 36.0 & d & $\begin{array}{l}\text { 1973-75 (no winter } \\
\text { records) }\end{array}$ & - & 215 & 06-13-74 & 2.5 & $01-21-74$ \\
\hline 12300500 & $\begin{array}{l}\text { Fortine Creek near } \\
\text { Trego }\end{array}$ & 112 & d & $1946-53$ & 84.7 & 1,810 & $05-16-50$ & 5.0 & $09-07-49$ \\
\hline 12301000 & $\begin{array}{l}\text { Grave Creek near } \\
\text { Fortine }\end{array}$ & 64.9 & d & $\begin{array}{l}\text { 1923-24 } \\
\quad \text { (intermittent) }\end{array}$ & - & 690 & $06-11-23$ & 18 & 04-01-24 \\
\hline 12301300 & $\begin{array}{l}\text { Tobacco River near } \\
\text { Eureka }\end{array}$ & 440 & $\begin{array}{l}\text { d } \\
\text { c }\end{array}$ & $\begin{array}{l}1958- \\
1971-85\end{array}$ & 264 & 3,180 & $05-13-91$ & ${ }^{1} 20$ & $01-11-63$ \\
\hline 12301500 & $\begin{array}{l}\text { Kootenai River near } \\
\text { Rexford }\end{array}$ & 8,420 & $\begin{array}{l}\text { d } \\
\text { c }\end{array}$ & $\begin{array}{l}1929-40,1967-71 \\
1967-72\end{array}$ & 10,130 & 79,900 & $06-18-33$ & 1,100 & $02-07-36$ \\
\hline 12301550 & $\begin{array}{l}\text { Pinkham Creek near } \\
\text { Rexford }\end{array}$ & 75.7 & d & $1972-81$ & 25.7 & 689 & 05-11-76 & 0 & $\begin{array}{l}\text { At times } \\
\text { most years }\end{array}$ \\
\hline 12301600 & $\begin{array}{l}\text { Lake Koocanusa } \\
\text { below Pinkham } \\
\text { Creek, near } \\
\text { Rexford }\end{array}$ & - & c & 1972-76 & - & - & -- & -- & - \\
\hline
\end{tabular}

${ }^{1}$ Lowest daily mean.

Deltaic deposits have hydraulic properties similar to those of glacial outwash. Coffin and others (1971) estimate the transmissivity of deltaic deposits to be $13,000 \mathrm{ft}^{2} / \mathrm{d}$. However, most deltaic deposits in the Tobacco Valley are unsaturated.

Wells completed in glacial outwash are capable of sustaining large yields, especially in the lower reaches of tributary valleys where the material is well-sorted. Coffin and others (1971) estimated the transmissivity of glacial outwash to be about $9,300 \mathrm{ft}^{2} / \mathrm{d}$, and reported that well yields range from 10 to $50 \mathrm{gal} / \mathrm{min}$.

No wells are known to produce from glacial-lakebed deposits in the Tobacco Valley, although some springs discharge from them. Drillers report difficulty completing and developing wells in the fine-grained, viscous material that constitutes these deposits (Coffin and others, 1971).

Glacial till generally is not a reliable aquifer because of its poor sorting and large percentage of fine-grained material. However, it is the only source of water on some lower mountain slopes. Wells completed in glacial till reportedly produce about $2 \mathrm{gal} / \mathrm{min}$ and ephemeral springs originating in till discharge up to $5 \mathrm{gal} / \mathrm{min}$. Lenses and ridges of till restrict horizontal ground-water flow. Layers of till locally confine and perch ground water in more permeable deposits (Coffin and others, 1971).

Because of the thickness of Quaternary deposits, wells are completed in bedrock only near outcrops and along the edges of the basin. These wells typically produce about 1 to $30 \mathrm{gal} / \mathrm{min}$ and have specific-capacity values of less than 1(gal/min)/ft (Coffin and others, 1971; Dutton and others, 1995).

A 1:750,000-scale potentiometric-surface map which includes the Tobacco Valley (Briar and others, in press), indicates that ground water generally flows from the uplands toward the flood plains, then northwestward, 
paralleling the Tobacco River. However, local ground-water flow patterns in the Tobacco Valley are complex, because of numerous lakes, bedrock outcrops, and laterally discontinuous impermeable layers. Coffin and others (1971, fig. 12, p. 23) produced a hypothetical water-table map of the Tobacco Plains area prior to the filling of Lake Koocanusa, based on a ground-water flow model. The model-generated water levels generally matched measured water levels (Coffin and others, 1971, pl. 2, scale 1:86,400), and indicated that the hydraulic gradient is small beneath the plain, and steepens toward the reach of the Kootenai River which Lake Koocanusa now fills.

Basin-fill aquifers are recharged by precipitation and snowmelt, springtime infiltration from streams and lakes, surplus irrigation water, leakage from canals, and subsurface flow from bedrock. Recharge from precipitation and snowmelt is substantial in the Tobacco Plains area because the permeable surface lacks an integrated drainage system. The ground-water contribution area for the basin (fig. 2, pl. 1) is about $560 \mathrm{mi}^{2}$. Infiltration anywhere within this area potentially could recharge basin-fill aquifers in the Tobacco Valley. Ground water discharges from basin-fill aquifers by evapotranspiration, withdrawals from wells, and seepage to springs, seeps, and stream channels. Withdrawals from wells potentially could be significant, but usage currently accounts for only a small percentage of ground-water discharge (Coffin and others, 1971). Synoptic streamflow measurements during the fall of 1966 indicated that the Tobacco River and its major tributaries received ground-water inflow throughout their reaches. Coffin and others (1971) provided a detailed ground-water budget for the Tobacco Plains prior to the filling of Lake Koocanusa.

Water-level data for the wells listed in table 83 are stored in the USGS WATSTORE database. Water levels were measured in these wells at least once annually during the periods of record.

Table 83. Summary of water-level data for selected wells in the Tobacco Valley, Montana

[Hydrogeologic unit: Qg, Pleistocene glacial deposits. Periods of record for observation wells that were being operated as of February 1995 are indicated by the first year of record followed by a dash only. Symbol: --, no data]

\begin{tabular}{|c|c|c|c|c|c|c|c|}
\hline \multirow[b]{2}{*}{ Location number } & \multirow{2}{*}{$\begin{array}{c}\text { Depth of } \\
\text { well, in feat } \\
\text { below land } \\
\text { eurfece }\end{array}$} & \multirow{2}{*}{$\begin{array}{l}\text { Hydro- } \\
\text { geologle } \\
\text { unit }\end{array}$} & \multirow{2}{*}{$\begin{array}{l}\text { Period of } \\
\text { record }\end{array}$} & \multicolumn{4}{|c|}{ Water level, in feet below land surface } \\
\hline & & & & Higheat & $\begin{array}{c}\text { Date(s) of } \\
\text { highest }\end{array}$ & Lowest & $\begin{array}{l}\text { Date of } \\
\text { lowest }\end{array}$ \\
\hline 37N28W13CABB01 & 200 & Qg & $1975-82$ & 49.38 & $10-10-80$ & 83.07 & $\begin{array}{l}07-02-75 \\
08-18-75\end{array}$ \\
\hline 37N28W13CADB01 & 223 & Qg & $1972-82$ & 47.73 & $08-26-82$ & 95.24 & $06-05-73$ \\
\hline 37N27W06CABA01 & 217 & Qg & $1974-82$ & 36.43 & $09-15-76$ & 156.32 & 06-03-75 \\
\hline 37N27W06CBAA01 & 213 & Qg & $1973-82$ & 39.47 & $09-15-76$ & 201.5 & 04-14-76 \\
\hline $37 \mathrm{~N} 27 \mathrm{~W} 14 \mathrm{CBCCO} 1$ & 299 & Qg & $1967-91$ & 63.29 & $07-16-81$ & 114.21 & 03-09-78 \\
\hline 37 N27W21CBAB01 & 45.0 & $\mathbf{Q g}$ & $1973-92$ & 9.57 & $08-15-91$ & 24.29 & $10-07-88$ \\
\hline 37N27W24BABB01 & 230 & $\mathrm{Qg}$ & $1977-$ & 97.42 & $09-20-90$ & 178.40 & $06-22-77$ \\
\hline $37 \mathrm{~N} 27 \mathrm{~W} 24 \mathrm{BDCC} 01$ & 201 & $\mathrm{Qg}_{\mathrm{g}}$ & $1977-91$ & 112.29 & $03-13-80$ & 188.00 & $07-19-78$ \\
\hline 37 N27W27ACCB01 & 320 & Qg & 1977 - & 138.48 & $08-15-91$ & 153.57 & $05-25-78$ \\
\hline $37 \mathrm{~N} 27 \mathrm{~W} 33 \mathrm{DCCC} 01$ & 237 & $\mathrm{Qg}_{8}$ & $1966-91$ & 49.69 & $09-25-75$ & 78.66 & $11-19-72$ \\
\hline $37 \mathrm{~N} 27 \mathrm{~W} 35 \mathrm{DDCD} 01$ & - & Qg & $1966-91$ & 124.48 & $12-01-78$ & 140.48 & $03-17-73$ \\
\hline 36N28W01ADC 01 & 206 & Qg & $1972-$ & 96.48 & $10-12-76$ & 125.29 & $05-30-72$ \\
\hline 36N28W11AADB01 & 290 & Qg & 1971- & 23.06 & 08-30-76 & 181.41 & $05-30-72$ \\
\hline 36N27W05DCBC01 & 168 & Qg & $1966-$ & 26.74 & $10-24-75$ & 68.23 & 02-23-79 \\
\hline
\end{tabular}

The quality of ground water in the basin was determined on the basis of 14 samples analyzed for major ions and measured dissolved-solids concentrations and 6 samples in which dissolved-solids concentrations were estimated from specific-conductance measurements. In two areas--south of Fortine and west of Sophie Lake-ground water is a calcium magnesium bicarbonate type. In the rest of the basin, the ground water is a mixed-cation bicarbonate type--with calcium, magnesium and sodium the primary cations. The concentration of dissolved solids in ground water generally is less than $250 \mathrm{mg} / \mathrm{L}$ everywhere except near Lake Koocanusa and along the Tobacco River north of Fortine, where dissolved-solids concentrations ranged from about 250 to $500 \mathrm{mg} / \mathrm{L}$ (Clark and Dutton, in press). 


\section{Selected References}

Briar, D.W., Lawlor, S.M., Stone, M.A.J., Parliman, D.J., Schaefer, J.L., and Kendy, Eloise, in press, Ground-water levels in intermontane basins of the Northern Rocky Mountains, Montana and Idaho: U.S. Geological Survey Hydrologic Investigations Atlas 738-B, 1 sheet, scale 1:750,000.

Ciliberti, Vito A., Jr., 1980, The Libby Dam project--An ex-post facto analysis of selected environmental impacts, mitigation commitments, recreation usage and hydroelectric power production: Montana Water Resources Research Center Report No. 106, Project No. A-106-MONT, Agreement No. 14-34-0001-8028, Montana State University, Bozeman, 138 p.

Clark, D.W., and Dutton, D.M., in press, Quality of ground water and surface water in intermontane basins of the Northern Rocky Mountains, Montana and Idaho: U.S. Geological Survey Hydrologic Investigations Atlas 738-C, 1 sheet, scale 1:750,000.

Coffin, D.L, 1970, A preliminary evaluation of bank storage associated with Libby Reservoir in northwestern Montana: U.S. Geological Survey Water-Supply Paper 1899-L, 25 p.

Coffin, D.L., Brietkrietz, Alex, and McMurtrey, R.G., 1971, Surficial geology and water resources of the Tobacco and upper Stillwater River Valleys, northwestern Montana: Montana Bureau of Mines and Geology Bulletin 81,48 p.

Dutton, D.M., Lawlor, S.M., Briar, D.W., and Tresch, R.E., 1995, Hydrogeologic data for the Northern Rocky Mountains intermontane basins, Montana: U.S. Geological Survey Open-File Report 95-143, 94 p.

Garland, G.D., Kanasewich, E.R., and Thompson, T.L., 1961, Gravity measurements over the southern Rocky Mountain Trench area of British Columbia: Journal of Geophysical Research, v. 66, no. 8, p. 2,495-2,505.

Harrison, J.E., Cressman, E.R., and Whipple, J.W., 1992, Geologic and structure maps of the Kalispell $1^{\circ} \times 2^{\circ}$ quadrangle, Montana, and Alberta and British Columbia: U.S. Geological Survey Miscellaneous Investigations Series Map I-2267, 2 sheets, scale 1:250,000.

Johns, W.M., 1970, Geology and mineral deposits of Lincoln and Flathead Counties, Montana: Montana Bureau of Mines and Geology Bulletin 79, 182 p.

[Montana] State Engineer's Office, 1965a, Water resources survey, Flathead and Lincoln Counties, Montana--Part 1, History of land and water use on irrigated areas: Helena, Mont., State Engineers Office, 56 p.

1965b, Water resources survey, Flathead and Lincoln Counties, Montana--Part 2, Maps showing irrigated areas: Helena, Mont., State Engineer's Office, 26 p.

National Oceanic and Atmospheric Administration, 1992, Monthly normals of temperature, precipitation, and heating and cooling degree days, 1961-90, Montana: Asheville, N.C., Climatography of the United States no. 81, unpaged.

Noble, R.A., Bergantino, R.N., Patton, T.W., Sholes, B.C., Daniel, Faith, and Schofield, Judeykay, 1982, Occurrence and characteristics of ground water of Montana--Volume 2, The Rocky Mountain Region: Montana Bureau of Mines and Geology Open-File Report 99, 132 p.

Reichmuth, D.R., 1986, Fluvial systems in the wetland environment, in Proceedings of the Great Basin/Desert and Montane Regional Wetland Functions Workshop, Logan, Utah, February 27-28, 1986: Amherst, University of Massachusetts at Amherst, The Environmental Institute Publication No. 90-4, p. 23-59.

Sahinen, U.M., Johns, W.M., and Lawson, D.C., 1967, Geochemical investigations in Lincoln and Flathead Counties, Montana: Montana Bureau of Mines and Geology Bulletin 61, $18 \mathrm{p}$.

Shields, R.R., Knapton, J.R., White, M.K., Brosten, T.M., and Chambers, C.L., 1993, Water resources data, Montana, water year 1992: U.S. Geological Survey Water-Data Report MT-92-1, 534 p.

Tuck, L.K., Briar, D.W., and Clark, D.W., in press, Geologic history and hydrogeologic units of intermontane basins of the Northem Rocky Mountains, Montana and Idaho: U.S. Geological Survey Hydrologic Investigations Atlas 738-A, 2 sheets, scale 1:750,000.

U.S. Geological Survey, issued annually, Water resources data, Montana: Helena, Mont., U.S. Geological Survey Water-Data Report. 


\section{Townsend Valley}

\section{Geography}

The Townsend Valley is a north-northwest-trending intermontane basin in west-central Montana. The $510-\mathrm{mi}^{2}$ basin is bounded by the Elkhom Mountains on the west, the Spokane Hills on the northwest, Canyon Ferry Dam on the north, the Big Belt Mountains on the east, and the Hossfeldt Hills on the southeast (pl. 1). The Missouri River flows northward through the basin at an average gradient of about $5 \mathrm{ft} / \mathrm{mi}$. Nearly one-third of the basin consists of relatively level valley bottoms, or flood plains, bordering streams. The Missouri River flood plain ranges from about 1 to $6 \mathrm{mi}$ wide; tributary flood plains are narrower. Three levels of benches (Pardee, 1925) flank the flood plains. These benches, or pediments, are long, planar features that slope gently from the mountain fronts into the central part of the basin. East of Canyon Ferry Lake, steep-sided gullies dissect the benches. In a few places, bedrock hills protrude from the valley floor. The Townsend Valley ranges in altitude from about 3,800 ft at Canyon Ferry Dam to about 5,900 ft on the highest bench.

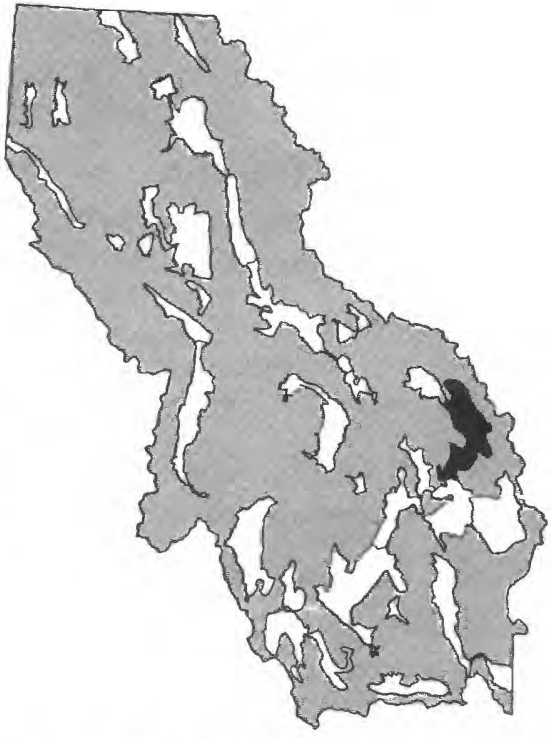

The climate of the Townsend Valley is typical of mid-elevation intermontane basins of the Northern Rocky Mountains east of the Continental Divide, with cold winters and dry summers. On the basis of the 1961-90 period of record, the average annual precipitation at Townsend (altitude 3,840 ft) is $11.28 \mathrm{in}$. and the average annual temperature is $45.1^{\circ} \mathrm{F}$ (National Oceanic and Atmospheric Administration, 1992). The average last occurrence of $32^{\circ} \mathrm{F}$ is May 27 and the average first occurrence is September 13 (Natural Resources Conservation Service, U.S. Department of Agriculture, unpub. data, 1994). Figure 28 shows mean monthly climatic data for Townsend.
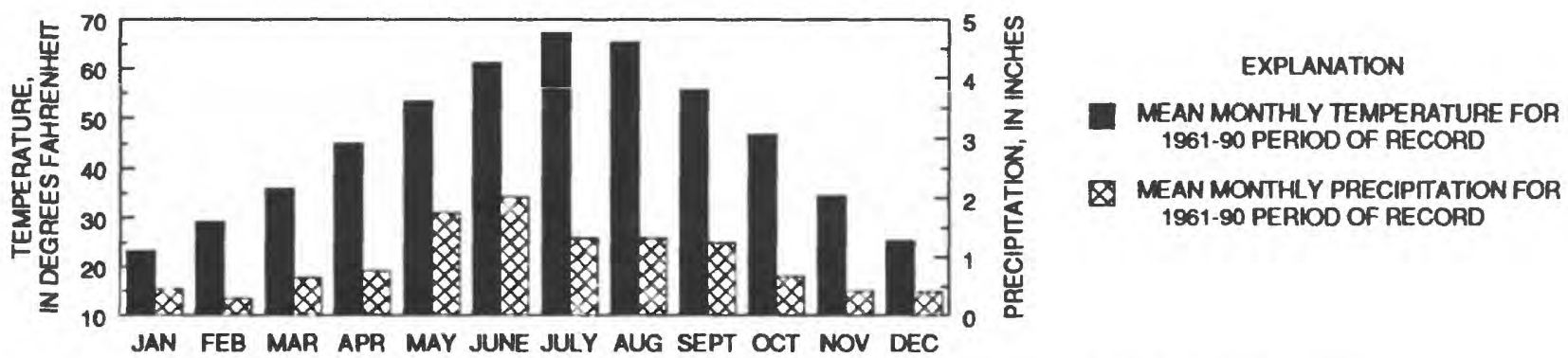

Figure 28. Mean monthly precipitation and temperature at Townsend, Mont. Data from National Oceanic and Atmospheric Administration (1992).

Land uses in the Townsend Valley include livestock grazing and dryland and irrigated farming. Dryland wheat and barley are grown extensively on benches. Irrigated seed potatoes are produced in the southern part of the basin. Other irrigated crops include hay, sugar beets, com, and sunflowers. About 3,000 people reside in the Townsend Valley, including 1,635 in the City of Townsend, 82 in the unincorporated community of Winston, 29 in the unincorporated community of Toston, and 46 in the unincorporated community of Radersburg (1990 census).

Mining, which in the 1860's and 1870's was the chief industry in the area, has declined significantly, although a few placer operations currently produce gold from the Big Belt and Elkhorn Mountains. Limestone is quarried in the Indian Creek drainage area west of Townsend. In addition, several companies are exploring for gold, limestone, and graphite in the Indian Creek area (McCulloch, 1993, p. 12, 18, 22, 41). 
Irrigation began in the Townsend Valley in the 1860 's with small diversions from tributary streams. Largescale irrigation began around the turn of the century. In 1939, the State Water Conservation Commission completed a dam that diverts water from the Missouri River near Toston to irrigated benches and valley bottoms to the west (Lorenz and McMurtrey, 1956). About 15,500 acres, or one-fourth of the irrigated land, is served by diversions from the Missouri River ([Montana] State Engineer's Office, 1956a). The rest of the irrigation supply is provided by tributary diversions, except for about 2 billion gallons per year which is pumped from 27 wells in the Radersburg area (Wyatt, 1984).

\section{Geology}

The Townsend Valley dropped down relative to the Big Belt and Elkhom Mountains along normal range-front faults. The northwestern end of the basin is bounded by the Lewis and Clark Line (fig. 4), a northwest-trending zone of high-angle normal, reverse, and right-lateral strike-slip faults. The southem basin boundary is irregular and may be a depositional or complexly faulted contact between basin fill and bedrock. More than 8,000 ft of basin fill overiie bedrock in the northeastern part of the basin. Several cross-cutting faults displace Tertiary strata throughout the basin (Kinoshita and others, 1964, 1965; Noble and others, 1982).

Several investigators have examined the geology of the Townsend Valley (table 84). The geologic units described by previous investigators are summarized below. These geologic units are referenced to hydrogeologic units defined in this study (table 2) to provide a consistent regional framework. In the following discussion, the hydrogeologic-unit abbreviations are italicized.

Metasedimentary, sedimentary, and igneous bedrock surround the Townsend Valley. To the east, the Big Belt Mountains are composed of argillite, siltstone, shale, quartzite, sandstone, dolomite, and limestone of the Middle Proterozoic Belt Supergroup (Yms). Paleozoic to Mesozoic sedimentary rocks crop out along the northern, western, and southem basin boundaries. The Paleozoic rocks $(P z l s)$ consist of interbedded carbonates, sandstone, quartzite, conglomerate, siltstone, mudstone, and shale. Permeable Mississippian limestone crops out west of Radersburg. Mesozoic rocks (Mzsh) include shale, sandstone, and limestone of Jurassic and Cretaceous age. Late Cretaceous Elkhom Mountains Volcanics ( $Q T K e$ ), which range in composition from basalt to andesite, border the northwestern side of the basin and crop out as erosional remnants within the basin. Igneous rocks (TKi), including granite, monzonite, diabase, and gabbro, have intruded the Elkhorn and Big Belt Mountains (Lorenz and McMurtrey, 1956; Kinoshita and others, 1964, 1965; Pardee, 1925; Klepper and others, 1957, 1971; Mertie and others, 1951).

Tertiary sediments (Ts) fill the basin and crop out as large, gently sloping pediments, or benches. Robinson (1967) correlated Tertiary sediments in the Townsend Valley with the Bozeman Group of other southwestern Montana basins. At the base of the group is the Climbing Arrow Formation, which in the Townsend Valley is of early Oligocene age. The Climbing Arrow consists of $1,200 \mathrm{ft}$ of varicolored tuffaceous mudstone and conglomerate with some lignitic coal, overlain by $1,500 \mathrm{ft}$ of red, bentonitic mudstone and conglomerate. Conformably overlying these deposits is the Dunbar Creek Formation of middle Oligocene age--1,600 ft of lightcolored, tuffaceous siltstone and mudstone with small amounts of freshwater limestone. The Climbing Arrow and Dunbar Creek Formations are equivalent to the more widely used "Renova Formation" or "Renova equivalents" (Fields and others, 1985). The upper part of the Bozeman Group is the Sixmile Creek Formation of Miocene to Pliocene age, which unconformably overlies the Renova equivalents. This formation consists of more than 4,000 $\mathrm{ft}$ of coarse-grained, light-colored tuffaceous fanglomerate and sandstone with silt, freshwater limestone, and rhyodacitic volcanic ash. The uppermost 1,000 ft of the Sixmile Creek Formation contains extensive sands and gravels (Robinson, 1967). 
Table 84. Geologic and geophysical maps of the Townsend Valley, Montana

\begin{tabular}{|c|c|c|c|c|}
\hline Type of map & Scale & Location & Map features & Reference \\
\hline $\begin{array}{l}\text { Bouguer gravity } \\
\text { and generalized } \\
\text { geology }\end{array}$ & $1: 62,500$ & North of lat $46^{\circ} 30^{\prime} \mathrm{N}$. & $\begin{array}{l}\text { Gravity contour interval } 5 \text { milligals. All } \\
\text { basin fill designated as Cenozoic } \\
\text { sedimentary deposits. Includes } 2 \text { cross } \\
\text { sections }\end{array}$ & $\begin{array}{l}\text { Davis and others, } \\
\text { 1963, sheet } 1\end{array}$ \\
\hline Aeromagnetic & $1: 62,500$ & North of lat $46^{\circ} 30^{\prime} \mathrm{N}$. & Contour intervals 20,100 , and 500 gammas & $\begin{array}{l}\text { Davis and others, } \\
\text { 1963, sheet } 2\end{array}$ \\
\hline Geology & $1: 48,000$ & $\begin{array}{l}\text { Westem and central part of } \\
\text { Townsend Valley }\end{array}$ & $\begin{array}{l}\text { Differentiates } 13 \text { Tertiary and Quaternary } \\
\text { basin-fill units }\end{array}$ & $\begin{array}{l}\text { Freeman and others, } \\
\text { 1958, pl. } 42\end{array}$ \\
\hline Aeromagnetic & $1: 250,000$ & Entire Townsend Valley & Contour intervals 20 and 100 gammas & $\begin{array}{l}\text { Johnson and others, } \\
1965\end{array}$ \\
\hline $\begin{array}{l}\text { Bouguer gravity } \\
\text { and generalized } \\
\text { geology }\end{array}$ & $1: 62,500$ & Lat $45^{\circ} 15^{\prime} \mathrm{N}$. to $45^{\circ} 30^{\prime} \mathrm{N}$. & $\begin{array}{l}\text { Gravity contour interval } 5 \text { milligals. All } \\
\text { basin fill designated as Cenozoic basin } \\
\text { deposits. Includes two east-west geologic } \\
\text { sections }\end{array}$ & $\begin{array}{l}\text { Kinoshita and } \\
\text { others, } 1964 \text {, } \\
\text { sheet } 1\end{array}$ \\
\hline Aeromagnetic & $1: 62,500$ & Lat $45^{\circ} 15^{\prime} \mathrm{N}$. to $45^{\circ} 30^{\prime} \mathrm{N}$. & Contour intervals 20 and 100 gammas & $\begin{array}{l}\text { Kinoshita and } \\
\text { others, 1964, } \\
\text { sheet } 2\end{array}$ \\
\hline $\begin{array}{l}\text { Bouguer gravity } \\
\text { and generalized } \\
\text { geology }\end{array}$ & $1: 62,500$ & Lat $45^{\circ} \mathrm{N}$. to $45^{\circ} 15^{\circ} \mathrm{N}$. & $\begin{array}{l}\text { Gravity contour interval } 5 \text { milligals. All } \\
\text { basin fill designated as Cenozoic basin } \\
\text { deposits }\end{array}$ & $\begin{array}{l}\text { Kinoshita and } \\
\text { others, } 1965 \text {, } \\
\text { sheet } 1\end{array}$ \\
\hline Aeromagnetic & $1: 62,500$ & Lat $45^{\circ} \mathrm{N}$. to $45^{\circ} 15^{\prime} \mathrm{N}$. & Contour intervals 20 and 100 gammas & $\begin{array}{l}\text { Kinoshita and } \\
\text { others, } 1965 \text {, } \\
\text { sheet } 2\end{array}$ \\
\hline Geology & $1: 48,000$ & $\begin{array}{l}\text { East flank of the Elkhom } \\
\text { Mountains and adjacent } \\
\text { area of Townsend Valley }\end{array}$ & $\begin{array}{l}\text { Differentiates } 3 \text { Tertiary and } 10 \text { Quatemary } \\
\text { basin-fill units }\end{array}$ & $\begin{array}{l}\text { Klepper and others, } \\
1971 \text {, pl. } 1\end{array}$ \\
\hline Geology & $1: 48,000$ & $\begin{array}{l}\text { Canyon Ferry quadrangle } \\
\text { (lat } 46^{\circ} 30^{\prime} \mathrm{N} \text {. to } 46^{\circ} 45^{\prime} \mathrm{N} \text {., } \\
\text { long } 111^{\circ} 30^{\prime} \mathrm{W} \text {. to } \\
111^{\circ} 45^{\circ} \mathrm{W} \text {.) }\end{array}$ & $\begin{array}{l}\text { Differentiates } 4 \text { Tertiary and } 2 \text { Quaternary } \\
\text { basin-fill units }\end{array}$ & $\begin{array}{l}\text { Mertie and others, } \\
\text { 1951, pl. } 1\end{array}$ \\
\hline Geology & $1: 31,680$ & $\begin{array}{l}\text { Beaver Creek area (Range } 1 \\
\text { east, Township } 9 \text { north) }\end{array}$ & $\begin{array}{l}\text { Emphasizes bentonite deposits in Tertiary } \\
\text { sediments. Differentiates } 2 \text { Tertiary and } 2 \\
\text { Quaternary basin-fill units. }\end{array}$ & $\begin{array}{l}\text { Mertie and others, } \\
\text { 1951, pl. } 1\end{array}$ \\
\hline Geology & $1: 62,500$ & $\begin{array}{l}\text { Duck Creek Pass quadrangle } \\
\text { (lat } 46^{\circ} 15^{\prime} \mathrm{N} \text {. to } 46^{\circ} 30^{\prime} \mathrm{N} \text {., } \\
\text { long } 111^{\circ} 15^{\prime} \mathrm{W} \text {. to } \\
111^{\circ} 30^{\circ} \mathrm{W} \text {.) }\end{array}$ & $\begin{array}{l}\text { Differentiates } 2 \text { Tertiary and } 6 \text { Quatemary } \\
\text { basin-fill units }\end{array}$ & Nelson, 1963, pl. 1 \\
\hline $\begin{array}{l}\text { Cenozoic basin- } \\
\text { fill thickness }\end{array}$ & $1: 500,000$ & $\begin{array}{l}\text { Entire Townsend } \\
\text { Valley }\end{array}$ & Contour interval $1,000 \mathrm{ft}$. & $\begin{array}{l}\text { Noble and others, } \\
1982 \text {, fig. II-17, } \\
\text { p. } 66\end{array}$ \\
\hline Geology & $1: 24,000$ & $\begin{array}{l}\text { Toston quadrangle (lat } 46^{\circ} \mathrm{N} \text {. } \\
\text { to } 46^{\circ} 15^{\prime} \mathrm{N} \text {., long } \\
111^{\circ} 15^{\prime} \mathrm{W} \text {. to } 111^{\circ} 30^{\prime} \mathrm{W} \text {.) }\end{array}$ & $\begin{array}{l}\text { Differentiates } 6 \text { Tertiary and } 3 \text { Quaternary } \\
\text { basin-fill units. Includes geologic cross } \\
\text { sections }\end{array}$ & $\begin{array}{l}\text { Robinson, } 1967 \text {, } \\
\text { pl. } 1 \text { and } 2\end{array}$ \\
\hline Geology & $1: 63,360$ & Radersburg drainage area & $\begin{array}{l}\text { Generalized geology compiled from } \\
\text { previously published maps. All basin fill } \\
\text { designated as undifferentiated Tertiary and } \\
\text { Quatemary sedimentary rocks and } \\
\text { sediments }\end{array}$ & Wyatt, 1984, pl. 1 \\
\hline Isothermal & $1: 126,720$ & Radersburg drainage area & $\begin{array}{l}\text { Contour interval } 3^{\circ} \mathrm{C} \text {. Based on water } \\
\text { temperatures measured in wells and } \\
\text { springs }\end{array}$ & $\begin{array}{l}\text { Wyatt, } 1984 \text {, fig. } 6 \text {, } \\
\text { p. } 52\end{array}$ \\
\hline
\end{tabular}

Quatemary deposits cover much of the Townsend Valley. Many of the bench surfaces are mantled by $0-40 \mathrm{ft}$ of windblown silt and coarse-grained colluvium of Quatemary age (QTd). These deposits thin with distance from the mountain fronts. Quaternary alluvium (Qal) underlies flood plains of the Missouri River and its major 
tributaries. Along the Missouri River, alluvium consists of well-sorted and well-rounded sand and gravel interbedded with clay. In contrast, alluvium deposited by tributaries tends to be poorly sorted and poorly rounded and varies in lithologic content and grain size according to source area. For example, along Crow Creek, which drains a terrane of Elkhom Mountains Volcanics, alluvium contains large andesite cobbles, coarse gravel, and sand. Because Quatemary alluvium is difficult to distinguish from the underlying Sixmile Creek Formation, its thickness is uncertain, but is assumed to be about $60 \mathrm{ft}$ (Robinson, 1967; Lorenz and McMurtrey, 1956; Wyatt, 1984).

\section{Hydrology}

The Missouri River enters the southeastem edge of the basin through a bedrock gorge near Toston and flows northward through the basin into Canyon Ferry Lake. At Canyon Ferry Dam, the river leaves the Townsend Valley. Nine perennial streams contribute flow to the Missouri River from the Belt Mountains on the east side of the basin and two from the Elkhom Mountains on the west. The largest tributaries, Crow Creek and Deep Creek, provide about half of the total tributary inflow to the Missouri River in the Townsend Valley (Pardee, 1925).

The river is regulated by an irrigation dam at Toston and by Canyon Ferry Dam. In 1953, Canyon Ferry Dam replaced a smaller dam which impounded Lake Sewell, a reservoir about $8 \mathrm{mi}$ long which Canyon Ferry Lake now covers. With a usable capacity of 2,043,000 acre- $\mathrm{ft}$, Canyon Ferry Lake provides power, flood control, irrigation water, recreation, and a supplemental water supply for Helena (Shields and others, 1994, p. 114).

Streamflow data for gaging stations listed in table 85 are stored in the USGS WATSTORE database. Locations of these stations are shown on plate 1. In addition, the USGS has published monthend reservoir volume and elevation records for Canyon Ferry Lake near Helena (gaging station 06058500, drainage area 15,904 mi²) since 1953. Records of monthend contents of Lake Sewell near Helena (gaging station 06057500, drainage area 15,894 $\mathrm{mi}^{2}$ ) are available for 1936-1953. Data for years prior to 1961 are published in Water-Supply Papers; more recent data are in annual Water-Data Reports (U.S. Geological Survey, issued annually).

The quality of water from the Missouri River was determined on the basis of 155 water samples collected at Toston (gaging station 06054500). Analyses indicate that the water is a calcium sodium bicarbonate type with an average dissolved-solids concentration of $206 \mathrm{mg} / \mathrm{L}$ (Clark and Dutton, in press).

The Missouri River in the Townsend Valley sometimes contains concentrations of arsenic greater than drinking-water standards. The Madison River, a major tributary to the Missouri River, has high concentrations of arsenic because of the inflow of naturally arsenic-enriched geothermal water from Yellowstone National Park. Surface-water samples were collected at several sites in the Townsend Valley (gaging stations 06053400, 06054500, 06055500, and 06058502) and analyzed for arsenic under various hydrologic conditions from 1985 to 1987 . Results indicated that tributaries to the Missouri River (other than the Madison River) had small concentrations of total recoverable arsenic (undetected to $1 \mu \mathrm{g} / \mathrm{L}$ ), but the Missouri River had significant concentrations (Knapton and Horpestad, 1987; Knapton and Brosten, 1987). From 1973 to 1994, the concentration of total recoverable arsenic in the Missouri River at Toston (gaging station 06054500) ranged from 10 to $69 \mu \mathrm{g} / \mathrm{L}$. The U.S. Environmental Protection Agency (1991) has established a maximum contaminant level of $50 \mu \mathrm{g} / \mathrm{L}$ arsenic for treated drinking water. In general, the largest arsenic concentrations were documented during low flows in the summer of 1994; and the smallest concentrations occurred during high flows in the spring of 1993 (U.S. Geological Survey, issued annually). At low flow, the great majority of the arsenic is in the dissolved phase, as would be expected from a geothermal source.

At the base of the Elkhom Mountains, tributaries have good quality water. On the basis of 11 samples from Crow Creek (gaging station 06055500) and 12 samples from Beaver Creek (gaging station 06057400), these streams have a calcium bicarbonate type water with average dissolved-solids concentrations of 44 and $47 \mathrm{mg} / \mathrm{L}$, respectively (Clark and Dutton, in press). However, occasional sampling near the mouth of Crow Creek in 1973 revealed that turbidity, sodium, chloride, and sulfate concentrations increased as the stream traversed agricultural areas between Radersburg and the Missouri River (Braico and Botz, 1974). 
Table 85. Summary of data for U.S. Geological Survey streamflow-gaging stations in the Townsend Valley, Montana

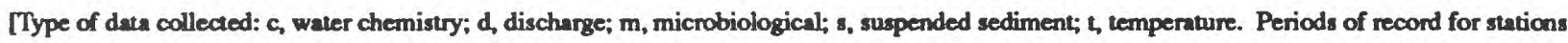
that were being operated as of November 1994 are indicated by the first year of record followed by a dash only. Abbreviations: $\mathrm{ft}^{3} / \mathrm{s}$, cubic feet per second. Symbol: --, no data]

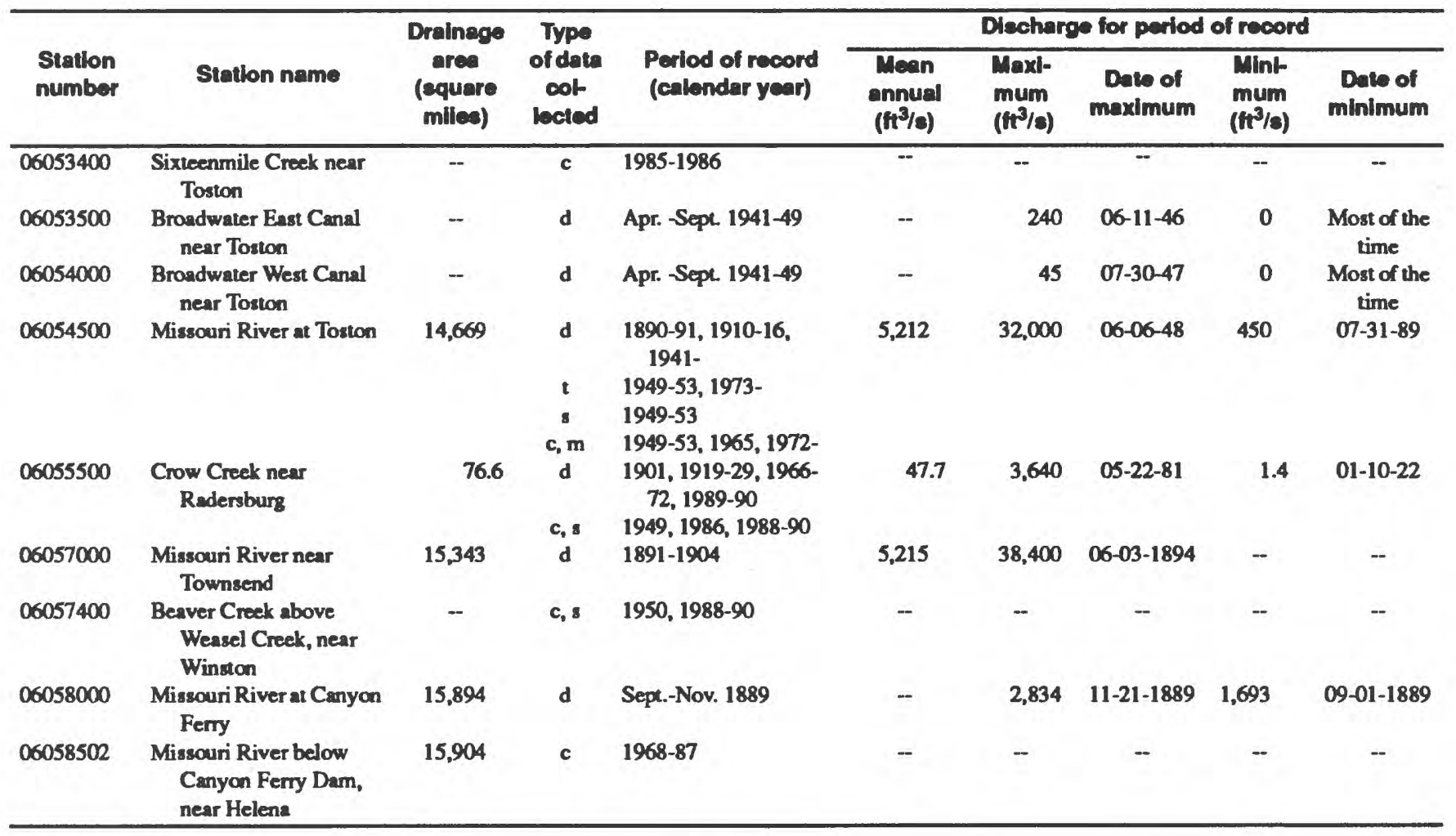

Wright and others (1974) determined that nitrate loading to the Missouri River increased between Toston and Townsend because of agricultural runoff. However, agricultural activities evidently did not affect phosphate concentrations in the same reach (Wright and others, 1974).

Nitrogen enrichment in the Missouri River causes eutrophication of Canyon Ferry Lake, which often results in thick algae blooms (Montana Department of Health and Environmental Sciences, 1994, p. 28). Nitrogen-fixing blue-green algae further increase nitrate concentrations in the lake. As a result, nitrate concentrations are higher in the Missouri River below Canyon Ferry Dam than above the reservoir. Ortho-phosphorus concentrations are also higher below the dam (Wright and others, 1974).

Ground water is an important resource in the Townsend Valley. It provides the municipal-water supply for Townsend, irrigation water near Radersburg, and domestic-water supplies throughout the basin. Ground water is withdrawn from three hydrogeologic units in the Townsend Valley: Quaternary alluvium, Tertiary sediments, and bedrock.

Wells completed in Quaternary alluvium withdraw sufficient ground-water supplies for domestic and stock use. Beneath flood plains of the Missouri River and its major tributaries, alluvium typically yields at least 10 $\mathrm{gal} / \mathrm{min}$ to wells. In basin-marginal areas, where bedrock is shallow, alluvium beneath perennial stream valleys is the most reliable source of water. Yield and specific-capacity data for alluvial wells are summarized in table 86. Most ground water in Quaternary alluvium is unconfined in the Townsend Valley.

The yield of wells completed in Tertiary sediments varies widely depending on local permeability, the hydraulic connection between permeable layers, and sources of recharge to the sediments. The large variation in yield and specific-capacity values for wells completed in Tertiary sediments (table 86) attests to the variability of 
Table 86. Summary of data for yield and specific capacity of wells completed in selected hydrogeologic units in the Townsend Valley, Montana

[Source: Dutton and others, 1995. Hydrogeologic unit: Qal, Holocene and Pleistocene alluvial deposits; Ts, Tertiary sedimentary deposits and rocks. Abbreviations: gal/min, gallon per minute; (gal/min)/fh, gallon per minute per fook]

\begin{tabular}{|c|c|c|c|c|c|c|c|c|c|c|}
\hline \multirow{2}{*}{$\begin{array}{l}\text { Hydro- } \\
\text { geologic } \\
\text { unit }\end{array}$} & \multirow[b]{2}{*}{$\begin{array}{c}\text { Number of } \\
\text { wells }\end{array}$} & \multicolumn{4}{|c|}{ Yleld (gal/min) } & \multirow[b]{2}{*}{$\begin{array}{c}\text { Number of } \\
\text { wells }\end{array}$} & \multicolumn{4}{|c|}{ Specilic capecity [(gal/min)/ft] } \\
\hline & & Maan & Modian & $\begin{array}{l}\text { Mint } \\
\text { mum }\end{array}$ & $\begin{array}{l}\text { Maxt } \\
\text { mum }\end{array}$ & & Mean & Medlan & $\begin{array}{l}\text { Minl- } \\
\text { mum }\end{array}$ & $\begin{array}{l}\text { Mext- } \\
\text { mum }\end{array}$ \\
\hline Qal & 10 & 180 & 22 & 5.5 & 650 & 8 & 24 & 4.6 & 0.6 & 130 \\
\hline Ts & 42 & 870 & 480 & 3.5 & 3,400 & 37 & 18 & 12 & .1 & 120 \\
\hline
\end{tabular}

these factors within the Townsend Valley. The wells with the largest yields were completed in permeable, generally thick, sandy layers beneath the Radersburg area, which is adjacent to saturated Mississippian limestone (Wyatt, 1984). In contrast, most of the wells with smaller yields are distributed throughout the rest of the basin, primarily on benches.

Wyatt (1984) determined hydraulic characteristics of the aquifer in Quaternary and Tertiary basin-fill in the Radersburg area. Thirty-six specific-capacity tests of 34 domestic, stock, and observation wells resulted in estimated transmissivity values ranging from 20 to $13,000 \mathrm{ft}^{2} / \mathrm{d}$ and averaging $880 \mathrm{ft}^{2} / \mathrm{d}$; the average estimated hydraulic-conductivity value was $72 \mathrm{ft} / \mathrm{d}$. Twenty-nine specific-capacity tests of 23 large-diameter irrigation wells gave estimated transmissivity values ranging from 1,300 to $130,000 \mathrm{ft}^{2} / \mathrm{d}$ and averaging $6,700 \mathrm{ft}^{2} / \mathrm{d}$; the estimated hydraulic conductivity average was $58 \mathrm{ft} / \mathrm{d}$. Analyses of a 44-hour aquifer test resulted in a transmissivity of 40,000 $\mathrm{ft}^{2} / \mathrm{d}$, a hydraulic conductivity of $240 \mathrm{ft} / \mathrm{d}$, and a storage coefficient of $1.6 \times 10^{-3}$. This small storage coefficient is indicative of a confined aquifer. However, ground water in shallower Tertiary deposits that are not overlain by finegrained deposits may be unconfined.

Although most bedrock surrounding the Townsend Valley yields limited amounts of water to wells, Mississippian limestone is an important aquifer. Karst and evaporite-solution breccias, fracturing, and possibly dolomitization create secondary permeability in the otherwise impermeable limestone. Transmissivity values estimated from nine specific-capacity tests of eight wells completed in Mississippian limestone near Radersburg ranged from 13 to $2,700 \mathrm{ft}^{2} / \mathrm{d}$ and averaged $800 \mathrm{ft}^{2} / \mathrm{d}$ (Wyatt, 1984). Several large springs issue from Mississippian limestone near the eastern and southwestem basin boundaries including Big Spring (04N03E05CCBD), which discharges more than $5 \mathrm{Mgal} / \mathrm{d}$ (Lorenz and McMurtrey, 1956). Temperature and chemical data indicate that ground water from the limestone recharges basin-fill aquifers (Wyatt, 1984). Other bedrock formations may yield small quantities to wells or springs locally. These are the Lower Cretaceous Kootenai Formation, the Middle Pennsylvanian Quadrant Formation, the Middle and Upper Devonian Jefferson Limestone, the Upper Cambrian Pilgrim Limestone, the Middle Cambrian Meagher Limestone, and some of the formations in the Middle Proterozoic Belt Supergroup (Lorenz and McMurtrey, 1956).

A substantial quantity of ground-water data is available for the Townsend Valley. In 1921, Pardee (1925) measured depths to water in 38 wells prior to the onset of large-scale irrigation. Pardee (1925) observed that the water table had permanently risen by as much as $30 \mathrm{ft}$ in local irrigated areas and small areas had already become too waterlogged for cultivation. Years of flood imigation in the Townsend Valley had caused the water table to rise to the extent that waterlogging became a serious problem. Large areas of land that were productive in the 1930's were "barely suitable for grazing" by the 1950's (Lorenz and McMurtrey, 1956, p. 213). With the completion of Canyon Ferry Dam in 1953, much of the waterlogged area was covered by Canyon Ferry Lake.

Interest in ground water in the Radersburg area prompted a USGS data-collection effort involving long-term water-level measurements in 17 wells (table 87). Since the well field was developed in the 1960's, water levels have declined about $0.4 \mathrm{ft} / \mathrm{yr}$ (Wyatt, 1984). However, comparison between potentiometric-surface maps representing several periods (table 88) shows that the overall ground-water flow direction has remained toward the east and 
northeast. In the Townsend Valley as a whole, ground water generally flows from the uplands toward the Missouri River flood plain, then northward, paralleling the Missouri River.

Table 87. Summary of water-level data for selected wells in the Townsend Valley, Montana [Hydrogeologic unit: Ts, Tertiary sedimentary deposits and rocks]

\begin{tabular}{|c|c|c|c|c|c|c|c|}
\hline \multirow[b]{2}{*}{ Location number } & \multirow{2}{*}{$\begin{array}{l}\text { Depth of } \\
\text { well, in feet } \\
\text { below land } \\
\text { surface }\end{array}$} & \multirow{2}{*}{$\begin{array}{l}\text { Hydro- } \\
\text { geologic } \\
\text { unit }\end{array}$} & \multirow{2}{*}{$\begin{array}{l}\text { Perlod of } \\
\text { record }\end{array}$} & \multicolumn{4}{|c|}{ Water levd, in feet bolow land surface } \\
\hline & & & & Higheat & $\begin{array}{l}\text { Date of } \\
\text { highest }\end{array}$ & Loweat & $\begin{array}{l}\text { Date of } \\
\text { lowest }\end{array}$ \\
\hline 05N01E27CCBB01 & 215 & Ts & $1962-91$ & 75.11 & $11-02-83$ & 97.17 & $10-07-89$ \\
\hline 05N01E33BACD01 & 252 & Ts & $1967-91$ & 118.79 & $04-25-77$ & 132.38 & $12-07-79$ \\
\hline 05N01E34CCCC01 & 325 & Ts & $1971-91$ & 80.00 & 04-04-71 & 94.02 & 04-30-91 \\
\hline 05N01E34DCCD01 & 108 & Ts & $1977-91$ & 47.00 & $04-25-77$ & 56.75 & 04-30-91 \\
\hline 04N01E02BBCC01 & 191 & Ts & $1977-92$ & 31.85 & $05-15-79$ & 56.54 & $04-25-77$ \\
\hline 04N01E02CCBB01 & 275 & Ts & $1977-91$ & 44.49 & $04-25-77$ & 68.19 & $11-04-80$ \\
\hline 04N01E02CCCB01 & 250 & Ts & $1964-91$ & 39.60 & $10-21-64$ & 59.58 & $07-29-80$ \\
\hline 04N01E03BABA01 & 220 & Ts & $1977-91$ & 68.56 & $04-25-77$ & 86.67 & $07-29-80$ \\
\hline 04N01E09ADB 01 & 349 & Ts & $1977-91$ & 117.87 & $04-21-82$ & 147.20 & $11-16-77$ \\
\hline 04N01E10BBCB01 & 447 & Ts & $1958-92$ & 93.79 & $06-20-78$ & 127.96 & $09-08-92$ \\
\hline 04N01E10BCCC01 & 186 & Ts & $1977-91$ & 107.66 & $06-05-81$ & 143.30 & $12-01-82$ \\
\hline 04N01E11BCCB01 & 404 & Ts & $1964-91$ & 45.00 & $08-08-64$ & 65.30 & $05-01-91$ \\
\hline 04N01E11CBDD01 & 202 & Ts & $1977-91$ & 45.86 & $04-12-77$ & 57.87 & $12-01-82$ \\
\hline 04N01E13BCBC01 & 240 & Ts & $1977-91$ & 30.00 & $04-01-77$ & 40.81 & $09-23-88$ \\
\hline 04N01E15BCBB01 & 348 & Ts & $1967-92$ & 123.00 & $05-29-67$ & 146.34 & $09-26-91$ \\
\hline 04N01E15CDBA01 & 342 & Ts & $1972-91$ & 119.86 & $04-25-77$ & 140.78 & $11-16-77$ \\
\hline 04N01E23BAC 01 & 332 & Ts & $1964-91$ & 59.50 & $06-27-64$ & 78.14 & $05-01-91$ \\
\hline
\end{tabular}

Table 88. Potentiometric-surface maps of the Townsend Valley, Montana

\begin{tabular}{|c|c|c|c|c|}
\hline Location & $\begin{array}{l}\text { Datee water lovels were } \\
\text { measured }\end{array}$ & Scale & $\begin{array}{l}\text { Contour } \\
\text { Interval, } \\
\text { in feet }\end{array}$ & Reference \\
\hline Entire Townsend Valley & Summer 1991 & $1: 750,000$ & 100 & Briar and others, in press \\
\hline Entire Townsend Valley & Summers of 1949 and 1950 & $1: 62,500$ & 10 & $\begin{array}{l}\text { Lorenz and McMurtrey, } 1956 \text {, } \\
\text { pl. } 20\end{array}$ \\
\hline Radersburg drainage area & May 1979 to Apr. 1980 & $1: 126,720$ & 20 & Wyatt, 1984 , fig. 4 , p. 44 \\
\hline
\end{tabular}

Basin-fill aquifers in the Townsend Valley are recharged by precipitation and snowmelt, surplus irrigation water, leakage from canals, infiltration from tributary streams, possible subsurface flow from the Westem Three Forks Valley, and subsurface inflow from bedrock. The ground-water contribution area for the basin (fig. 2, pl. 1), is about $1,240 \mathrm{mi}^{2}$. Infiltration anywhere within this area potentially could recharge basin-fill aquifers in the Townsend Valley. Sulfate- and strontium-enrichment and elevated temperatures in the basin-fill aquifer indicate that the Mississippian limestone aquifer recharges the basin fill near Radersburg (Wyatt, 1984). The presence of geothermal springs provides further evidence of subsurface inflow from bedrock. Bedford Hot Spring (07N01E23BAAD) about $0.5 \mathrm{mi}$ northwest of Townsend, discharges water with a temperature of $23.6^{\circ} \mathrm{C}$ from Tertiary sediments at a rate of $1,500 \mathrm{gal} / \mathrm{min}$. Greyson Spring (06N02E21BAAA), which issues from Tertiary sediments about $0.6 \mathrm{mi}$ southeast of Townsend, has somewhat elevated water temperatures averaging about $18^{\circ} \mathrm{C}$ (Sonderegger and Bergantino, 1981). Water discharges from basin-fill aquifers by evapotranspiration, pumpage from wells, possible subsurface flow to the Helena Valley, and seepage into springs, seeps, irrigation drains, stream channels, and Canyon Ferry Lake. 
The quality of ground water in the basin was determined on the basis of 57 samples analyzed for major ions and measured dissolved-solids concentrations and 20 samples in which dissolved-solids concentrations were estimated from specific-conductance measurements. Most of the ground water in the Townsend Valley is a calcium bicarbonate type with dissolved-solids concentrations of less than $500 \mathrm{mg} / \mathrm{L}$. However, ground water in the southem third of the basin is a mixed-cation bicarbonate type, in which calcium, magnesium, and sodium are the dominant cations. Southwest of Toston and northeast of Canyon Ferry Lake sulfate is the dominant anion. Dissolved-solids concentrations exceed $500 \mathrm{mg} / \mathrm{L}$ around most of Canyon Ferry Lake and in other local areas (Clark and Dutton, in press).

Use of Missouri River water to irrigate crops in the Townsend Valley has raised concems that arsenic-enriched irrigation water may have increased arsenic concentrations in the basin-fill aquifers. However, recent analyses indicate arsenic concentrations of less that $20 \mu \mathrm{g} / \mathrm{L}$ in wells that are completed beneath irrigated fields in the basin (L.K. Tuck, U.S. Geological Survey, written commun., 1995).

\section{Selected References}

Briar, D.W., Lawlor, S.M., Stone, M.A.J., Parliman, D.J., Schaefer, J.L., and Eloise Kendy, in press, Ground-water levels in intermontane basins of the Northern Rocky Mountains, Montana and Idaho: U.S. Geological Survey Hydrologic Investigations Atlas 738-B, 1 sheet, scale 1:750,000.

Braico, R.D., and Botz, M.K., 1974, Water quality inventory and management plan, Missouri-Sun-Smith basin, Montana: Montana Department of Health and Environmental Sciences, $162 \mathrm{p}$.

Clark, D.W., and Dutton, D.M., in press, Quality of ground water and surface water in intermontane basins of the Northern Rocky Mountains, Montana and Idaho: U.S. Geological Survey Hydrologic Investigations Atlas 738-C, 1 sheet, scale 1:750,000.

Davis, W.E., Kinoshita, W.T., and Smedes, H.W., 1963, Bouguer gravity, aeromagnetic, and generalized geologic map of East Helena and Canyon Ferry quadrangles and part of the Diamond City quadrangle, Lewis and Clark, Broadwater and Jefferson Counties, Montana: U.S. Geological Survey Geophysical Investigations Map GP-444, 2 sheets, scale 1:250,000.

Dutton, D.M., Lawlor, S.M., Briar, D.W., and Tresch, R.E., 1995, Hydrogeologic data for the Northern Rocky Mountains intermontane basins, Montana: U.S. Geological Survey Open-File Report 95-143, 94 p.

Fields, R.W., Rasmussen, D.L., Tabrum, A.R., and Nichols, Ralph, 1985, Cenozoic rocks of the intermontane basins of western Montana and eastern Idaho--A summary, in Flores, R.M., and Kaplan, S.S., eds., Cenozoic paleogeography of west-central United States: Denver, Colo., Society of Economic Paleontologists and Mineralogists, Rocky Mountain Section, p. 9-36.

Freeman, V.L., Ruppel, E.T., and Klepper, M.R., 1958, Geology of part of the Townsend Valley, Broadwater and Jefferson Counties, Montana: U.S. Geological Survey Bulletin 1042N, p. 481-556.

Johnson, R.W., Jr., Henderson, J.R., and Tyson, N.S., 1965, Aeromagnetic map of the Boulder batholith area, southwestem Montana: U.S. Geological Survey Geophysical Investigations Map GP-538, scale 1:250,000.

Kaczmarek, M.B., 1974, Geothermometry of selected Montana hot springs: Bozeman, Montana State University, M.S. thesis, $141 \mathrm{p}$.

Kinoshita, W.T., Davis, W.E., and Robinson, G.D., 1965, Aeromagnetic, Bouguer gravity, and generalized geologic map of Toston and Radersburg quadrangles and part of the Devils Fence quadrangle, Gallatin, Broadwater, and Jefferson Counties, Montana: U.S. Geological Survey Geophysical Investigations Map GP-496, 2 sheets, scale 1:62,500.

Kinoshita, W.T., Davis, W.E., Smedes, H.W., and Nelson, W.H., 1964, Bouguer gravity, aeromagnetic, and generalized geologic map of Townsend and Duck Creek Pass quadrangles, Broadwater County, Montana: U.S. Geological Survey Geophysical Investigations Map GP-439, 2 sheets, scale 1:62,500.

Klepper, M.R., Weeks, R.A., and Ruppel, E.T., 1957, Geology of the southern Elkhorn Mountains, Jefferson and Broadwater counties, Montana: U.S. Geological Survey Professional Paper 292, 82 p.

Klepper, M.R., Ruppel, E.T., Freeman, V.L., and Weeks, R.A., 1971, Geology and mineral deposits, east flank of the Elkhorn Mountains, Broadwater County, Montana: U.S. Geological Survey Professional Paper 665, 66 p.

Knapton, J.R., and Brosten, T.M., 1987, Supplemental arsenic data for selected streams in the Missouri River basin, Montana, 1987: U.S. Geological Survey Open-File Report 87-697, 14 p. 
Knapton, J.R., and Horpestad, A.A., 1987, Arsenic data for streams in the upper Missouri River basin, Montana and Wyoming: U.S. Geological Survey Open-File Report 87-124, 25 p.

Lorenz, H.W., and McMurtrey, R.G., 1956, Geology and occurrence of ground water in the Townsend Valley, Montana, with a section on Chemical quality of the water, by H.A. Swenson: U.S. Geological Survey Water-Supply Paper 1360-C, p. 171290.

McCulloch, Robin, 1993, Montana mining directory 1992: Montana Bureau of Mines and Geology Bulletin 131, 76 p.

Mertie, J.B., Jr., Fischer, R.P., and Hobbs, S.W., 1951, Geology of the Canyon Ferry quadrangle, Montana: U.S. Geological Survey Bulletin 972, 97 p.

Montana Department of Health and Environmental Sciences, 1994, Montana water quality, 1994: Helena, Water Quality Bureau, Montana 305(b) Report, 159 p.

[Montana] State Engineer's Office, 1956a, Water resources survey, Broadwater County, Montana--Part 1, History of land and water use on irrigated areas: Helena, Mont., State Engineer's Office, 37 p.

1956b, Water resources survey, Broadwater County, Montana--Part 2, Maps showing irrigated areas: Helena, Mont., State Engineer's Office, 19 p.

1957a, Water resources survey, Lewis and Clark County, Montana--Part 1, History of land and water use on irrigated areas: Helena, Mont, State Engineer's Office, 59 p.

1957b, Water resources survey, Lewis and Clark County, Montana--Part 2, Maps showing irrigated areas: Helena, Mont. State Engineer's Office, 43 p.

National Oceanic and Atmospheric Administration, 1992, Monthly normals of temperature, precipitation, and heating and cooling degree days, 1961-90, Montana: Asheville, N.C., Climatography of the United States no. 81, unpaged.

Nelson, W.H., 1963, Geology of the Duck Creek Pass quadrangle, Montana: U.S. Geological Survey Bulletin 1121-J, 56 p.

Noble, R.A., Bergantino, R.N., Patton, T.W., Sholes, B.C., Daniel, Faith, and Schofield, Judeykay, 1982, Occurrence and characteristics of ground water of Montana--Volume 2, The Rocky Mountain Region: Montana Bureau of Mines and Geology Open-File Report 99, 132 p.

Pardee, J.T., 1925, Geology and ground-water resources of Townsend Valley, Montana: U.S. Geological Survey Water-Supply Paper 539,61 p.

Robinson, G.D., 1967, Geologic map of the Toston quadrangle, southwest Montana: U.S. Geological Survey Miscellaneous Geological Investigations Map I-486, scale 1:24,000.

Shields, R.R., White, M.K., Broston, T.M., and Chambers, C.L., 1994, Water resources data, Montana, water year 1993: U.S. Geological Survey Water-Data Report MT-93-1, 512 p.

Sonderegger, J.L., and Bergantino, R.N., 1981, Geothermal resources map of Montana: Montana Bureau of Mines and Geology Hydrogeologic Map 4, scale 1:1,000,000.

Tuck, L.K., Briar, D.W., and Clark, D.W., in press, Geologic history and hydrogeologic units of intermontane basins of the Northern Rocky Mountains, Montana and Idaho: U.S. Geological Survey Hydrologic Investigations Atlas 738-A, 2 sheets, scale 1:750,000.

U.S. Environmental Protection Agency, 1991, Maximum contaminant levels (subpart B of part 141, National primary drinkingwater regulations): U.S. Code of Federal Regulations, Title 40, Parts 100 to 149, revised July 1, 1991, p. 585-588.

U.S. Geological Survey, 1914, Profile surveys of Missouri River from Great Falls to Three Forks, Montana: U.S. Geological Survey Water-Supply Paper 367, 8 p., 13 plates, scale 1:31,680. issued annually, Water resources data, Montana: Helena, Mont., U.S. Geological Survey Water-Data Report.

Wright, J.C., Rada, Ronald, and Martin, Chadwick, 1974, An investigation into the extent and cause of eutrophication in Canyon Ferry Reservoir, Montana: Bozeman, Mont, Montana University Joint Water Resources Research Center Report 50, 33 p.

Wyatt, G.M., 1984, Hydrogeology and geothermal potential of the Radersburg Valley, Broadwater County, Montana: Bozeman, Montana State University, M.S. thesis, 160 p. 


\section{Geography}

The Upper Blackfoot River Valley consists of two northwest-trending lobes connected by the southwest-flowing Blackfoot River (pl. 1). The $100-\mathrm{mi}^{2}$ basin is bounded by the Alice Mountains on the northeast, the Continental Divide on the southeast, Dalton Mountain on the west, and Stonewall and Red Mountains on the northwest. The eastem, upstream, half of the basin has hummocky topography characteristic of glaciated terrane, with numerous ponds and wetlands. In contrast, the relatively level flood plain of the Blackfoot River is the major topographic feature in the westem half of the basin. The Upper Blackfoot River Valley ranges in altitude from about $4,500 \mathrm{ft}$ where the Blackfoot River flows out of the basin to about $7,000 \mathrm{ft}$ on the highest mountain foothill.

The climate of the Upper Blackfoot River Valley is typical of higherelevation intermontane basins of the Northern Rocky Mountains west of the

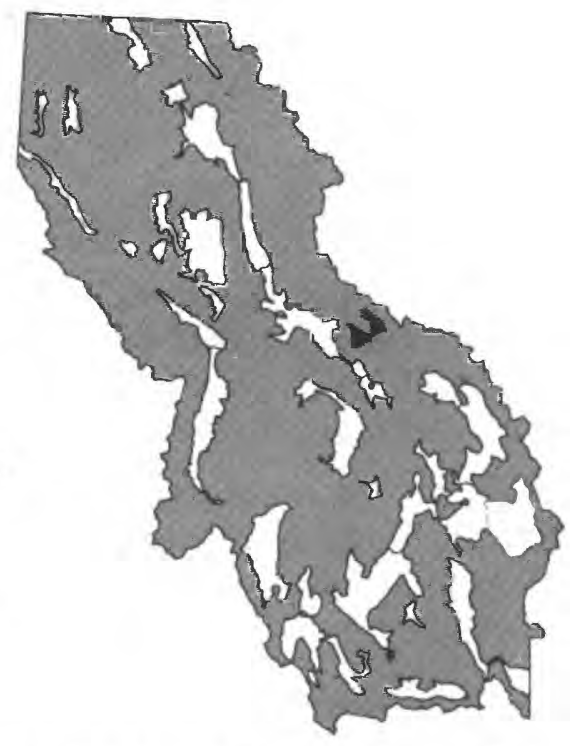
Continental Divide, with cold, humid winters and mild summers. On the basis of the 1961-90 period of record, the average annual precipitation at the Lincoln Ranger Station (altitude 4,580 ft), which is about $1 \mathrm{mi}$ east of Lincoln, is $18.88 \mathrm{in}$. and the average annual temperature is $40.7^{\circ} \mathrm{F}$ (National Oceanic and Atmospheric Administration, 1992). The average last occurrence of $32^{\circ} \mathrm{F}$ is July 8 , and the average first occurrence is August 13 (Natural Resources Conservation Service, U.S. Department of Agriculture, unpub. data, 1994). Mean monthly climatic data for the Lincoln Ranger Station are plotted in figure 29.

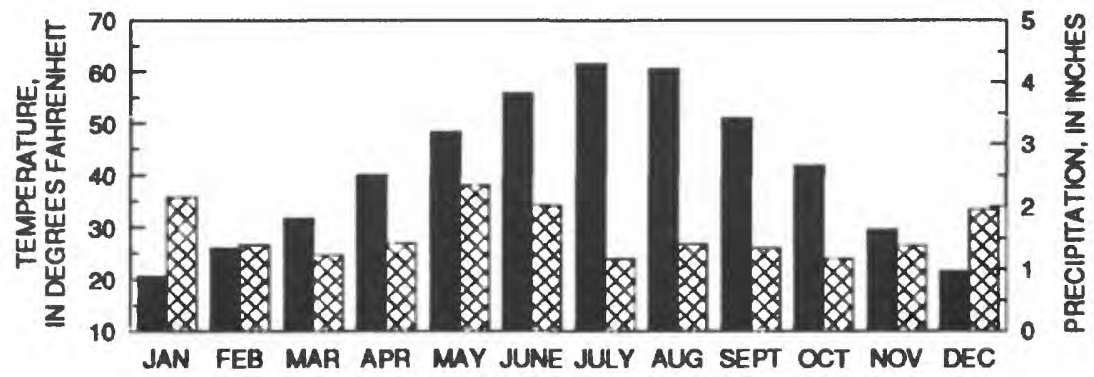

EXPLANATION

MEAN MONTHLY TEMPERATURE FOR 1961-90 PERIOD OF RECORD

Q MEAN MONTHLY PRECIPITATION FOR 1961-90 PERIOD OF RECORD

Figure 29. Mean monthly precipitation and temperature at the Lincoln Ranger Station, Mont. Data from National Oceanic and Atmospheric Administration (1992).

Land uses include timber harvesting, livestock grazing, limited irrigated hay production, and residential development (J.C. Eggen, Agricultural Stabilization and Conservation Service, oral commun., 1993). Diversions from the Blackfoot River irrigate about 400 acres and tributary diversions supply an additional 1,500 acres within the Blackfoot River drainage area ([Montana] State Engineer's Office, 1957a). About 1,000 people reside in the Upper Blackfoot River Valley, including 657 in the unincorporated community of Lincoln (1990 census). Residential development, while not a major land use, has increased in recent years.

Mining has been an important land use in the mountains surrounding the Upper Blackfoot River Valley for more than 100 years. Gold and lead are actively mined in the Poorman Creek drainage 5 mi southeast of Lincoln and gold is placer-mined about 3 mi northwest of Lincoln. In addition, exploration is underway for gold, silver, and copper in the Blackfoot River headwaters area (McCulloch, 1993, p. 1, 16, 44, 45). If permitted, a proposed mining 
operation near the confluence with the Landers Fork would use cyanide heap-leaching to extract an estimated 3.7 million ounces of gold from about $\mathbf{4 0 0}$ million tons of rock (Len Iwanski, Associated Press, Helena Independent Record, Oct. 11, 1994, p. 1A)

\section{Geology}

The Upper Blackfoot River Valley formed by dropping down along three subparallel normal faults. These faults are associated with the Lewis and Clark Line (fig. 4), a northwest-trending zone of high-angle normal, reverse, and right-lateral, strike-slip faults (Mudge and others, 1982; Wallace, 1987). The Upper Blackfoot River Valley intermontane basin is filled with more than $6,000 \mathrm{ft}$ of Cenozoic sediments (Noble and others, 1982, p. 48-51).

Several investigators have examined the geology of the upper Blackfoot River Valley (table 89). The geologic units described by previous investigators are summarized below. These geologic units are referenced to hydrogeologic units defined in this study (table 2) to provide a consistent regional framework. In the following discussion, the hydrogeologic-unit abbreviations are italicized.

Table 89. Geologic and geophysical maps of the Upper Blackfoot River Valley, Montana

\begin{tabular}{|c|c|c|c|c|}
\hline Type of map & Scale & Location & Map features & Reference \\
\hline Geology & $1: 48,000$ & $\begin{array}{l}\text { Entire Upper } \\
\text { Blackfoot River } \\
\text { Valley }\end{array}$ & $\begin{array}{l}\text { Differentiates four Quaternary basin-fill units: } \\
\text { alluvium, glacial-lakebed deposits, glacial } \\
\text { outwash, and till. Five geologic sections are } \\
\text { shown in fig. } 6 \text {. }\end{array}$ & $\begin{array}{l}\text { Coffin and Wilke, 1971, } \\
\text { fig. } 5\end{array}$ \\
\hline $\begin{array}{l}\text { Aeromagnetic } \\
\text { and simplified } \\
\text { geology }\end{array}$ & $1: 250,000$ & $\begin{array}{l}\text { Entire Upper } \\
\text { Blackfoot River } \\
\text { Valley }\end{array}$ & Contour interval 20 gammas & $\begin{array}{l}\text { Kleinkopf and Mudge, } \\
\text { 1972, pl. } 1\end{array}$ \\
\hline Geology & $1: 250,000$ & North of lat $47^{\circ} \mathrm{N}$. & $\begin{array}{l}\text { Differentiates three basin-fill units: Tertiary lake } \\
\text { deposits, Quatemary glacial deposits, and } \\
\text { Quaternary alluvial and colluvial deposits. }\end{array}$ & Mudge and others, 1982 \\
\hline Geology & $1: 250,000$ & South of lat $47^{\circ} \mathrm{N}$. & $\begin{array}{l}\text { Differentiates two basin-fill units: Tertiary } \\
\text { sedimentary deposits and rocks, and } \\
\text { Quatemary surficial deposits. }\end{array}$ & Wallace, 1987 \\
\hline
\end{tabular}

Metasedimentary and igneous bedrock bound the basin. The metasedimentary rocks that border the basin on the north and southwest consist of argillite, siltite, and quartzite, whereas the rocks that border the basin on the west also include limestone and dolomite. North of the basin, the metasedimentary rocks have been intruded by large diorite sills and local dikes of Proterozoic age (Mudge and others, 1982; Wallace, 1987). A 500-ft thick diorite sill crosses beneath the basin near Alice Creek, and several wells penetrate diorite beneath basin fill in the northeastem part of the basin (Coffin and Wilke, 1971). Tertiary basaltic and andesitic volcanic rocks (QTKe) crop out near the center of the basin (Mudge and others, 1982; Wallace, 1987).

Tertiary sediments (Ts) overlie Proterozoic bedrock in much of the basin and crop out south of the Blackfoot River near its confluence with Alice Creek. These sediments may be a much as $380 \mathrm{ft}$ thick and consist of gray, yellowish-gray, and gray-brown silt, sandy silt, clay, shale, marl, and tuff, with some poorly sorted conglomerate, thin beds of carbonate rock, and thin coal seams (Mudge and others, 1982).

Quaternary deposits in the Upper Blackfoot River Valley include Pleistocene glacial till $(Q g)$, glacial-lakebed deposits $(Q g)$, glacial outwash (Qal); and Holocene alluvium (Qal). More than $100 \mathrm{ft}$ of glacial till, representing at least two glacial advances, overlie Tertiary sediments in much of the basin. Lesser thicknesses mantle bedrock at higher elevations. These unsorted deposits consist of sand, gravel, cobbles and boulders in a light-red to pink, silty, clayey matrix with local lenses of sand and gravel less than $10 \mathrm{ft}$ thick. Silt and clay generally account for more 
than half of the material, although the percentage of larger clasts increases with proximity to bedrock (Coffin and Wilke, 1971).

Pleistocene glacial-lake deposits consisting of varved, light-pinkish gray, silt and clay crop out in a 1-mi area $^{2}$ in the northeastern part of the basin. The deposit interfingers with alluvium at its extremities and is more than $30 \mathrm{ft}$ thick at its center (Coffin and Wilke, 1971).

Glacial outwash consists of reworked glacial till deposited by glacial meltwater. At least $80 \mathrm{ft}$ of light-red to pink glacial outwash underlies several tributary valleys. Whereas glacial till deposits tend to form hummocky, irregular terrain, glacial outwash deposits form smoother, flatter slopes. Glacial outwash tends to be similar in composition to till, but with less silt and clay (Coffin and Wilke, 1971).

Downstream, glacial outwash grades into moderately sorted alluvium beneath the flood plains of the Blackfoot River and its major tributaries. Along the Blackfoot River, alluvium averages 90 to $100 \mathrm{ft}$ thick and consists of well-sorted coarse sand to medium gravel with some thin beds containing 40 to 60 percent clay, silt, and very fine sand, and some thick beds containing poorly sorted material of all sizes. Alluvium also underlies smaller tributary valleys, where it is poorly sorted and contains a large percentage of fine-grained material (Coffin and Wilke, 1971).

\section{Hydrology}

Surface water is one of the most important natural resources in this basin. The Blackfoot River is classified as a Class I trout stream by the Montana Department of Fish, Wildlife and Parks. Surface water from the river and its tributaries is used extensively for irrigation and for instream uses such as wildlife habitat, fishing, boating, and other types of recreation. Numerous lakes and wetlands provide nesting sites for the area's abundant waterfowl.

The Blackfoot River flows westward from its headwaters at the Continental Divide to its confluence with the Clark Fork at Milltown. Its average gradient through the Upper Blackfoot River Valley is about $25 \mathrm{ft} / \mathrm{mi}$ (Coffin and Wilke, 1971). Streamflow data for gaging stations listed in table 90 are stored in the USGS WATSTORE database. Locations of the stations are shown on plate 1.

Table 90. Summary of data for U.S. Geological Survey streamflow-gaging stations in the upper Blackfoot River Valley, Montana

[Type of data collected: $\mathrm{c}$, water chemistry; $\mathrm{d}$, discharge. Abbreviations: $\mathrm{ft}^{3} / \mathrm{s}$, cubic feet per second. Symbol: --, no data]

\begin{tabular}{|c|c|c|c|c|c|c|c|c|c|}
\hline \multirow[b]{2}{*}{$\begin{array}{l}\text { Station } \\
\text { number }\end{array}$} & \multirow[b]{2}{*}{ Station name } & \multirow{2}{*}{$\begin{array}{l}\text { Drainage } \\
\text { area } \\
\text { (square } \\
\text { milea) }\end{array}$} & \multirow{2}{*}{$\begin{array}{l}\text { Type } \\
\text { of data } \\
\text { cole } \\
\text { lected }\end{array}$} & \multirow{2}{*}{$\begin{array}{l}\text { Perlod of } \\
\text { record } \\
\text { (coliendar } \\
\text { year) }\end{array}$} & \multicolumn{5}{|c|}{ Diecharge for period of record } \\
\hline & & & & & $\begin{array}{l}\text { Moan } \\
\text { annuel } \\
\left(\mathrm{ft}^{3} / \mathrm{s}\right)\end{array}$ & $\begin{array}{l}\text { Maxl- } \\
\text { mum } \\
\left(\mathrm{t}^{3} / \mathrm{s}\right)\end{array}$ & $\begin{array}{l}\text { Date of } \\
\text { maximum }\end{array}$ & $\begin{array}{l}\text { Minl } \\
\text { mum } \\
\left(\mathrm{ft}^{3} / \mathrm{s}\right)\end{array}$ & $\begin{array}{l}\text { Date of } \\
\text { minimum }\end{array}$ \\
\hline 12334600 & $\begin{array}{l}\text { Blackfoot River near } \\
\text { Lincoln }\end{array}$ & 15.1 & $\begin{array}{l}\mathrm{d} \\
\mathrm{c}\end{array}$ & $\begin{array}{l}1968-70 \\
1969-70\end{array}$ & 16.35 & 294 & $05-18-70$ & 0.7 & $03-24-69$ \\
\hline 12334650 & $\begin{array}{l}\text { Blackfoot River below } \\
\text { Alice Creek, near } \\
\text { Lincoln }\end{array}$ & 96.9 & $c, d$ & $1970-75$ & 78.0 & 3,890 & $06-19-75$ & 2.3 & $02-24-73$ \\
\hline 12334700 & $\begin{array}{l}\text { Blackfoot River below } \\
\text { Seven-Up Pete Creek, } \\
\text { near Lincoln }\end{array}$ & 255 & c & 1973 & - & - & -- & - & - \\
\hline 12334800 & $\begin{array}{l}\text { Blackfoot River at Dalton } \\
\text { Mountain Road, near } \\
\text { Lincoln }\end{array}$ & 399 & c & 1973 & - & - & -- & - & -- \\
\hline
\end{tabular}


Water in the Upper Blackfoot River is a calcium bicarbonate type with an average dissolved-solids concentration of $95 \mathrm{mg} / \mathrm{L}$, based on analyses of 59 samples from the Blackfoot River below Alice Creek, near Lincoln (gaging station 12334650) (Clark and Dutton, in press). From 1968 to 1970, sulfate ranged in concentration from 16 to $75 \mathrm{mg} / \mathrm{L}$. The concentration of dissolved solids is highest during periods of runoff, whereas the concentration of sulfate is lowest during runoff (Coffin and Wilke, 1971).

Historical mining in the headwaters area has affected water quality and aquatic habitat in the Blackfoot River watershed. More recently, logging, grazing, and hay production have significantly increased sediment loads (Montana Department of Health and Environmental Sciences, 1994, p. 50-51).

Moore and others (1991) measured metal concentrations in benthic biota, fish livers, water, and fine-grained sediment along the Blackfoot River from its headwaters to its mouth. They concluded that although concentrations of most solute and particulate contaminants resulting from mining activities decreased downstream, the most mobile metals, including cadmium, zinc, and copper, remained bioavailable throughout the river system.

Ground water also is an important resource in the Upper Blackfoot River Valley, as wells and springs provide drinking water for all basin residents. The primary aquifer is the coarse-grained Quatemary alluvium beneath the flood plains of the Blackfoot River and Landers Fork. Water within alluvium is generally shallow in the Upper Blackfoot River Valley--the water table is less than $10 \mathrm{ft}$ below land surface beneath Lincoln (Wilke, 1976). Analyses of two aquifer tests about 8 miles northeast of Lincoln indicate an average transmissivity of $46,000 \mathrm{ft}^{2} / \mathrm{d}$. Upstream, alluvium grades into less permeable glacial outwash. Alluvium within tributary valleys tends to have a larger component of silt and clay, and therefore is less transmissive than alluvium beneath large flood plains. Alluvial aquifers are unconfined everywhere in the basin (Coffin and Wilke, 1971).

Glacial till and glacial-lakebed deposits generally inhibit the flow of ground water and locally confine underlying permeable deposits. However, in a few places, wells completed in till produce water from discontinuous semi-confined lenses of sand and gravel (Coffin and Wilke, 1971).

Tertiary sediments transmit water through thin beds of sandstone and conglomerate. However, they are not used extensively because they typically underlie more productive aquifers. Bailing tests of wells completed in Tertiary sediments indicate a wide range of hydraulic characteristics, which attest to the heterogeneity of the deposits. Test results indicate that about 8 mi northeast of Lincoln. Tertiary sediments have a transmissivity of about $1,300 \mathrm{ft}^{2} / \mathrm{d}$, whereas west of Alice Creek they are almost impermeable. Water is confined in Tertiary sediments in the Upper Blackfoot River Valley (Coffin and Wilke, 1971).

Bedrock surrounding the basin has a wide range of hydraulic characteristics. Tertiary volcanic rocks occupy topographically high positions and are commonly unsaturated in the vicinity of the Upper Blackfoot River Valley. Therefore, no wells are completed in these rocks. Fractures in rocks of the Middle Proterozoic Belt Supergroup can yield sufficient water for domestic use. Proterozoic diorite sills transmit water through fractures and weathered zones. According to one aquifer test, the transmissivity of a 7-ft weathered zone at the top of a diorite sill is $890 \mathrm{ft}^{2} / \mathrm{d}$. The sill underlies $123 \mathrm{ft}$ of sedimentary basin fill (Coffin and Wilke, 1971).

Potentiometric-surface maps of the Upper Blackfoot River Valley (table 91) indicate that ground water generally flows from the uplands toward the flood plains, then southwest, paralleling the Blackfoot River. Groundwater flow adjacent to the river is interrupted in two places near the mouth of Alice Creek by deposits of poorly permeable glacial till and outwash, which essentially dam lateral ground-water flow in the alluvium. Wetlands are present where the "dams" cause ground water to flow to the surface (Coffin and Wilke, 1971).

Basin-fill aquifers are recharged by precipitation and snowmelt, surplus irrigation water, leakage from canals, subsurface flow from bedrock, and infiltration from tributary streams and the upper reaches of the Blackfoot River. The ground-water contribution area for the basin (fig. 2, pl. 1) is about $420 \mathrm{mi}^{2}$. Infiltration anywhere within this area potentially could recharge basin-fill aquifers in the Upper Blackfoot River Valley. On the basis of streamflow measurements on October 23, 1970, Coffin and Wilke (1971) concluded that the Blackfoot River recharged underlying alluvium at an average rate of $6.3 \mathrm{ft}^{3} / \mathrm{s}$ per mi between Landers Fork and Lincoln. Ground water 
Table 91. Potentiometric-surface maps of the Upper Blackioot River Valley, Montana

\begin{tabular}{|c|c|c|c|c|}
\hline Location & $\begin{array}{l}\text { Dates water levels were } \\
\text { messured }\end{array}$ & Scale & $\begin{array}{l}\text { Contour } \\
\text { interval } \\
\text { In feot }\end{array}$ & Reference \\
\hline Entire Upper Blackfoot River Valley & Summer 1991 & $1: 750,000$ & 100 & Briar and others, in press \\
\hline Lincoln area & Sept. 1974 and June 1975 & $1: 12,000$ & 5 & Wilke, 1976 , sheets 1 and 2 \\
\hline
\end{tabular}

discharges from basin-fill aquifers by evapotranspiration, withdrawals from wells, and seepage to springs, seeps, irrigation drains, and stream channels. Ground water discharges to the Blackfoot River about 3 mi downstream from Lincoln, where bedrock constricts the basin (Coffin and Wilke, 1971).

Water-levels in the wells listed in table 92 are stored in the USGS WATSTORE database. Water levels were measured in these wells at least once annually during the periods of record.

Table 92. Summary of water-level data for selected wells in the Upper Blackfoot River Valley, Montana

[Hydrogeologic unit: Qal, Holocene and Pleistocene alluvial deposits; Qg, Pleistocene glacial deposits; TKi, Tertiary through Cretaceous intrusive rocks]

\begin{tabular}{|c|c|c|c|c|c|c|c|}
\hline \multirow[b]{2}{*}{ Station name } & \multirow{2}{*}{$\begin{array}{l}\text { Depth of well, } \\
\text { In feet below } \\
\text { land surfece }\end{array}$} & \multirow{2}{*}{$\begin{array}{l}\text { Hydro- } \\
\text { geologic } \\
\text { unit }\end{array}$} & \multirow[b]{2}{*}{$\begin{array}{l}\text { Perlod of } \\
\text { record }\end{array}$} & \multicolumn{4}{|c|}{ Water level, in feot below land surfece } \\
\hline & & & & Higheat & $\begin{array}{l}\text { Date of } \\
\text { higheat }\end{array}$ & Lowest & $\begin{array}{l}\text { Date of } \\
\text { loweat }\end{array}$ \\
\hline 15N07W16CCC 01 & 98.0 & Qg & $1970-91$ & 16.76 & $07-18-74$ & 27.78 & 09-19-73 \\
\hline 15N07W21CBB 01 & 263 & Qg & $1970-75$ & 15.60 & $05-10-72$ & 28.67 & $12-03-74$ \\
\hline 15N07W28ABB 01 & 130 & TKi & $1970-86$ & 1.32 & $08-19-70$ & 8.57 & $09-19-73$ \\
\hline 14N07W05CDD 02 & 200 & Qal & $1973-91$ & 9.16 & $05-15-75$ & 22.92 & $12-03-74$ \\
\hline
\end{tabular}

The quality of ground water in the basin was determined on the basis of 12 samples analyzed for major ions and measured dissolved-solids concentrations. Ground water is consistently a calcium bicarbonate type with dissolved-solids concentrations of less than $250 \mathrm{mg} / \mathrm{L}$ throughout the basin. Magnesium is also a major constituent (Clark and Dutton, in press). The concentration of nitrate plus nitrite (as nitrogen) in 41 wells sampled in 1974 and 1975 in the Lincoln area ranged from 0.01 to $0.75 \mathrm{mg} / \mathrm{L}$ (Wilke, 1976).

\section{Selected References}

Boettcher, A.J., and Gosling, A.W., 1977, Water resources of the Clark Fork basin upstream from St. Regis, Montana: Montana Bureau of Mines and Geology Bulletin 104, 28 p.

Briar, D.W., Lawlor, S.M., Stone, M.A.J., Parliman, D.J., Schaefer, J.L., and Kendy, Eloise, in press, Ground-water levels in intermontane basins of the Northern Rocky Mountains, Montana and Idaho: U.S. Geological Survey Hydrologic Investigations Atlas 738-B, 1 sheet, scale 1:750,000.

Cantwell, John, 1980, A gravity study of the Blackfoot-Nevada Valley area, northwestem Montana: Missoula, University of Montana, M.S. thesis, 39 p.

Clark, D.W., and Dutton, D.M., in press, Quality of ground water and surface water in intermontane basins of the Northem Rocky Mountains, Montana and Idaho: U.S. Geological Survey Hydrologic Investigations Atlas 738-C, 1 sheet, scale $1: 750,000$.

Coffin, D.L., and Wilke, K.R., 1971, Water resources of the upper Blackfoot River Valley, west-central Montana: Water Resources Division, Montana Department of Natural Resources and Conservation Technical Report Series No. 1, 82 p.

Dutton, D.M., Lawlor, S.M., Briar, D.W., and Tresch, R.E., 1995, Hydrogeologic data for the Northern Rocky Mountains intermontane basins, Montana: U.S. Geological Survey Open-File Report 95-143, 94 p. 
Kleinkopf, M.D., and Mudge, M.R., 1972, Aeromagnetic, Bouguer gravity, and generalized geologic studies of the Great FallsMission Range area, northwestern Montana: U.S. Geological Survey Professional Paper 726-A, 19 p.

McCulloch, Robin, 1993, Montana mining directory 1992, Montana Bureau of Mines and Geology Bulletin 131, 76 p.

Montana Department of Health and Environmental Sciences, 1994, Montana Water Quality, 1994: Helena, Water Quality Bureau, Montana 305(b) Report, 159 p.

[Montana] State Engineer's Office, 1957a, Water resources survey, Lewis and Clark County, Montana--Part 1, History of land and water use on irrigated areas: Helena, Mont., State Engineer's Office, 59 p.

1957b, Water resources survey, Lewis and Clark County, Montana--Part 2, Maps showing irrigated areas: Helena, Mont., State Engineer's Office, 43 p.

Moore, J.N., Luoma, S.N., and Peters, Donald, 1991, Downstream effects of mine effluent on an intermontane riparian system: Canadian Journal of Fisheries and Aquatic Sciences, v. 48, no. 2, p. 222-232.

Mudge, M.R., Earhart, R.L., Whipple, J.W., and Harrison, J.E., 1982, Geologic and structure maps of the Choteau $1^{\circ} \times 2^{\circ}$ quadrangle, western Montana: U.S. Geological Survey Miscellaneous Investigations Series Map I-1300, 2 sheets, scale $1: 250,000$.

National Oceanic and Atmospheric Administration, 1992, Monthly normals of temperature, precipitation, and heating and cooling degree days, 1961-90, Montana: Asheville, N.C., Climatography of the United States no. 81, unpaged.

Noble, R.A., Bergantino, R.N., Patton, T.W., Sholes, B.C., Daniel, Faith, and Schofield, Judeykay, 1982, Occurrence and characteristics of ground water of Montana--Volume 2, The Rocky Mountain Region: Montana Bureau of Mines and Geology Open-File Report 99, 132 p.

Tuck, L.K., Briar, D.W., and Clark, D.W., in press, Geologic history and hydrogeologic units of intermontane basins of the Northern Rocky Mountains, Montana and Idaho: U.S. Geological Survey Hydrologic Investigations Atlas 738-A, 2 sheets, scale 1:750,000.

U.S. Geological Survey, issued annually, Water resources data, Montana: Helena, Mont., U.S. Geological Survey Water-Data Report.

Wallace, C.A., 1987, Generalized geologic map of the Butte $1^{\circ} \times 2^{\circ}$ quadrangle, Montana: U.S. Geological Survey Miscellaneous Field Studies Map MF-1924, scale 1:250,000.

Weisel, G.F., and Newell, R.L., 1970, Quality and seasonal fluctuation of headwater streams in westem Montana: Montana Forest and Conservation Experiment Station Bulletin 38, 15 p.

Wilke, K.R., 1976, Ground-water levels and chemical quality of ground water in Lincoln, Montana: U.S. Geological Survey Open-File Map 76-333, 4 sheets, scale 1:12,000. 


\section{Upper Clark Fork Valley}

\section{Geography}

The Upper Clark Fork Valley as defined in this study includes the Deer Lodge Valley, which extends from Gregson Hot Springs to Garrison; the Flint Creek Valley below Stone; and the narrow reach of the Clark Fork Valley that connects the two. The Deer Lodge and Flint Creek Valleys trend northnortheast, and the connecting reach of the Clark Fork Valley trends north west. The $380-\mathrm{mi}^{2}$ Upper Clark Fork Valley is bounded by the Garnet Range on the north, the Continental Divide on the east, the Anaconda Range on the south, and the John Long Mountains on the west. The Flint Creek Range separates the Deer Lodge Valley from the Flint Creek Valley and parallels both (pl. 1). The Flint Creek and Deer Lodge Valleys are broad structural basins with extensive, dissected terraces flanking central flood plains. In contrast, the northwest-trending valley between them is narrow and has an undulating surface. The Clark Fork of the Columbia River begins in

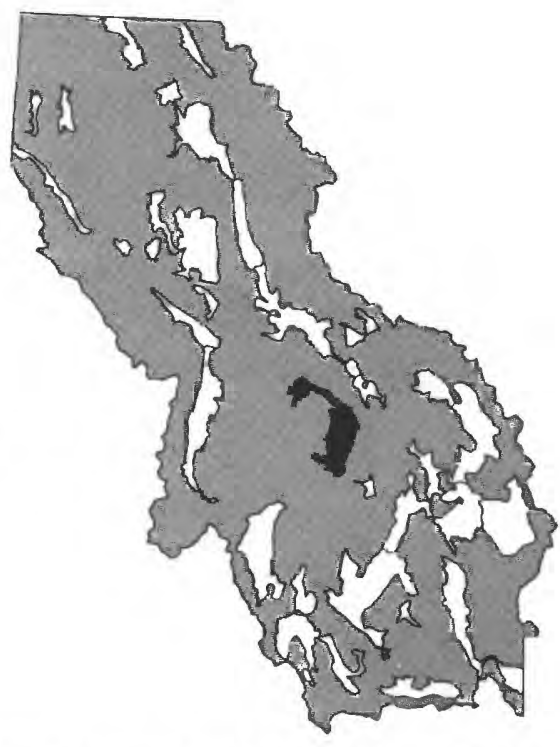
the Deer Lodge Valley and flows northwestward to its confluence with Flint Creek at the north end of the Flint Creek Valley. The Upper Clark Fork Valley ranges in altitude from about $3,900 \mathrm{ft}$ where the Clark Fork leaves the intermontane basin, to about $6,000 \mathrm{ft}$ on the highest terrace.

The temperature of the Upper Clark Fork Valley is typical of mid-elevation intermontane basins of the Northern Rocky Mountains, with cold winters and mild summers. However, the high mountains to the west shadows the Upper Clark Fork Valley from precipitation comparable to other basins west of the Continental Divide. On the basis of the 1961-90 period of record, the average annual precipitation $3 \mathrm{mi}$ west of Deer Lodge (altitude $4,850 \mathrm{ft}$ ) is $10.70 \mathrm{in}$. and the average annual temperature is $39.7^{\circ} \mathrm{F}$ (National Oceanic and Atmospheric Administration, 1992). The average last occurrence of $32^{\circ} \mathrm{F}$ is July 1, and the average first occurrence is August 27 (Natural Resources Conservation Service, U.S. Department of Agriculture, unpub. data., 1994). In contrast, at the lower altitude of $3,940 \mathrm{ft}$, Drummond has an average annual temperature of $42.9^{\circ} \mathrm{F}$ and a longer growing season. Drummond also receives nearly 3 in. per year more precipitation than Deer Lodge (National Oceanic and Atmospheric Administration, 1992; Natural Resources Conservation Service, U.S. Department of Agriculture, unpub. data, 1994). Mean monthly climatic data for the station $3 \mathrm{mi}$ west of Deer Lodge are plotted in figure 30.
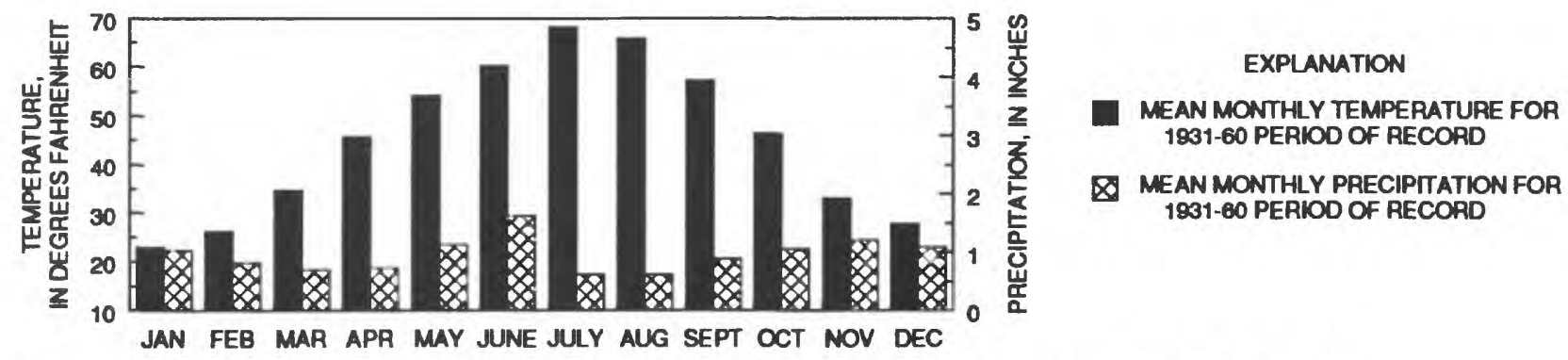

Figure 30. Mean monthly precipitation and temperature 3 miles west of Deer Lodge, Mont. Data from National Oceanic and Atmospheric Administration (1992).

Land uses include livestock grazing, irrigated hay and pasture farming, and limited irrigated and dryland grain production (J.C. Eggen, Agricultural Stabilization and Conservation Service, oral commun., 1993). Numerous diversions from Flint Creek, the Clark Fork, and their tributaries provide irrigation water for the basin. About 
16,000 people reside in the Upper Clark Fork Valley, including 3,378 in the City of Deer Lodge, 694 in the unincorporated community of Opportunity, 402 in the unincorporated community of Warm Springs, 264 in the Town of Drummond, and 205 in the unincorporated community of Galen (1990 census).

Large-scale mining, milling, and smelting have been conducted in the basin and its tributaries for more than 125 years. Moore and Luoma (1990) discussed the environmental impacts of historical mining practices. Among the minerals recently mined are gold, lead, zinc, silver, silica, copper, molybdenum, and phosphate. Currently, exploration is underway for gold, silver, platinum, and sapphires. Open-stope, open-pit, placer, and underground mining methods are used to extract the minerals (McCulloch, 1993, p. 1-4, 17, 41-42, 48-49).

\section{Geology}

The Upper Clark Fork Valley formed as a result of batholith emplacement, regional extension, and movement along the Lewis and Clark Line. During Late Cretaceous time, intrusion of the Boulder Batholith (fig. 4) probably resulted in a regional topographic low in the Deer Lodge Valley. Tertiary block faulting subsequently increased topographic relief. Gravity data, substantiated by oil exploration wells, indicate that more than $10,000 \mathrm{ft}$ of unconsolidated sediments fill the basin at its deepest point, about $4 \mathrm{mi}$ northwest of Deer Lodge. The Flint Creek Valley lies within the Lewis and Clark Line (fig. 4), a northwest-trending zone of high-angle normal, reverse, and right-lateral strike-slip faults. Several faults abut its west side and possibly underlie the valley; a normal fault defines its southwestem margin. Basin fill is more than 6,000 ft deep in the Flint Creek Valley. Between the Flint Creek Valley and the Deer Lodge Valley, the northwest-flowing reach of the Clark Fork trends along the Lewis and Clark Line. The depth to bedrock in this reach is less than 3,000 ft between Goldcreek and Drummond, but increases along the valley to the northwest and southeast (Noble and others, 1982, p. 61-64; Wallace and others, 1986; Wallace, 1987).

Several investigators have examined the geology of the Upper Clark Fork Valley. Princeton University graduate students, including Csejtey (1962) and Mutch (1960), provided much of the early mapping and interpretations of local geological features. Subsequent geologic and geophysical maps of the basin are listed in table 93. The geologic units described by previous investigators are summarized below. These geologic units are referenced to hydrogeologic units defined in this study (table 2) to provide a consistent regional framework. In the following discussion, the hydrogeologic-unit abbreviations are italicized.

Metasedimentary, sedimentary, and igneous bedrock bounds the basin. The John Long Mountains contain quartzite, argillite, and siltite of the Middle Proterozoic Belt Supergroup ( $Y m s$ ), and the Middle Cambrian Flathead Quartzite $\left(P_{z} l s\right)$. Calcareous rocks of the Belt Supergroup (Yms) border the Flint Creek Valley on the south. The Anaconda and Flint Creek Ranges and the south flank of the Garnet Range contain Paleozoic and Mesozoic sedimentary rocks. The Paleozoic rocks ( $\left.P_{2} l s\right)$ are dominantly limestone, but also include dolomite, phosphatic sandstone, quartzite, siltstone, mudstone, and shale. In contrast, the Mesozoic sedimentary rocks (Mzsh) are principally marine shale interbedded with non-marine mudstone, siltstone, sandstone, conglomerate, and minor amounts of limestone. East of the Deer Lodge Valley, the Boulder Batholith (fig. 4), a granodioritic to monzogranitic Cretaceous intrusion (TKi), is flanked by Cretaceous to Tertiary volcanic rocks (QTKe) ranging in composition from basalt to hyolite (Wallace and others, 1987). Volcanic rocks also border the Deer Lodge Valley on the southwest (Wanek and Barclay, 1966).

More than $10,000 \mathrm{ft}$ of unconsolidated to consolidated Cretaceous(?) and Tertiary sediments (Ts) fill the basin. At the base is 2,500 to $4,000 \mathrm{ft}$ of Cretaceous(?) conglomerate interlayered with siltstone, sandstone, tuff, and carbonaceous shale. Overlying this sequence are Oligocene bentonitic conglomerate and arkose and Miocene 
Table 93. Geologic and geophysical maps of the Upper Clark Fork Valley, Montana

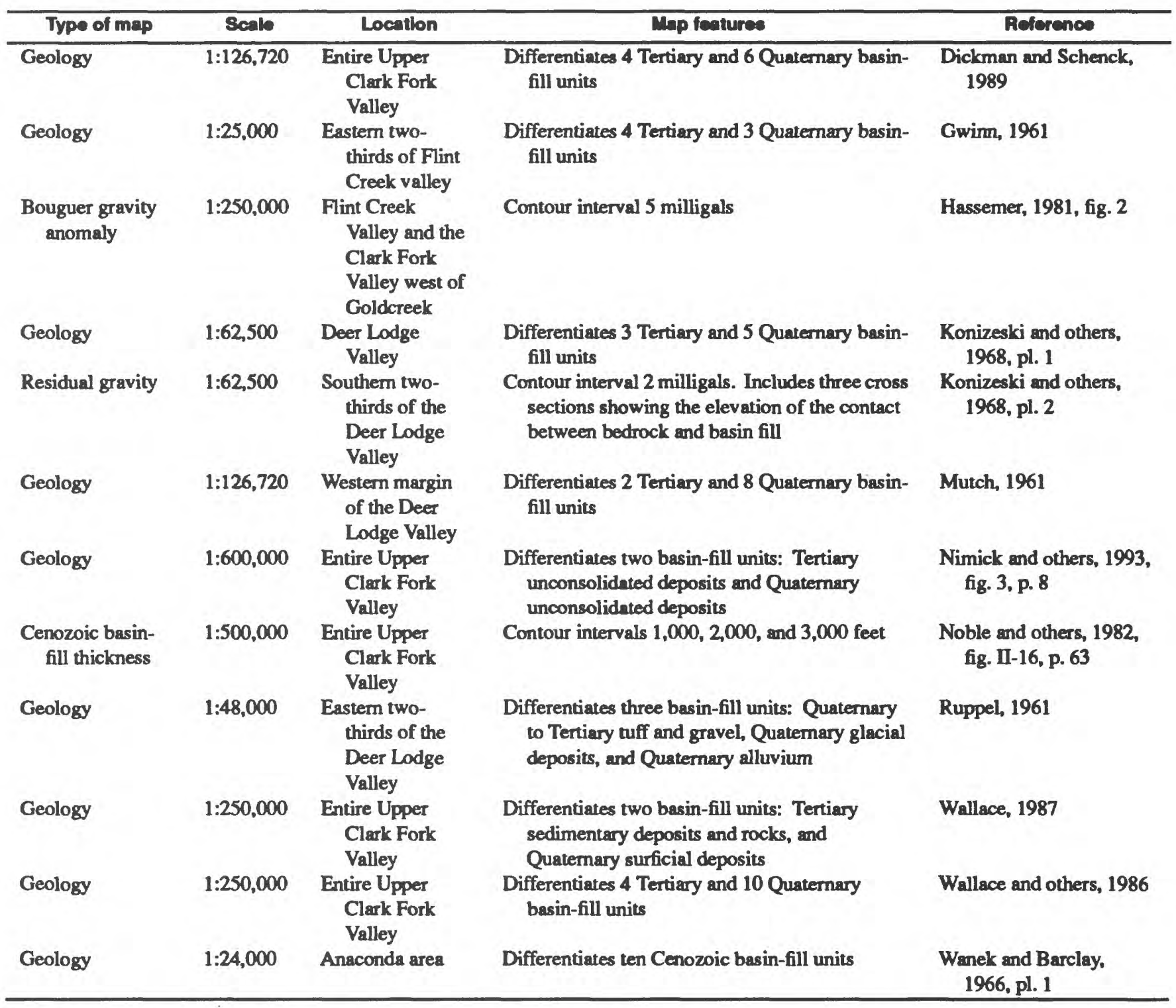

fluvial clay, silt, sand, and conglomerate. Several hundred feet of Pliocene colluvium and fan deposits, consisting of thin-bedded silt with lenses of sand and gravel and occasional volcanic ash, form high terraces that flank the flood plains of the Flint Creek and Deer Lodge Valleys. Tertiary volcanic rocks are interbedded with Tertiary sediments throughout the basin (Nimick and others, 1993; Noble and others, 1982, p. 61-64; Konizeski and others, 1968).

Quaternary deposits in the Upper Clark Fork Valley include glacial till $(Q g)$, glacial outwash (Qal), and floodplain alluvium (Qal). Unstratified mixtures of deeply weathered boulders and gravel extend a short distance into the basin from the Flint Creek Range. Konizeski and others (1968) considered these to be relics of Pleistocene glacial moraines. Pleistocene glacial outwash, consisting of well-sorted, unconsolidated sand and gravel, underlies several tributary valleys from the Flint Creek Range and forms large outwash plains on the west sides of the Flint Creek and Deer Lodge Valleys. Holocene alluvium underlies the flood plains of Flint Creek, the Clark Fork, and several lower-elevation tributaries. The alluvium may be as much as $300 \mathrm{ft}$ thick, but is typically less than $100 \mathrm{ft}$ thick, and consists of interbedded lenses of gravel, sand, silt, lignitic clay, and caliche capped by carbonaceous soil (Nimick and others, 1993; Wallace and others, 1986; Konizeski and others, 1968). 


\section{Hydrology}

The Clark Fork of the Columbia River begins in the Upper Clark Fork Valley at the confluence of Warm Springs Creek and Silver Bow Creek. It flows northward through the Deer Lodge Valley, then bends to the northwest near Kohrs (pl. 1). Flow in the Clark Fork is affected by numerous diversions for irrigation and by settling ponds on Silver Bow Creek near Warm Springs. The Little Blackfoot River enters the Clark Fork from the northeast at Garrison, typically doubling the flow of the Clark Fork during the irrigation season and increasing the flow by 25 to 50 percent the rest of the year.

Flint Creek originates at Georgetown Lake in the southern end of the Flint Creek Range and flows northward for about $36 \mathrm{mi}$ through the Philipsburg Valley to its confluence with the Clark Fork at Drummond. Flow in Flint Creek is augmented during the irrigation season by interbasin diversion from the East Fork of Rock Creek. Flow also may be augmented by diversion from Silver Lake to Georgetown Lake, or reduced by pumping from Georgetown Lake to Silver Lake, which flows into Warm Springs Creek, a tributary to the Clark Fork in the Deer Lodge Valley (Shields and others, 1993). Georgetown Lake was constructed in 1905 to supply water for ore processing by the Anaconda Copper Mining Company at Anaconda. Today, Georgetown Lake is used for irrigation, power, and recreation (Shields and others, 1993).

Streamflow data for gaging stations listed in table 94 are stored in the USGS WATSTORE database. Locations of these stations are shown on plate 1. In addition, the USGS has published records of monthend reservoir volumes for Georgetown Lake (gaging station 12325000, drainage area $50.1 \mathrm{mi}^{2}$ ) since 1939. Data for years prior to 1961 are published in Water-Supply Papers; more recent data are in annual Water-Data Reports (U.S. Geological Survey, issued annually).

Analyses of 12 samples from the Clark Fork near Galen (gaging station 12323800) indicate a calcium sulfate type water with an average dissolved-solids concentration of $335 \mathrm{mg} / \mathrm{L}$. Downstream, sulfate concentrations decrease relative to bicarbonate, but the average dissolved-solids concentration remains relatively stable, based on analyses of nine samples from the Clark Fork at Deer Lodge (gaging station 12324200) (Clark and Dutton, in press).

Surface-water quality in the Clark Fork has been affected by mining and smelting activities in Anaconda, Butte, and the surrounding area. Between 1880 and 1982, an estimated 100 million tons of tailings containing arsenic, cadmium, copper, lead, and zinc entered the Clark Fork. Erosion, dissolution, and redeposition of sulfiderich tailings have distributed arsenic- and metal-enriched flood-plain and streambed sediments downstream from their sources for more than $100 \mathrm{mi}$ (Axtmann and Luoma, 1991; Nimick and Moore, 1994). The U.S. Environmental Protection Agency (EPA) designated about $80 \mathrm{mi}$ of the Clark Fork as priority sites under the Comprehensive Environmental Response Compensation and Liability Act of 1980 (CERCLA); combined, they compose the largest contiguous CERCLA site in the nation. The effort to investigate and remediate the CERCLA sites has produced scores of technical documents which are available from the EPA. Johnson and Schmidt (1988) prepared a comprehensive summary of work completed and underway through 1988; more recent status reports are available from the EPA. Mining in the headwaters of Flint Creek may have affected water quality in that drainage, as well (Nimick and others, 1993).

Lambing (1991) analyzed suspended-sediment and trace-element concentrations in the Clark Fork near Galen and at Deer Lodge and in Flint Creek near Drummond (gaging stations 12323800, 12324200, and 12331500) throughout a wide range of hydrologic conditions during 1985-90. The median suspended-sediment concentration in the Clark Fork near Galen was $8 \mathrm{mg} / \mathrm{L}$, whereas the median concentration in Flint Creek was $43 \mathrm{mg} / \mathrm{L}$. Flint Creek contributed 6.2 percent of the average annual suspended-sediment load and 20 percent of the average annual total-recoverable arsenic load to the Clark Fork at Milltown. Arsenic and lead concentrations occasionally equaled or exceeded drinking-water standards (U.S. Environmental Protection Agency, 1989) during the reporting period in both Flint Creek and the Clark Fork. Trace-element concentrations in some samples from Flint Creek exceeded aquatic-life criteria (U.S. Environmental Protection Agency, 1986) for total-recoverable cadmium, copper, lead, 
Table 94. Summary of data for U.S. Geological Survey streamflow-gaging stations in the Upper Clark Fork Valley, Montana

[Type of data collected: $c$, water chemistry; $d$, discharge; $s$ suspended sediment. Periods of record for stations that were being operated as of November 1994 are indicated by the first year of record followed by a dash only. Abbreviations: $\mathrm{ft}^{3} / \mathrm{s}$, cubic feet per second. Symbol: --, no data]

\begin{tabular}{|c|c|c|c|c|c|c|c|c|c|}
\hline \multirow[b]{2}{*}{$\begin{array}{l}\text { Station } \\
\text { number }\end{array}$} & \multirow[b]{2}{*}{ Station name } & \multirow{2}{*}{$\begin{array}{l}\text { Drainage } \\
\text { area } \\
\text { (equare } \\
\text { miles) }\end{array}$} & \multirow{2}{*}{$\begin{array}{l}\text { Type } \\
\text { of data } \\
\text { col- } \\
\text { locted }\end{array}$} & \multirow[b]{2}{*}{$\begin{array}{l}\text { Period of record } \\
\text { (calendar year) }\end{array}$} & \multicolumn{5}{|c|}{ Diecharge for perlod of record } \\
\hline & & & & & $\begin{array}{c}\text { Mean } \\
\text { annual } \\
\left(t^{3} / 8\right)\end{array}$ & $\begin{array}{l}\text { Maxl- } \\
\text { mum } \\
\left(\mathrm{ft}^{3} / \mathrm{s}\right)\end{array}$ & $\begin{array}{l}\text { Date of } \\
\text { maximum }\end{array}$ & $\begin{array}{l}\text { Mint- } \\
\text { mum } \\
\left(t^{3} / s\right)\end{array}$ & $\begin{array}{l}\text { Date of } \\
\text { minimum }\end{array}$ \\
\hline 12323600 & $\begin{array}{l}\text { Silver Bow Creek at } \\
\text { Opportunity }\end{array}$ & 284 & $\begin{array}{l}\text { d } \\
\text { c }\end{array}$ & $\begin{array}{l}1988 . \\
1993\end{array}$ & 44.9 & 654 & 03-09-89 & $T_{13}$ & $08-07-90$ \\
\hline 12323750 & $\begin{array}{l}\text { Silver Bow Creek at } \\
\text { Warm Springs }\end{array}$ & 483 & $\begin{array}{l}\mathrm{d} \\
\mathrm{c}\end{array}$ & $\begin{array}{l}1972-79,1993- \\
1971,1993\end{array}$ & 137 & 1,320 & $06-20-75$ & $1_{15}$ & $09-12-73$ \\
\hline 12323770 & $\begin{array}{l}\text { Warm Springs Creek at } \\
\text { Warm Springs }\end{array}$ & 163 & $\begin{array}{l}\text { d } \\
\text { c }\end{array}$ & $\begin{array}{l}1983- \\
1992-93\end{array}$ & 41.4 & 462 & $06-21-84$ & 0 & $08-04-88$ \\
\hline 12323800 & Clark Fork near Galen & 793 & $\begin{array}{c}\mathrm{d} \\
\mathrm{c}, \mathrm{s}\end{array}$ & $\begin{array}{l}1988- \\
1971-74,1988-\end{array}$ & 104 & 795 & $06-07-91$ & 19.7 & $08-11-88$ \\
\hline 12324000 & $\begin{array}{l}\text { Racetrack Creek near } \\
\text { Anaconda }\end{array}$ & 30 & d & $\begin{array}{l}1911-13 \\
\quad \text { (intermittent) }\end{array}$ & - & 515 & $06-10-12$ & 16 & $\begin{array}{c}02 \text { and } \\
03-12\end{array}$ \\
\hline 12324100 & $\begin{array}{l}\text { Racetrack Creek below } \\
\text { Granite Creek, near } \\
\text { Anaconda }\end{array}$ & 39.5 & d & $1914-17,1957-73$ & 59.1 & 537 & $06-17-65$ & 6.2 & $03-19-70$ \\
\hline 12324200 & Clark Fork at Deer Lodge & 1,005 & $\begin{array}{c}\text { d } \\
c, s\end{array}$ & $\begin{array}{l}1978- \\
1962-63,1968-71, \\
1978-83,1984-\end{array}$ & 260 & 2,500 & $05-23-81$ & ${ }^{1} 22$ & $08-18-88$ \\
\hline 12324590 & $\begin{array}{l}\text { Little Blackfoot River } \\
\text { near Garrison }\end{array}$ & 407 & $\begin{array}{c}\mathrm{d} \\
\mathrm{c}, \mathrm{s}\end{array}$ & $\begin{array}{l}1972- \\
1962-63,1984-\end{array}$ & 155 & 8,650 & $05-21-81$ & 6.0 & $08-24-77$ \\
\hline 12324600 & Clark Fork at Garrison & 1,550 & c & $1963,1969-71$ & - & - & -- & -- & -- \\
\hline 12324660 & Gold Creek at Goldcreek & 64.1 & d & $1963-66$ & 26.9 & 488 & $06-09-64$ & 2.3 & $05-25-66$ \\
\hline 12324680 & Clark Fork at Goldcreek & 1,704 & $\begin{array}{l}\text { d } \\
\text { c }\end{array}$ & $\begin{array}{l}1977- \\
1991-\end{array}$ & 522 & 12,000 & $05-22-81$ & ${ }_{155}$ & $09-04-88$ \\
\hline 12329000 & $\begin{array}{l}\text { Flint Creek above } \\
\text { Maxville Siding, at } \\
\text { Maxville }\end{array}$ & 207 & d & $1939-41$ & 54.15 & 290 & $06-01-41$ & 21 & $01-03-41$ \\
\hline 12329500 & Flint Creek at Maxville & 208 & $\begin{array}{c}\mathrm{d} \\
\mathrm{c}, \mathrm{s}\end{array}$ & $\begin{array}{l}1941- \\
1990-93\end{array}$ & 97.3 & 1,680 & $03-28-43$ & 15 & $02-25-62$ \\
\hline 12330000 & $\begin{array}{l}\text { Boulder Creek at } \\
\text { Maxville }\end{array}$ & 71.3 & d & $1939-$ & 45.7 & 1,460 & 06-19-75 & 12.8 & $10-13-91$ \\
\hline 12330100 & $\begin{array}{l}\text { Flint Creek below } \\
\text { Boulder Creek, near } \\
\text { Maxville }\end{array}$ & - & c & 1971 & -- & - & -- & -- & - \\
\hline 12330500 & Flint Creek near Maxville & 325 & d & $\begin{array}{l}1946-49 \\
\quad \text { (intermittent) }\end{array}$ & -- & 1,700 & $06-04-48$ & 24 & $07-16-49$ \\
\hline 12331000 & Flint Creek near Hall & 325 & d & 1939 May-Sept. & - & 269 & $06-20-39$ & 3.5 & 09-18-39 \\
\hline 12331500 & $\begin{array}{l}\text { Flint Creek near } \\
\text { Drummond }\end{array}$ & 490 & $\begin{array}{l}\mathrm{d} \\
\mathrm{c}\end{array}$ & $\begin{array}{l}1948-49,1990- \\
1971-73,1984-\end{array}$ & 91.1 & 539 & $06-16-93$ & ${ }^{1} .6$ & $05-06-92$ \\
\hline 12331600 & Clark Fork at Drummond & 2,378 & d & $\begin{array}{l}1967-68,1970, \\
1971-83 \\
1971-74\end{array}$ & 889 & 15,800 & $05-23-81$ & 58 & $08-15-73$ \\
\hline
\end{tabular}

${ }^{1}$ Lowest daily mean.

zinc, and iron, and for dissolved lead. Some samples from the Clark Fork exceeded aquatic-life criteria for totalrecoverable arsenic, cadmium, copper, iron, lead, and zinc, and for dissolved copper and lead.

Algae blooms are a relatively recent phenomenon. As mine tailings are gradually removed and stabilized in the Clark Fork headwaters areas, the concentration of copper in stream waters is slowly decreasing. However, an increase in algae has accompanied the decrease in metals. Complaints of excess algae growth in the river began in 
the early 1970's, soon after efforts were undertaken to control metals contamination (Montana Department of Health and Environmental Sciences, 1994, p. 24). Algae blooms in the Clark Fork below Deer Lodge were attributed at least in part to effluent from the Deer Lodge sewage-treatment lagoon. The excess algae decreased concentrations of dissolved oxygen especially during low flows, affecting a 100-mi reach of the Clark Fork above Rock Creek (Casne and others, 1975, p. 88, 118). More recently, phosphorus detergent bans and improved industrial waste treatment appear to be reducing the phosphorus load to the Clark Fork. The reduction in nutrient levels is expected to improve the algae situation and the corresponding depletion of dissolved oxygen (Montana Department of Health and Environmental Sciences, 1994, p. 24).

Toxic response to chlorinated drinking water from a broken water line caused a fish kill in Cottonwood Creek, a tributary to the Clark Fork near Deer Lodge. This was one of eight fish kills reported in Montana in 1992-94 (Montana Department of Health and Environmental Sciences, 1994, p. 23).

Ground water is an important resource in the Upper Clark Fork Valley, as the basin-fill aquifer system provides domestic water for almost all basin residents, including municipal supplies for Anaconda and Deer Lodge. Hydrogeology of the Upper Clark Fork Valley has been relatively well-studied, particularly in the areas affected by mining-related activities. Yield and specific-capacity data reported for wells completed in the Upper Clark Fork Valley are summarized in table 95 . Table 96 summarizes transmissivity data for basin fill and bedrock. In addition, numerous private contractors have determined aquifer characteristics for local study areas associated with the CERCLA sites. These data are available from the Natural Resource Information System, Montana State Library, Helena, Mont.

Table 95. Summary of data for yield and specific capacity of wells completed in selected hydrogeologic units in the Upper Clark Fork Valley, Montana

[Source of summary data: Nimick and others, 1993. Hydrogeologic uait: Qal, Holocene and Pleistocene alluvial deposits; Ts, Tertiary sedimentary deposits and rocks; Bdrk, undifferentiated Precambrian through Tertiary bedrock. Abbreviations: gal/min, gallon per minute; (gal/min)/ft, gallon per minute per fook]

\begin{tabular}{|c|c|c|c|c|c|c|c|c|c|c|}
\hline \multirow{2}{*}{$\begin{array}{l}\text { Hydro } \\
\text { geologle } \\
\text { unit }\end{array}$} & \multirow[b]{2}{*}{$\begin{array}{l}\text { Number } \\
\text { of wells }\end{array}$} & \multicolumn{4}{|c|}{ Yleld (gal/min) } & \multirow[b]{2}{*}{$\begin{array}{l}\text { Number } \\
\text { of wells }\end{array}$} & \multicolumn{4}{|c|}{ Specifle capadty $[(g a V m i n) / f t]$} \\
\hline & & Mean & Medien & $\begin{array}{l}\text { Mint- } \\
\text { mum }\end{array}$ & $\begin{array}{l}\text { Maxt- } \\
\text { mum }\end{array}$ & & Mean & Median & $\begin{array}{l}\text { Mint- } \\
\text { mum }\end{array}$ & $\begin{array}{l}\text { Maxl- } \\
\text { mum }\end{array}$ \\
\hline Qब & 35 & 63 & 30 & 3 & $580^{\circ}$ & 29 & 12 & 6.0 & 0.4 & 55 \\
\hline Ts & 36 & 113 & 20 & 10 & 2,400 & 24 & 7.8 & 1.2 & .2 & 200 \\
\hline Bdrk $^{1}$ & 12 & 21 & 14 & 3.0 & 70 & 11 & 2.2 & .5 & .1 & 10 \\
\hline
\end{tabular}

TMay include wells completed along basin margins, outside the area of basin fill.

Table 96. Summary of data for transmissivity of aquifers in the Upper Clark Fork Valley, Montana

[Hydrogeologic unit: Qal, Holocene and Pleistocene alluvial deposits; Ts, Tertiary sedimentary deposits and rocks; Bdrk, undifferentiated Precambrian through Tertiary bedrock. Abbreviation: $\mathrm{ft}^{2} / \mathrm{d}$, foot squared per day]

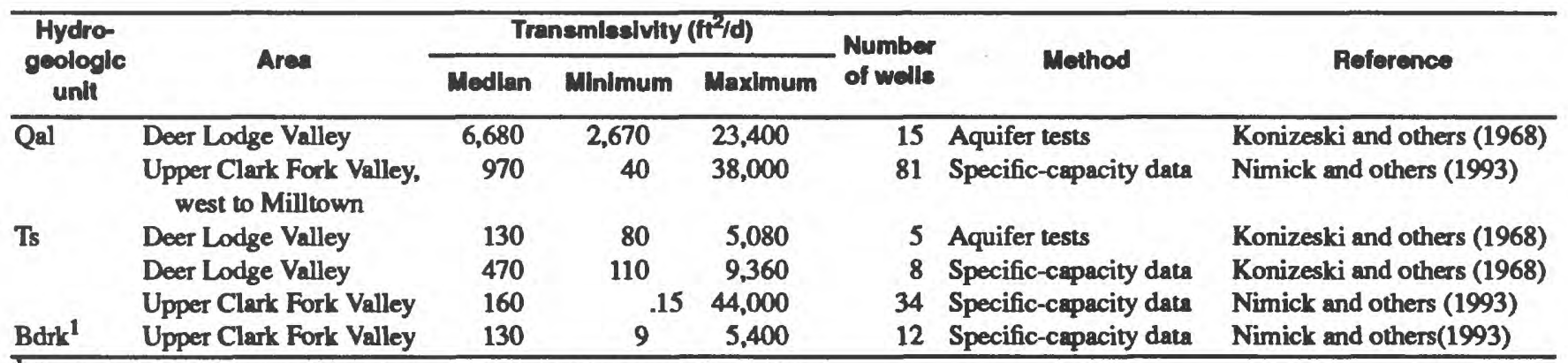

May include wells completed along basin margins, outside the area of besin fill. 
Quaternary alluvium and glacial outwash are the primary aquifers in the basin. Quatemary alluvium is primarily used for domestic supply, whereas glacial outwash also provides water for irrigation (Nimick and others, 1993). Well depths generally are less than $70 \mathrm{ft}$ in these aquifers. Yields of as much as $580 \mathrm{gal} / \mathrm{min}$, specific capacities of more than 50 ( $\mathrm{gal} / \mathrm{min}) / \mathrm{ft}$, and transmissivities of as much as $38,000 \mathrm{ft}^{2} / \mathrm{d}$ have been reported (tables 95 and 96).

Tertiary sediments yield water to wells from sand and gravel lenses. Well depths range from about 30 to 440 ft. In general, Tertiary sediments are not as productive as Quatemary alluvium and glacial outwash. Yields typically are less than $20 \mathrm{gal} / \mathrm{min}$, with some reported yields as low as $5 \mathrm{gal} / \mathrm{min}$ (Dutton and others, 1995). Specific-capacity values typically are about 1 (gal/min)/ft (table 95$)$. However, in certain areas such as the terrace northwest of Racetrack, water-bearing zones are extensive, and wells are capable of producing up to $2,400 \mathrm{gal} / \mathrm{min}$ with specific capacities of 200 (gal/min)/ft. Transmissivities of Tertiary sediments typically range from about 100 to $500 \mathrm{ft}^{2} / \mathrm{d}$, but have been reported as large as $44,000 \mathrm{ft}^{2} / \mathrm{d}$ (table 96 ).

Wells completed in bedrock generally are less productive than wells completed in Tertiary sediments, but withdrawals from bedrock aquifers provide domestic-water supplies near outcrops. A 300-ft, 14-in.-diameter well completed in Tertiary volcanic rocks northeast of Deer Lodge (08N09W11DBA01) had a reported yield of $750 \mathrm{gal} /$ $\mathrm{min}$ and a specific capacity of 13 (gal/min)/ft (Dutton and others, 1995). Depths of wells completed in bedrock range from about 10 to $300 \mathrm{ft}$.

Potentiometric-surface maps of the Upper Clark Fork Valley (table 97) indicate that ground water generally flows from the uplands toward the flood plains, then parallel to Flint Creek and the Clark Fork. Water levels in the basin range from more than $250 \mathrm{ft}$ below, to a few feet above, land surface (Konizeski and others, 1968).

Table 97. Potentiometric-surface maps of the Upper Clark Fork Valley, Montana

\begin{tabular}{ccccc}
\hline Locatlon & $\begin{array}{c}\text { Dates water } \\
\text { levels were } \\
\text { measured }\end{array}$ & Scale & $\begin{array}{c}\text { Contour } \\
\text { Interval } \\
\text { in feot }\end{array}$ & Roference \\
\hline $\begin{array}{c}\text { Southern Deer } \\
\text { Lodge Valley }\end{array}$ & June 1993 & $1: 24,000$ & 20 & $\begin{array}{c}\text { Environmental Science and Engineering, } \\
\text { Inc., 1993, pl. 3 }\end{array}$ \\
$\begin{array}{c}\text { Deer Lodge Valley } \\
\text { Entire Upper Clark } \\
\text { Fork Valley }\end{array}$ & $\begin{array}{c}\text { June } 1960 \\
1985-1987\end{array}$ & $1: 62,500$ & 50 & $\begin{array}{c}50 \text { Konizeski and others, 1968, pl. 1 } \\
\text { Nimick and others, 1993, pl. 1 }\end{array}$ \\
\hline
\end{tabular}

Basin-fill aquifers are recharged by precipitation and snowmelt, surplus irrigation water, leakage from irrigation canals, subsurface flow from bedrock, and infiltration from the Clark Fork and its tributary streams. The ground-water contribution area for the basin (fig. 2, pl. 1) is about $1,420 \mathrm{mi}^{2}$. Infiltration anywhere within this area could potentially recharge aquifers in the Upper Clark Fork Valley. Ground water discharges from the basin-fill aquifers by evapotranspiration, pumpage from wells, and seepage into springs, seeps, irrigation drains, stream channels, and adjacent aquifers.

The presence of several hot springs indicates subsurface inflow of geothermal water from bedrock (Chadwick and Leonard, 1979). Warm Springs (05N10W24A) discharge water with a temperature of $78^{\circ} \mathrm{C}$ at a rate of $61 \mathrm{gal} / \mathrm{min}$; Gregson Hot Springs (03N10W02BDCA) discharge water with a temperature of $70^{\circ} \mathrm{C}$ at a rate of $40 \mathrm{gal} / \mathrm{min}$; Anaconda Hot Springs (04N11W13AAA) discharge water with a temperature of $22^{\circ} \mathrm{C}$ at a rate of $2.9 \mathrm{gal} / \mathrm{min}$; and Deer Lodge Prison Hot Springs (07N10W29BC) discharge water at a temperature of $26^{\circ} \mathrm{C}$ at a rate of $100 \mathrm{gal} / \mathrm{min}$ (Sonderegger and Bergantino, 1981).

Nimick and others (1993) investigated the interaction between ground water and surface water in the Upper Clark Fork Valley, based on streamflow characteristics and water chemistry. They found that two reaches of the Clark Fork receive significant inflow from ground water. The first reach, between Racetrack and Garrison, probably receives ground water from irrigation return flow through basin fill. The second reach, which is mostly downstream from Drummond, receives ground-water inflow from bedrock. 
Water-levels for the wells listed in table 98 are stored in the USGS WATSTORE database. Water levels were measured in these wells at least once annually during the periods of record. Water levels in the flood-plain alluvium correspond to river and stream stages, with water levels peaking during spring runoff, indicating hydraulic connection with surface water. Water levels in Tertiary sediments beneath irrigated benches rise throughout the irrigation season, peaking at the end of summer as irrigation ceases (Nimick and others, 1993).

Table 98. Summary of water-level data for selected wells in the Upper Clark Fork Valley, Montana [Hydrogeologic unit: Qal, Holocene and Pleistocene alluvial deposits; Ts, Tertiary sedimentary deposits and rocks]

\begin{tabular}{|c|c|c|c|c|c|c|c|}
\hline \multirow[b]{2}{*}{ Station name } & \multirow{2}{*}{$\begin{array}{l}\text { Depth of } \\
\text { well, in feet } \\
\text { below land } \\
\text { eurfece }\end{array}$} & \multirow{2}{*}{$\begin{array}{l}\text { Hydro- } \\
\text { geologic } \\
\text { unit }\end{array}$} & \multirow[b]{2}{*}{$\begin{array}{c}\text { Perlod of } \\
\text { record }\end{array}$} & \multicolumn{4}{|c|}{ Water level, in feet below land surfece } \\
\hline & & & & Highest & $\begin{array}{l}\text { Date of } \\
\text { hgheet }\end{array}$ & Loweat & $\begin{array}{l}\text { Date of } \\
\text { lowest }\end{array}$ \\
\hline 08N09W27BDDD01 & 95. & Ts & $1985-92$ & 22.75 & $05-28-86$ & 27.21 & $08-17-92$ \\
\hline 07N09W08ADD 01 & 12.7 & Qal & $1957-92$ & 6.47 & $\begin{array}{l}08-01-57 \\
09-03-57\end{array}$ & 10.99 & 02-03-58 \\
\hline 07N09W31CDD 01 & 53.0 & Ts & $1957-79$ & 32.25 & $08-26-75$ & 52.12 & $05-26-76$ \\
\hline 06N10W15AAD 01 & 12.6 & Qal & $1957-82$ & 5.16 & 07-01-59 & 12.20 & 03-03-69 \\
\hline 06N10W27CCCC01 & 88.7 & Ts & $1960-91$ & 30.14 & $08-23-78$ & 66.17 & 06-09-69 \\
\hline 06N09W21CDBC01 & 150 & Ts & $1960-92$ & 88.97 & $08-20-68$ & 93.24 & $03-29-73$ \\
\hline 05N10W10CCBC01 & 115 & Ts & $1985-91$ & 71.22 & $09-25-86$ & 81.80 & $06-02-87$ \\
\hline 04N10W10DC 02 & 20.0 & Qal & $1960-92$ & 2.87 & $02-14-77$ & 5.65 & $10-31-90$ \\
\hline
\end{tabular}

Ground water throughout the basin is a calcium bicarbonate type with significant magnesium content (Clark and Dutton, in press), based on analyses of 41 samples analyzed for major ions and measured dissolved-solids concentrations and 34 samples in which dissolved-solids concentrations were estimated from specific-conductance measurements. Dissolved-solids concentrations in ground water in most areas are less than $400 \mathrm{mg} / \mathrm{L}$, but near the mouth of Flint Creek, dissolved-solids concentrations exceed $500 \mathrm{mg} / \mathrm{L}$ (Nimick and others, 1993). Geothermal water in the Deer Lodge Valley has dissolved-solids concentrations ranging from $170 \mathrm{mg} / \mathrm{L}$ at Deer Lodge Prison Hot Springs to 2,310 mg/L at Anaconda Hot Springs (Sonderegger and Bergantino, 1981). Nitrate concentrations are elevated in agricultural areas, but typically do not exceed drinking-water standards (U.S. Environmental Protection Agency, 1991). Mining-related activities apparently have affected ground-water quality only in close proximity to contaminant sources (Nimick and others, 1993). For example, concentrations of arsenic are elevated in alluvial ground water within $300 \mathrm{ft}$ of the Clark Fork and concentrations of cadmium are elevated downstream from some tailings ponds. Locally, increased sulfate concentrations result from influx of geothermal water or leachate from mine wastes (Nimick and others, 1993).

\section{Selected References}

Alden, W.C., 1953, Physiography and glacial geology of western Montana and adjacent areas: U. S. Geological Survey Professional Paper 231, $200 \mathrm{p}$.

Axtmann, E.V., and Luoma, S.N., 1991, Large-scale distribution of metal contamination in the fine-grained sediments of the Clark Fork River, Montana, U.S.A.: Applied Geochemistry, v. 6, p. 75-88.

Baken, J.F., 1984, The structural geology and tectonic history of the northem Flint Creek Range, western Montana: Bozeman, Montana State University, M.S. thesis, 125 p.

Boettcher, A.J., and Gosling, A.W., 1977, Water resources of the Clark Fork basin upstream from St. Regis, Montana: Montana Bureau of Mines and Geology Bulletin 104, 28 p.

Briar, D.W., Lawlor, S.M., Stone, M.A.J., Parliman, D.J., Schaefer, J.L., and Kendy, Eloise, in press, Ground-water levels in intermontane basins of the Northern Rocky Mountains, Montana and Idaho: U.S. Geological Survey Hydrologic Investigations Atlas 738-B, 1 sheet, scale 1:750,000.

Casne, E.W., Botz, M.K., and Pasichnyk, M.J., 1975, Water quality inventory and management plan, upper Clark Fork basin, Montana: Montana Department of Health and Environmental Sciences, 148 p. 
Chadwick, R.A., and Leonard, R.B., 1979, Structural controls of hot-spring systems in southwestem Montana: U.S. Geological Survey Open-File Report 79-1333, 25 p.

Clark, D.W., and Dutton, D.M., in press, Quality of water and surface water in intermontane basins of the Northern Rocky Mountains, Montana and Idaho: U.S. Geological Survey Hydrologic Investigations Atlas 738-C, 1 sheet, scale 1:750,000.

Cremer, E.A., III, 1966, Gravity determination of basement configuration, southem Deer Lodge Valley, Montana: Missoula, University of Montana, M.S. thesis, 23 p.

Csejtey, Jr., Be'la, 1962, Geology of the southeast flank of the Flint Creek Range, western Montana: Princeton, N.J., Princeton University, Ph.D. dissertation, 159 p.

Dickman, Lynne, and Schenck, Don, 1989, Preliminary geologic map of the Deerlodge National Forest, Montana (west half): Montana Bureau of Mines and Geology Open-File Report 225-A, scale 1:126,720.

Dutton, D.M., Lawlor, S.M., Briar, D.W., and Tresch, R.E., 1995, Hydrogeologic data for the Northern Rocky Mountains intermontane basins, Montana: U.S. Geological Survey Open-File Report 95-143, 94 p.

Environmental Science and Engineering, Inc., 1993, Anaconda regional water and waste operable unit, data summary reports, second quarter 1993--Volume I, Technical report draft, and volume II, Appendices draft: Butte, Montana, various paging.

Gwinn, V.E., 1961, Geology of the Drummond area, central-western Montana: Montana Bureau of Mines and Geology Geological Map GM 4, scale 1:125,000.

Halvorson, J.W., and Wideman, C.J., 1980, A geophysical investigation of the Warm Springs, Montana, area: Montana Bureau of Mines and Geology Open-File Report 37, 11 p.

Hassemer, J.H., 1981, Principal facts and complete Bouguer gravity anomaly map for the west half of the Butte $1^{\circ} \times 2^{\circ}$ quadrangle, Montana: U.S. Geological Survey Open-File Report 81-949, 39 p., scale 1:250,000.

Johnson, H.E., and Schmidt, C.L., 1988, Clark Fork Basin Project status report and action plan: Helena, Mont., Clark Fork Basin Project, Office of the Governor, variously paged.

Konizeski, R.L., 1965, Tertiary deposits in basins marginal to the Flint Creek Range, in Billings Geological Society 16th Annual Field Conference Guidebook to Geology of the Flint Creek Range, Montana: [Billings, Mont.], Billings Geological Society, p. 10-18.

Konizeski, R.L., Brietkrietz, Alex, and McMurtrey, R.G., 1961, Geology and ground-water resources of the northern part of the Deer Lodge Valley, Montana: Montana Bureau of Mines and Geology Bulletin 21, 24 p.

Konizeski, R.L., McMurtrey, R.G., and Brietkrietz, Alex, 1962, Preliminary report on the geology and ground-water resources of the southem part of the Deer Lodge Valley, Montana: Montana Bureau of Mines and Geology Bulletin 31, 24 p. 1968, Geology and ground-water resources of the Deer Lodge Valley, Montana with a section on Gravimetric survey, by E.A. Cremer, III: U.S. Geological Survey Water-Supply Paper 1862, 55 p.

Lambing, J.H., 1987, Water-quality data for the Clark Fork and selected tributaries from Deer Lodge to Milltown, Montana, March 1985 to June 1986: U.S. Geological Survey Open-File Report 87-110, 48 p.

1988, Water-quality data (July 1986 through September 1987) and statistical summaries (March 1985 through September 1987) for the Clark Fork and selected tributaries from Deer Lodge to Missoula, Montana: U.S. Geological Survey OpenFile Report 88-308, 55 p.

1989, Water-quality data (October 1987 through September 1988) and statistical summaries (March 1985 through September 1988) for the Clark Fork and selected tributaries from Galen to Missoula, Montana: U.S. Geological Survey OpenFile Report 89-299, 51 p.

1990, Water-quality data (October 1988 through September 1989) and statistical summaries (March 1985 through September 1989) for the Clark Fork and selected tributaries from Galen to Missoula, Montana: U.S. Geological Survey OpenFile Report 90-168, 68 p.

1991. Water-quality and transport characteristics of suspended sediment and trace elements in streamflow of the upper Clark Fork basin from Galen to Missoula, Montana, 1985-1990: U.S. Geological Survey Water-Resources Investigations Report $91-4139,73$ p.

Mariner, R.H., Presser, T.S., and Evans, W.C., 1976, Chemical characteristics of the major thermal springs of Montana: U.S. Geological Survey Open-File Report 76-480, 31 p.

McCulloch, Robin, 1993, Montana mining directory 1992: Montana Bureau of Mines and Geology Bulletin 131, 76 p. 
McLeod, PJ., 1987, The depositional history of the Deer Lodge basin, western Montana: Missoula, University of Montana, M.S. thesis, $61 \mathrm{p}$.

Montana Department of Health and Environmental Sciences, 1994, Montana water quality, 1994: Helena, Water Quality Bureau, Montana 305(b) Report, 159 p.

[Montana] State Engineer's Office, 1959a, Water resources survey, Granite County, Montana--Part 1, History of land and water use on irrigated areas: Helena, Mont., State Engineer's Office, 47 p.

1959b, Water resources survey, Granite County, Montana--Part 2, Maps showing irrigated areas: Helena, Mont., State Engineer's Office, 22 p.

Moore, J.N., Brook, E.J., and Johns, C., 1989, Floodplain sediment--Clark Fork River, Montana, U.S.A: Environmental Geology and Water Science, v. 14, no. 2, p. 107-115.

Moore, J.N., and Luoma, S.N., 1990, Hazardous wastes from large-scale metal extraction--a case study: Environmental Science and Technology, v. 24, p. 1,279-1,285.

Mutch, T.A., 1960, Geology of the northeast flank of the Flint Creek Range, Montana: Princeton, NJ., Princeton University, Ph.D. dissertation, $159 \mathrm{p}$.

1961, Geology of the northeast fiank of the Flint Creek Range, western Montana: Montana Bureau of Mines and Geology Geologic Map GM 5, scale 1:126,720.

National Oceanic and Atmospheric Administration, 1992, Monthly normals of temperature, precipitation, and heating and cooling degree days, 1961-90, Montana: Asheville, N.C., Climatography of the United States no. 81, unpaged.

Nimick, D.A., Brooks, Tom, Dodge, K.A., and Tuck, L.K., 1993, Hydrology and water chemistry of shallow aquifers along the upper Clark Fork, western Montana: U.S. Geological Survey Water-Resources Investigations Report 93-4052, 63 p.

Nimick, D. A., and Moore, J.N., 1994, Stratigraphy and chemistry of sulfidic flood-plain sediments in the Upper Clark Fork Valley, Montana, in Alpers, C.N., and Blowes, D.W., eds., 1994, Environmental Geochemistry of Sulphide Oxidation: Washington, D.C., American Chemical Society Symposium Series 550, Chapter 19, p. 276-288.

Noble, R.A., Bergantino, R.N., Patton, T.W., Sholes, B.C., Daniel, Faith, and Schofield, Judeykay, 1982, Occurrence and characteristics of ground water of Montana--Volume 2, The Rocky Mountain Region: Montana Bureau of Mines and Geology Open-File Report 99, 132 p.

Rasmussen, D.L.,1989, Depositional environments, paleoecology, and biostratigraphy of Arikareean Bozeman group strata west of the Continental Divide in Montana, in Montana Geological Society 1989 Field Conference Guidebook, Montana Centennial Edition, Volume I--Geologic resources of Montana: [Billings, Mont.], Montana Geological Society, p. 205215.

Ruppel, E.T., 1961, Reconnaissance geologic map of the Deer Lodge quadrangle, Powell, Deer Lodge, and Jefferson Counties, Montana: U.S. Geological Survey Mineral Investigations Map MF-174, scale 1:48,000.

Shields, R.R., Knapton, J.R., White, M.K., Brosten, T.M., and Chambers, C.L., 1993, Water resources data, Montana, water year 1992: U.S. Geological Survey Water-Data Report MT-92-1, 534 p.

Sonderegger, J.L., 1984, D.O.E. [U.S. Department of Energy] final report--A summary of geothermal studies in Montana, 1980 through 1983: Montana Bureau of Mines and Geology Open-File Report 142, 33 p.

Sonderegger, J.L., and Bergantino, R.N., 1981, Geothermal resources map of Montana: Montana Bureau of Mines and Geology Hydrogeologic Map 4, scale 1:1,000,000.

Stickney, M.C., and Downey, PJ., 1993, Preliminary geologic map of the Deer Lodge area, southwestern Montana: Montana Bureau of Mines and Geology Open-File Report 271, scale 1:50,000.

Tuck, L. K., Briar, D.W., and Clark, D.W., in press, Geologic history and hydrogeologic units of intermontane basins of the Northern Rocky Mountains, Montana and Idaho: U.S. Geological Survey Hydrologic Investigations Atlas 738-A, 2 sheets, scale 1:750,000.

U.S. Environmental Protection Agency, 1986, Quality criteria for water 1986: Washington, D.C., Office of Water Regulations and Standards, EPA 440/5-86-001, unpaged.

1989, Maximum contaminant levels (subpart B of part 141, National primary drinking-water regulations): U.S. Code of Federal Regulations, Title 40, Parts 100 to 149 , revised as of July 1, 1989, p. 547-551. 
1991, Maximum contaminant levels (subpart B of part 141, National primary drinking-water regulations): U.S. Code of Federal Regulations, Title 40, Parts 100 to 149, revised July 1, 1991, p. 585-588.

U.S. Geological Survey, 1914, Profile surveys in the basin of the Clark Fork of the Columbia River, Montana-Idaho-Washington: U.S. Geological Survey Water-Supply Paper 346.

issued annually, Water resources data, Montana: Helena, Mont., U.S. Geological Survey Water-Data Report.

Wallace, C.A., 1987, Generalized geologic map of the Butte $1^{\circ} \times 2^{\circ}$ quadrangle, Montana: U.S. Geological Survey Miscellaneous Field Studies Map MF-1924, scale 1:250,000.

Wallace, C.A., Schmidt, R.G., Lidke, D.J., Waters, M.R., Elliott, J.E., French, A.B., Whipple, J.W., Zarske, S.E., Blaskowski, M.J., Heise, B.A., Yeoman, R.A., O'Neill, J.M., Lopez, D.A., Robinson, G.D., and Klepper, M.R., 1986, Preliminary geologic map of the Butte $1^{\circ} \times 2^{\circ}$ quadrangle, western Montana: U.S. Geological Survey Open-File Report 86-292, scale $1: 250,000$.

Wanek, A.A., and Barclay, C.S.V., 1966, Geology of the northwest quarter of the Anaconda quadrangle, Deer Lodge County, Montana: U.S. Geological Survey Bulletin 1222-B, 28 p.

Wideman, C.J., Sonderegger, J.L, Crase, Edward, and Peterson, Janet, 1982, Deer Lodge Valley investigations, western Montana, in Geothermal Direct Heat Program, Roundup Technical Conference Proceedings: University of Utah Research Institution, Earth Sciences Laboratory Publication 98, p. 122-140. 


\section{Upper Madison RIver Valley}

\section{Geography}

The Upper Madison River Valley is a $110-\mathrm{mi}^{2}$, northwest-trending intermontane basin that is bounded by the Continental Divide on the southwest, the Madison River Valley on the northwest, the Madison Range on the north, and the Wyoming-Montana border on the east (pl. 1). Although the structural basin continues eastward into Yellowstone National Park, the state boundary marks the eastem edge for this study. Hebgen Lake is the major geographical feature of the basin. Surrounding the lake is a large, relatively level plain, flanked in places by smooth, rolling terraces, and in other places by steep mountains. A few alluvial fans extend from the mountains to the plain, particularly along the northem basin margin. The Madison River flows into Hebgen Lake from the southeast, and exits the lake on the northwest. From there, it flows westward through a relatively narrow canyon. Just before leaving the basin, the river is again impounded, in the narrow

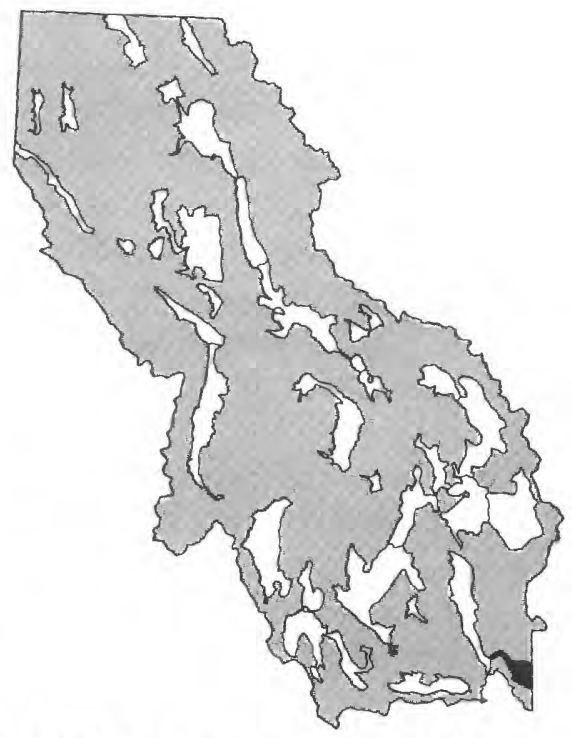
Earthquake Lake. The Upper Madison River Valley ranges in altitude from about 6,300 ft where the Madison River flows out of the basin, to about $7,400 \mathrm{ft}$ on the highest terrace.

The climate of the Upper Madison River Valley is characterized by cool summers and cold winters. One of the coldest temperatures recorded in the conterminous United States was $-66^{\circ} \mathrm{F}$ at West Yellowstone (altitude 6,670 $\mathrm{ft}$ ) in February 1933. Mean monthly climatic data for West Yellowstone are plotted in figure 31. On the basis of the 1961-90 period of record, the average annual precipitation at West Yellowstone is $22.14 \mathrm{in}$. and the average annual temperature is $35.0^{\circ} \mathrm{F}$ (National Oceanic and Atmospheric Administration, 1992). The average last occurrence of $32^{\circ} \mathrm{F}$ is July 6 and the average first occurrence is August 18. In contrast, Hebgen Dam (altitude 6,490 $\mathrm{ft}$ ) has a normal growing season from June 23 to August 29 (Natural Resources Conservation Service, U.S. Department of Agriculture, unpub. data, 1994). The average annual precipitation at Hebgen Dam is 30.11 in. and the average annual temperature is $36.4^{\circ} \mathrm{F}$ (National Oceanic and Atmospheric Administration, 1992).

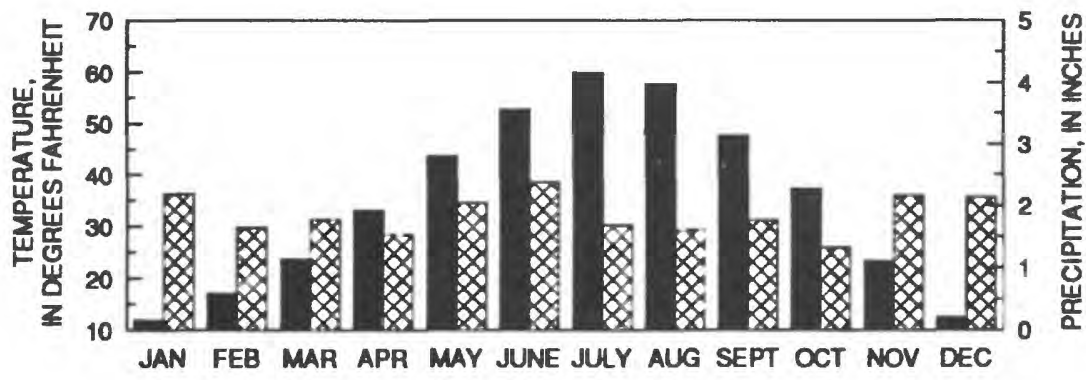

EXPLANATION

MEAN MONTHLY TEMPERATURE FOR 1961-90 PERЮD OF RECORD

Figure 31. Mean monthly precipitation and temperature at West Yellowstone, Mont. Data from National Oceanic and Atmospheric Administration (1992).

Land uses include timber harvesting, livestock grazing, and limited irrigated hay and pasture farming. Tourism is the major economic base, as West Yellowstone is a popular "gateway" to Yellowstone National Park (J.C. Eggen, Agricultural Stabilization and Conservation Service, oral commun., 1993). About 1,000 people reside in the Upper Madison River Valley, including 913 in the Town of West Yellowstone (1990 census). 


\section{Geology}

The Upper Madison River Valley is a downdropped fault block bounded by Tertiary normal faults (Witkind and others, 1964; Haller and others, 1993). Cross-cutting faults offset unconsolidated Quaternary deposits within the basin (U.S. Geological Survey, 1964).

On August 17, 1959, an earthquake registering a magnitude of 7.1 on the Richter scale, the largest magnitude recorded in Montana, ruptured two major normal faults near the northem basin margin. Eighteen miles of fault scarps appeared along the two faults, and several miles of smaller scarps offset unconsolidated deposits within the basin. Hebgen Lake locally subsided as much as $22 \mathrm{ft}$. The earthquake triggered dozens of landslides, including one that blocked the Madison River, creating Earthquake Lake at the northwestern edge of the basin (U.S. Geological Survey, 1964). Continued seismic activity was evidenced by about $0.3 \mathrm{in} / \mathrm{yr}$ of horizontal extension along the fault zone from 1973 to 1987 (Savage and others, 1993).

A few investigators have examined the geology of the Upper Madison River Valley (table 99). The geologic units described by previous investigators are summarized below. These geologic units are referenced to hydrogeologic units defined in this study (table 2) to provide a consistent regional framework. In the following discussion, the hydrogeologic-unit abbreviations are italicized.

Table 99. Geologic maps of the Upper Madison River Valley, Montana

\begin{tabular}{|c|c|c|c|c|}
\hline Type of map & Scale & Location & Map features & Reference \\
\hline Geology & $1: 250,000$ & $\begin{array}{l}\text { Entire Upper } \\
\text { Madison } \\
\text { River Valley }\end{array}$ & $\begin{array}{l}\text { All basin fill designated as QT, which includes } \\
\text { Quatemary alluvium, pyroclastic rocks, } \\
\text { landslides, glacial material, and late Tertiary } \\
\text { lake beds }\end{array}$ & Egbert, 1960 \\
\hline Geology & $1: 62,500$ & $\begin{array}{l}\text { Entire Upper } \\
\text { Madison } \\
\text { River Valley }\end{array}$ & $\begin{array}{l}\text { Differentiates } 19 \text { Quaternary sedimentary } \\
\text { deposits and nine Tertiary to Quaternary } \\
\text { volcanic units }\end{array}$ & $\begin{array}{l}\text { U.S. Geological Survey, } \\
1964\end{array}$ \\
\hline
\end{tabular}

Precambrian through Tertiary bedrock bounds the Upper Madison River Valley. Archean metamorphic rocks $(K A m)$, including gneiss, schist, amphibolite, dolomite, and quartzite compose the southern Madison Range and also crop out near the center of the basin. Paleozoic and Mesozoic sedimentary rocks border the basin north of Hebgen Lake. The Paleozoic rocks ( $P$ zls) are dominantly limestone, conglomerate, and sandstone, with some siltstone and shale. The Mesozoic rocks (Mzsh) are typically finer grained, and include shale, sandstone, limestone, claystone, and mudstone (Witkind and others, 1964). Tertiary volcanic rocks (QTKe) floor the basin (Lane and others, 1967). Quaternary volcanic rocks ( $Q T K e$ ) cover the older rocks and interfinger with Pleistocene glacial deposits along the eastern basin margin (Hamilton, 1964).

Tertiary sediments (TS) do not crop out in the Upper Madison River Valley. However, it is possible that they are present in the subsurface of this basin as in similarly formed nearby basins.

Pleistocene glacial till $(Q g)$ from at least two glaciations extends into the Upper Madison River Valley from the surrounding mountains. Till representing the earliest (pre-Bull Lake) glaciation crops out only locally, but underlies surficial deposits at depth. The younger till, correlated with the Bull Lake glaciation, forms smooth, rolling moraines along the basin margin, most notably southwest of West Yellowstone. Boulders are scattered atop the moraine surfaces, but are not abundant, and a layer of eolian silt 6 in. to $2 \mathrm{ft}$ thick mantles the till. Associated with the glacial till are local exposures of silty, clayey glacial lakebed deposits and sand-and-gravel kame deposits (Richmond, 1964).

Quaternary alluvium (Qal) composed primarily of interglacial obsidian sand overlies glacial-lakebed deposits and covers most of the basin. The subangular to angular sand ranges in thickness from about 40 to $100 \mathrm{ft}$ and averages 80 to $90 \mathrm{ft}$ thick. Grain sizes range from fine-grained sand to fine gravel, with thin beds of clean, very fine- 
grained sand and silt with a few thin pebble layers. The upper few feet of the sand deposit contain more gravel than the deeper layers (Richmond, 1964).

Other Quaternary deposits crop out locally. Alluvial fans slope into the basin in several places. Typically, the fan deposits (Qal) consist of angular to subrounded, locally derived gravel. Glacial outwash and alluvium (Qal) underlie a broad channel along the Madison River which is incised in the obsidian sand plain. The outwash typically consists of gravelly sand. In contrast, the alluvium is generally finer grained, consisting of humic sandy silt or silty sand with some gravel lenses (Richmond, 1964).

\section{Hydrology}

The Madison River originates in Yellowstone National Park and traverses the Upper Madison River Valley, through Hebgen and Earthquake Lakes. Below Earthquake Lake, the river flows through a narrow canyon, from which it enters the Madison River Valley and flows northward to Ennis Lake.

Streamflow data for gaging stations listed in table 100 are stored in the USGS WATSTORE database. Locations of the stations are shown on plate 1 . The record high flow at gaging station 06038500 was caused by a wave over Hebgen Dam during the 1959 earthquake; otherwise, the maximum flow at the station was $5,090 \mathrm{ft}^{3} / \mathrm{s}$, recorded on June 3, 1943 (Shields and others, 1994, p. 92). Daily volume and elevation records for Hebgen Lake (gaging station 06038000 , drainage area $904 \mathrm{mi}^{2}$ ) dating back to 1936 are maintained at the Helena office of the USGS. Monthend contents, in acre-ft, are published in the annual U.S. Geological Survey Water-Data Report (U.S. Geological Survey, issued annally).

Table 100. Summary of data for U.S. Geological Survey streamflow-gaging stations in the Upper Madison Aiver Valley, Montana

[Type of data collected: $c_{0}$ water chemistry; d, discharge. Periods of recond for stations that were being operated as of November 1994 are indicated by the first year of recond followed by a dash only. Abbreviations: $\mathrm{ft}^{3} / \mathrm{s}$, cubic feet per second. Symbol: -- , no data]

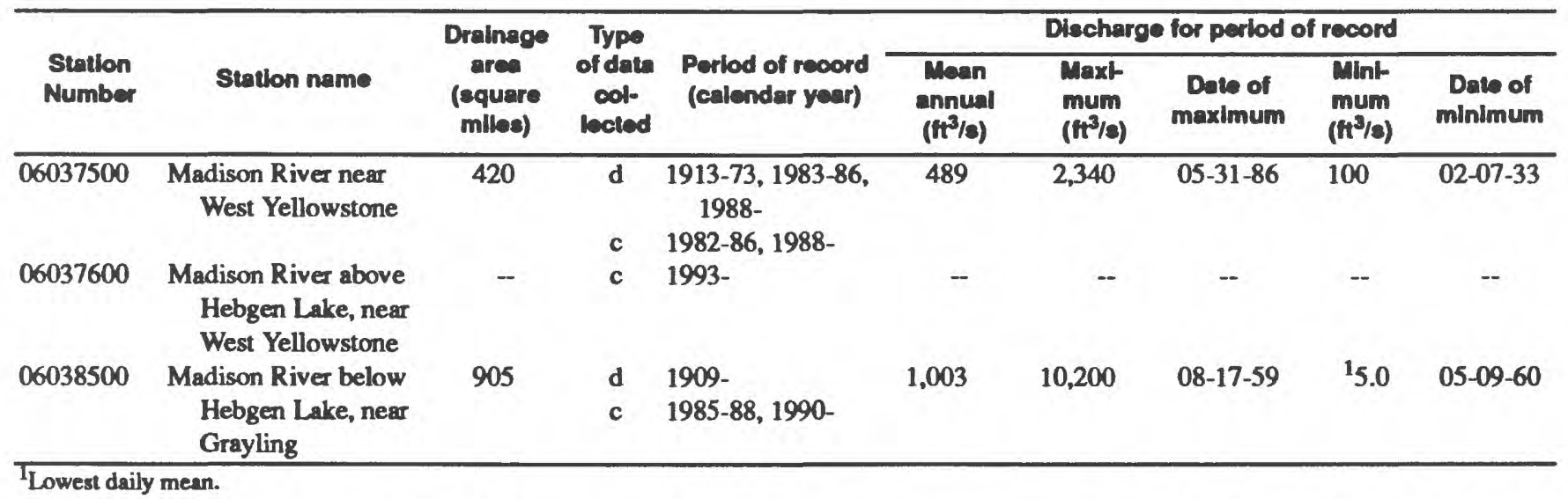

The quality of water in the Madison River is influenced by sources in Yellowstone National Park. Analyses of ten samples from the Madison River near West Yellowstone (gaging station 06037500) indicate a sodium bicarbonate type water with an average dissolved-solids concentration of $213 \mathrm{mg} / \mathrm{L}$. The source of the sodium ions is geothermal water, which has sodium as the only cation and chloride and bicarbonate as the predominant anions. Weathering of volcanic rocks may also contribute to the relatively large sodium concentrations (Clark and Dutton, in press).

Madison River water has high concentrations of arsenic because of the inflow of naturally enriched geothermal water from Yellowstone National Park. The concentration of total recoverable arsenic in the Madison River ranged from 0.110 to $0.370 \mathrm{mg} / \mathrm{L}$ above Hebgen Lake (gaging stations 06037500 and 06037600 ), and from 0.078 to $0.240 \mathrm{mg} / \mathrm{L}$ below Hebgen Lake (gaging station 06038500 ) from 1985 to 1994 . In general, large arsenic 
concentrations were recorded during low flows in the summer of 1994, and small concentrations occurred during high flows in the spring of 1993 (Knapton and Brosten, 1987, 1989; Knapton and Horpestad, 1987; U.S. Geological Survey, issued annually). At low flow, the great majority of the arsenic is in the dissolved phase as would be expected from the geothermal source. The U.S. Environmental Protection Agency (1991) has established a maximum contaminant level of $50 \mu \mathrm{g} / \mathrm{L}$ arsenic for treated drinking water.

Water in Hebgen Lake is a sodium bicarbonate type with relatively low concentrations of other major ions. Nutrient levels in the lake are fairly high; plankton productivity is limited by $20-\mathrm{ft}$ annual drawdowns, rather than by nutrient availability (Martin, 1967). Primary productivity in Earthquake Lake is limited by nutrient availability, and varies with releases from Hebgen Lake, which has higher nutrient levels (Ameson and Wright, 1967).

Ground water is an important resource in the Upper Madison River Valley, as wells provide domestic water for most basin residents, including the municipal supply for West Yellowstone. However, little is known about the aquifers that contain this resource. Drillers' logs indicate that well depths typically are about 100 to $150 \mathrm{ft}$ throughout most of the basin, with shallower wells completed in Holocene flood-plain alluvium, and wells as deep as $300 \mathrm{ft}$ completed in glacial till along the basin margins. Well yields reported by drillers range from about 10 to $50 \mathrm{gal} / \mathrm{min}$ in 6-in.-diameter domestic wells to $300 \mathrm{gal} / \mathrm{min}$ in an 8-in., 115-ft-deep subdivision supply well (12S04E24C). Reported water levels range from a few feet below the flood plain near the Madison River, to more than $100 \mathrm{ft}$ below glacial moraines along the basin margins. Although no flowing wells have been reported, shallow water levels in some deep wells suggest that fine-grained material such as glacial-lakebed deposits may confine ground water to some degree at depth (Montana Bureau of Mines and Geology, unpub. data, 1994).

Basin-fill aquifers are recharged by subsurface flow from Yellowstone National Park (Custer and others, 1994), precipitation and snowmelt, surplus irrigation water, and infiltration from tributary streams. The groundwater contribution area west of Yellowstone (fig. 2, pl. 1) is about $400 \mathrm{mi}^{2}$. Infiltration anywhere within this area could potentially recharge aquifers in the Upper Madison River Valley. Ground water discharges from basin-fill aquifers by evapotranspiration, withdrawals from wells, and seepage to springs, seeps, stream channels, and lakes.

The quality of ground water in the basin was determined on the basis of 35 samples analyzed for major ions and dissolved-solids concentrations. Ground water in most of the basin is a mixed-cation bicarbonate type, in which calcium, magnesium, and sodium are the major cations. Exceptions are a small area around Grayling, where sulfate is the dominant anion, and the southeastern part of the basin, including West Yellowstone, which has a sodium bicarbonate type ground water. Upstream from Hebgen Lake, the large percentage of sodium in ground water is probably related to the large sodium concentrations in the Madison River derived from geothermal water. The concentration of dissolved solids throughout the basin is less than $250 \mathrm{mg} / \mathrm{L}$ (Clark and Dutton, in press).

\section{Selected References}

Ameson, R.D., and Wright, J.C., 1967, Primary productivity research on Quake Lake, Montana [abs.]: Montana Academy of Sciences [Proceedings], v. 27, p. 34.

Bailey, J.P., 1977, Seismicity and contemporary tectonics of the Hebgen Lake-Centennial Valley, Montana, area: Salt Lake City, University of Utah, M.S. thesis, 115 p.

Briar, D.W., Lawlor, S.M., Stone, M.A.J., Parliman, D.J., Schaefer, J.L., and Kendy, Eloise, in press, Ground-water levels in intermontane basins of the Northern Rocky Mountains, Montana and Idaho: U.S. Geological Survey Hydrologic Investigations Atlas 738-B, 1 sheet, scale 1:750,000.

Clark, D.W., and Dutton, D.M., in press, Quality of ground water and surface water in intermontane basins of the Northern Rocky Mountains, Montana and Idaho: U.S. Geological Survey Hydrologic Investigations Atlas 738-C, 1 sheet, scale 1:750,000.

Custer, S.G., Michels, D.E., Sill, W.R., Sonderegger, J.L., Weight, Willis, and Woessner, W.W., 1994, Two strategies for Yellowstone National Park hydrothermal protection in light of scientific uncertainty, in Effects of Human-Induced Changes on Hydrologic Systems, Annual Summer Symposium of the American Water Resources Association [Proceedings]: Jackson Hole, Wyo., p. 821-840. 
Dutton, D.M., Lawlor, S.M., Briar, D.W., and Tresch, R.E., 1995, Hydrogeologic data for the Northern Rocky Mountains intermontane basins, Montana: U.S. Geological Survey Open-File Report 95-143, 94 p.

Egbert, R.L., 1960, Geologic map of the Madison Valley--Hebgen Lake, in Billings Geological Society 11 th Annual Field Conference, September 7-10, 1960, Guidebook for West Yellowstone-Earthquake area: Billings, Mont., Billings Geological Society, scale 1:250,000.

Haller, K.M., Dart, R.L., and Stickney, M.C., 1993, A compilation of major active faults for parts of Montana and Idaho [abs.]: Geological Society of America Abstracts with Programs, v. 25, no. 5, p. 46.

Hamilton, Warren, 1964, Volcanic rocks of the West Yellowstone and Madison Junction quadrangles, Montana, Wyoming, and Idaho: U.S. Geological Survey Professional Paper 435-S, p. 208-221.

Knapton, J.R., and Brosten, T.M., 1987, Supplemental arsenic data for selected streams in the Missouri River basin, Montana, 1987: U.S. Geological Survey Open-File Report 87-697, 14 p.

1989, Arsenic and chloride data for five stream sites in the Madison River drainage, Montana, 1988: U.S. Geological Survey Open-File Report 88-722, 12 p.

Knapton, J.R., and Horpestad, A.A., 1987, Arsenic data for streams in the upper Missouri River basin, Montana and Wyoming: U.S. Geological Survey Open-File Report 87-124, 25 p.

Lane, B.B., Hupp, Bill, and Walthall, B.H., 1967, First day geologic road log, West Yellowstone to Lima Reservoir, in Montana Geological Society 18th Annual Field Conference, August 9-12, 1967, Guidebook for Centennial Basin of Southwest Montana: Billings, Mont., Montana Geological Society, p. I-VI.

Martin, D.B., 1967, Limnological studies on Hebgen Lake, Montana: Bozeman, Montana State University, Ph.D. dissertation, $126 \mathrm{p}$.

[Montana] State Engineer's Office, 1953a, Water resources survey, Gallatin County, Montana--Part 1, History of land and water use on irrigated areas: Helena, Mont., State Engineer's Office, 62 p.

1953b, Water resources survey, Gallatin County, Montana--Part 2, Maps showing irrigated areas: Helena, Mont., State Engineer's Office, 53 p.

National Oceanic and Atmospheric Administration, 1992, Monthly normals of temperature, precipitation, and heating and cooling degree days, 1961-90, Montana: Asheville, N.C., Climatography of the United States no. 81, unpaged.

Richmond, G.M., 1964, Glacial geology of the West Yellowstone basin and adjacent parts of Yellowstone National Park: U.S. Geological Survey Professional Paper 435-T, p. 222-236.

Savage, J.C., Lisowski, Michael, Prescott, W.H., and Pitt, A.M., 1993, Deformation from 1973 to 1987 in the epicentral area of the 1959 Hebgen Lake, Montana, earthquake $\left(M_{8}=7.5\right)$ : Journal of Geophysical Research, v. 98, no. B2, p. 2145-2153.

Shields, R.R., White, M.K., Brosten, T.M., and Chambers, C.L., 1994, Water resources data, Montana, water year 1993: U.S. Geological Survey Water-Data Report MT-93-1, 512 p.

Tuck, L.K., Briar, D.W., and Clark, D.W., in press, Geologic history and hydrogeologic units of intermontane basins of the Northern Rocky Mountains, Montana and Idaho: U.S. Geological Survey Hydrologic Investigations Atlas HA-738-A, 2 sheets, scale 1:750,000.

U.S. Environmental Protection Agency, 1991, Maximum contaminant levels (subpart B of part 141, National primary drinkingwater regulations): U.S. Code of Federal Regulations, Title 40, Parts 100 to 149, revised July 1, 1991, p. 585-588.

U.S. Geological Survey, 1964, The Hebgen Lake, Montana, earthquake of August 17, 1959: U.S. Geological Survey Professional Paper 435, 242 p. issued annually, Water resources data, Montana: Helena, Mont., U.S. Geological Survey Water-Data Report.

Witkind, IJ., 1960, The Hebgen Lake, Montana, earthquake of August 17, 1959, in Billings Geological Society 11th Annual Field Conference, September 7-10, 1960, Guidebook for West Yellowstone-Earthquake area: Billings, Mont., Billings Geological Society, p. 31-44.

Witkind, IJ., Hadley, J.B., and Nelson, W.H., 1964, Pre-Tertiary stratigraphy and structure of the Hebgen Lake area: U.S. Geological Survey Professional Paper 435-R, p. 198-207. 


\section{Upper Ruby Valley}

\section{Geography}

The Upper Ruby Valley is a north-northeast-trending intermontane basin southwestem Montana. The $40-\mathrm{mi}^{2}$ basin is bounded by the Ruby Range on the northwest, the Ruby River Reservoir on the north, the Greenhorn Range on the east, the Snowcrest Range on the south, and the low divide between the drainages of the Ruby River and Blacktail Deer Creek on the southwest (pl. 1). The Ruby River enters the basin from the southeast and flows northward toward the Ruby River Reservoir. The flood plain is less than one mile wide and is flanked by grass- and sage-covered pediments. The Upper Ruby Valley ranges in altitude from about $5,400 \mathrm{ft}$ at the Ruby River Reservoir, to about $6,400 \mathrm{ft}$ on the highest pediment.

The climate of the Upper Ruby Valley is typical of higher-elevation intermontane basins in southwestern Montana, with cold, dry winters and mild

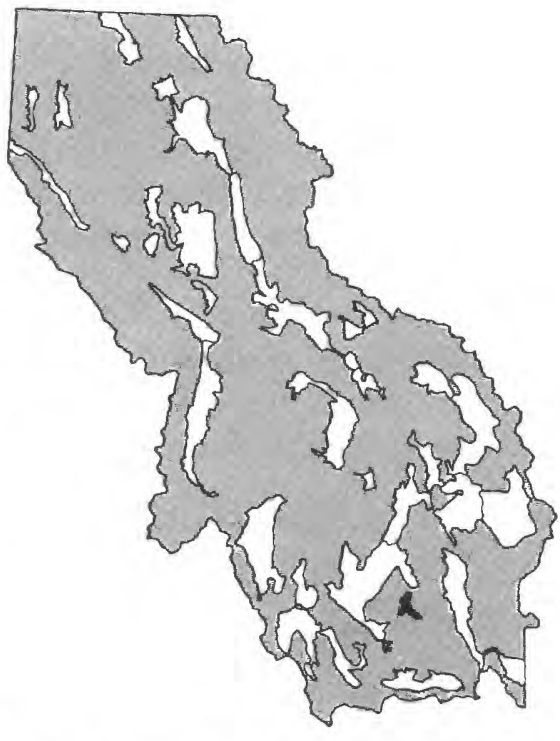
summers. On the basis of the 1961-90 period of record, the average annual precipitation at the National Weather Service station $17 \mathrm{mi}$ south of Alder (station Alder $17 \mathrm{~S}$, altitude 5,800 ft) is $13.29 \mathrm{in}$., and the average annual temperature is $41.4^{\circ} \mathrm{F}$ (National Oceanic and Atmospheric Administration, 1992). The average last occurrence of $32^{\circ} \mathrm{F}$ is June 23 and the average first occurrence is August 30 (Natural Resources Conservation Service, U.S. Department of Agriculture, unpub. data, 1994). Mean monthly climatic data for the Alder 17 S station are plotted in figure 32.

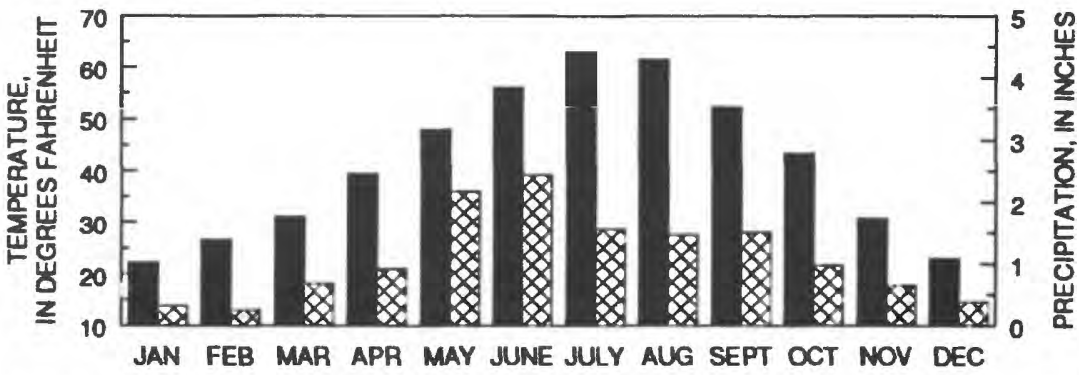

EXPLANATION

MEAN MONTHLY TEMPERATURE FOR 1961-90 PERIOD OF RECORD

囚 MEAN MONTHLY PRECIPITATION FOR 1961-90 PERIOD OF RECORD

Figure 32. Mean monthly precipitation and temperature 17 miles south of Alder, Mont. Data from National Oceanic and Atmospheric Administration (1992).

Land uses in the Upper Ruby Valley primarily are agricultural. The pediments, which account for most of the basin area, are used for rangeland, while the narrow flood plains of the Ruby River and major tributaries are irrigated for hay and pasture production. Runoff from the Upper Ruby Valley accumulates in the Ruby Reservoir, which is used to irrigate the lower Ruby River basin (J.C. Eggen, Agricultural Stabilization and Conservation Service, oral commun., 1993). Less than 100 people reside in the basin (1990 census).

Mining is an important land use in the mountains surrounding the Upper Ruby Valley. Currently, two openpit mines produce talc from the crest of the Ruby Range and exploration for gypsum deposits is occurring in the Gravelly Range (McCulloch, 1993, p. 32-33, 46). 


\section{Geology}

The Upper Ruby Valley formed by Cenozoic extensional tectonics that downdropped the bedrock floor of the basin relative to adjacent mountains. The basin is bounded by normal and strike-slip faults. Readily visible fault scarps indicate Quatemary and Holocene displacement along the Gravelly Range front. Gravity data indicate that at least two faults cross the basin, creating subsidence centers. At the largest subsidence center, in the northern part of the basin, basin fill is about $9,500 \mathrm{ft}$ thick (Ruppel, 1993, p. 24-27).

Several investigators have examined the geology of the Upper Ruby Valley (table 101). The geologic units described by previous investigators are summarized below. These geologic units are referenced to hydrogeologic units defined in this study (table 2 ) to provide a consistent regional framework. In the following discussion, the hydrogeologic-unit abbreviations are italicized.

Table 101. Geologic and geophysical maps of the Upper Ruby Valley, Montana

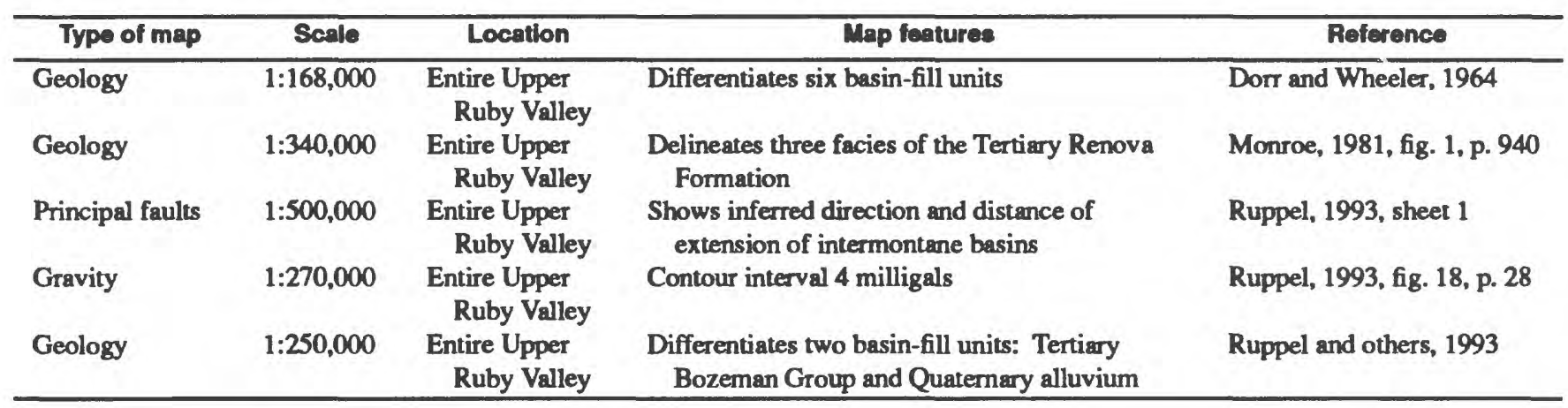

The basin is bounded by Archean rocks $(K A m)$ that range in composition from quartzofeldspathic gneiss to ultramafic schist (Ruppel, 1993; Ruppel and others, 1993). In 1984, an oil-exploration drill hole in the western part of the basin (08S05W27AD) penetrated Archean bedrock beneath 3,263 ft of Cenozoic basin fill (Montana Board of Oil and Gas Conservation, unpub. data, 1990).

Tertiary sediments (Ts) in the Upper Ruby Valley have been the subject of several geological investigations (Becker, 1961; Dorr and Wheeler, 1964; Monroe, 1974, 1976; Monroe, 1981; Fritz and Sears, 1993; Cheney and others, 1994). The sediments comprise the Bozeman Group, which is subdivided into two units. Dorr and Wheeler (1964) designated the lower and upper units as the Passamari Formation and the Madison Valley equivalent, respectively, whereas Monroe (1976) correlated the deposits with the Renova and Sixmile Creek Formations, as recognized in other intermontane basins of southwestern Montana.

The lower Tertiary unit consists of more than $1,800 \mathrm{ft}$ of very fine-grained, light-tan, buff, and gray, fissile and blocky shale and smectitic mudstone with very fine-grained, partly tuffaceous sandstone, siltstone, mudstone, limestone, and conglomerate of late Oligocene to early Miocene age. The unit is primarily lacustrine in origin (Dorr and Wheeler, 1964), but also represents nearshore, deltaic, fluvial, and alluvial-fan environments (Becker,1961; Monroe, 1981).

The upper Tertiary unit is unconformable with the lower unit and consists of more than $1,500 \mathrm{ft}$ of abundant conglomerate and fine- to coarse-grained tuffaceous, partly feldspathic sandstone, with thin beds of siltstone, mudstone, tuff, and tuffaceous limestone of late Miocene to middle Pliocene age (Dorr and Wheeler, 1964; Monroe, 1976). These deposits reflect mostly fluvial deposition (Monroe, 1981).

Quaternary alluvium (Qal) consisting of silt, sand, and gravel largely is confined to Holocene flood plains (Ruppel and others, 1993). Late Pliocene to Holocene arching eroded much of the Quaternary alluvial veneer that once covered Tertiary sediments on the pediments of the Upper Ruby Valley (Ruppel, 1993). 


\section{Hydrology}

The Ruby River drains the entire basin (pl. 1). Streamflow data recorded for gaging stations listed in table 102 are stored in the USGS WATSTORE database. Locations of these stations are shown on plate 1. In addition, the USGS has published monthend volume records for Ruby River Reservoir (gaging station 06020500, drainage area $596 \mathrm{mi}^{2}$ ) since its construction in 1938. Data for years prior to 1961 are published in Water-Supply Papers; more recent data are in annual Water-Data Reports (U.S. Geological Survey, issued annually).

Table 102. Summary of data for U.S. Geological Survey streamflow-gaging stations in the Upper Ruby Valley, Montana

[Type of data collected: d, discharge. Periods of record for stations that were being openated as of November 1994 are indicatd by the first year of record followed by a dash only. Abbreviations: $\mathrm{ft}^{3} 3 \mathrm{~s}$, cubic feet per second]

\begin{tabular}{|c|c|c|c|c|c|c|c|c|c|}
\hline \multirow[b]{2}{*}{$\begin{array}{l}\text { Station } \\
\text { number }\end{array}$} & \multirow[b]{2}{*}{ Station name } & \multirow{2}{*}{$\begin{array}{l}\text { Drainage } \\
\text { area } \\
\text { (equare } \\
\text { miles) }\end{array}$} & \multirow{2}{*}{$\begin{array}{l}\text { Type } \\
\text { of data } \\
\text { col- } \\
\text { lected }\end{array}$} & \multirow{2}{*}{$\begin{array}{l}\text { Perlod of record } \\
\text { (calendar year) }\end{array}$} & \multicolumn{5}{|c|}{ Diecharge for perlod of record } \\
\hline & & & & & $\begin{array}{l}\text { Mean } \\
\text { ennual } \\
\left(\mathrm{ti}^{3} / \mathrm{s}\right)\end{array}$ & $\begin{array}{l}\text { Maxt- } \\
\text { mum } \\
\left(\mathrm{t}^{3} / \mathrm{s}\right)\end{array}$ & $\begin{array}{l}\text { Dale of } \\
\text { maximum }\end{array}$ & $\begin{array}{l}\text { Minl- } \\
\text { mum } \\
\left(\mathrm{t}^{3} / e\right)\end{array}$ & $\begin{array}{l}\text { Date of } \\
\text { minimum }\end{array}$ \\
\hline 06019000 & $\begin{array}{l}\text { Ruby River above Warm } \\
\text { Springs Creek, near } \\
\text { Alder }\end{array}$ & 145 & d & $\begin{array}{l}\text { 1948-53 (No } \\
\text { winter records } \\
\text { after 1951) }\end{array}$ & 67.9 & 1,230 & $05-03-52$ & 6.8 & $11-05-50$ \\
\hline 06020000 & $\begin{array}{l}\text { Ruby River at dam site, } \\
\text { near Alder }\end{array}$ & 592 & d & $1911-14,1935-37$ & ${ }^{1} 118$ & 1,800 & $08-14-36$ & 39 & $07-08-36$ \\
\hline 06020600 & $\begin{array}{l}\text { Ruby River below } \\
\text { Reservoir, near Alder }\end{array}$ & 596 & d & $1962-$ & 209 & 3,010 & $05-16-84$ & 1.4 & $12-05-74$ \\
\hline
\end{tabular}

Data for water year 1936.

Although ground water is not extensively developed in the Upper Ruby Valley, it is an important resource. Ground water is used for domestic and livestock purposes and provides drinking water for all area residents. However, little is known about the aquifers that contain this resource. Reported yields of five wells completed in Tertiary sediments in the Upper Ruby Valley ranged from 12 to $45 \mathrm{gal} / \mathrm{min}$, with a median value of $18 \mathrm{gal} / \mathrm{min}$; these wells range in depth from 51 to $250 \mathrm{ft}$. The 250 - $\mathrm{ft}$-deep well is on a pediment near the southwestern edge of the basin (09S05W12CCDD01) and has a static water level of about $200 \mathrm{ft}$ below the land surface. The other four wells are located within about $1 \mathrm{mi}$ of the Ruby River and are each less than $120 \mathrm{ft}$ deep. Specific-capacity values of three wells are $0.9,1.0$, and $4.0(\mathrm{gal} / \mathrm{min}) / \mathrm{ft}$. Water levels in these wells are within $70 \mathrm{ft}$ of land surface (Dutton and others, 1995).

Little is known about ground-water flow in this basin. However, a 1:750,000-scale potentiometric-surface map which includes the Upper Ruby Valley (Briar and others, in press) indicates that ground water generally flows from the basin margins toward the Ruby River, then northward into the Ruby River Reservoir.

Basin-fill aquifers are recharged by precipitation and snowmelt, subsurface flow from bedrock, and infiltration from the Ruby River and its tributaries. The ground-water contribution area for the basin (fig. 2, pl. 1) is about 600 $\mathrm{mi}^{2}$. Infiltration anywhere within this area potentially could recharge basin-fill aquifers in the Upper Ruby Valley. The presence of Pullers Hot Springs (08S05W01AACC01) indicates subsurface inflow of geothermal water from bedrock (Chadwick and Leonard, 1979). The spring discharges water with a temperature of $44^{\circ} \mathrm{C}$ at a rate of $50 \mathrm{gal} / \mathrm{min}$ (Sonderegger and Bergantino, 1981). Ground water discharges from basin-fill aquifers by evapotranspiration, underflow to the Ruby River Reservoir, withdrawals from wells, and seepage to springs, seeps, and stream channels.

The quality of ground water in the basin was determined on the basis of three samples analyzed for major ions and measured dissolved-solids concentrations and two samples in which dissolved-solids concentrations were estimated from specific-conductance measurements. These samples had dissolved-solids concentrations ranging from about 250 to $500 \mathrm{mg} / \mathrm{L}$ (Clark and Dutton, in press). Water issuing from Pullers Hot Springs has a dissolvedsolids concentration of $1,160 \mathrm{mg} / \mathrm{L}$ (Sonderegger and Bergantino, 1981). 


\section{Selected References}

Becker, H.F., 1961, Oligocene plants from the upper Ruby River basin, southwestern Montana: Geological Society of America Memoir 82, $127 \mathrm{p}$.

Briar, D.W., Lawlor, S.M., Stone, M.A.J., Parliman, D.J., Schaefer, J.L., and Kendy, Eloise, in press, Ground-water levels in intermontane basins of the Northern Rocky Mountains, Montana and Idaho: U.S. Geological Survey Hydrologic Investigations Atlas 738-B, 1 sheet, scale 1:750,000.

Chadwick, R.A., and Leonard, R.B., 1979, Structural controls of hot-spring systems in southwestem Montana: U.S. Geological Survey Open-File Report 79-1333, 25 p.

Cheney, E.S., Hanneman, D.L., and Wideman, C.J., 1994, Tectonics of the Yellowstone hotspot wake in southwestern Montana--Comment: Geology, v. 22, no. 2, p. 185-6.

Clark, D.W., and Dutton, D.M., in press, Quality of ground water and surface water in intermontane basins of the Northern Rocky Mountains, Montana and Idaho: U.S. Geological Survey Hydrologic Investigations Atlas 738-C, 1 sheet, scale 1:750,000.

Dorr, J.A., Jr., and Wheeler, W.H., 1964, Cenozoic paleontology, stratigraphy, and reconnaissance geology of the upper Ruby River basin, southwestern Montana: Contributions from the Museum of Paleontology, University of Michigan, v. 13, p. 297-339.

Dutton, D.M., Lawlor, S.M., Briar, D.W., and Tresch, R.E., 1995, Hydrogeologic data for the Northern Rocky Mountains intermontane basins, Montana: U.S. Geological Survey Open-File Report 95-143, 94 p.

Fields, R.W., and Petkewich, R.M., 1967, Tertiary stratigraphy and geologic history of the upper Jefferson, Ruby, lower Beaverhead, and lower Big Hole River Valleys, in Montana Geological Society 18th Annual Field Conference Guidebook for the Centennial Basin of Southwest Montana: [Billings, Mont.], Montana Geological Society, p. 71-77.

Fritz, W.J., and Sears, J.W., 1993, Tectonics of the Yellowstone hotspot wake in southwestern Montana: Geology, v. 21, p. 427 430.

McCulloch, Robin, 1993, Montana mining directory 1992: Montana Bureau of Mines and Geology Bulletin 131, 76 p.

[Montana] State Engineer's Office, 1954a, Water resources survey, Madison County, Montana--Part 1, History of land and water use on irrigated areas: Helena, Mont., State Engineer's Office, 68 p.

1954b, Water resources survey, Madison County, Montana--Part 2, Maps showing irrigated areas: Helena, Mont., State Engineer's Office, $62 \mathrm{p}$.

Monroe, J.S., 1974, Tertiary stratigraphy of the upper Ruby River Basin, southwestern Montana [abs.]: Geological Society of America Abstracts with Programs, Rocky Mountain Section., v. 6, no. 5, p. 460.

1976, Vertebrate paleontology, stratigraphy and sedimentation of the upper Ruby River basin, Madison County, Montana: Missoula, University of Montana, Ph.D dissertation, 301 p.

Monroe, Stewart, 1981, Late Oligocene-Early Miocene facies and lacustrine sedimentation, upper Ruby River basin, southwestem Montana: Journal of Sedimentary Petrology, v. 51, no. 3, p. 939-951.

National Oceanic and Atmospheric Administration, 1992, Monthly normals of temperature, precipitation, and heating and cooling degree days, 1961-90, Montana: Asheville, N.C., Climatography of the United States no. 81, unpaged.

Ruppel, E.T., 1993, Cenozoic tectonic evolution of southwest Montana and east-central Idaho: Montana Bureau of Mines and Geology Memoir 65, 62 p.

Ruppel, E.T., O'Neill, J.M., and Lopez, D.A., 1993, Geologic map of the Dillon $1^{\circ} \times 2^{\circ}$ quadrangle, Idaho and Montana: U.S. Geological Survey Miscellaneous Investigations Series Map I-1803-H, scale 1:250,000.

Sonderegger, J.L., and Bergantino, R.N., 1981, Geothermal resources map of Montana: Montana Bureau of Mines and Geology Hydrogeologic Map 4, scale 1:1,000,000.

Tuck, L.K., Briar, D.W., and Clark, D.W., in press, Geologic history and hydrogeologic units of intermontane basins of the Northern Rocky Mountains, Montana and Idaho: U.S. Geological Survey Hydrologic Investigations Atlas 738-A, 2 sheets, scale $1: 750,000$.

U.S. Geological Survey, issued annually, Water resources data, Montana: Helena, Mont., U.S. Geological Survey Water-Data Report. 


\section{Western Three Forks Valley}

\section{Geography}

This intermontane basin has in various studies been referred to as all or part of "Three Forks Valley" (Fields and others, 1985; Hanneman and Wideman, 1991), "Three Forks Basin" (Robinson, 1961; Davis and others, 1965), and "Gallatin Valley" (Alden, 1953). For the purposes of this study, the large intermontane basin bounded on the east by the Bridger and Gallatin Ranges and on the west by the Tobacco Root Mountains has been subdivided into two separate entities: "Western Three Forks Valley" refers to that part of the intermontane basin west of the Madison Plateau and "Gallatin Valley" refers to the portion east of and including the Madison Plateau (pl. 1).

The Western Three Forks Valley is about $380 \mathrm{mi}^{2}$ in area. It is bounded by the southern Elkhom Mountains on the north, the Hossfeldt Hills on the northeast, the Madison Plateau on the east, the Madison Range on the south-

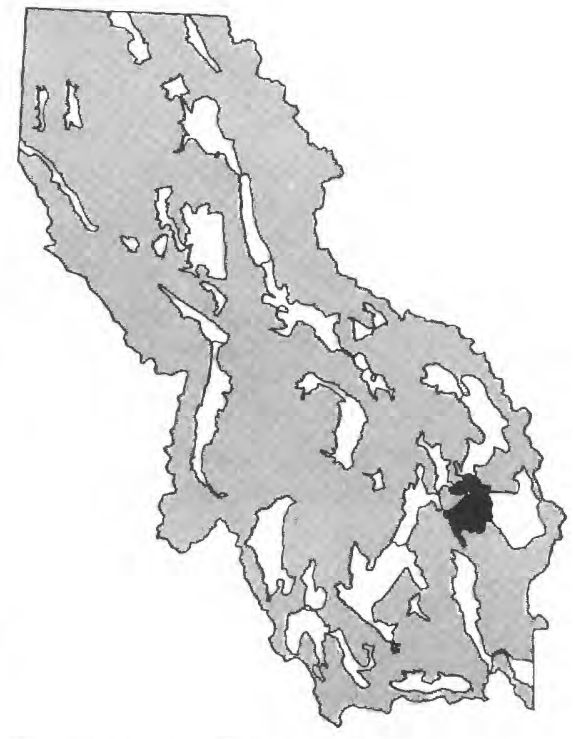
east, the Tobacco Root Mountains on the southwest and west, and the London Hills on the northwest (pl. 1).

Two rivers drain the basin. The Jefferson River enters the basin east of the London Hills and meanders along the northwestem basin margin. The Madison River enters the southeastem part of the basin and flows northward to its confluence with the Jefferson River near Three Forks. Less than $1 \mathrm{mi}$ downstream, the Gallatin River joins the Madison and Jefferson Rivers from the east. The confluence of the Madison, Jefferson, and Gallatin Rivers--the "three forks" for which the basin is named--marks the headwaters of the Missouri River.

Topographically, the basin is different from the other intermontane basins. It is the only intermontane basin in Montana with south-to-north drainage, but east-to-west elongation. The basin consists of the river flood plains and four broad benches, or terraces, that rise steplike above them (Robinson, 1963). The benches are difficult to discern. Those that rise to the south and drain essentially northward to the Jefferson River are interrupted by rugged ridges, across which streams traverse from one terrace to another. These north- to northwest-draining terraces comprise about three-fourths of the basin. South of the Jefferson River, the terraces are broad and steeply dissected. North of the river, they are small and irregular. The Madison River flood plain abuts against near-vertical 300- to 500 -ft-high cliffs (the westem edge of the Madison Plateau) on the east, dissected terraces on the southwest, and low, rolling hills on the northwest. The Jefferson and Madison Rivers adjoin the north and west edges of their flood plains and, whereas their tributaries are entrenched, the river channels are close to the flood-plain surfaces (Robinson, 1961). The Western Three Forks Valley ranges in altitude from about 4,000 ft at the confluence of the Jefferson and Madison Rivers, to about 5,700 ft on the highest terrace.

The climate of the Western Three Forks Valley is typical of mid-elevation intermontane basins of the Northem Rocky Mountains east of the Continental Divide, with cold winters and mild summers. The National Weather Service has no long-term records for the central part of the basin but does maintain weather stations at Pony, Norris, and Trident. On the basis of the 1961-90 period of record, the average annual precipitation at Trident (altitude 4,040 $\mathrm{ft}$ ) is $12.17 \mathrm{in}$. and the average annual temperature is $45.4^{\circ} \mathrm{F}$ (National Oceanic and Atmospheric Administration, 1992). The average last occurrence of $32^{\circ} \mathrm{F}$ is May 21 and the average first occurrence is September 18 (Natural Resources Conservation Service, U.S. Department of Agriculture, unpub. data, 1994). Because of its location and low elevation, Trident probably has less temperature fluctuation, a longer growing season, and perhaps less precipitation than the higher benches that represent most of the Western Three Forks Valley. Norris and Pony, both of which are situated in mountain foothills, receive about $17.5 \mathrm{in.} \mathrm{of} \mathrm{precipitation} \mathrm{annually.} \mathrm{However,} \mathrm{the} \mathrm{average}$ frost-free period extends from May 8 to September 26 at Norris (altitude 4,750 ft), but only from June 7 to September 11 at Pony (altitude 5,580 ft). Average annual temperatures are $46.9^{\circ} \mathrm{F}$ at Norris and $41.7^{\circ} \mathrm{F}$ at Pony (Natural Resources Conservation Service, U.S. Department of Agriculture, unpub. data, 1994; National Oceanic and Atmospheric Administration, 1992). Mean monthly climatic data for Pony are plotted in figure 33. 


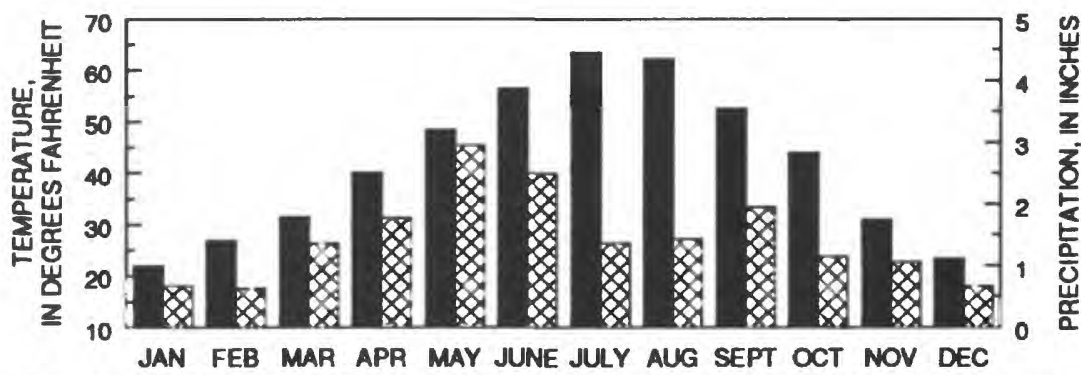

EXPLANATION

MEAN MONTHLY TEMPERATURE FOR 1961-90 PERIOD OF RECOAD

$\otimes$ MEAN MONTHLY PRECIPITATION FOR 1981-90 PERIOD OF RECORD

Figure 33. Mean monthly precipitation and temperature at Pony, Mont. Data from National Oceanic and Atmospheric Administration (1992).

About 2,000 people reside in the Western Three Forks Valley, including 1,203 in the Town of Three Forks and 164 in the unincorporated community of Pony (1990 census). The population primarily is concentrated along the rivers and creeks; the south-central part of the basin (north of Norris) is virtually uninhabited.

Land in the Western Three Forks Valley primarily is used for livestock grazing, irrigated hay and pasture farming, and dryland grain production. The benches are used as livestock range, with some dryland small-grain production (J.C. Eggen, Agricultural Stabilization and Conservation Service, oral commun., 1993). The flood plains of the Jefferson and Madison Rivers and Willow Creek are flood-irrigated, mainly for wheat and alfalfa production ([Montana] State Engineer's Office, 1953a, 1953b). Sprinkler irrigation began in the 1960's, after about 100 years of flood irrigation (Sonderegger and others, 1989b).

Mining is an important land use in the mountains surrounding the Western Three Forks Valley. Tungsten and silver historically were mined from the Tobacco Root Mountains (Eyde, 1958). Currently, exploration for gold is underway near Pony (McCulloch, 1993, p. 46). In 1994, the Montana Department of Health and Environmental Sciences determined that cyanide leaking from a closed gold mill above Pony had impacted ground water beneath that community (The Helena Independent Record, Dec. 6, 1994, p. 5A; Dec. 8, 1994, p. 3A).

\section{Geology}

The Western Three Forks Valley, with the Gallatin Valley, forms an eastward-tilted graben (downdropped crustal block). The northern, western, and southern basin boundaries are not marked by obvious faults and may be depositional contacts between Cenozoic basin fill and pre-Cenozoic bedrock. The eastem boundary of the Gallatin Valley is a series of normal faults along the Bridger and Gallatin Range fronts (Robinson, 1961). The Western Three Forks Valley probably was continuous with the Jefferson River Valley to the west until late Tertiary time, when uplift of the London Hills separated the two basins (Aram, 1981, p. 291). Tertiary deformation is evidenced by several broad folds with flanks dipping as steeply as $30^{\circ}$ (Robinson, 1961) and by possible block faulting along the westem edge of the Madison Plateau (Schneider, 1970). Seismic activity continues to the present time, although modem seismicity apparently is not related to Cenozoic block faulting (Stickney, 1990).

Geology of most of the Western Three Forks Valley has not been mapped in detail. Geologic and geophysical maps that are available are listed in table 103. The geologic units described by previous investigators are summarized below. These geologic units are referenced to hydrogeologic units defined in this study (table 2) to provide a consistent regional framework. In the following discussion, the hydrogeologic-unit abbreviations are italicized. 
Table 103. Geologic and geophysical maps of the Western Three Forks Valley, Montana

\begin{tabular}{|c|c|c|c|c|}
\hline Type of map & Scale & Location & Map features & Roference \\
\hline $\begin{array}{l}\text { Bouguer gravity } \\
\text { and generalized } \\
\text { geology }\end{array}$ & $1: 62,500$ & $\begin{array}{l}\text { Entire Westem Three } \\
\text { Forks Valley }\end{array}$ & $\begin{array}{l}\text { Gravity contour interval } 5 \text { milligals. All } \\
\text { basin fill designated as Cenozoic basin } \\
\text { deposits }\end{array}$ & $\begin{array}{l}\text { Davis and others, } \\
1965 \text {, sheet } 1\end{array}$ \\
\hline Aeromagnetic & $1: 62,500$ & $\begin{array}{l}\text { Entire Western Three } \\
\text { Forks Valley }\end{array}$ & Contour intervals 20 and 100 gammas & $\begin{array}{l}\text { Devis and others, } \\
1965 \text {, sheet } 2\end{array}$ \\
\hline Geology & $1: 165,000$ & $\begin{array}{l}\text { Southwestern part of } \\
\text { Western Three Forks } \\
\text { Valley, including Pony, } \\
\text { Norris and Harrison }\end{array}$ & $\begin{array}{l}\text { Differentiates two basin-fill units: Tertiary } \\
\text { basin deposits, and Holocene alluvium and } \\
\text { Pleistocene glacial drift (undifferentiated) }\end{array}$ & Eyde, 1958, pl. 2 \\
\hline Aeromagnetic & $1: 250,000$ & $\begin{array}{l}\text { Entire Westem Three } \\
\text { Forks Valley }\end{array}$ & Contour intervals 20 and 100 gammas & $\begin{array}{l}\text { Johnson and others, } \\
1965\end{array}$ \\
\hline Geology & $1: 24,000$ & $\begin{array}{l}\text { Norris quadrangle (lat } \\
45^{\circ} 30^{\prime} \mathrm{N} \text {., to } \\
45^{\circ} 37^{\prime} 30^{\prime \prime} \mathrm{N} \text {., long. } \\
11^{\circ} 37^{\prime} 30^{\prime \prime} \mathrm{N} \text {., to } \\
11^{\circ} 45^{\prime} \mathrm{N} \text {.) }\end{array}$ & $\begin{array}{l}\text { Differentiates } 2 \text { Tertiary and } 4 \text { Quatemary } \\
\text { basin-fill units }\end{array}$ & Kellogg, 1994 \\
\hline
\end{tabular}

Metamorphic, metasedimentary, sedimentary, volcanic, and intrusive bedrock bound the Western Three Forks Valley. Precambrian rocks floor most of the basin (Robinson, 1961). Archean metamorphic rocks (KAm) including gneiss and schist border the basin on the south and protrude from basin fill north of Willow Creek Reservoir. Arkose and conglomeratic rocks of the Middle Proterozoic Belt Supergroup (Yms) crop out in places along the northwestern basin boundary. Folded and faulted Paleozoic and Mesozoic sedimentary rocks crop out sporadically along the southern, western, and northerm basin boundaries. The Paleozoic rocks $\left(P_{z} l s\right)$ are mainly marine carbonates, whereas the Mesozoic rocks (Mzsh) are dominantly shales. Late Cretaceous Elkhom Mountains Volcanics (QTKe), which range in composition from basalt to andesite, border the northwestem part of the basin (Robinson, 1961, 1963). A Late Cretaceous or early Tertiary monzonite batholith (TKi) cores the central Tobacco Root Mountains west of the basin (Eyde, 1958).

The basin is filled with at least 2,500 ft of Tertiary sediments (Ts) of the Bozeman Group, which Robinson (1963) divided into four formations. The oldest is the Sphinx Conglomerate, a reddish limestone conglomerate about $100 \mathrm{ft}$ thick, exposed at the bases of some limestone ridges. A product of rapid erosion during the Late Cretaceous to early Tertiary Laramide Orogeny, this unit has been correlated with the Beaverhead Group of southwestern Montana. The conglomerate grades into the Milligan Creek Formation, a thick-bedded, fine-grained white tuffaceous limestone as much as $300 \mathrm{ft}$ thick that crops out in places along the Jefferson River. The overlying Climbing Arrow Formation is about $1,000 \mathrm{ft}$ thick and consists of olive, poorly consolidated, thick-bedded, sandy bentonitic clay and coarse-grained sand with small amounts of siltstone, sandstone, conglomerate, and limestone. This unit is widely exposed in the northwestern part of the basin, where resistant limestone, sandstone, and conglomerate layers support hills and ridges. Overlying this unit is the Dunbar Creek Formation, more than $800 \mathrm{ft}$ of white to grayish-yellow, well-consolidated, thick-bedded tuffaceous siltstone interspersed with sandstone and conglomerate lenses and small amounts of bentonitic clay and white limestone. The Dunbar Creek Formation crops out on steeply dissected benches along the Madison River (Robinson, 1961, 1963). The Milligan Creek, Climbing Arrow, and Dunbar Creek Formations are equivalent to the more widely used "Renova Formation" or "Renova equivalents" of Eocene to early Miocene age (Fields and others, 1985). Aside from a few probable erosional remnants, Tertiary sediments of late Miocene and Pliocene age are absent from this basin, although a thick sequence is present to the east, in the adjoining Gallatin Valley (Robinson, 1961, 1963).

"Old alluvium" (Robinson, 1963), including Quaternary and upper Tertiary deposits (QTd), is exposed over large areas, predominantly flanking Holocene alluvial flood plains. The proportion of gravel increases as the 
deposits thin from about $400 \mathrm{ft}$ along the Jefferson River, to about $15 \mathrm{ft}$ on high benches. Old alluvium near the Jefferson River has large volumes of sand and silt, whereas the same unit on bench tops is all gravel. Clasts are wellrounded on river flood plains and subrounded in tributary valleys (Robinson, 1963).

Quaternary glacial till $(Q g)$ composed of unsorted, unstratified clay, sand, gravel, and boulders, some of which exceed $25 \mathrm{ft}$ in diameter, underlie the U-shaped valley of Willow Creek and the upper reaches of other stream valleys emerging from the Tobacco Root Mountains. Clasts principally are gneiss, amphibolite, leptite, quartz monzonite, and aplite. Downvalley, the U-shape grades to a V-shape, and the underlying deposits grade from glacial till to glacial outwash (Qal) consisting of reworked glacial debris (Eyde, 1958).

Quaternary alluvial-fan deposits (QTd) mantle pediment surfaces north of Three Forks and crop out intermittently along the basin margin at altitudes below $4,900 \mathrm{ft}$. The fan material is angular to subangular gravel with or without a sand, silt, or clay matrix, and has well-developed caliche at the base. Most fan deposits are very thin, but some may be as much as $50 \mathrm{ft}$ thick (Robinson, 1963).

The most extensive Quatemary deposit in the basin is the Holocene alluvium (Qal) which underlies the flood plains of the Madison and Jefferson Rivers and their major tributaries. Along the rivers, alluvium is dominantly subrounded to rounded, clean, moderately well-sorted gravel and sand; beneath swampy areas, alluvium also probably contains significant amounts of silt and clay. Along tributaries, alluvium typically is poorly sorted, subangular, silty and sandy gravel with many boulders. In places, Holocene alluvium is more than $100 \mathrm{ft}$ thick. However, because it is difficult to discem Holocene alluvium from underlying deposits, its total thickness is uncertain. (Robinson, 1961, 1963).

\section{Hydrology}

The Jefferson and Madison Rivers are the principal streams in the Western Three Forks Valley. Flow in the Jefferson River is regulated by the Clark Canyon and Ruby River Reservoirs; flow in the Madison River is regulated by Ennis and Hebgen Lakes. Tributaries to the Jefferson River include Willow Creek and Norwegian Creek. Tributaries to the Madison River are Hot Springs Creek, Cherry Creek, and Elk Creek. The largest body of water in the Western Three Forks Valley is the Willow Creek Reservoir, which the State Water Conservation Board completed in 1938. Water from the reservoir is used to irrigate acreage between the reservoir and the Jefferson River to the north. Numerous diversions from the Jefferson and Madison Rivers and some of their tributaries irrigate flood plains and some terraces throughout the basin ([Montana] State Engineer's Office, 1953a, 1953b, 1954a, 1954b).

Streamflow data recorded for gaging stations listed in table 104 are stored in the USGS WATSTORE database. Locations of these stations are shown on plate 1.

Little is known about the major-ion chemistry of surface water in the Western Three Forks Valley. However, analyses of 253 samples from the Jefferson River near Twin Bridges (gaging station 06026500), about $20 \mathrm{mi}$ upstream from the Western Three Forks Valley, indicate a calcium bicarbonate type water with an average dissolvedsolids concentration of $213 \mathrm{mg} / \mathrm{L}$. Analyses of 15 samples from the Madison River below Ennis Lake, near McAllister (gaging station 06041000), about 10 mi upstream from Norris, indicate a calcium sodium bicarbonate type water with an average dissolved-solids concentration of $190 \mathrm{mg} / \mathrm{L}$. Analyses of four samples from the Madison River at Three Forks (gaging station 06042600) indicate that the major-ion composition is essentially unchanged after the river traverses the Westem Three Forks Valley, although the average dissolved-solids concentration is $158 \mathrm{mg} / \mathrm{L}$ (Clark and Dutton, in press).

Madison River water has relatively high concentrations of arsenic because of the inflow of naturally enriched geothermal water from Yellowstone National Park. As part of a reconnaissance survey of arsenic in the upper Missouri River basin, water at several USGS streamflow-gaging stations in the Western Three Forks Valley was sampled for arsenic under various hydrologic conditions from 1985 to 1987 . Results indicate that, while the Madison River had significant concentrations of total recoverable arsenic, ranging from 42 to $87 \mu \mathrm{g} / \mathrm{L}$, concentrations in the Jefferson River and tributaries to the Madison River were almost always less than $5 \mu \mathrm{g} / \mathrm{L}$ (Knapton and Horpestad, 1987; Knapton and Brosten, 1987). Continued sampling at selected stations through 1994 
Table 104. Summary of data for U.S. Geological Survey streamflow-gaging stations in the Western Three Forks Valley, Montana

[Type of data collected: $c_{\mathbf{v}}$ water chemistry; d, discharge. Periods of recond for stations that were being operated as of November 1994 are indicated by the first year of record followed by a dash only. Abbreviations: $\mathrm{ft}^{3} / \mathrm{s}$, cubic feet per second. Symbol: --, no data]

\begin{tabular}{|c|c|c|c|c|c|c|c|c|c|}
\hline \multirow[b]{2}{*}{$\begin{array}{l}\text { Station } \\
\text { number }\end{array}$} & \multirow[b]{2}{*}{ Station name } & \multirow{2}{*}{$\begin{array}{l}\text { Drainage } \\
\text { area } \\
\text { (equare } \\
\text { miles) }\end{array}$} & \multirow{2}{*}{$\begin{array}{l}\text { Type } \\
\text { of } \\
\text { data } \\
\text { col- } \\
\text { lected }\end{array}$} & \multirow[b]{2}{*}{$\begin{array}{l}\text { Perlod of record } \\
\text { (calendar year) }\end{array}$} & \multicolumn{5}{|c|}{ Discharge for perlod of record } \\
\hline & & & & & $\begin{array}{l}\text { Mean } \\
\text { annual } \\
\left(\mathrm{ft}^{3} / \mathrm{s}\right)\end{array}$ & $\begin{array}{l}\text { Maxj- } \\
\operatorname{mum} \\
\left(\mathrm{ft}^{3} / s\right)\end{array}$ & $\begin{array}{l}\text { Date of } \\
\text { maximum }\end{array}$ & $\underset{\substack{\text { Munt } \\
\left(\mathrm{ft}^{3} / \mathrm{s}\right)}}{\operatorname{lin}}$ & $\begin{array}{l}\text { Dale of } \\
\text { minimum }\end{array}$ \\
\hline 06034500 & $\begin{array}{l}\text { Jefferson River at } \\
\text { Sappington }\end{array}$ & 9,277 & d & $\begin{array}{l}1895-1905,1938- \\
69\end{array}$ & 2,125 & 21,000 & $06-23-1899$ & 84 & $08-03-66$ \\
\hline 06035000 & $\begin{array}{l}\text { Willow Creek near } \\
\text { Harrison }\end{array}$ & 83.8 & d & $\begin{array}{l}\text { 1938-82, 1982- } \\
\text { (seasonal } \\
\text { records only) }\end{array}$ & 40.7 & 813 & 02-03-63 & 32 & $07-21-88$ \\
\hline 06035500 & $\begin{array}{l}\text { Norwegian Creek near } \\
\text { Harrison }\end{array}$ & 22.4 & d & $1938-43,1946-51$ & 6.66 & 28 & $07-20-48$ & .8 & $\begin{array}{l}08-03-39 \\
\text { and } \\
08-15-40\end{array}$ \\
\hline 06036500 & $\begin{array}{l}\text { Willow Creek near } \\
\text { Willow Creek }\end{array}$ & 165 & d & $\begin{array}{l}1919-32,1946, \\
1947-53,1955- \\
56 \\
1985-86\end{array}$ & 51.0 & 650 & $07-31-48$ & 3 & $02-01-51$ \\
\hline 06036650 & $\begin{array}{l}\text { Jefferson River near } \\
\text { Three Forks }\end{array}$ & 9,532 & $\begin{array}{l}\text { d } \\
\text { c }\end{array}$ & $\begin{array}{l}1978- \\
1980-81,1985-87\end{array}$ & 1,931 & 15,900 & $05-24-81$ & 43 & 08-19-88 \\
\hline 06041300 & $\begin{array}{l}\text { Hot Springs Creek } \\
\text { near Norris }\end{array}$ & 72.5 & c & 1985-86, 1993- & -- & -- & - & -- & - \\
\hline 06041500 & $\begin{array}{l}\text { Madison River near } \\
\text { Norris }\end{array}$ & 2,288 & $\begin{array}{l}\text { d } \\
\text { c }\end{array}$ & $\begin{array}{l}\text { 1890-93, } 1910 \\
1993-\end{array}$ & $1,695.3$ & 6,420 & $05-30-1890$ & 850 & $08-26-10$ \\
\hline 06041700 & $\begin{array}{l}\text { Cherry Creek near } \\
\text { Norris }\end{array}$ & - & c & $1985-86,1993$ & -- & - & - & -- & - \\
\hline 06042000 & $\begin{array}{l}\text { Madison River below } \\
\text { Cherry Creek, near } \\
\text { Norris }\end{array}$ & 2,387 & d & $1897-1905$ & $2,008.6$ & 10,275 & 06-16-1899 & - & -- \\
\hline $\begin{array}{l}453916 \\
\quad 111311001\end{array}$ & $\begin{array}{l}\text { Elk Creek at mouth, } \\
\text { near Norris }\end{array}$ & - & c & $1993-$ & -- & -- & - & -- & -- \\
\hline 06042500 & $\begin{array}{l}\text { Madison River near } \\
\text { Three Forks }\end{array}$ & 2,511 & d & $\begin{array}{l}1893-97,1928-32 \\
1941-50\end{array}$ & 1,650 & 8,175 & $06-19-1896$ & 416 & $02-27-30$ \\
\hline 06042600 & $\begin{array}{l}\text { Madison River at } \\
\text { Three Forks }\end{array}$ & -- & c & $\begin{array}{l}\text { 1985-87, 1989-90, } \\
\text { 1993- }\end{array}$ & -- & - & -- & - & -- \\
\hline
\end{tabular}

indicated that arsenic concentrations remained low in the tributaries, but ranged from 48 to $99 \mu \mathrm{g} / \mathrm{L}$ in the Madison River near Norris (gaging station 06041500) and from 42 to $92 \mu \mathrm{g} / \mathrm{L}$ in the Madison River at Three Forks (gaging station 06042600). In general, higher arsenic concentrations were documented during low flows in the summer of 1994, and lower concentrations occurred during high flows in the spring of 1993. During low flow, the great majority of arsenic is in the dissolved phase (U.S. Geological Survey, issued annually). The U.S. Environmental Protection Agency (1991) has established a maximum contaminant level of $50 \mu \mathrm{g} / \mathrm{L}$ arsenic for treated drinking water.

Geothermal water influences the chemistry of Hot Springs Creek near Norris (gaging station 06041300), a tributary to the Madison River. Although arsenic concentrations usually are not elevated, one sample collected during high flow ( $21 \mathrm{ft}^{3} / \mathrm{s}$ in May 1986) had $22 \mu \mathrm{g} / \mathrm{L}$ total recoverable arsenic (Knapton and Horpestad, 1987; U.S. Geological Survey, issued annually). Geothermal water flows into the creek from Norris Hot Springs (Mariner and others, 1976; Chadwick and others, 1978; Peterson, 1983).

Ground water is an important resource in the Westem Three Forks Valley, as it provides the only source of drinking water in the basin, and the only source of livestock water for remote rangeland, primarily in the southem half of the basin. In general, Holocene flood-plain alluvium is the most reliable aquifer. The heterogeneity, fine- 
grained texture, and poor hydraulic connection to recharge sources makes the older deposits less reliable. Even close proximity to a river does not guarantee plentiful good-quality ground water in this basin, because the rivers tend to cut into fine-grained Tertiary deposits, which limit the amount of river water that can recharge aquifers. Owners of a group of houses on the northwest bank of the Jefferson River (02N01E28D), for example, drilled several wells to different depths in Tertiary sediments, and had problems ranging from dry wells to high sulphur content of the water.

Most wells completed in Quaternary alluvium are located on flood plains and typically are less than $80 \mathrm{ft}$ deep. Table 105 summarizes the yields and specific capacities of selected wells completed in alluvium. Of the data used to compile the table, three wells are 16-in.-diameter irrigation wells with discharges ranging from 280 to $450 \mathrm{gal} / \mathrm{min}$ and seven are 6-in.-diameter domestic and livestock wells with yields of 6 to $60 \mathrm{gal} / \mathrm{min}$ (Dutton and others, 1995). Most ground water in Quatemary alluvium is unconfined in the Western Three Forks Valley.

Table 105. Summary of data for yield and specific capacity of wells completed in selected hydrogeologic units in the Western Three Forks Valley, Montana

[Source: Dutton and others, 1995. Hydrogeologic unit: Qal, Holocene and Pleistocene alluvial deposits; Ts, Tertiary sedimentary deposits and rocks. Abbreviations: $\mathrm{g}$ al/min, gallon per minute; (gal/min)/ft, gallon per minute per foot]

\begin{tabular}{|c|c|c|c|c|c|c|c|c|c|c|}
\hline \multirow{2}{*}{$\begin{array}{l}\text { Hydro- } \\
\text { geologlc } \\
\text { unlt }\end{array}$} & \multirow[b]{2}{*}{$\begin{array}{c}\text { Number of } \\
\text { wells }\end{array}$} & \multicolumn{4}{|c|}{ Vield (gal/min) } & \multirow[b]{2}{*}{$\begin{array}{c}\text { Number of } \\
\text { wells }\end{array}$} & \multicolumn{4}{|c|}{ Speciflc capacity [(gal/min)/ft] } \\
\hline & & Mean & Median & $\begin{array}{l}\text { Mint } \\
\text { mum }\end{array}$ & $\begin{array}{l}\text { Maxł } \\
\text { mum }\end{array}$ & & Mean & Median & $\begin{array}{l}\text { Minl- } \\
\text { mum }\end{array}$ & $\begin{array}{l}\text { Maxl } \\
\text { mum }\end{array}$ \\
\hline Qal & 10 & 130 & 42 & 6.0 & 450 & 9 & 4.4 & 2.1 & 0.3 & 12 \\
\hline Ts & 26 & 150 & 20 & .2 & 1,200 & 19 & 2.6 & .7 & .1 & 16 \\
\hline
\end{tabular}

Tertiary sediments have a wide range of production capabilities, from dry holes to large-capacity irrigation wells. The data summarized in table 105 reflect this variability. Three of the wells used to compile table 105 are 16-in.-diameter irrigation wells that produce 900 to $1,200 \mathrm{gal} / \mathrm{min}$ with specific capacities of 6 to 16 (gal/min)/ft. The rest are small-capacity 6-in. wells (Dutton and others, 1995). Two of the irrigation wells are in the northwestem part of the basin, north of the Jefferson River. One of these (02N01E04BCAA) might be completed partly in bedrock that underlies basin fill. Drilling through Tertiary sediments and into bedrock in this area does not necessarily guarantee an irrigation supply. Nearby (02N01E17), a 2,030-ft-deep well penetrated "hard lime and dolomite" beneath $1,686 \mathrm{ft}$ of interbedded "shale and limestone", according to the driller's log. This well was located along the trend of two Mississippian limestone outcrops on either side of basin fill (Robinson, 1963), which apparently do not recharge the overlying sediments. Production from the well was insufficient for an irrigation supply and the well was abandoned (Stanley Kimm, landowner, oral commun., 1991). In contrast, the narrow band of Tertiary sediments east of the Madison River does appear to produce large yields fairly consistently. Several 16in.-diameter irrigation wells, including one of the wells used to compile table 105 , produce about $1,000 \mathrm{gal} / \mathrm{min}$ each. One well that probably is typical for this area (01S02E03DCCC02) is $404 \mathrm{ft}$ deep and is perforated through $147 \mathrm{ft}$ of sandstone and shale, according to the driller's log. The high terraces in the south-central part of the basin are underlain by fine-grained Tertiary sediments that yield only small quantities of ground water. Because no other sources are available, the minor aquifer in the Tertiary sediments has been developed for livestock wells. Most of these wells are several hundred feet deep and have specific capacities of less than 1 ( $\mathrm{gal} / \mathrm{min}$ )/ft (Dutton and others, 1995). Water in Tertiary sediments is unconfined or semiconfined to various degrees by laterally discontinuous layers of fine-grained material. A 600-ft-deep flowing well is completed in Tertiary sediments in the Milligan Creek area (02N01W22ADDD01).

Except for Mississippian limestone, the Paleozoic and Mesozoic sedimentary rocks that border and underlie the Westem Three Forks Valley generally do not yield large quantities of water to wells. Where Mississippian limestone is below the water table, however, it potentially is a dependable aquifer because ground water moves easily through joints, fractures, bedding planes, and other openings enlarged by dissolution of carbonate minerals. Mississippian limestone is a leaky confined system underlying Tertiary sediments in the Milligan Creek area (Krothe 
and Bergeron, 1981a), where geochemical data suggest that the limestone recharges Tertiary sediments (Krothe and Bergeron, 1981b).

Fractures in other bedrock units can potentially yield sufficient quantities of ground water to supply domestic and livestock wells. Three wells completed in the Middle Proterozoic Belt Supergroup reportedly produce 10, 15, and $30 \mathrm{gal} / \mathrm{min}$ (Dutton and others, 1995).

Few historical ground-water data exist for parts of this basin. Water levels measured in long-term monitoring well 01N01 W28BBA01 are stored in the USGS WATSTORE database. The 55- $\mathrm{ft}$ well is completed in Quaternary alluvium. During the 1965 to 1983 period of record, the water level in the well fluctuated between $27.31 \mathrm{ft}$ below land surface (Aug. 8, 1967) and $5.72 \mathrm{ft}$ below land surface (Oct. 19, 1982). Krothe and Bergeron (1981a, 1981b) compiled a 1:217,000-scale potentiometric-surface map of the Milligan Creek area with a 100-ft contour interval. In the mid-1980's, water levels were measured in wells completed in Quaternary alluvium beneath the flood plain of the Madison River. Although the data were not published, they were the basis for a published water-table map with 30-ft contours (Sonderegger and Ohguchi, 1988, fig. 5a, p. 158; Sonderegger and others, 1989b, fig. 1b, p. 687). More recently, Briar and others (in press) included the Western Three Forks Valley in a 1:750,000-scale potentiometric-surface map with 100 -ft contours. This map indicates that ground water generally flows from the uplands toward the river flood plains, then flows parallel to the Jefferson and Madison Rivers.

Basin-fill aquifers are recharged by precipitation and snowmelt, surplus irrigation water, leakage from canals, subsurface flow from bedrock, and infiltration from tributary streams. The ground-water contribution area for the basin (fig. 2, pl. 1) is about $680 \mathrm{mi}^{2}$. Infiltration anywhere within this area potentially could recharge basin-fill aquifers in the Western Three Forks Valley. Ground water discharges from the basin-fill aquifers by evapotranspiration, withdrawals from wells, seepage into springs, seeps, and stream channels, and possible subsurface flow to the Townsend Valley.

The quality of ground water in the basin was determined on the basis of 55 samples analyzed for major ions and measured dissolved-solids concentrations and 26 samples in which dissolved-solids concentrations were estimated from specific-conductance measurements. Beneath the flood plain of the Jefferson River, ground water is a calcium bicarbonate type with dissolved-solids concentrations ranging from about 250 to $500 \mathrm{mg} / \mathrm{L}$, increasing downstream to more than $500 \mathrm{mg} / \mathrm{L}$. Elsewhere in the basin, ground water has large sodium and sulfate concentrations, with some dissolved-solids concentrations exceeding $1,000 \mathrm{mg} / \mathrm{L}$. Near the Madison River, large sodium concentrations could be a result of the ground water being at least partially recharged by return flow of Madison River irrigation water (Clark and Dutton, in press).

In the Milligan Creek area, ground water changes along flow paths from calcium bicarbonate in recharge areas, to calcium sulfate in the center of the subbasin, to sodium bicarbonate in the discharge area. This sequence can be explained by chemical reactions between ground water and the geological formations along the flow paths (Krothe and Bergeron, 1981b).

Arsenic concentrations as high as $176 \mu \mathrm{g} / \mathrm{L}$ have been found in some wells completed in basin-fill deposits beneath the Madison River flood plain (L.K. Tuck, U.S. Geological Survey, written commun., 1995). Elevated arsenic levels have been attributed to the diversion and application of river-derived irrigation water. Madison River water, which contains naturally occurring arsenic from geothermal sources, normally does not significantly recharge basin-fill aquifers. However, a pathway from the river to the aquifer has been created by diverting river water to canals and applying it to the land surface overlying the permeable alluvial aquifer (Sonderegger and Ohguchi, 1988; Sonderegger and others, 1989a,b).

\section{Selected References}

Alden, W.C., 1953, Physiography and glacial geology of western Montana and adjacent areas: U.S.Geological Survey Professional Paper 231, 200 p. 
Andretta, D.B., and Alsup, S.A., 1960, Geology and Cenozoic history of the Norris-Elk Creek area, southwest Montana, in Billings Geological Society, 22nd Annual Field Conference, September 7-10, 1960, Guidebook for West Yellowstone-Earthquake area: Billings, Mont, Billings Geological Society, p. 185-190.

Aram, R.B., 1981, Geologic history of Lewis and Clark Caverns, Montana, in Montana Geological Society Field Conference and Symposium Guidebook to Southwest Montana: [Billings, Mont], Montana Geological Society, p. 285-300.

Berry, G.W., 1943, Stratigraphy and structure of Three Forks, Montana: New York, Cornell University, Ph.D dissertation, 49 p. 1943, Stratigraphy and structure at Three Forks, Montana: Geological Society of America Bulletin, v. 54, no. 1, p. 1-30.

Briar, D.W., Lawlor, S.M., Stone, M.A.J., Parliman, D.J., Schaefer, J.L., and Kendy, Eloise, in press, Ground-water levels in intermontane basins of the Northern Rocky Mountains, Montana and Idaho: U.S. Geological Survey Hydrologic Investigations Atlas 738-B, 1 sheet, scale 1:750,000.

Chadwick, R.A., Weinheimer, G.J., Rose, C.C., and Boyer, C.I., 1978, Geophysical investigations and thermal water circulation at Hunters and Norris Hot Springs, Montana: Northwest Geology, v. 7, p. 26-33.

Clark, D.W., and Dutton, D.M., in press, Quality of ground water and surface water in intermontane basins of the Northern Rocky Mountains, Montana and Idaho: U.S. Geological Survey Hydrologic Investigations Atlas 738-C, 1 sheet, scale 1:750,000.

Davis, W.E., Kinoshita, W.T., and Robinson, G.D., 1965, Bouguer gravity, aeromagnetic, and generalized geologic map of the western part of the Three Forks basin, Jefferson, Broadwater, Madison, and Gallatin Counties, Montana: U.S. Geological Survey Geophysical Investigations Map GP-497, 2 sheets, scale 1:62,500.

Dutton, D.M., Lawlor, S.M., Briar, D.W., and Tresch, R.E., 1995, Hydrogeologic data for the Northern Rocky Mountains intermontane basins, Montana: U.S. Geological Survey Open-File Report 95-143, 94 p.

Eyde, T.H., 1958, The Potosi tungsten district, Madison County, Montana: Montana Bureau of Mines and Geology Information Circular 21, 51 p.

Feichtinger, S.H., 1970, Geology of a portion of the Norris quadrangle, with emphasis on Tertiary sediments, Madison and Gallatin counties, Montana: Bozeman, Montana State University, M.S. thesis, 89 p.

Fields, R.W., Rasmussen, D.L., Tabrum, A.R., and Nichols, Ralph, 1985, Cenozoic rocks of the intermontane basins of western Montana and eastem Idaho-A summary, in Flores, R.M., and Kaplan, S.S., eds., Cenozoic paleogeography of west-central United States, Society of Economic Paleontologists and Mineralogists, Rocky Mountain Section, Denver, Colo., p. 9-36.

Hanneman, D.L., and Wideman, C.J., 1991, Sequence stratigraphy of Cenozoic continental rocks, southwestern Montana: Geological Society of America Bulletin, v. 103, p. 1,335-1,345.

Johnson, R.W., Jr., Henderson, J.R., and Tyson, N.S., 1965, Aeromagnetic map of the Boulder batholith area, southwestern Montana: U.S. Geological Survey Geophysical Investigations Map GP-538, scale 1:250,000.

Kellogg, K.S., 1994, Geologic map of the Norris quadrangle, Madison County, Montana: U.S. Geological Survey Geologic Quadrangle Map GQ-1738, scale 1:24,000.

Knapton, J.R., and Brosten, T.M., 1987, Supplemental arsenic data for selected streams in the Missouri River basin, Montana, 1987: U.S. Geological Survey Open-File Report 87-697, 14 p.

Knapton, J.R., and Horpestad, A.A., 1987, Arsenic data for streams in the upper Missouri River basin, Montana and Wyoming: U.S. Geological Survey Open-File Report 87-124, 25 p.

Krothe, N.C., and Bergeron, M.P., 1981a, Hydrochemical facies in a Tertiary basin in the Milligan Canyon area, southwest Montana: Ground Water, v. 19, no. 4, p. 392-399.

1981b, The relationship between fracture traces and joints in a Tertiary basin, southwest Montana: Ground Water, v. 19, no. 2, p. 138-143.

Mariner, R.H., Presser, T.S., and Evans, W.C., 1976, Chemical characteristics of the major thermal springs of Montana: U.S. Geological Survey Open-File Report 76-480, 31 p.

McCulloch, Robin, 1993, Montana mining directory 1992: Montana Bureau of Mines and Geology Bulletin 131, 76 p.

[Montana] State Engineer's Office, 1953a, Water resources survey, Gallatin County, Montana--Part 1, History of land and water use on irrigated areas: Helena, Mont., State Engineer's Office, 62 p.

1953b, Water resources survey, Gallatin County, Montana--Part 2, Maps showing irrigated areas: Helena, Mont., State Engineer's Office, 53 p. 
1954a, Water resources survey, Madison County, Montana--Part 1, History of land and water use on irrigated areas: Helena, Mont., State Engineer's Office, 68 p.

1954b, Water resources survey, Madison County, Montana--Part 2, Maps showing irrigated areas: Helena, Mont., State Engineer's Office, 62 p.

1956a, Water resources survey, Jefferson County, Montana--Part 1, History of land and water use on irrigated areas: Helena, Mont., State Engineer's Office, 54 p.

1956b, Water resources survey, Jefferson County, Montana--Part 2, Maps showing irrigated areas: Helena, Mont., State Engineer's Office, 29 p.

National Oceanic and Atmospheric Administration, 1992, Monthly normals of temperature, precipitation, and heating and cooling degree days, 1961-90, Montana: Asheville, N.C., Climatography of the United States no. 81, unpaged.

Noble, R.A., Bergantino, R.N., Patton, T.W., Sholes, B.C., Daniel, Faith, and Schofield, Judeykay, 1982, Occurrence and characteristics of ground water of Montana--Volume 2, The Rocky Mountain Region: Montana Bureau of Mines and Geology Open-File Report 99, 132 p.

Parrett, Charles, and Johnson, D.R., 1988, Estimation of surface withdrawals for irrigation and irrigated acreage, 1985, Gallatin County, Montana, in Proceedings of the Symposium on Water-Use Data for Water Resources Management: Bethesda, Md., American Water Resources Association, p. 641-647.

Peterson, J.L., 1983, An analysis of resistivity surveys at Norris Hot Springs, in Peterson, J.L., Wideman, C.J., and Sonderegger, J.L, 1983, Geothermal studies in Montana: Montana Bureau of Mines and Geology Open-File Report 108, 30 p.

Robinson, G.D., 1961, Origin and development of the Three Forks basin, Montana: Geological Society of America Bulletin, v. 72, p. 1,003-1,014.

1963, Geology of the Three Forks quadrangle, Montana: U.S. Geological Survey Professional Paper 370, 143 p.

Schneider, G.B., 1970, Cenozoic stratigraphy of the Madison Bluffs area, Gallatin County, Montana [abstract]: Geological Society of America Abstracts with Programs, v. 2, p. 348.

Sonderegger, J.L., and Ohguchi, Takeshi, 1988, Irrigation related arsenic contamination of a thin, alluvial aquifer, Madison River Valley, Montana, USA: Environmental Geology and Water Sciences, v. 11, no. 2, p. 153-161.

Sonderegger, J.L., Schofield, Judeykay, Berg, R.B., and Mannick, M.L., 1982, The Upper Centennial Valley, Beaverhead and Madison Counties, Montana, with a section on The Madison Valley thermal springs, by G.J. Weinheimer: Montana Bureau of Mines and Geology Memoir 50, $53 \mathrm{p}$.

Sonderegger, J.L., Sholes, B.R., and Ohguchi, Takeshi, 1989a, Arsenic contamination of aquifers caused by irrigation with diluted geothermal water in the lower Madison Valley, Montana: Montana Bureau of Mines and Geology Open-File Report 210, 23 p.

$1989 \mathrm{~b}$, Arsenic contamination of aquifers caused by irrigation with diluted geothermal water, in Woessner, W.W., and Potts, D.F., eds., Proceedings of the Symposium on Headwaters Hydrology: American Water Resources Association Technical Publication Series TPS-89-1, p. 685-694.

Stickney, M.C., 1990, Recent seismicity in the Three Forks Basin, Montana [abs.]: Geological Society of America, Abstracts with Programs, Rocky Mountain Section, v. 22, p. 46.

Tuck, L.K., Briar, D.W., and Clark, D.W., in press, Geologic history and hydrogeologic units of intermontane basins of the Northern Rocky Mountains, Montana and Idaho: U.S. Geological Survey Hydrologic Investigations Atlas 738-A, 2 sheets, scale 1:750,000.

U.S. Environmental Protection Agency, 1991, Maximum contaminant levels (subpart B of part 141, National primary drinkingwater regulations): U.S. Code of Federal Regulations, Title 40, Parts 100 to 149, revised July 1, 1991, p. 585-588.

U.S. Geological Survey, issued annually, Water resources data, Montana: Helena, Mont., U.S. Geological Survey Water-Data Report. 